\title{
GROUND-WATER HYDROGRAPHS AND 5-YEAR GROUND-WATER-LEVEL CHANGES, 1984-93, FOR SELECTED AREAS IN AND ADJACENT TO NEW MEXICO
}

\author{
U.S. GEOLOGICAL SURVEY \\ Open-File Report 95-434
}

\author{
Prepared in cooperation with the \\ NEW MEXICO STATE ENGINEER OFFICE
}

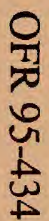




\section{TABLES-Concluded}

Tables 17-36. Well location and water-level data for selected:

17. Wells in the Portales monitoring area, Roosevelt County, New Mexico.

18. Wells in the Mimbres Basin monitoring area, Luna, Grant, Doña Ana, and Sierra Counties, New Mexico

19. Wells in the Mora monitoring area, Mora, San Miguel, and Colfax Counties, New Mexico.

20. Wells in the Nutt-Hockett monitoring area, Doña Ana, Luna, and Sierra Counties, New Mexico

21. Wells in the San Juan Basin monitoring area, San Juan, McKinley, and Rio Arriba Counties, New Mexico

22. Wells in the Lower Canadian monitoring area, Quay County, New Mexico....... 180

23. Wells in the Carlsbad monitoring area, Eddy County, New Mexico.

24. Wells in the Capitan Reef monitoring area, Eddy County, New Mexico.

25. Wells in the Animas monitoring area, Hidalgo County, New Mexico

26. Wells in the Playas monitoring area, Hidalgo and Grant Counties, New Mexico.

27. Wells in the Lordsburg monitoring area, Grant and Hidalgo Counties, New Mexico.

28. Wells in the Santa Fe County monitoring area, New Mexico.

29. Wells in the Upper Rio Grande monitoring area, Taos and Rio Arriba Counties, New Mexico, and Costilla County, Colorado

30. Shallow wells in the Roswell Basin monitoring area, Chaves, DeBaca, and Eddy Counties, New Mexico.

31. Artesian wells in the Roswell Basin monitoring area, Chaves, DeBaca, and Eddy Counties, New Mexico.

32. Wells in the Rio Hondo monitoring area, Lincoln County, New Mexico

33. Wells in the Rio Peñasco monitoring area, Chaves and Otero Counties, New Mexico.

34. Wells in the Grants-Bluewater monitoring area, Cibola County, New Mexico ... 254

35. Wells in the Lower Rio Grande monitoring area, Sierra and Doña Ana Counties, New Mexico

36. Wells in the Hueco monitoring area, Doña Ana and Otero Counties, New Mexico.

Multiply
inch
foot
mile

square mile acre

\section{CONVERSION FACTORS}

\begin{tabular}{l}
\multicolumn{1}{c}{ By } \\
25.4 \\
0.3048 \\
1.609 \\
2.590 \\
0.4047
\end{tabular}

To obtain

millimeter

meter

kilometer square kilometer hectare 


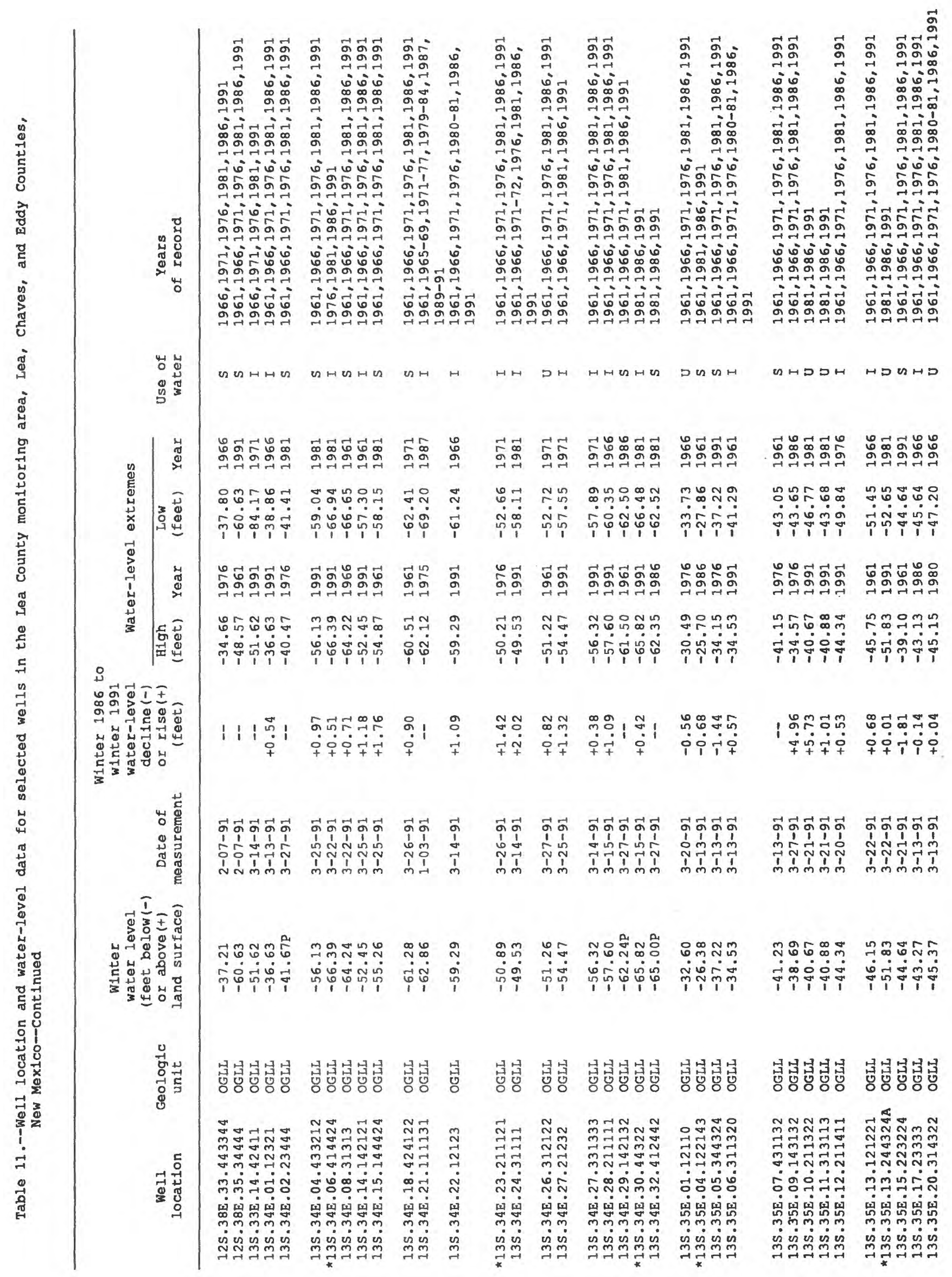




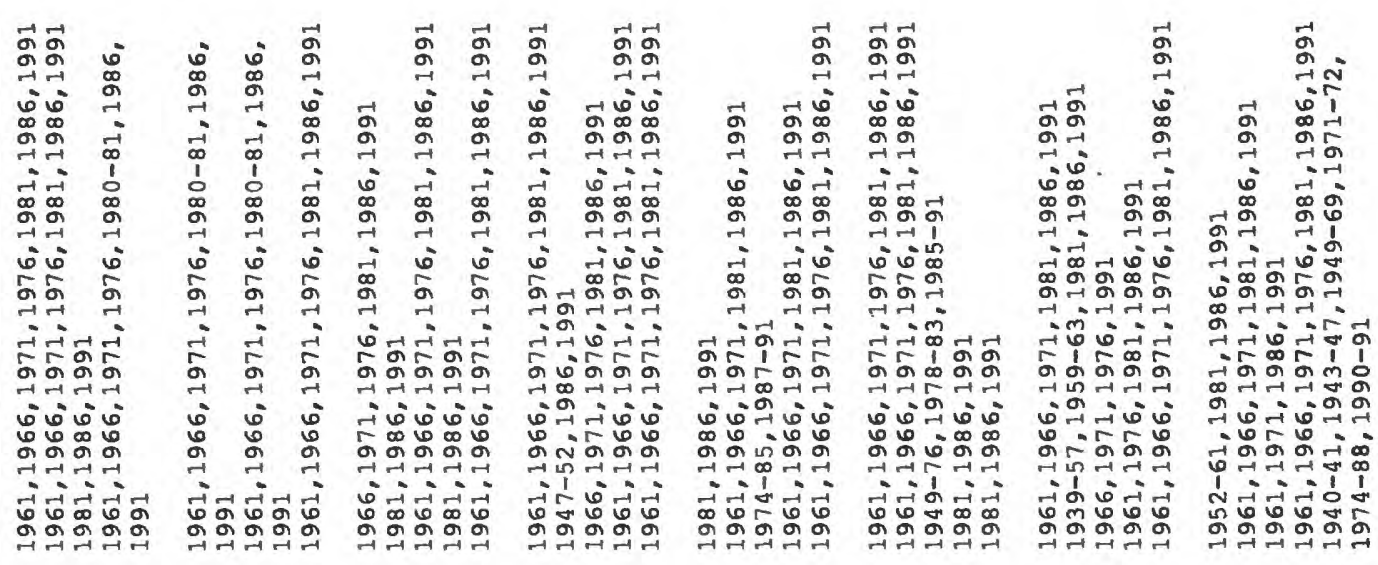

थ出HH H

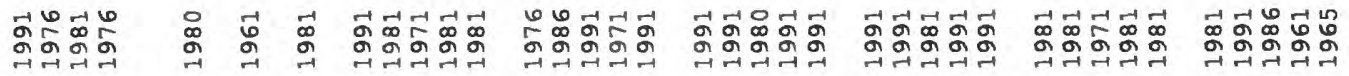

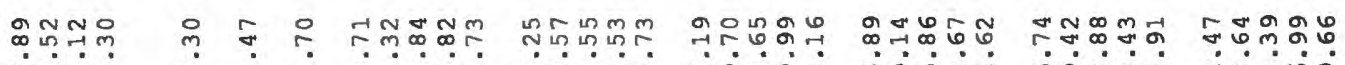

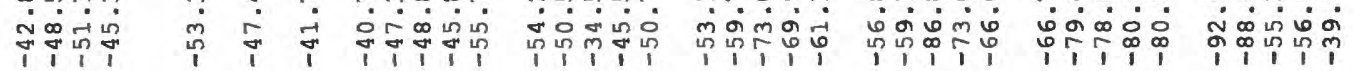

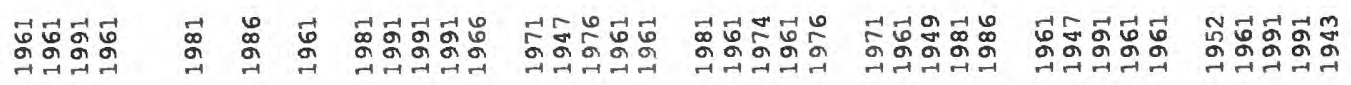

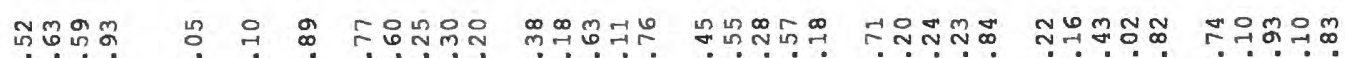

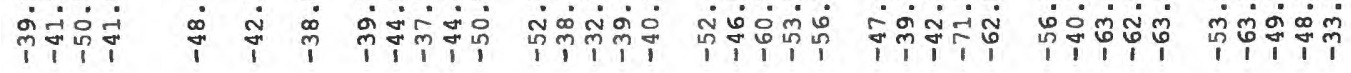

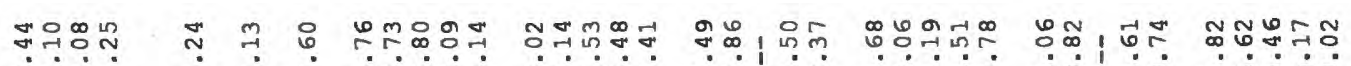

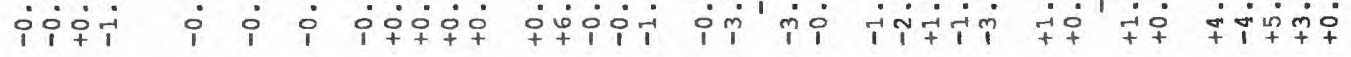

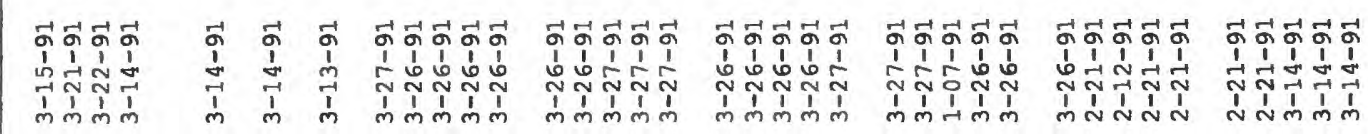

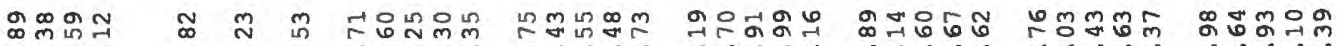

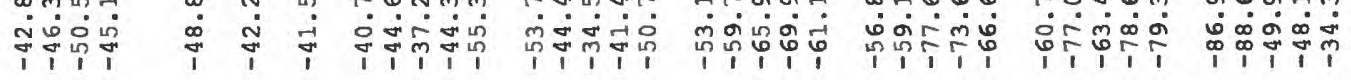

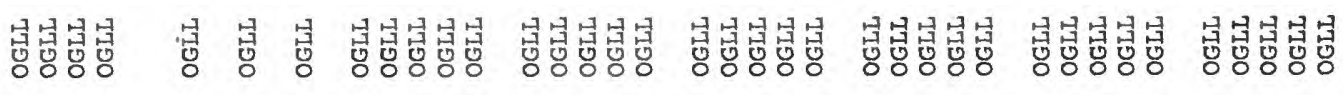

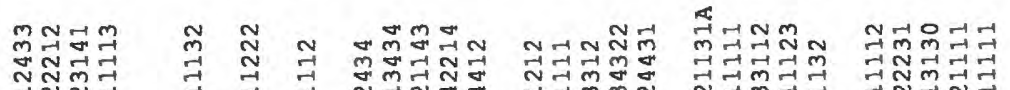

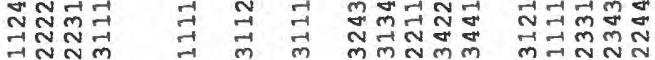

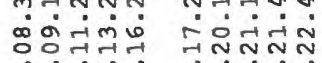

초ำ

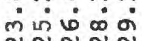

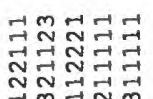

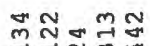

บูN

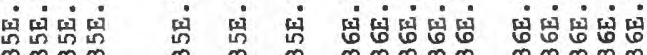

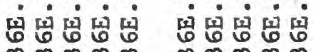

-im户்

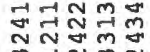

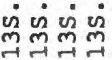

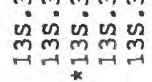

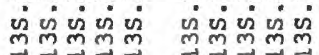

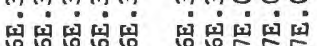

mimmm mmmmm

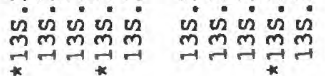




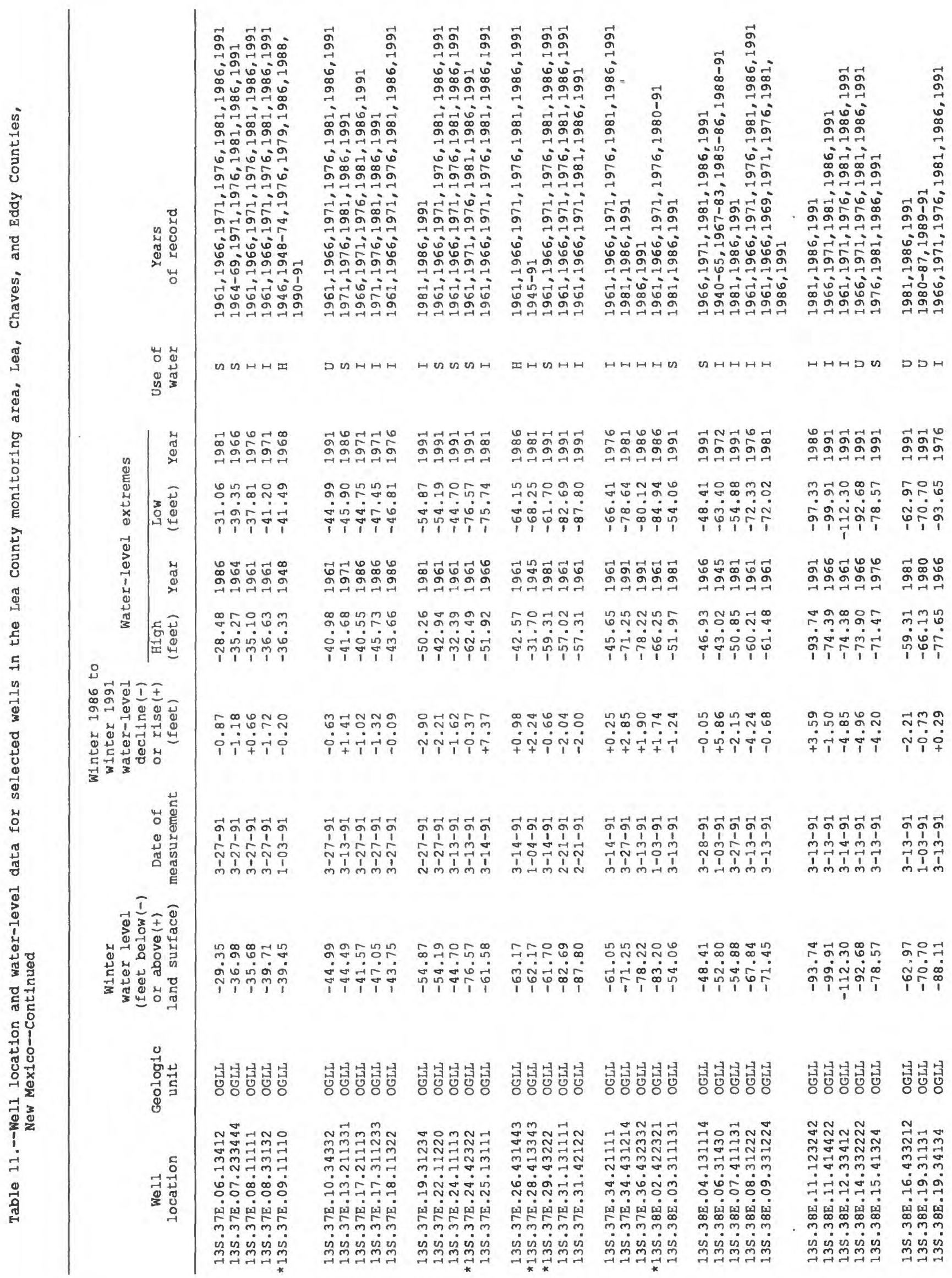




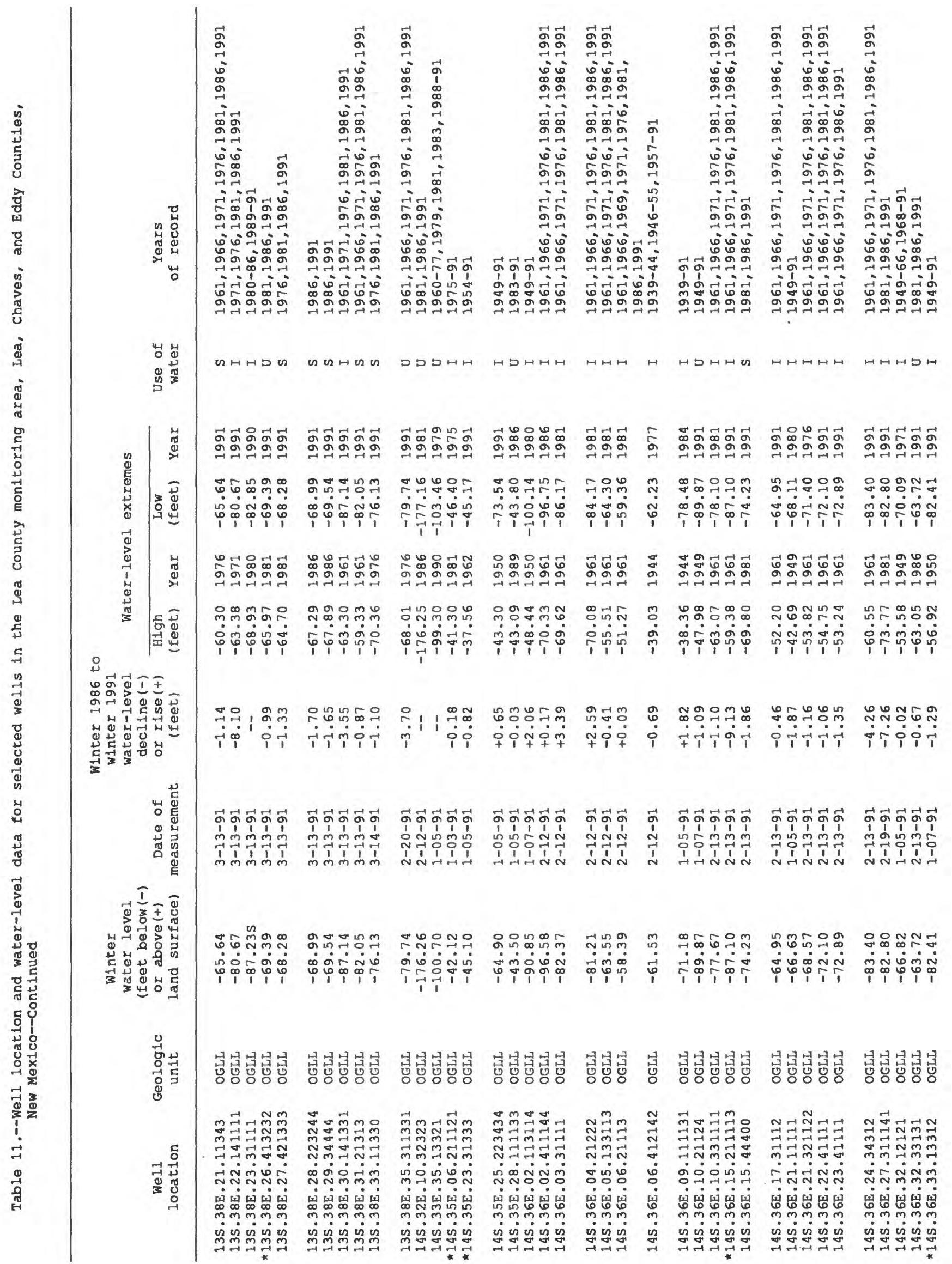




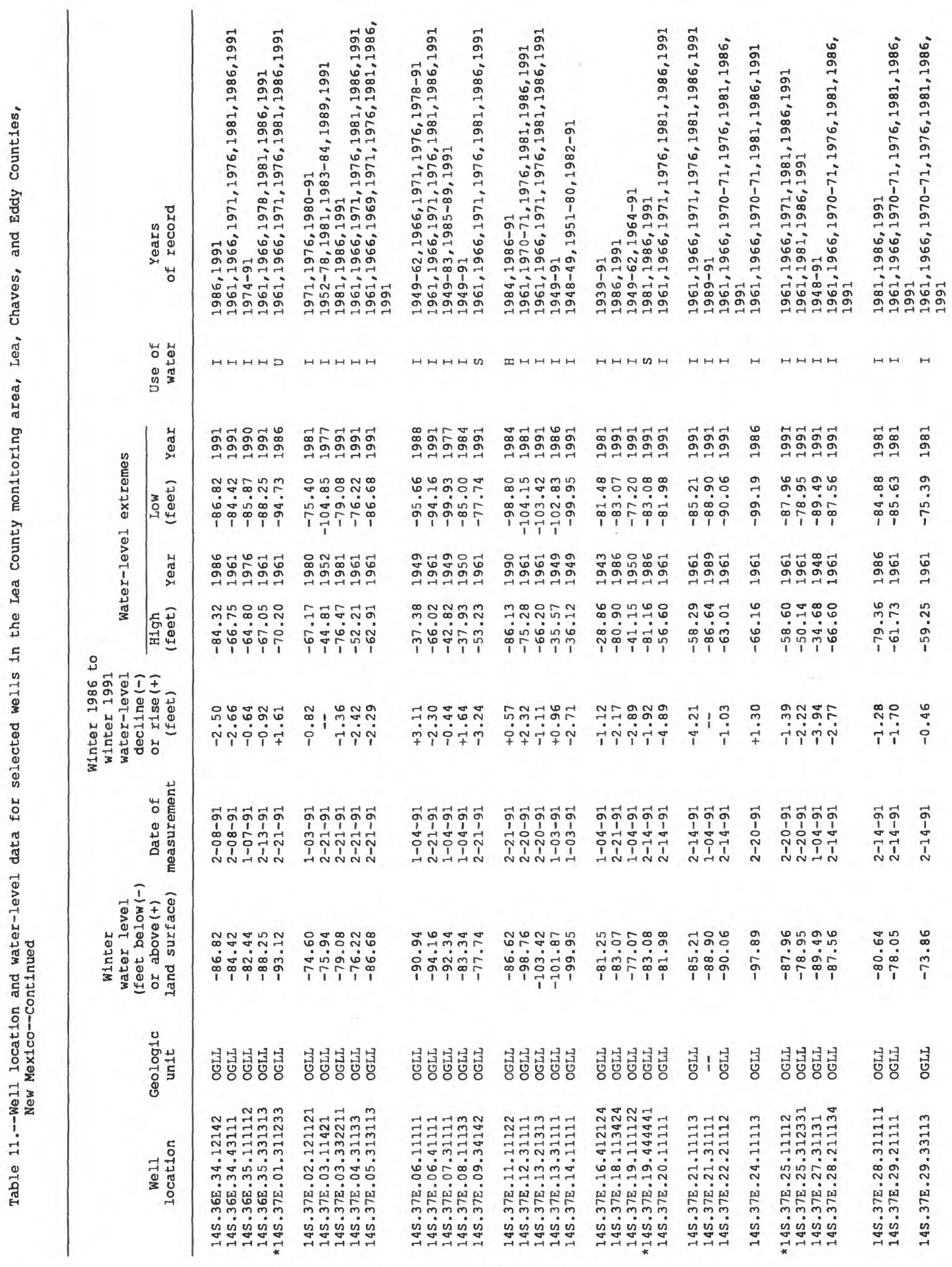




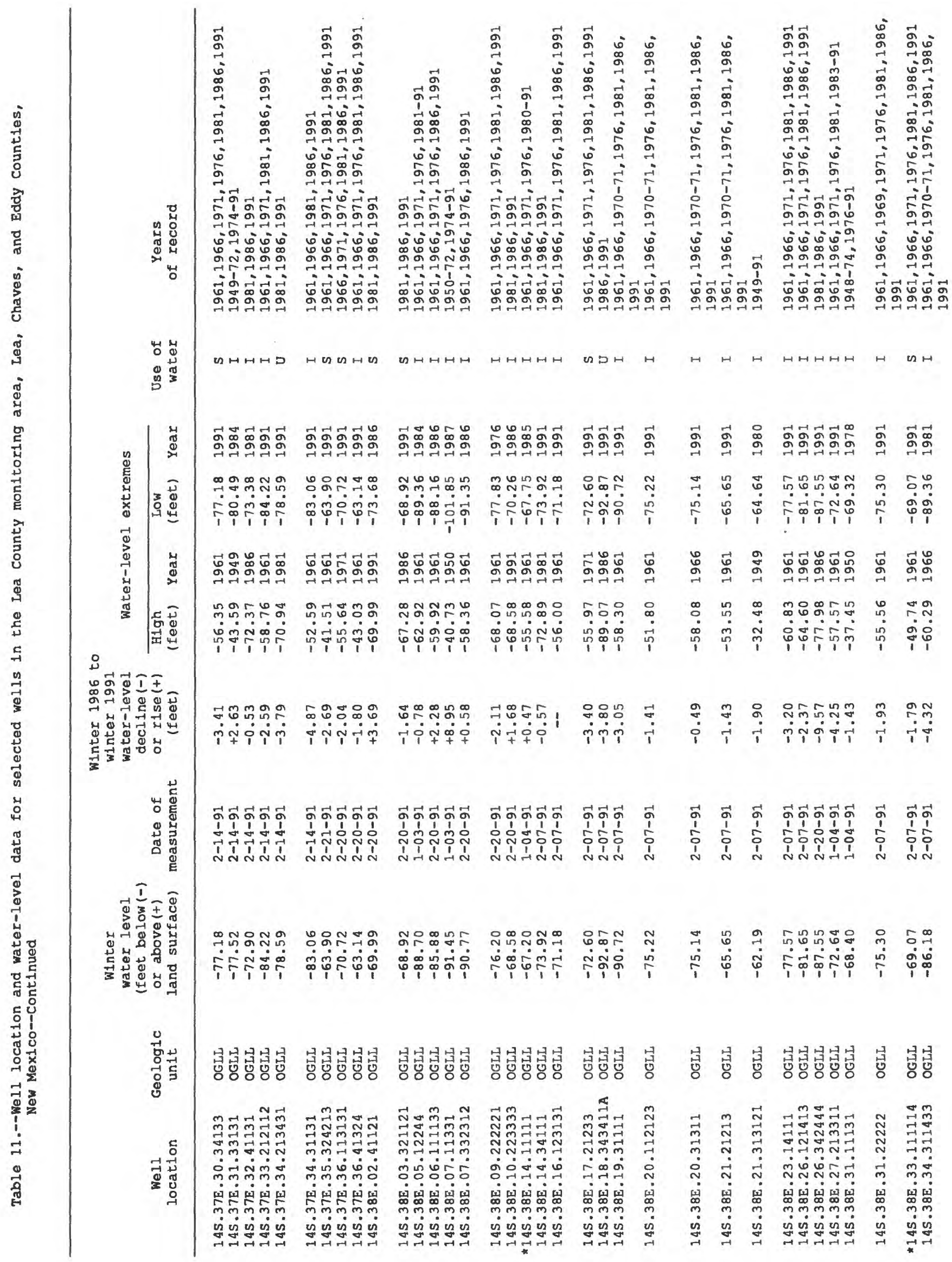




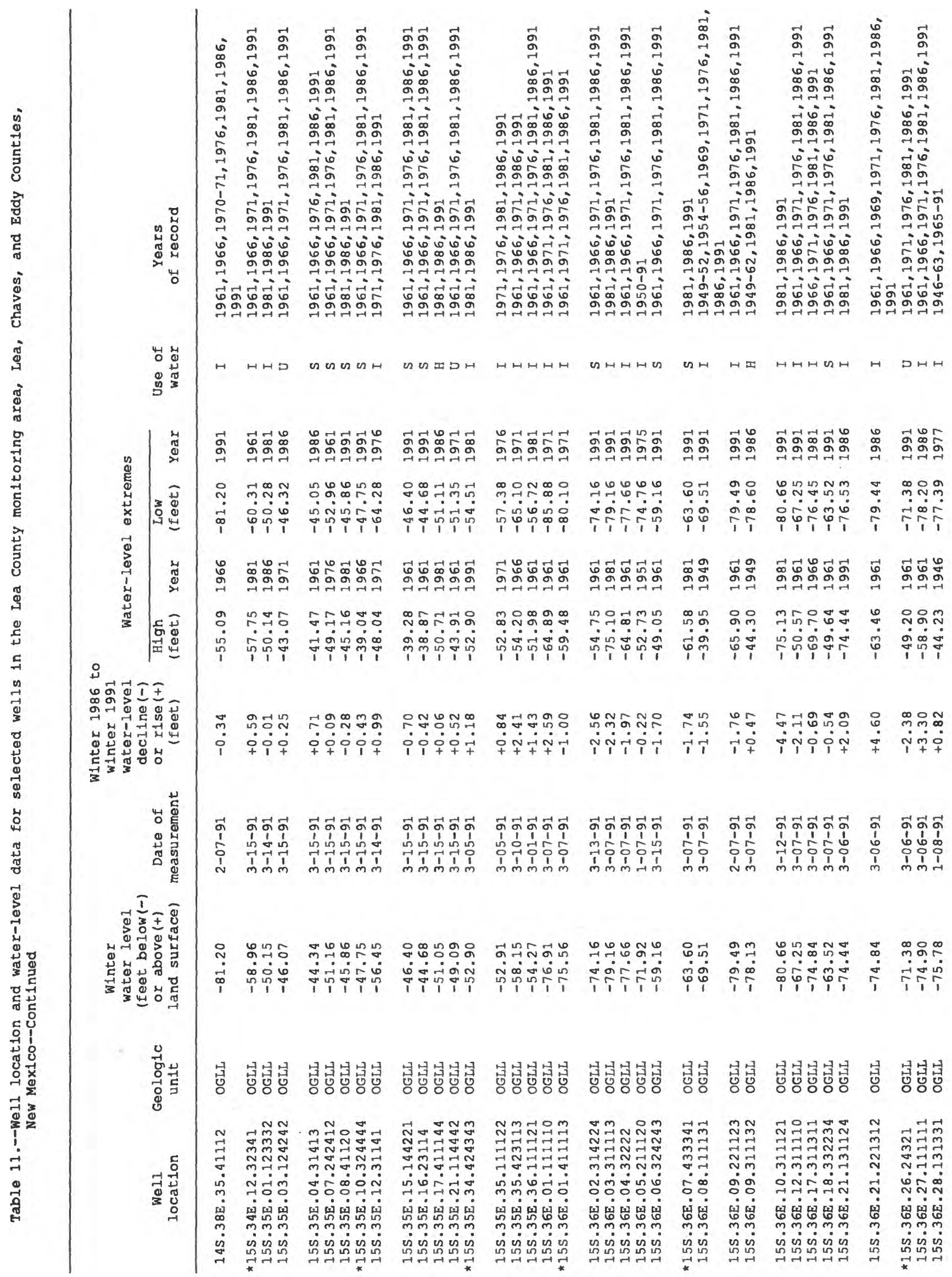




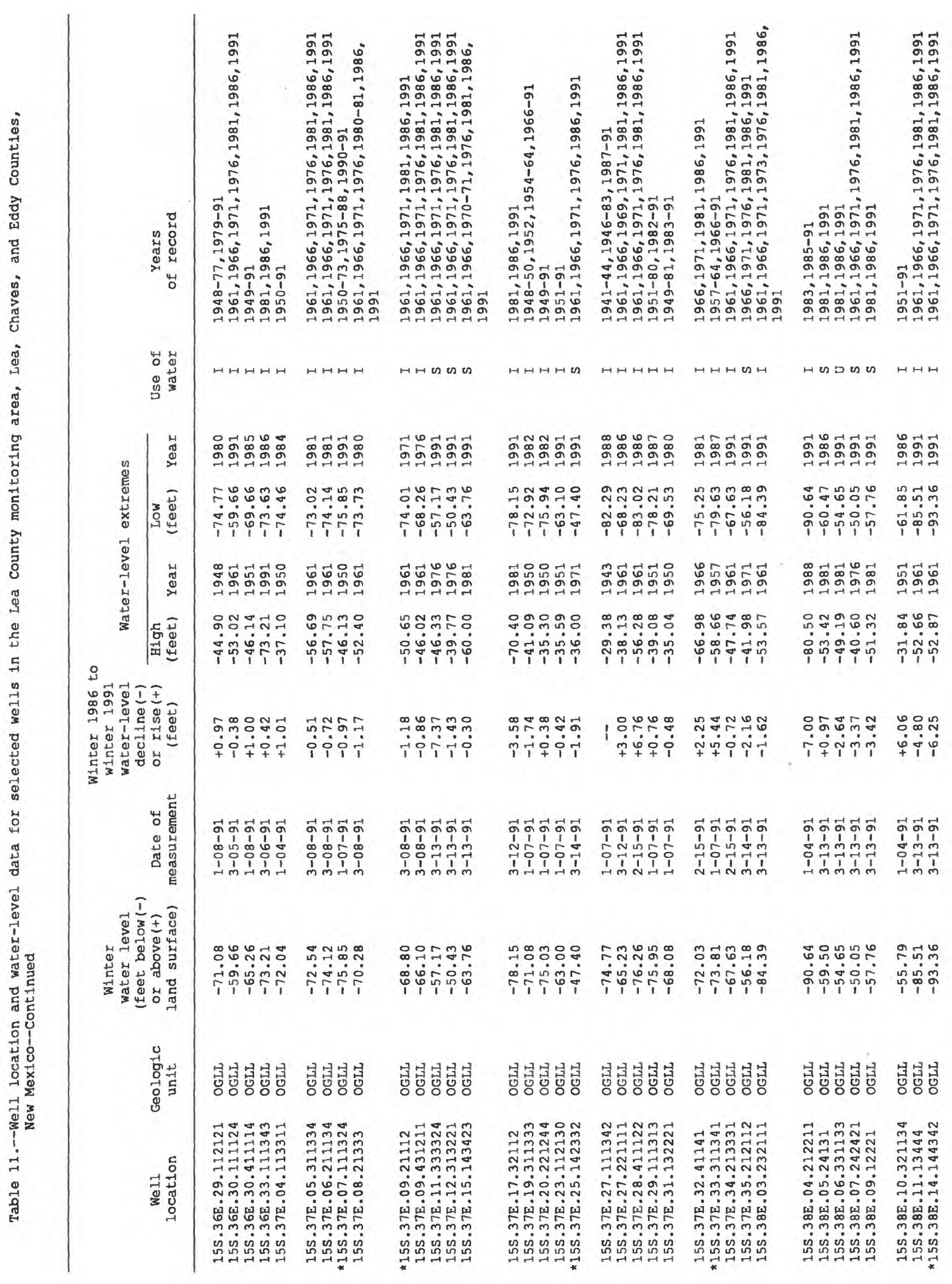




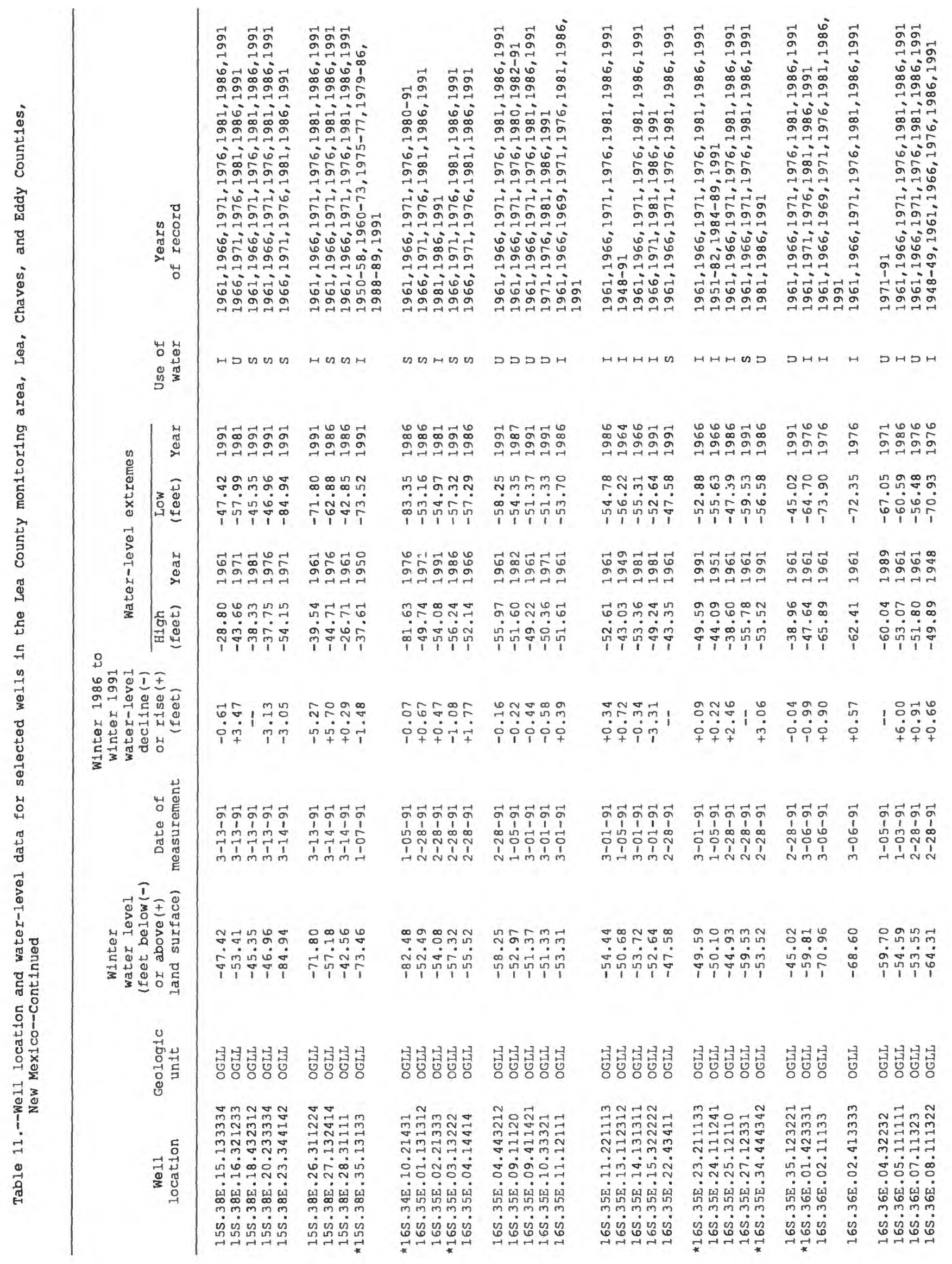




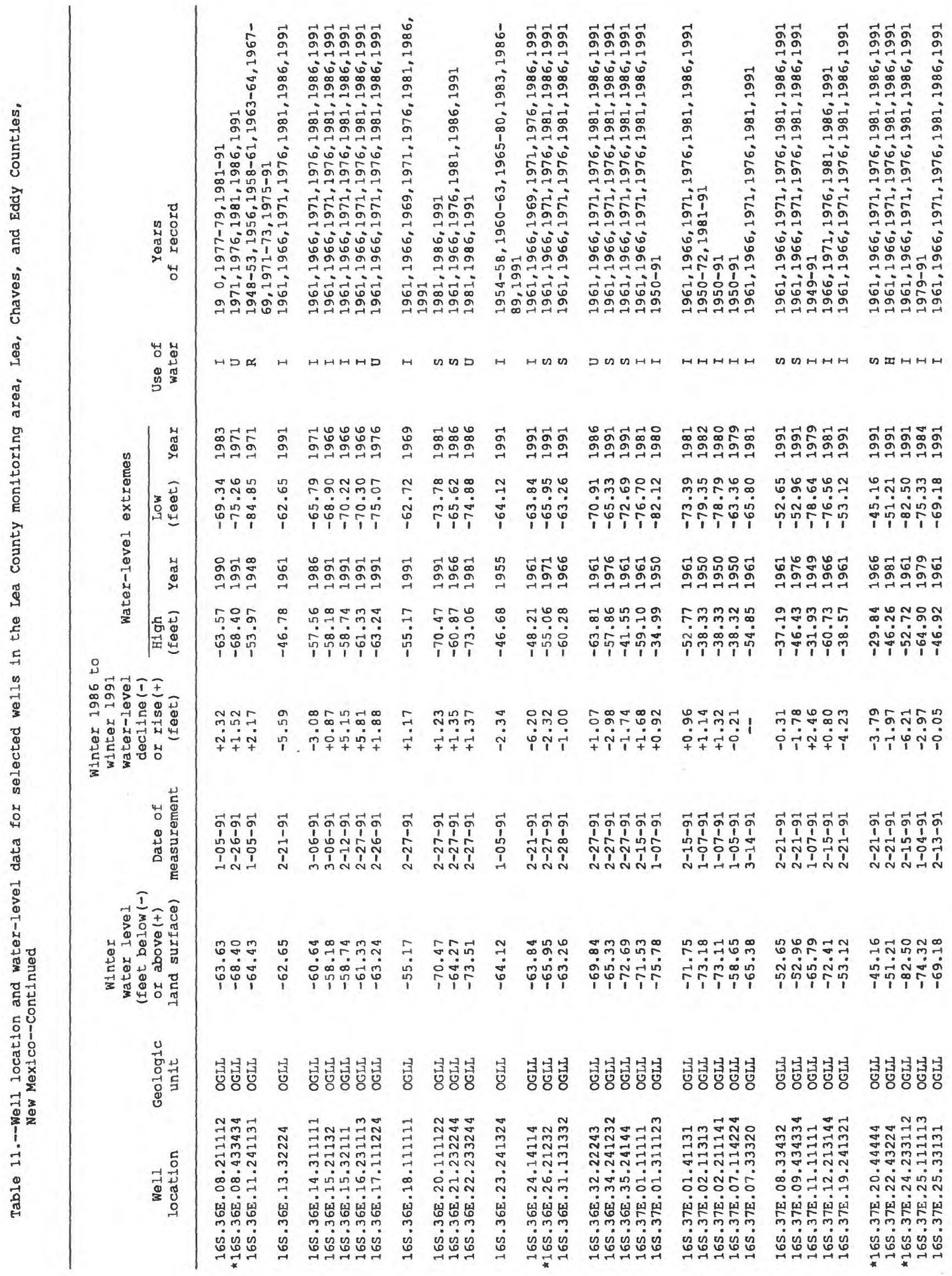





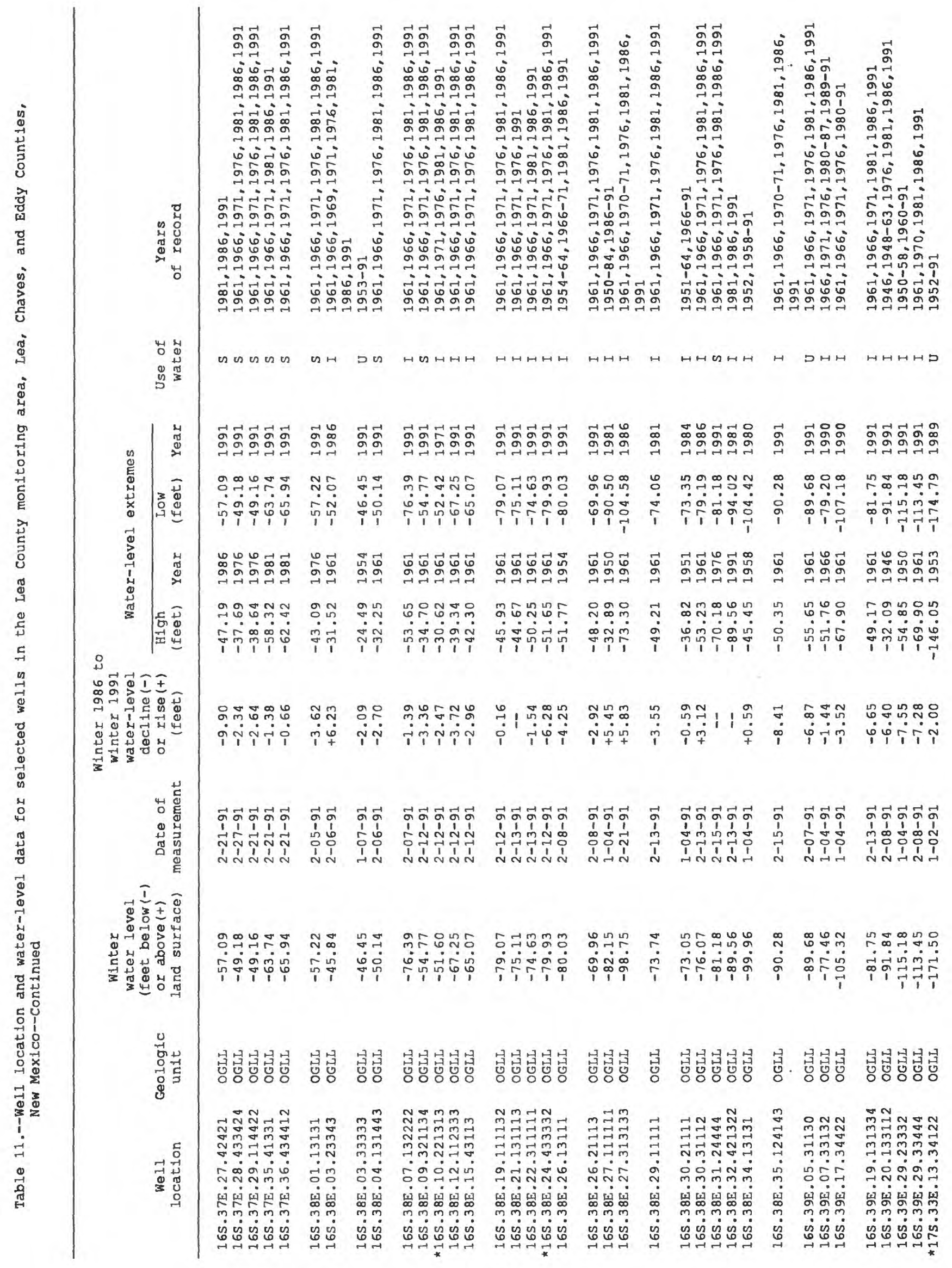




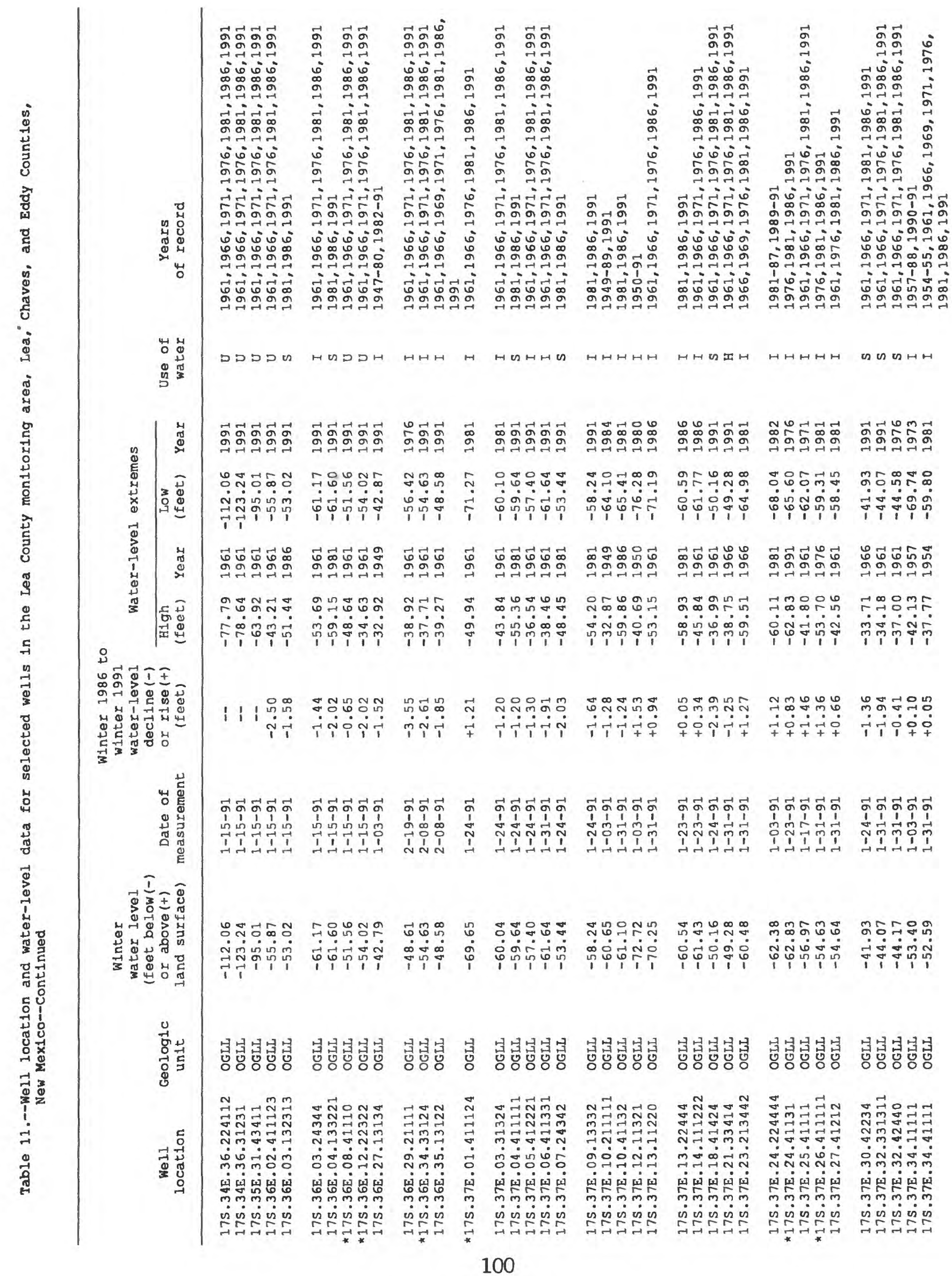




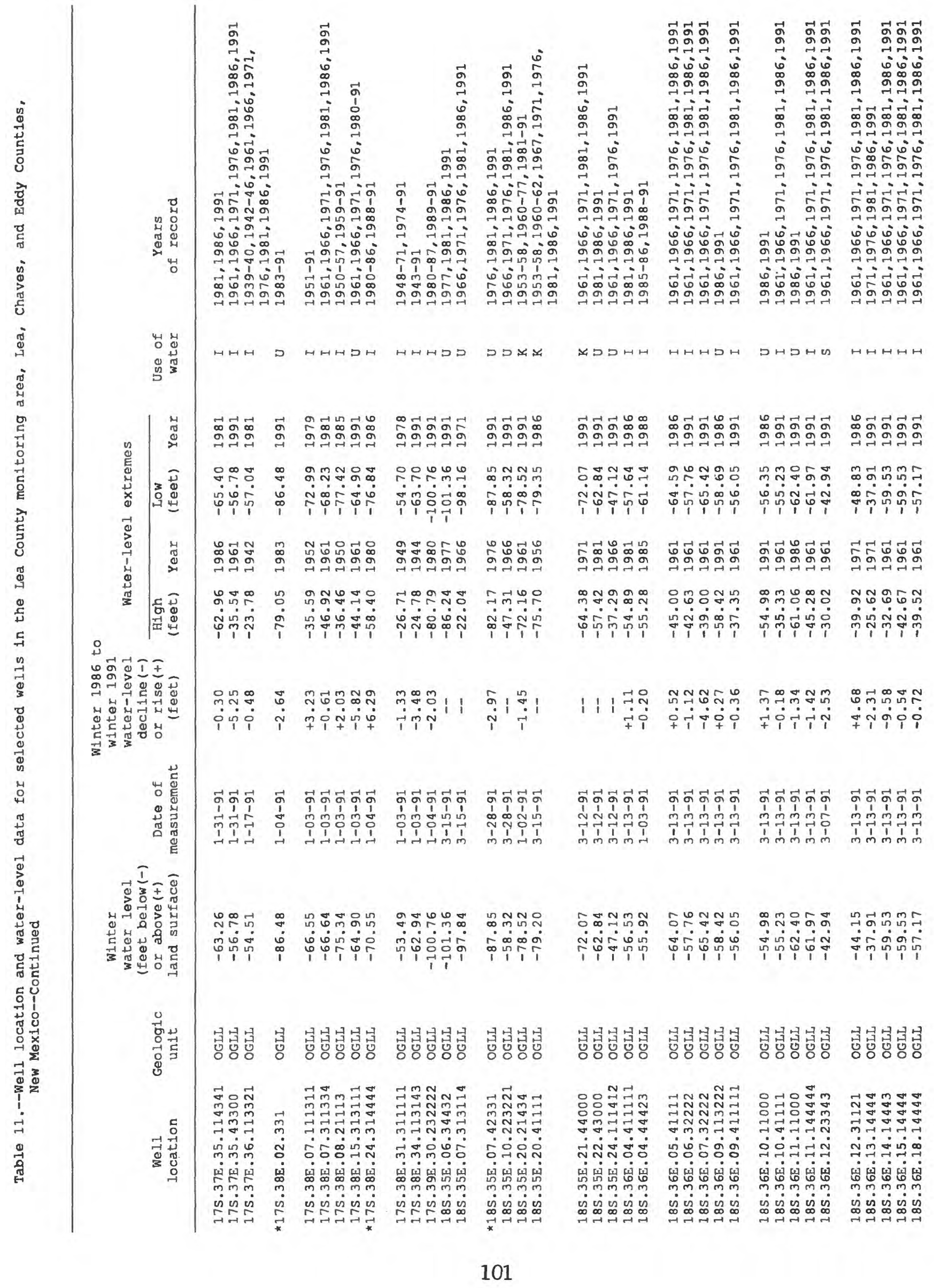




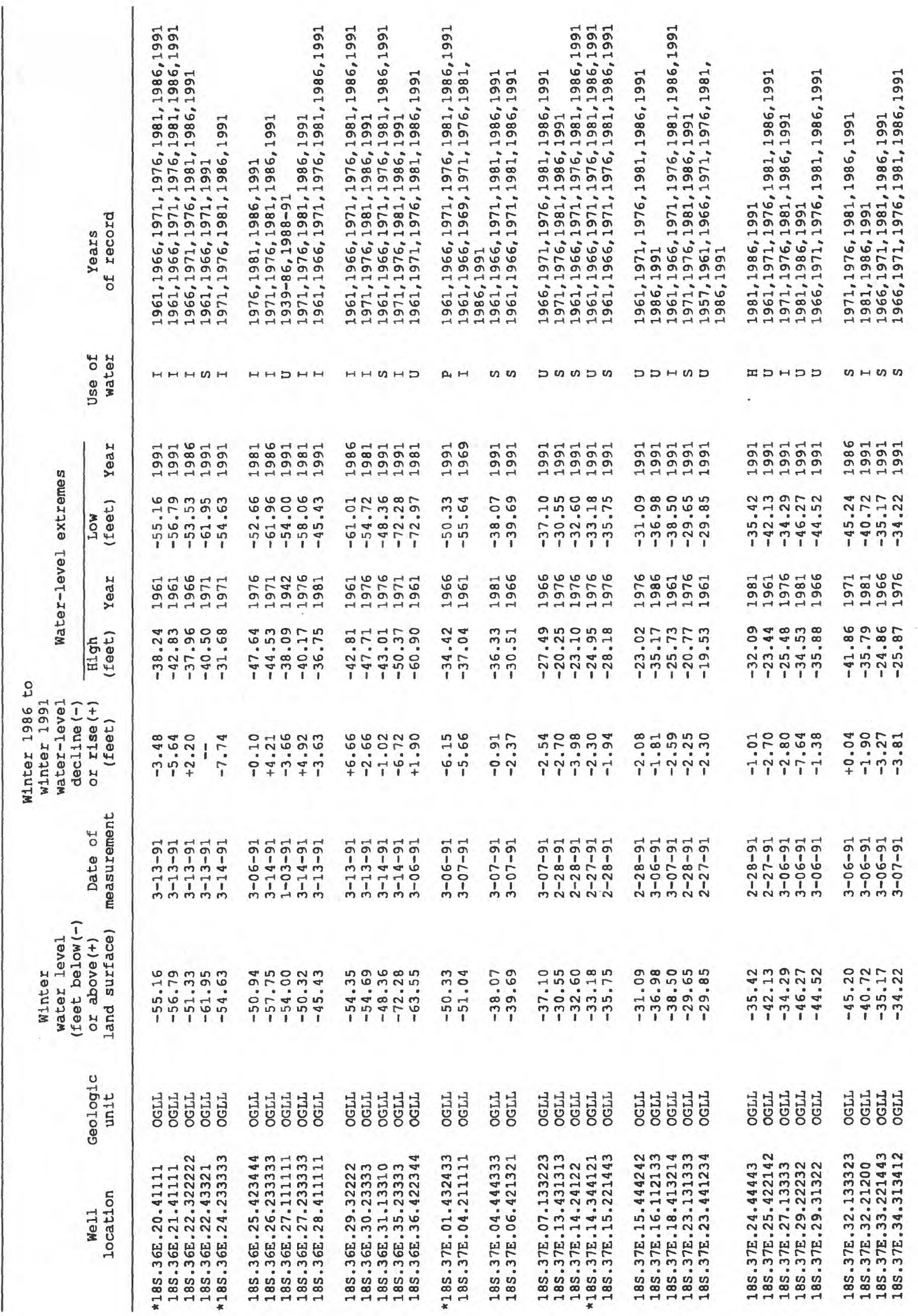




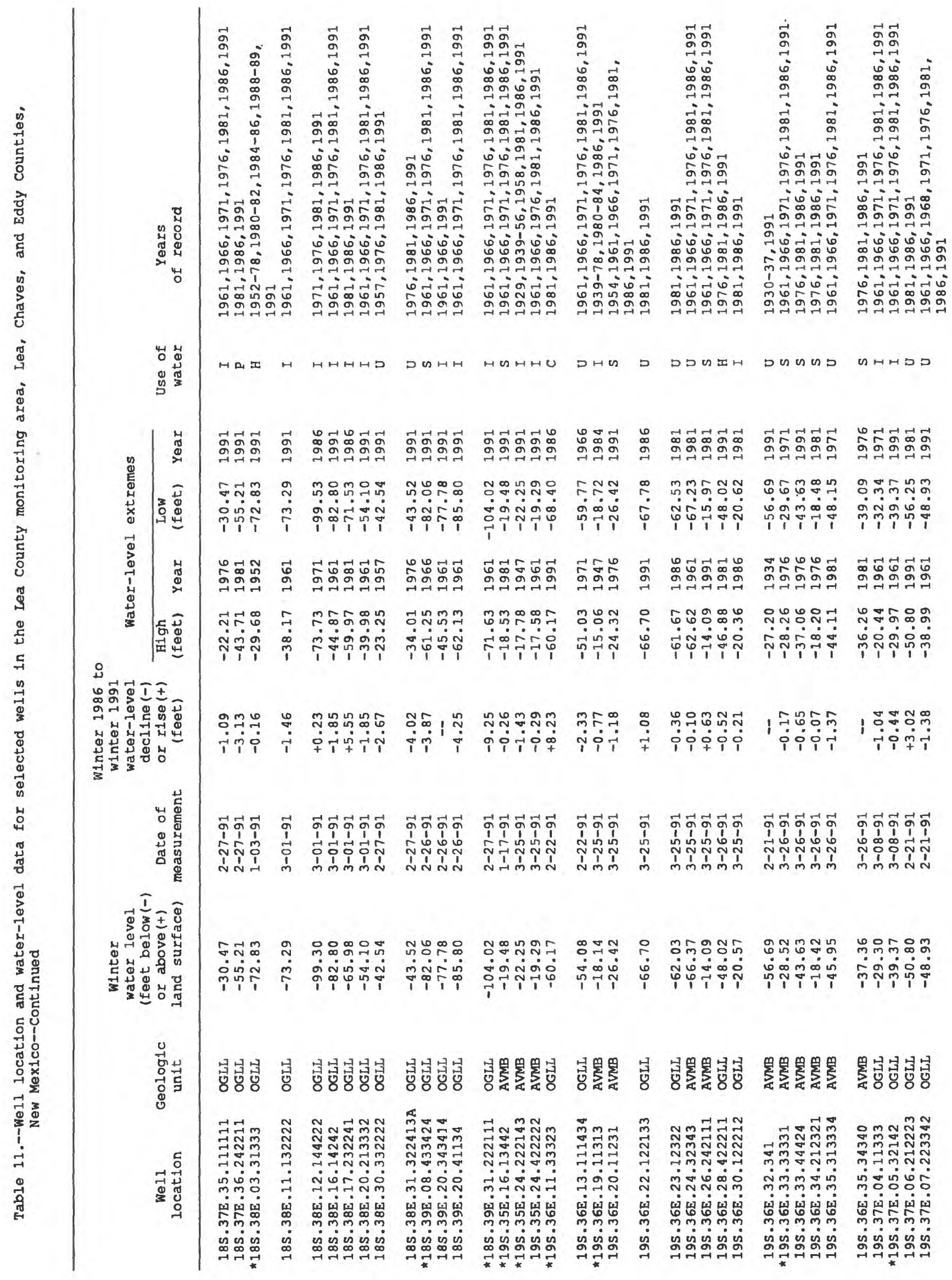




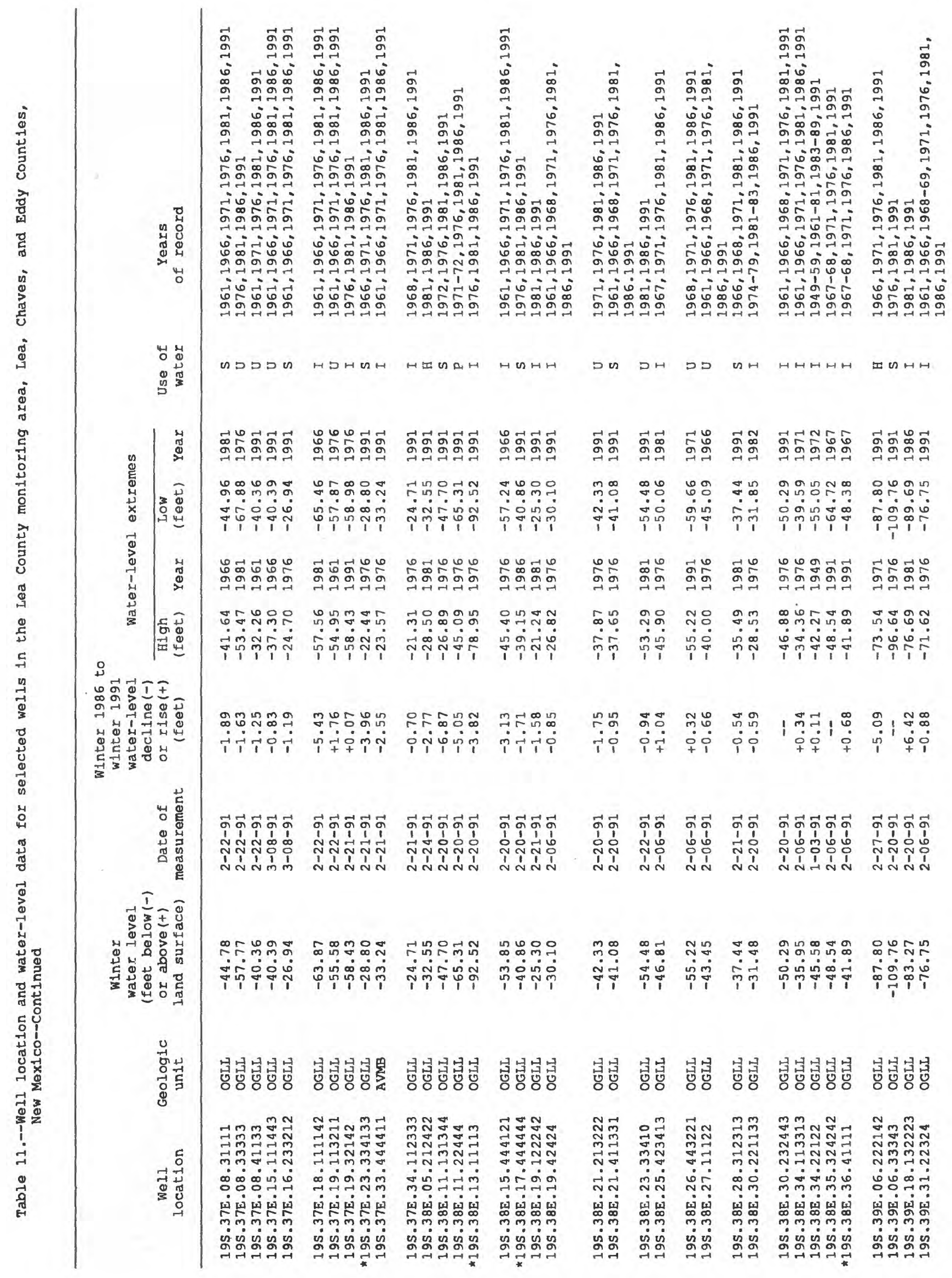




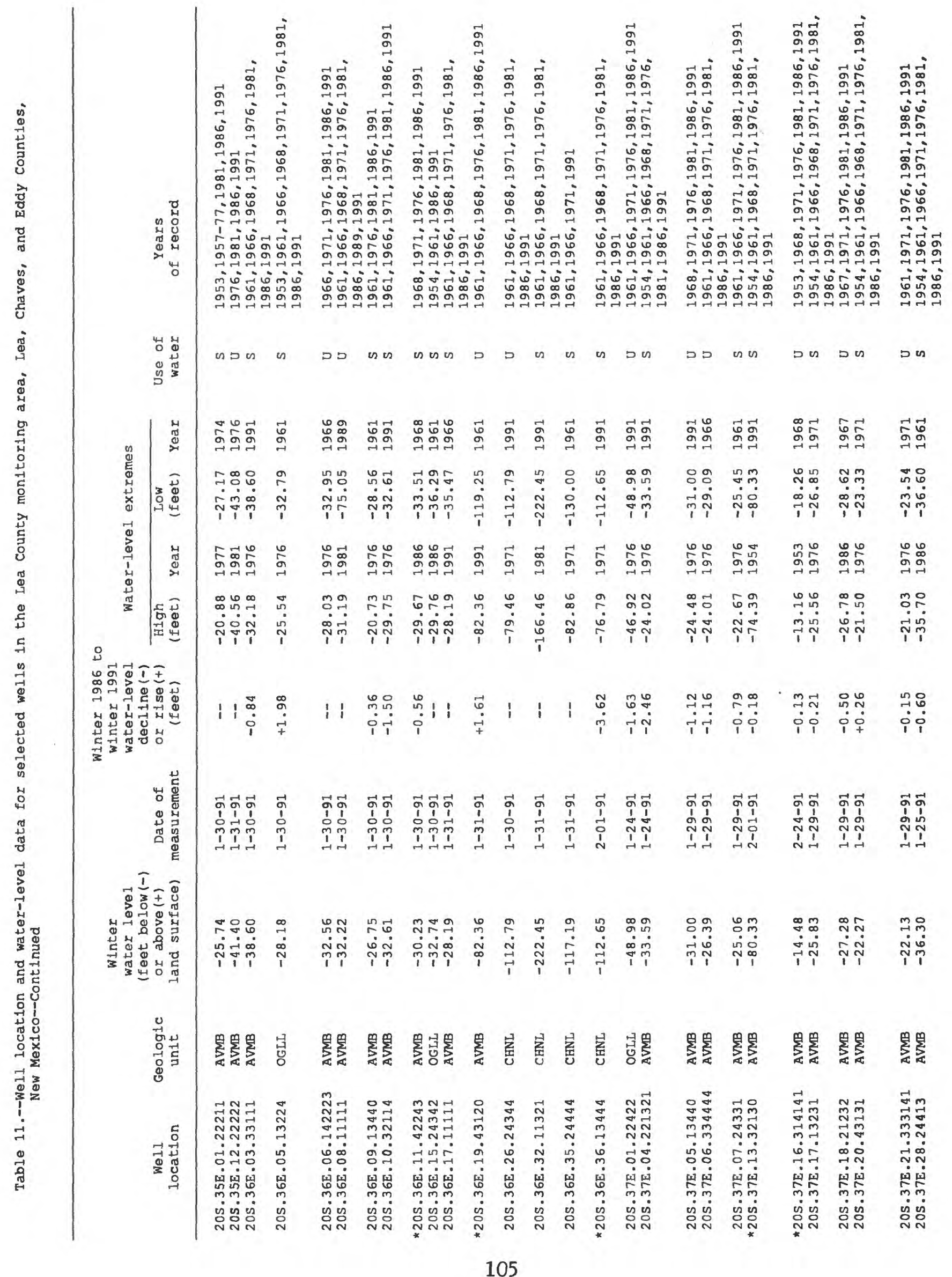




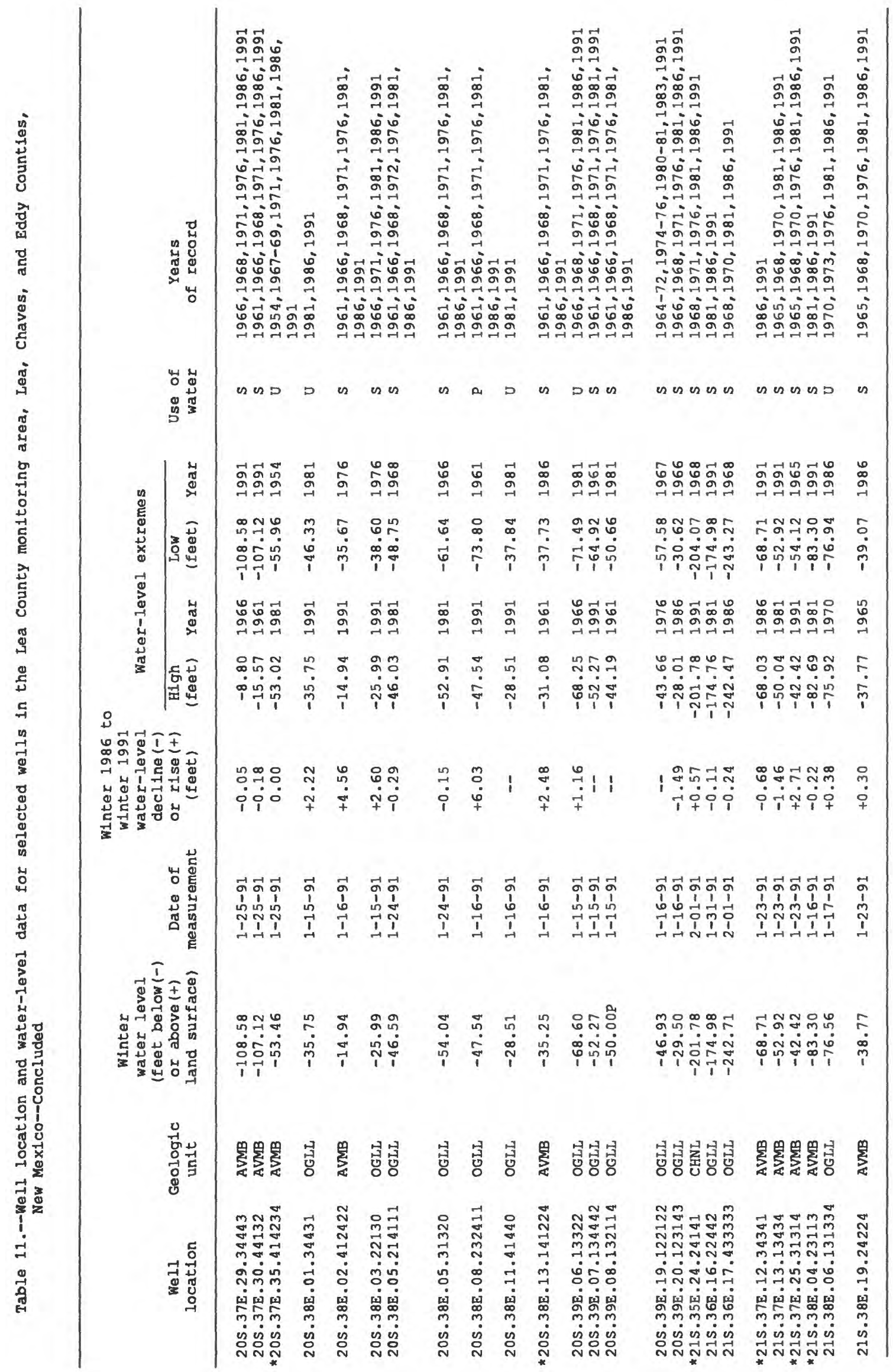




\section{Tularosa Basin Monitoring Area}

The Tularosa Basin monitoring area is located in western Otero and Lincoln Counties and southeastern Socorro County. Many water-level changes are rises ranging from less than 1 foot to more than 37 feet. Declines range from less than 1 foot to more than 31 feet. Two small areas that have declining water levels are in T. 5 S., R. 10 E. and Tps. 17 and 18 S., Rs. 9 and 10 E. 

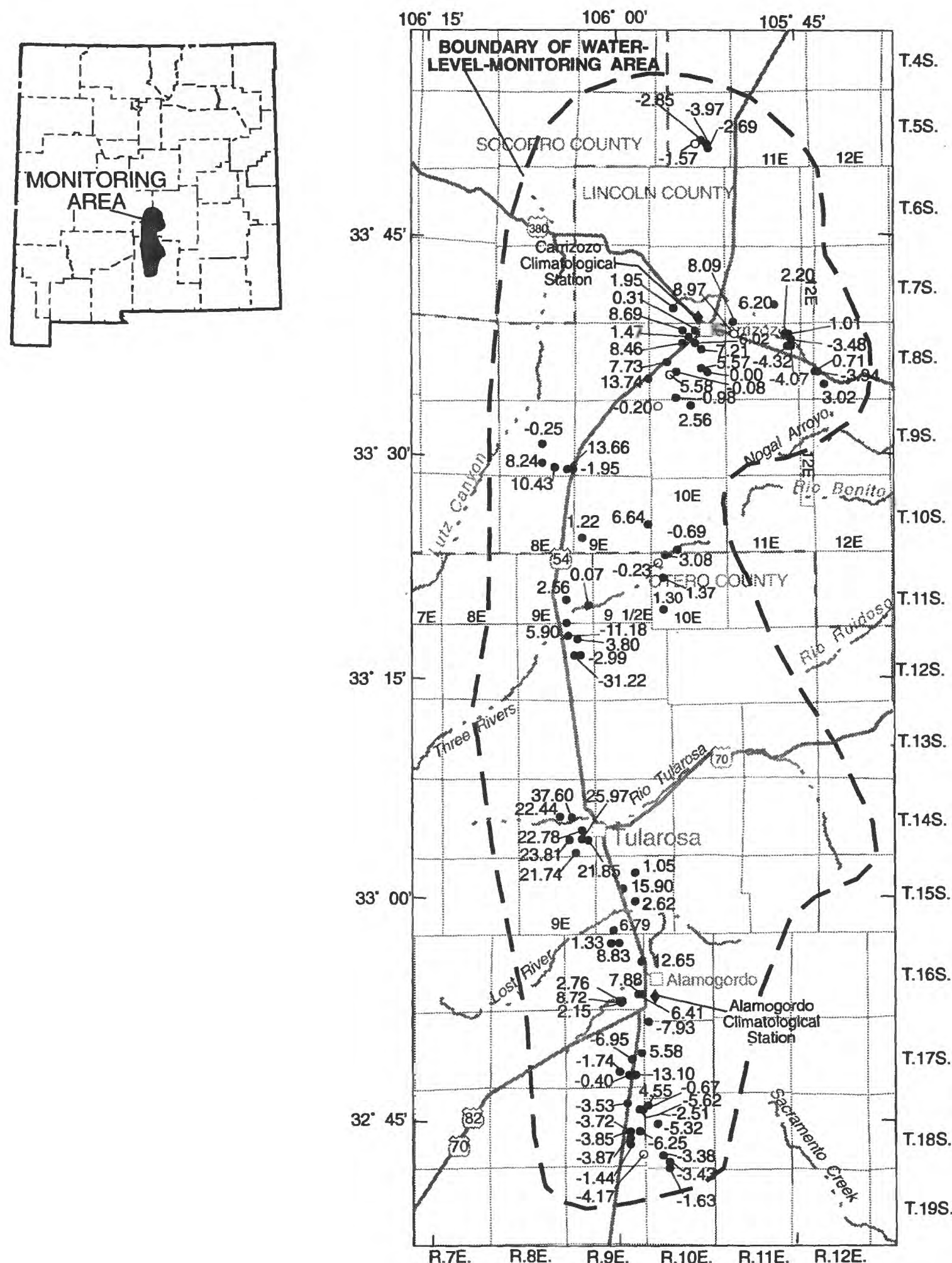

EXPLANATION

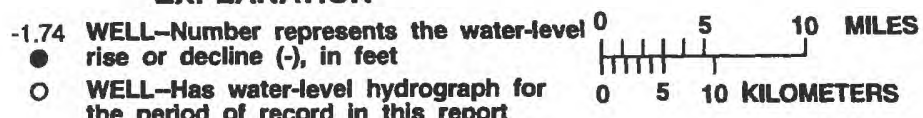

the period of record in this report

Figure 25.--Water-level changes for wells in the Tularosa Basin monitoring area, 1986-91. 


\title{
GROUND-WATER HYDROGRAPHS AND 5-YEAR GROUND-WATER-LEVEL CHANGES, 1984-93, FOR SELECTED AREAS IN AND ADJACENT TO NEW MEXICO \\ By D.W. Wilkins and B.M. Garcia
}

\begin{abstract}
A cooperative observation-well monitoring program was begun in New Mexico in 1925 between the U.S. Geological Survey and the New Mexico State Engineer Office. The majority of the wells are located in New Mexico; however, a few are in Texas east of Curry and Roosevelt County, New Mexico, and in Colorado along the Rio Grande. The program presently includes 22 wells equipped with continuous water-level recorders and 34 monitoring areas in which selected wells are measured periodically, usually every 5 years, to record changes in ground-water levels. These monitoring areas are those where ground water is used in large quantities for irrigation, municipal, or industrial purposes. Water-level data and water-level changes computed from these data are used to determine areas of ground-water-level rises and declines. This information is necessary for management of ground-water resources in New Mexico.

Included in this report are hydrographs of ground-water levels obtained from 22 wells equipped with continuous water-level recorders and maps of ground-water-level changes computed for a 5-year period in each of 34 monitoring areas. Well locations and ground-waterlevel data for a 5-year period are listed in tables for each monitoring area. Where available, plots of annual precipitation data for climatological stations within or adjacent to each monitoring area are included.
\end{abstract}

\section{INTRODUCTION}

A systematic program of ground-water-level measurements in New Mexico was begun in 1925 as part of a cooperative observation-well program between the U.S. Geological Survey and the New Mexico State Engineer Office. Starting in the Roswell area, the program has been expanded from time to time to obtain information about water-level changes in areas of significant ground-water withdrawals. Water-level data and changes computed from these data are used to determine areas of ground-water rises and declines. This information may be used to manage the ground-water resources in New Mexico.

The majority of the wells are located in New Mexico, with a few in Texas adjacent to Curry and Roosevelt Counties and a few in Colorado along the Rio Grande. Water levels in areas in Texas and Colorado are measured to have continuity of hydrologic data across the New Mexico State line. The location and approximate extent of 34 areas designated for ground-water-level monitoring in and adjacent to New Mexico as of February 1993 and the measurement schedule for each area are shown in figure 1. Data collection and report preparation are in cooperation with the New Mexico State Engineer Office.

\section{Purpose and Scope}

This report presents hydrographs of ground-water-level data collected through 1993 from 22 wells equipped with continuous water-level recorders, maps of changes in ground-water levels using water-level data collected at 5-year intervals during 1984-93 in 34 monitoring areas, and hydrographs of 5-year or more frequent water levels measured in selected wells in each monitoring area. Tables of well location and ground-water data for the wells measured in each monitoring area are included.. Where available, annual precipitation data for climatological stations within or adjacent to each monitoring area are presented. Only data collected in cooperation with the State Engineer Office for this specific program are included in the report. 

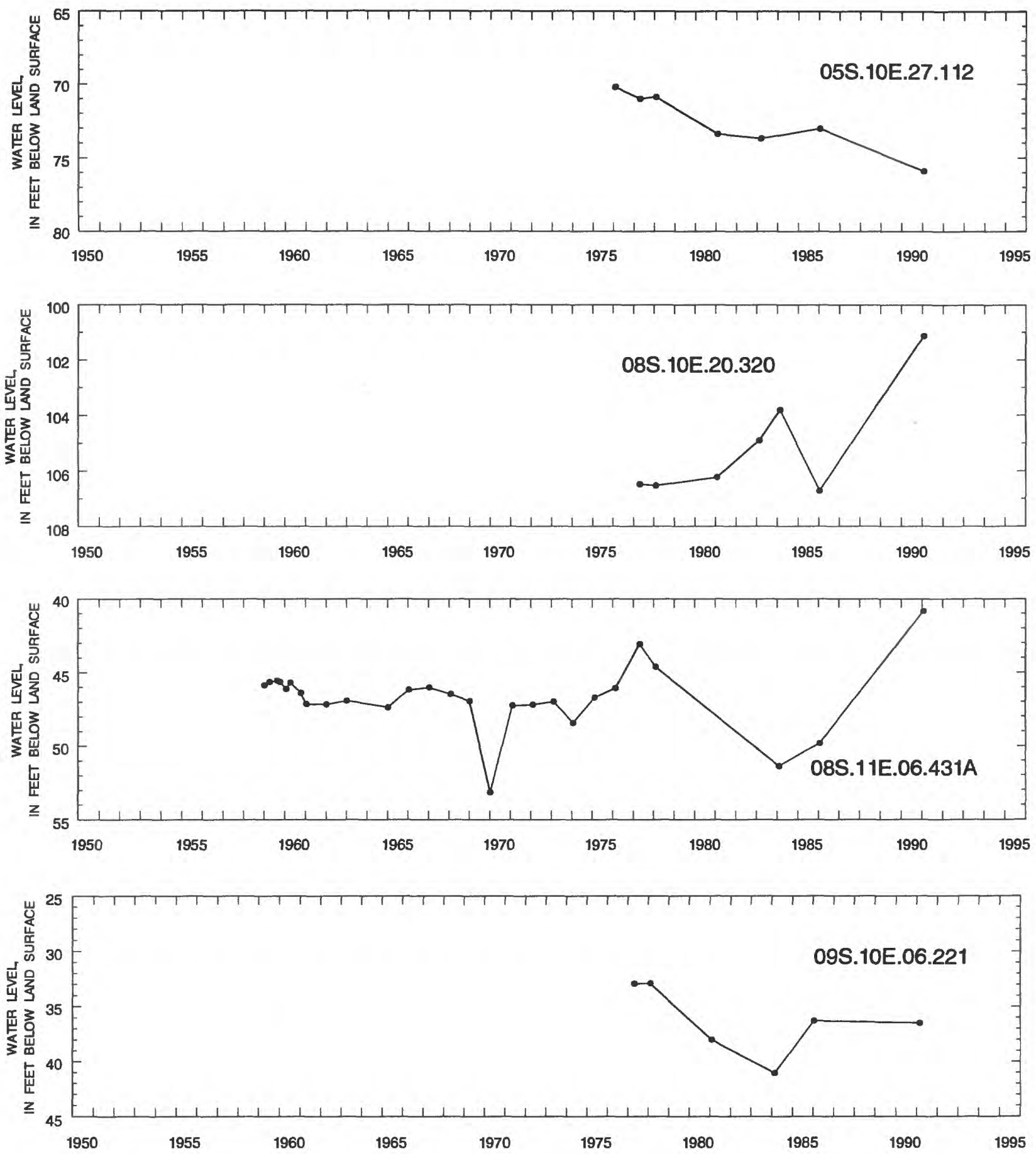

Figure 26.--Water-level data for selected wells in the Tularosa Basin monitoring area and annual precipitation at the Carrizozo and Alamogordo Climatological Stations. See figure 25 for location of wells and stations. 

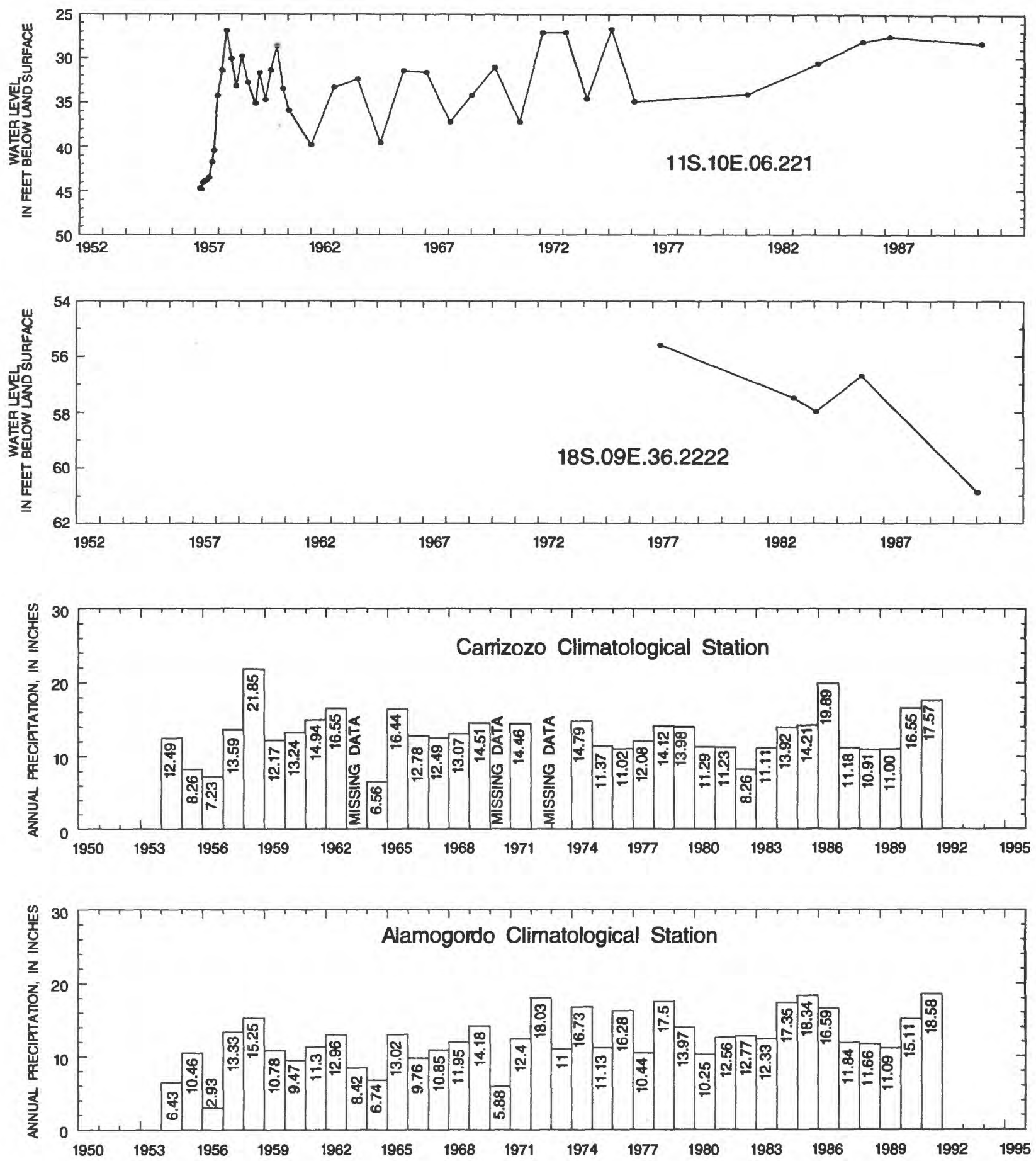

Figure 26.--Water-level data for selected wells in the Tularosa Basin monitoring area and annual precipitation at the Carrizozo and Alamogordo Climatological Stations. See figure 25 for location of wells and stations--Concluded. 


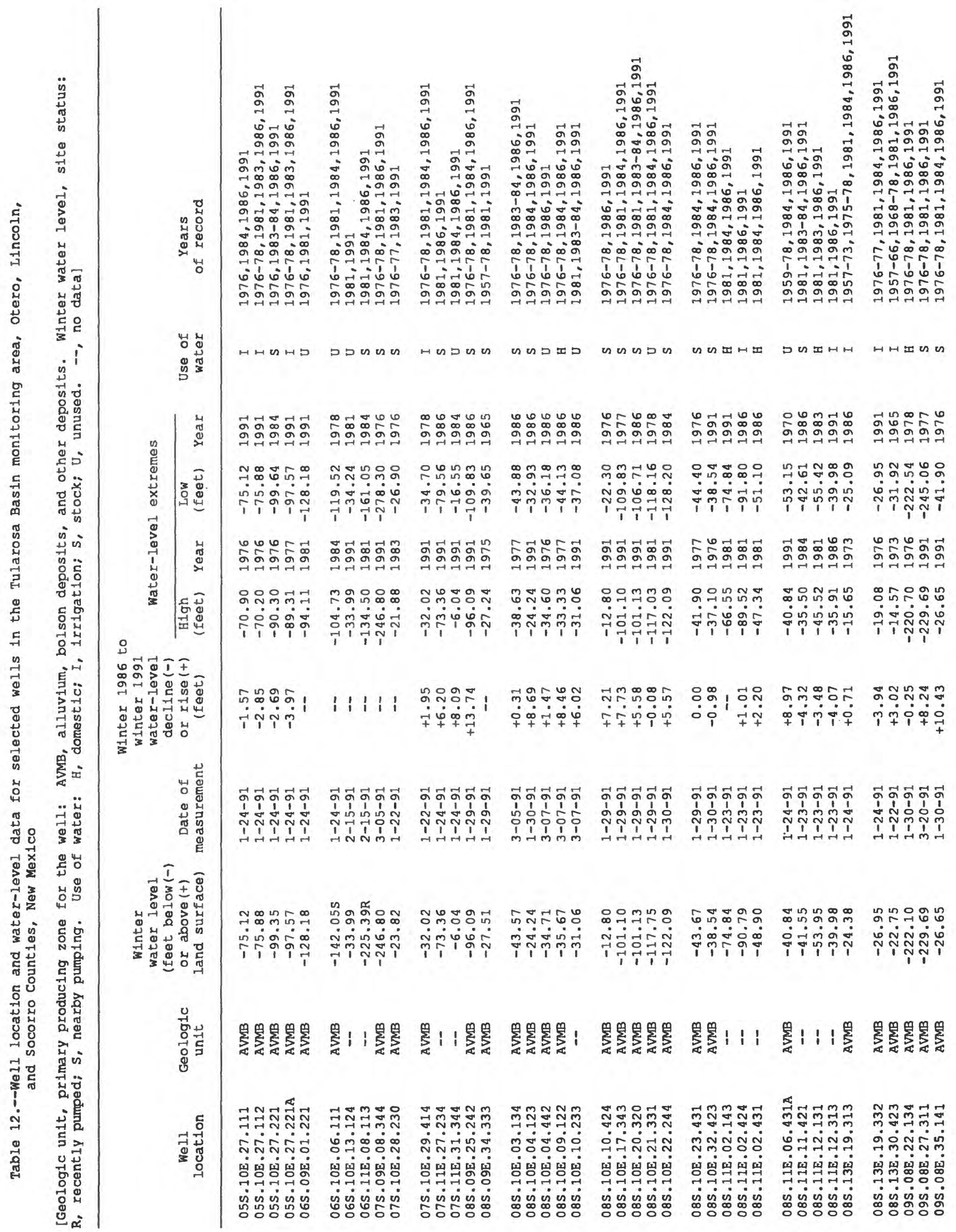




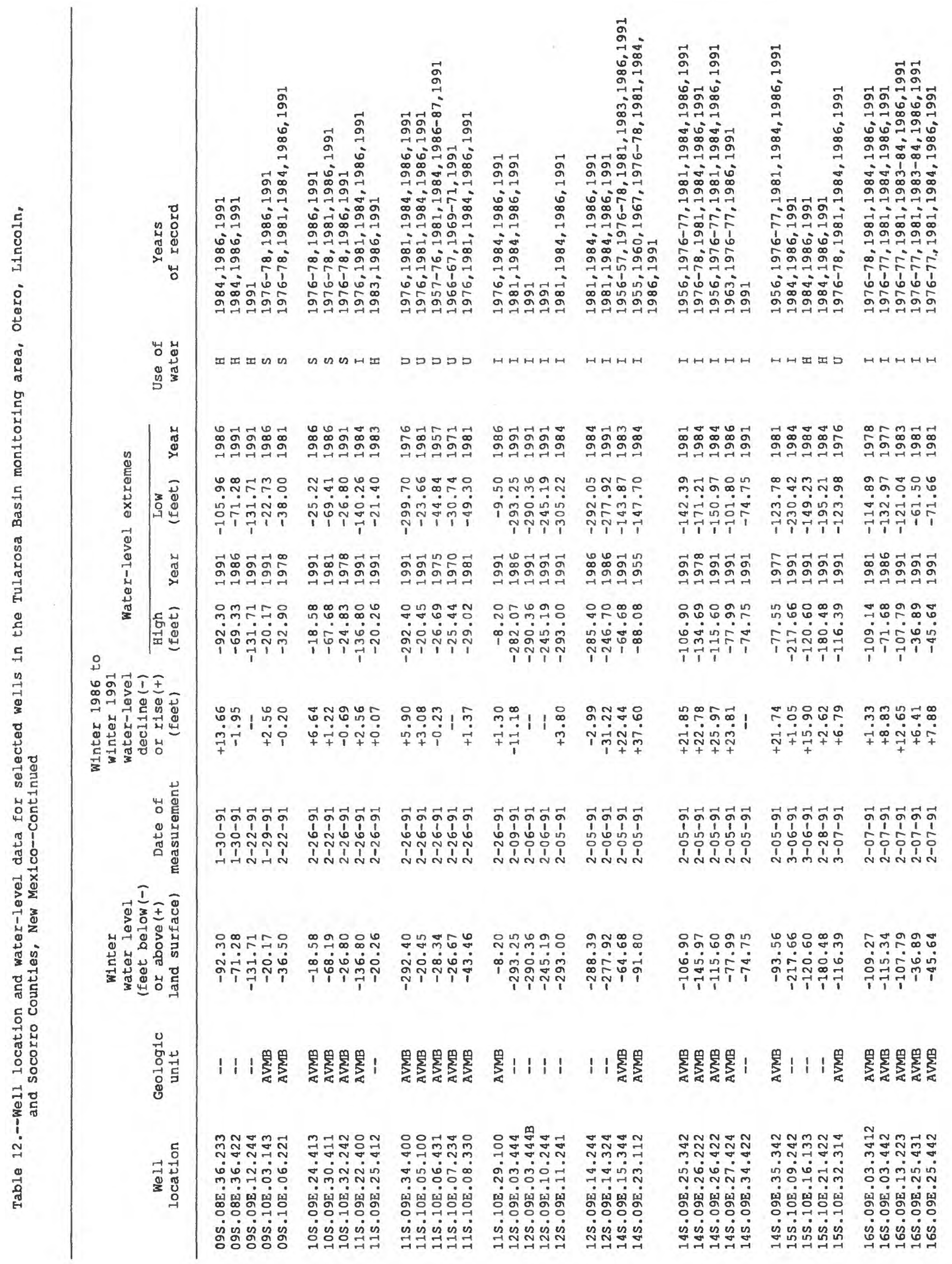




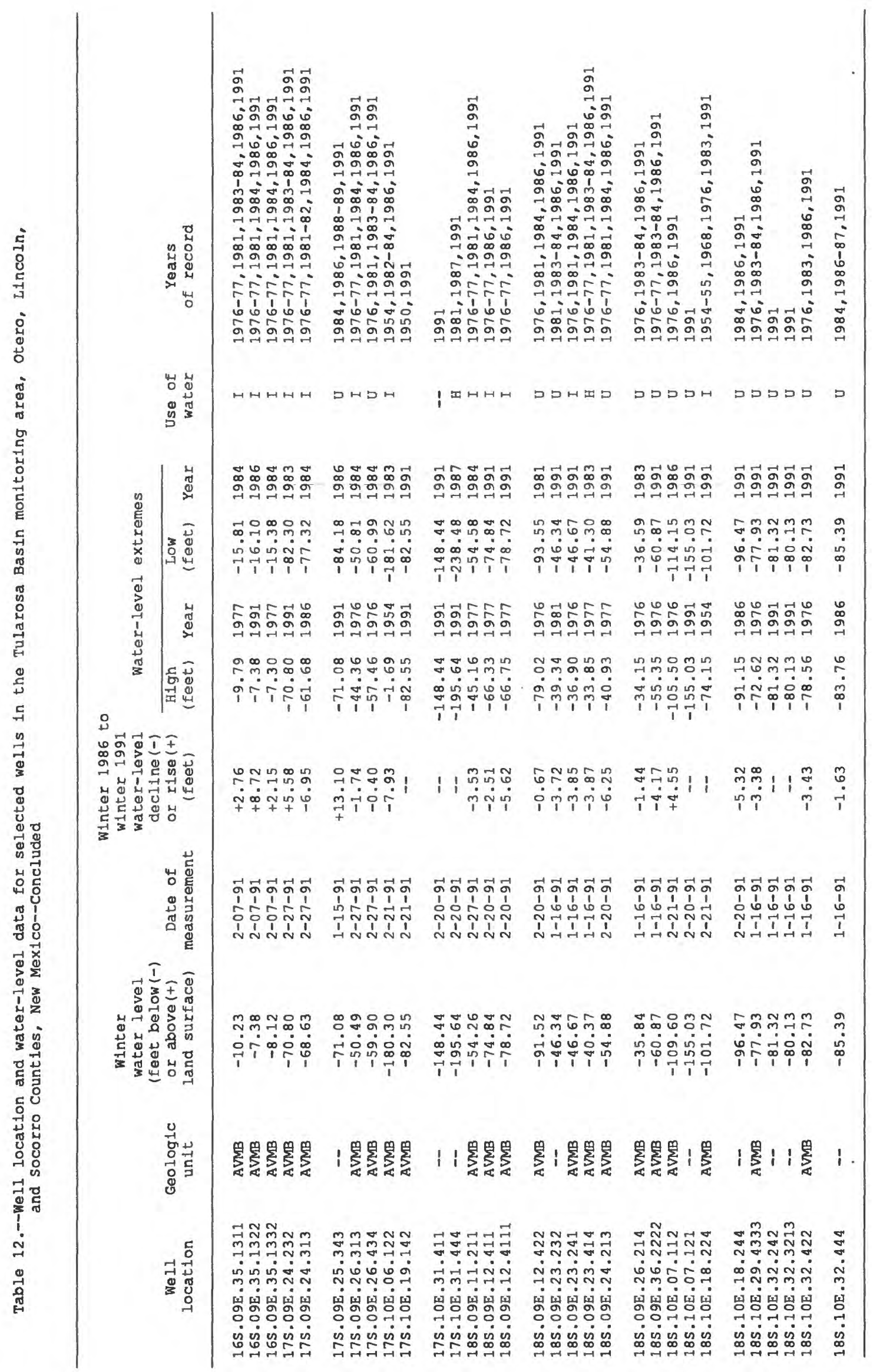




\section{San Agustin Plains Monitoring Area}

The San Agustin Plains monitoring area is located in Catron and Socorro Counties, westcentral New Mexico. Water-level data were not collected in 1986, thus computation of water-level changes was not possible. Depth-to-water data were collected in 1991 and are shown in the map and table. 


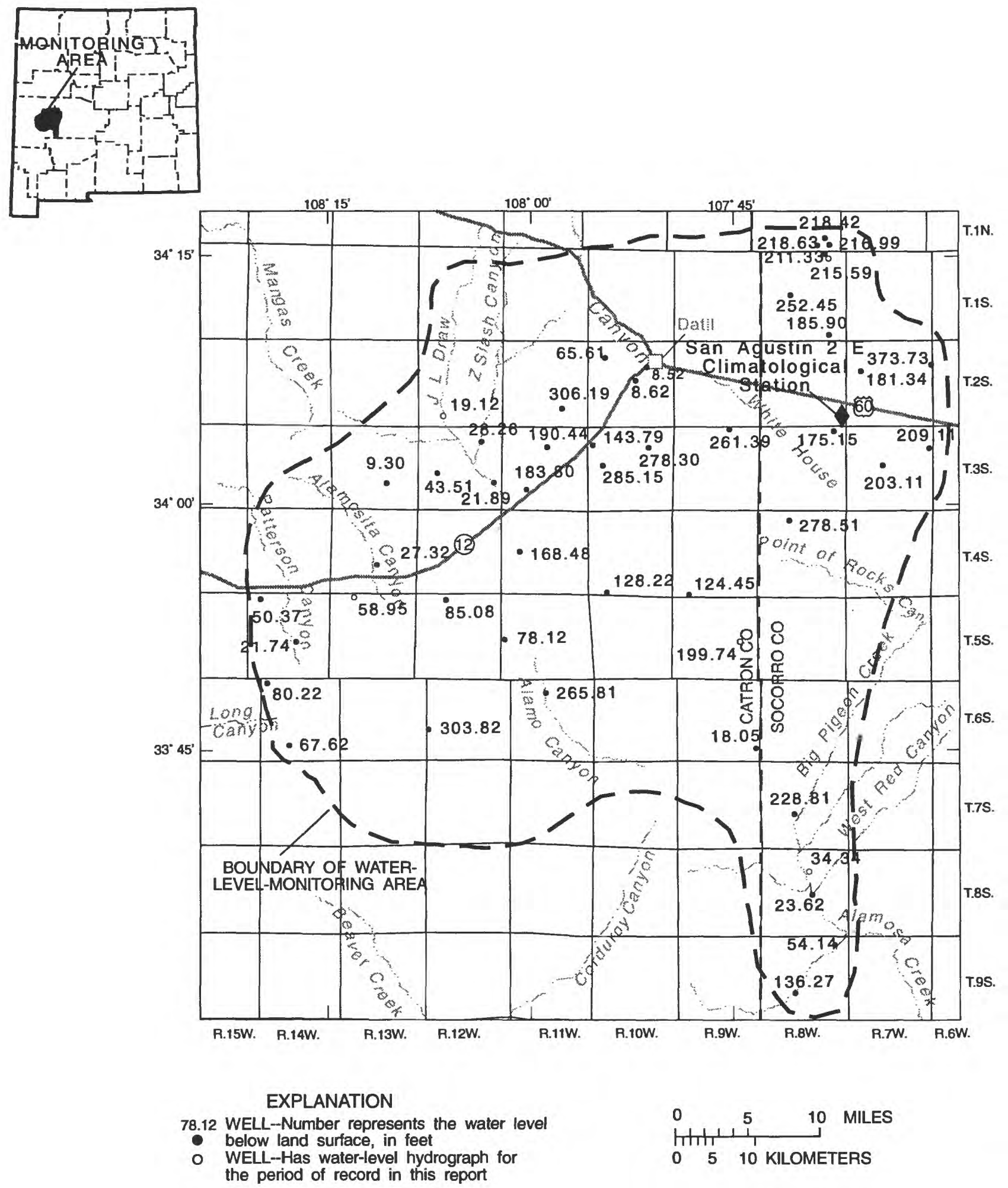

Figure 27.--Water levels for wells in the San Agustin Plains monitoring area, 1991. 

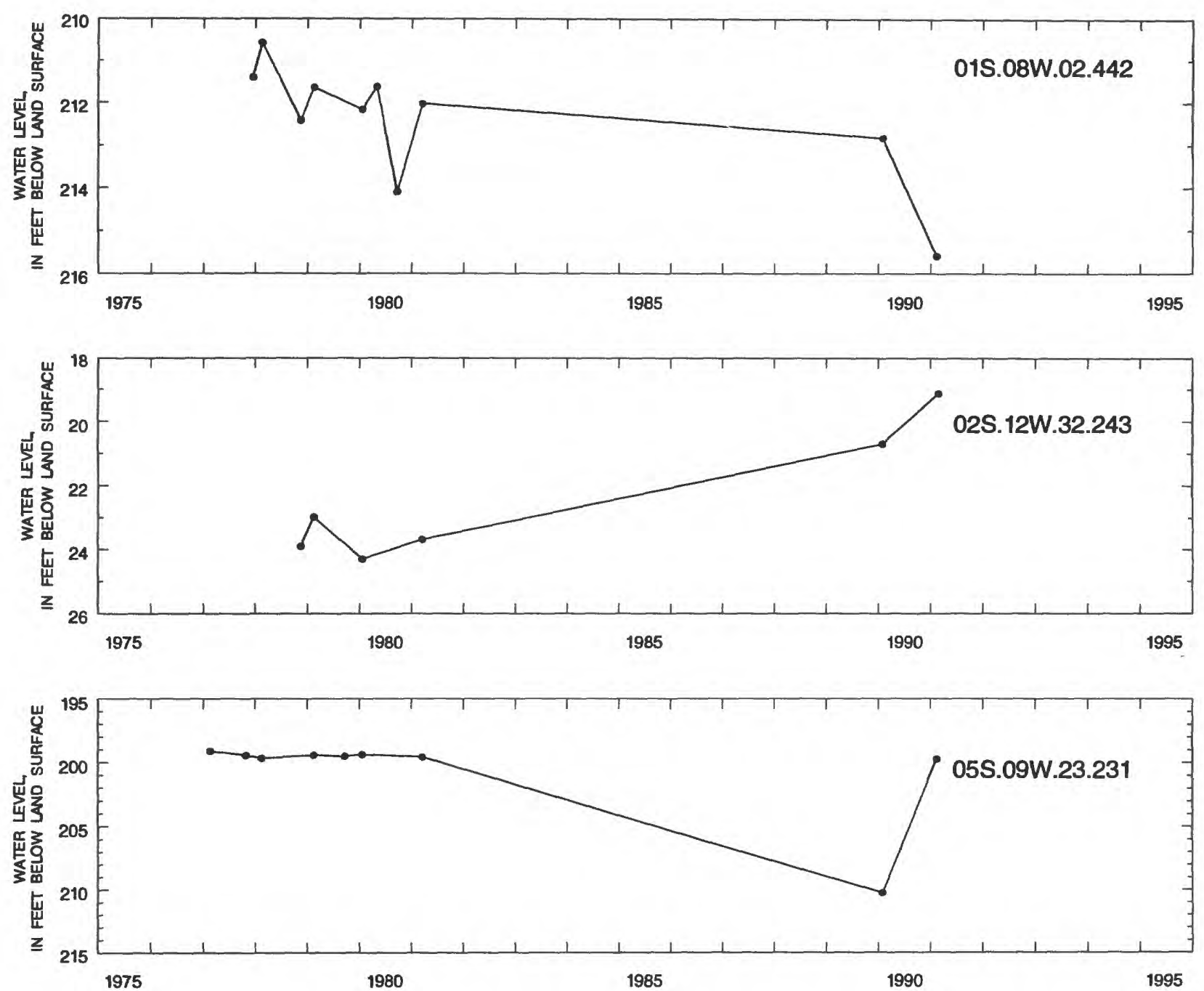

Figure 28.--Water-level data for selected wells in the San Agustin Plains monitoring area and annual precipitation at the San Agustin 2 E Climatological Station. See figure 27 for location of wells and station. 

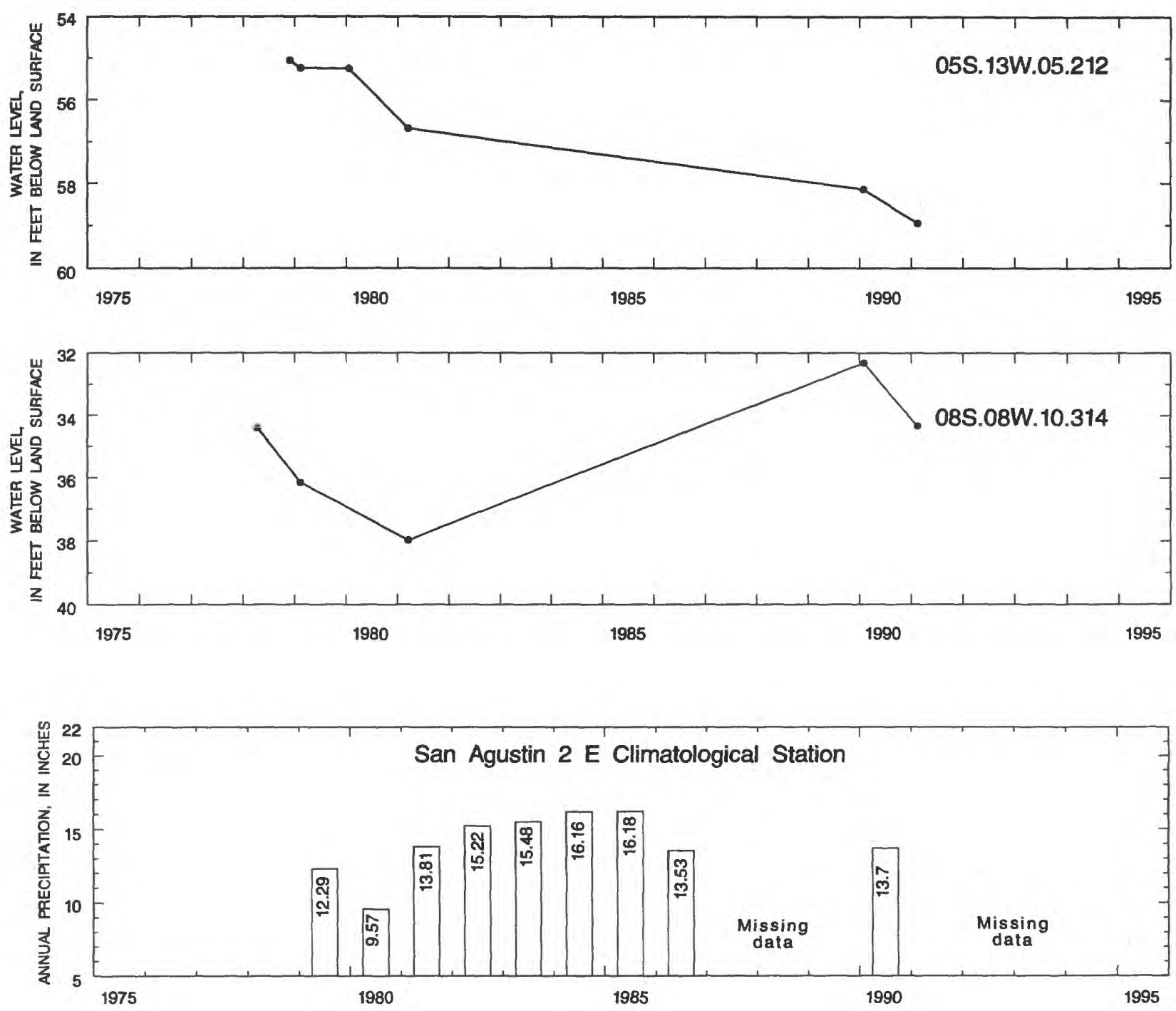

Figure 28.--Water-level data for selected wells in the San Agustin Plains monitoring area and annual precipitation at the San Agustin 2 E Climatological Station. See figure 27 for location of wells and station--Concluded. 


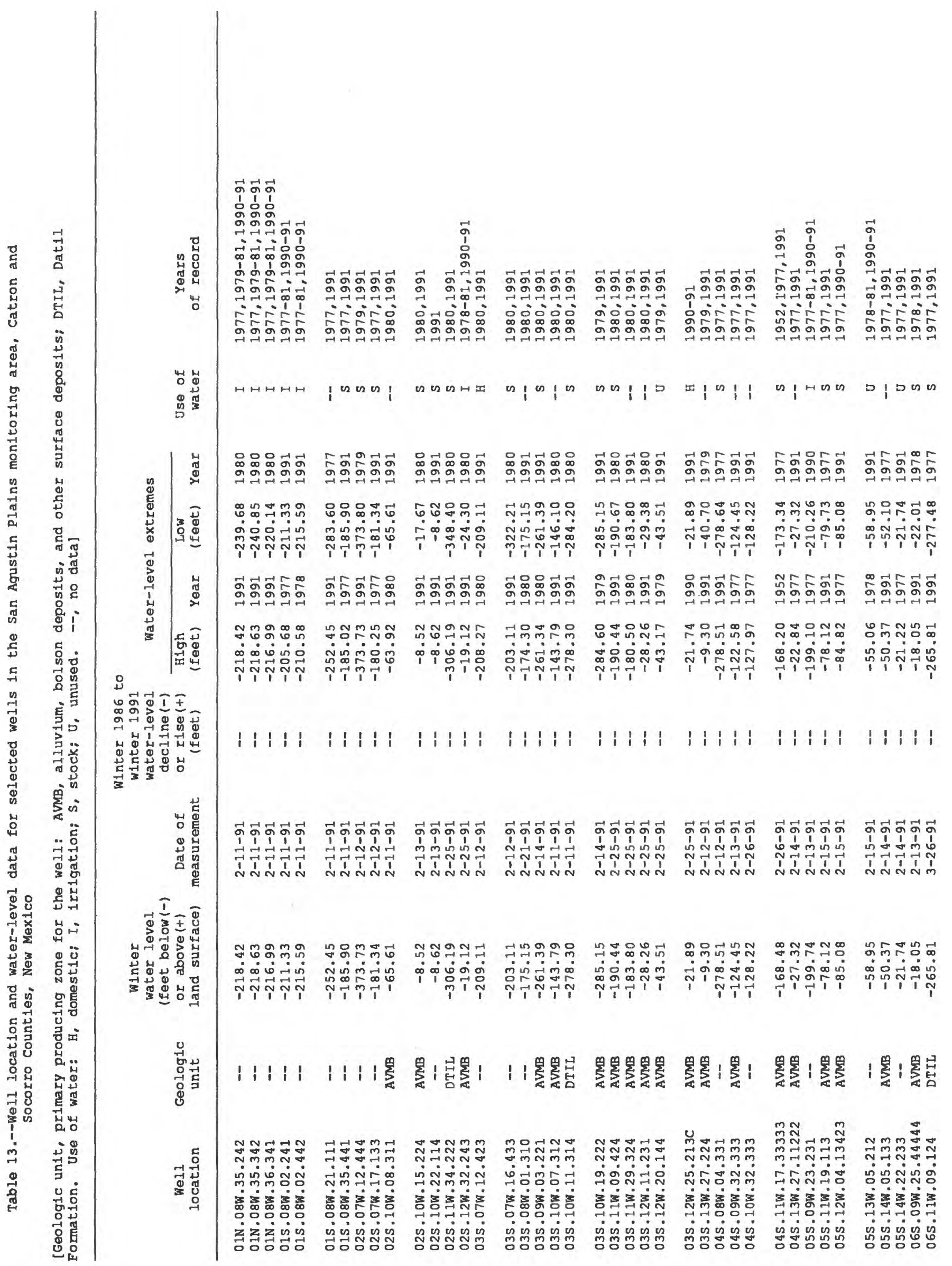




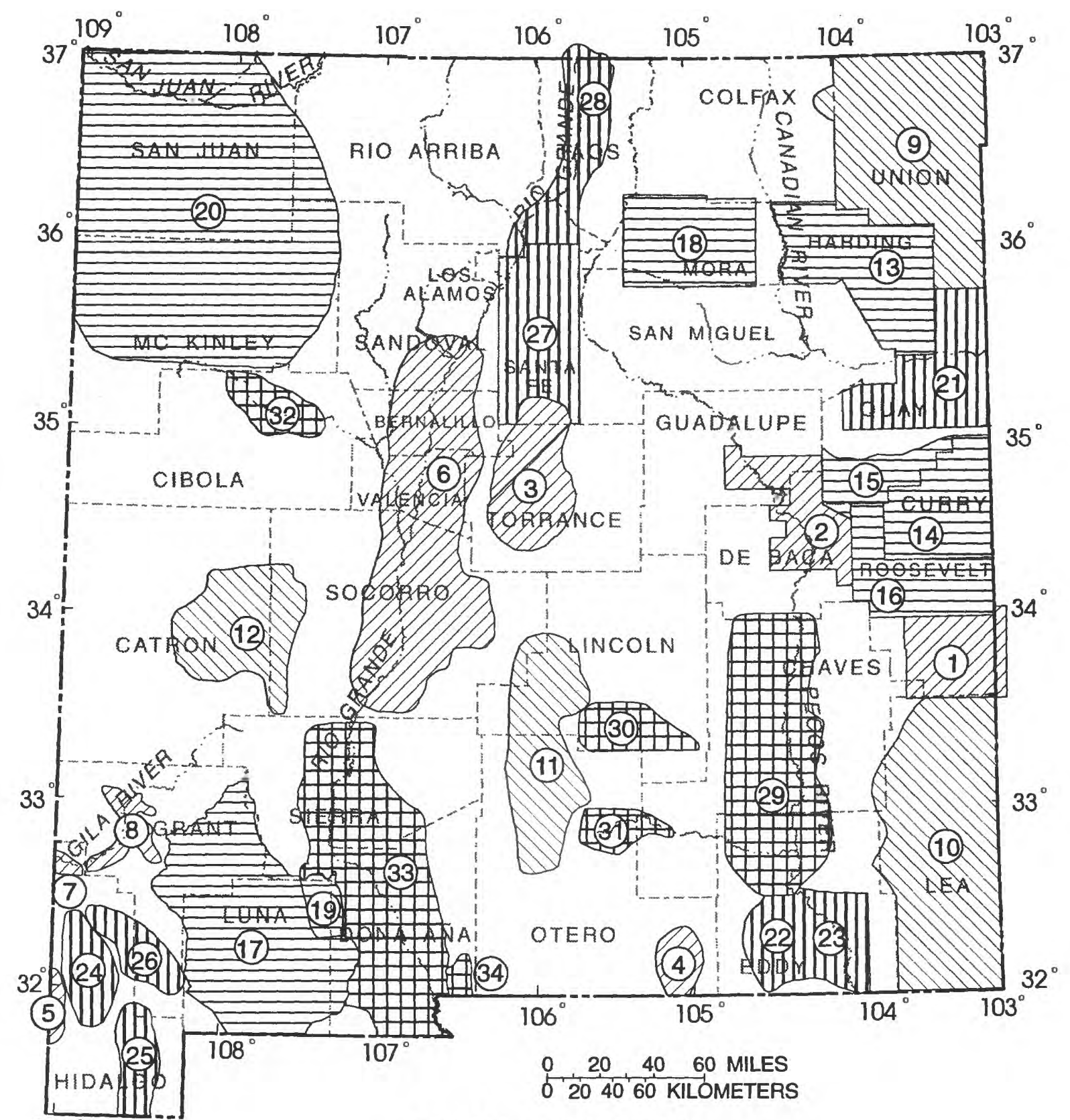

109

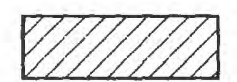

$1985 / 1990$

1. CAUSEY-LINGO

2. FT. SUMNER

3. ESTANCIA

4. SALT BASIN

5. SAN SIMON

6. MIDDLE RIO GRANDE

7. VIRDEN

8. GILA RIVER

EXPLANATION

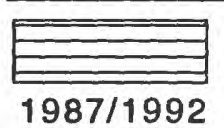

$1986 / 1991$

9. NORTHERN HIGH PLAINS

10. LEA COUNTY

11. TULAROSA BASIN

12. SAN AGUSTIN PLAINS

15. HOUSE

16. PORTALES

18. MORA

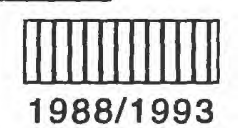

13. HARDING COUNTY 14. CURRY COUNTY

17. MIMBRES BASIN

19. NUTT-HOCKETT

20. SAN JUAN BASIN
21. LOWER CANADIAN 22. CARLSBAD

23. CAPITAN REEF

24. ANIMAS

25. PLAYAS

26. LORDSBURG

27. SANTA FE COUNTY

28. UPPER RIO GRANDE

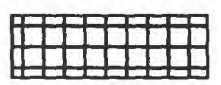

$1984 / 1989$

29. ROSWELL BASIN

30. RIO HONDO

31. RIO PENAASCO

32. GRANTS-BLUEWATER

33. LOWER RIO GRANDE 34. HUECO

Figure 1.--Location of water-level-monitoring areas and years measured, 1984-93. 


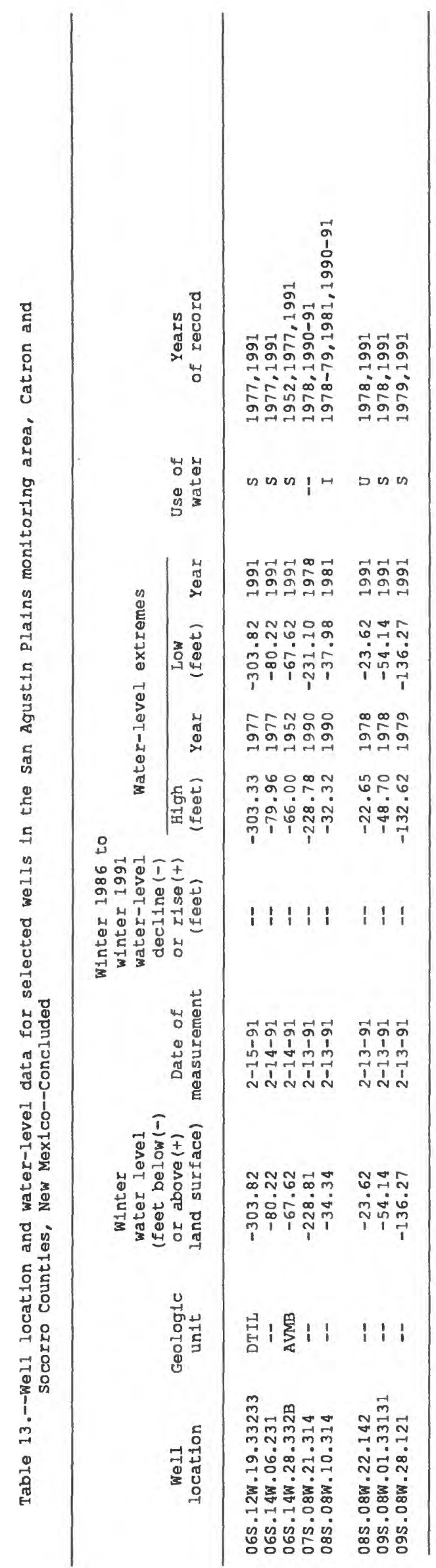




\section{Harding County Monitoring Area}

The Harding County monitoring area is in northeastern New Mexico. Water-level measurements in all parts of the monitoring area indicate declines from less than 1 foot to more than 4 feet and rises from less than 1 foot to more than 28 feet. A narrow band of declining water levels starts in T. 23 N., Rs. 25 and 26 E., progressing south and east through Tps. 20 and $21 \mathrm{~N}$. and Rs. 26 through $33 \mathrm{E}$. South and east of Gallegos is an area of mostly ground-water rises. 


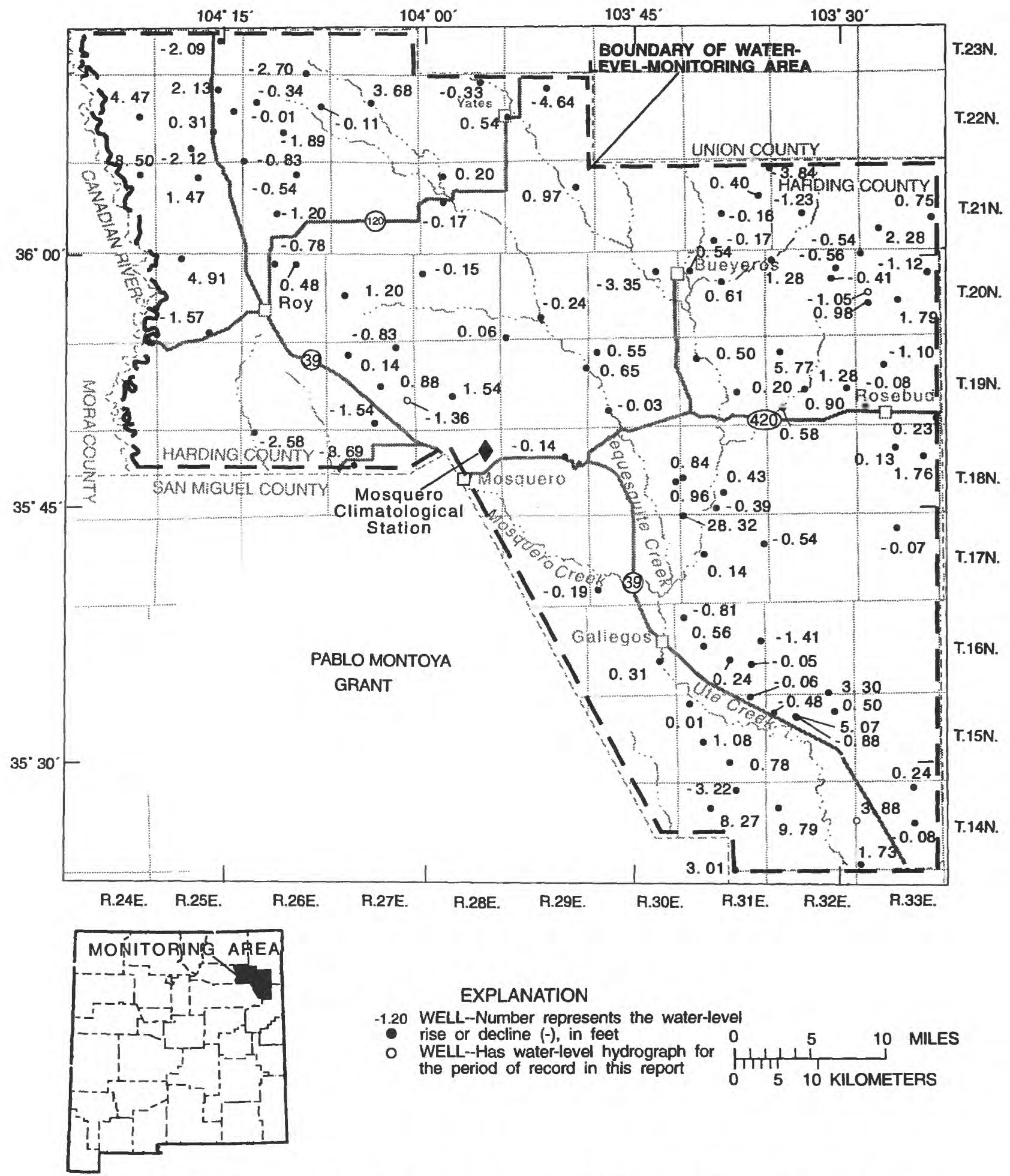

Figure 29.--Water-level changes for wells in the Harding County monitoring area, 1987-92. 

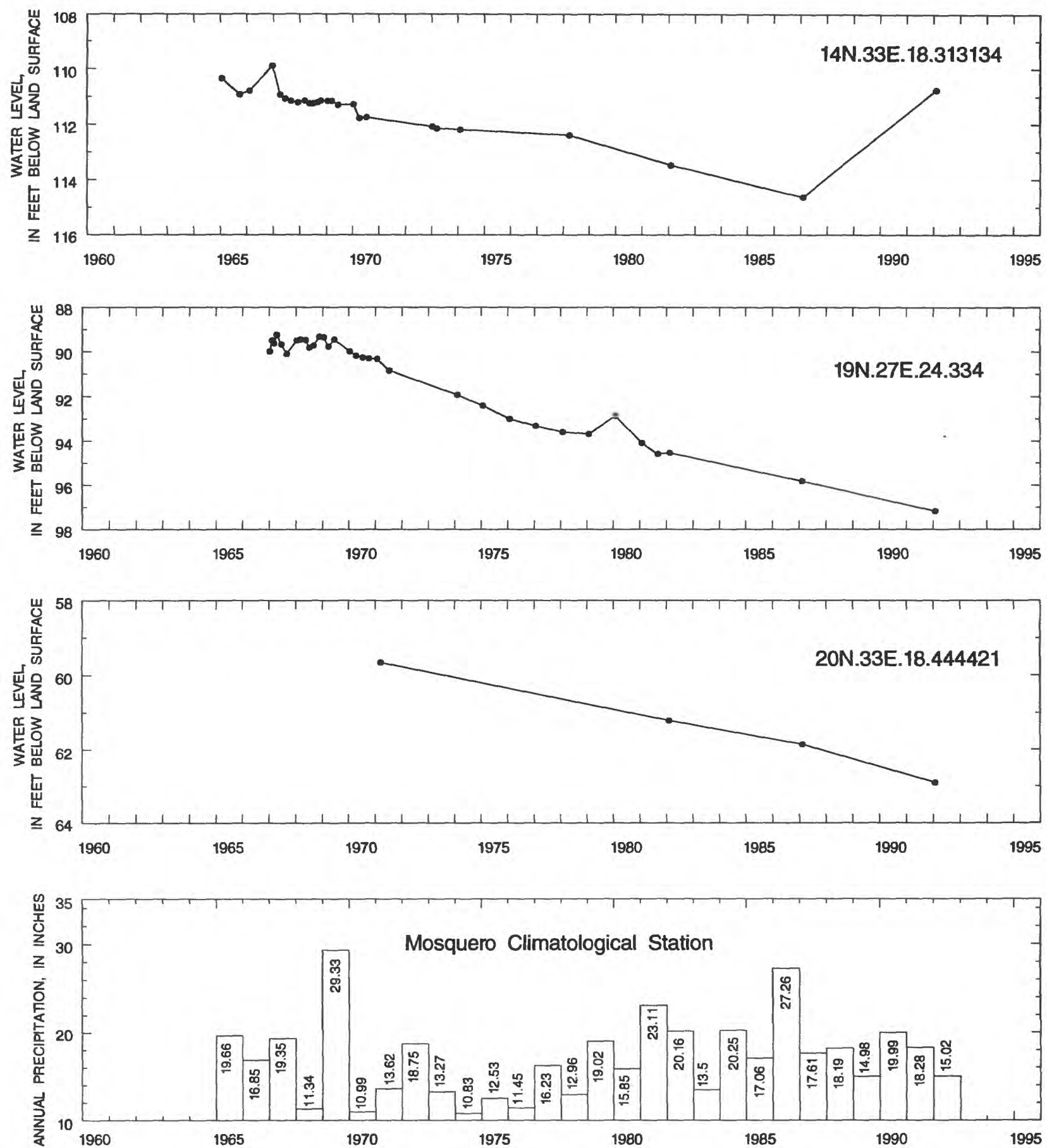

Figure 30.--Water-level data for selected wells in the Harding County monitoring area and annual precipitation at the Mosquero Climatological Station. See figure 29 for location of wells and station. 


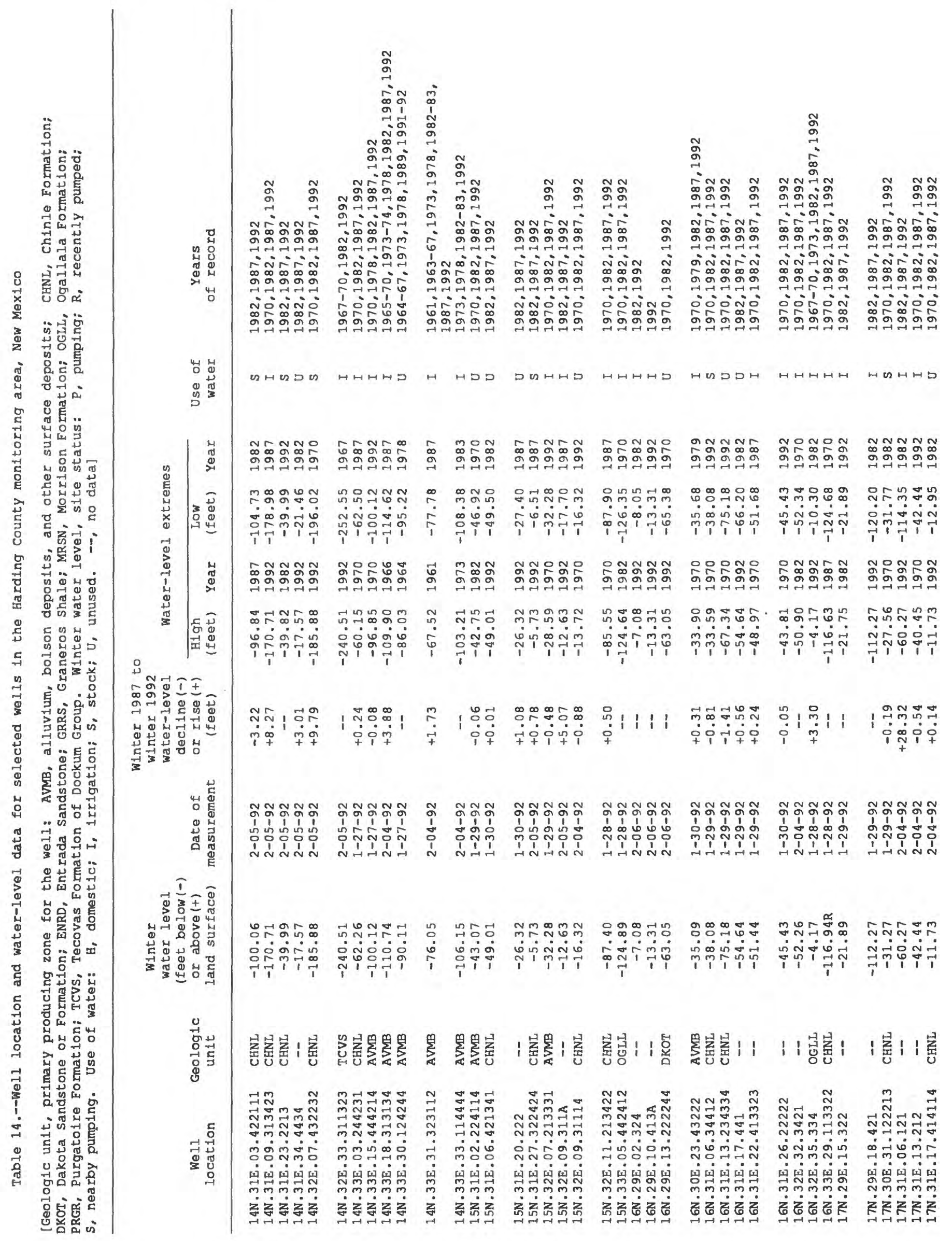




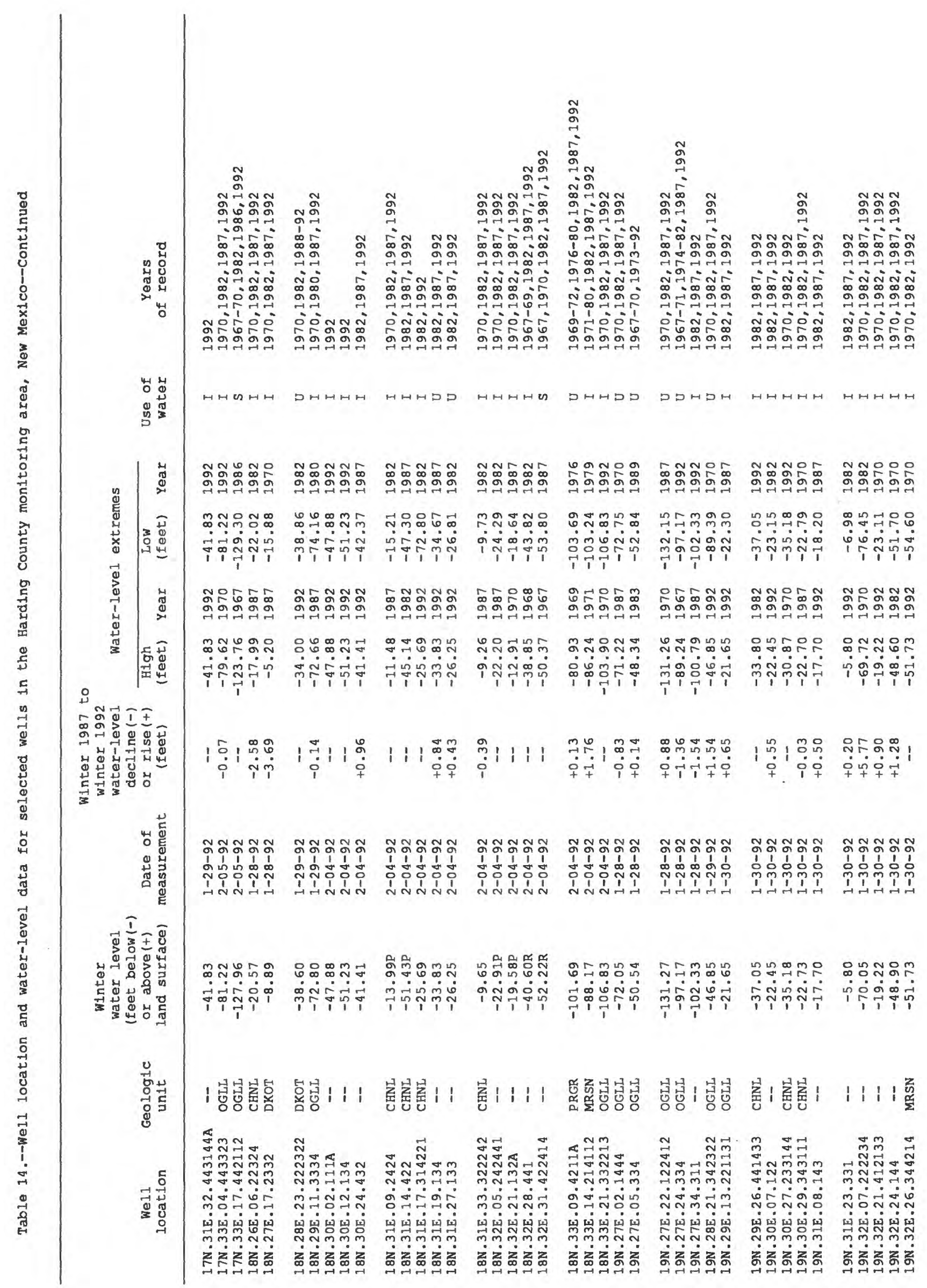




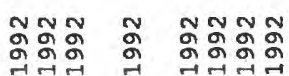

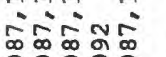

क्ष๐

첧ㅊ

निन्नेने

뭏ㅇㅇㅇ

isisi

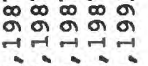

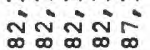

जิ

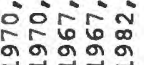

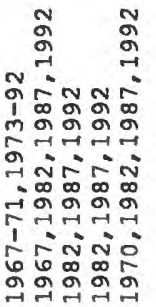

पै

䨔

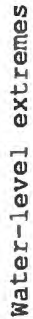

운

ธ้ว

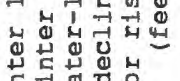

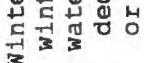

崩若

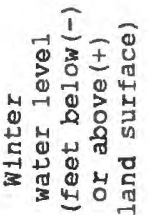

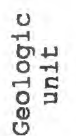

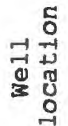

HDHHH MDDHD

$\mapsto \mapsto ロ D ワ$

トロトット

ルらロット

トルロコト

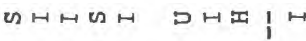

ฌ두우웅

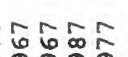

\section{ฉั}

이에요

궁ำ

พำกั

웅ํㄲ우웅

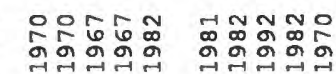

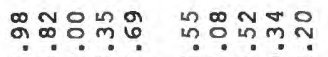

임유용ㅇ

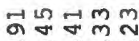

웅응유음

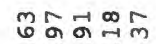

ํํำำ

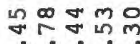

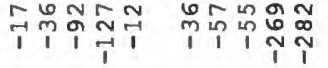

ㅇำำษ

कित्रिक्ष

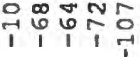

जरㅜㅝㄹ

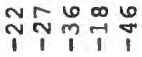

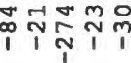

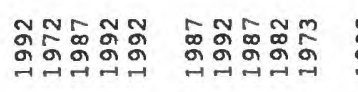

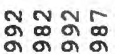

เิณำก

oOONN

कิธกลก

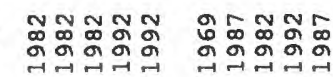

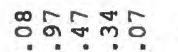

ดำำ?

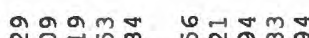

नेन्ने

पनतन

ㅇํํ유ำ

ำำำำ

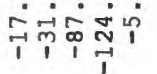

1़िए

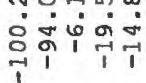

लंखंड़ं

ำๆㄱำำำ

ํํํํㅠำ

नेत्रें

ํㅜㅇㅠำ

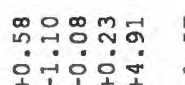

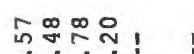

,

员

119

1ํㅟำ

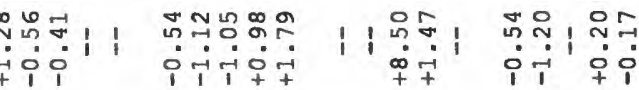

กับกล

\section{กำกำก}

กิํํำ

111 1101

สํำสำก

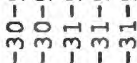

กูํํำ

1.

กูํํํํำ

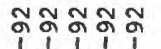

สูกสูกส ส

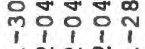

พ

4he

shy

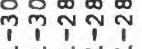

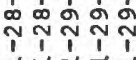

ㄱ.

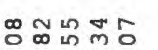

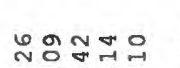

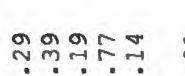

สีำรัตั

กำ

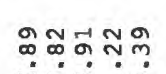

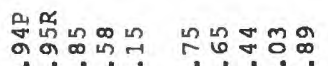

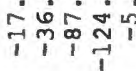

1

유ำ

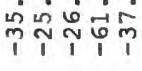

1क्षण

ㄸㅠㅠำ

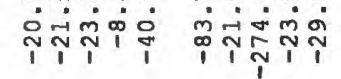

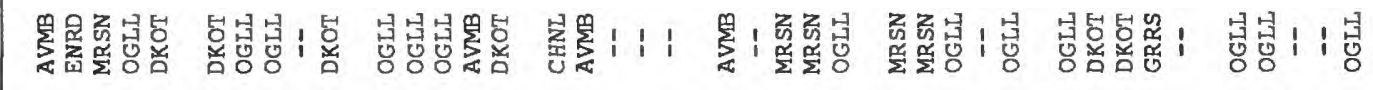

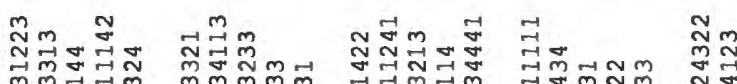

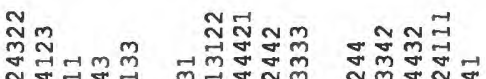

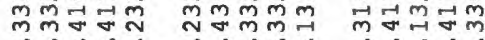

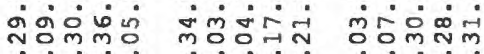

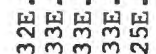

Fิำ

ㄷํำ

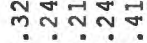

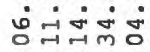

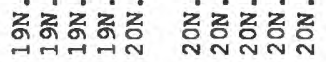

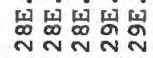

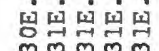

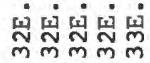

$\dot{z} z \dot{z}$

żżż

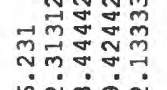

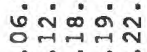

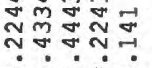

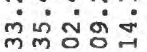

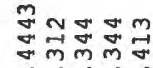

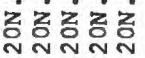

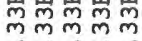

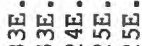

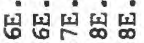

NN NNNN

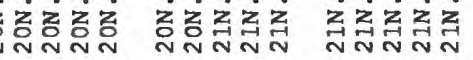




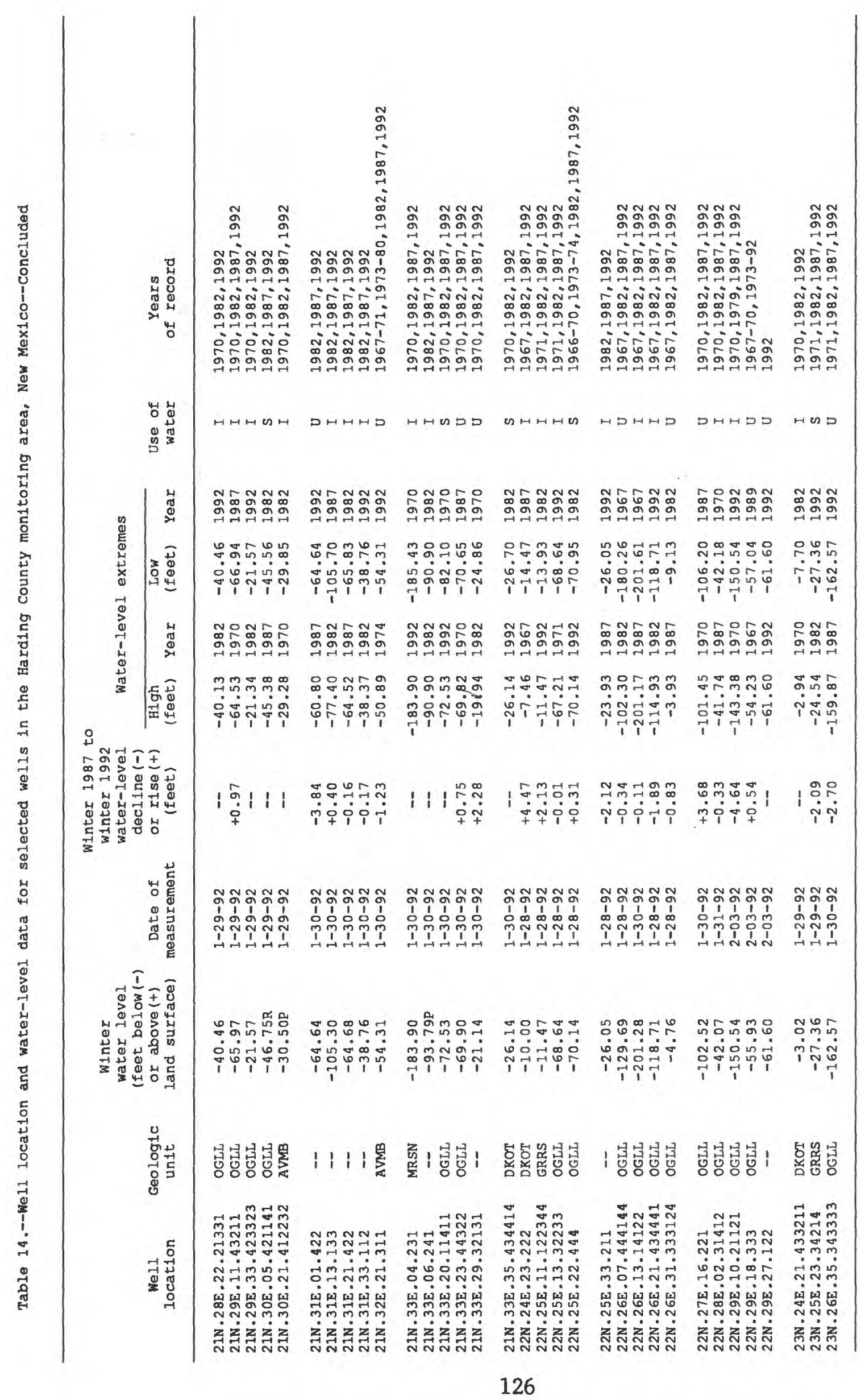




\section{Curry County Monitoring Area}

The Curry County monitoring area is in east-central New Mexico. Water-level changes range from a decline of more than 23 feet to a rise of more than 11 feet. Generally, water levels have declined on the eastern side and in the southwest corner of the monitoring area. A diagonal line drawn from T. 8 N., R. 37 E. to T. 1 N., R. 33 E. would show that most changes are declines on the east side of the line. West of the diagonal line the monitoring area shows water-level rises. 

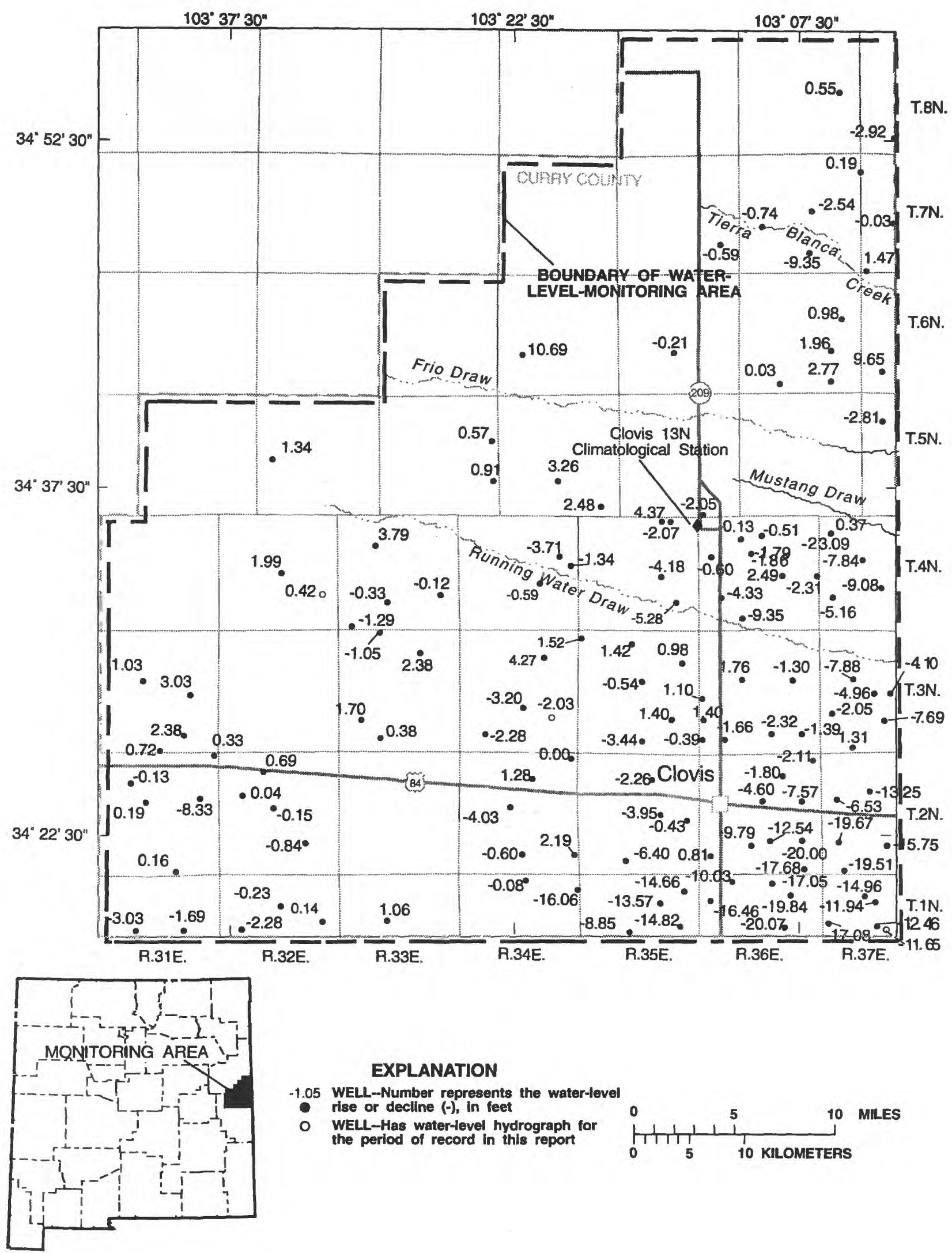

\section{EXPLANATION}

-1.05 WELL-Number represents the water-level

- WELL-Has water-level hydrograph for the period of record in this report

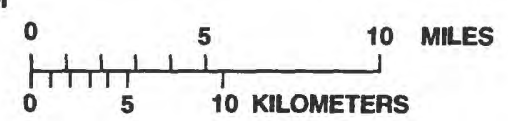

Figure 31.--Water-level changes for wells in the Curry County monitoring area, 1987-92. 


\section{Methods of Data Collection}

Twenty-two selected wells in various parts of New Mexico are equipped with continuous water-level recorders as of January 1993 (fig. 2; table 1). Each well is visited every few months. A check measurement of water level is made with a steel tape to determine if the recorder is measuring the correct water level. If adjustments to the recorder data are needed a notation is made and the data are retrieved from the recorder. The recorder is then reset to measure the correct water level, if needed, and continuous recording of data is resumed. Data from the recorders are checked and any adjustments are made to the data as noted at the time of the site visit. The data are subsequently entered into the Automated Data Processing System (ADAPS) data base.

Water levels are measured in selected observation wells in each of the monitoring areas. These monitoring areas and their measurement schedules are shown in figure 1. Measurements are generally made in January, February, or March, usually several months after pumping for irrigation has ceased and when water levels in most wells have recovered from the local effects of sustained withdrawals. Water levels that are affected by recent pumping in the well or in a nearby well are not used in computing 5-year changes. In some monitoring areas, water levels in some wells were measured in November or December of the year preceding the scheduled January, February, or March measurements. The water levels measured in November or December also are used to compute the 5-year ground-water-level changes because they represent nonpumping water levels. Water levels are obtained using a steel tape. Check measurements are made at each well to assure accurate water-level data. Computations of water levels are checked and the data are entered into the Ground-Water Site-Inventory System (GWSI) data base. Winter water-level measurements are compared with winter water-level measurements from 5 years previous to indicate increase or decrease of ground-water storage.

\section{Local Well-Numbering System}

The system of numbering wells in New Mexico is based on the common subdivision of public lands into sections (fig. 3). The well number, in addition to designating the well, locates its position in the land network. The number is divided into four segments. The first segment denotes the Township (T.) north or south of the New Mexico base line; the second denotes the Range (R.) east or west of the New Mexico principal meridian, and the third denotes the section. The fourth segment of the number, which consists of three or more digits, denotes the 160-, 40-, and 10-acre tracts, respectively, in which the well is situated. For this purpose, the section is divided into four quarters, numbered 1,2, 3, and 4, in the normal reading order, for the northwest, northeast, southwest, and southeast quarters, respectively. The first digit of the fourth segment gives the quarter section, which is a tract of 160 acres. Similarly, the quarter section is divided into four 40-acre tracts numbered in the same manner, and the second digit denotes the 40 -acre tract. Finally, the 40 -acre tract is divided into four 10 -acre tracts, and the third digit denotes the 10-acre tract. Thus, well 18S.09E.24.213 is in the SW1/4 NW1/4 NE1/4 sec. 24, T. 18 S., R. 09 E. If a well can be located accurately within tracts smaller than 10 acres, the same process of dividing the remaining area in quarters is continued as needed. If a well cannot be located accurately within a 10 -acre tract, a zero is used as the third digit, and if it cannot be located within a 40-acre tract, zeros are used for both the second and third digits. If a well cannot be located more closely than the section, the fourth segment of the well number is omitted. If later a well can be located more accurately, the proper digits are added or substituted for the zeros. Letters a, b, c, and so on are added to the last segment to designate the second, third, fourth, and succeeding wells in the same 10-acre tract. 

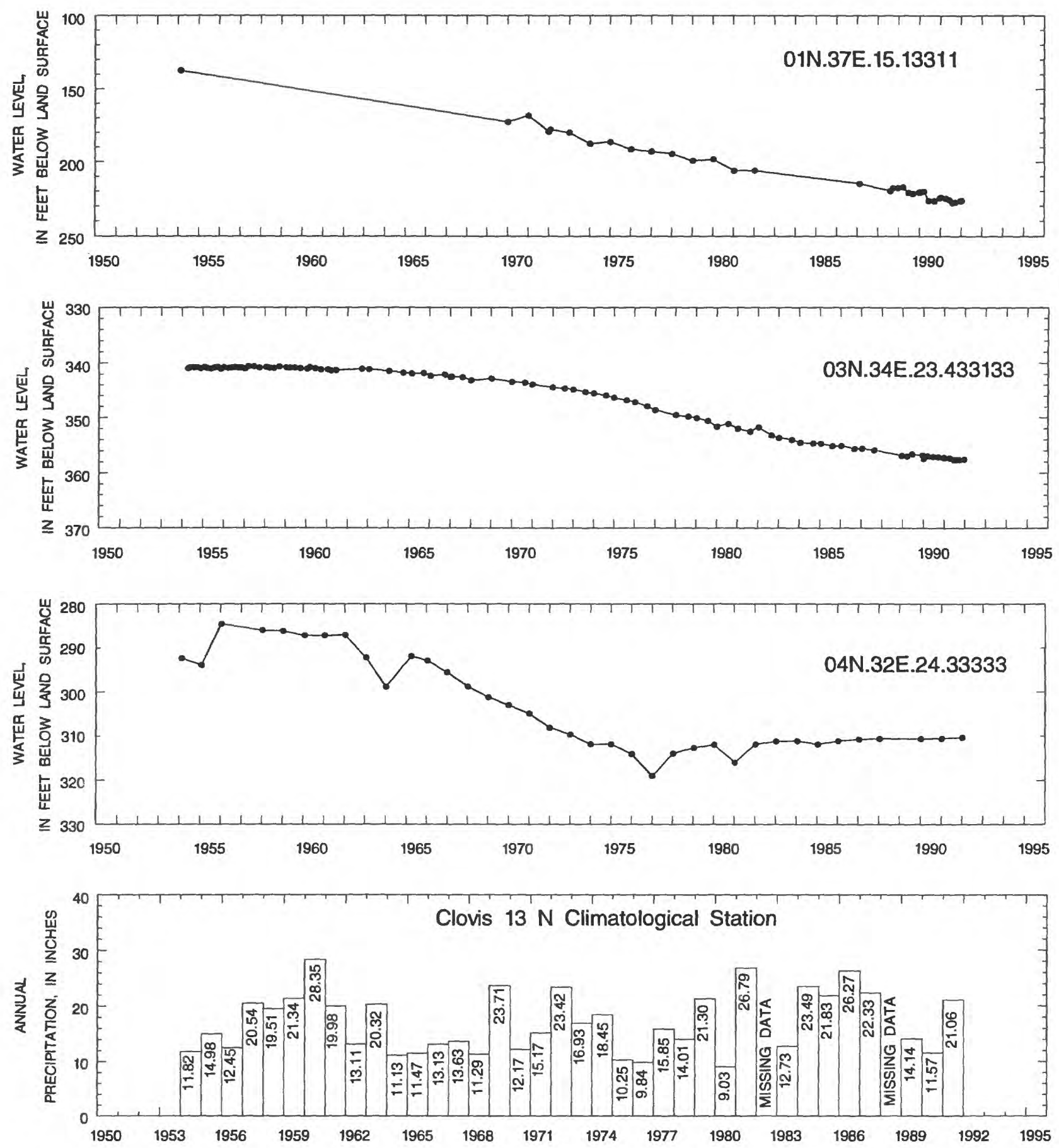

Figure 32.--Water-level data for selected wells in the Curry County monitoring area and annual precipitation at the Clovis $13 \mathrm{~N}$ Climatological Station. See figure 31 for location of wells and station. 


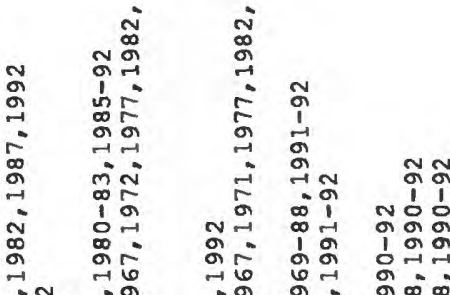

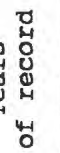

骂

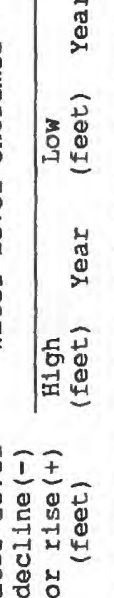

哭

in

获范的 i

을

范号

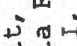

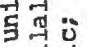

落需

엉형
๒ทロルே

us

ูํํํํำ

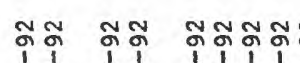

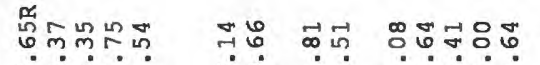

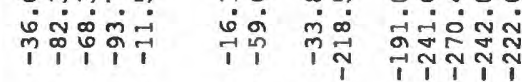

눙

5
7
0
0
0
0
0
ริำ

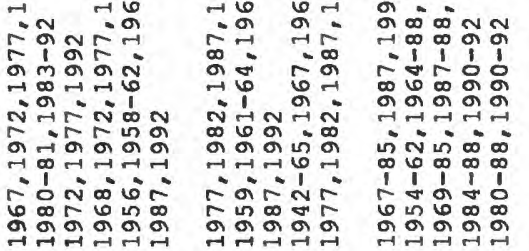

รัด

รั

ำสูลสู

둥ㅇㅇㅇㅡ

जढ़ने

S.

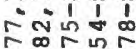

ลัต็ํำ

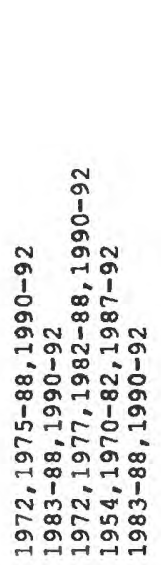

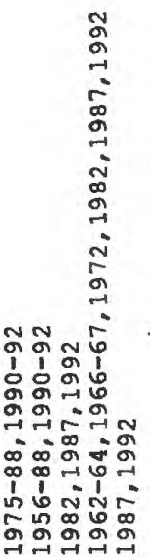

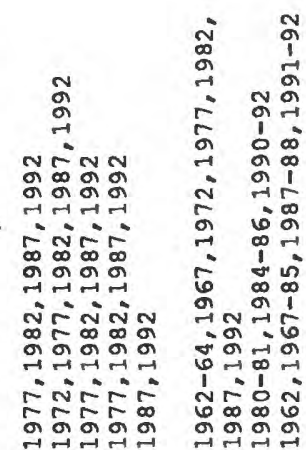

カト サートロ

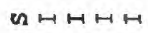

HHDDH

HHD约

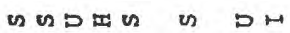

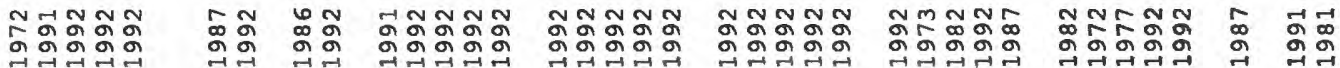

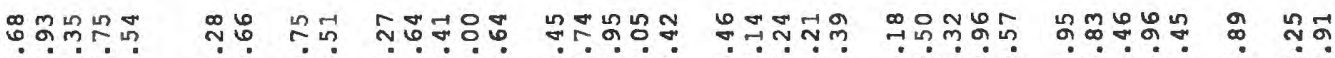

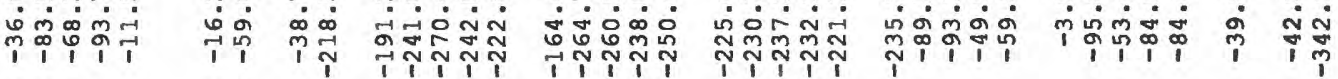

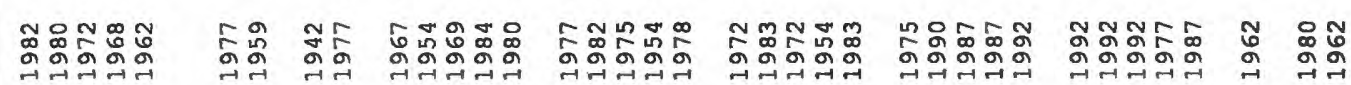

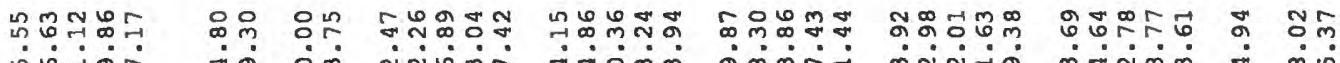

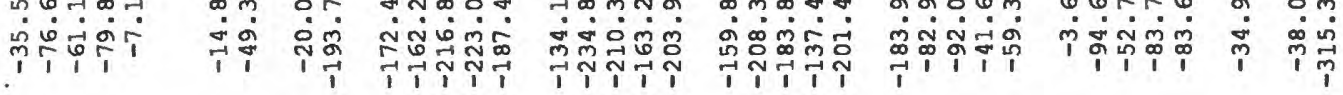

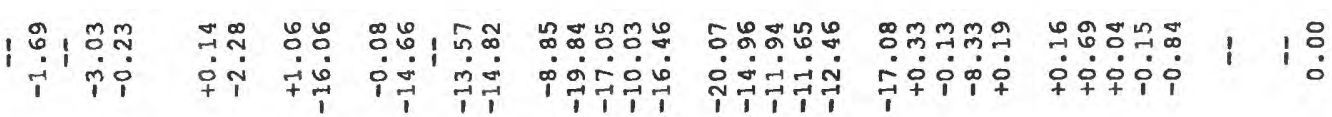

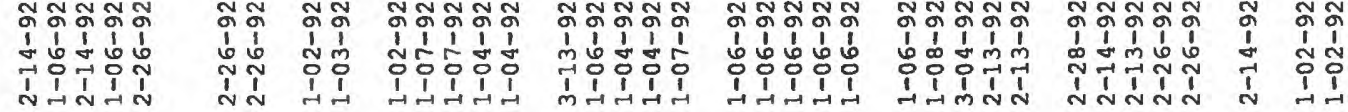

NกNNN

สูกสูกส

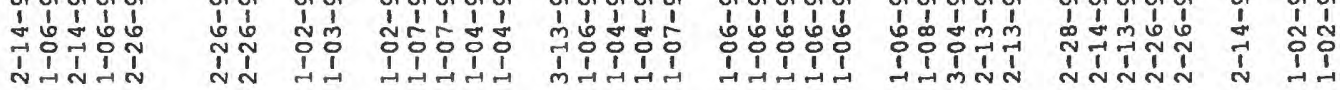

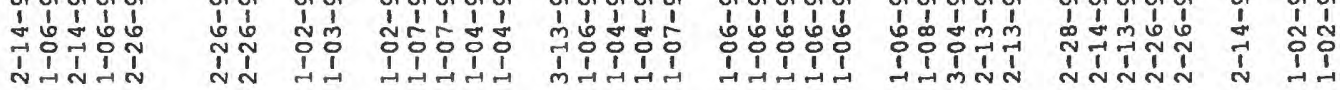

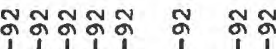

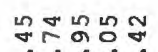

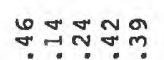

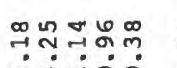

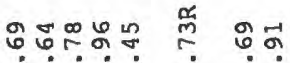
Siٔi்

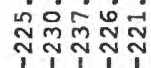

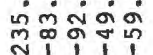

Pिंत्रिक्ष

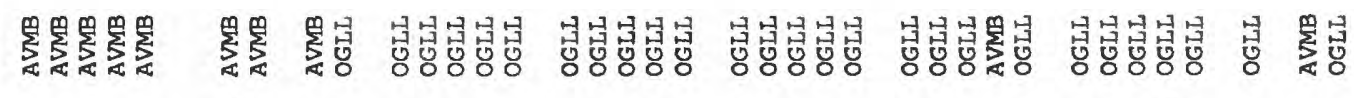

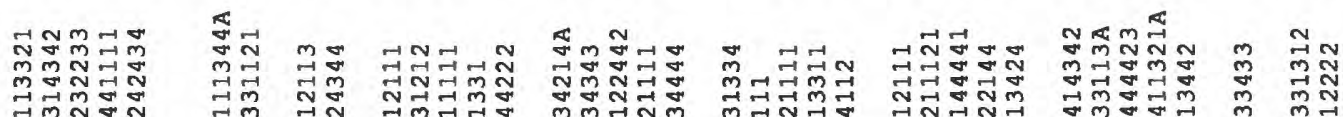

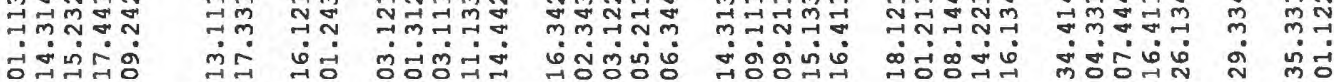

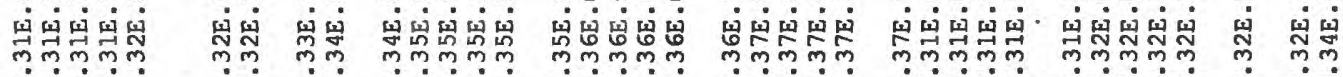

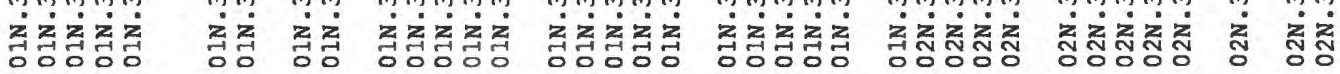




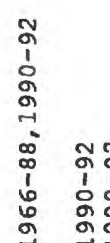

जू

to 1000

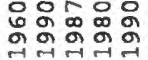

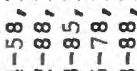

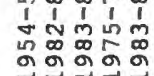

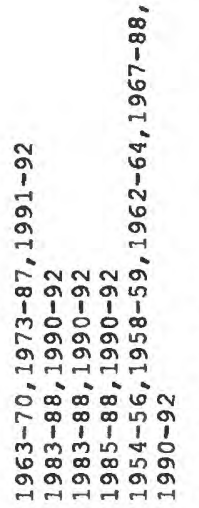

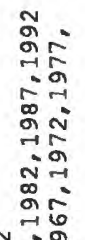

วิㄷำ

बने

क

(1)

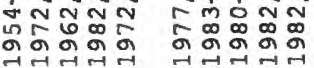

$\stackrel{1}{+2}$

4⿻ํㅇ क्ष

HHH

HDH

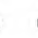

Hッカー

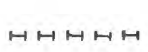

$\mapsto \mapsto \mapsto \mapsto \mapsto$

H n us

$D$

ロேルー

HルD政

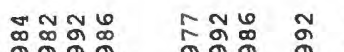

न्नेन्ने

궁ํํ

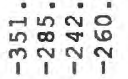

꽁

ก

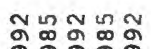

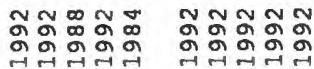

รํํำ?

告

$\overrightarrow{0}$

永

它莒

กิ๊

势

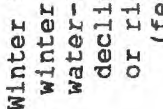

\section{กั}

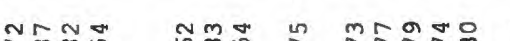

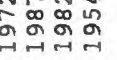

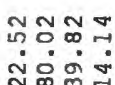

స్ํํำ

ㄱำ

둔당

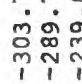

ก

न्ननजने

NN N

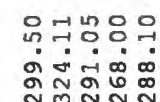

nm

TMT

พํํำ

ज्वiक

พันูำ

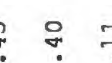

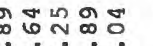

○ 00

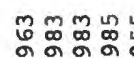

แn

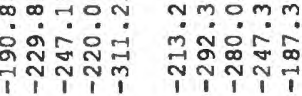

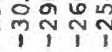

웅요

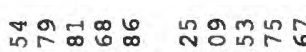

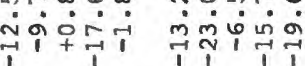

ํํำ

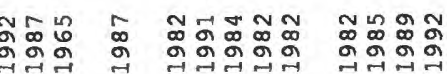

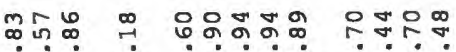

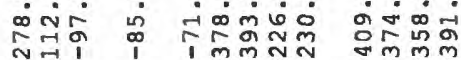

Ү

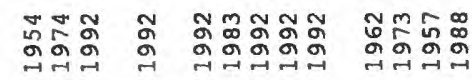

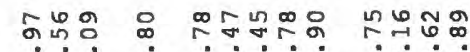

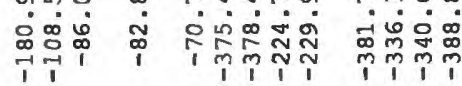

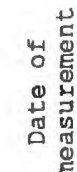

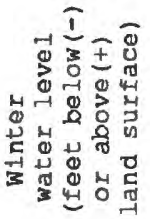

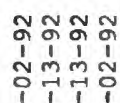

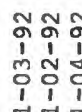

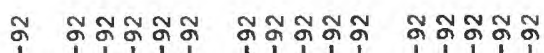

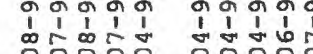

훙ㅎㅇㅇㅣ

$\begin{array}{llll}1 & 1 & 1 & 1 \\ 1 & 1 & 1 \\ 0 & 1 & 0 & 1 \\ 1 & 0 & 0 & 0 \\ 1 & 1 & 1 \\ 1 & 1 & 1\end{array}$

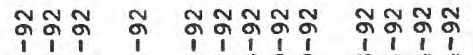

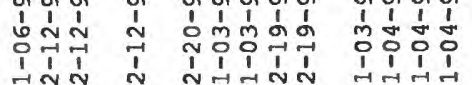

$\rightarrow$ mलn

$\min 2$

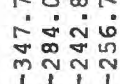

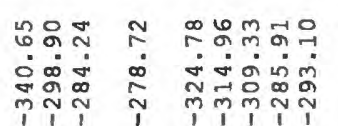

옹ำ

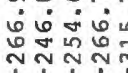

욱ㄱㄷㅇㅇㅇㅇㅇㅜ

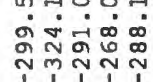

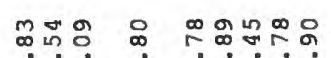

क्ष

0
oñ
0
0
0
0
0

벙벙병병

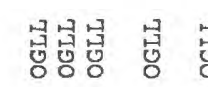

붕붕붕벙붕

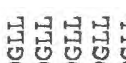

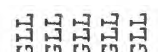

พก กับ

$\underset{\sim}{\mathcal{N}} \underset{\mathcal{N}}{\mathbb{N}} \underset{\sim}{\mathbb{N}} \mathbb{N}$

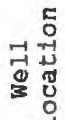

บัตับ

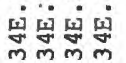

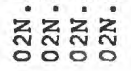

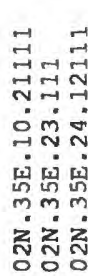

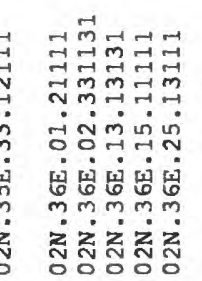

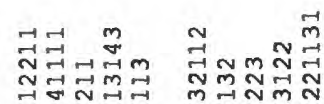

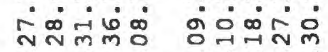

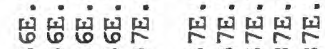

żżż mंmm

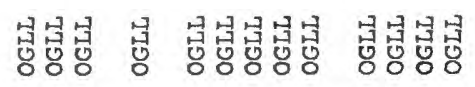

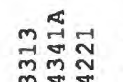

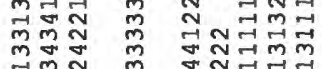

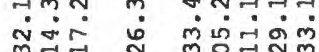

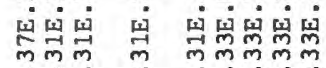

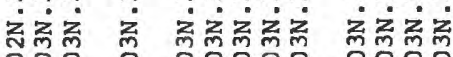




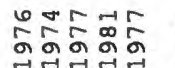

Sू̆

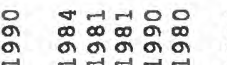

ถำสำ

드ํํำ

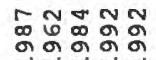

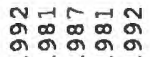

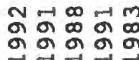

गูㄷำ

궁응

ติ คำำ

주행ำ

누움ำ

웅유응

무융유

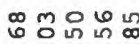

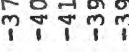

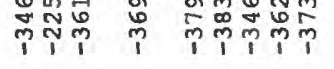

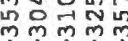

궁ㅇㅇㅇ

तेकेष्ठ

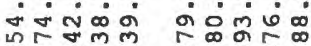

กัญูํํำ

50

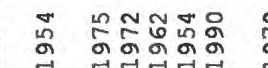

은

arom

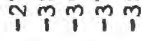

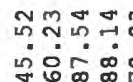

눙

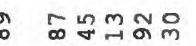

नิศสํำ

ㄱำำ

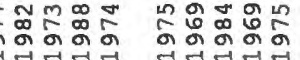

นำ

당ㅎㅇ유응

รูกุำ ริ

p당

윰중응

कूสํำ

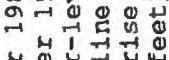

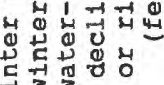

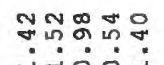

₹

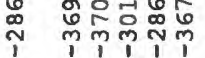

कुन्त

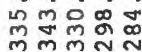

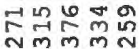

omi.

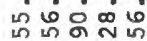

하훟하

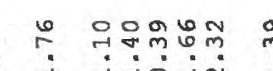

ํ, $\infty_{\infty}^{\infty}$ 응

ํํㅇำำ

ama

जभ

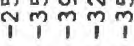

สูสำส

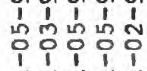

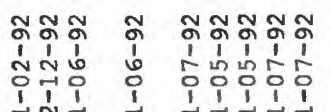

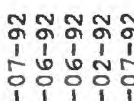

สูกัูำ

พ

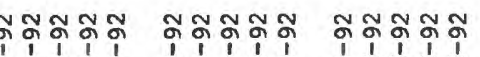
걱

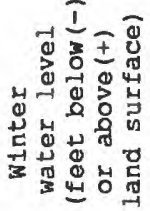

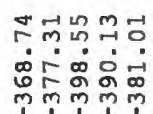

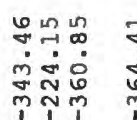

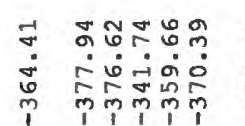

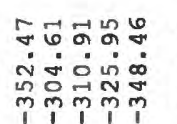

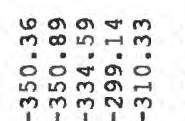

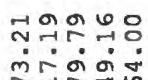

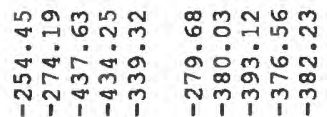

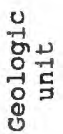

봉붕봉붕

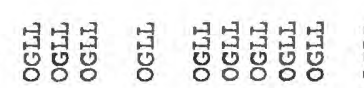

벙붕벙벙붕

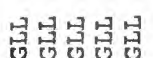

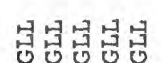

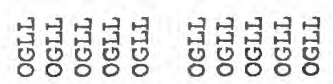

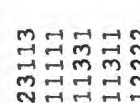

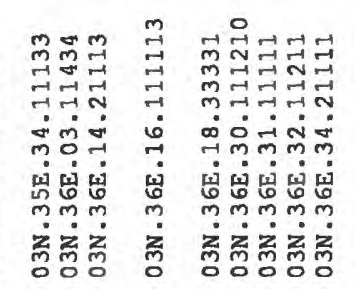

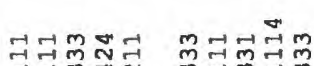

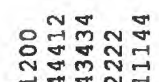

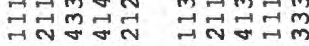

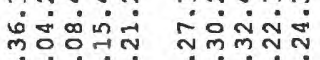

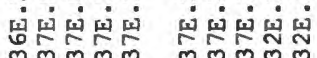

कं

ติ

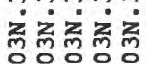

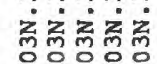

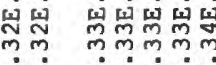

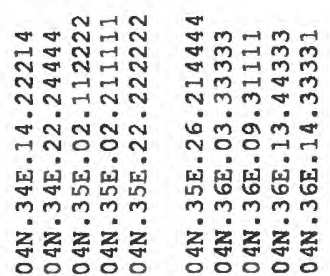




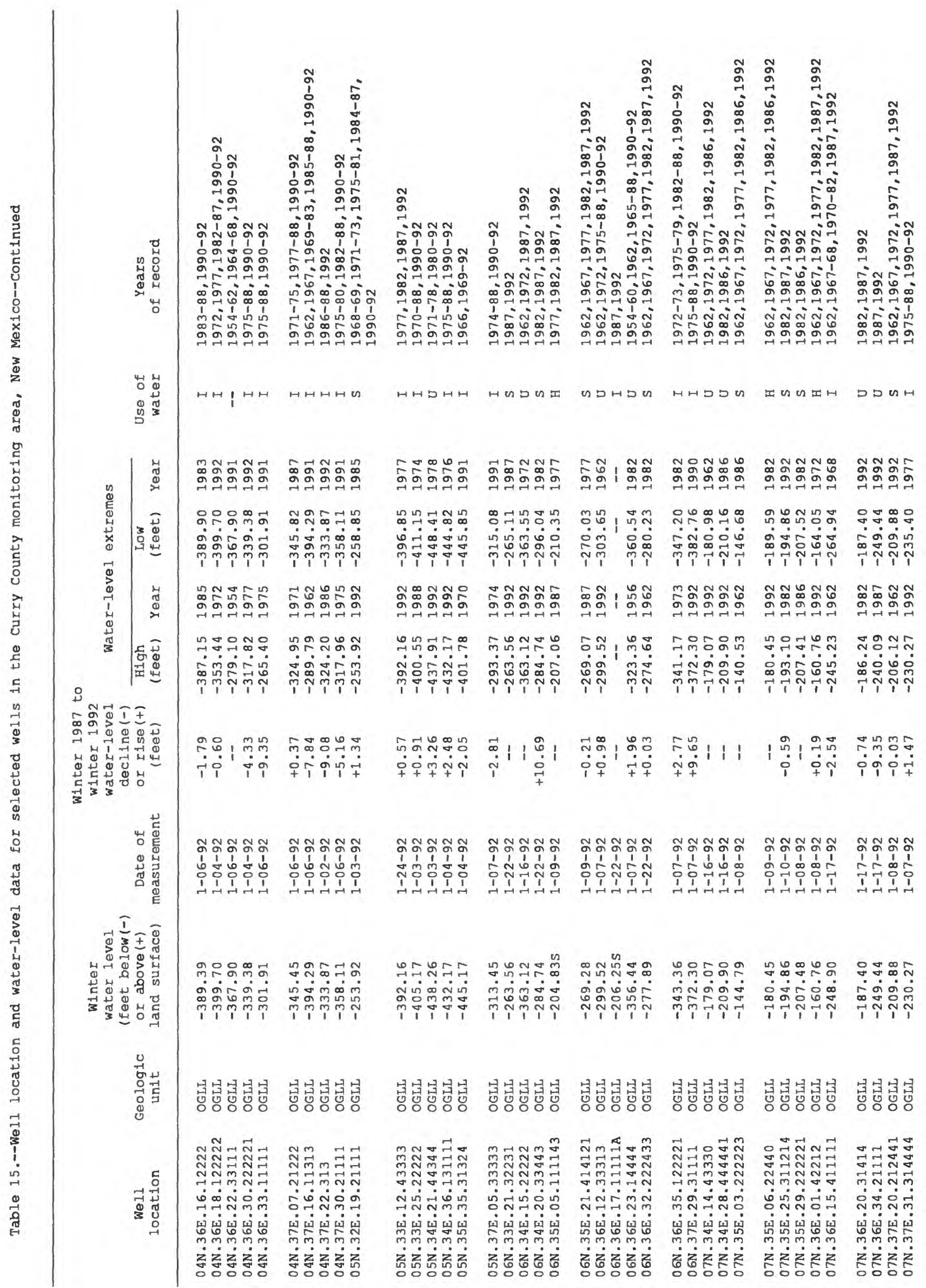




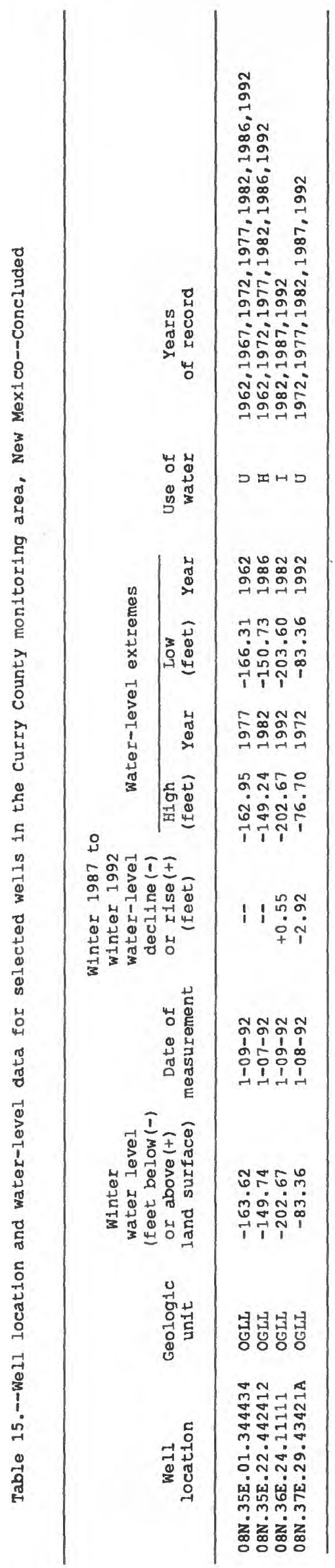




\section{House Monitoring Area}

The House monitoring area is in Quay County, east-central New Mexico. With the exception of six wells water-level changes are rises ranging from less than 1 foot to more than 4 feet. Declines are usually less than 1 foot, although one decline was more than 3 feet. 


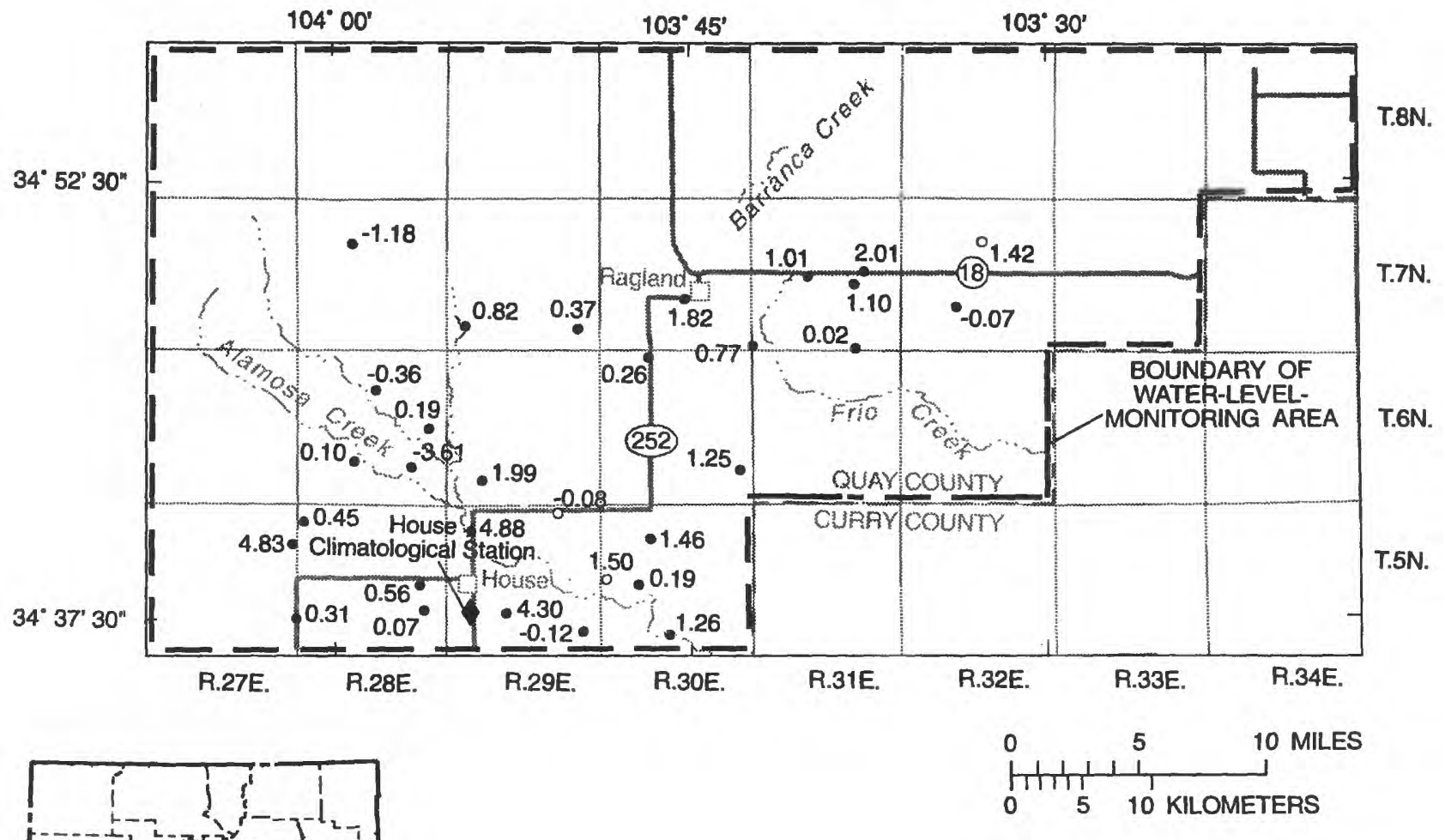

\section{EXPLANATION}

-118 WELL--Number represents the water-level

- rise or decline (-), in feet

- WELL--Has water-level hydrograph

for the period of record in this report

Figure 33.--Water-level changes for wells in the House monitoring area, 1987-92. 

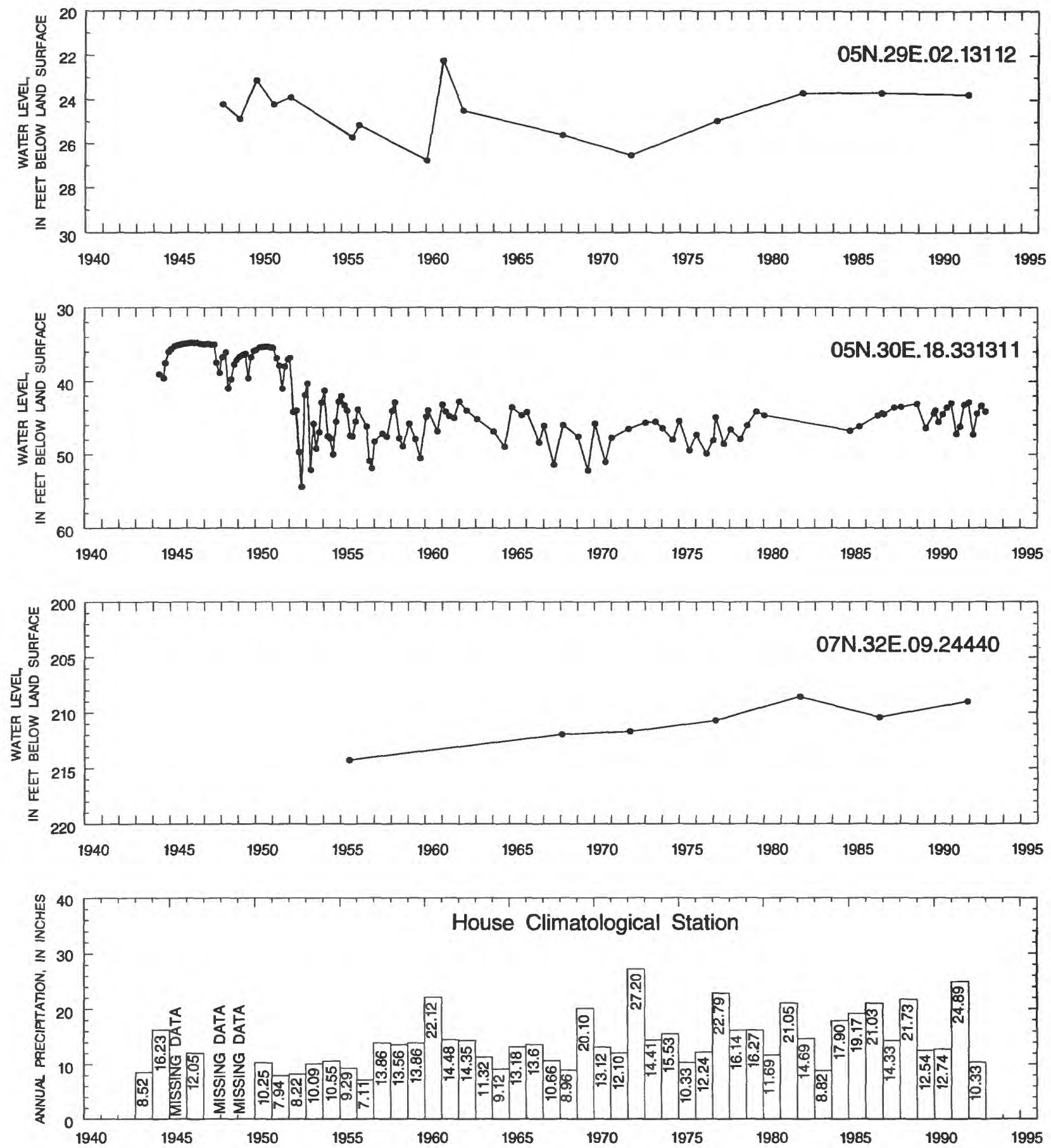

Figure 34.--Water-level data for selected wells in the House monitoring area and annual precipitation at the House Climatological Station. See figure 33 for location of wells and station. 


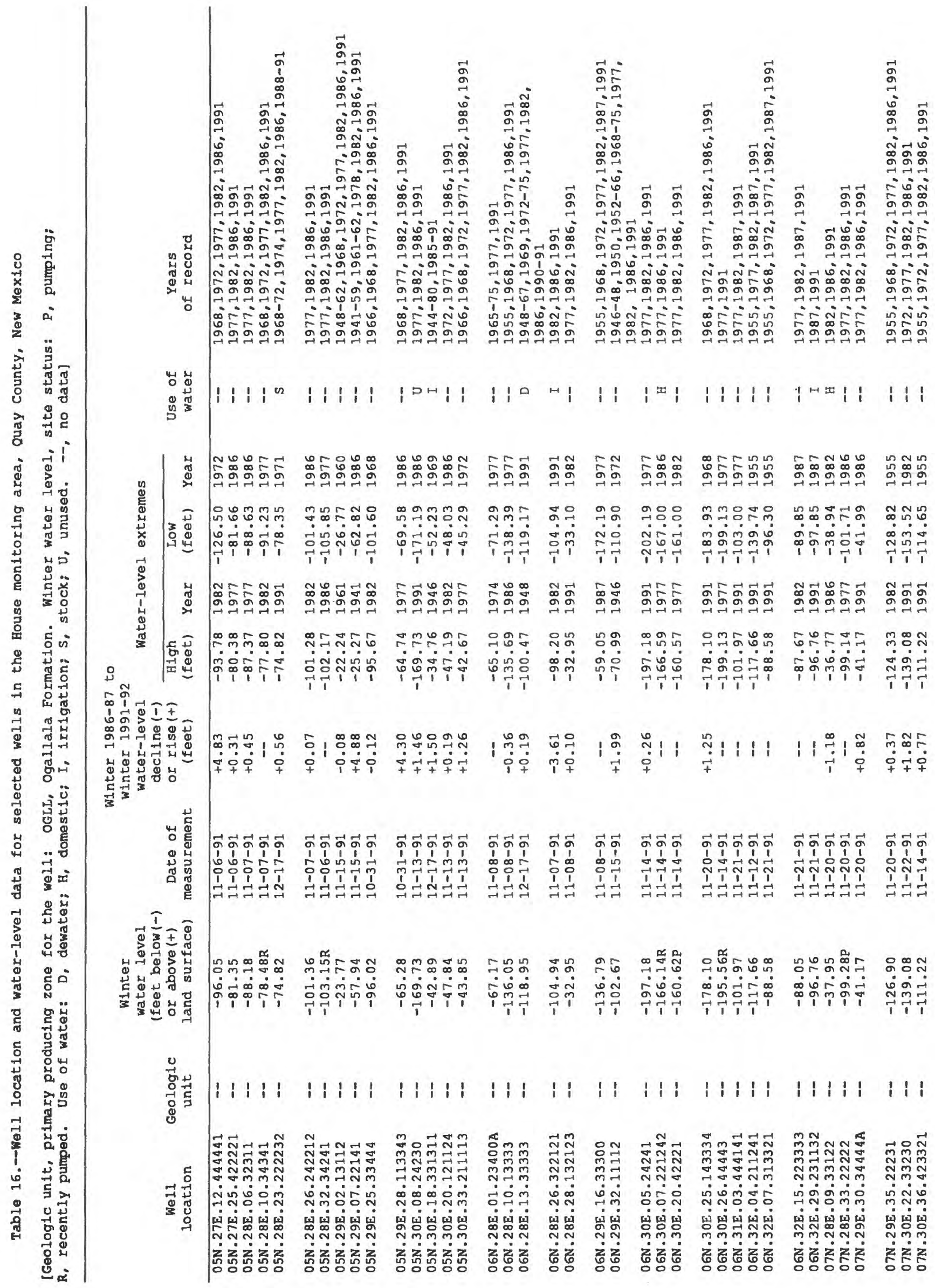




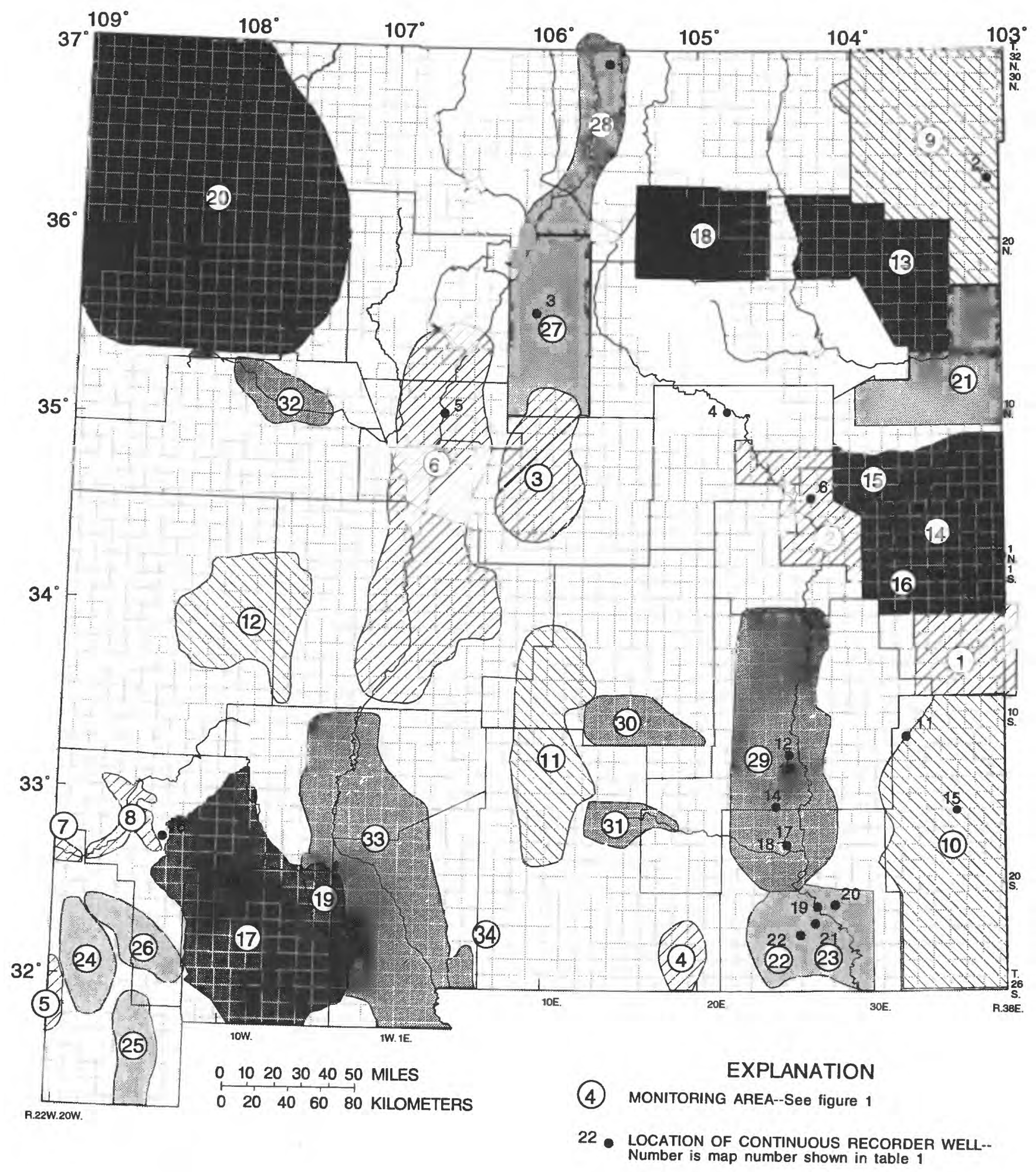

Figure 2.--Location of continuous recorder wells. 


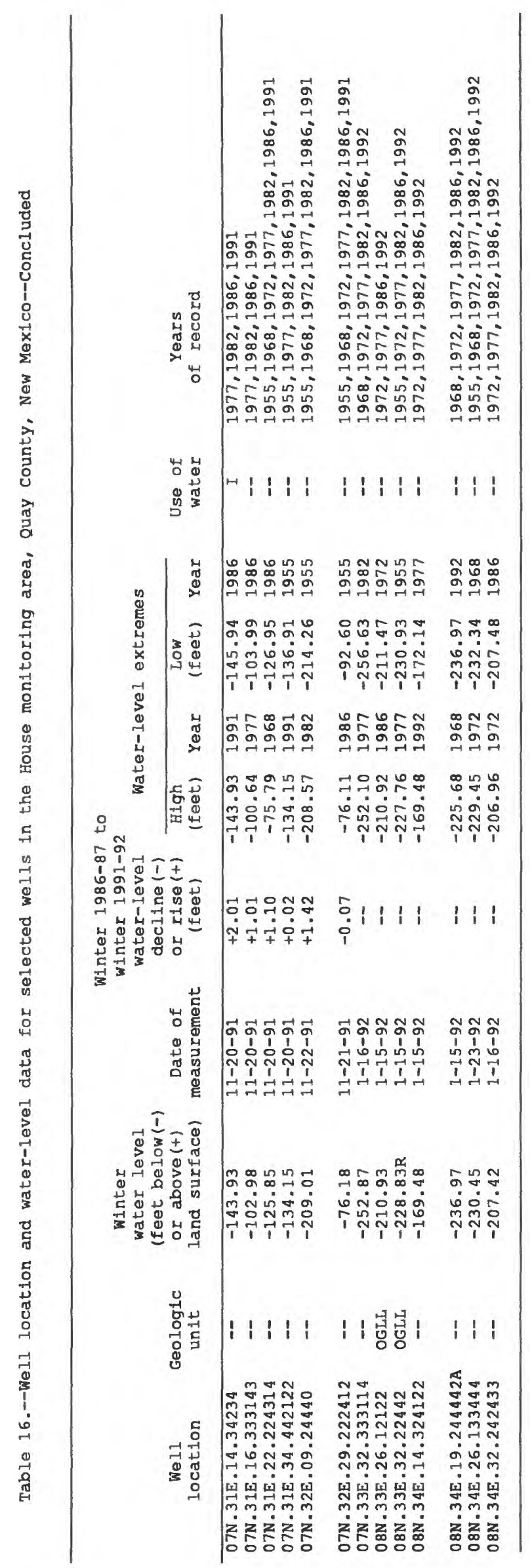




\section{Portales Monitoring Area}

The Portales monitoring area is in northern Roosevelt County, east-central New Mexico. Water-level declines range from less than 1 foot to more than 17 feet. Water-level rises range from less than 1 foot to more than 8 feet. Water-level rises in Tps. 2 and 3 N., Rs. 29 and 30 E. range from less than 1 foot to more than 8 feet. Northwest to southeast of Portales from Tps. 1 to $3 \mathrm{~S}$. and Rs. 32 to $35 \mathrm{E}$. water-level changes are rises ranging from less than 1 foot to more than 9 feet. Most other water-level changes are declines ranging from less than 1 foot to more than 17 feet. Declines are generally located in the northern and eastern parts of the monitoring area. 


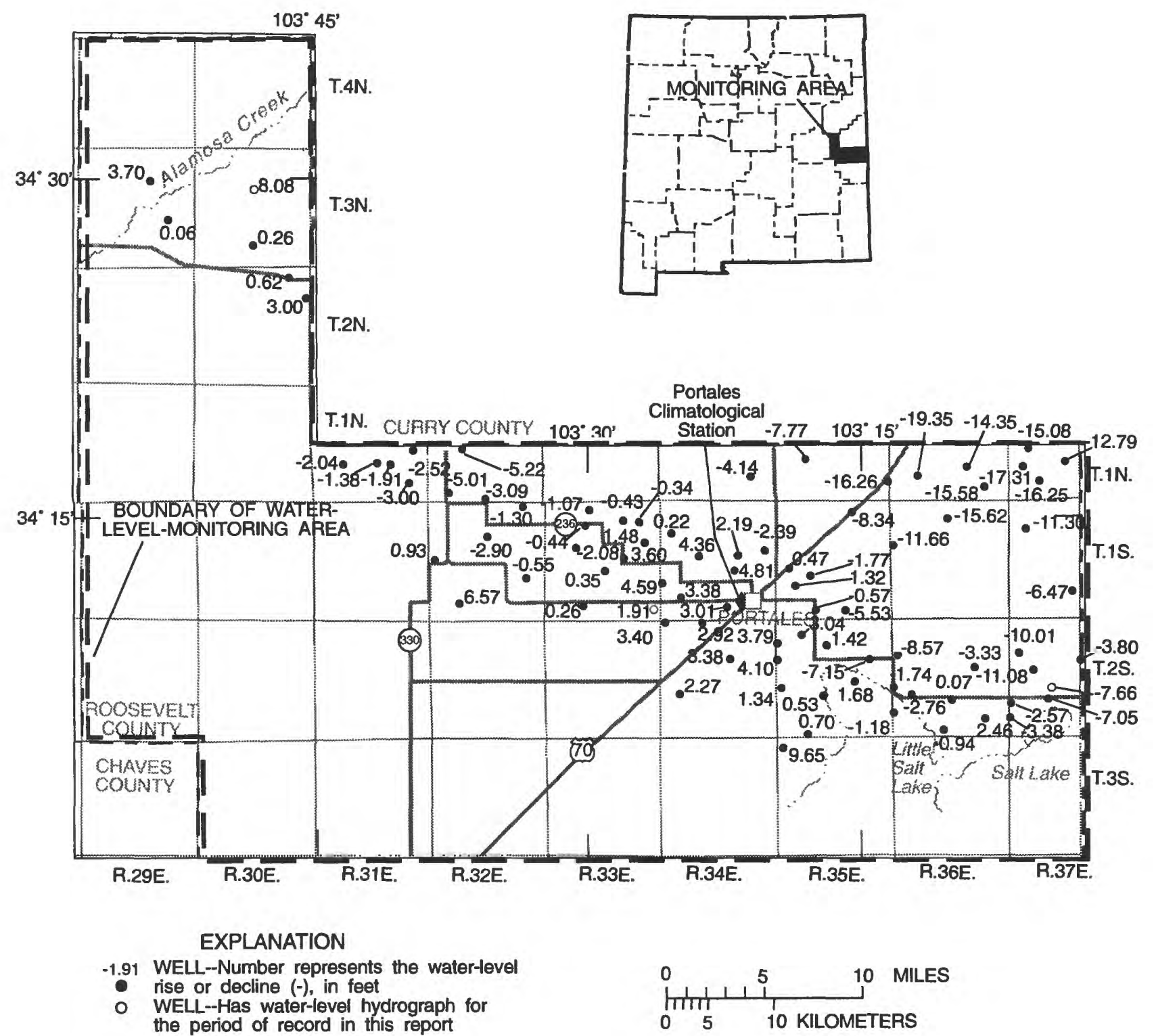

Figure 35.--Water-level changes for wells in the Portales monitoring area, 1987-92. 

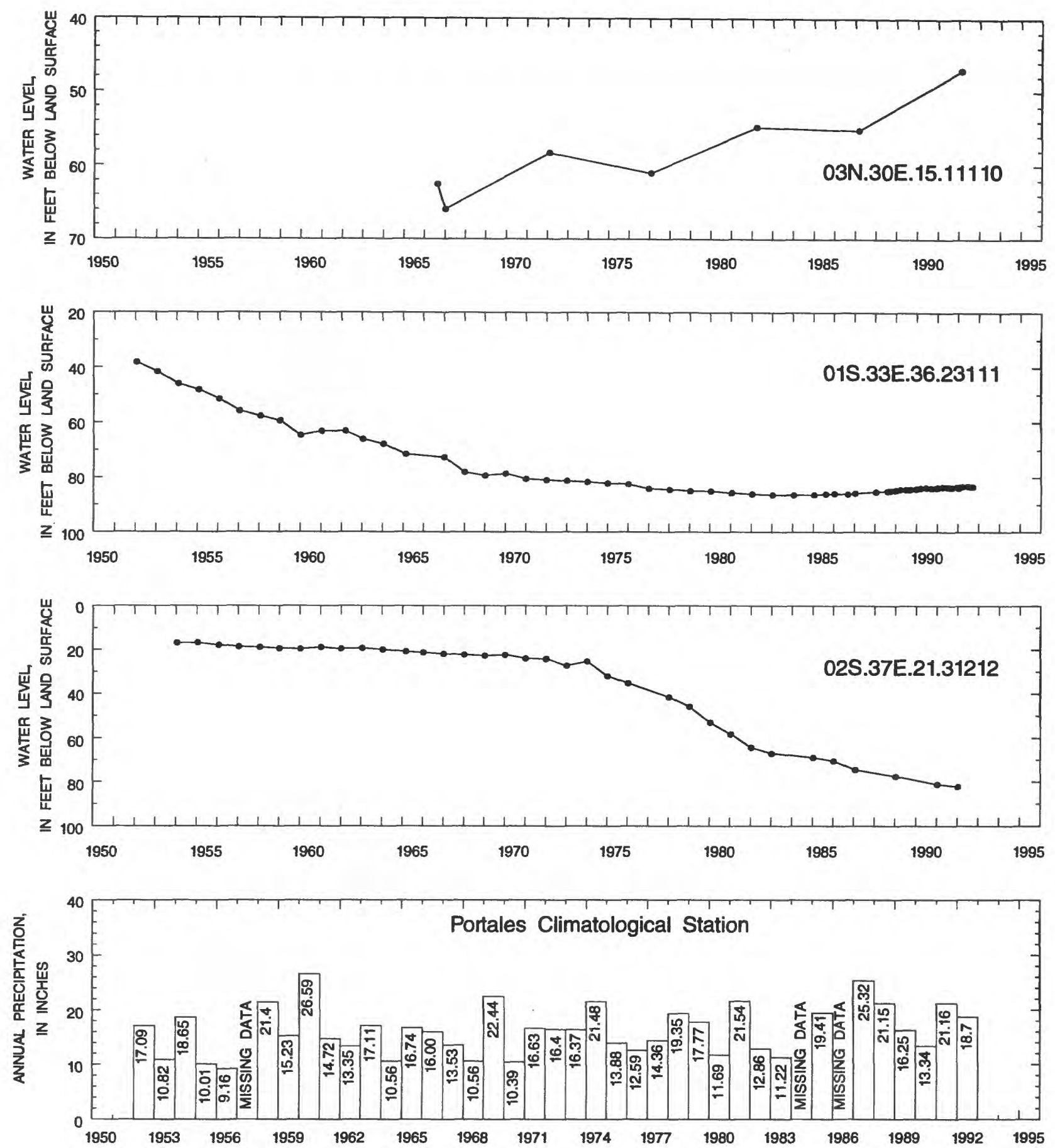

Figure 36.--Water-level data for selected wells in the Portales monitoring area and annual precipitation at the Portales Climatological Station. See figure 35 for location of wells and station. 


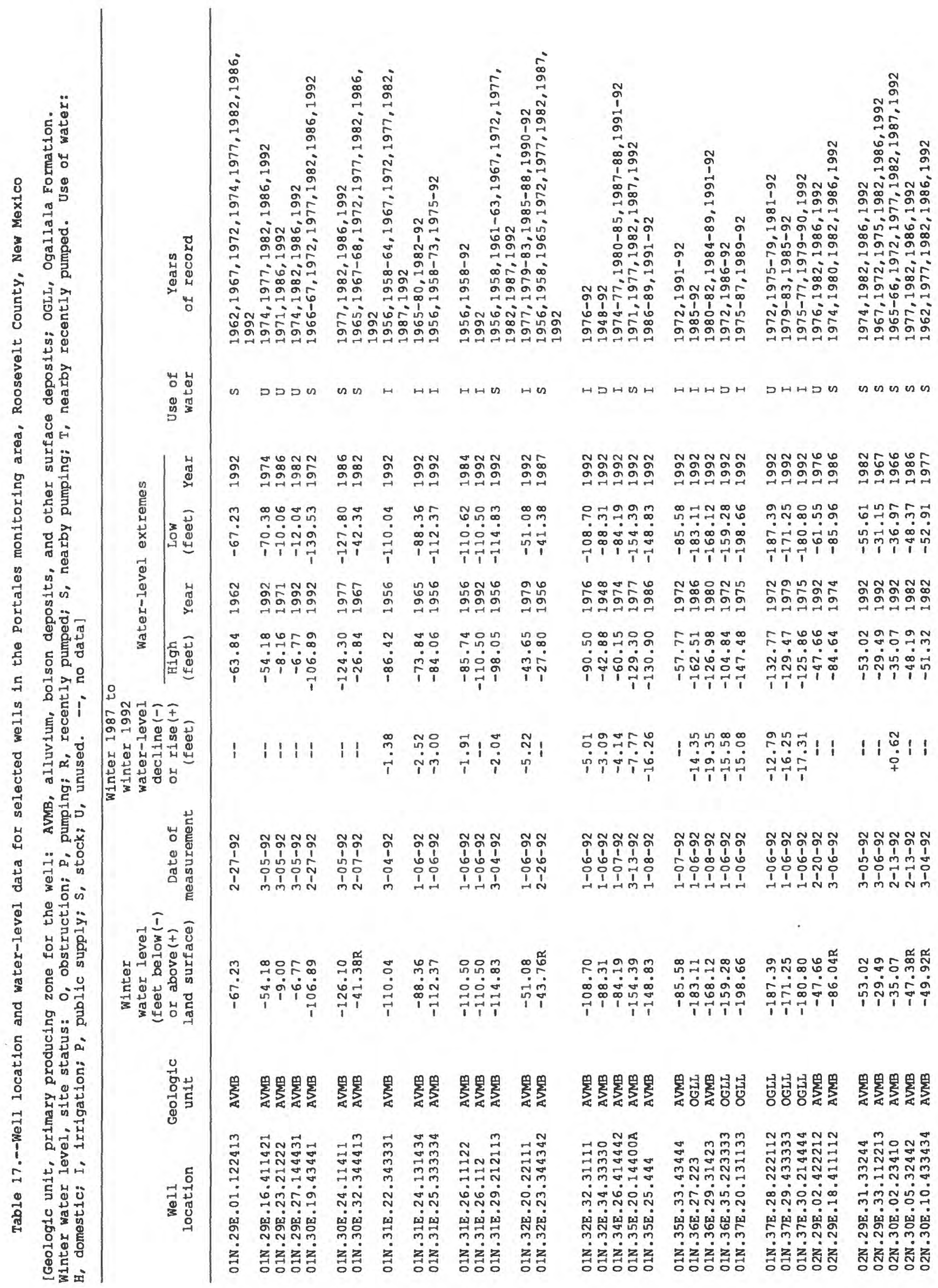



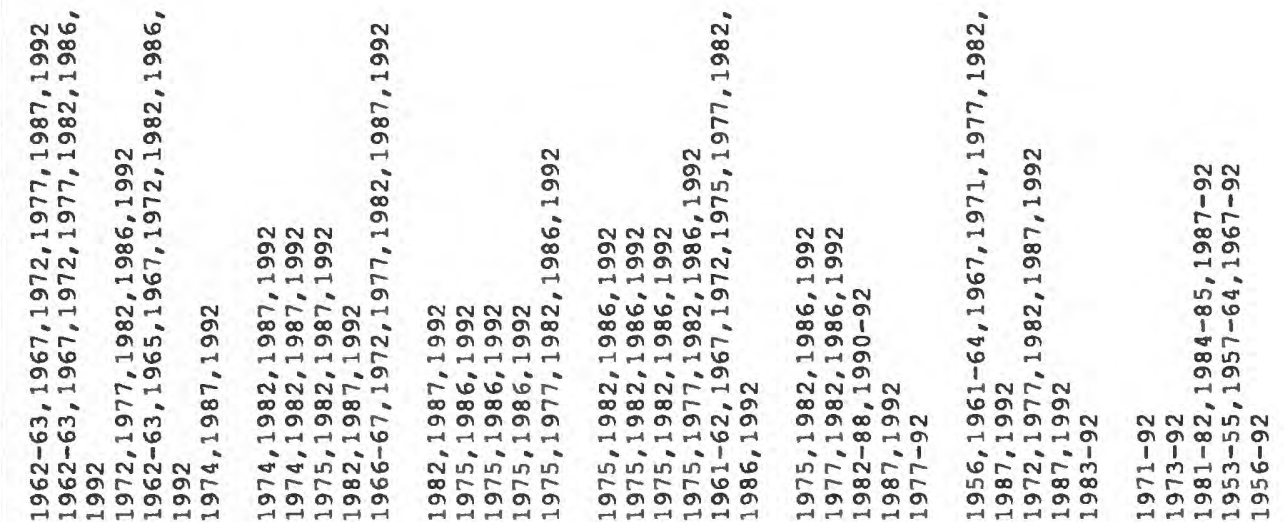

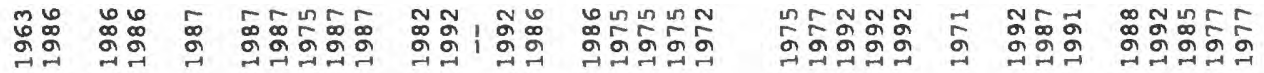

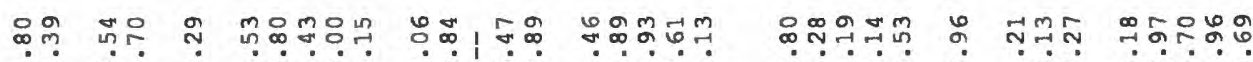
त्रि

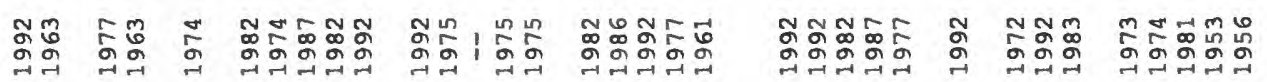

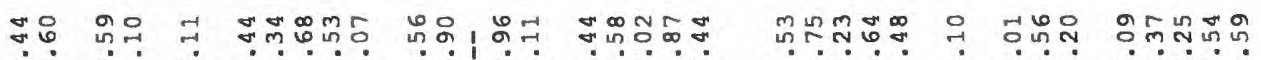

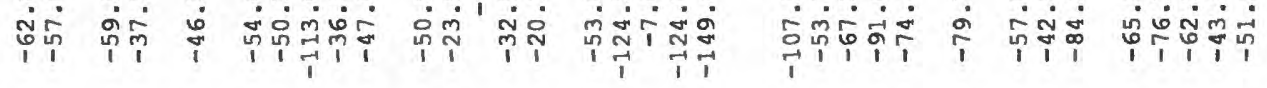

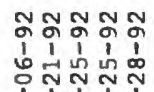

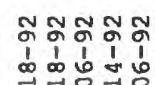

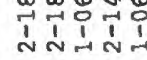

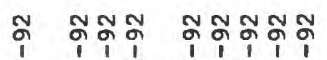
mำกำ

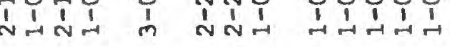

mกำ

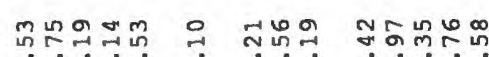
पु户

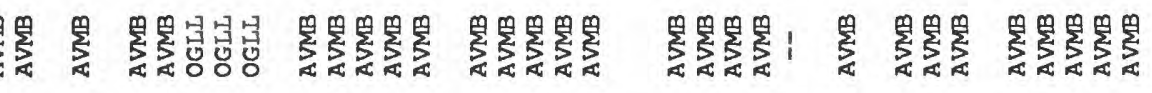
Nָ๊

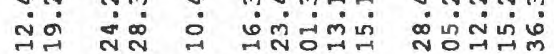

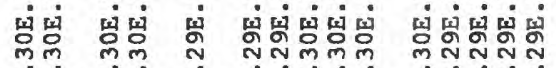

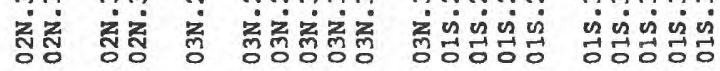

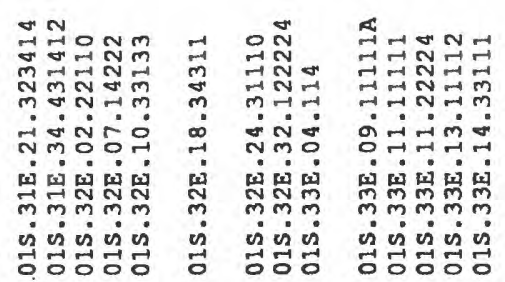




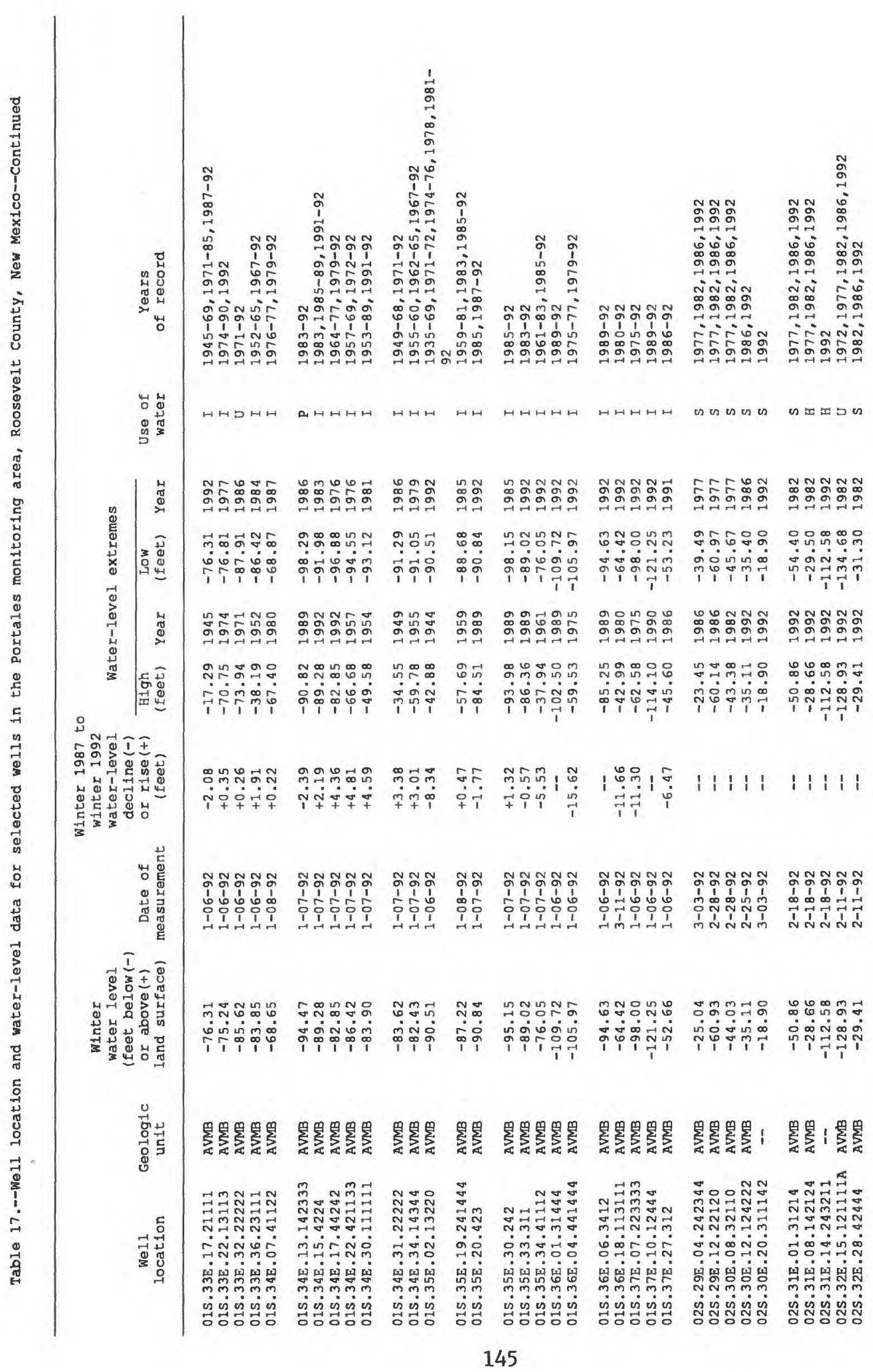




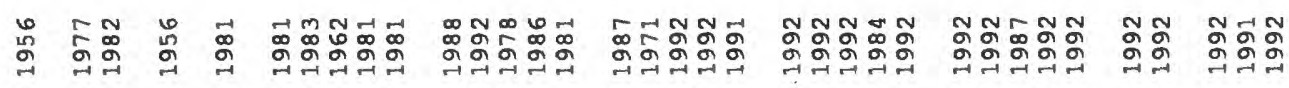

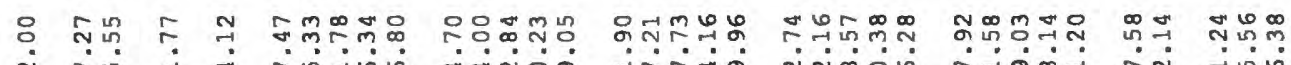
दु

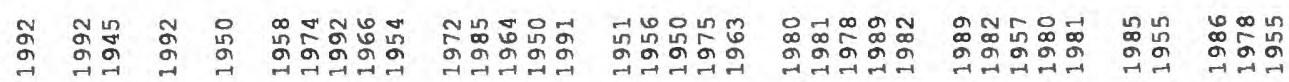
車

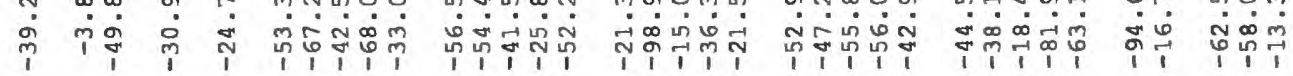
i)

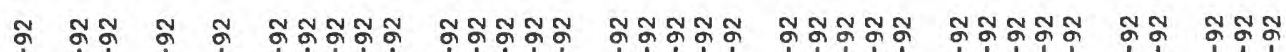

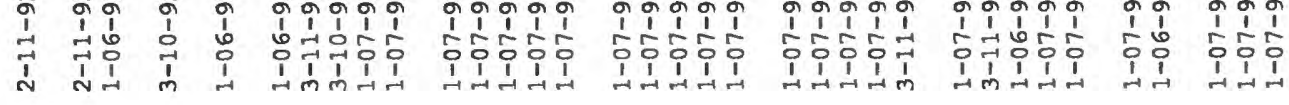

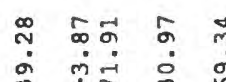

-

monor

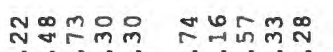

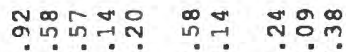
के भिक

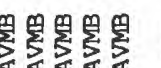

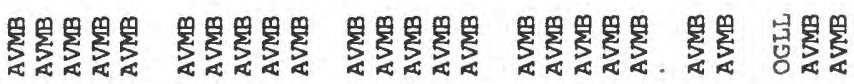

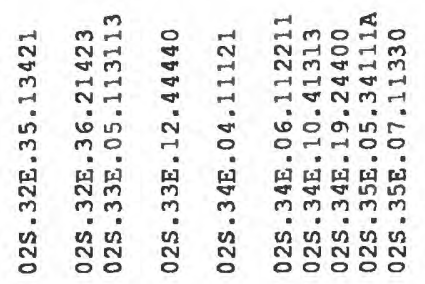

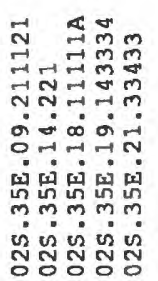

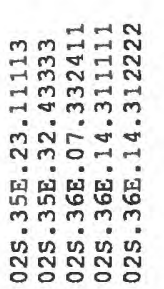

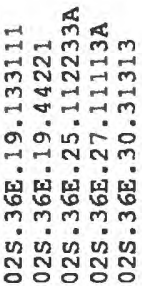

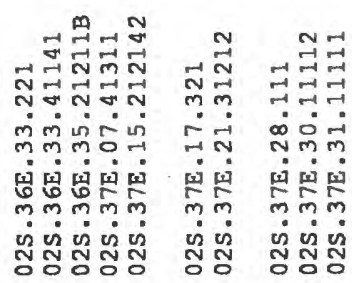




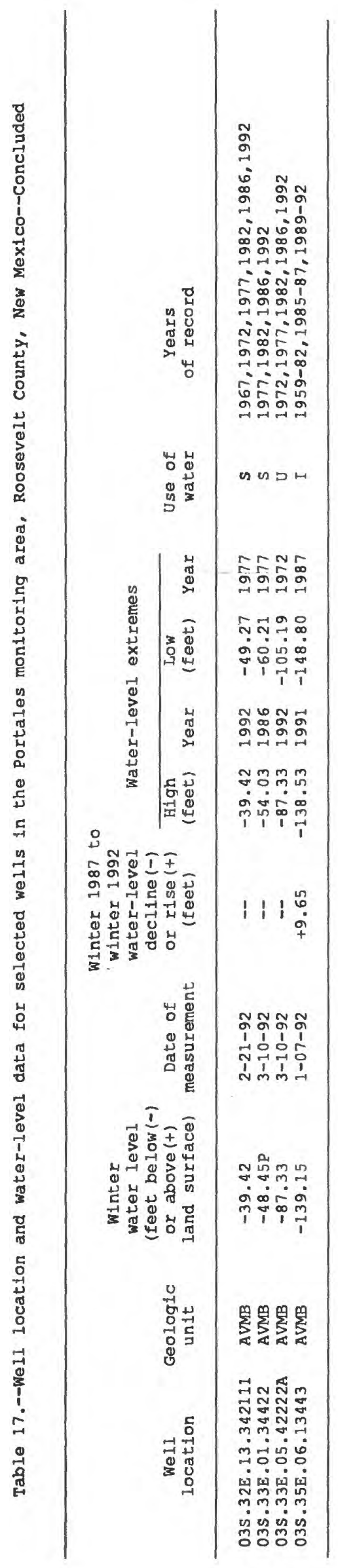




\section{Mimbres Basin Monitoring Area}

The Mimbres Basin monitoring area includes most of Luna County and parts of Grant, Doña Ana, and Sierra Counties, southwestern New Mexico. Not all water-level changes are shown on the map; however, all well locations and water-level data are listed in the table. Well locations worked with an asterisk (*) in the table are plotted on the map.

Water-level declines range from less than 1 foot to more than 30 feet. Water-level rises range from less than 1 to more than 23 feet. Water-level data indicate declines south of Deming in parts of Tps. 25 and $26 \mathrm{~S}$. and Rs. 8 through $11 \mathrm{~W}$. Declines are shown around Columbus in all or parts of Tps. 26 through 29 S. and Rs. 8 through $10 \mathrm{~W}$. and in T. 17 S. and parts of Rs. 10 and 11 W. Most water-level changes in the remainder of the monitoring area are rises. 


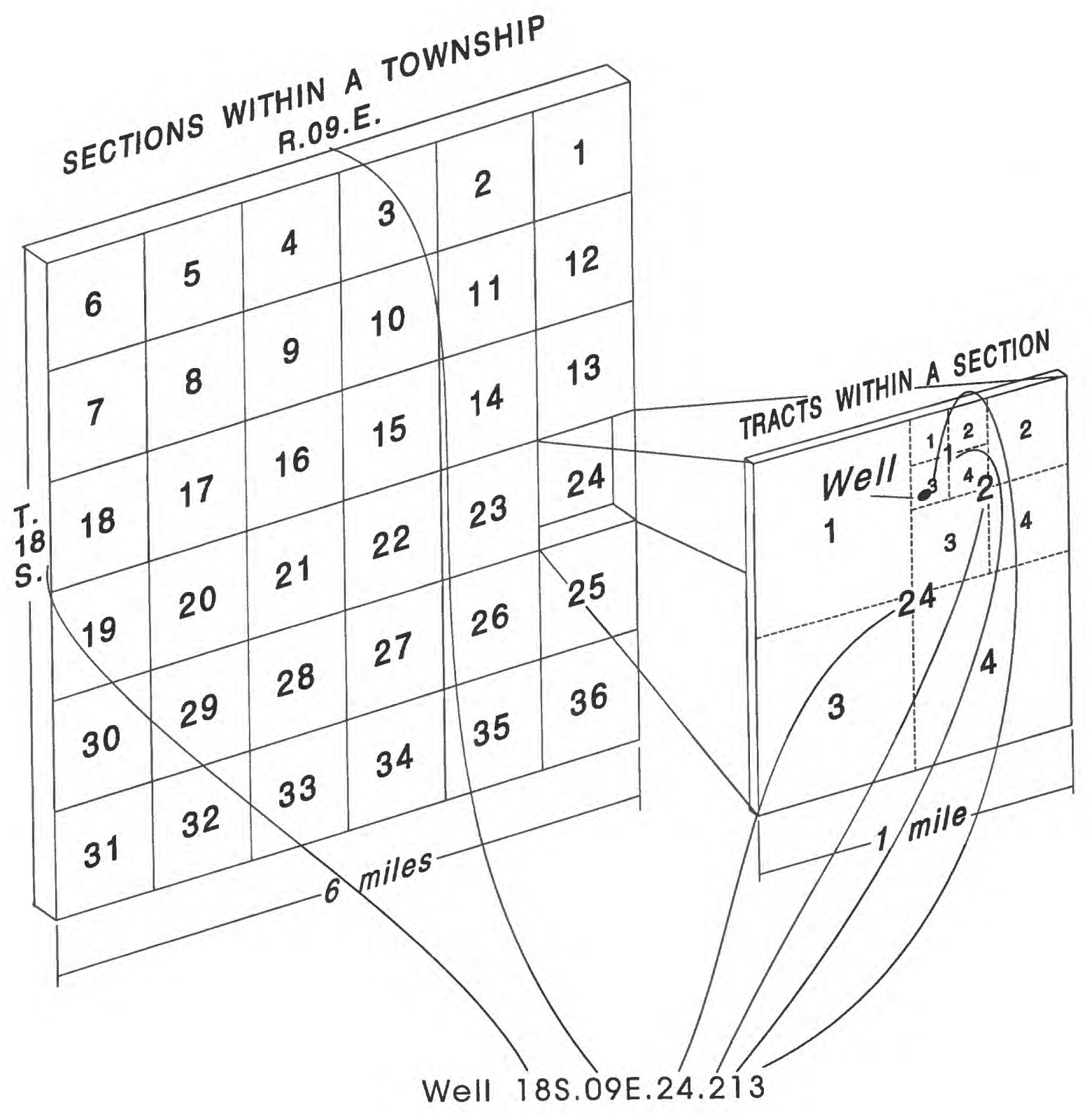

Figure 3.--Well-numbering system used in New Mexico. 

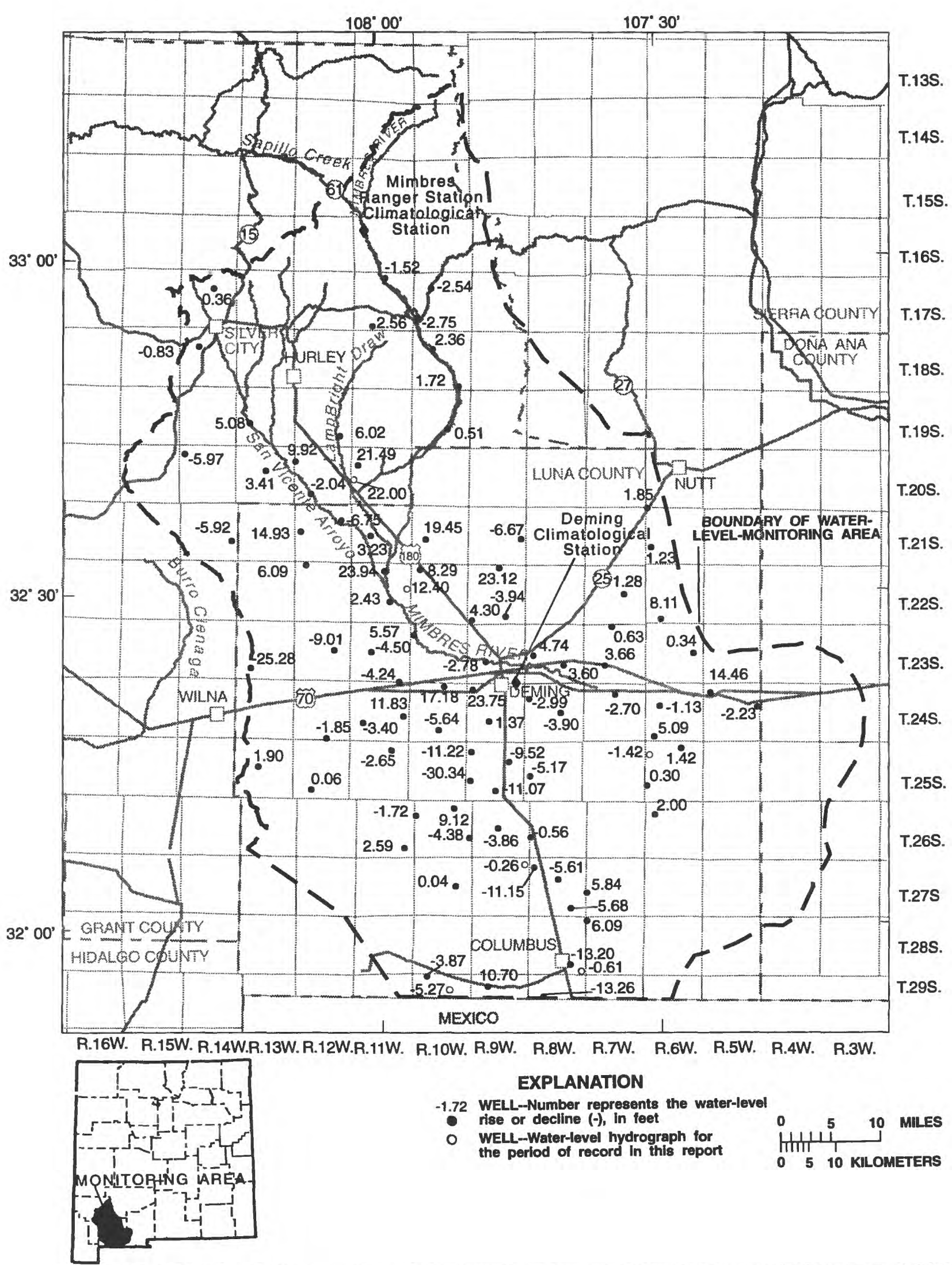

\section{EXPLANATION}

-1.72 WELL-Number represents the water-level

- rise or decline ( - ) in feet

WELL-Water-level hydrograph for

the period of record in this report

MILES

the period of record in this report $\quad 0^{2} 510$ KILOMETERS

Figure 37.--Water-level changes for selected wells in the Mimbres Basin monitoring area, 1987-92. 

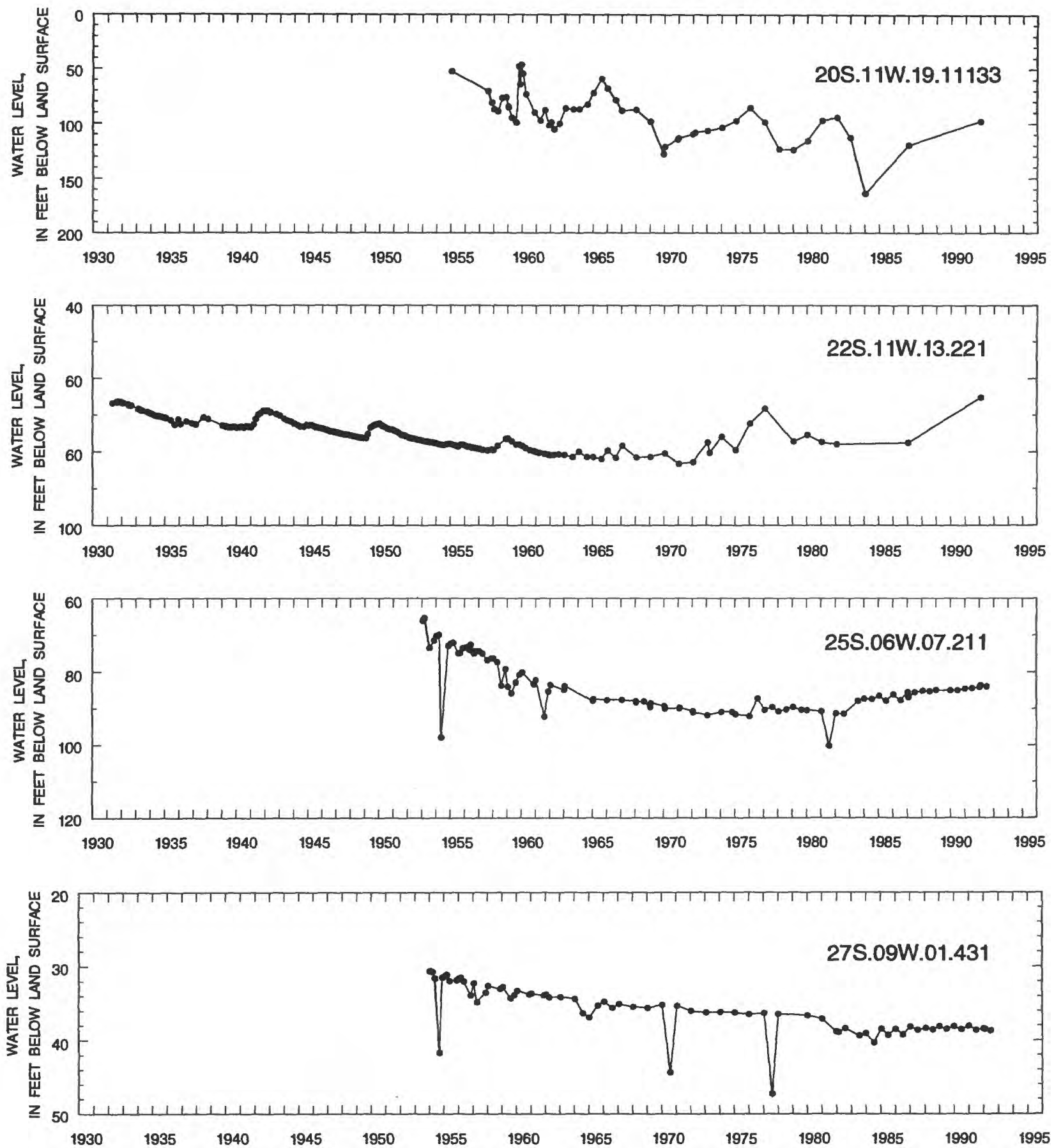

Figure 38.--Water-level data for selected wells in the Mimbres Basin monitoring area and annual precipitation at the Mimbres Ranger Station and Deming Climatological Stations. See figure 37 for location of wells and stations. 

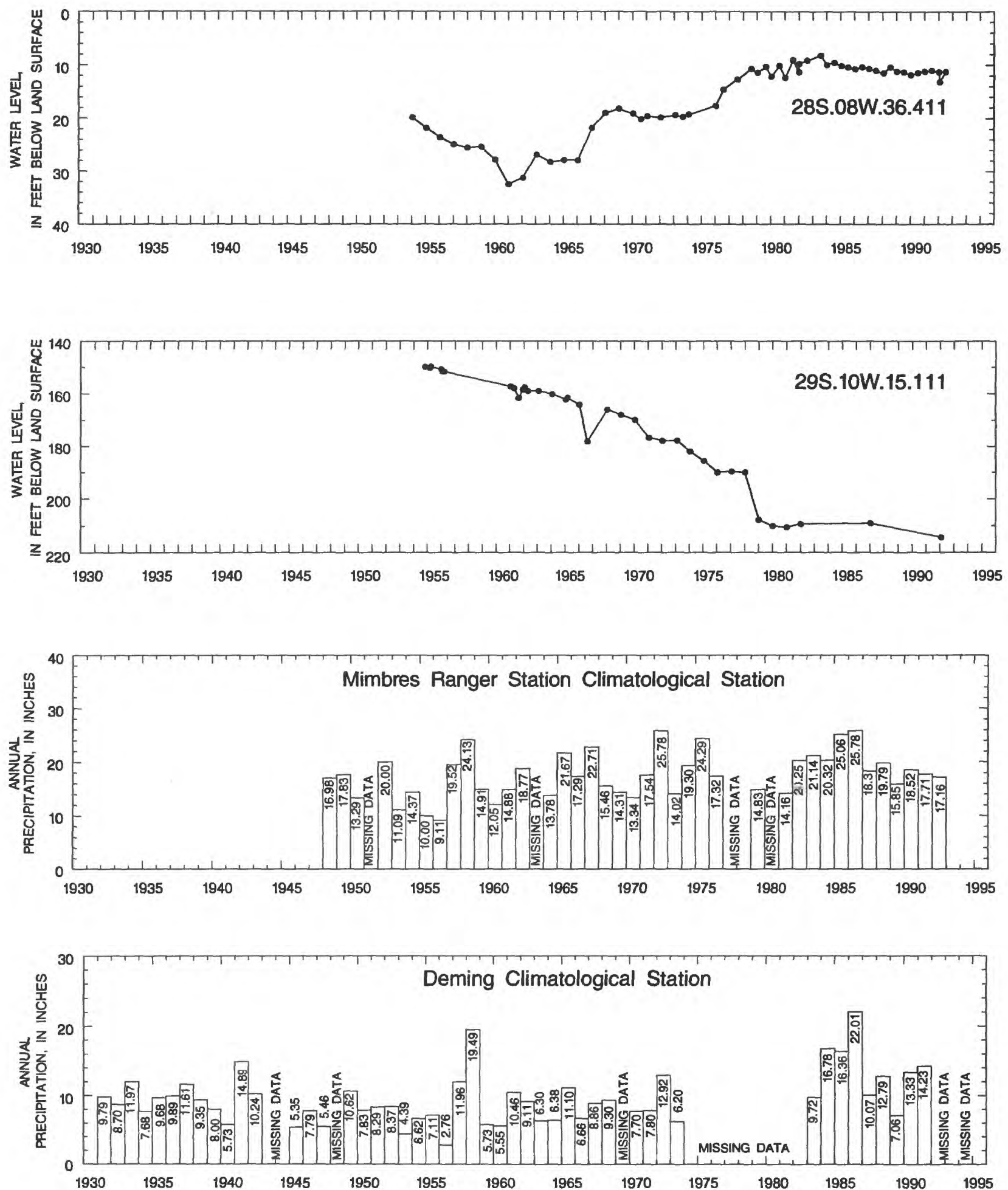

Figure 38.--Water-level data for selected wells in the Mimbres Basin monitoring area and annual precipitation at the Mimbres Ranger Station and Deming Climatological Stations. See figure 37 for location of wells and stations--Concluded. 


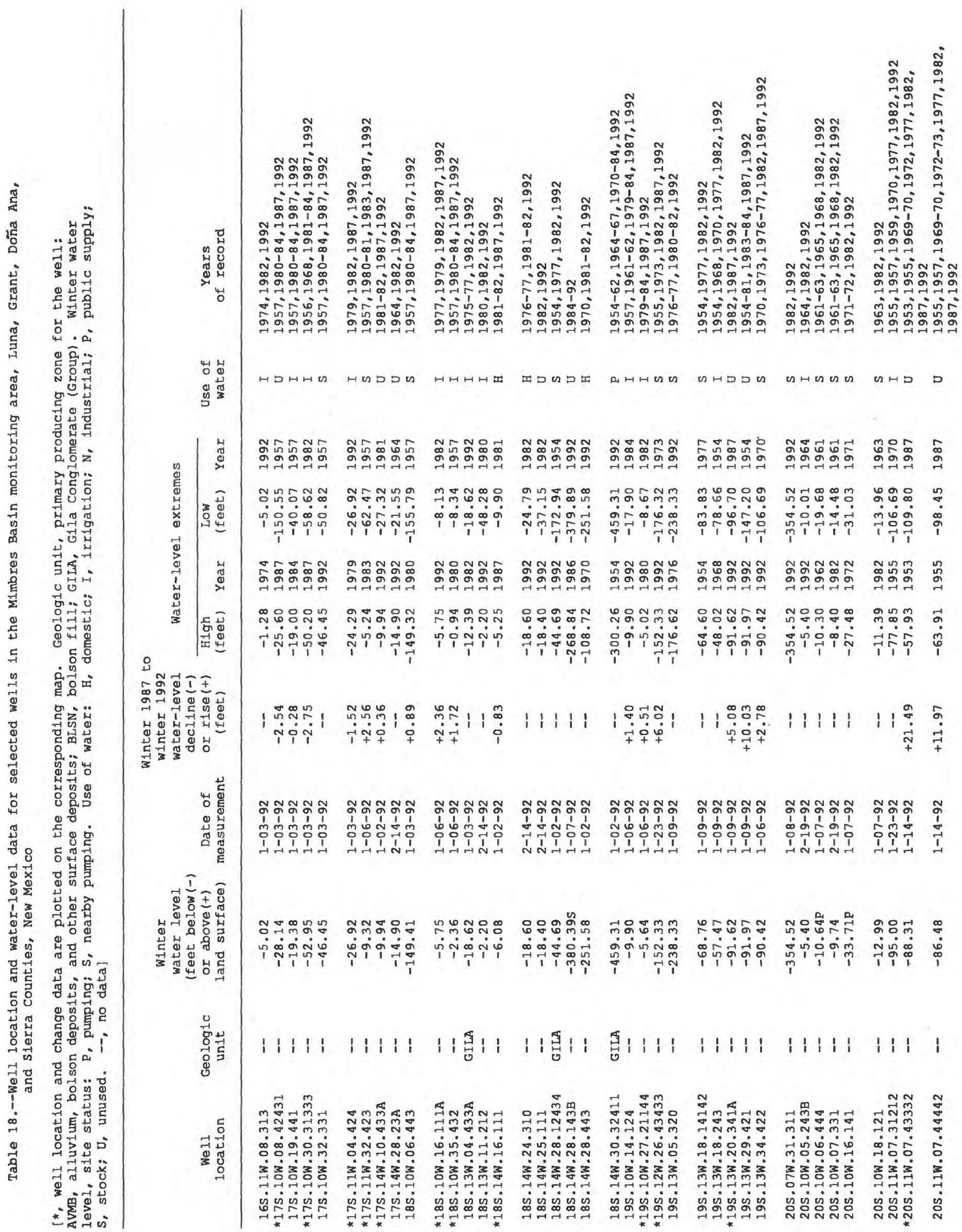




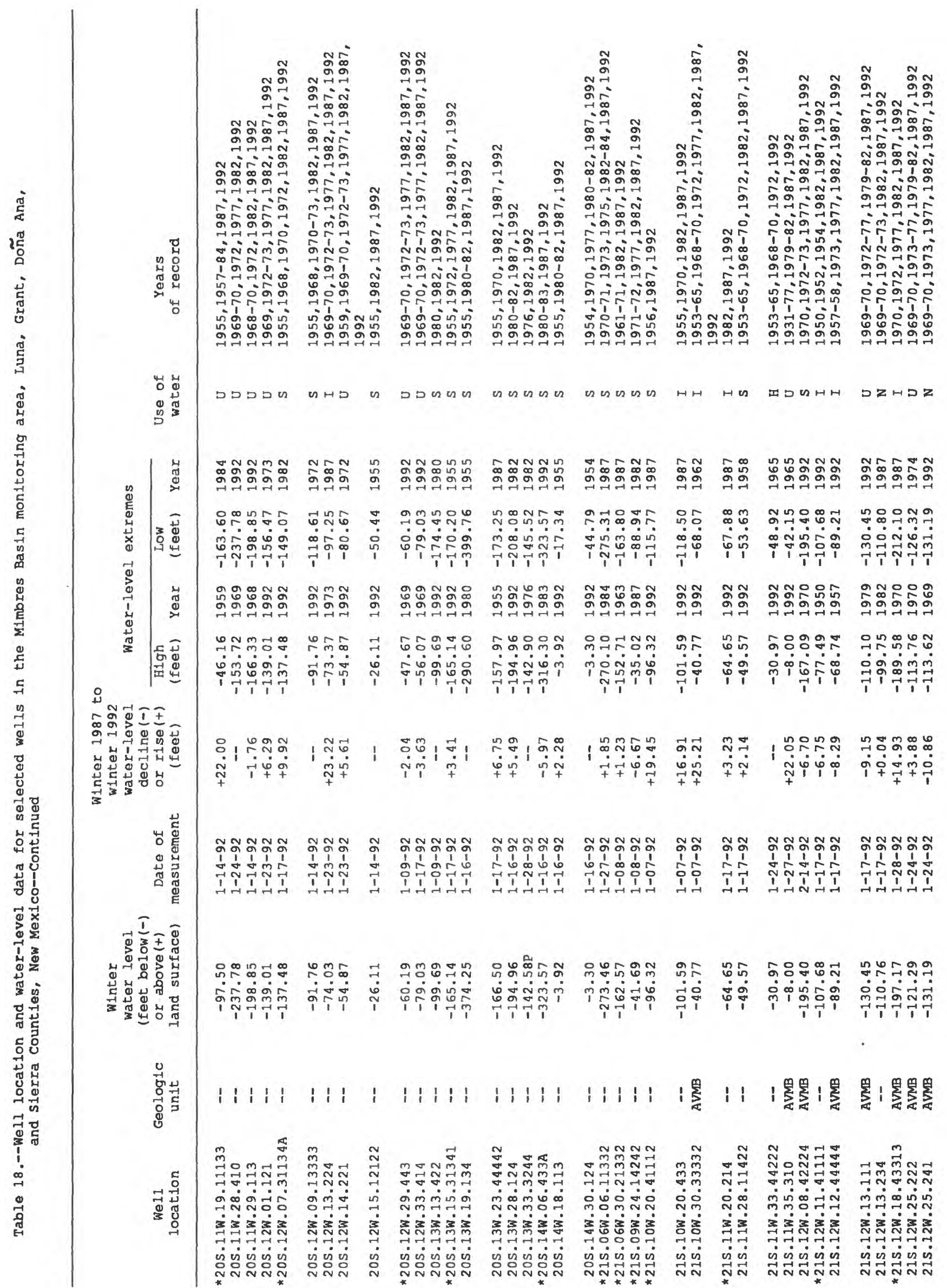




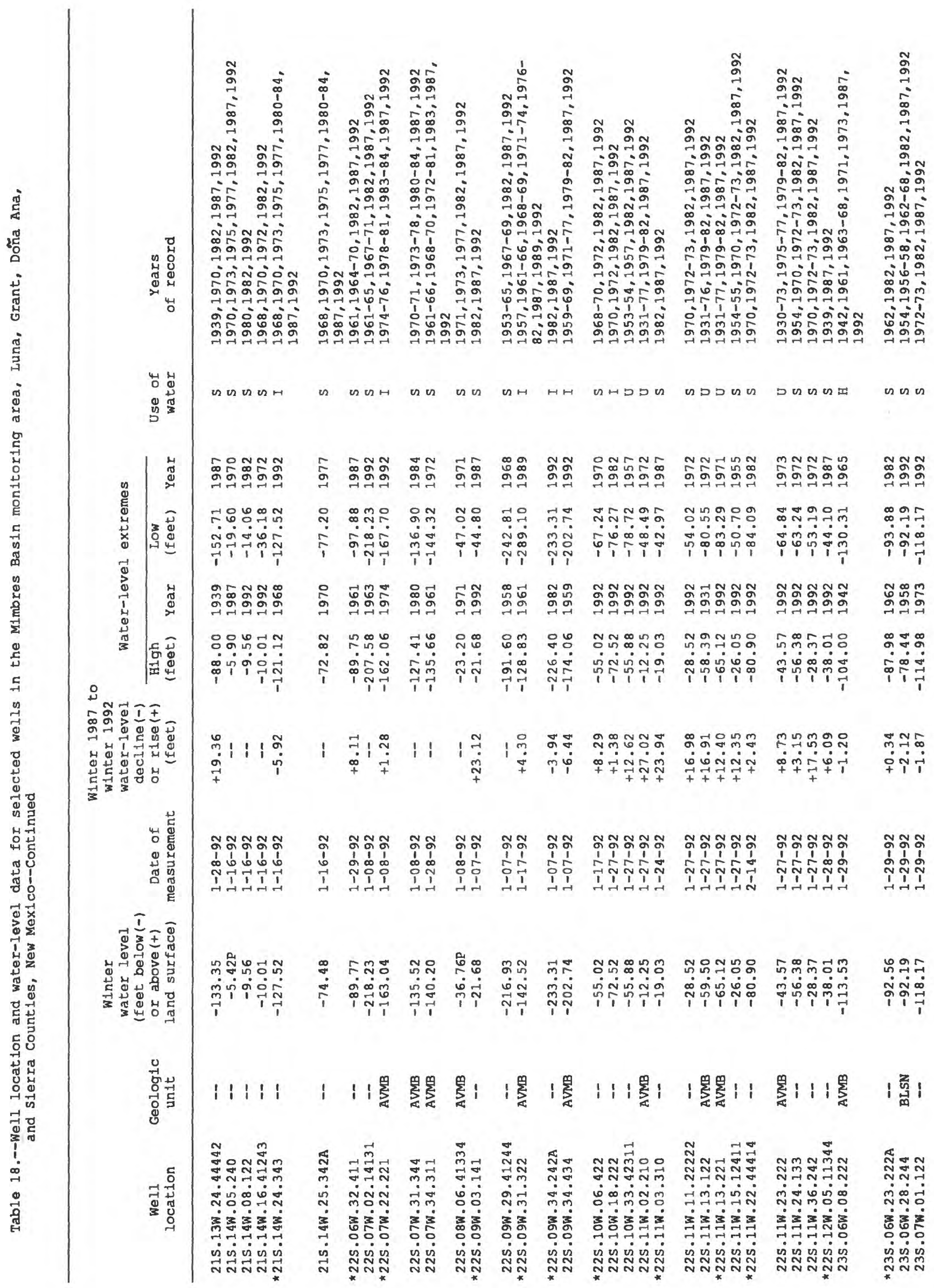




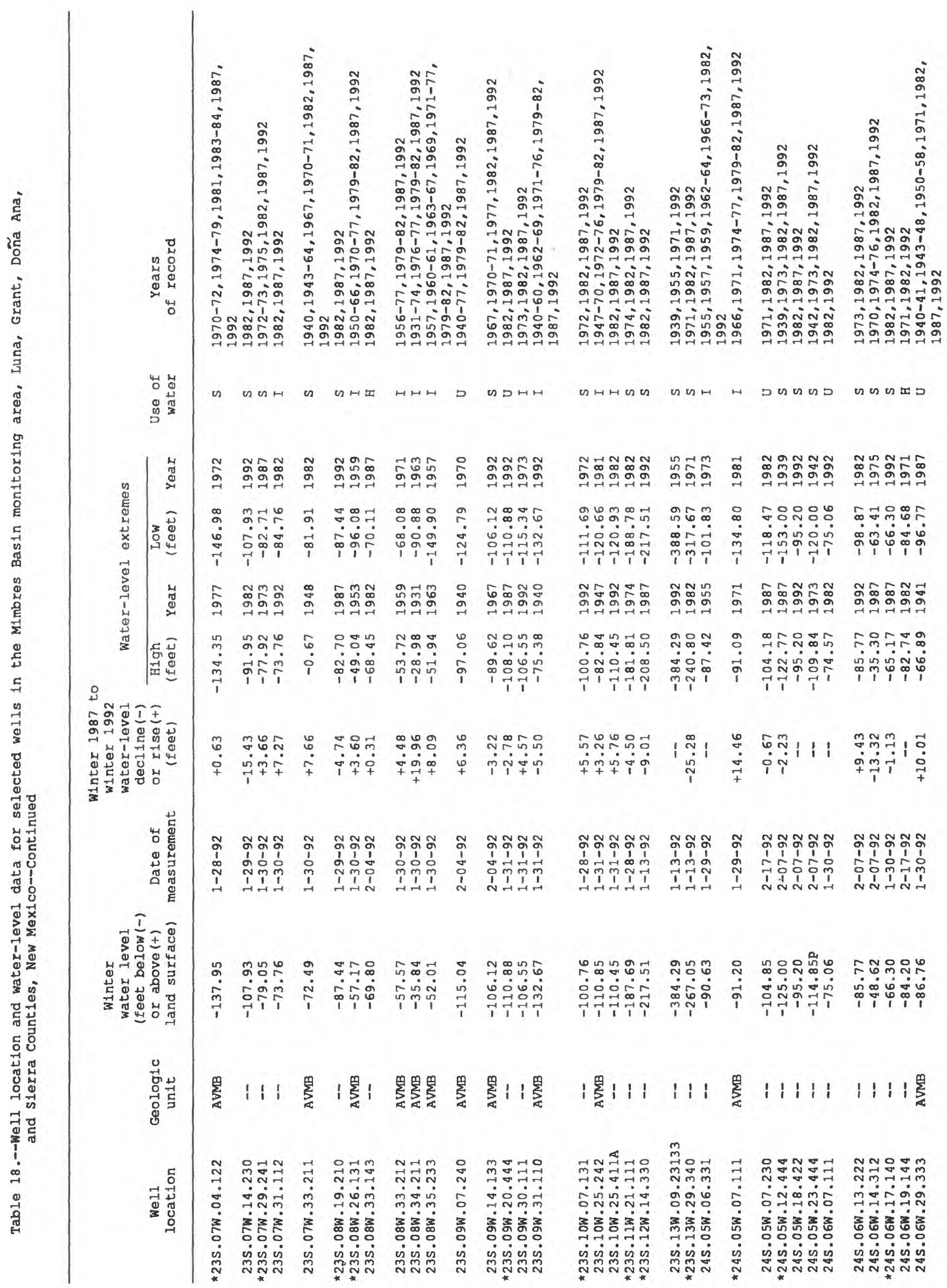




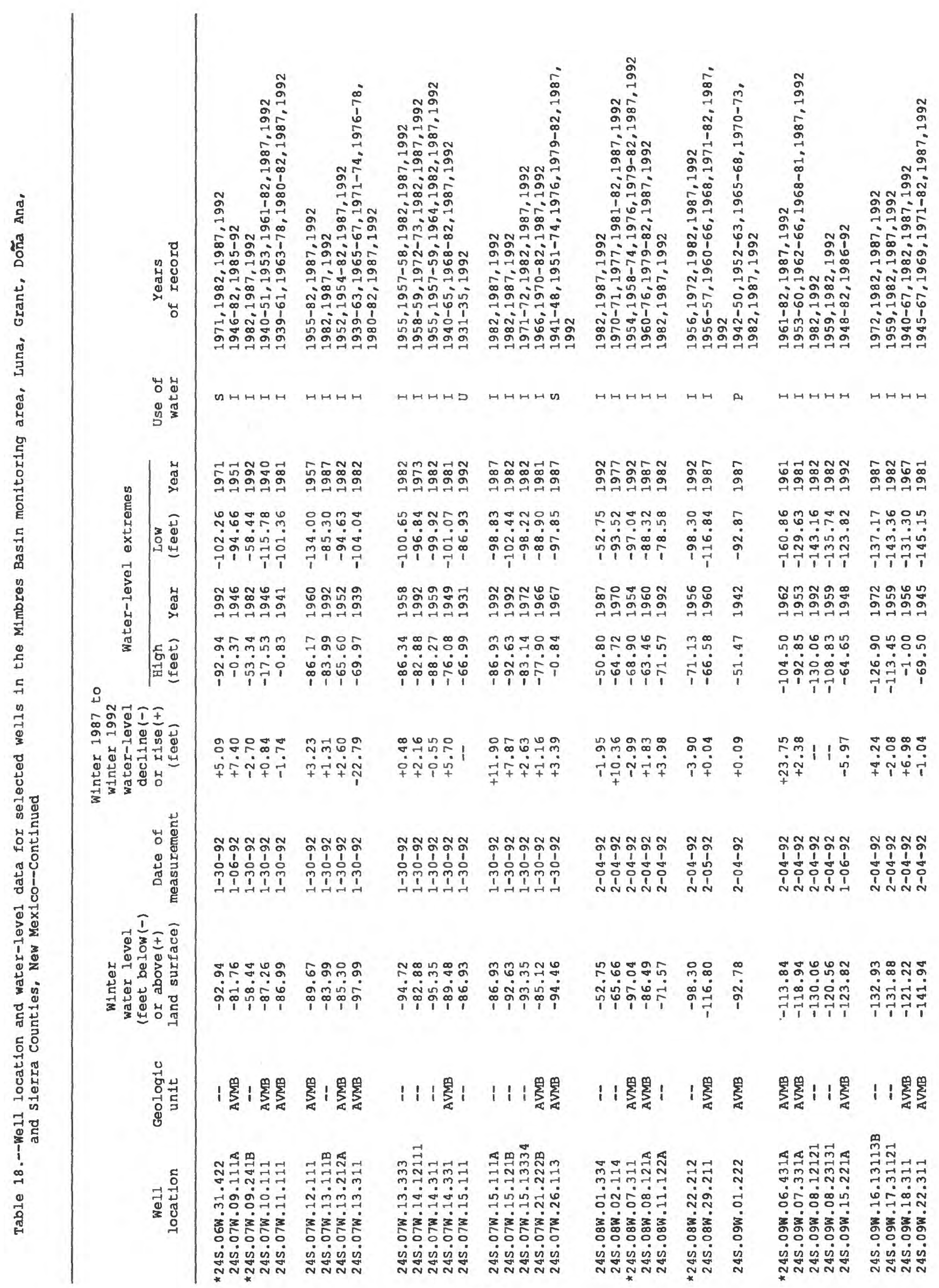




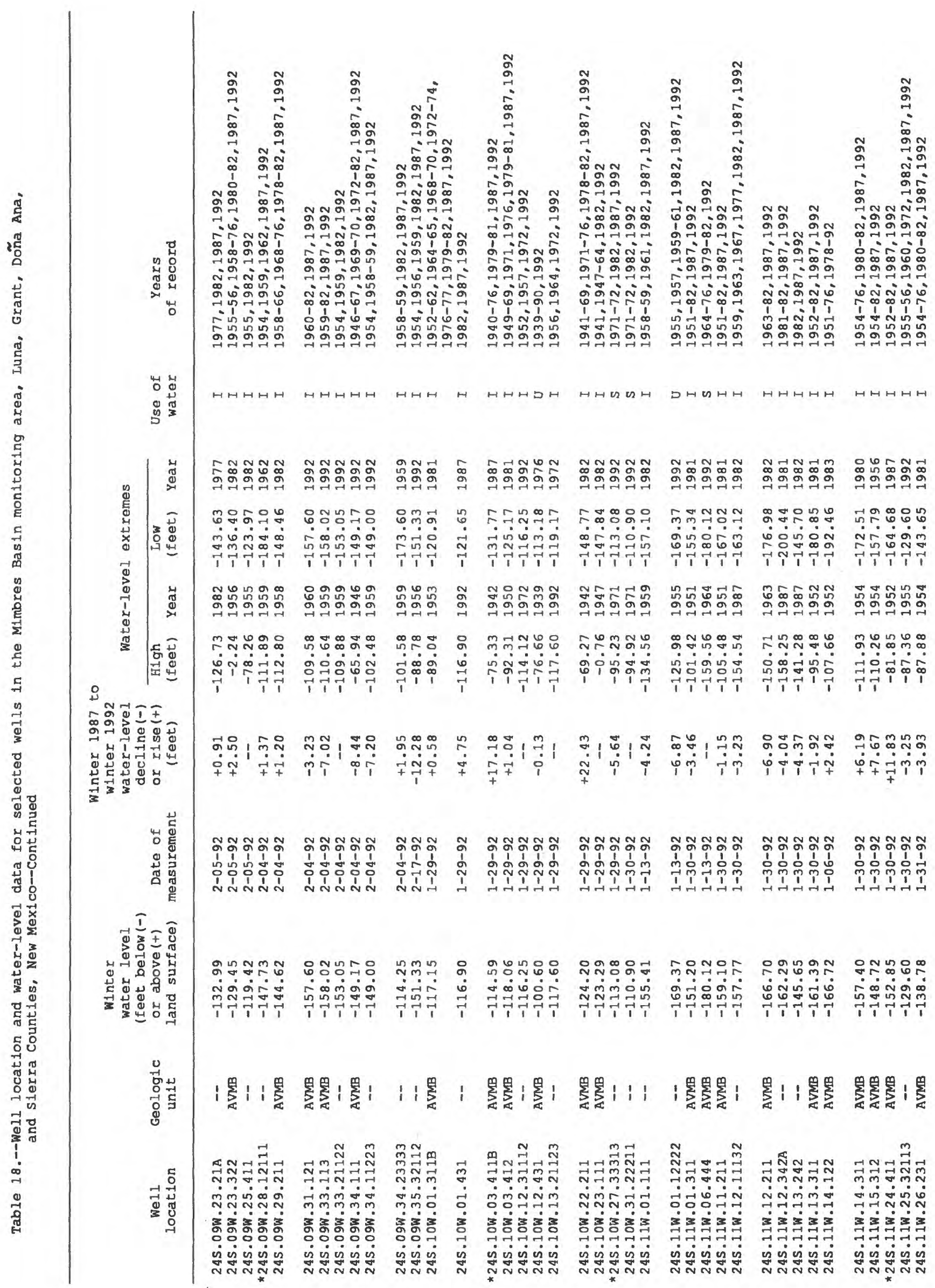




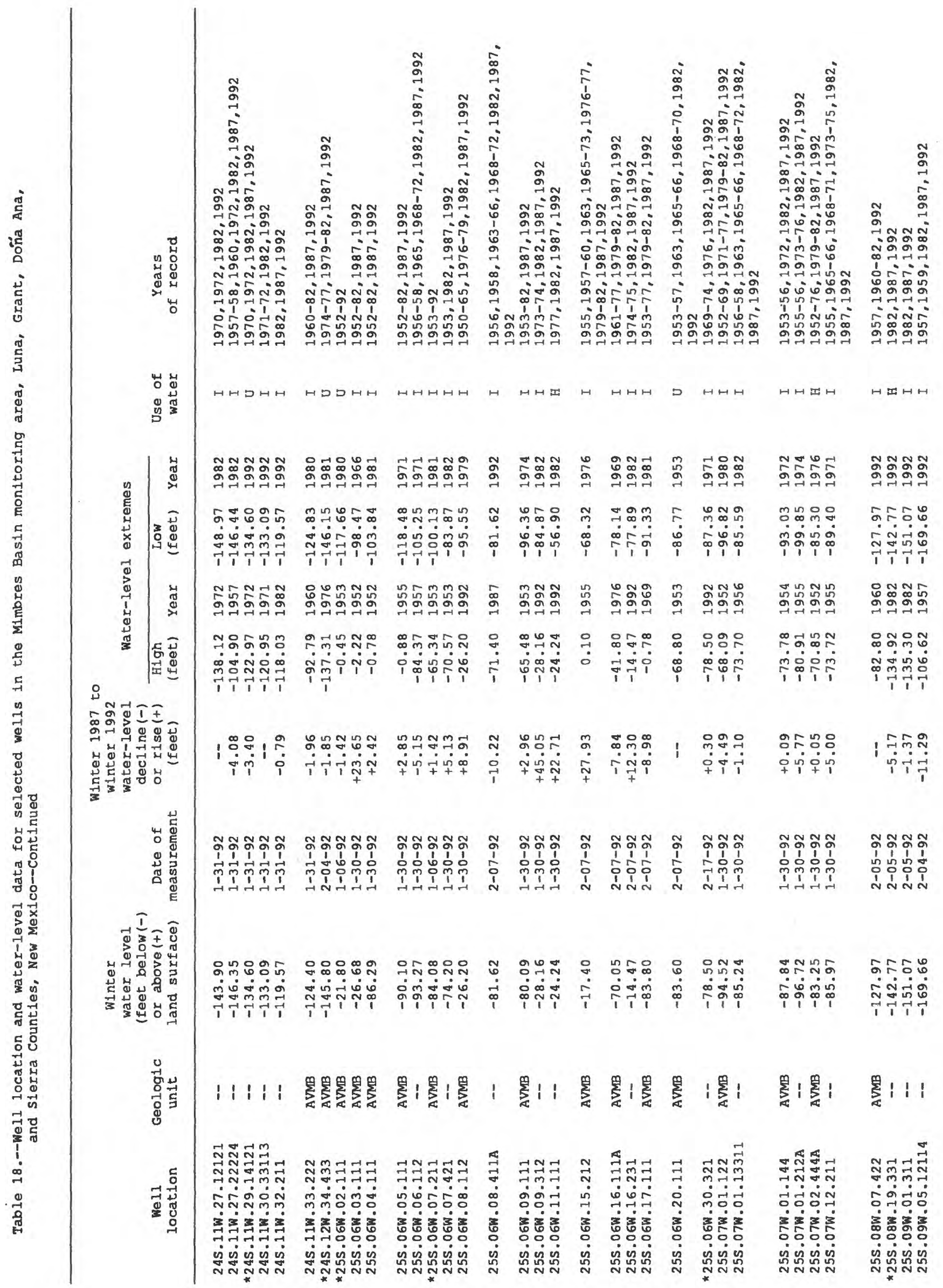


Land grants in Taos County were sectionized by extension of the Colorado land-grid system into New Mexico. Within the Sangre de Cristo Grant, townships south of the State line have been designated T. 1 S. and T. 2 S., whereas townships north of the State line are designated T. 1 N., T.2 N., and so on.

\section{GROUND-WATER-MONITORING DATA}

The ground-water-level monitoring program in New Mexico has two components. Selected wells are equipped with continuous water-level recorders. Data from these wells furnish information about daily and seasonal changes in the water levels. Every 5 years water levels in selected wells in each of the monitoring areas are measured. These data are used to compute the 5-year water-level changes in that particular area and to document long-term trends of water levels.

\section{Continuous Water-Level Data}

Locations of wells equipped with continuous recorders, the geologic unit that is the primary water-yielding unit to the well, and the years of record are listed in table 1. Hydrographs of water levels for these wells are shown in figure 4. Some continuous recorders have been in operation for 52 years, whereas others have only been equipped with recorders for 11 years. The hydrographs show either the entire period of record or, if the record exceeds 20 years, the latest 20-year period. Some wells have not had recorders installed for the entire period of record. Measurements made other than with recorders have been included in the hydrographs to present long-term ground-water-level trends.

\section{Five-Year Ground-Water-Level Changes}

Thirty-four areas have been designated for ground-water-level monitoring (fig. 1) on a 5year schedule. Each area was selected because it corresponds roughly to a New Mexico State Engineer designated ground-water basin or is in an area of significant ground-water withdrawals. All measurements in this report are given in feet below or above land surface at the well. Tables of ground-water data are provided for each monitoring area. Included in these tables are well location; geologic unit, which is the primary water-yielding unit for the well; the most recent instantaneous water level measured during 1984 through 1993 and the date of measurement; change in ground-water level during the most recent 5-year period; highest and lowest static water level ever measured in each well and the year of that measurement; use of water withdrawn from the well; and years water-level data were collected for each well.

Several areas have a large amount of data and all data points and associated ground-waterlevel changes could not be plotted on the map because of size limitations. For these areas a computer program was developed to thin the data presented on the map by selecting well locations and water-level changes at specified distance to be representative of water-level changes in the area. All data, however, are presented in the tables. Wells and ground-water-level changes that were plotted on maps are marked with an asterisk $\left(^{*}\right)$ in the tables. 


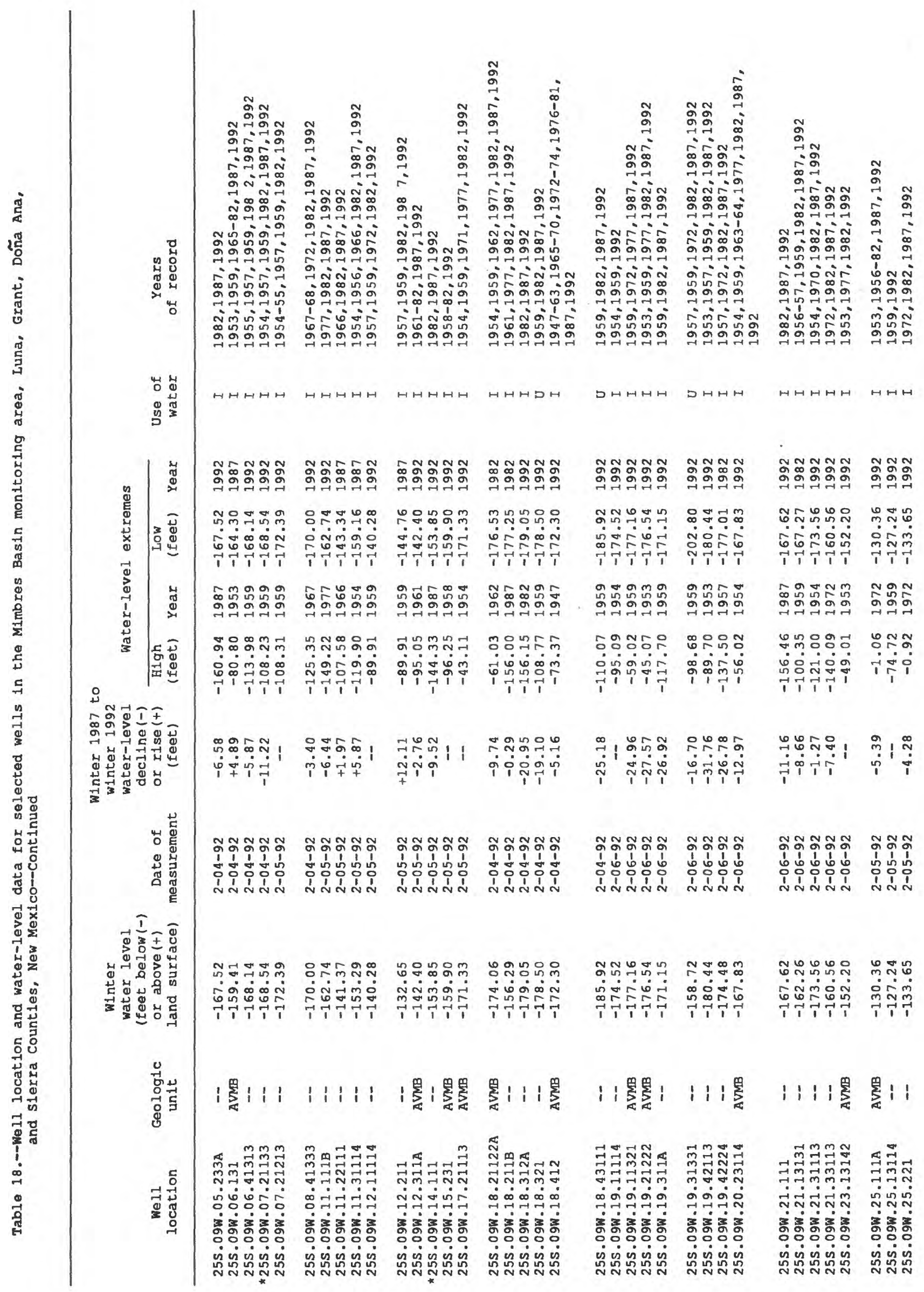




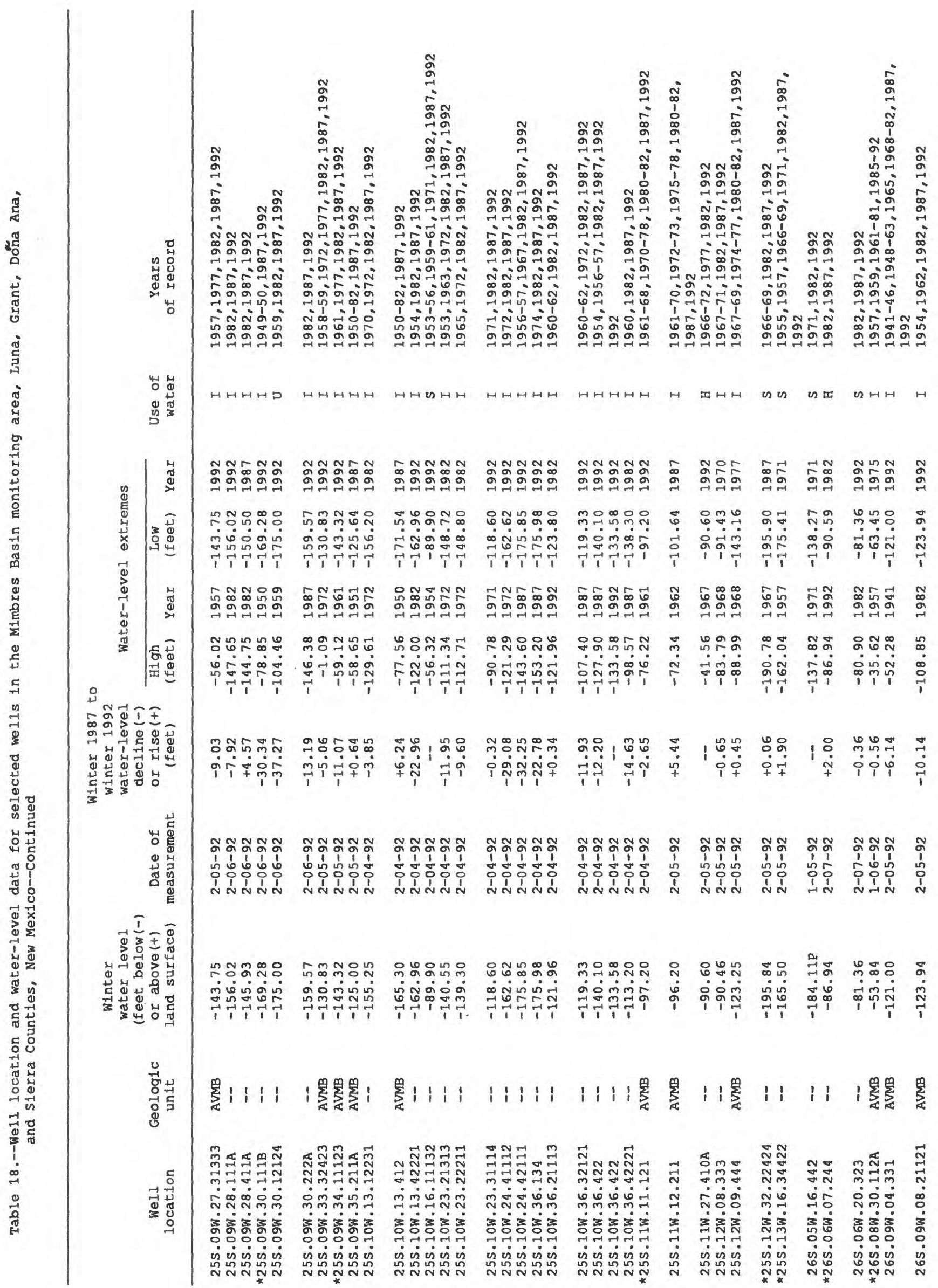




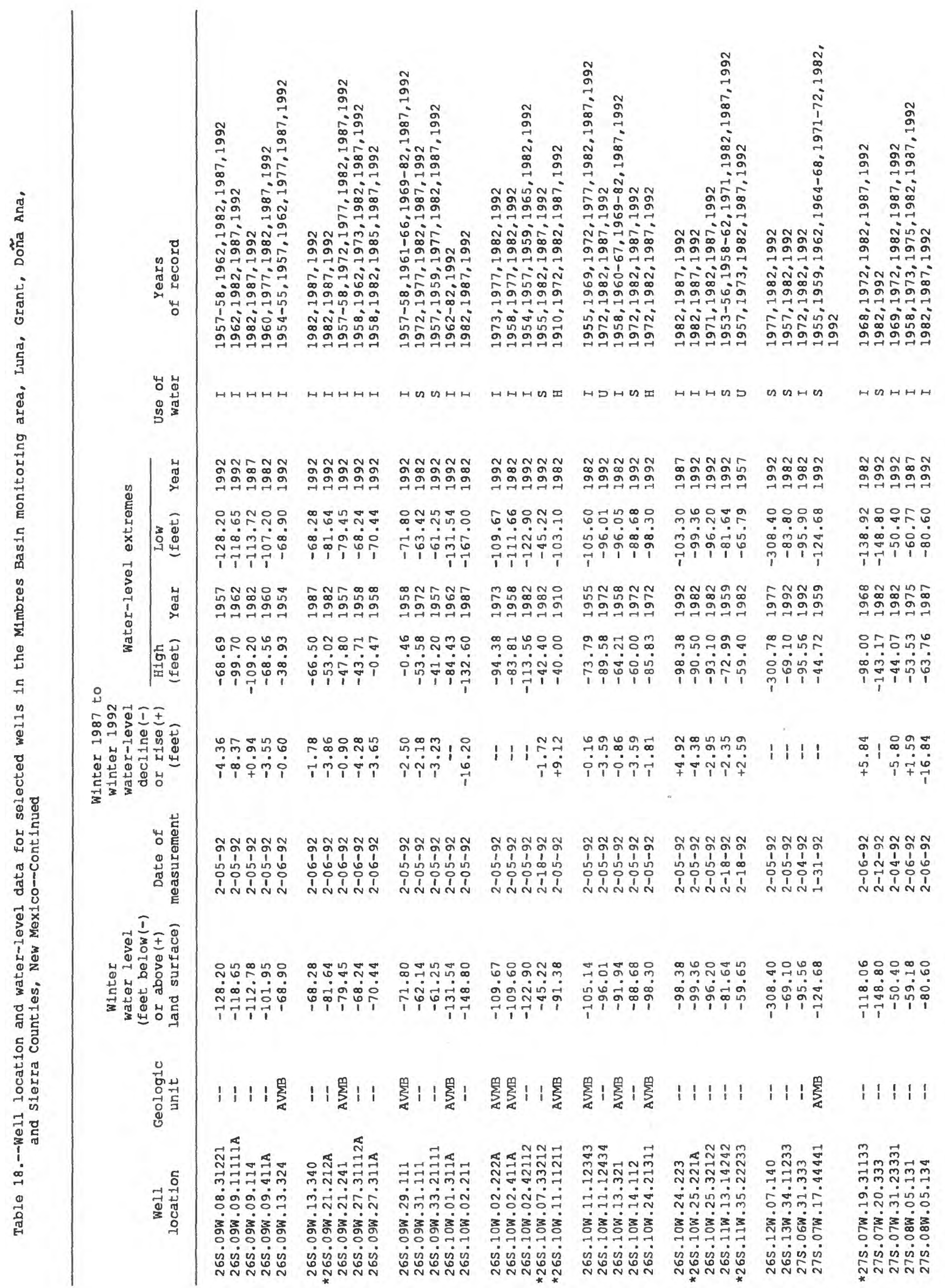




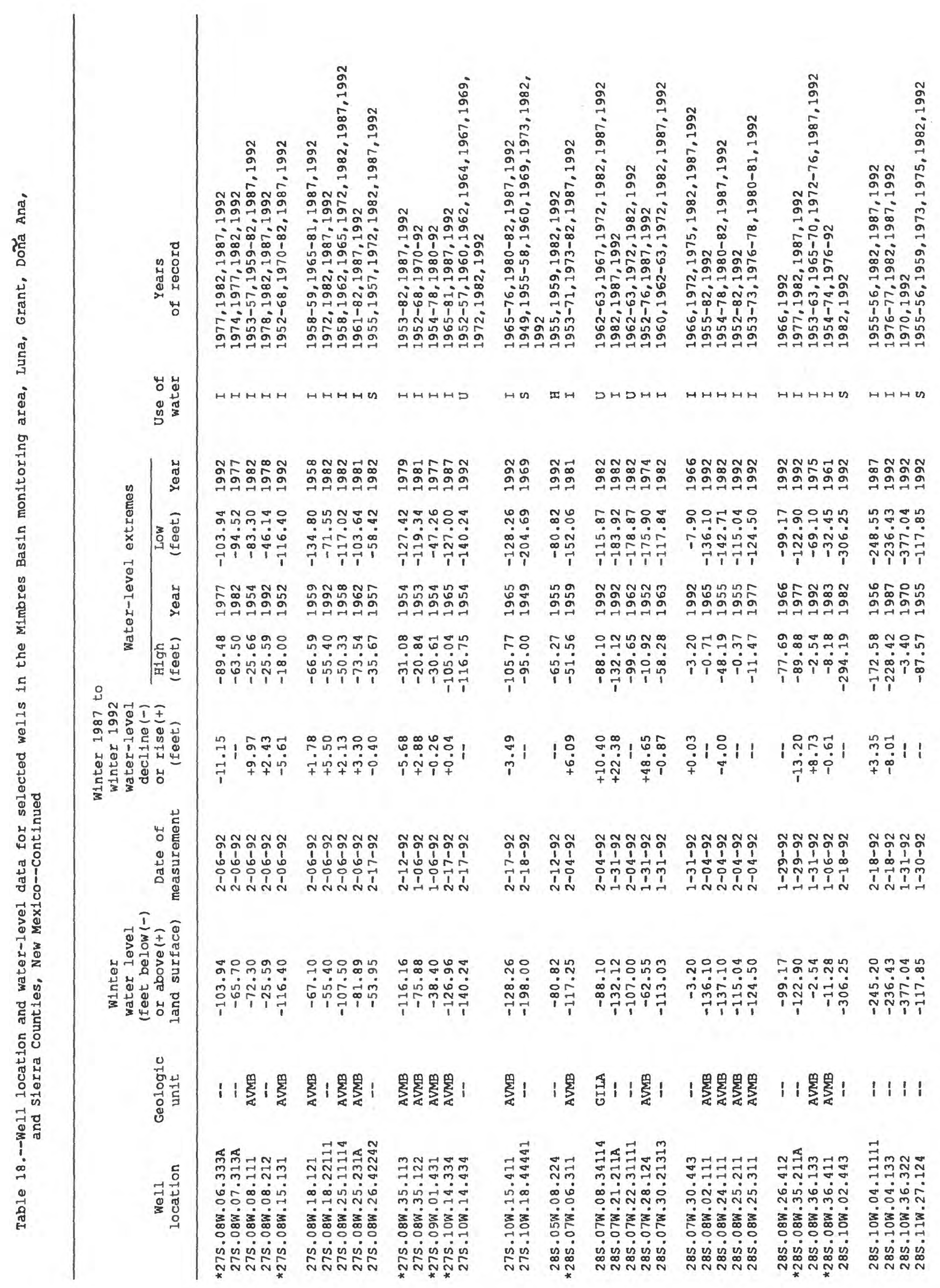




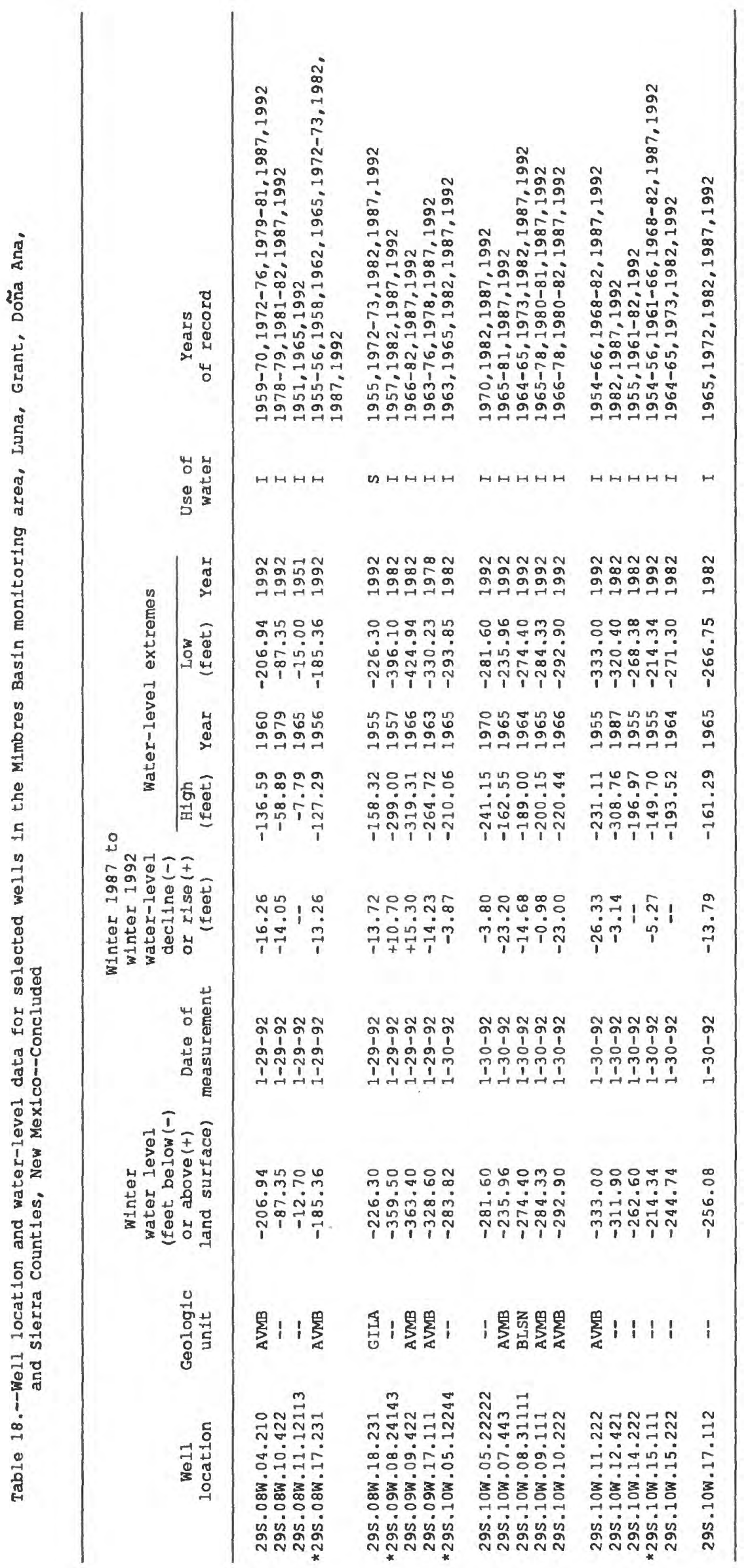




\section{Mora Monitoring Area}

The Mora monitoring area is in Mora and San Miguel Counties and the very southwestern part of Colfax County. Declines range from less than 1 foot to more than 10 feet. Rises range from less than 1 foot to more than 2 feet. 


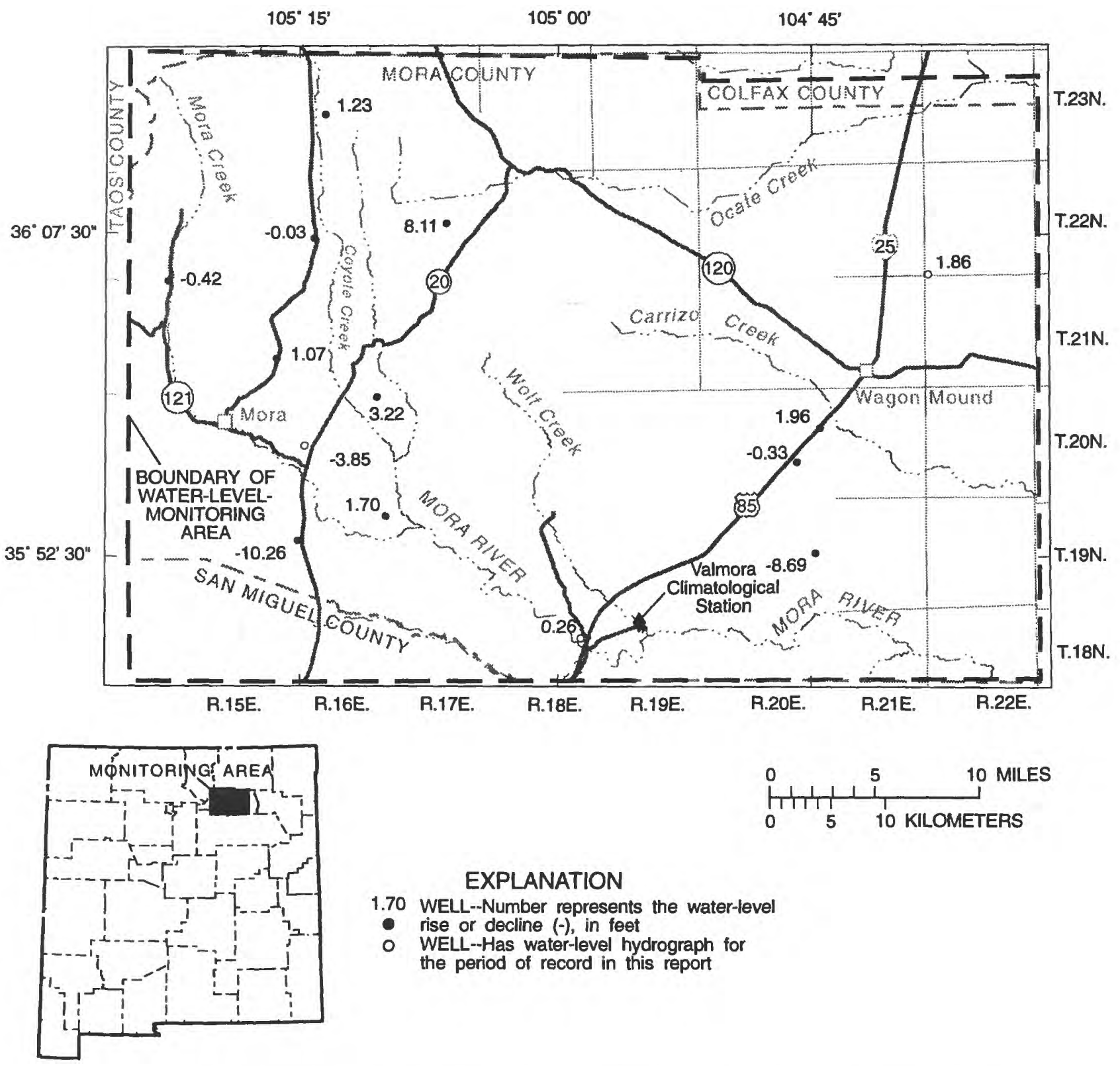

Figure 39.--Water-level changes for wells in the Mora monitoring area, 1987-92. 

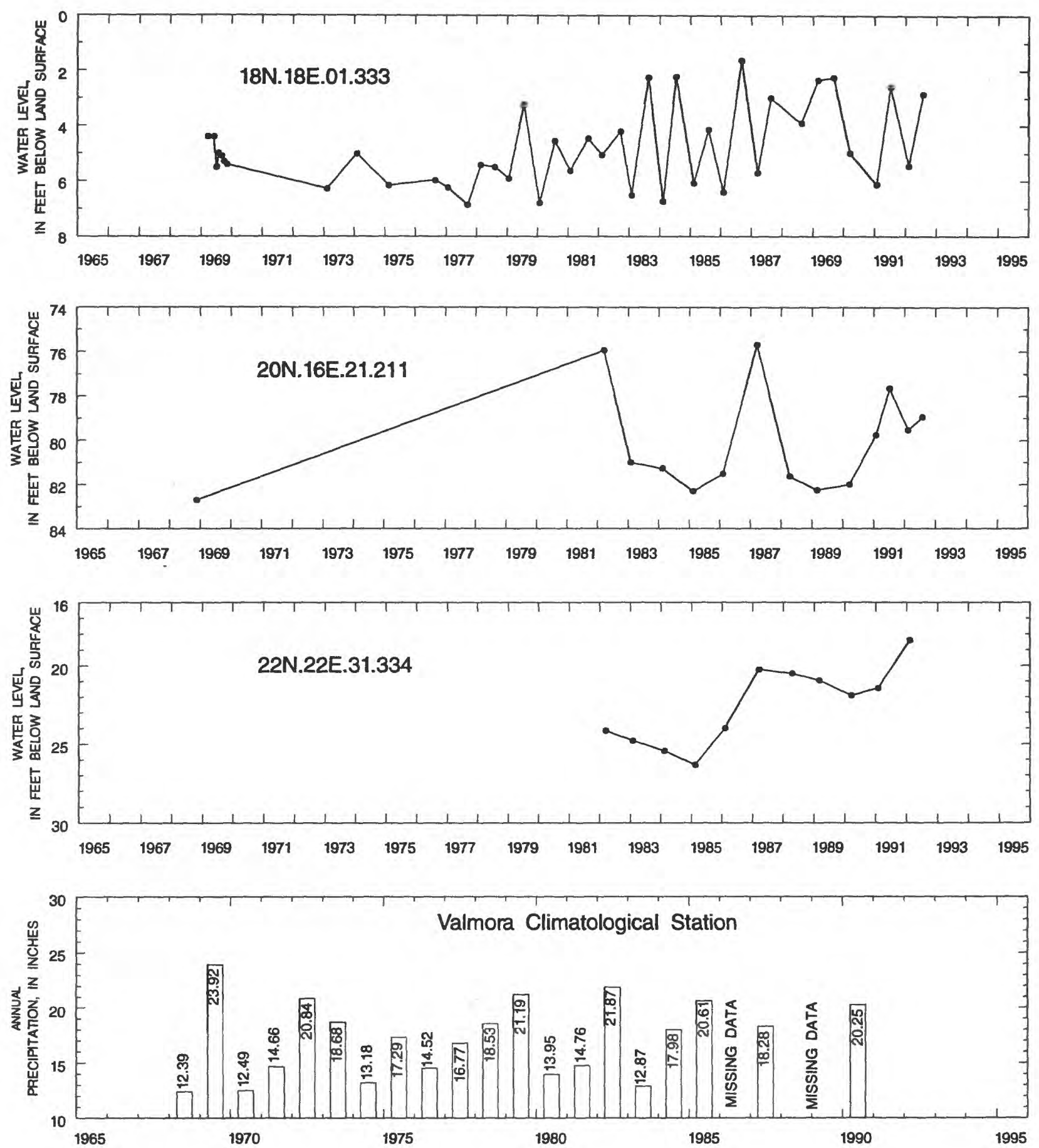

Figure 40.--Water-level data for selected wells in the Mora monitoring area and annual precipitation at the Valmora Climatological Station. See figure 39 for location of wells and station. 


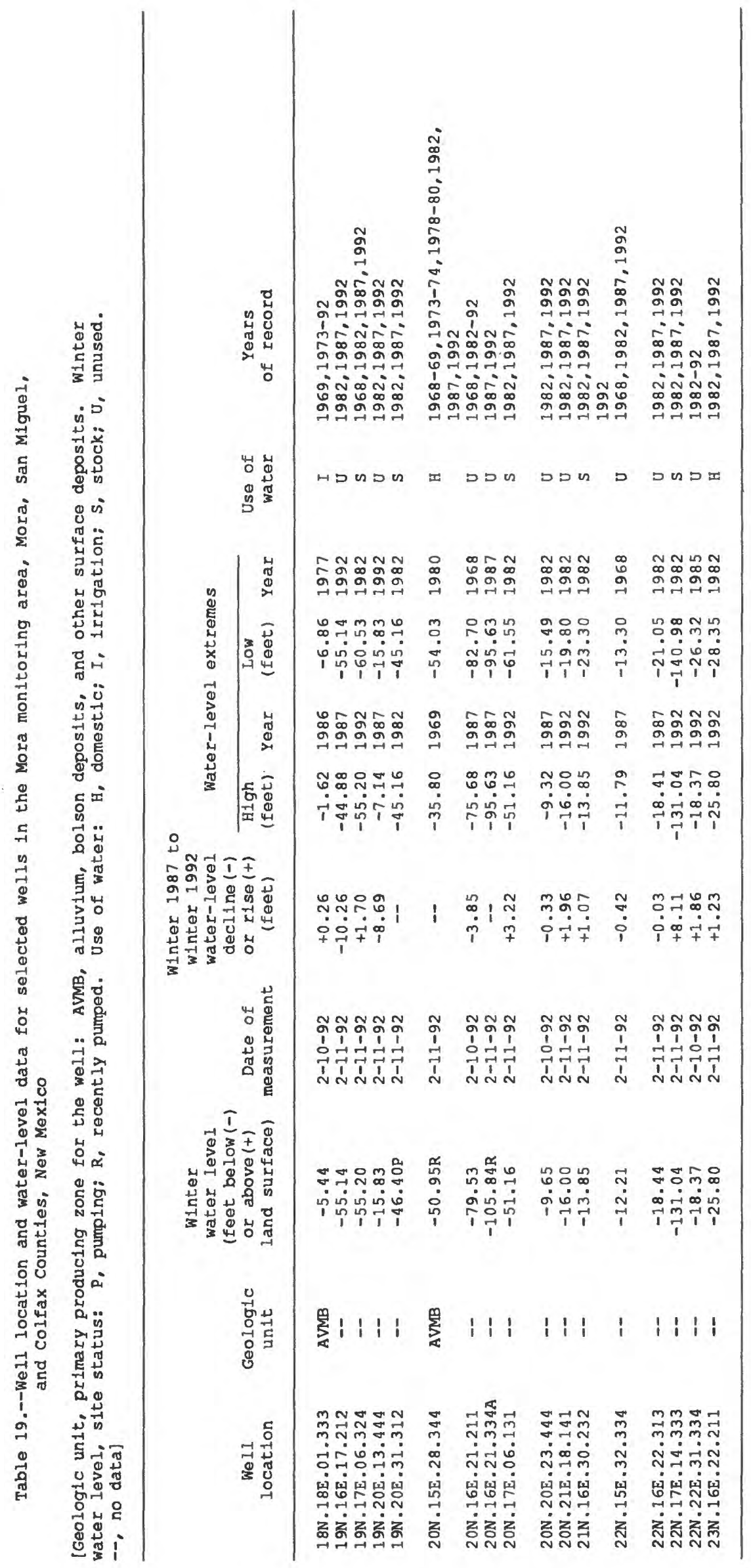




\section{Nutt-Hockett Monitoring Area}

The Nutt-Hockett monitoring area is in Doña Ana, Luna, and Sierra Counties in southern New Mexico. All changes are declines ranging from less than 4 feet to more than 28 feet. 
Table 1.--Well location and water-level data

for wells equipped with continuous

water-level recorders

[Geologic unit: primary water-yielding unit for the well. AVMB, alluvium, bolson deposits, and other surface deposits; CPTN, Capitan Limestone; GILA, Gila Conglomerate (Group);

OGLL, Ogallala Eormation; SADR, San Andres Ilmestone; SNRS, Santa

Rosa Sandstone; SNTF, Santa Fe Group; TSUQ, Tesuque Formation, undifferentiated unit]

\begin{tabular}{|c|c|c|c|}
\hline $\begin{array}{l}\text { Map } \\
\text { number } \\
\text { (fig. 2) }\end{array}$ & $\begin{array}{l}\text { Well } \\
\text { location }\end{array}$ & $\begin{array}{l}\text { Geologic } \\
\text { unit }\end{array}$ & $\begin{array}{c}\text { Years } \\
\text { of record }\end{array}$ \\
\hline 1 & $015.74 W .24 .244$ & AVMB & 1955 \\
\hline 2 & $24 \mathrm{~N} .36 \mathrm{E} .17 .244$ & OGLI & $1968-93$ \\
\hline 3 & $16 \mathrm{~N} .08 \mathrm{E} .26 .32112$ & TSUQ & $1973-93$ \\
\hline 4 & $10 \mathrm{~N} .20 \mathrm{E} .28 .2241$ & SADR & $1979-93$ \\
\hline 5 & $10 N .03 E .32 .314$ & SNTF & $1982-93$ \\
\hline 6 & $05 \mathrm{~N} .25 \mathrm{E} .34 .232220$ & SNRS & $1971-93$ \\
\hline 7 & $04 \mathrm{~N} .32 \mathrm{E} .22 .111114$ & OGLL & $1980-93$ \\
\hline 8 & 01N.37E.15.13311 & OGLL & $1954-93$ \\
\hline 9 & 01S.33E.36.23111 & AVMB & $1952-93$ \\
\hline 10 & $02 S .36 \mathrm{E} .14 .311111$ & AVMB & $1975-93$ \\
\hline 11 & 11S.32E.24.113222 & OGLI & $1977-93$ \\
\hline 12 & $12 \mathrm{~S} .25 \mathrm{E} .23 .344234 \mathrm{~A}$ & AVMB & $1966-93$ \\
\hline 13 & 12S.25E.23.344412 & SADR & $1964-93$ \\
\hline 14 & $15 \mathrm{~S} .24 \mathrm{E} .25 .433331$ & SADR & $1967-93$ \\
\hline 15 & $16 \mathrm{~S} .36 \mathrm{E} .04 .32232$ & OGLL & $1971-93$ \\
\hline 16 & $18 \mathrm{~S} .15 \mathrm{~W} .11 .323$ & GILA & $1945-93$ \\
\hline 17 & $18 \mathrm{~S} .26 \mathrm{E} .06 .442221 \mathrm{~A}$ & SADR & $1961-93$ \\
\hline 18 & $18 S .26 \mathrm{E} .06 .442212 \mathrm{~B}$ & AVMB & $1963-93$ \\
\hline 19 & $21 \mathrm{~S} .26 \mathrm{E} .36 .22110$ & CPTN & $1962-93$ \\
\hline 20 & $21 \mathrm{~S} .28 \mathrm{E} \cdot 30.14123$ & CPTN & $1963-93$ \\
\hline 21 & $22 S .26 E .25 .333333$ & AVMB & $1942-93$ \\
\hline 22 & $23 S .25 E .24 .21433$ & CPTN & $1963-93$ \\
\hline
\end{tabular}




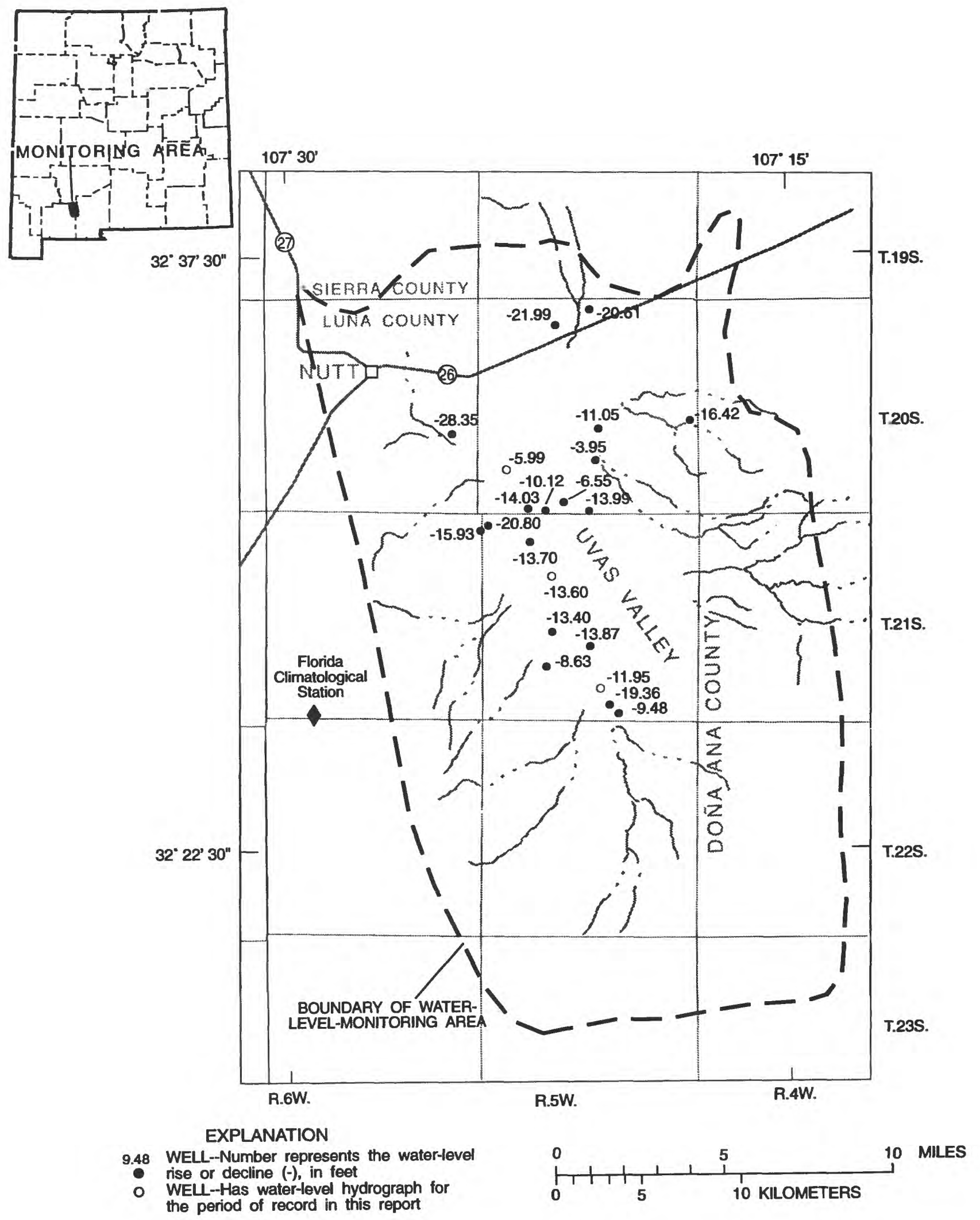

Figure 41.--Water-level changes for wells in the Nutt-Hockett monitoring area, 1987-92. 

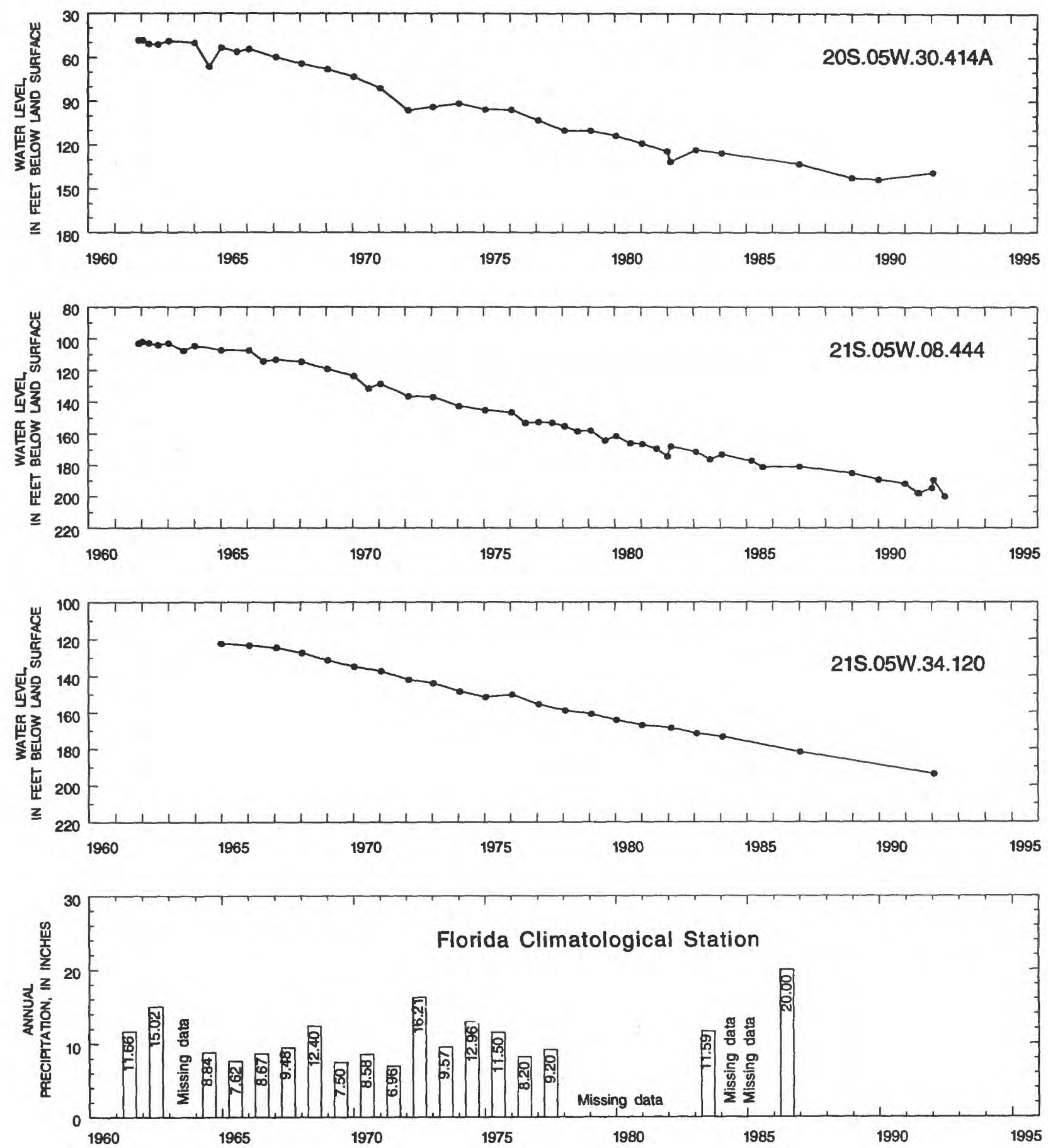

Figure 42.--Water-level data for selected wells in the Nutt-Hockett monitoring area and annual precipitation at the Florida Climatological Station. See figure 41 for location of wells and station. 


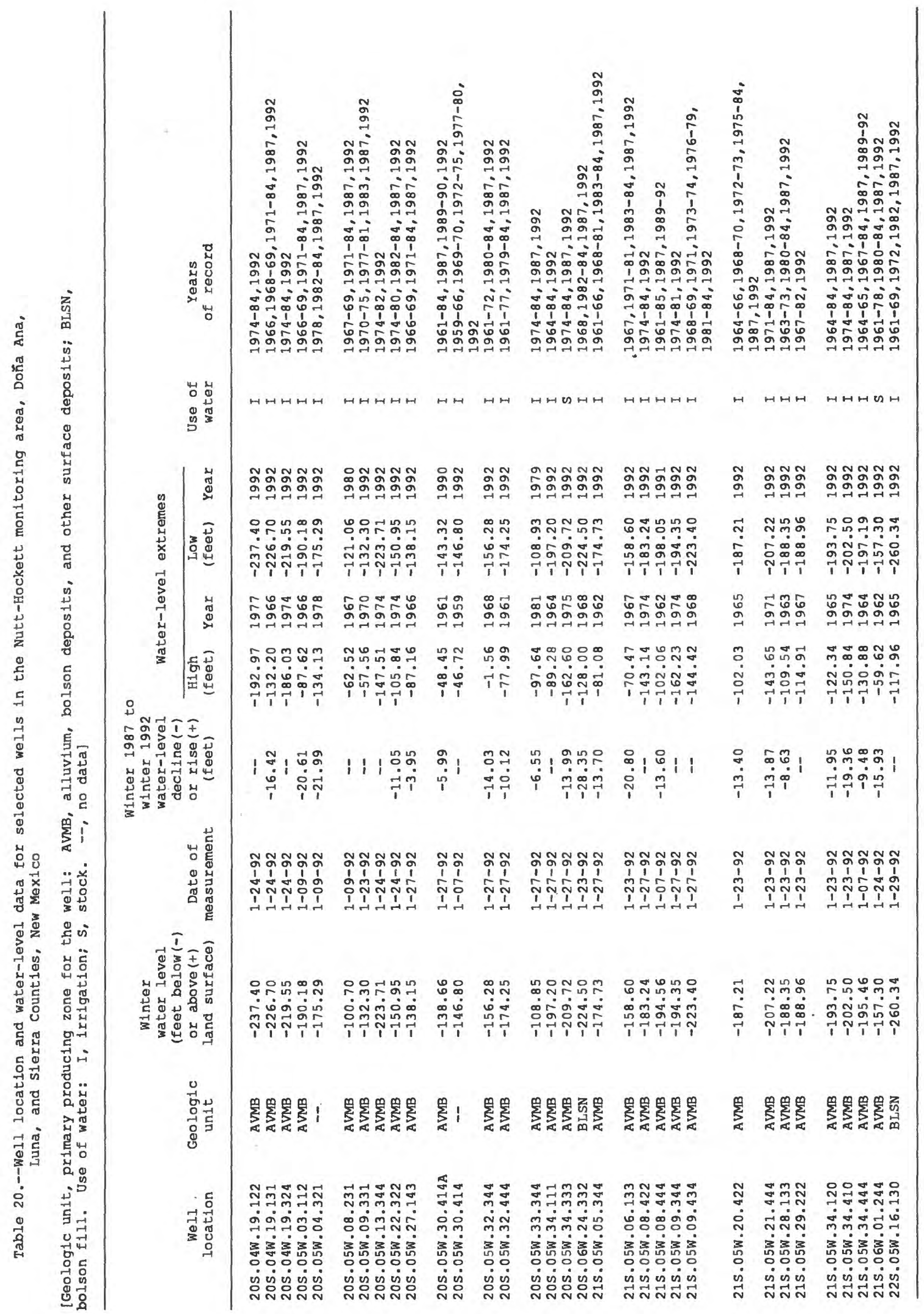




\section{San Juan Basin Monitoring Area}

The San Juan Basin monitoring area is in San Juan, McKinley, Rio Arriba, and Sandoval Counties, northwestern New Mexico. Depth-to-water data were first collected as part of the observation well program in 1992 and are presented. 


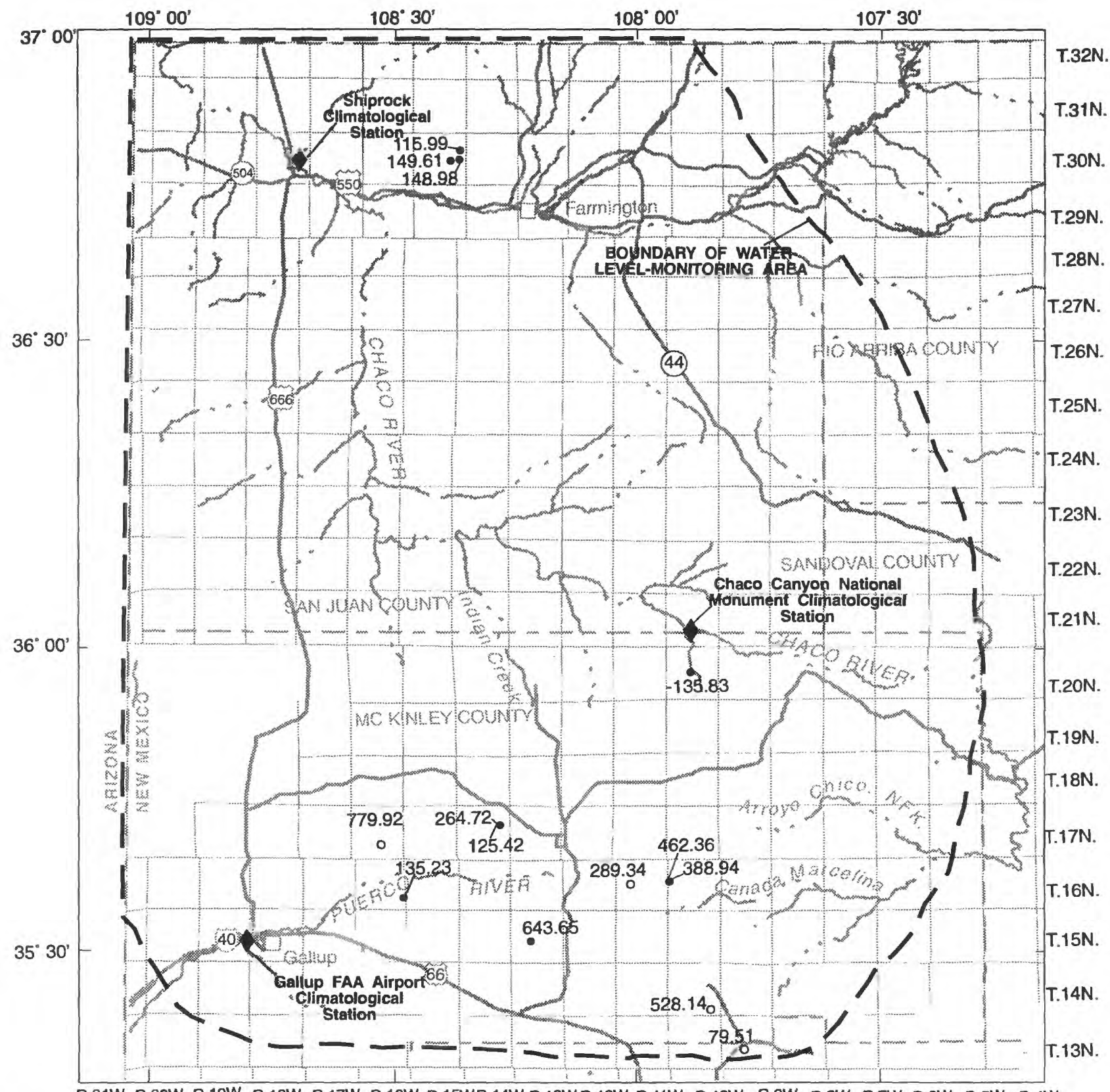

R.21W. R.20W. R.19W. R.18W. R.17W. R.16W. R.15WR.14W.R.13W.R.12W. R.11W. R.10W. R.9W. R.8W. R.7W. R.6W. R.5W. R.4W.

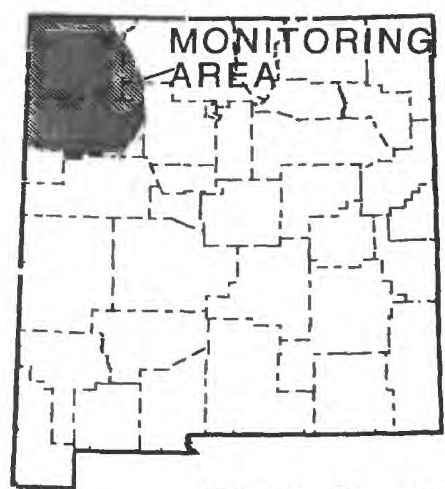

\section{EXPLANATION}

125.92 WELL-Number represents the water level

- below land surface, in feet

- WELL-Has water-level hydrograph for the period of record in this report

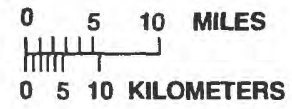

Figure 43.--Water levels for selected wells in the San Juan Basin monitoring area, 1992. 


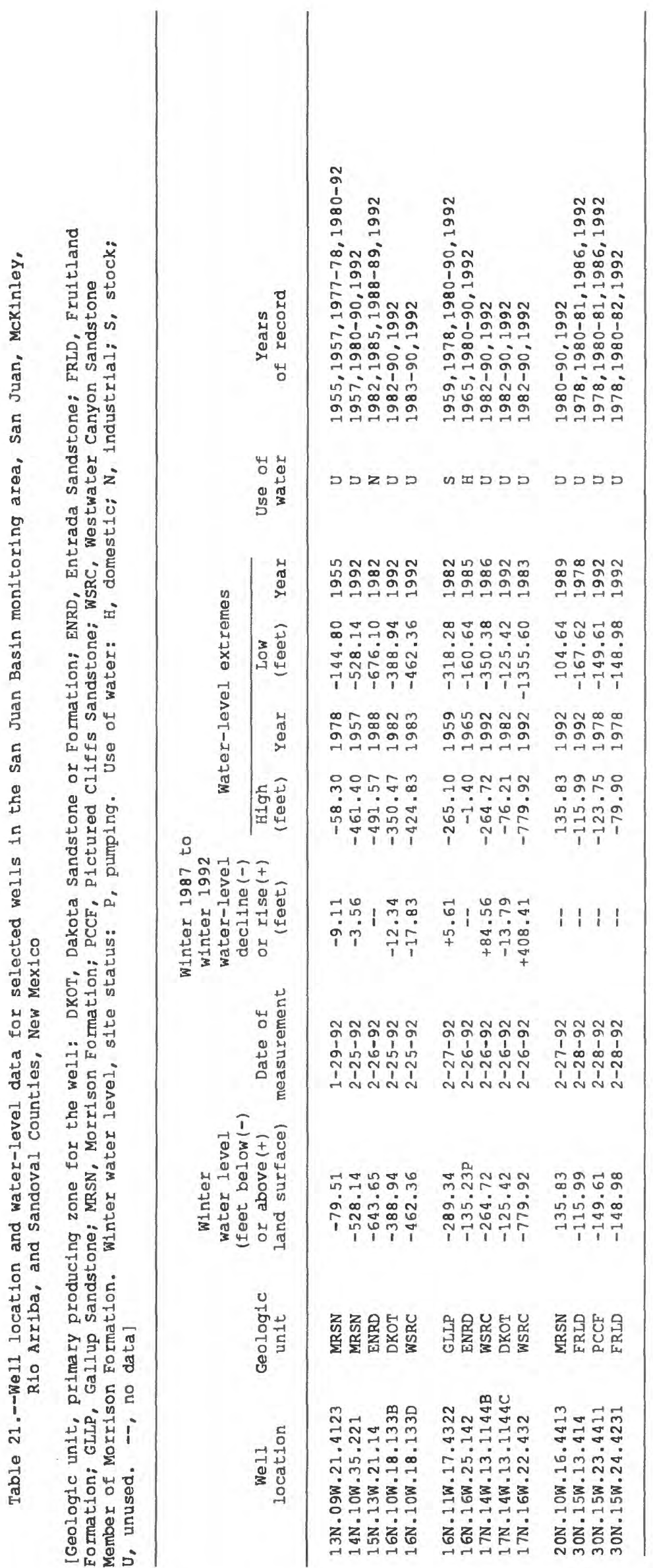




\section{Lower Canadian Monitoring Area}

The Lower Canadian monitoring area is in Quay County, east-central New Mexico. Not all water-level changes are shown on the map; however, all well locations and water-level data are listed in the table. Well locations marked with an asterisk $\left(^{*}\right)$ in the table are plotted on the map.

Water-level declines range from less than 1 to more than 7 feet. Water-level rises range from less than 1 foot to more than 20 feet. Water-level declines are located around the perimeter of the monitoring area and range from less than 1 foot to more than 7 feet. Data indicate rises in the central part of the monitoring area in a sinuous area from T. 17 N., R. 36 E. to Tps. 10 and 11 N., Rs. 29 through 36 E. Water-level rises range from less than 1 foot to more than 20 feet. 

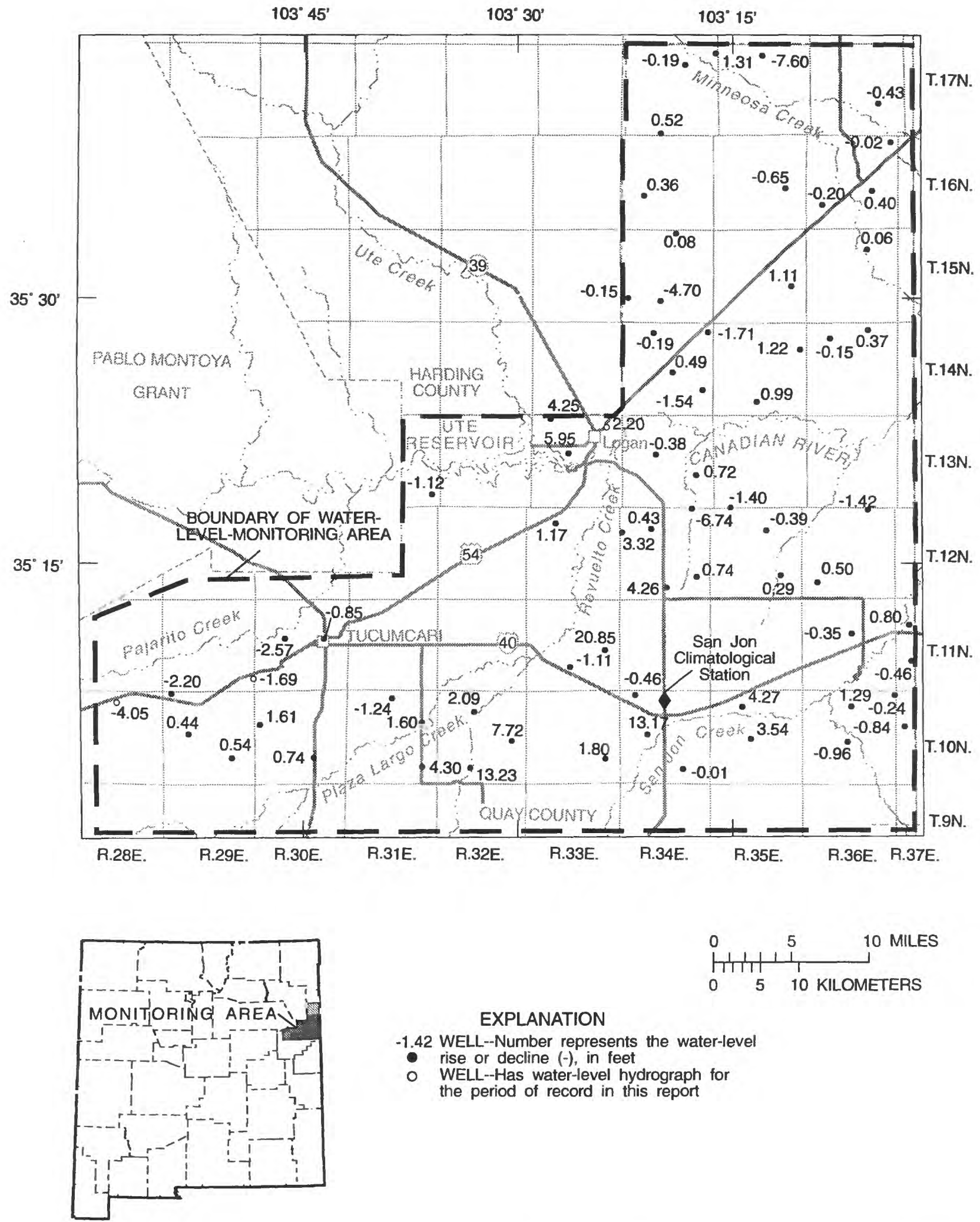

EXPLANATION

-1.42 WELL--Number represents the water-level

- rise or decline $(-)$, in feet

- WELL--Has water-level hydrograph for

the period of record in this report

Figure 45.--Water-level changes for selected wells in the Lower Canadian monitoring area, 1988-93. 

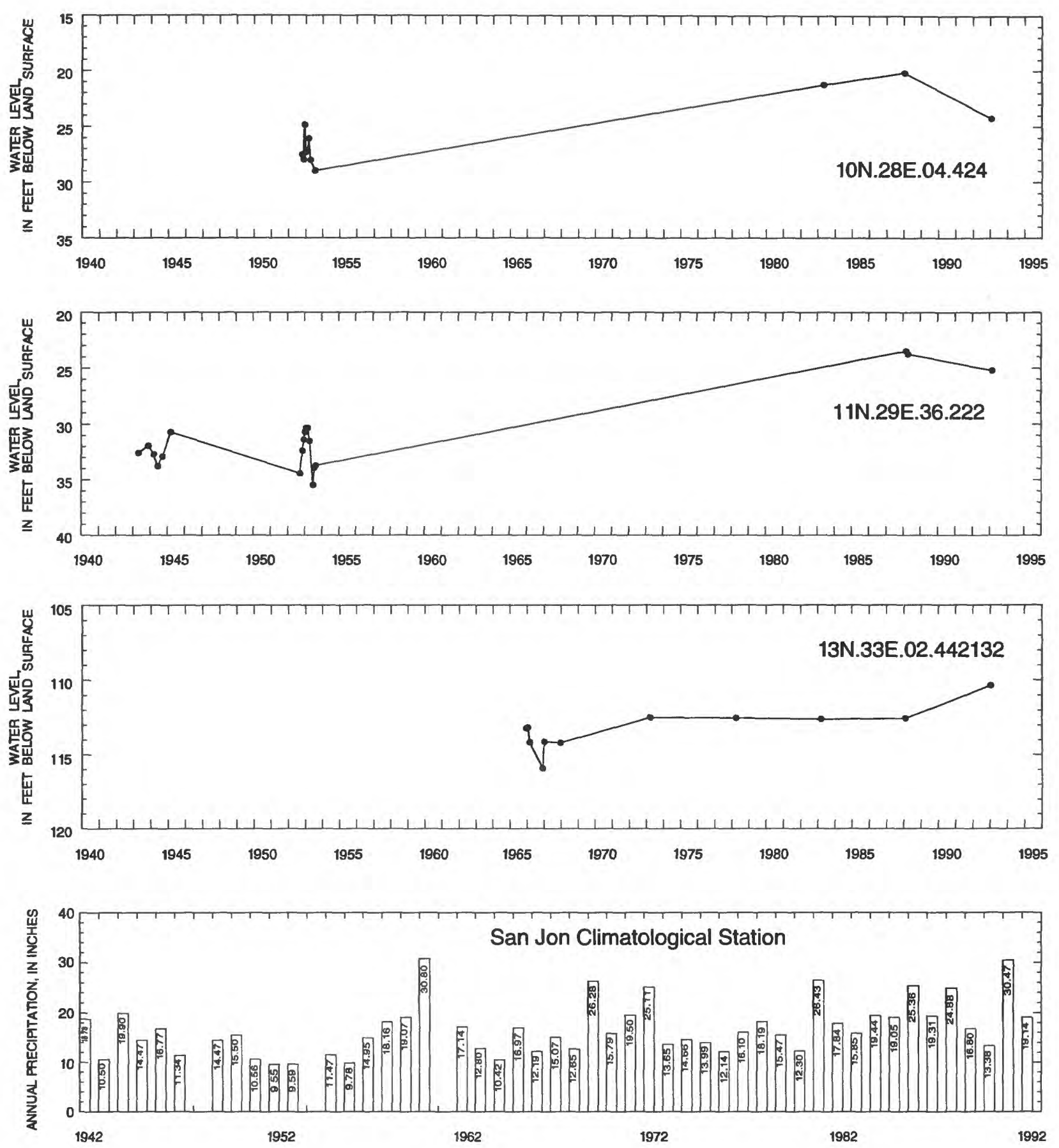

Figure 46.--Water-level data for selected wells in the Lower Canadian monitoring area and annual precipitation at the San Jon Climatological Station. See figure $\mathbf{4 5}$ for location of wells and station. 


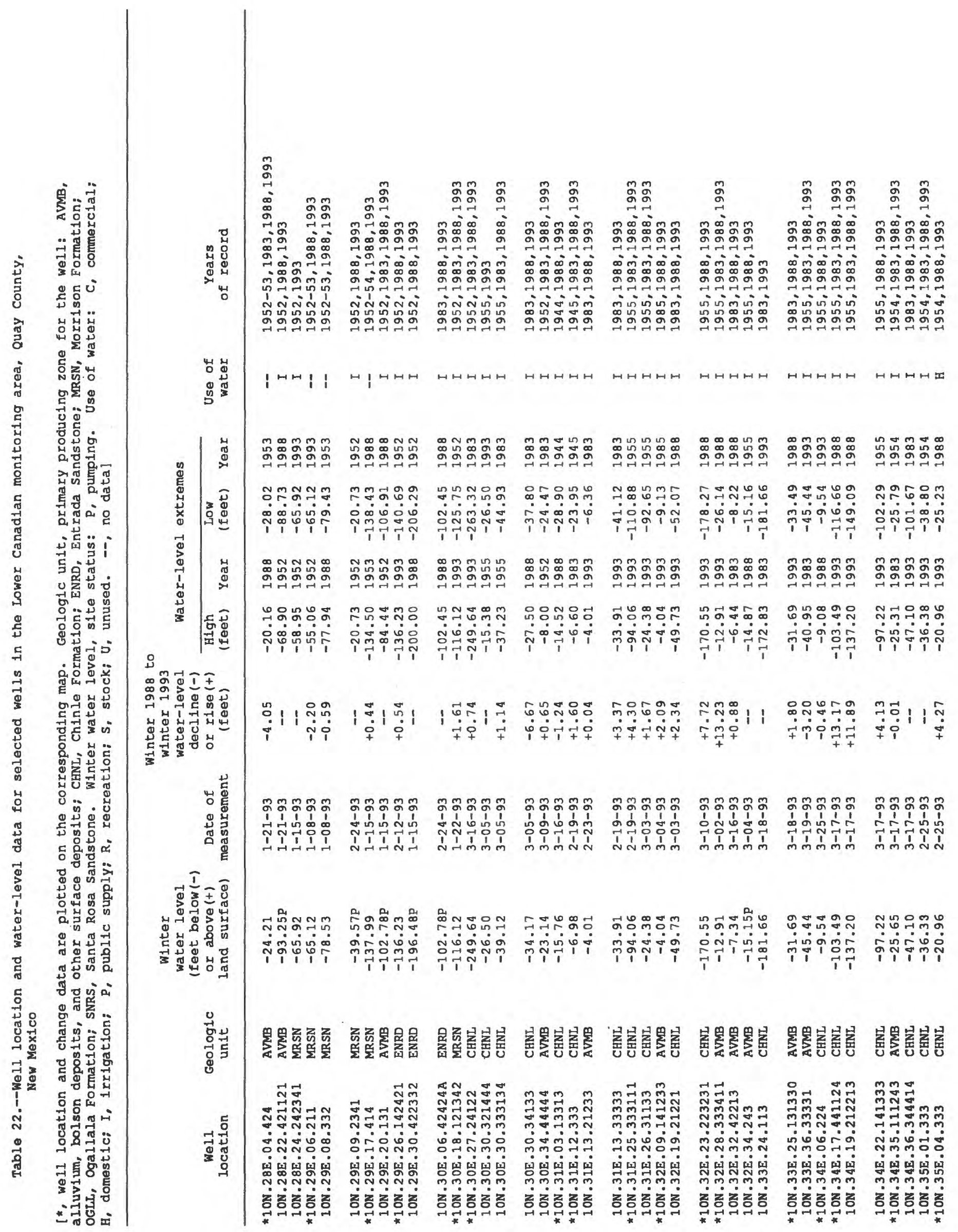



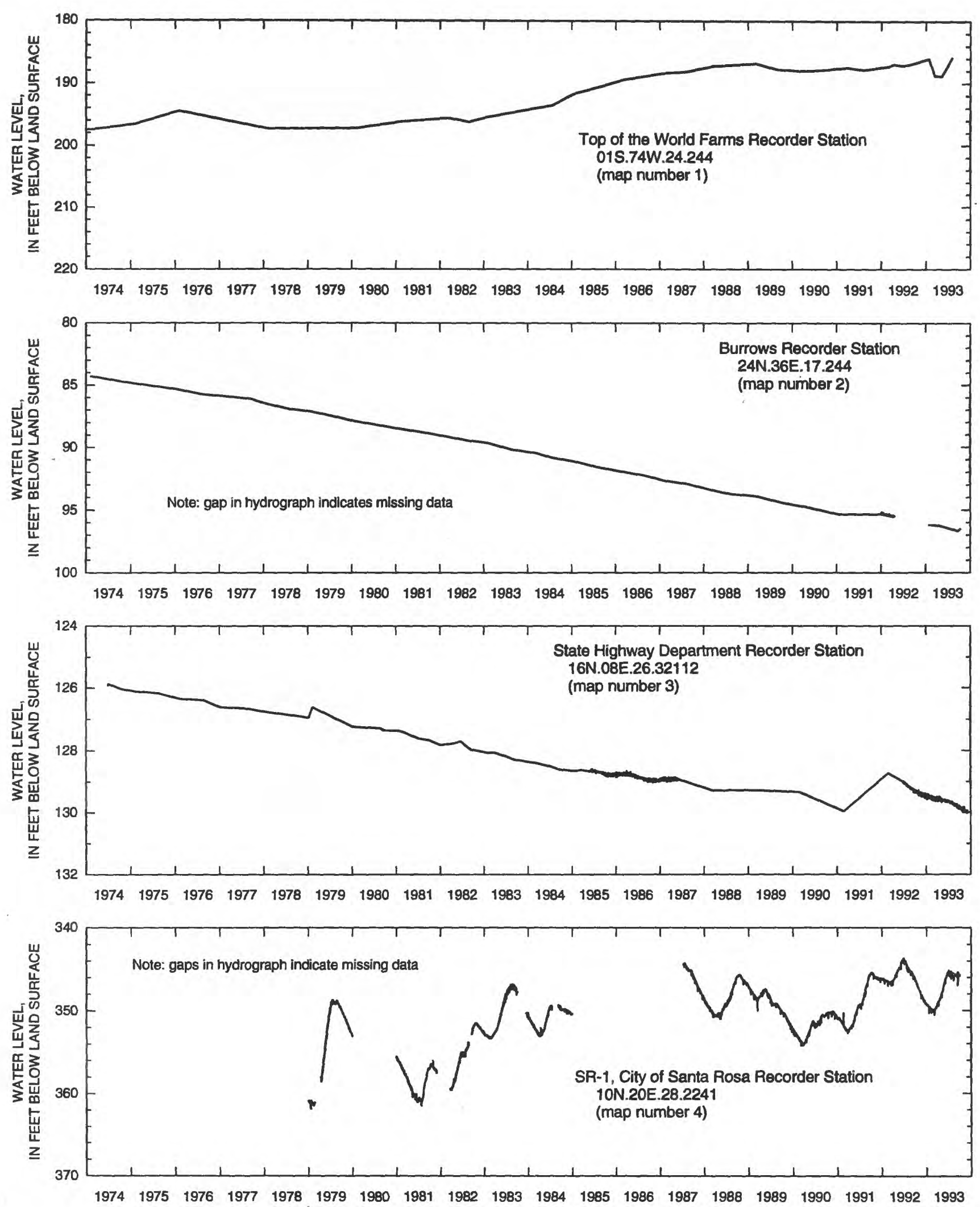

Figure 4.--Continuous water-level data for selected wells. See figure 2 and table 1 for locations. 


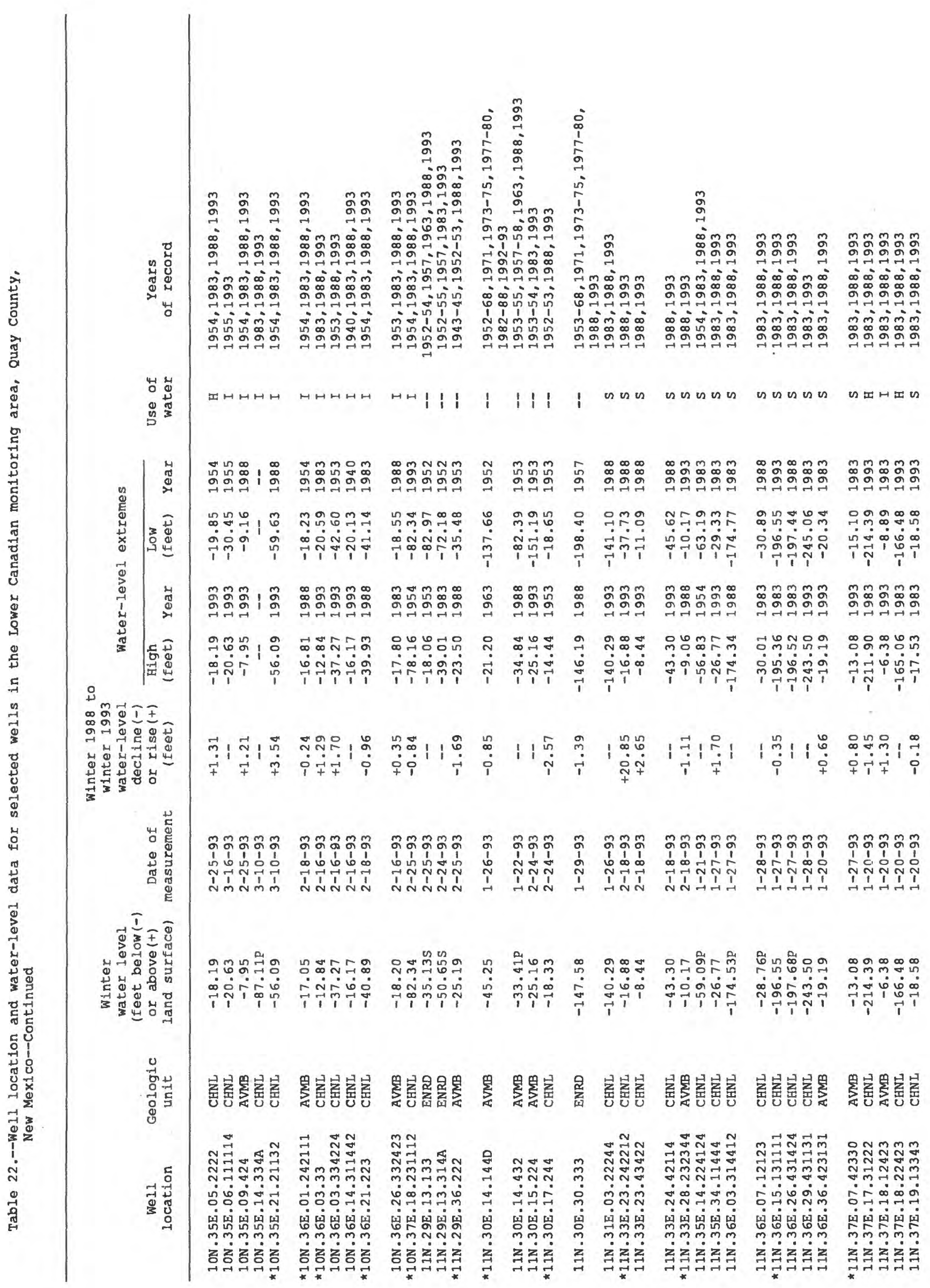




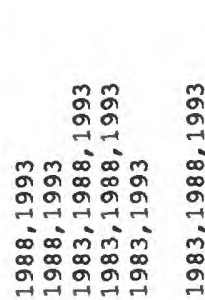

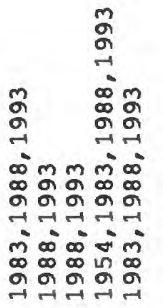

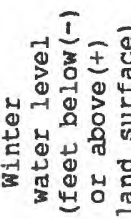

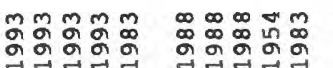

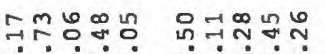

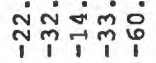

जिज्ञ

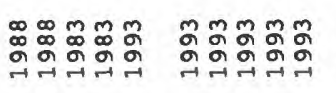

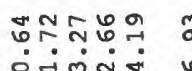

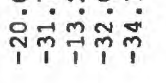

ตำㄴำㄴ?

पुंड़्र

|



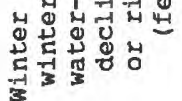

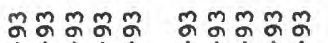

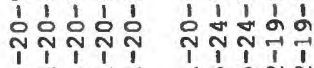

걱

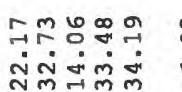
तैल क्ञ

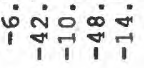

$\mapsto$ ロ $ロ$ 口

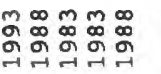

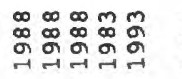

ที ํํำกุ

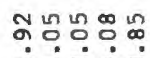

뮤ㄲㅠㅠำ

구궈ํํำ

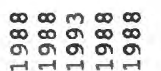

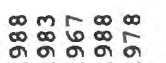

윤ㅉㅇㅇㅛ

ํํำ저

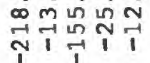

वर्षेत्ञ

혐구워

ํํำกำ응

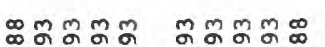

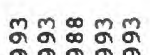

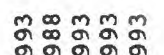

किक्ज

लिख्न

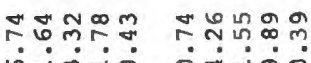

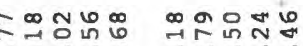

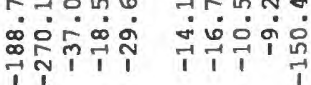

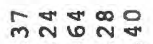

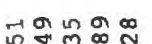

ถััํํำ

ถ้ํํำร

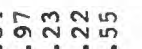

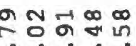

ज्ञ

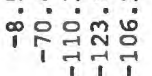

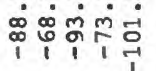

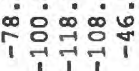

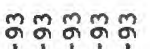

$\begin{aligned} & 1 \\ & 1 \\ & 1\end{aligned} \frac{1}{1} \frac{1}{1}=1$

ตั๊ ถูก

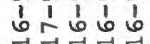

ตุ๊ิตร์ต

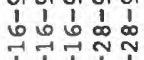

ตูตูตลำ

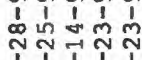

ลूกู๊ต

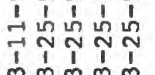

กำต

वरलna nana

กล⿻

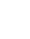

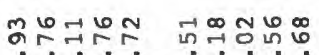

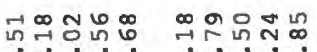

ติง ํํำำ

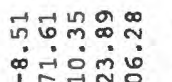

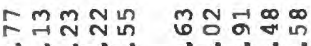

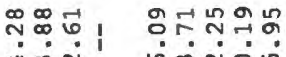

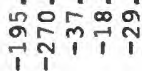

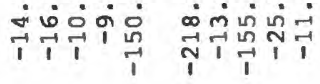

1जन्ने

की

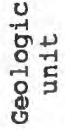

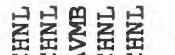

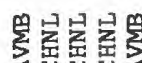

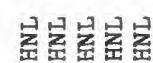

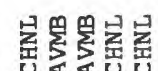

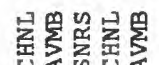

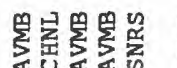

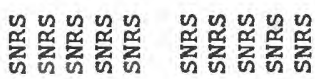

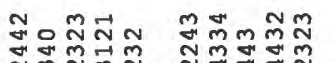

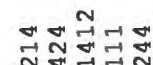

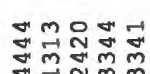

त्लmन्त

สNㅊำ

궈궉

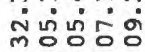

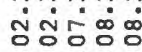

จิกิำกㄹ.

国舆国

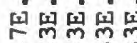

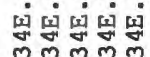

ฟન궈ำ

ज्ञलंखिं

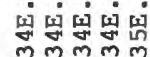

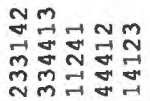

\section{政}

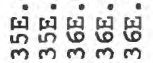

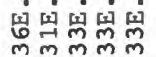

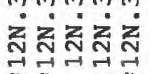

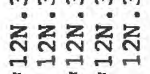

究总总总票

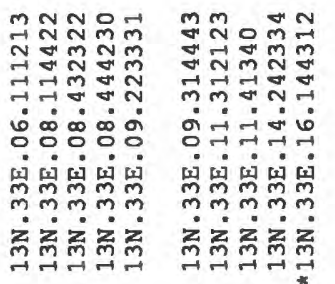




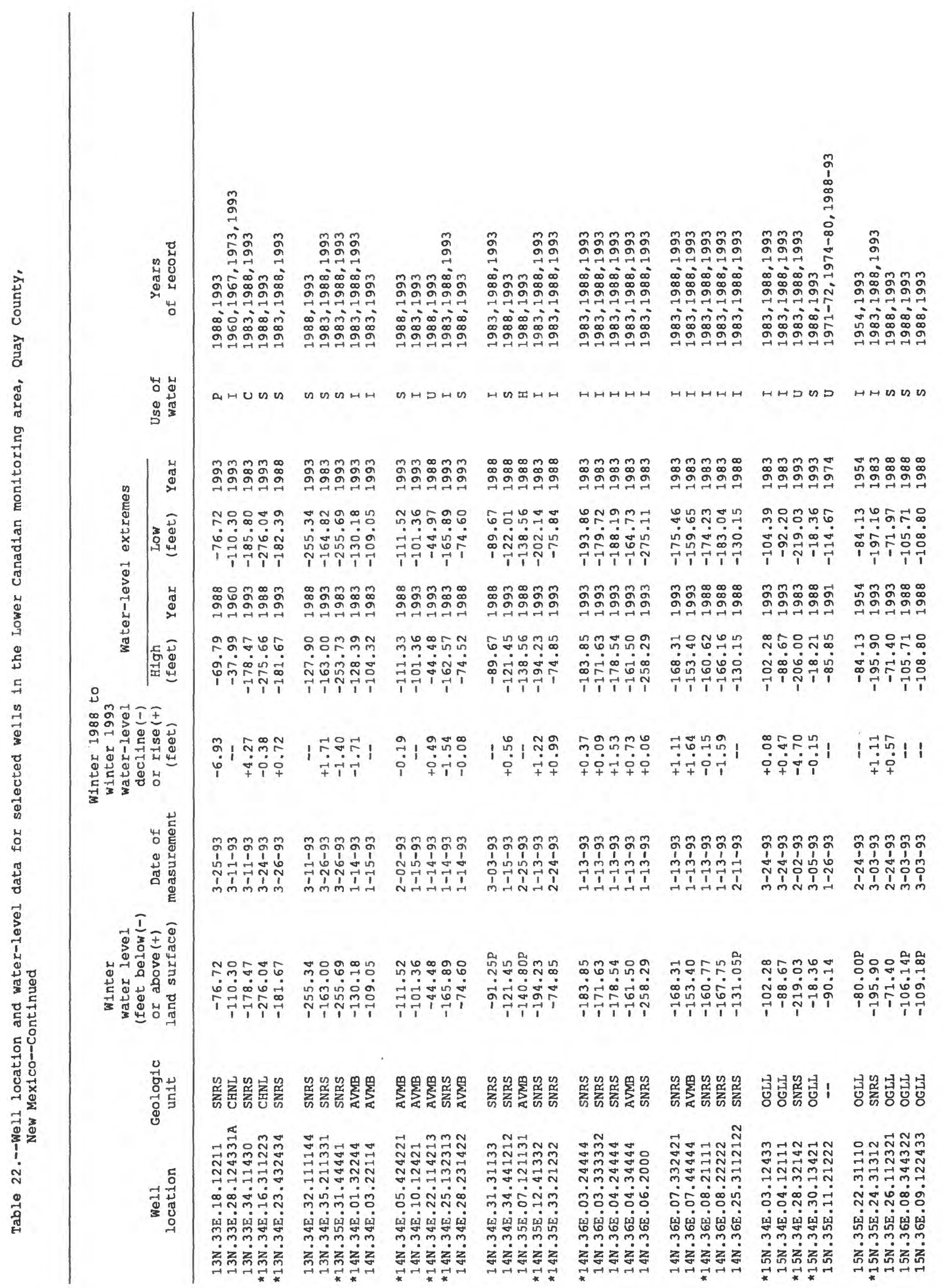




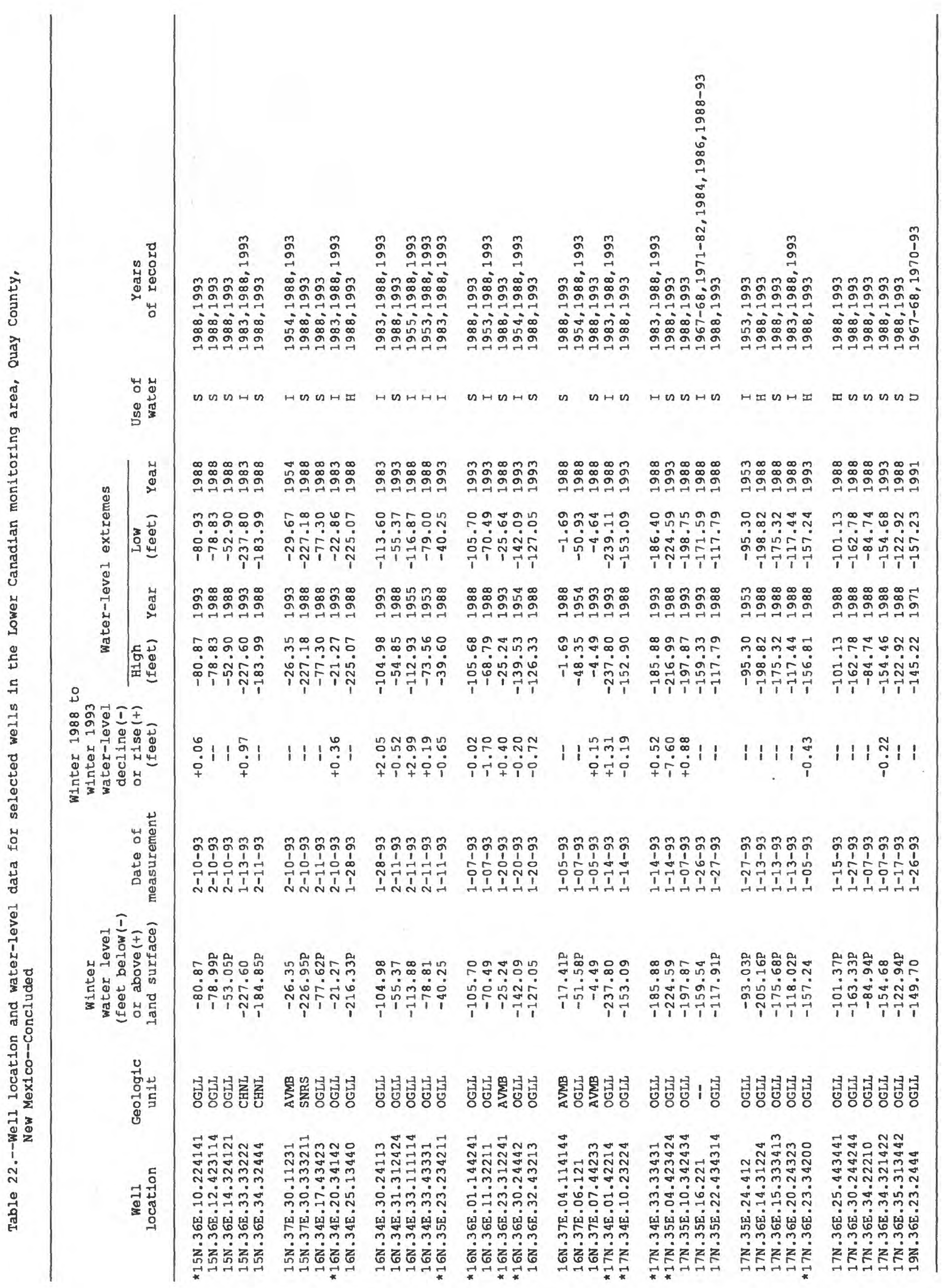




\section{Carlsbad Monitoring Area}

The Carlsbad monitoring area is located in Eddy County, southeastern New Mexico. This area has the same boundary as the Capitan Reef monitoring area. Wells completed in alluvial sediments are in the Carlsbad monitoring area, whereas wells completed in sediments other than alluvium are in the Capitan Reef monitoring area. Not all water-level changes are shown on the map; however, all well locations and water-level data are listed in the table. Well locations marked with an asterisk (*) in the table are plotted on the map.

Water-level declines range from less than 1 foot to more than 8 feet. Rises range from less than 1 foot to more than 5 feet. 


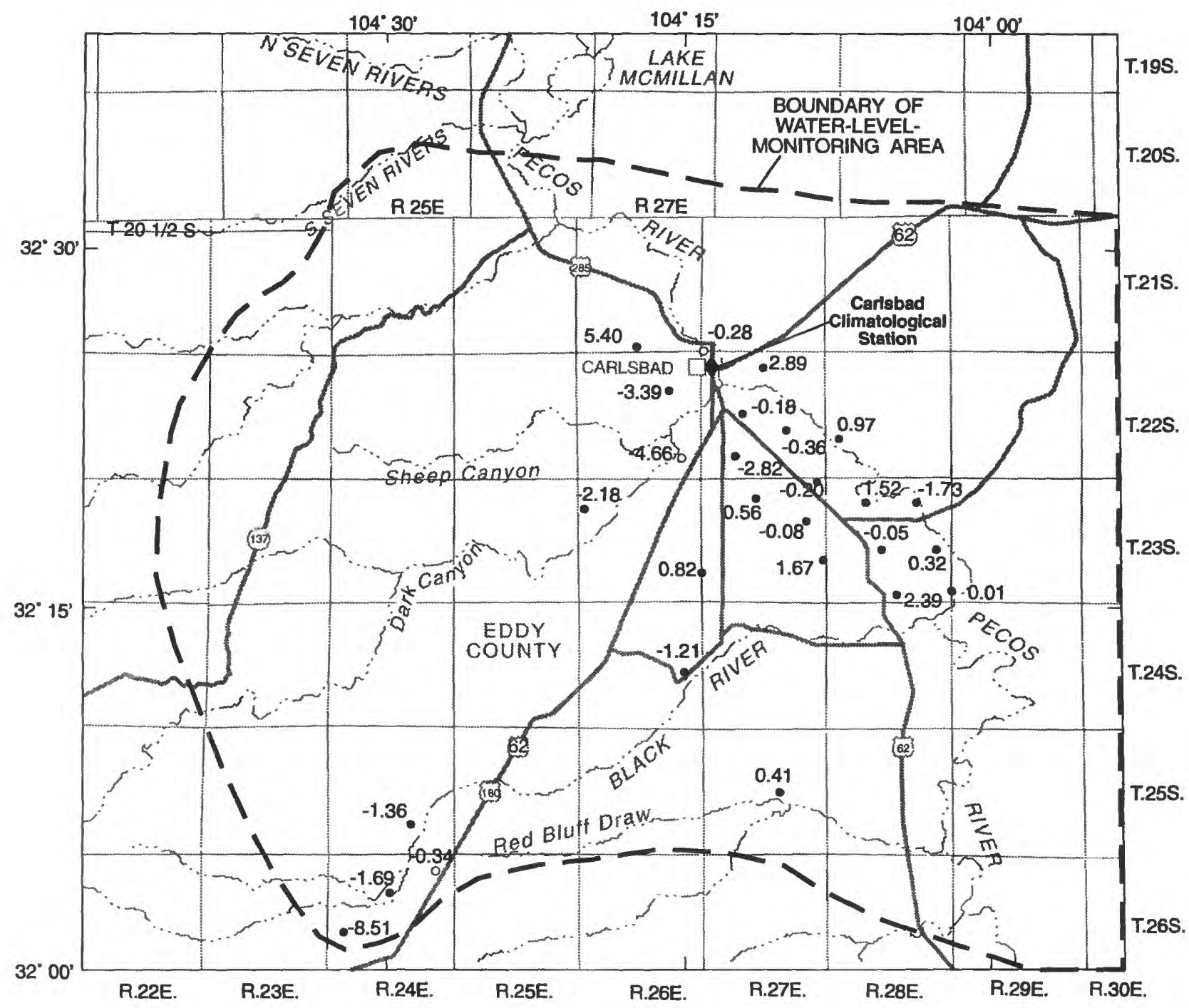

\section{EXPLANATION}

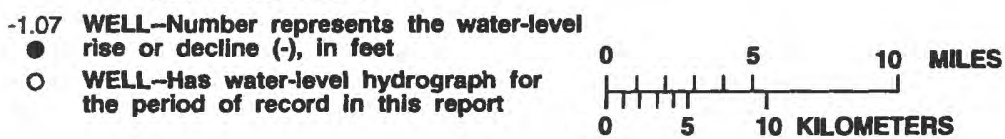

Figure 47.--Water-level changes for selected wells in the Carlsbad monitoring area, 1988-93. 

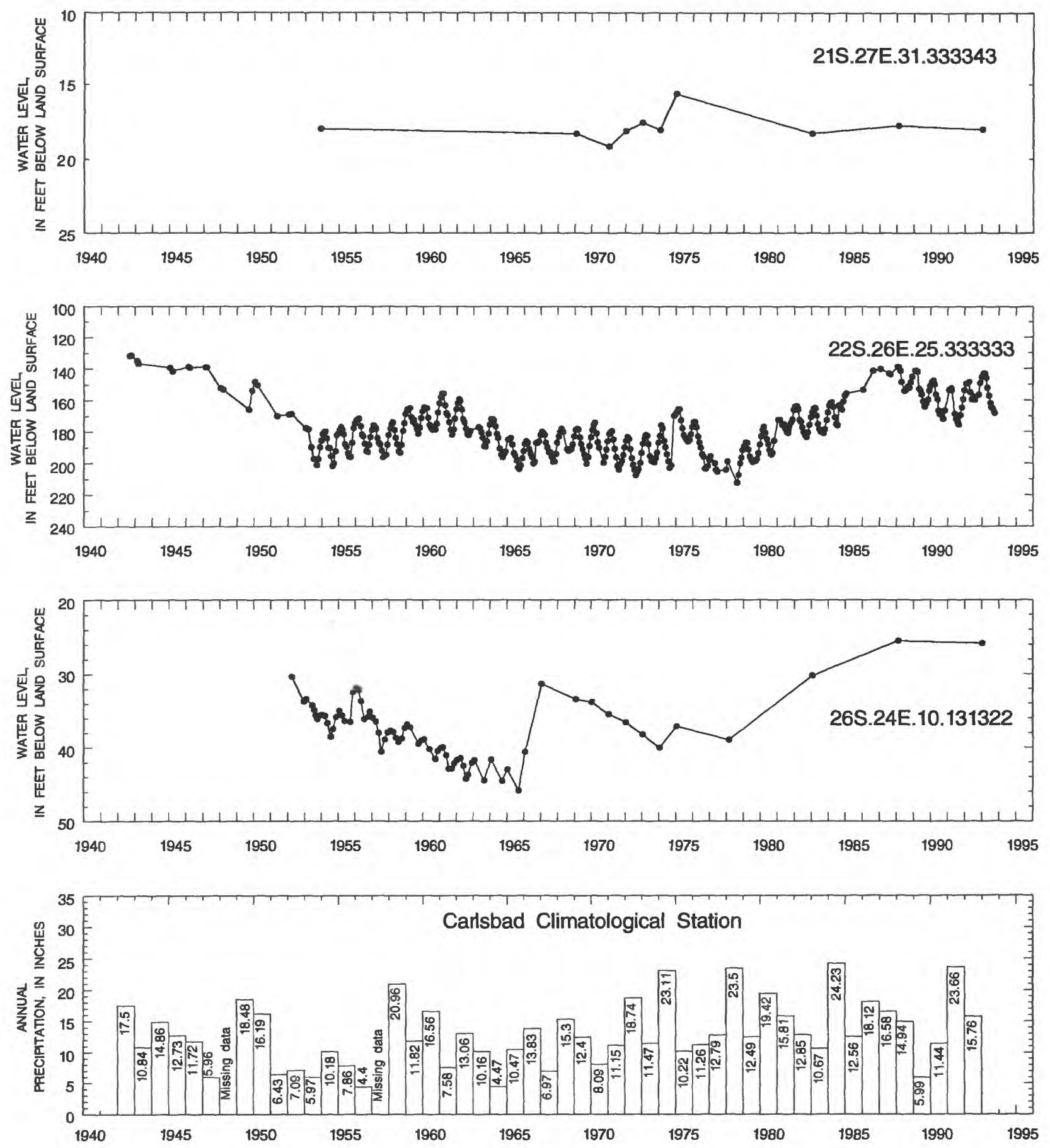

Figure 48.--Water-level data for selected wells in the Carlsbad monitoring area and annual precipitation at the Carlsbad Climatological Station. See figure 47 for location of wells and station. 


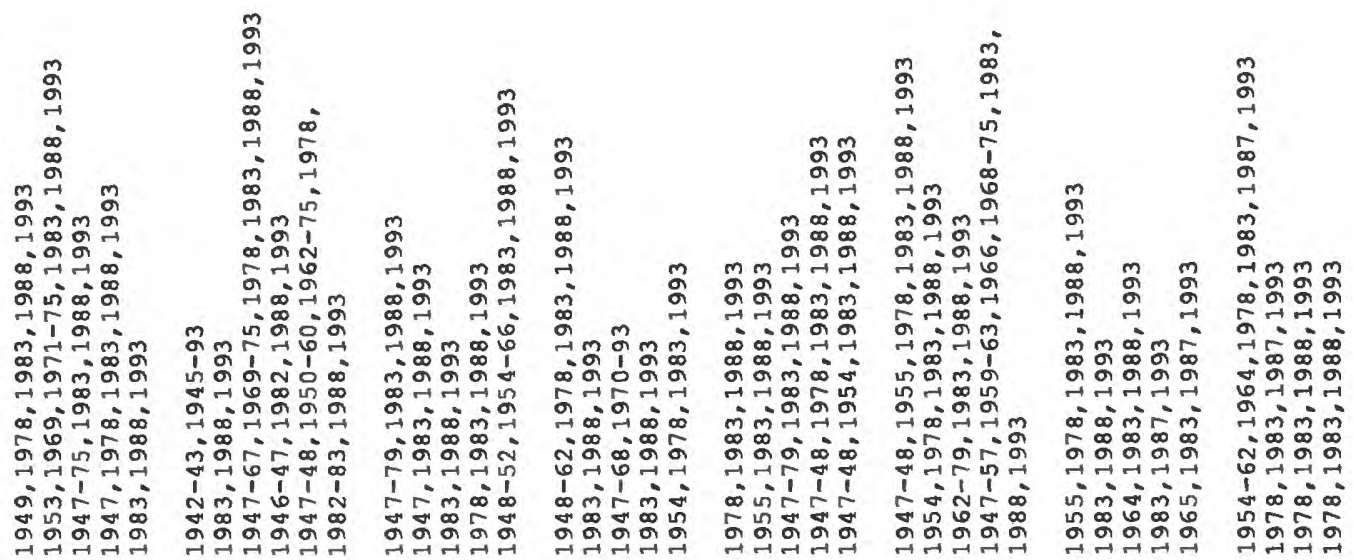

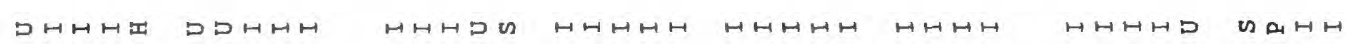

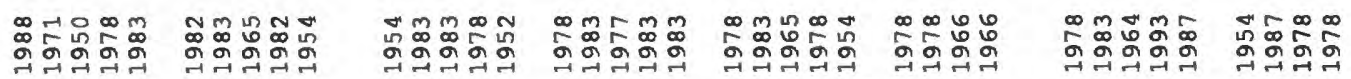

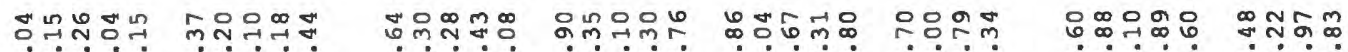

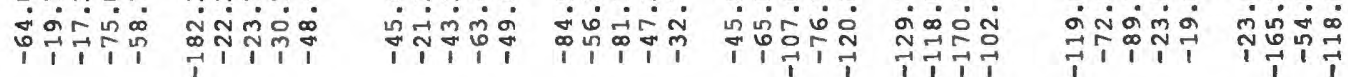

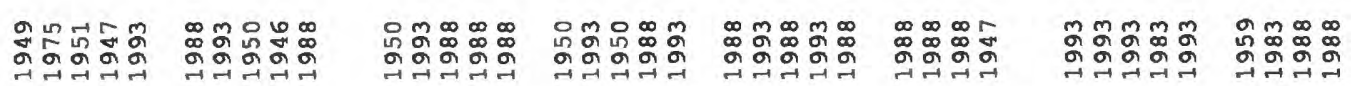

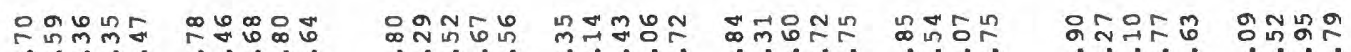

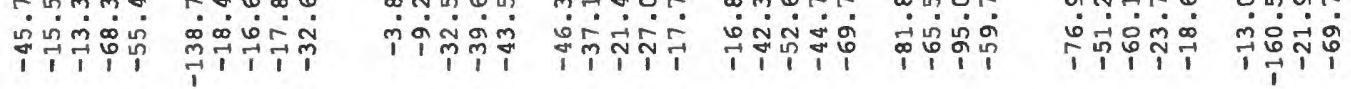

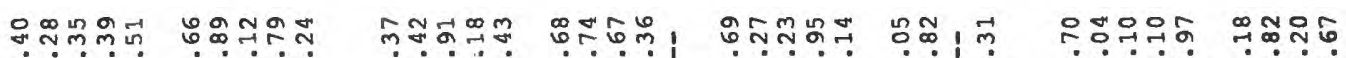

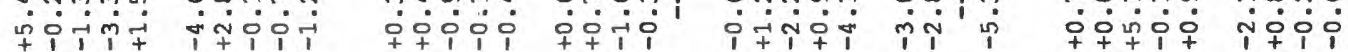

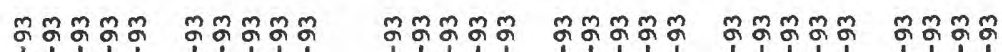

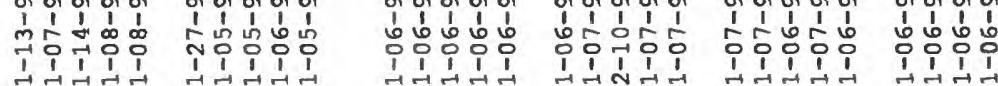

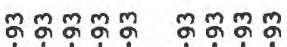

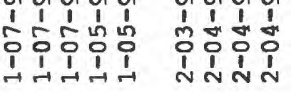
the

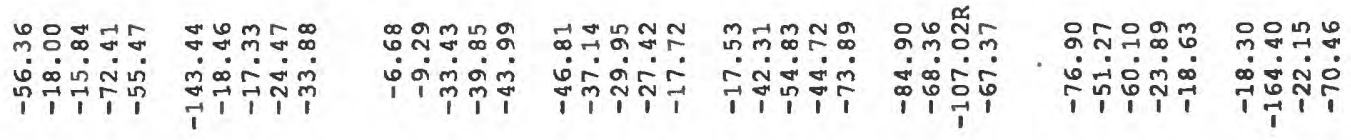
$\underbrace{+}_{\substack{1 \\ 0}}$

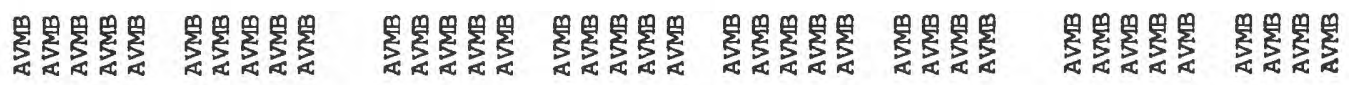

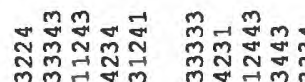
अुल

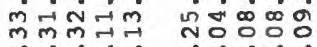
붕 由ं กักกั กักลก

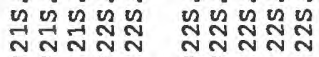

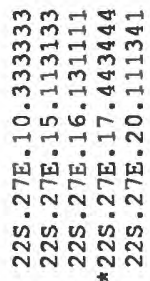

Simpim অ్m กี่ส่กี่ 这国 ลกลกล กู กกก सं山 กิกลกลก

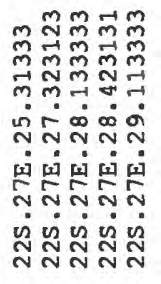

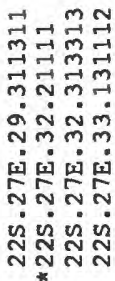




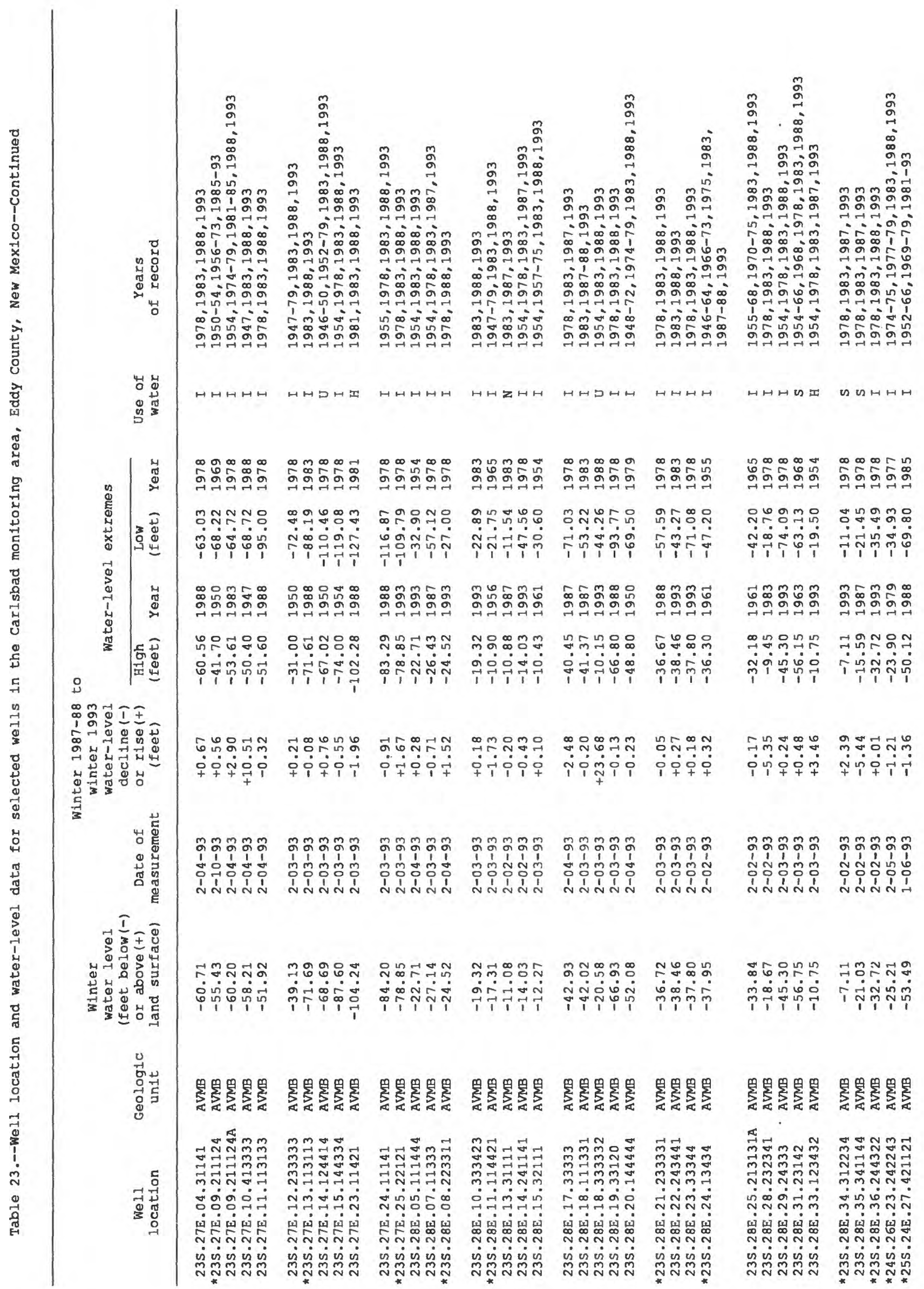




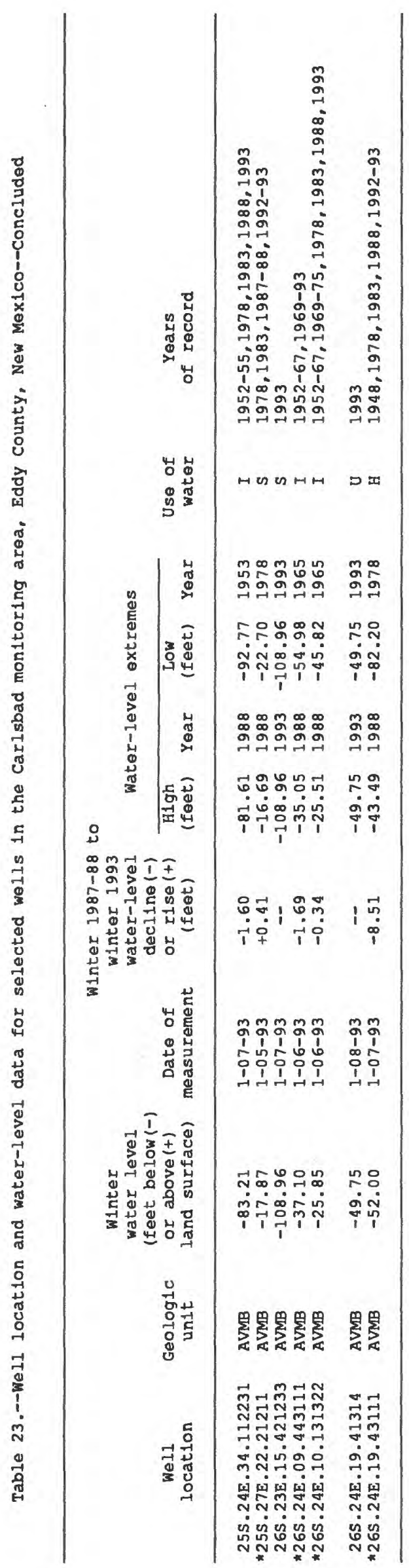




\title{
GROUND-WATER HYDROGRAPHS AND 5-YEAR \\ GROUND-WATER-LEVEL CHANGES, 1984-93, FOR \\ SELECTED AREAS IN AND ADJACENT TO NEW MEXICO
}

By D.W. Wilkins and B.M. Garcia

\author{
U.S. GEOLOGICAL SURVEY \\ Open-File Report 95-434
}

\begin{abstract}
Prepared in cooperation with the
NEW MEXICO STATE ENGINEER OFFICE
\end{abstract}

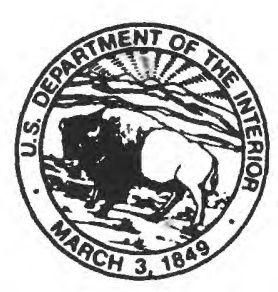

Albuquerque, New Mexico

1995 

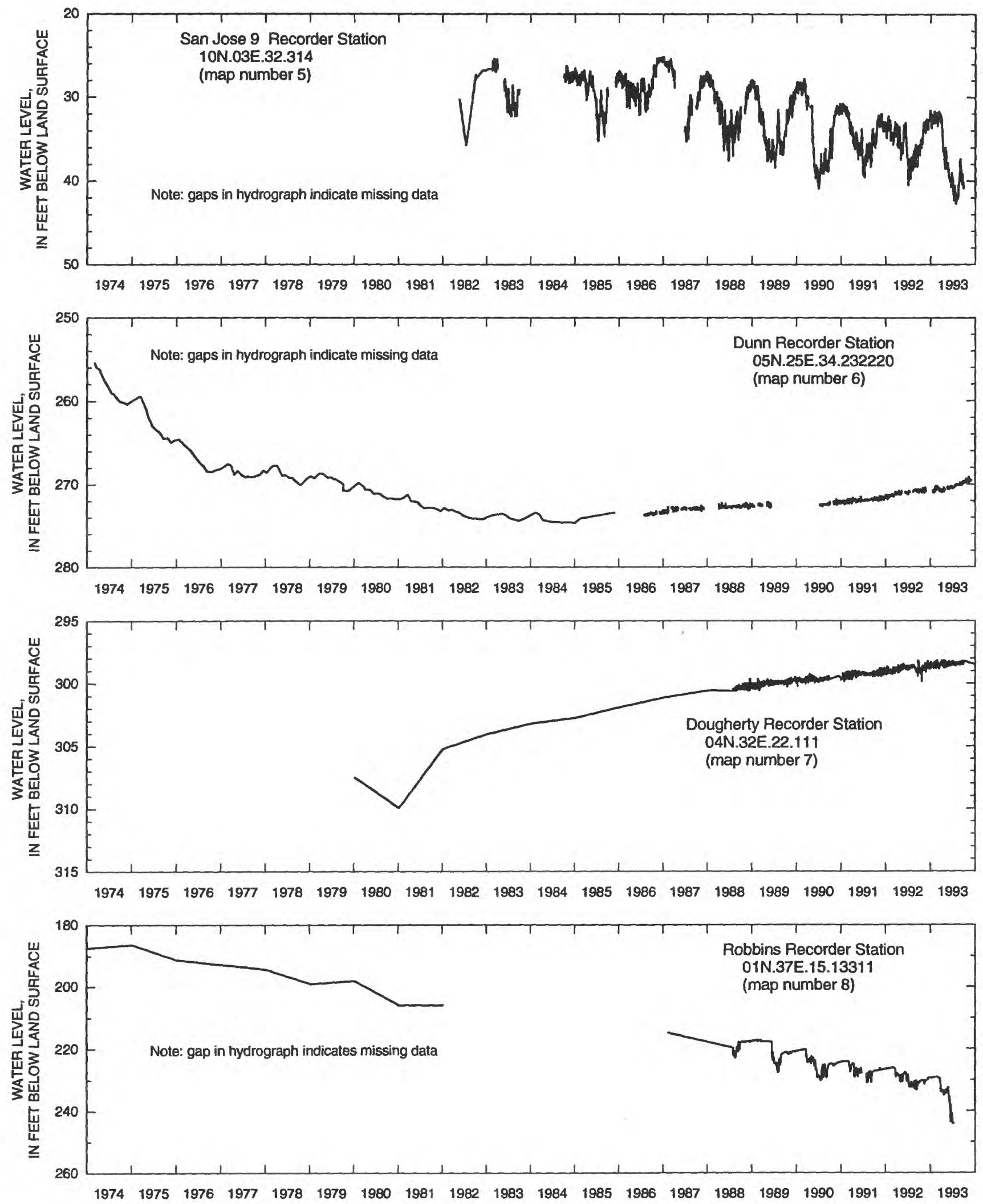

Figure 4.--Continuous water-level data for selected wells. See figure 2 and table 1 for location--Continued. 


\section{Capitan Reef Monitoring Area}

The Capitan Reef monitoring area is located in Eddy County, southeastern New Mexico. The Capitan Reef and Carlsbad monitoring areas have the same boundary for water-level monitoring. However, water-level changes in wells completed in sediments other than alluvium are monitored in the Capitan Reef area; water-level changes in wells completed in alluvial sediments are monitored in the Carlsbad area.

Water-level declines range from less than 1 foot to more than 5 feet. Rises range from less than 1 to more than 5 feet. Water-level changes indicate declines ranging from less than 1 foot to more than 3 feet around Carlsbad. Water-level changes show a rise east and west of Carlsbad, ranging from less than 1 foot east of Carlsbad to more than 5 feet west of Carlsbad. 


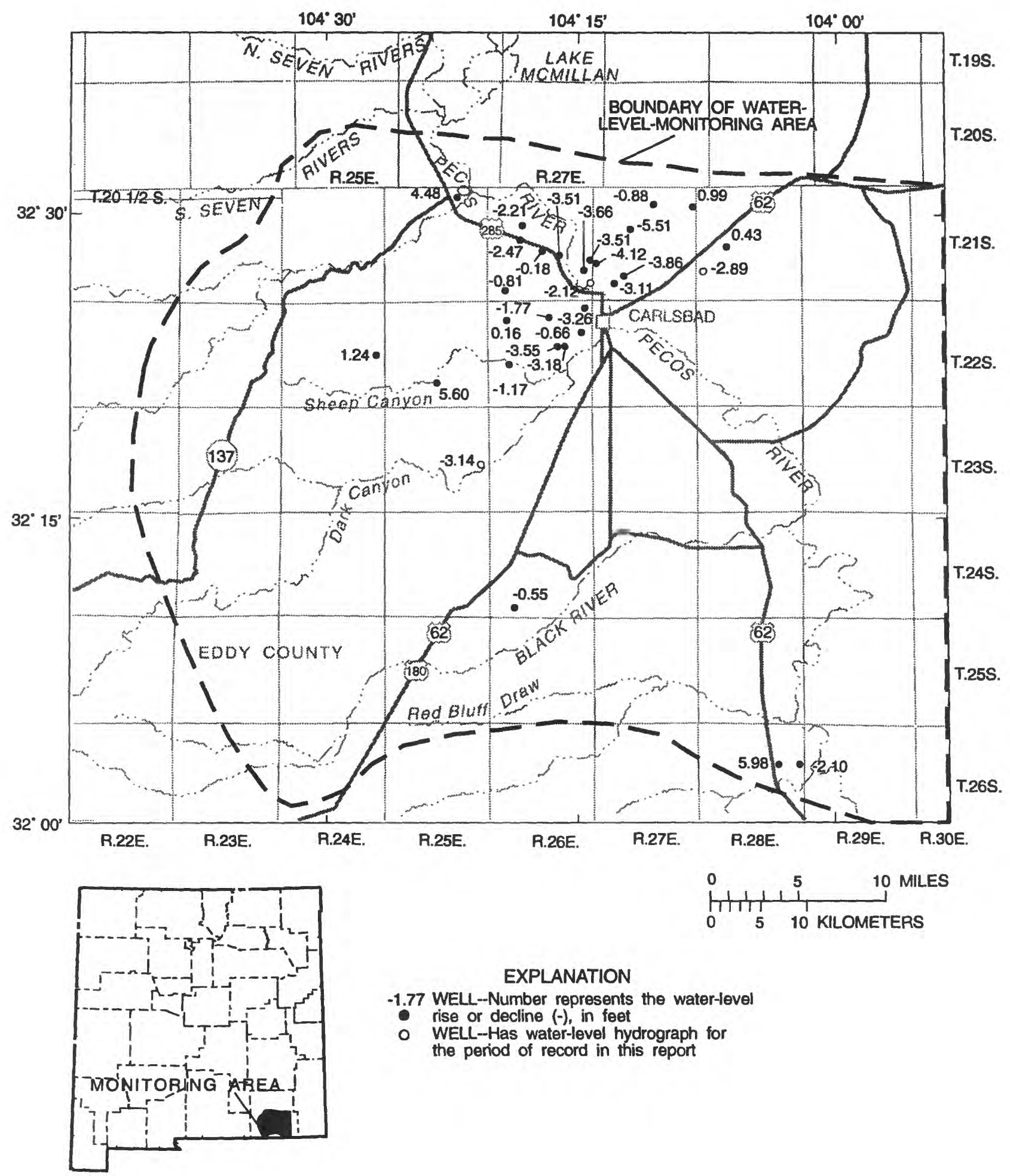

Figure 49.--Water-level changes for wells in the Capitan Reef monitoring area, 1988-93. 

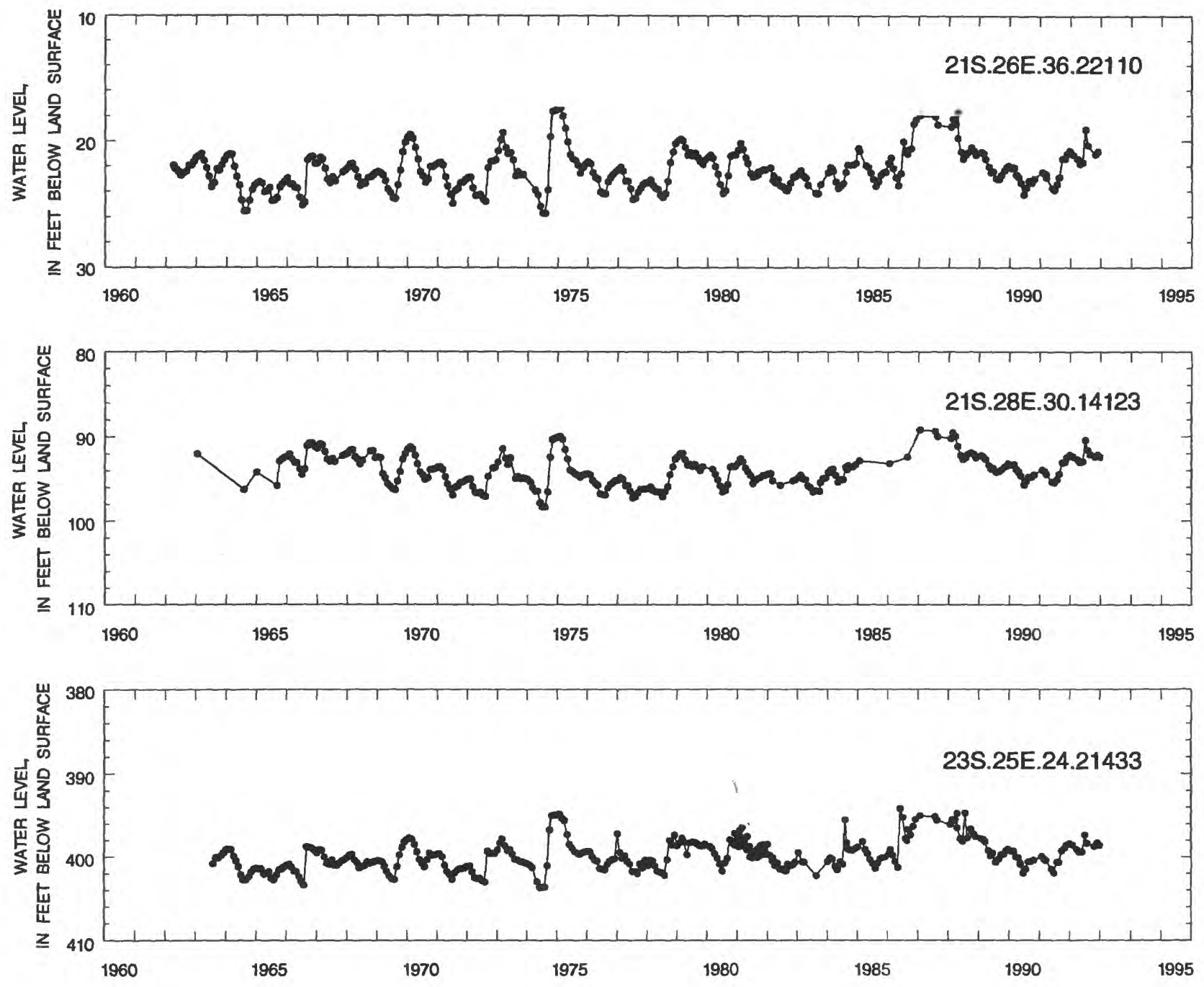

Figure 50.--Water-level data for selected wells in the Capitan Reef monitoring area. See figure 49 for location of wells. 


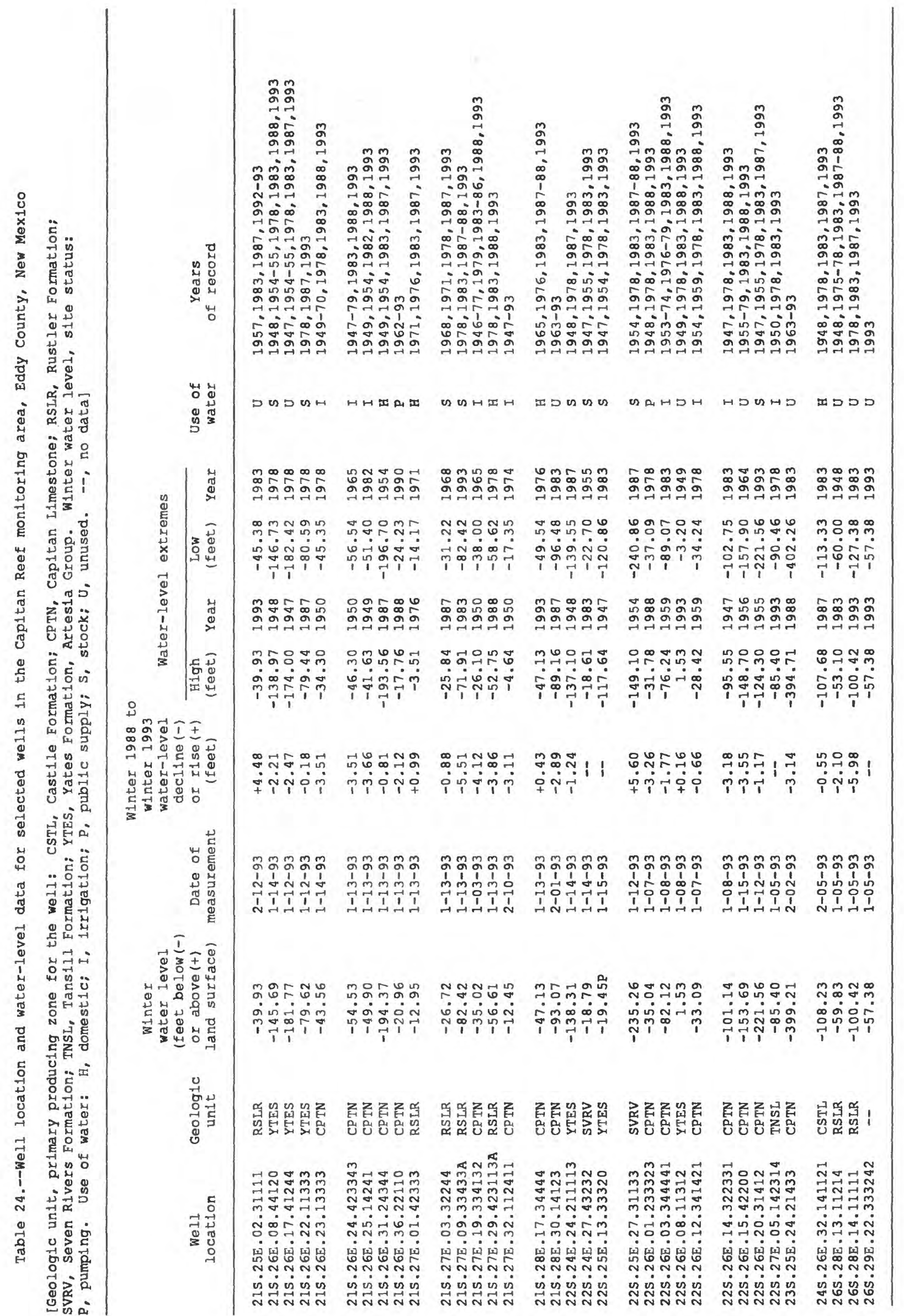




\section{Animas Monitoring Area}

The Animas monitoring area is in Hidalgo County, southwestern New Mexico. Water-level declines range from less than 1 foot to more than 16 feet. Rises range from less than 1 to more than 14 feet. Water-level declines in T. 24 S., R. 20 W. range from less than 1 foot to more than 3 feet. Parts of T. 25 S. and R. 20 W. have declines ranging from less than 1 foot to 9 feet. Waterlevel changes in three wells in T. 27 S., Rs. 19 and 20 W. are declines. Surrounding these areas of declines are rises ranging from greater than 14 feet in T. 28 S., R. 19 W. to less than 1 foot. 

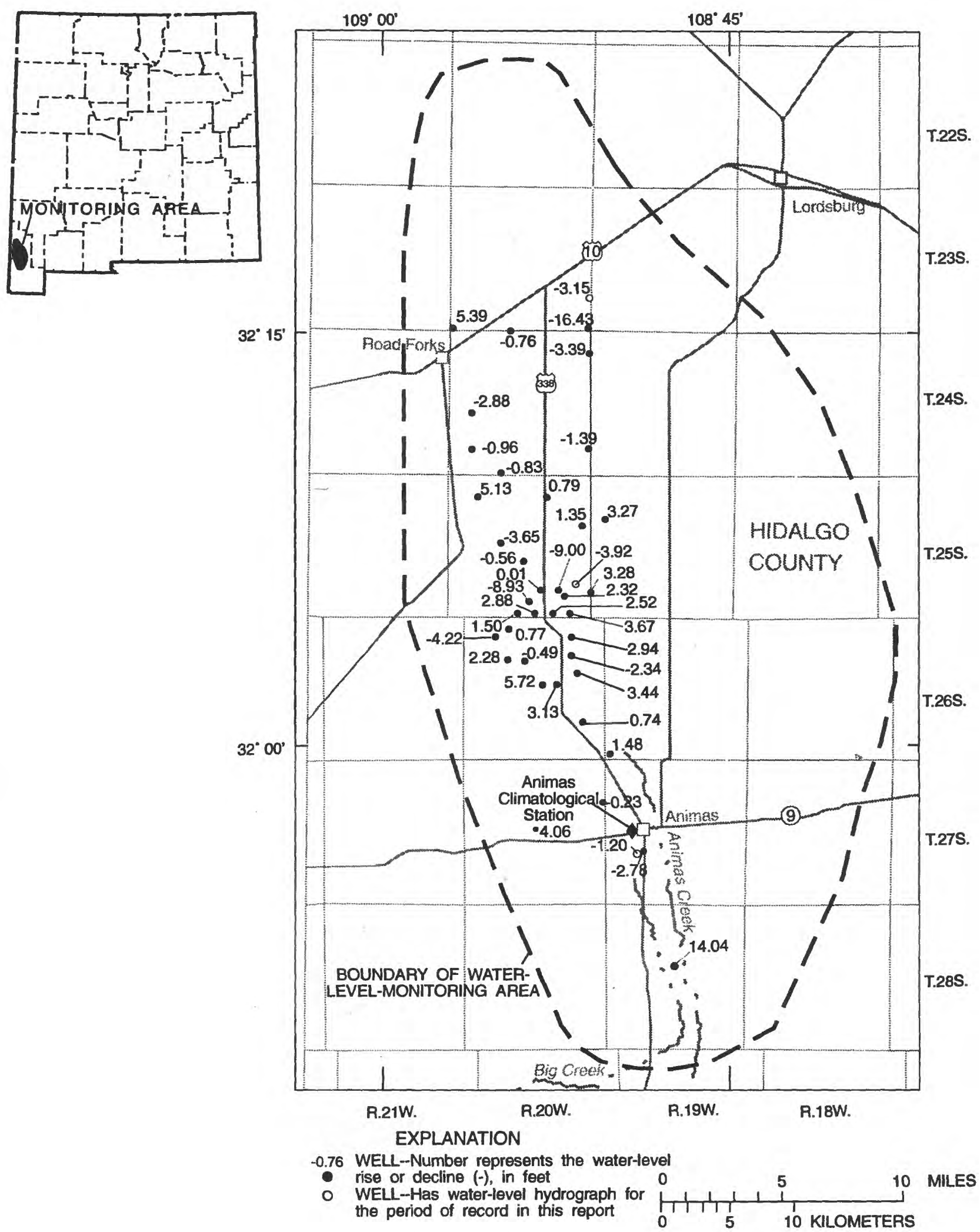

Figure 51.--Water-level changes for wells in the Animas monitoring area, 1988-93. 

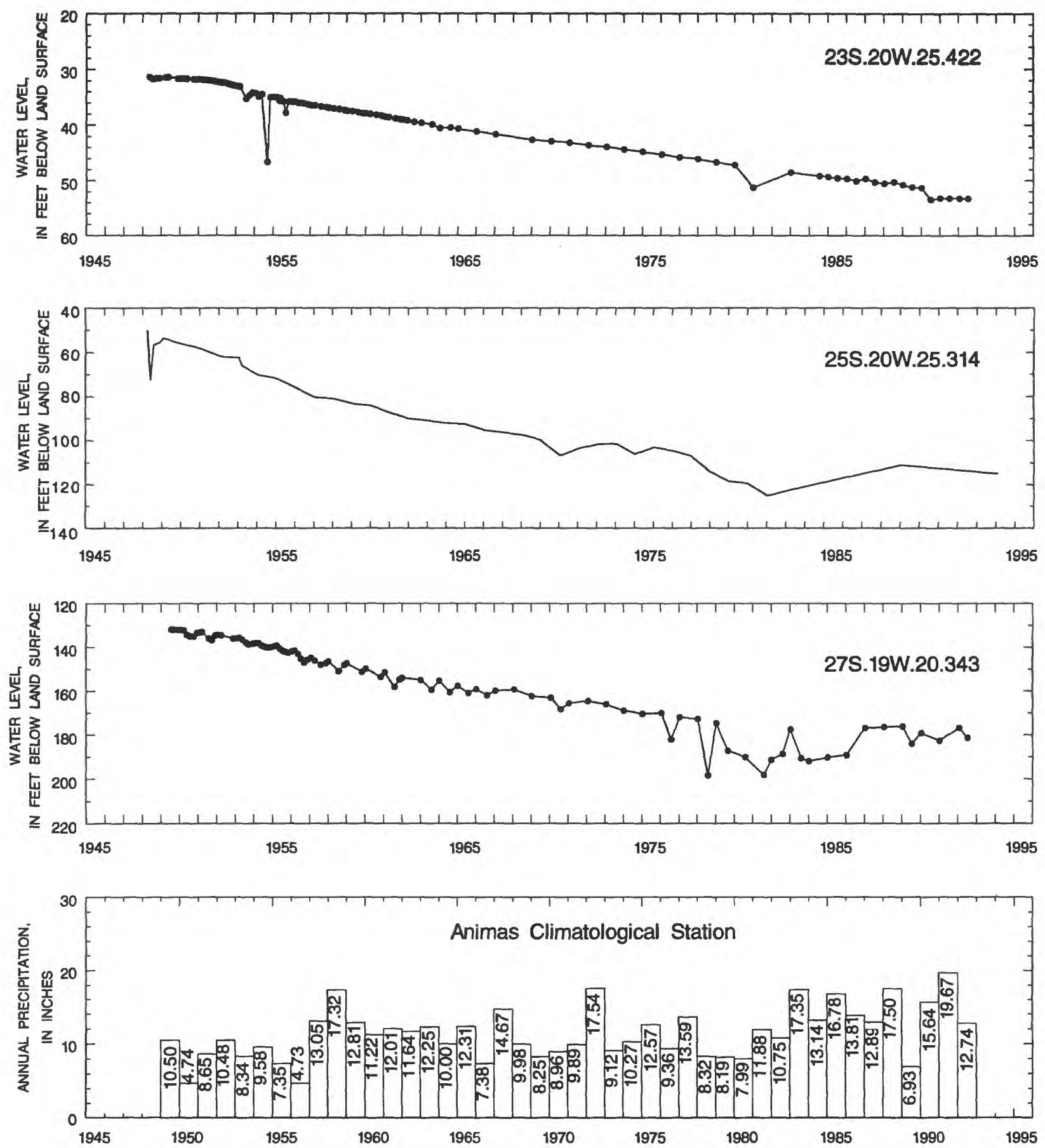

Figure 52.--Water-level data for selected wells in the Animas monitoring area and annual precipitation at the Animas Climatological Station. See figure 51 for location of wells and station. 


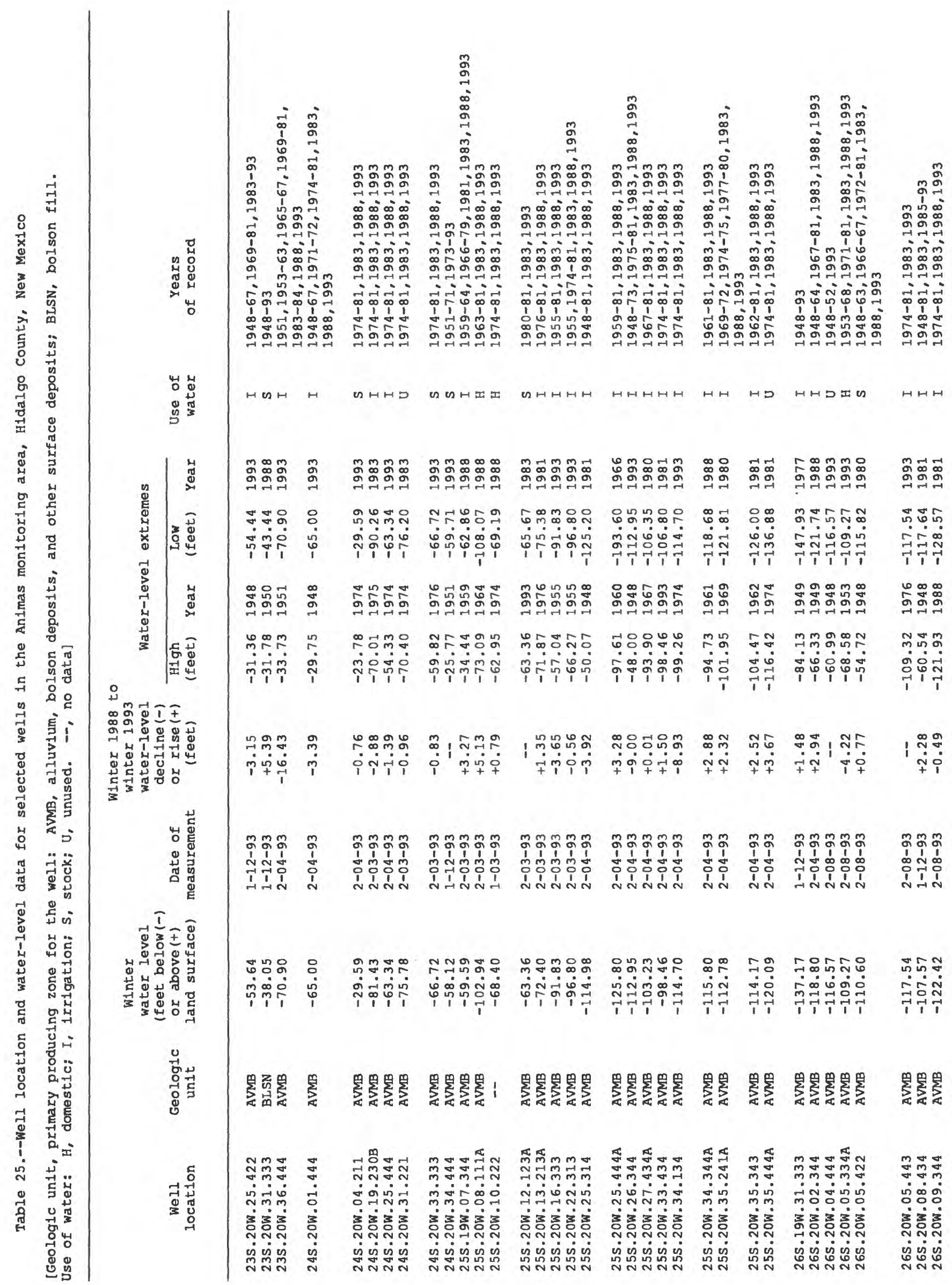




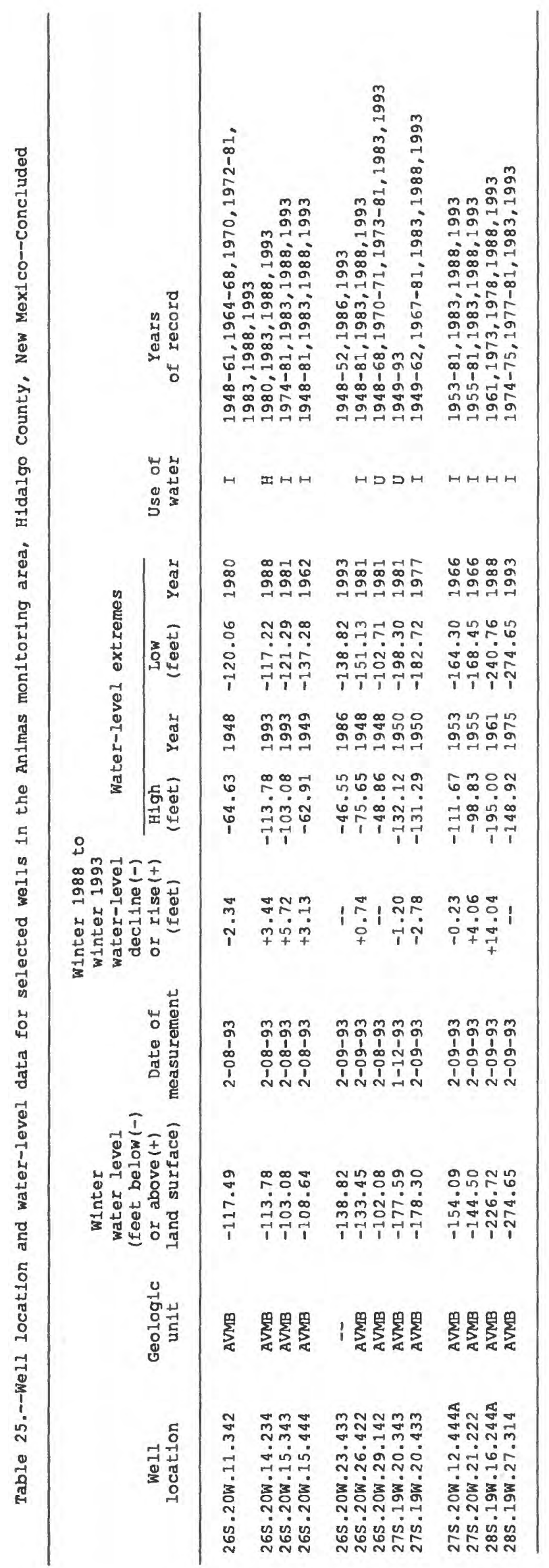




\section{Playas Monitoring Area}

The Playas monitoring area is in Hidalgo and Grant Counties, southwestern New Mexico. Water-level declines range from less than 1 to more than 13 feet. Rises range from less than 1 to more than 4 feet. Most water-level changes are rises. Two small areas in T. 32 S., R. 16 W. and T. 33 S., Rs. 16 and 17 W. show declines. 

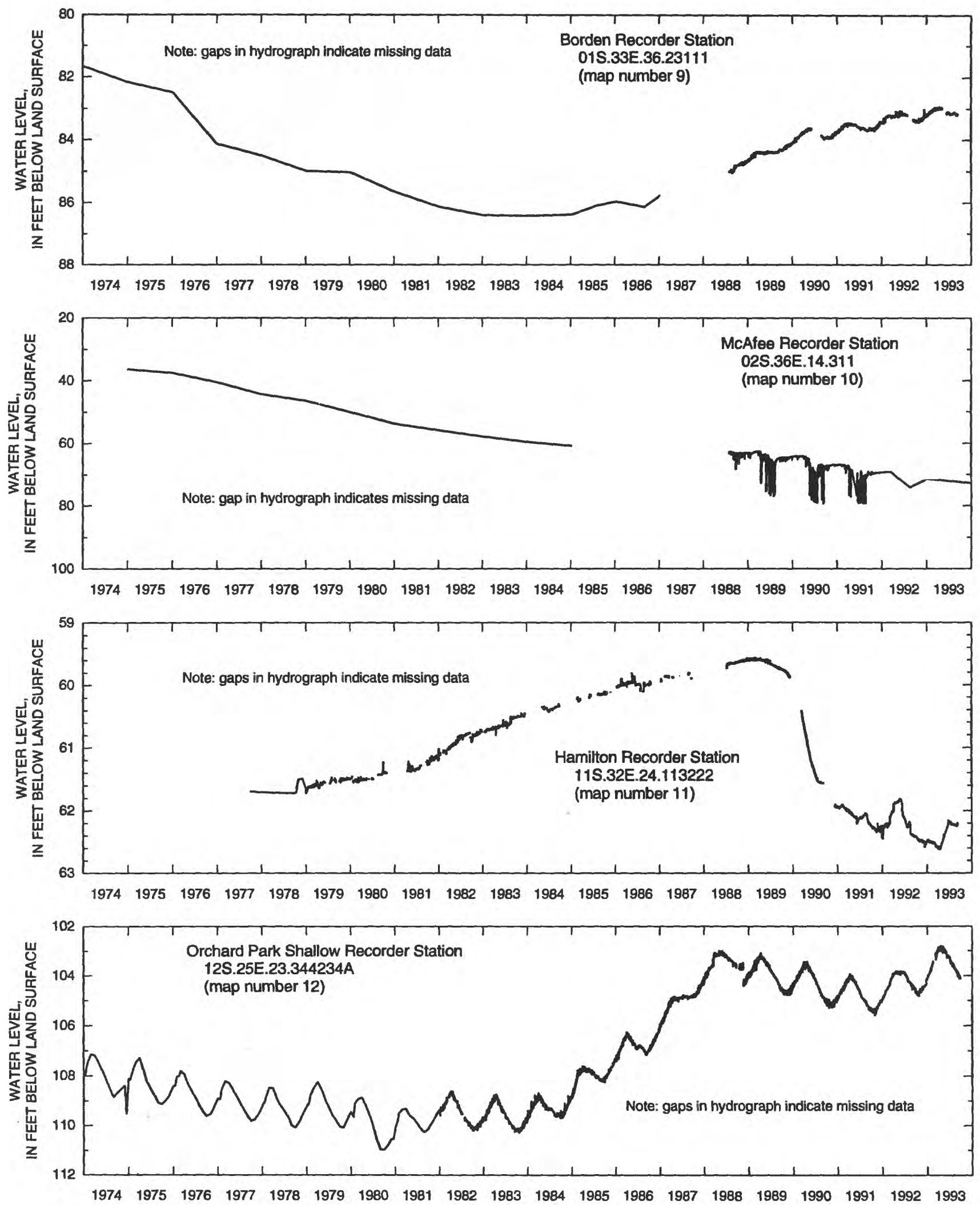

Figure 4.--Continuous water-level data for selected wells. See figure 2 and table 1 for locations--Continued. 

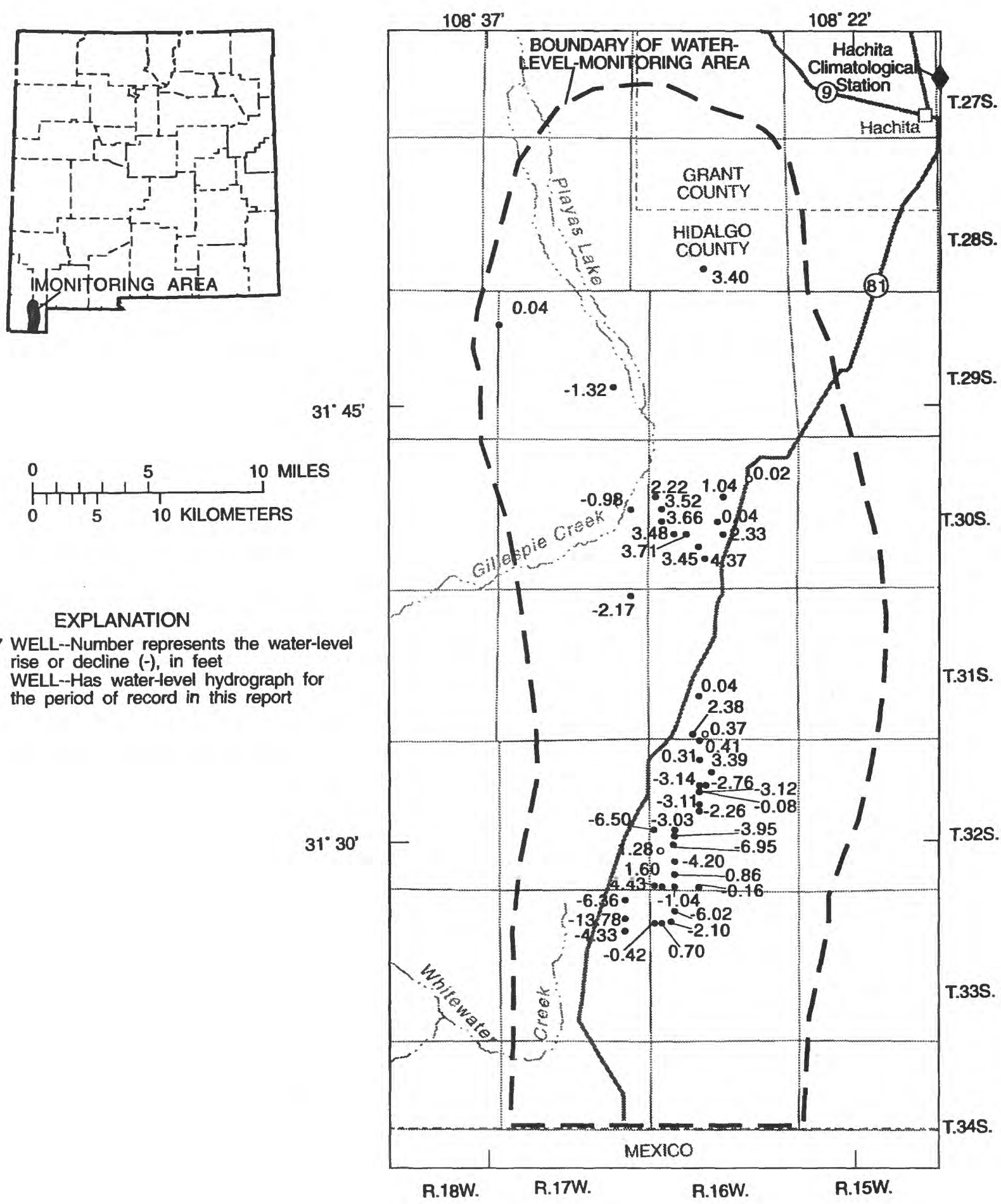

\section{EXPLANATION}

-2.17 WELL--Number represents the water-leve

- rise or decline $(-)$, in feet

- WELL--Has water-level hydrograph for the period of record in this report

10 MILES

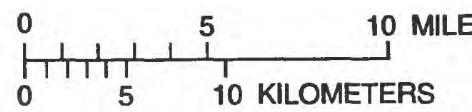

Figure 53.-Water-level changes for wells in the Playas monitoring area, 1988-93. 

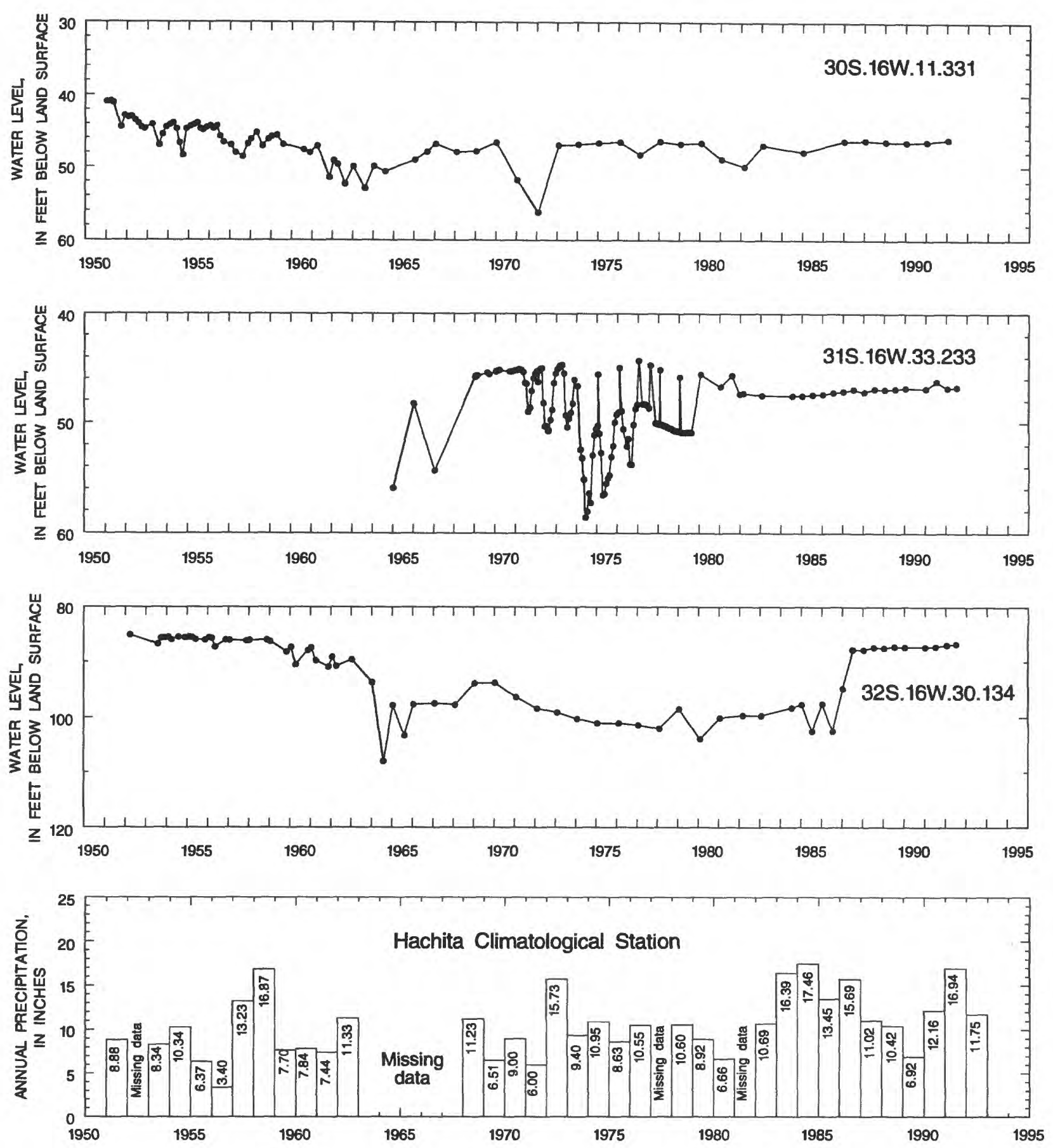

Figure 54.--Water-level data for selected wells in the Playas monitoring area and annual precipitation at the Hachita Climatological Station. See figure 53 for location of wells and station. 


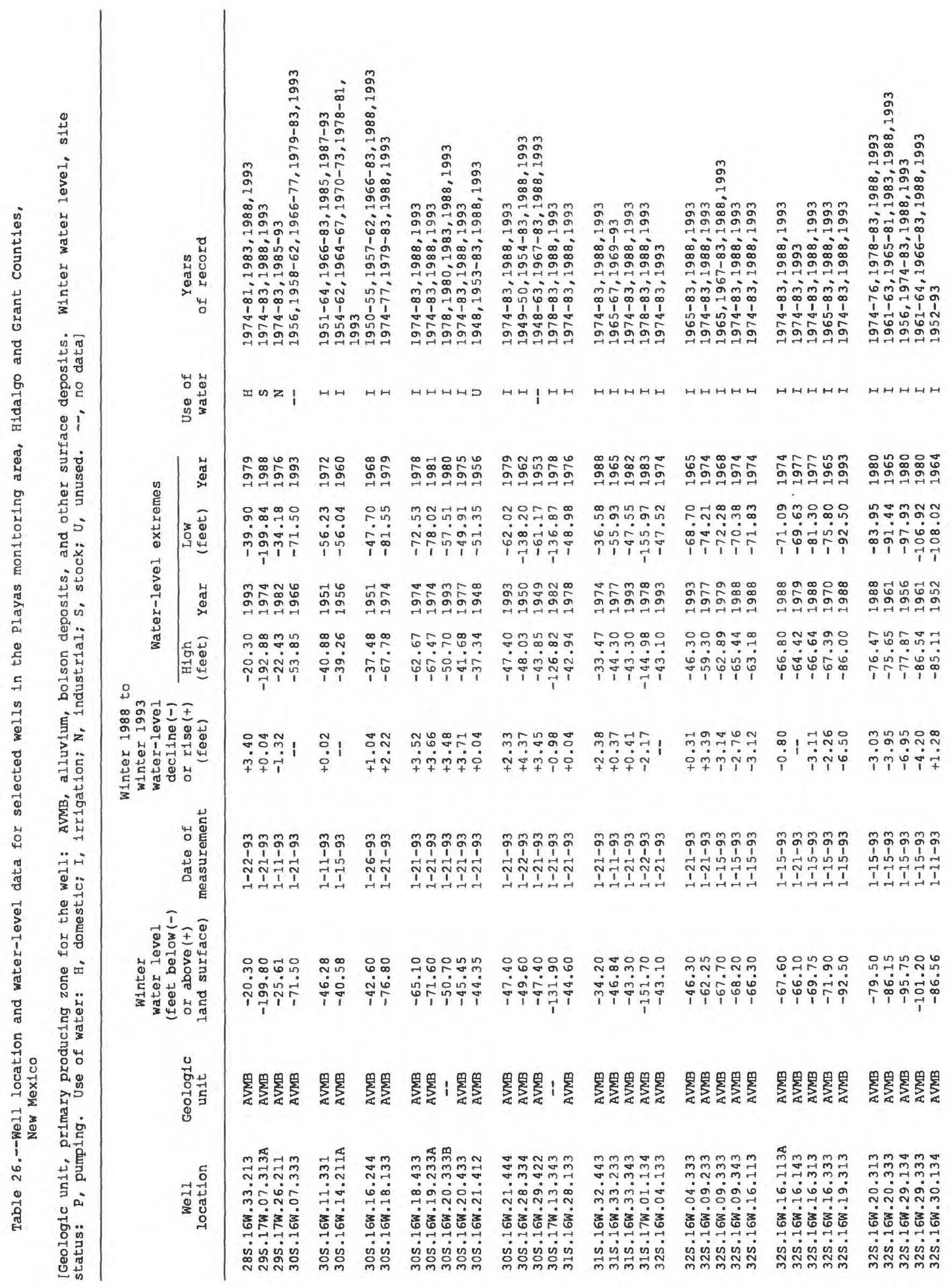




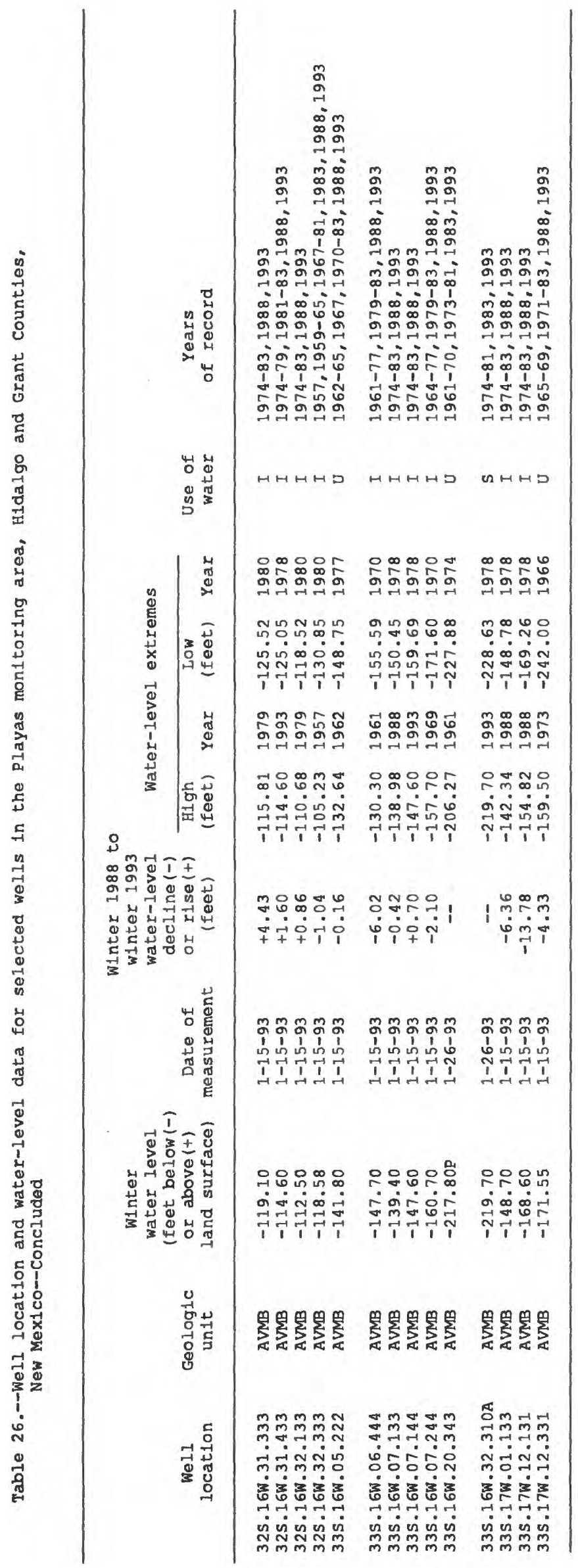




\section{Lordsburg Monitoring Area}

The Lordsburg monitoring area is in Grant, Hidalgo, and Luna Counties, southwestern New Mexico. No specific areas have predominant rises or declines. Rises range from less than 1 foot to more than 23 feet. Declines range from less than 1 foot to more than 8 feet. 

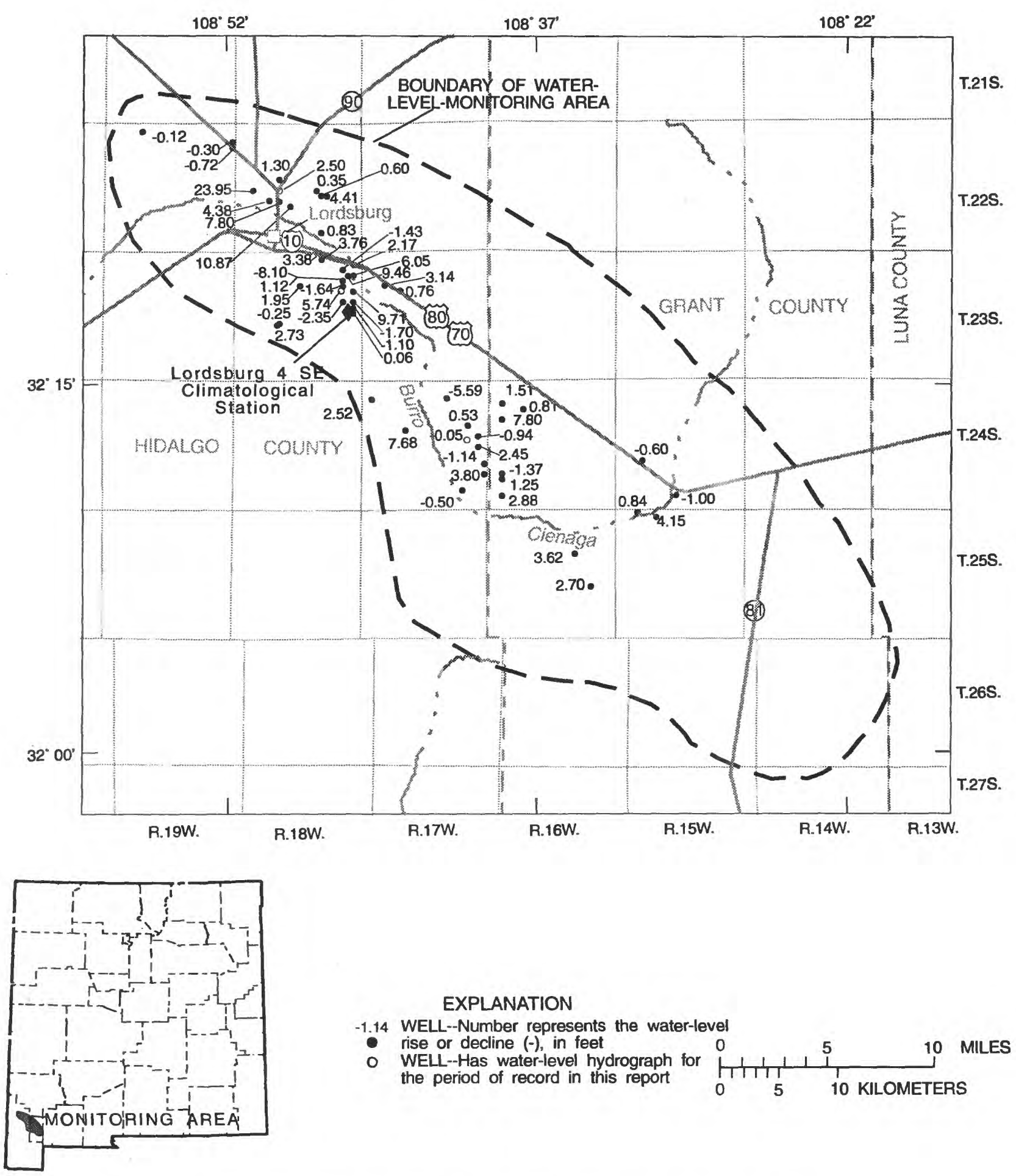

\section{EXPLANATION}

-1.14 WELL--Number represents the water-level

rise or decline $(-)$, in feet
WELL--Has water-level hydrograph for

the period of record in this report

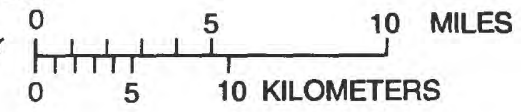

Figure 55.--Water-level changes for wells in the Lordsburg monitoring area, 1988-93. 

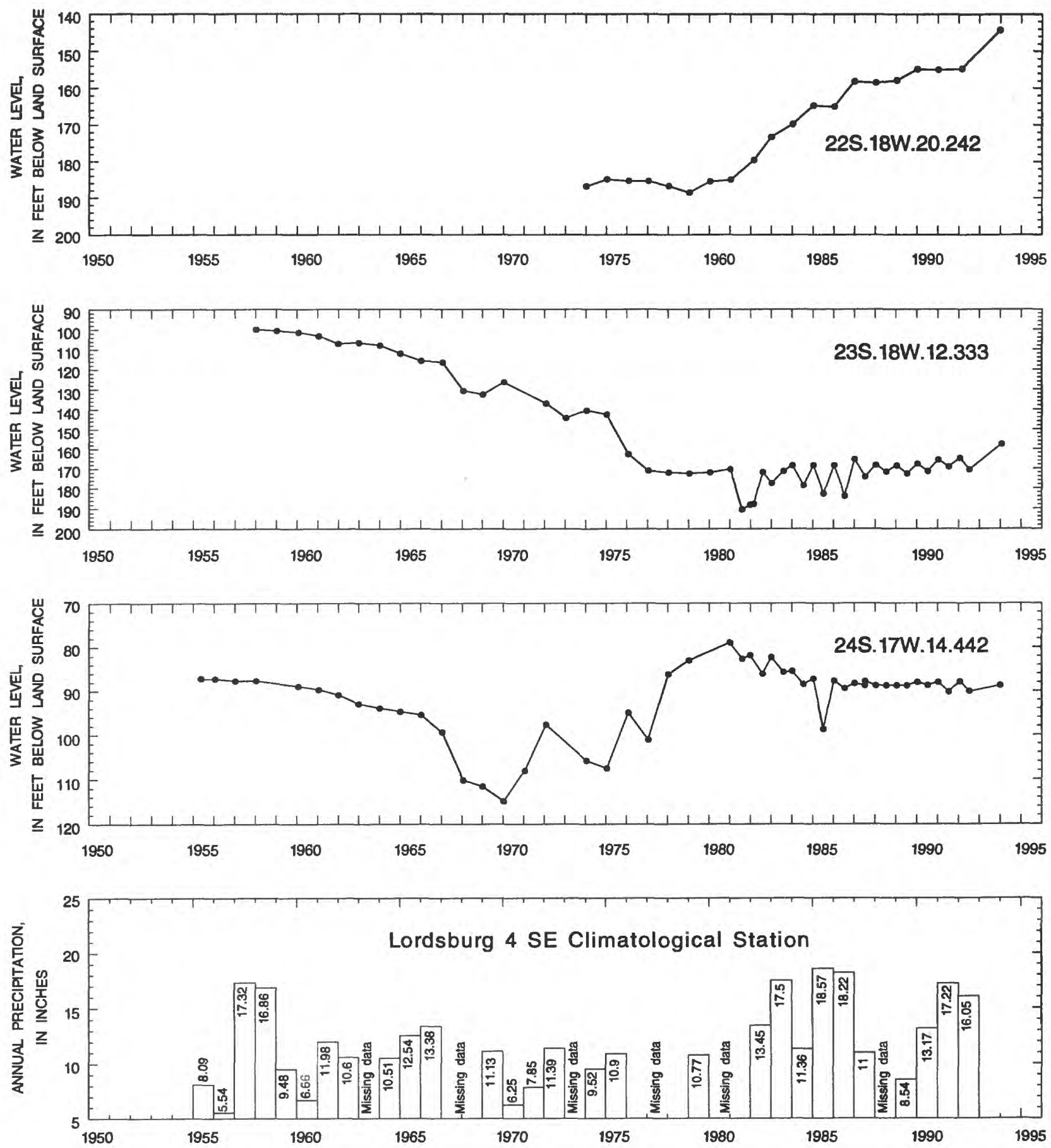

Figure 56.--Water-level data for selected wells in the Lordsburg monitoring area and annual precipitation at the Lordsburg 4 SE Climatological Station. See figure 55 for location of wells and station. 


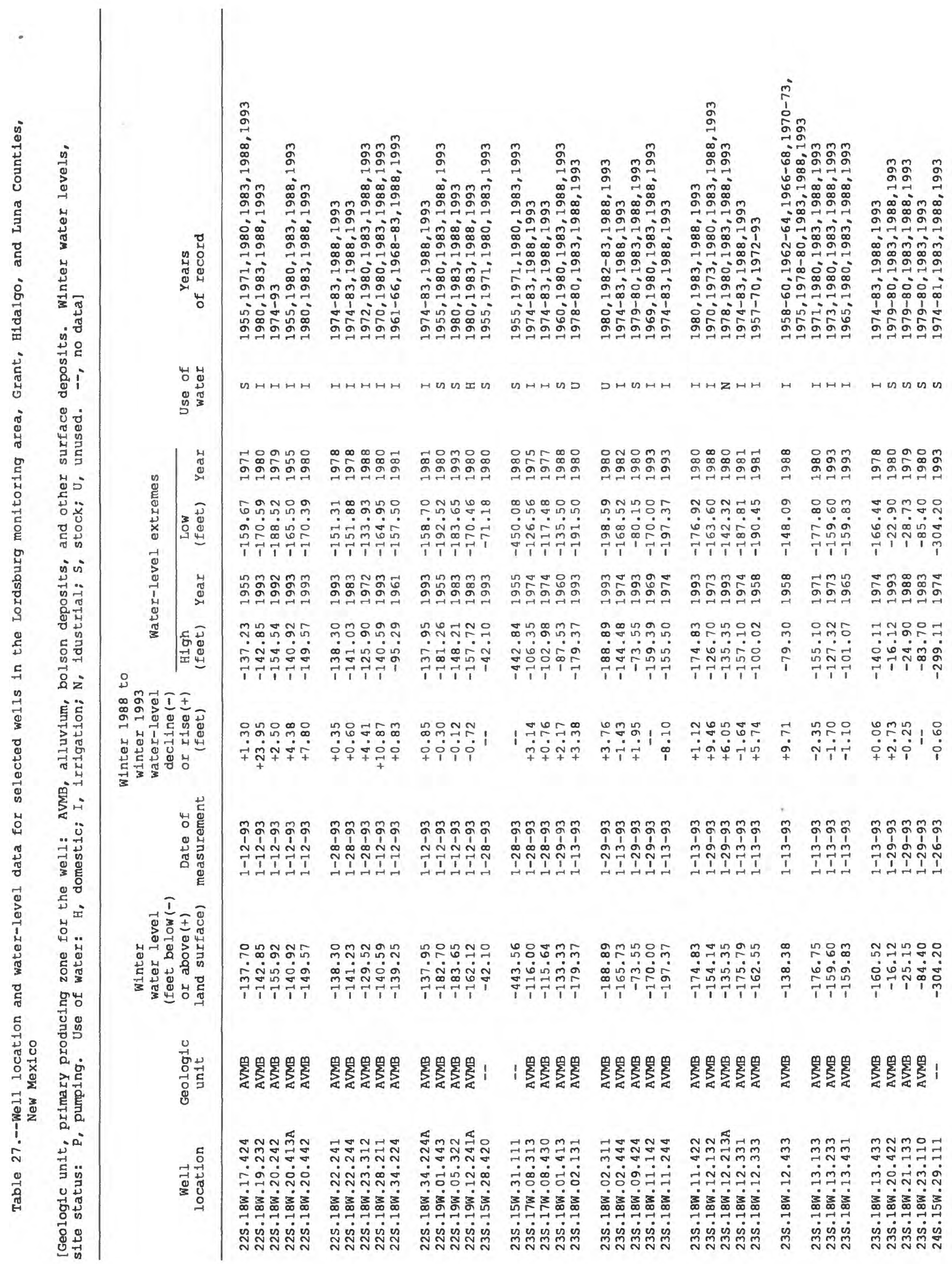




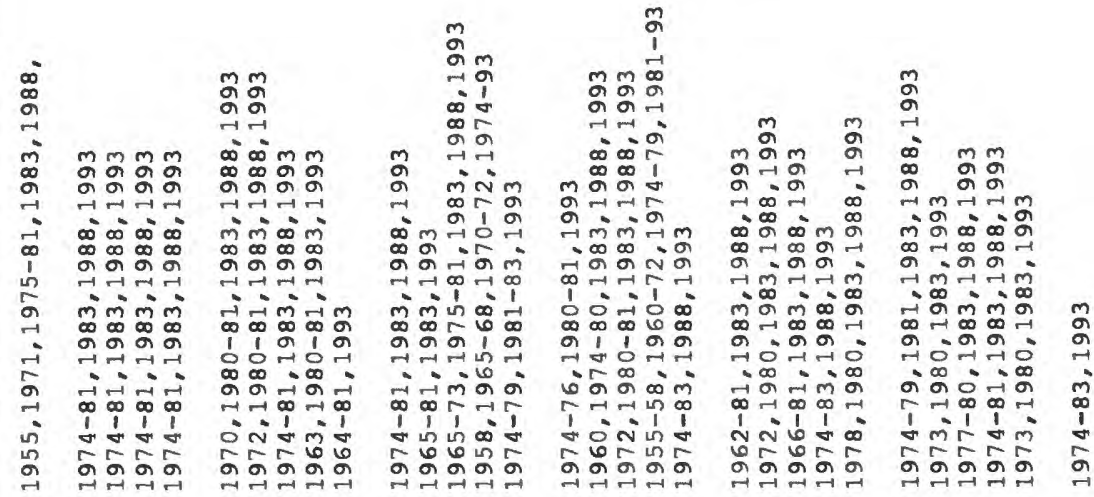

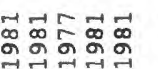

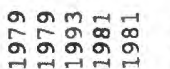

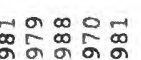

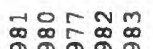

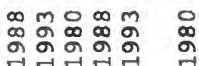

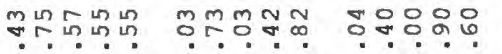

or

बं $\infty \dot{\infty}$

융ำ

낭다요

จे กิษ

१ิन

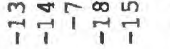

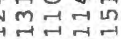

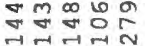

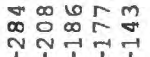

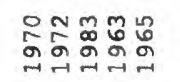

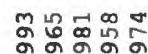

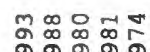

nmorm

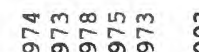

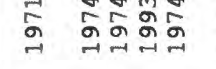

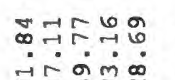

궝ํํํํㅇ

至

की कूलिए

i

œ

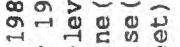

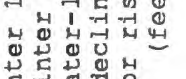

18

유무요.

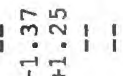

我1 ำกำ

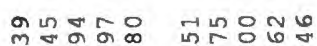

웅ํํ욤ำ

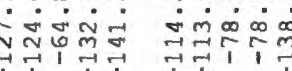

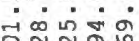

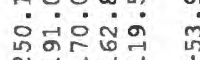

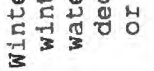

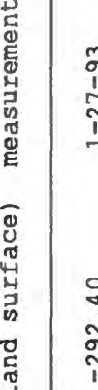

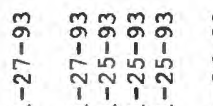

mommon

ตू๊ตัฒต

4

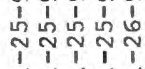

ตรณกา

ตू๊ตू๊ के

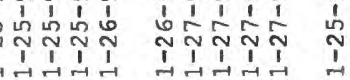

సิํำกำ

ำ

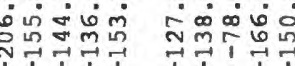

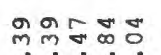

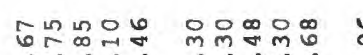

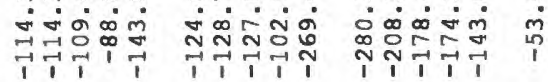

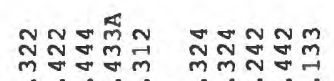
लें $\dot{m} \dot{0}: \infty$

西

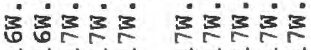

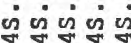

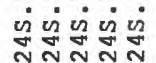

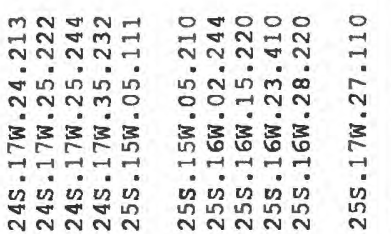




\section{Santa Fe County Monitoring Area}

The Santa Fe County monitoring area is in north-central New Mexico. Water-level rises range from less than 1 foot to more than 23 feet. The area has mixed rises and declines except for an area where declines are prevalent. The area of declines extends from north of Santa Fe to south and west of Santa Fe to T. 15 N., R. 8 E. and then turns eastward to T. 15 N., R. 10 E. Declines range from less than 1 foot to more than 19 feet. 

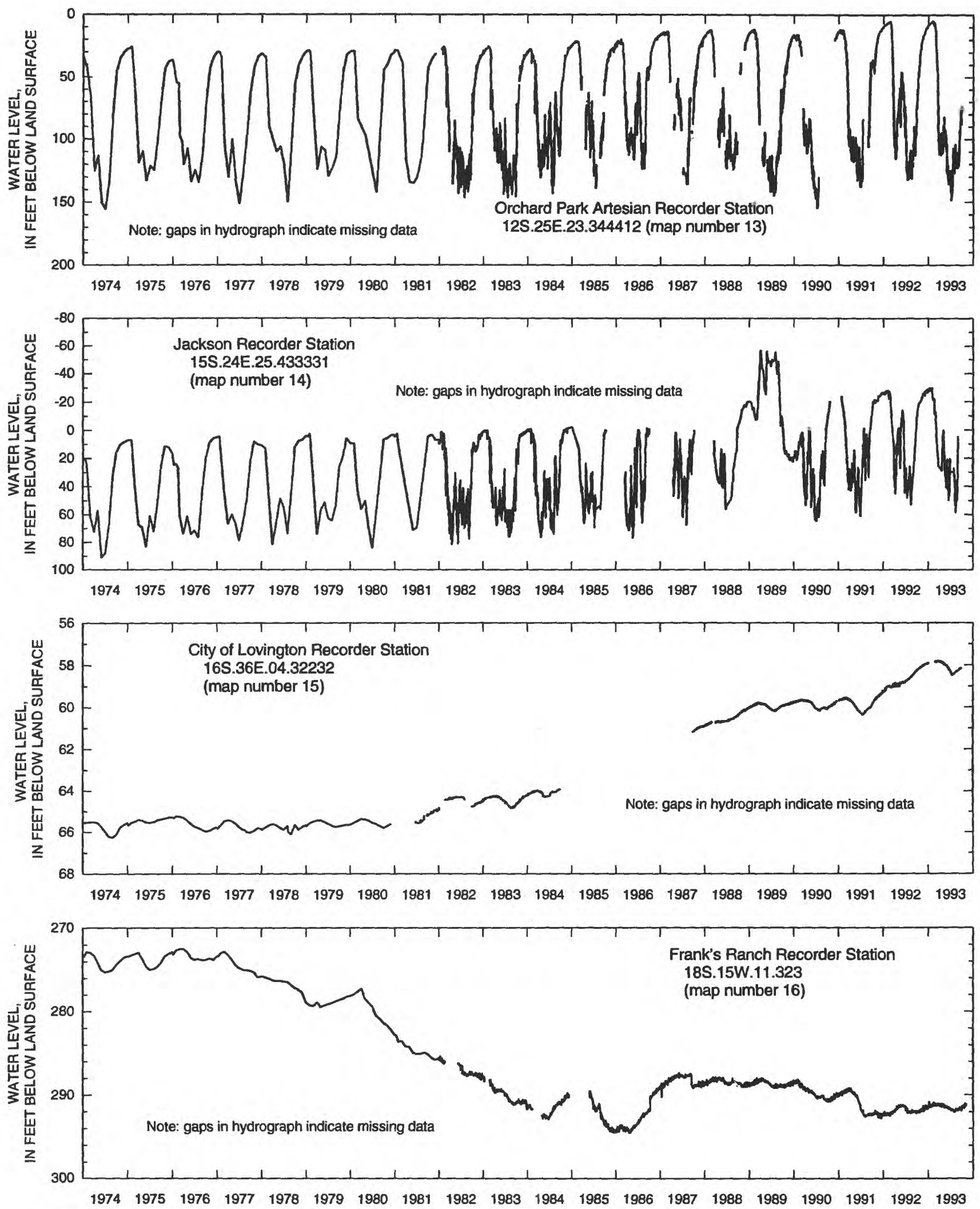

Figure 4.--Continuous water-level data for selected wells. See figure 2 and table 1 for locations--Continued. 

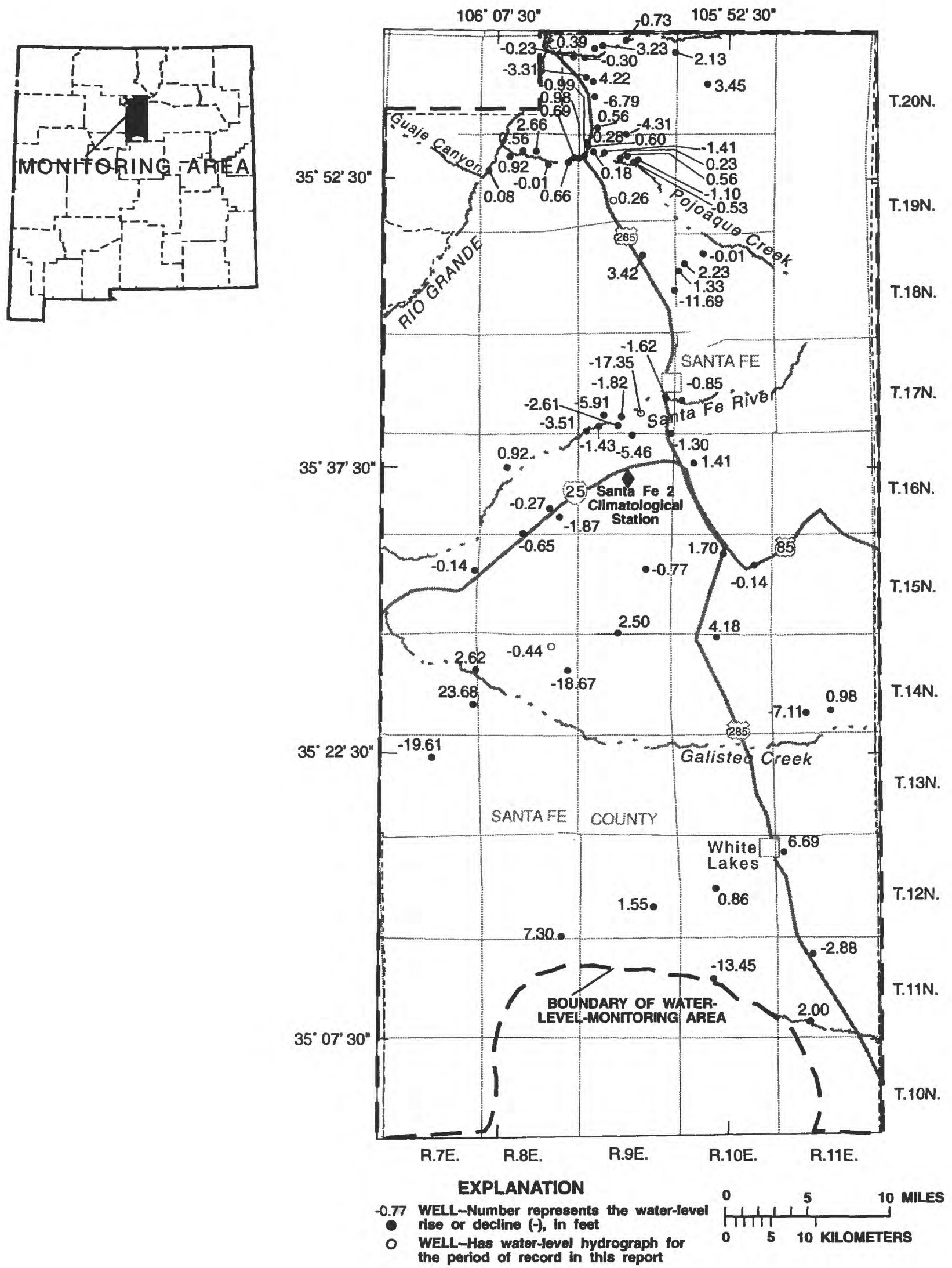

Figure 57.--Water-level changes for wells in the Santa Fe County monitoring area, 1988-93. 

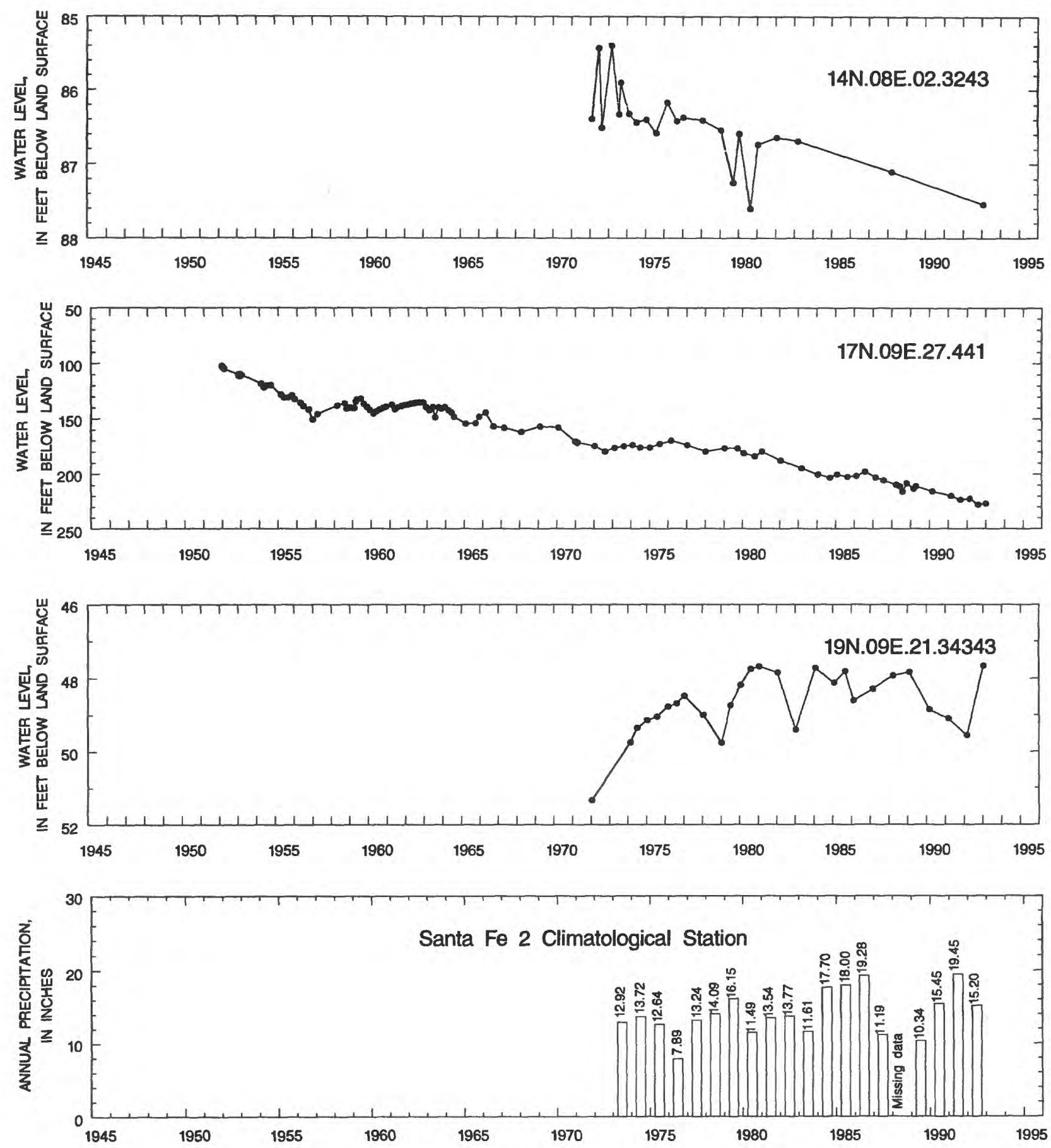

Figure 58.--Water-level data for selected wells in the Santa Fe County monitoring area and annual precipitation at the Santa Fe 2 Climatological Station. See figure 57 for location of wells and station. 


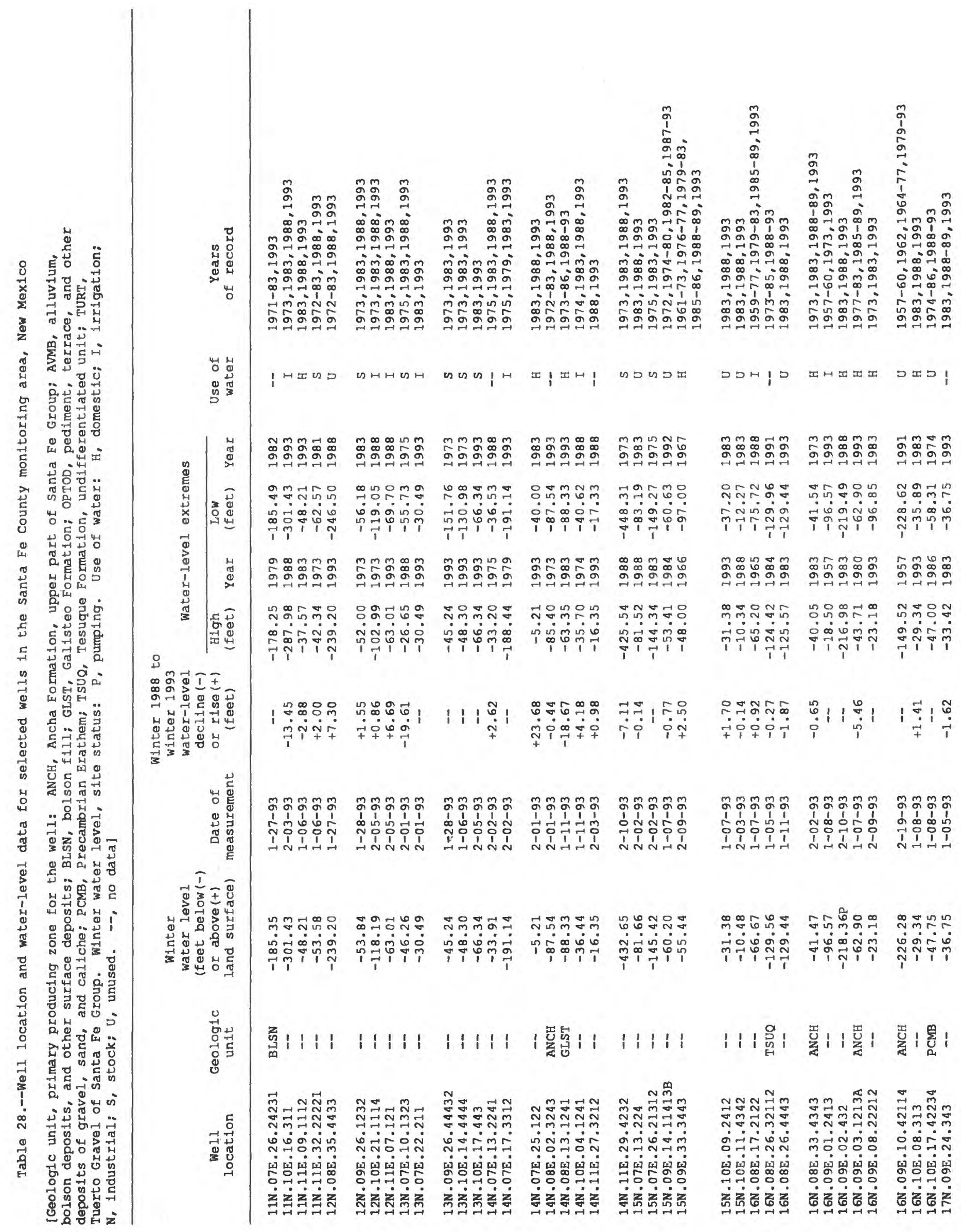




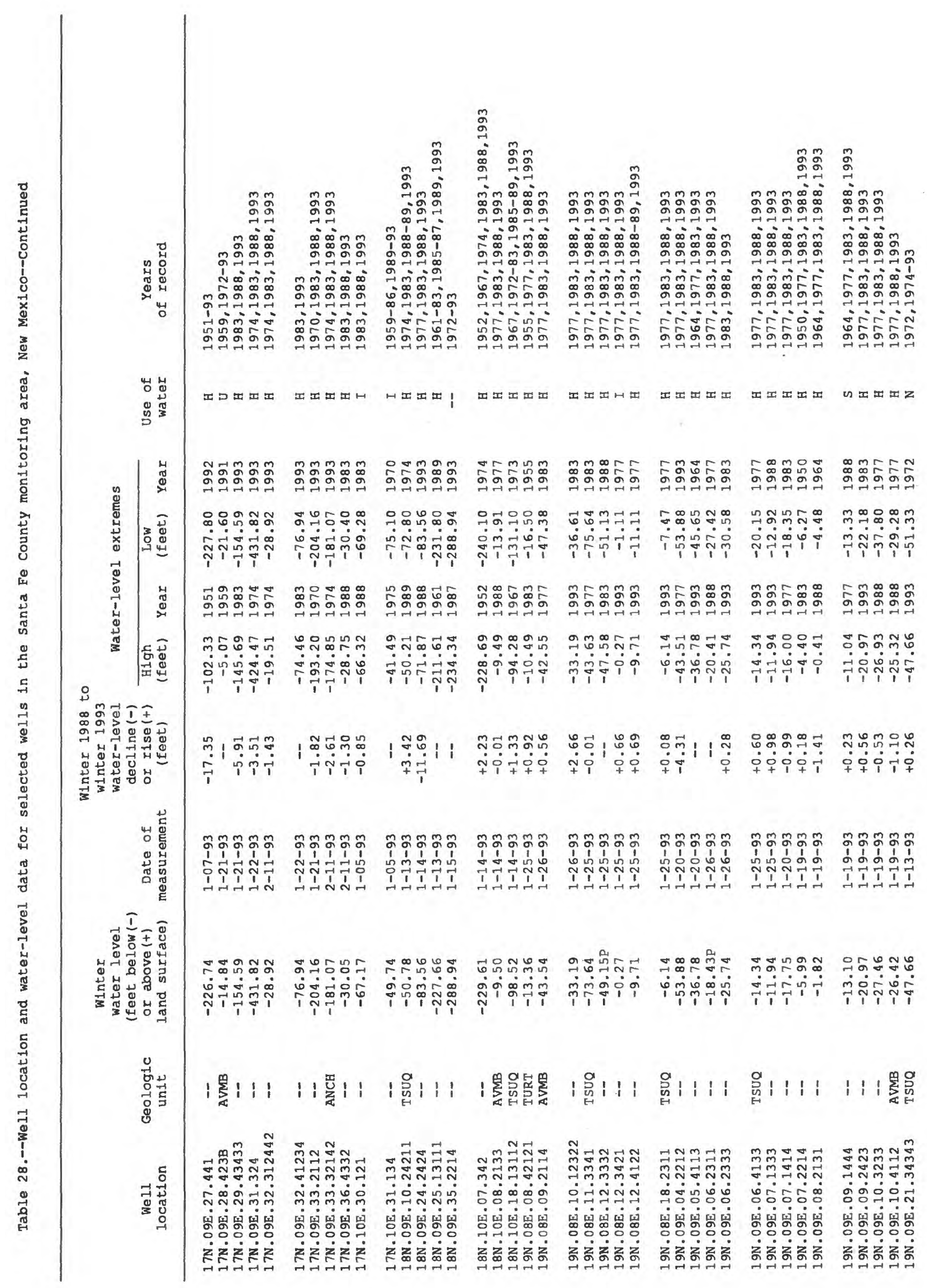




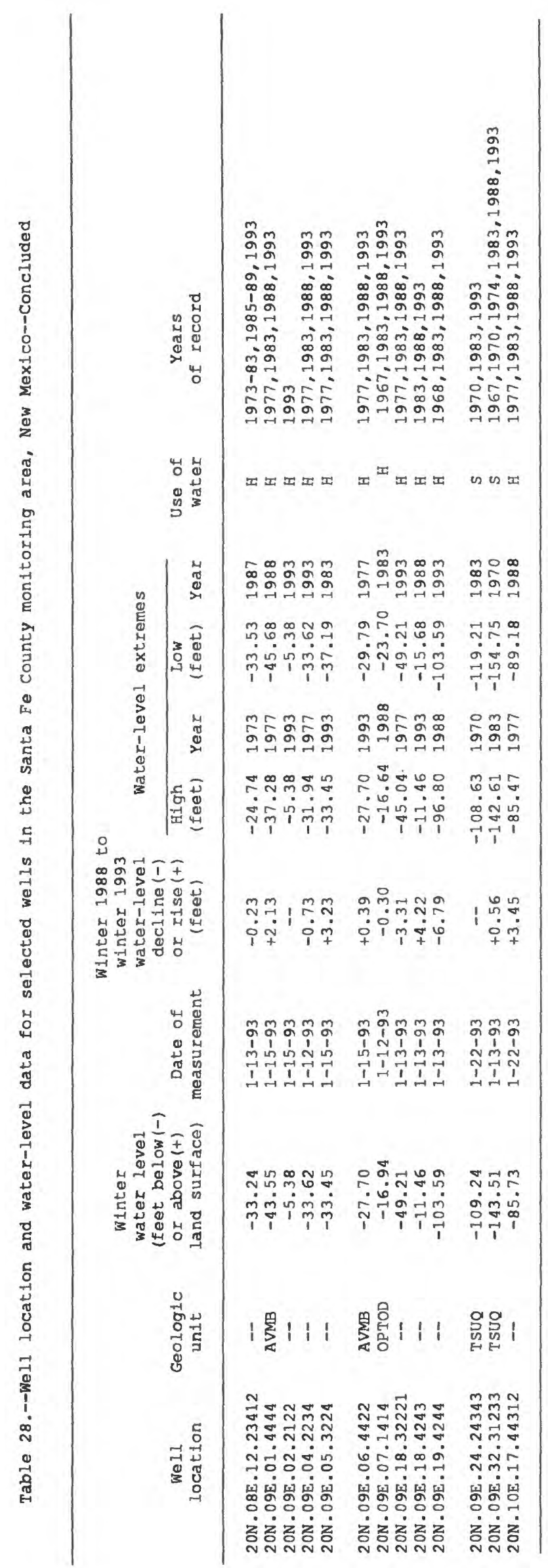




\section{Upper Rio Grande Monitoring Area}

The Upper Rio Grande monitoring area is in Taos and Rio Arriba Counties, north-central New Mexico, and a small area in Costilla County, Colorado. Water-level changes are mostly rises that range from less than 1 foot to more than 5 feet. A small area north of Cerro, New Mexico, has water-level declines that range from less than 1 foot to more than 3 feet. 

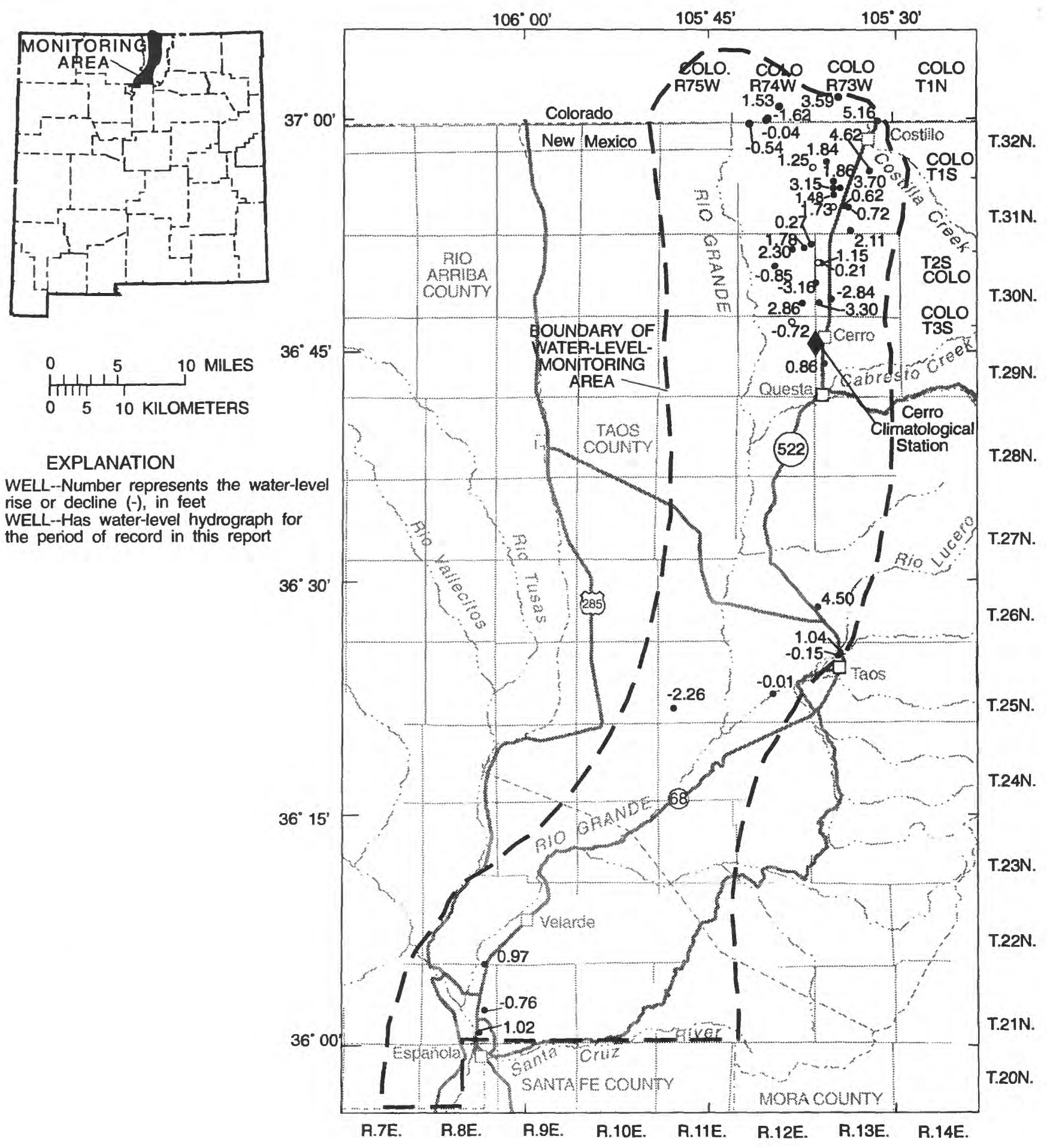

\section{EXPLANATION}

1.78 WELL--Number represents the water-leve rise or decline $(-)$, in feet WELL--Has water-level hydrograph for the period of record in this report

Figure 59.--Water-level changes for wells in the Upper Rio Grande monitoring area, 1988-93. 

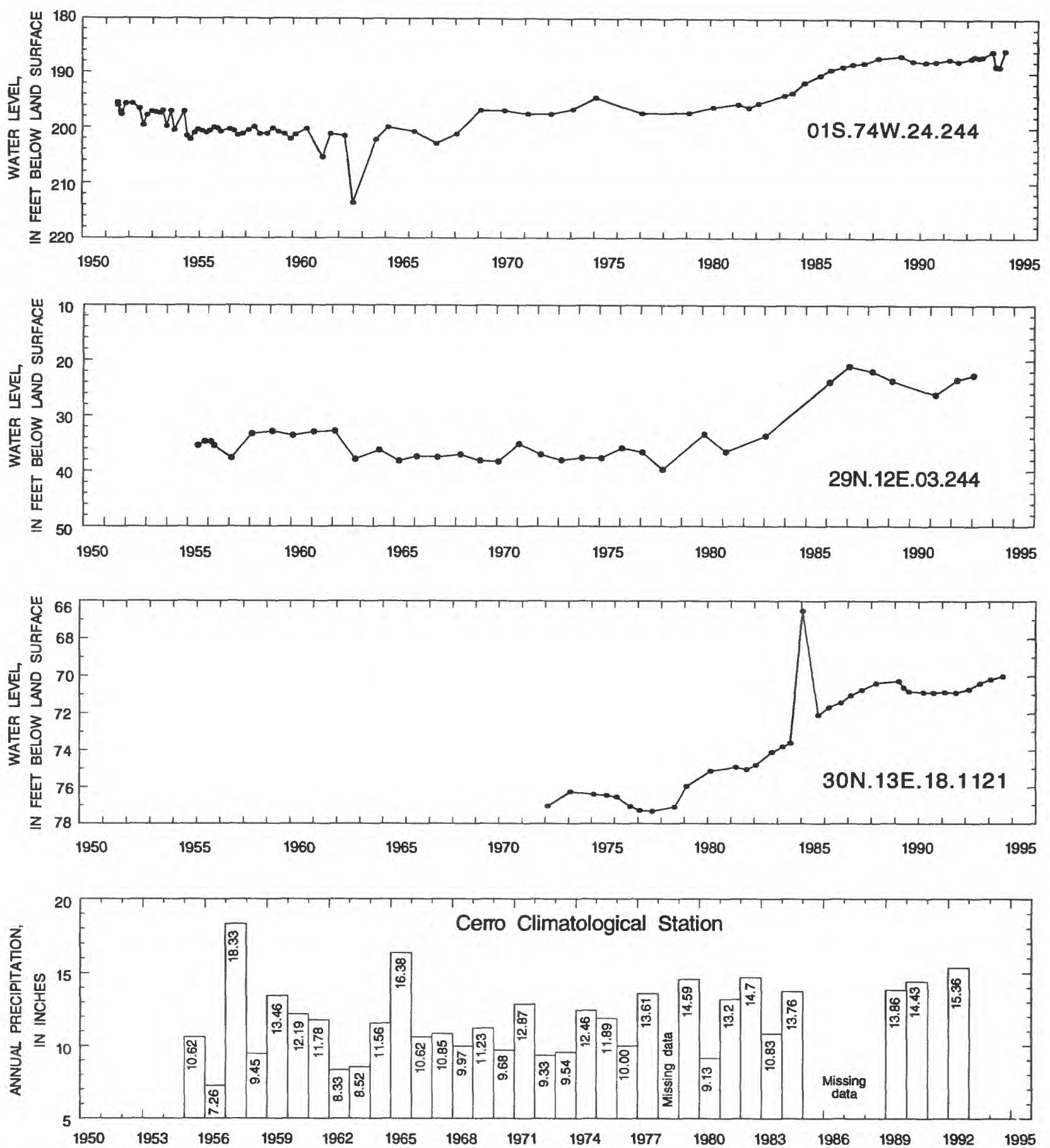

Figure 60.--Water-level data for selected wells in the Upper Rio Grande monitoring area and annual precipitation at the Cerro Climatological Station. See figure 59 for location of wells and station. 


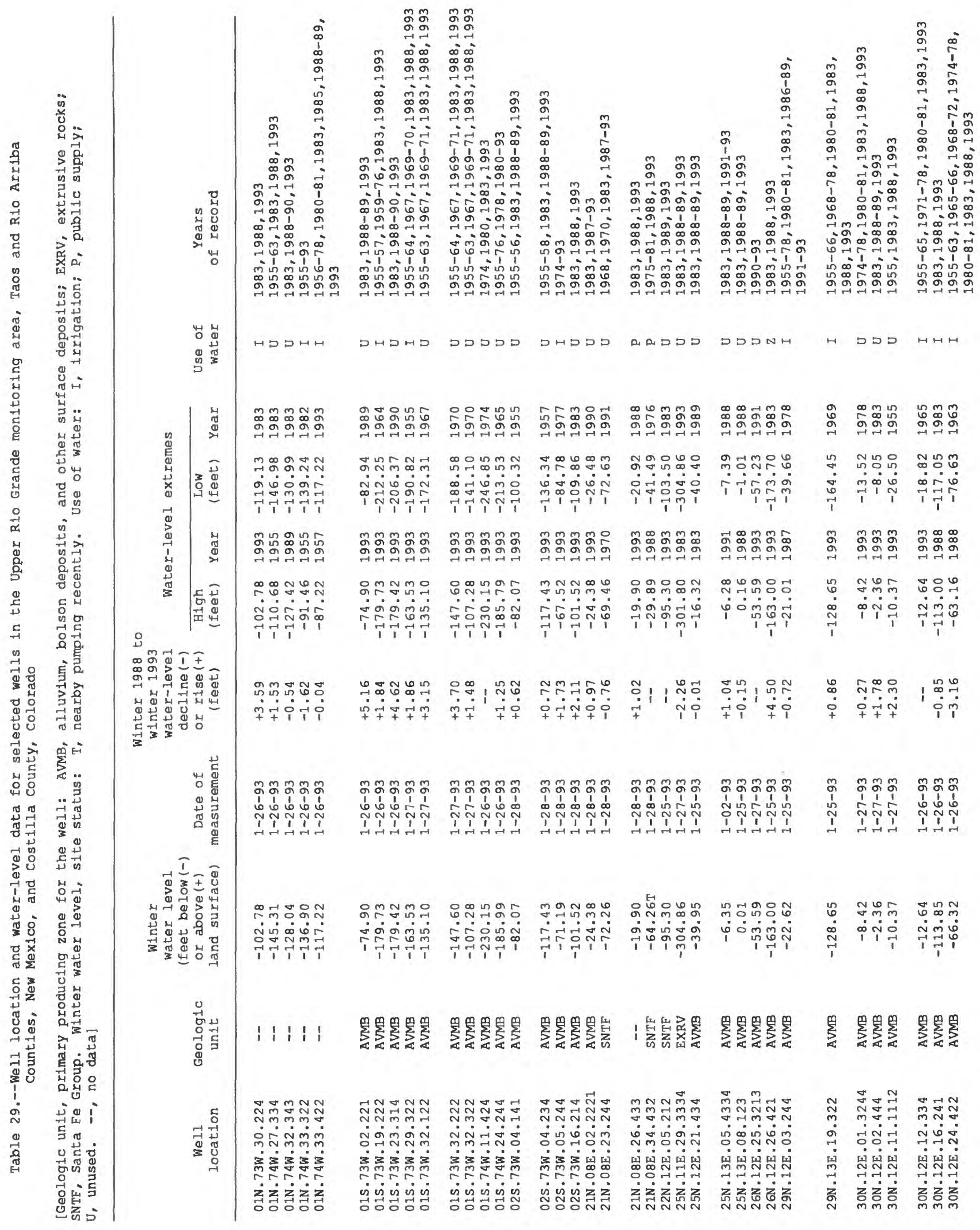




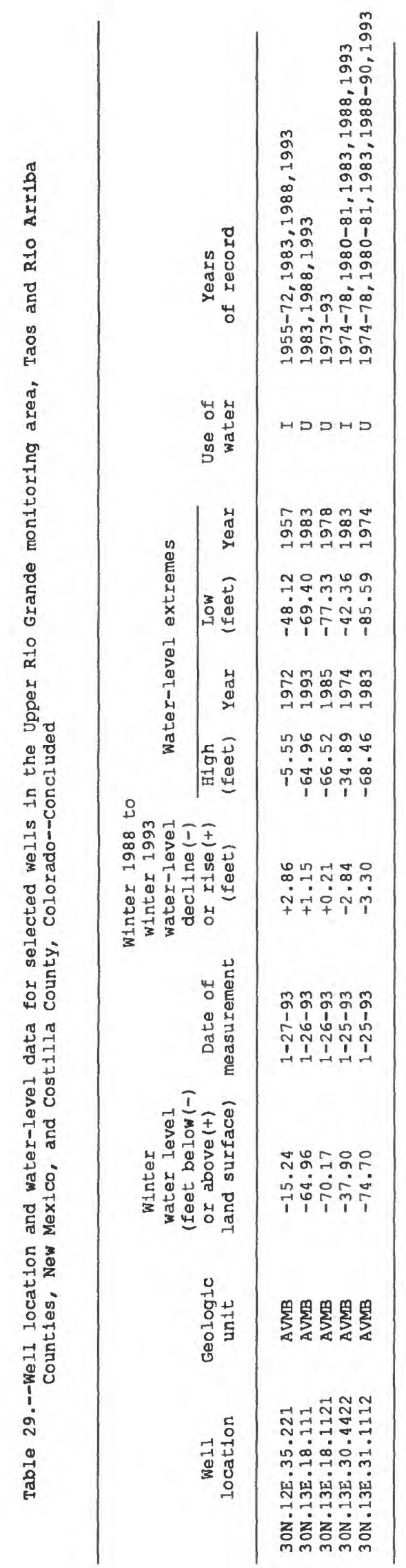



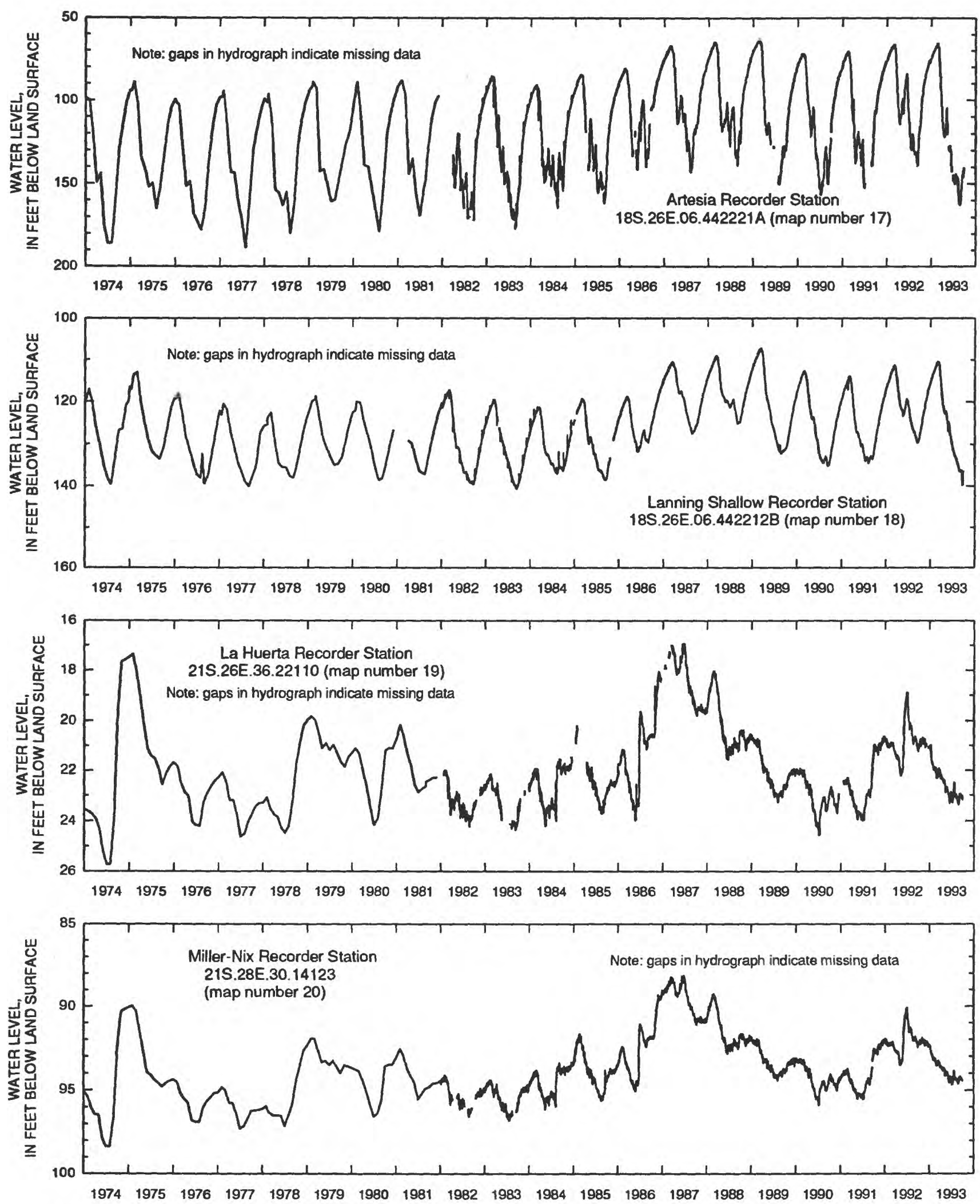

Figure 4.--Continuous water-level data for selected wells. See figure 2 and table 1 for locations--Continued. 


\section{Roswell Basin Monitoring Area (Shallow and Artesian)}

The Roswell Basin monitoring area is in Chaves, DeBaca, and Eddy Counties, southeastern New Mexico. Maps, tables, and hydrographs separate water-level data for the shallow and artesian wells within the monitoring area. Not all water-level changes are shown on the maps; however, all well locations and water-level data are listed in the tables. Well locations marked with an asterisk (*) in the table are plotted on the map.

Water-level changes for the shallow wells are mostly rises ranging from less than 1 foot to more than 34 feet. Declines are generally scattered throughout the area. Declines are shown in a small area in Tps. 14 and 15 S., Rs. 24 through 26 E. and in an area north of T. 7 S. Declines range from less than 1 foot to more than 4 feet.

Water-level changes for wells completed in the artesian aquifer are mostly rises. These rises range from less than 1 foot to more than 56 feet. Declines are scattered throughout the monitoring area and range from less than 1 foot to more than 14 feet. 

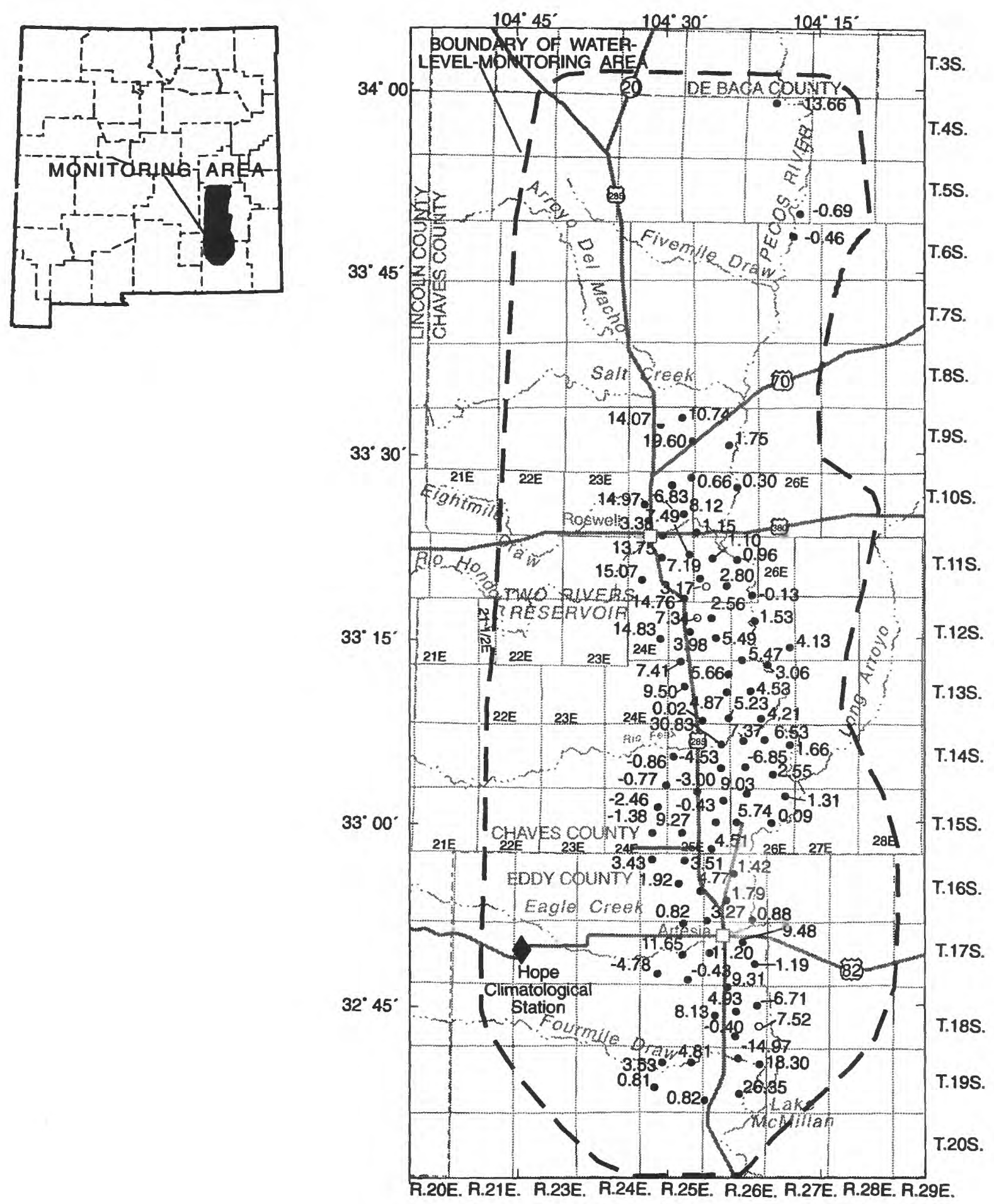

EXPLANATION

-0.77 WELL-Number represents the water-level

- rise or decline $(-)$, in feet

WELL-Has water-level hydrograph for
the period of record in this report

Figure 61.--Water-level changes for selected shallow wells in the Roswell Basin monitoring area, 1984-89. 

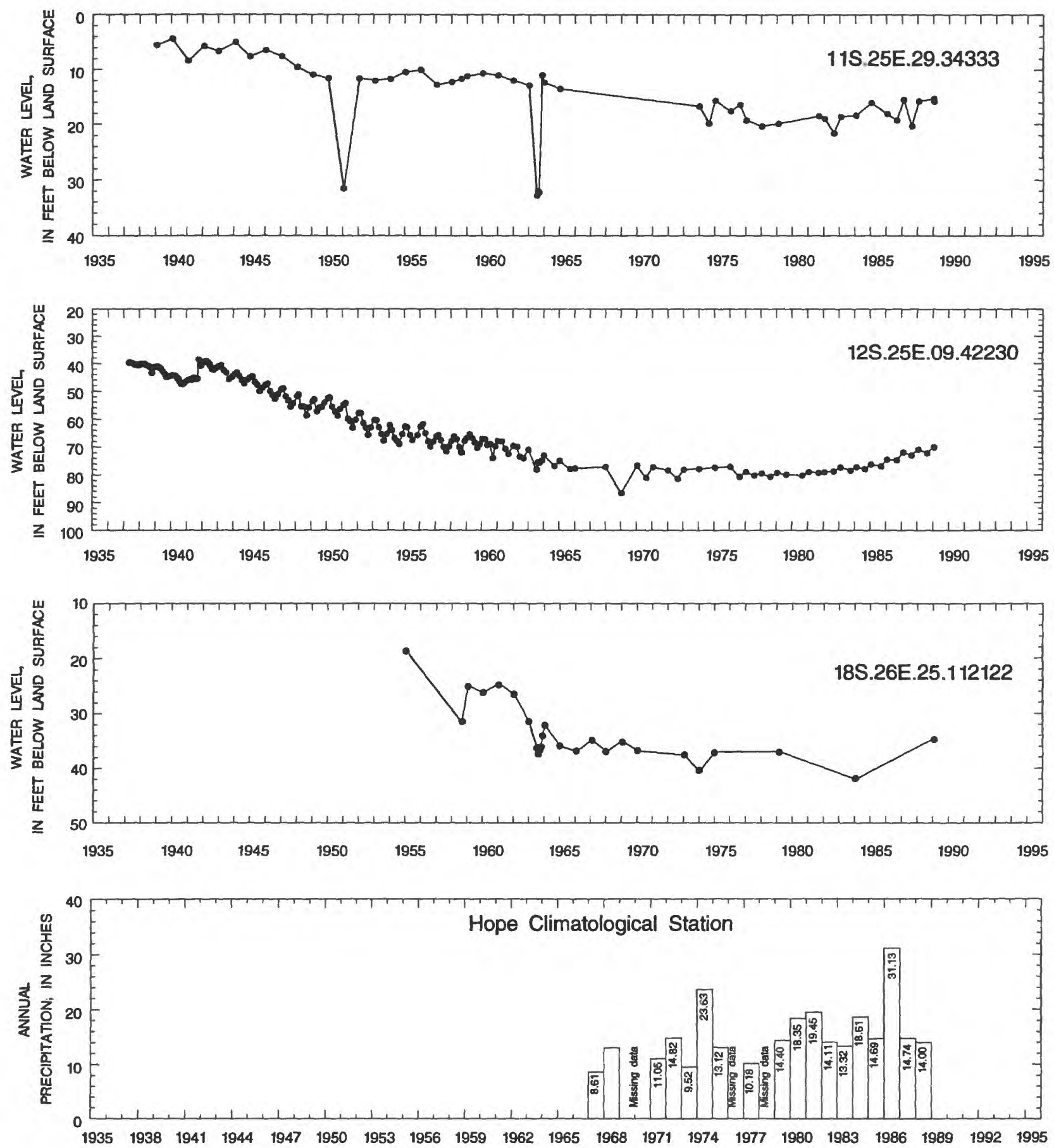

Figure 62.--Water-level data for selected shallow wells in the Roswell Basin monitoring area and annual precipitation at the Hope Climatological Station. See figure 61 for location of wells and station. 


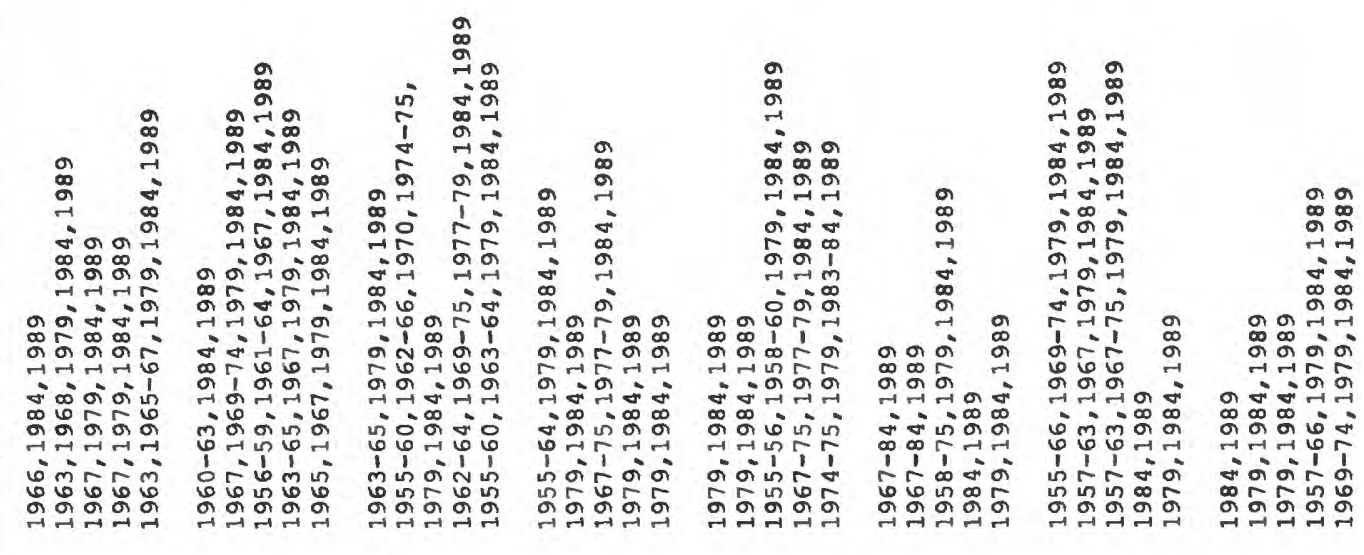

ル๐ロロル<smiles>C=[18O]</smiles>

\section{ळळळ} (2)

서에

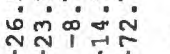

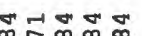

政

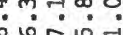

\section{min \\ 5}

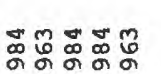
ơन

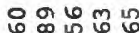
in

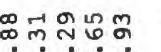

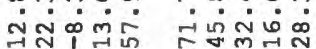

กำ

垔

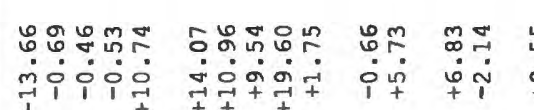
1 1

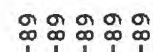

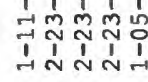

이용

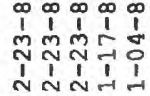

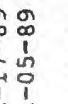 \\ 綒}

의용요

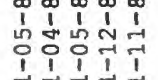

\section{a क्षे}

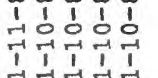

111

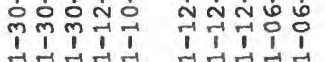

क이용

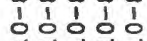

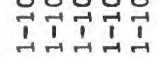

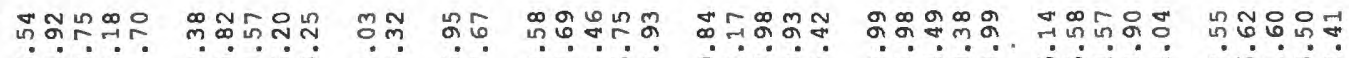

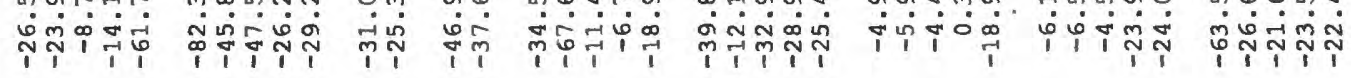

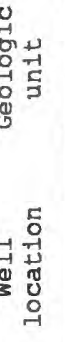

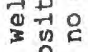
*.8 


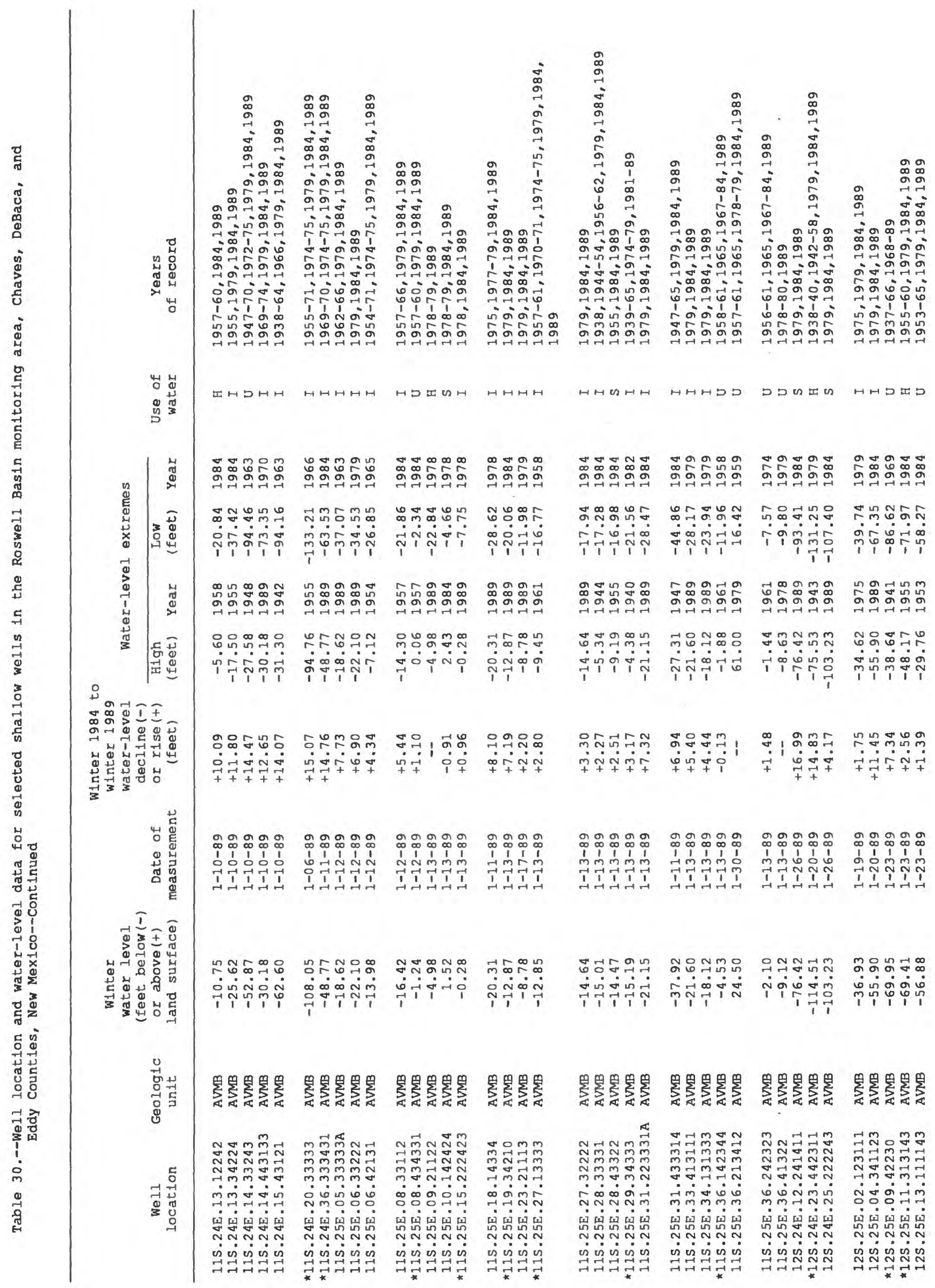




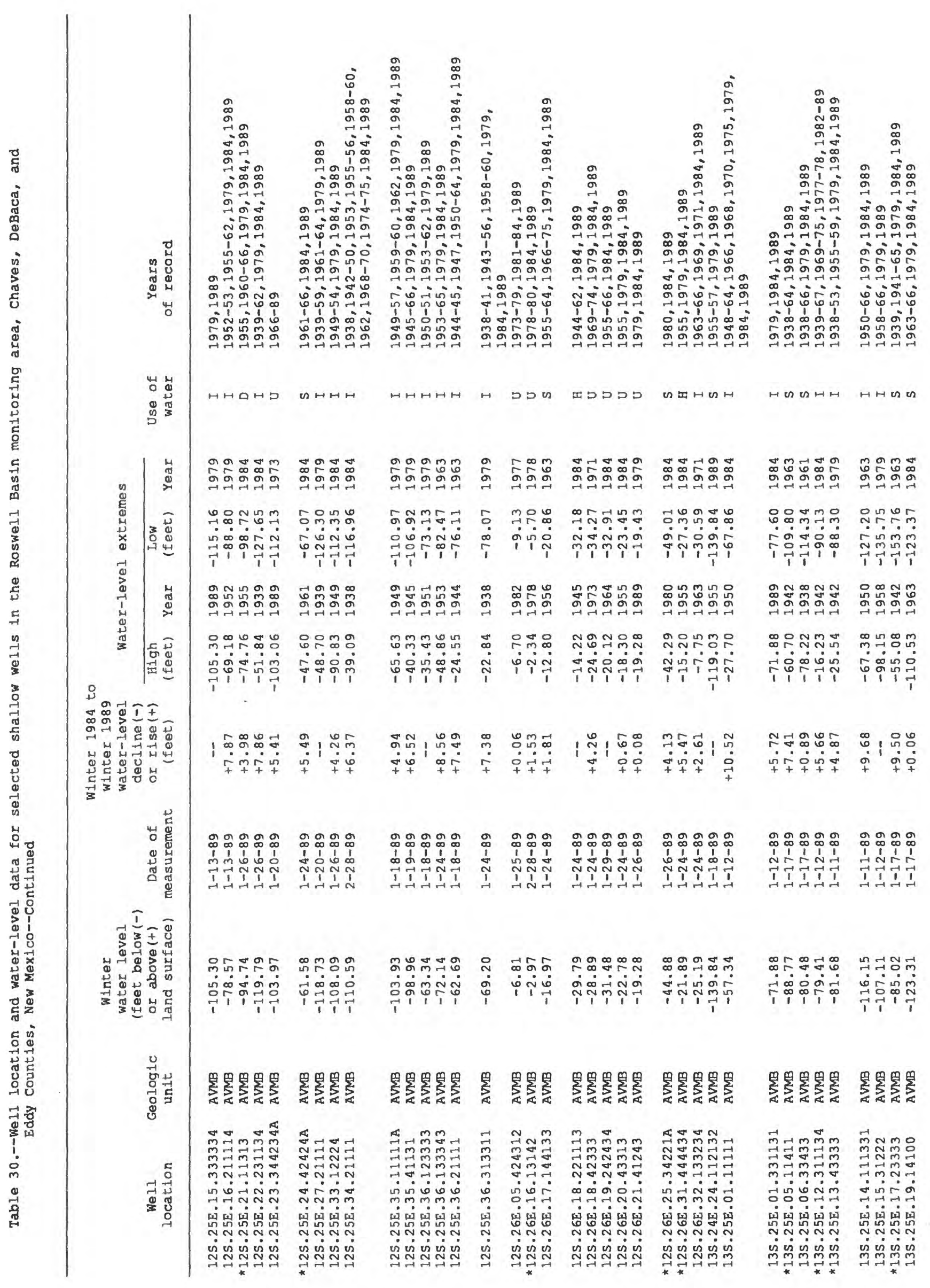




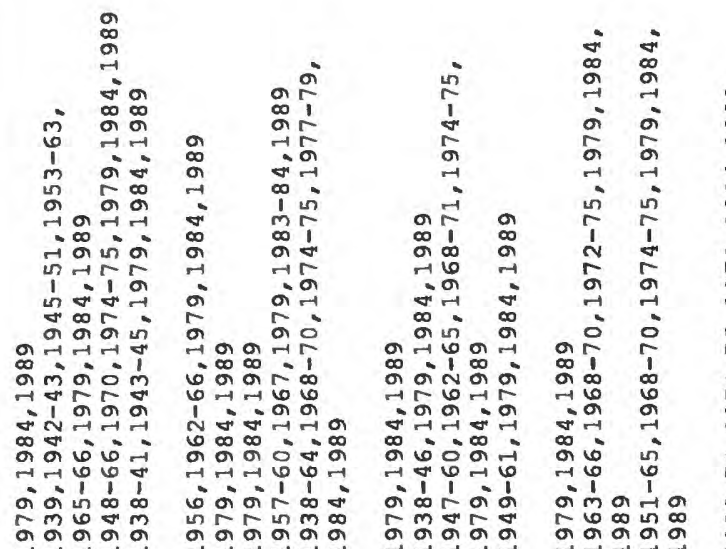

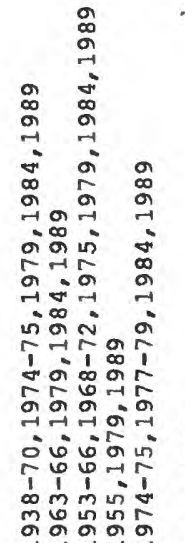
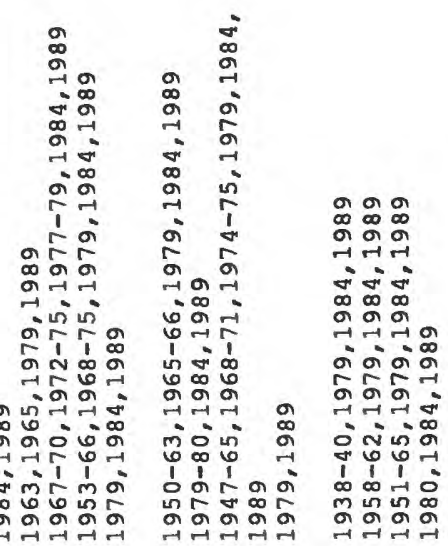

出嵒 范

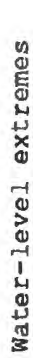

웅

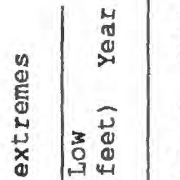

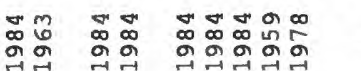

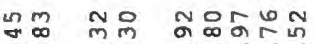

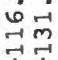

तิ

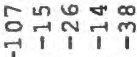

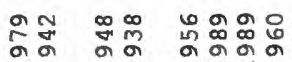

-

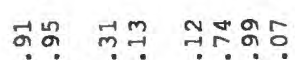

吾等

赵出

नें

क्न

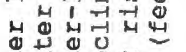

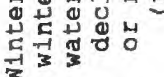

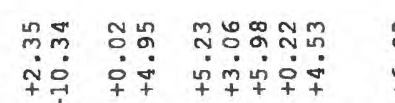

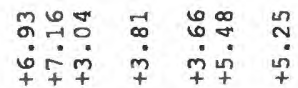

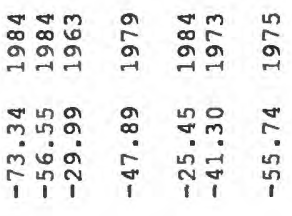

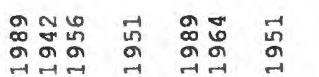

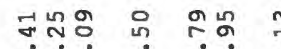

过苛

\section{중ํำ}

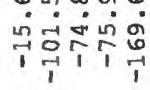

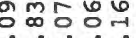

कंजिक्ष
2
0
0
10
10
エேトル
葋

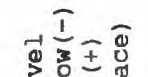

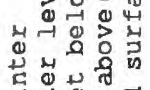

牙紫然总

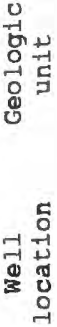

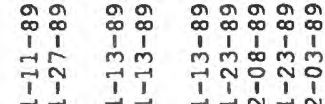
$\rightarrow$

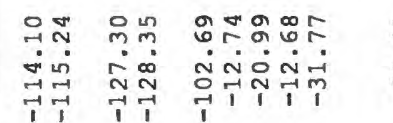

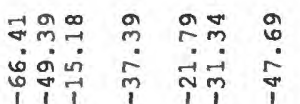

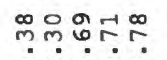

ज्ञलत्रत्र

옹ํㅜㅇำ

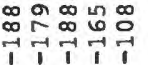

둥으 우 눙유용

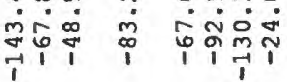

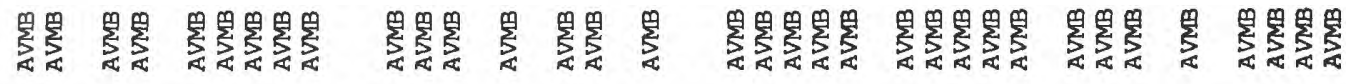

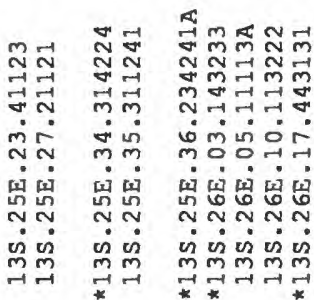

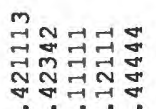

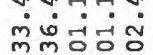

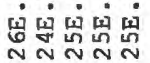

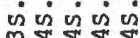

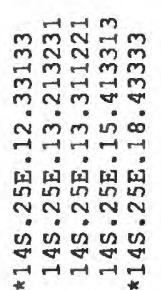

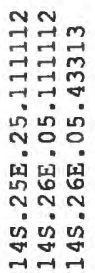

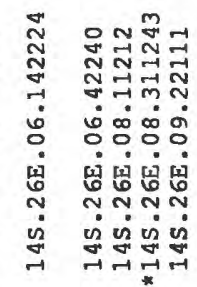




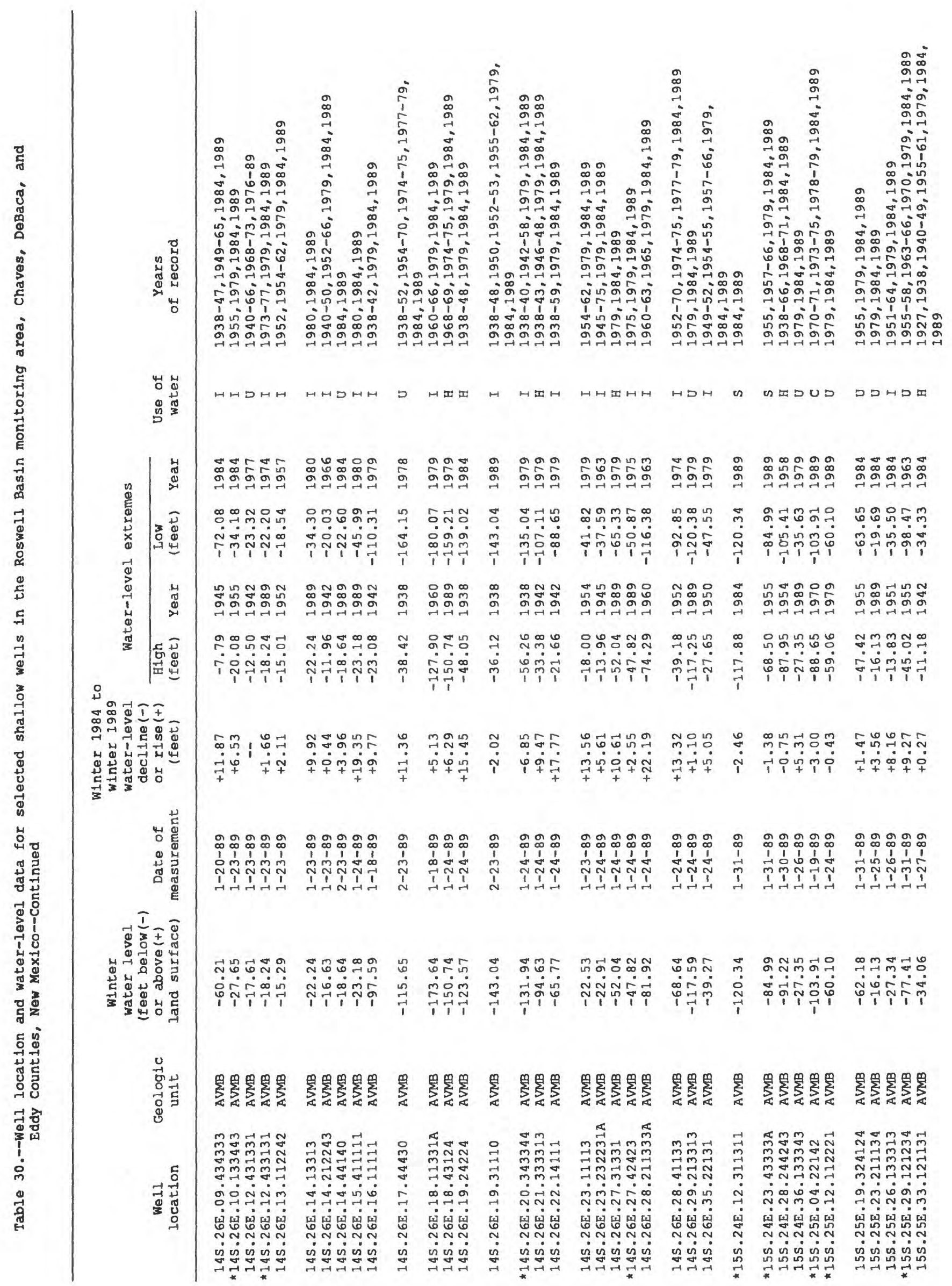




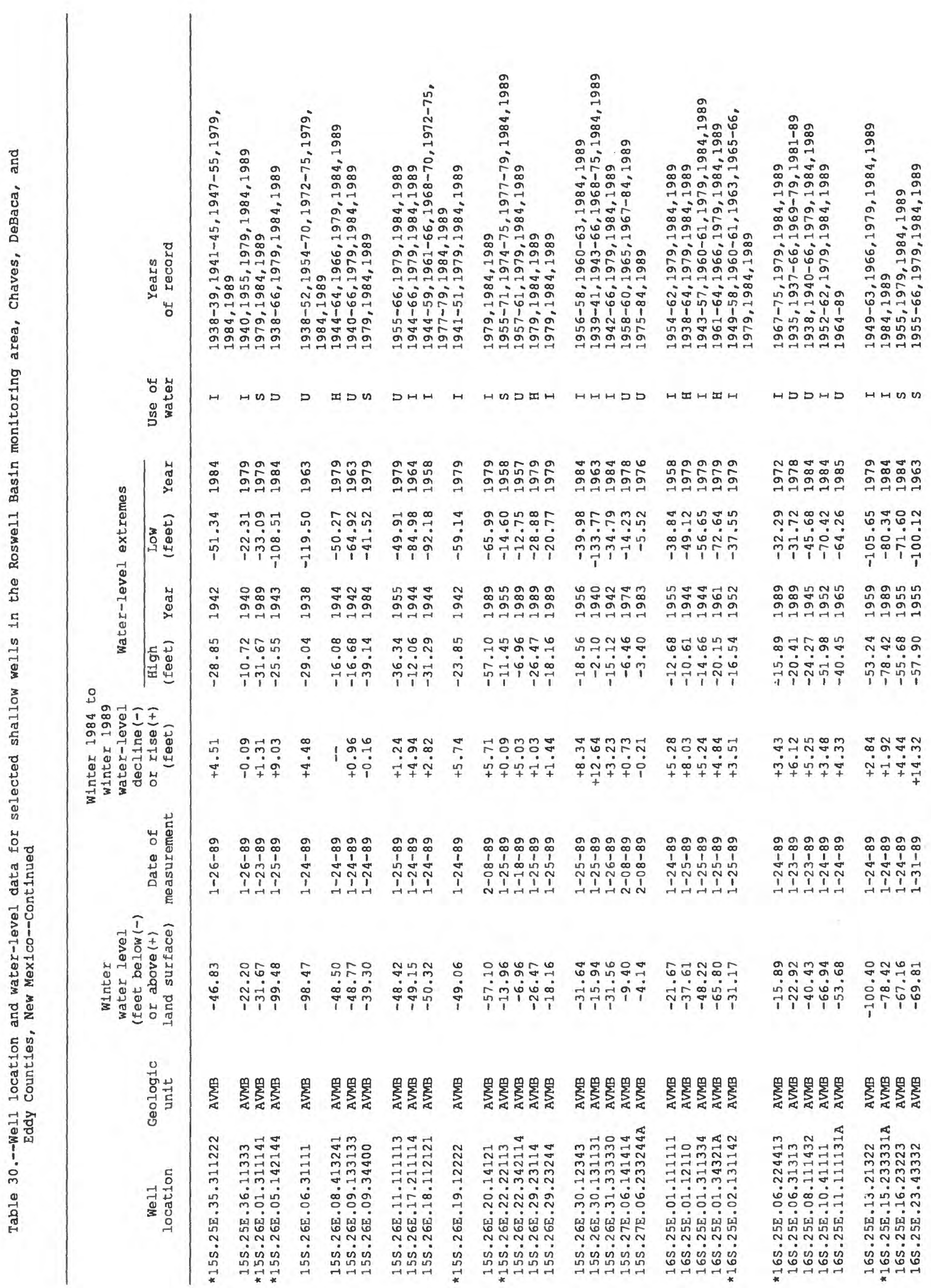




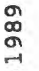

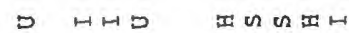<smiles>C1CCCCCC1</smiles>

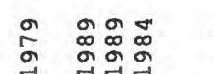

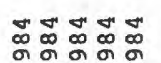

㤐恕

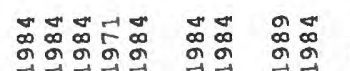

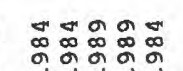

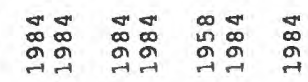

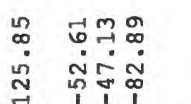

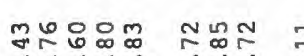

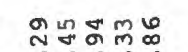

\%क

윰

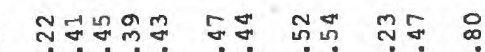
1 i

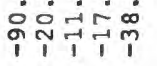

किं

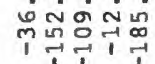

ำ

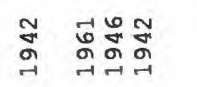

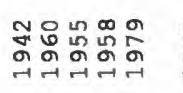

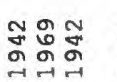

要

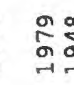

it

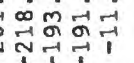

क्षे

₹ พูํํำ

कृ⿰彳

0
0
0
0
0
0

जे

অ워요

సั่

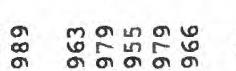

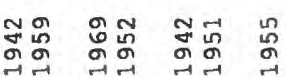

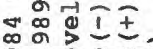

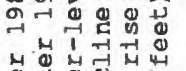

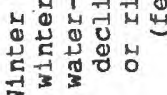

ก.

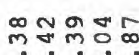

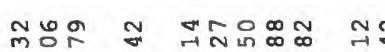

$\infty$

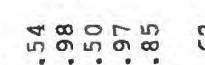

๓

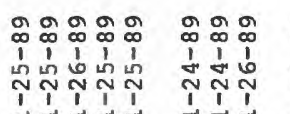

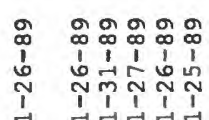

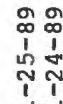

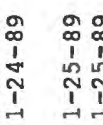

o

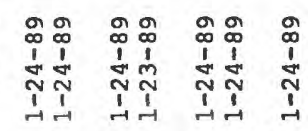

豪高现

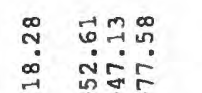

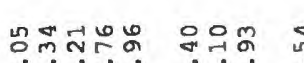

近

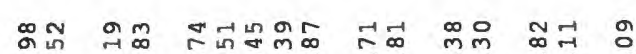

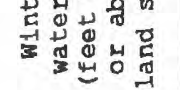
1
$\rightarrow$

क्षेत्र

†i்

कंक्षेत्र

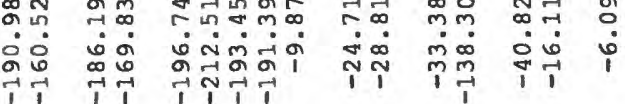

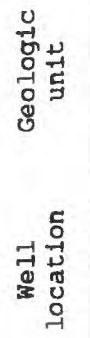

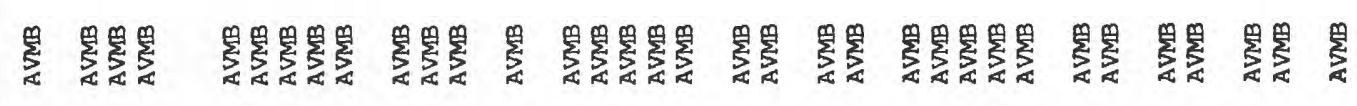

N

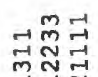

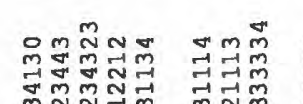

क्लुल ज़

ᄃ의

혀त

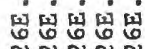

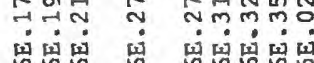

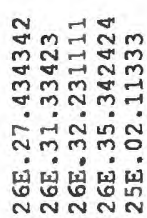

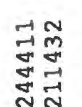

幽

.

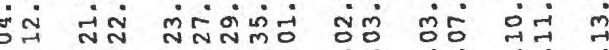

蕰

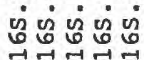

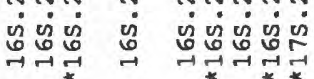

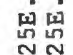

서

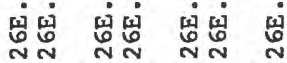

$\vec{x}$ 

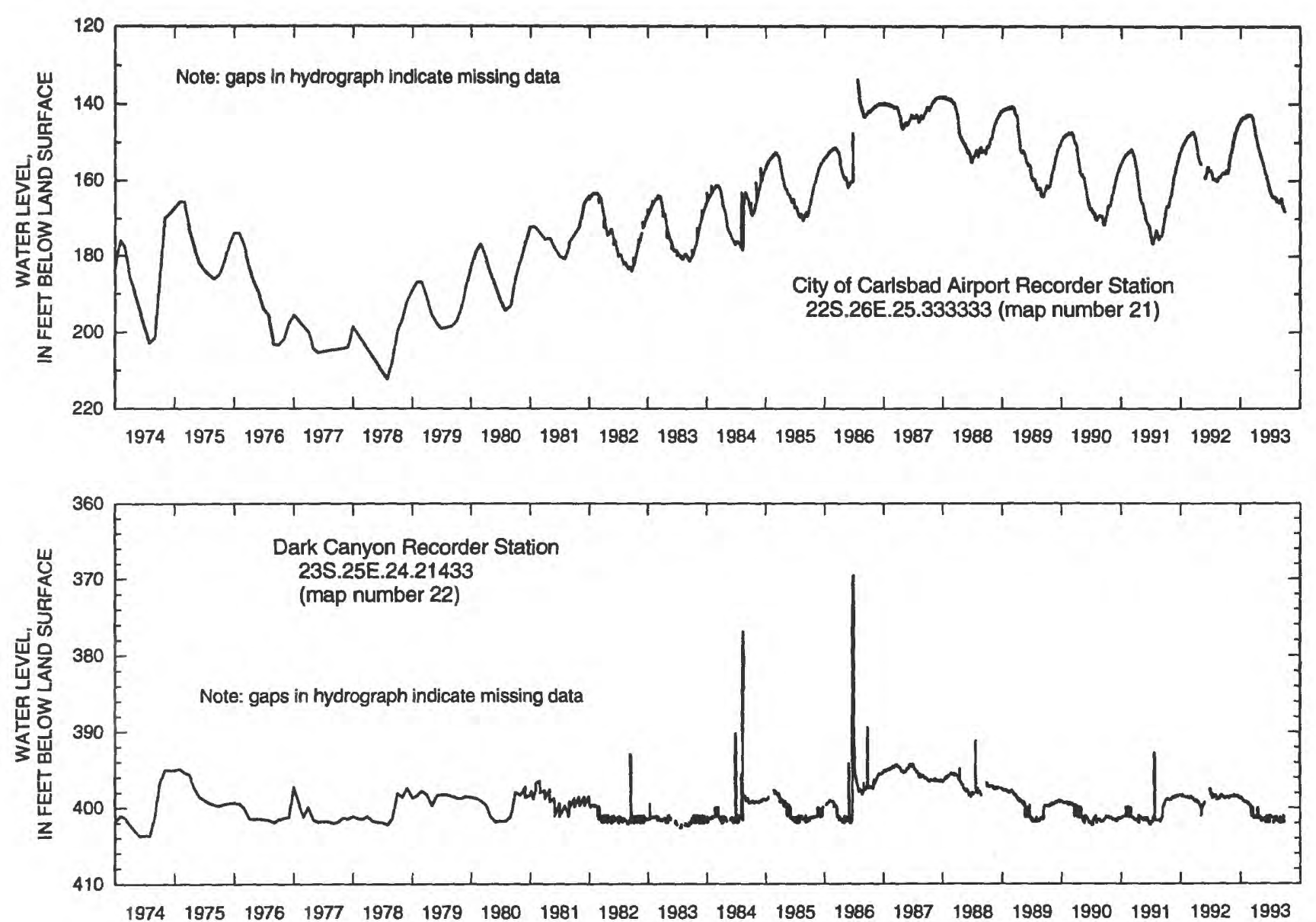

Figure 4.--Continuous water-level data for selected wells. See figure 2 and table 1 for locations--Concluded. 


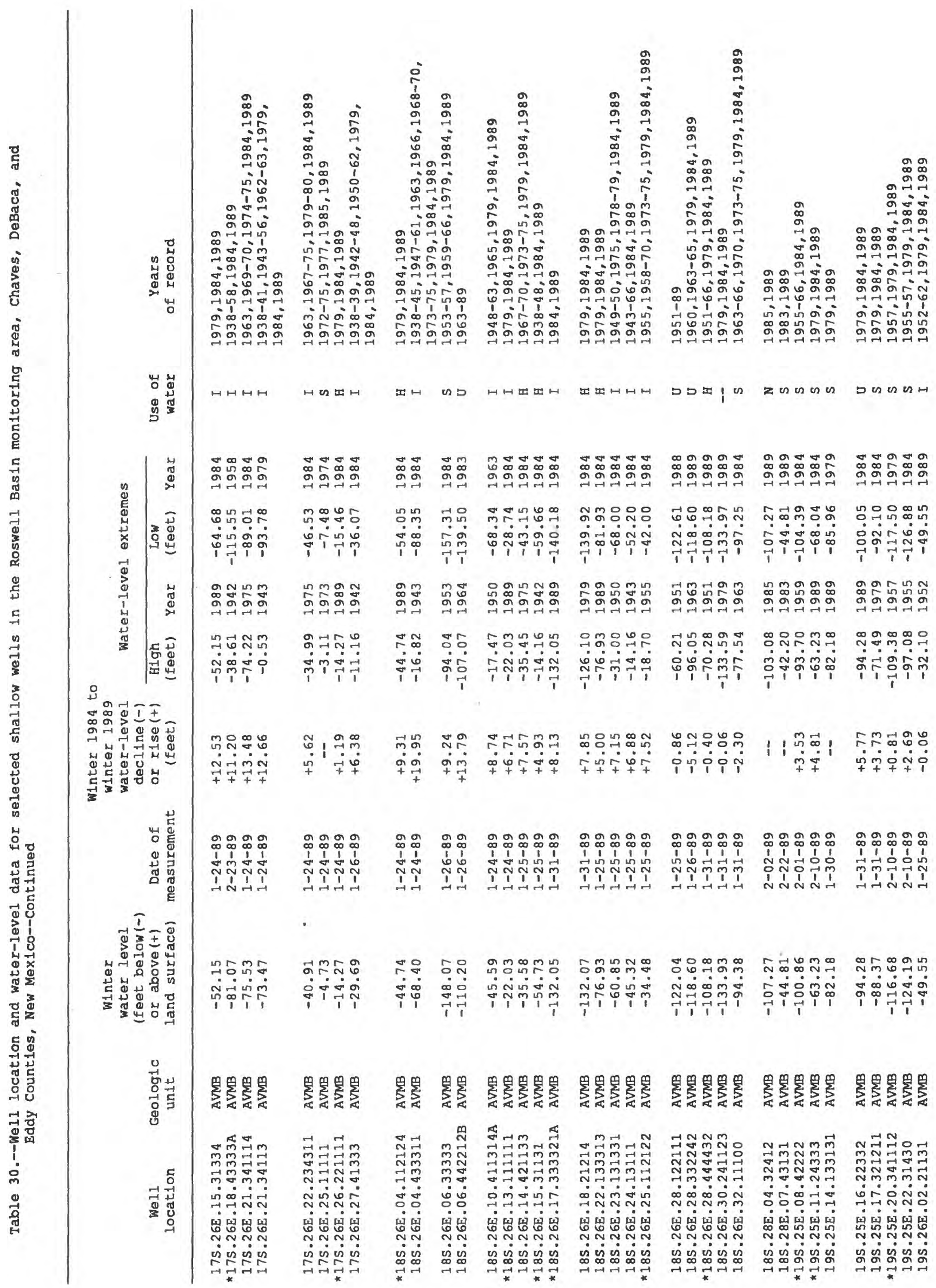




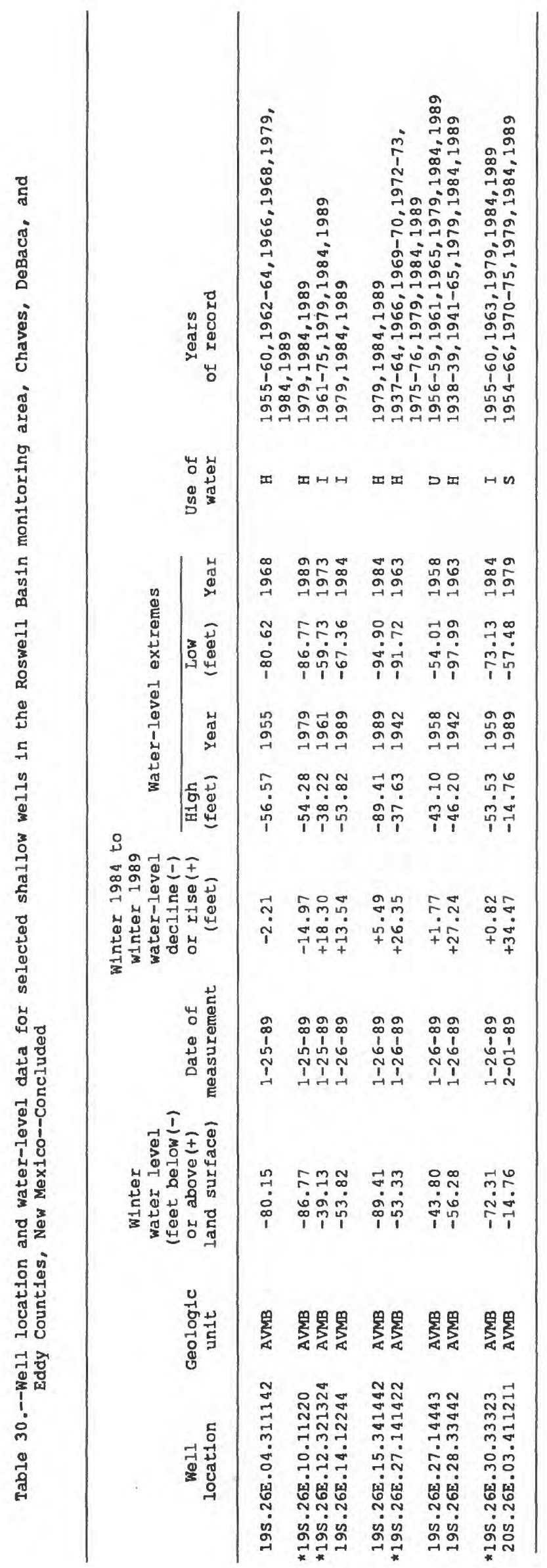



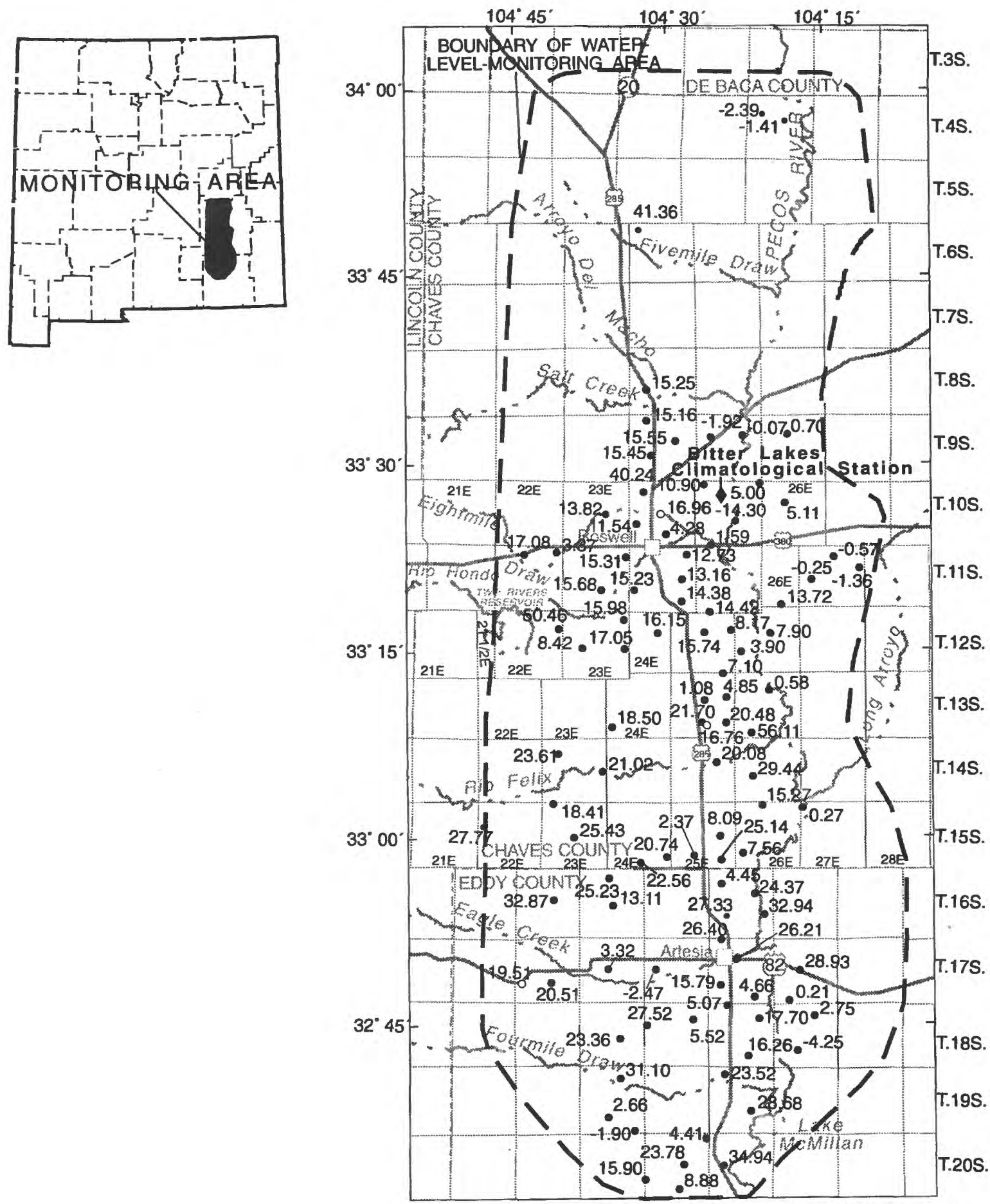

R.21E. R.23E. R.24E. R.25E. R.26E. R.27E. R.28E. R.29E.

\section{EXPLANATION}

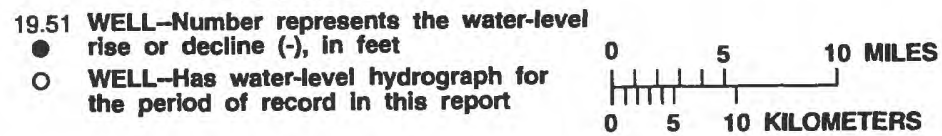

Figure 63.--Water-level changes for selected artesian wells in the Roswell Basin monitoring area, 1984-89. 

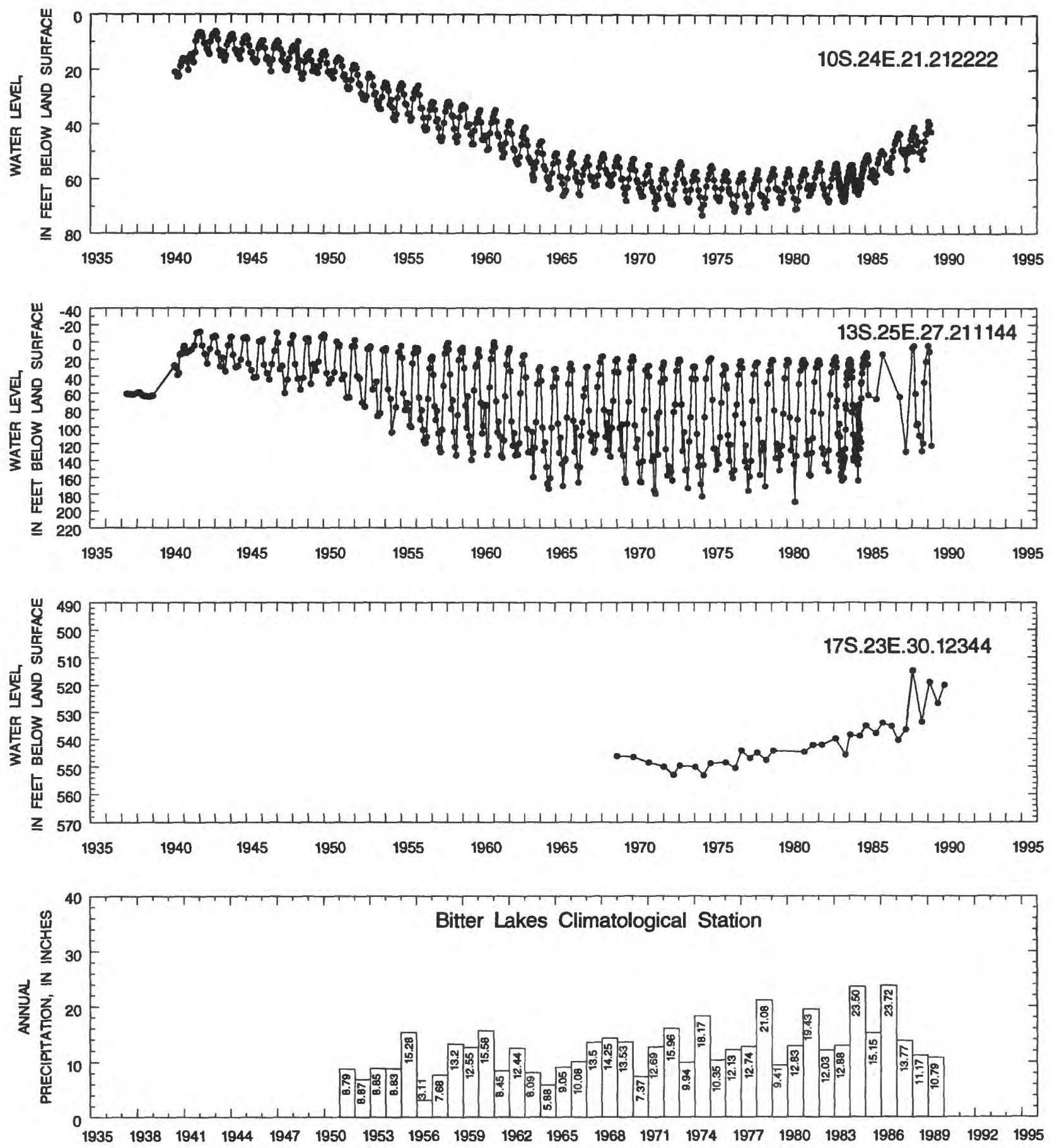

Figure 64.--Water-level data for selected artesian wells in the Roswell Basin monitoring area and annual precipitation at the Bitter Lakes Climatological Station. See figure 63 for location of wells and station. 


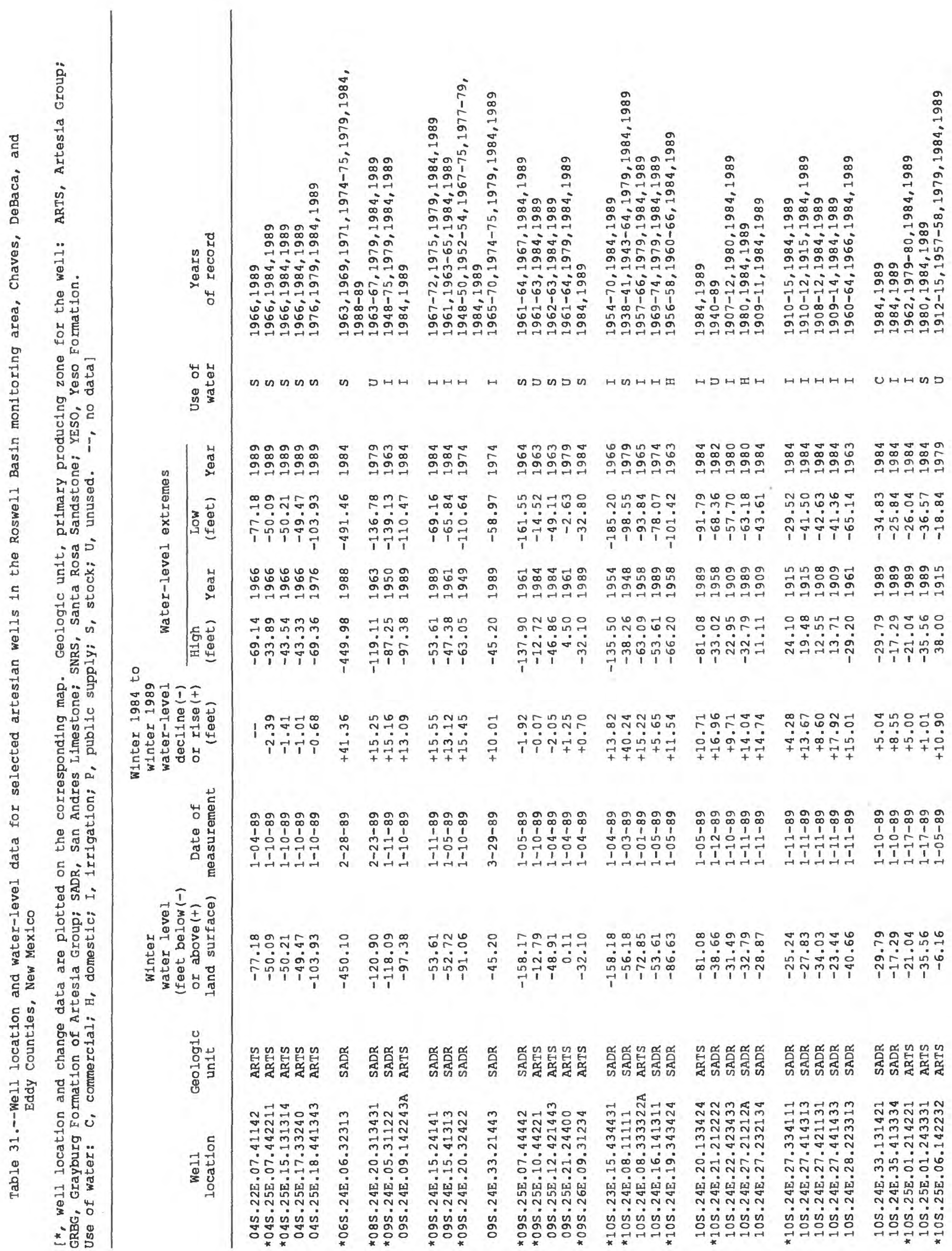




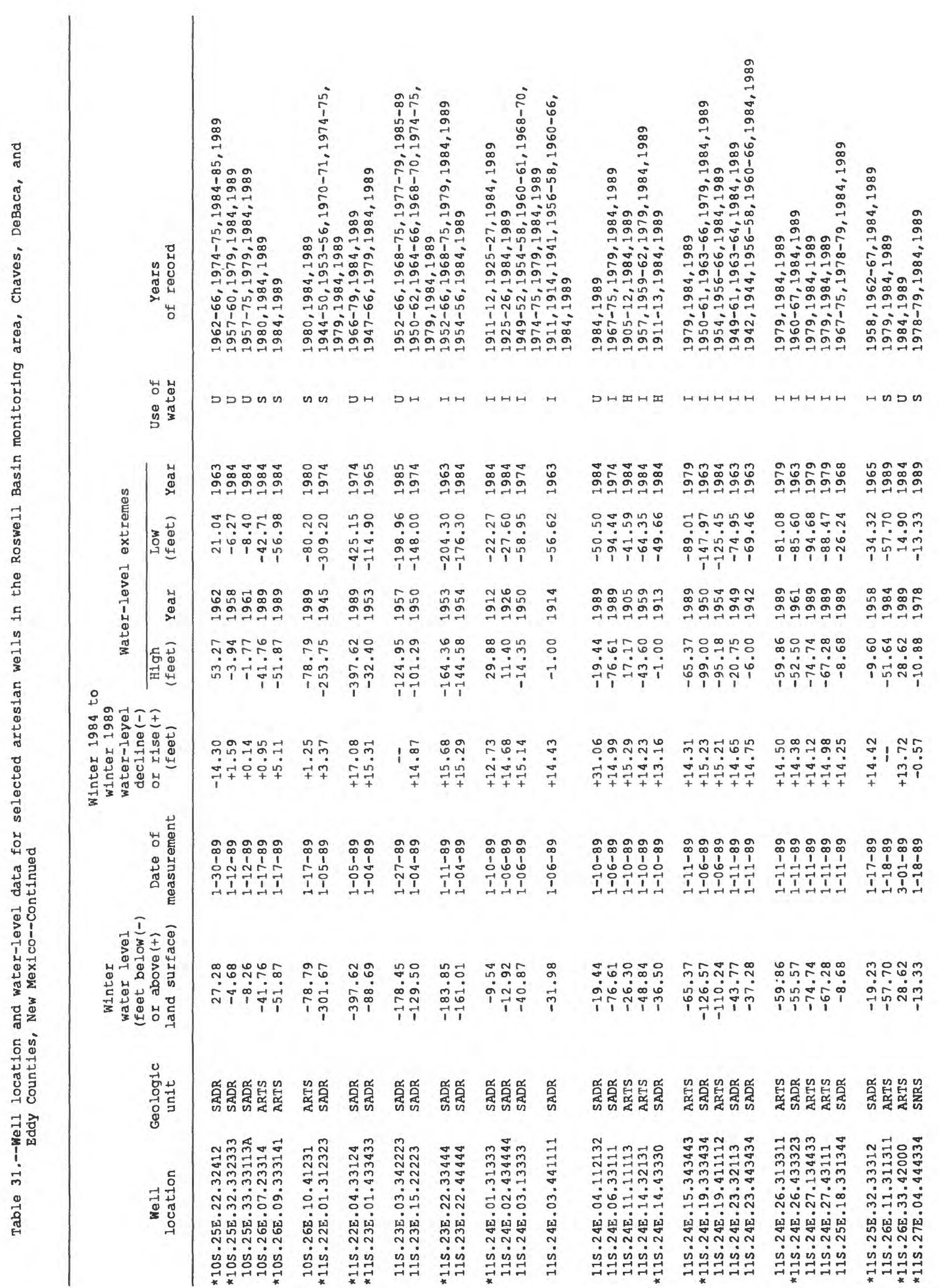




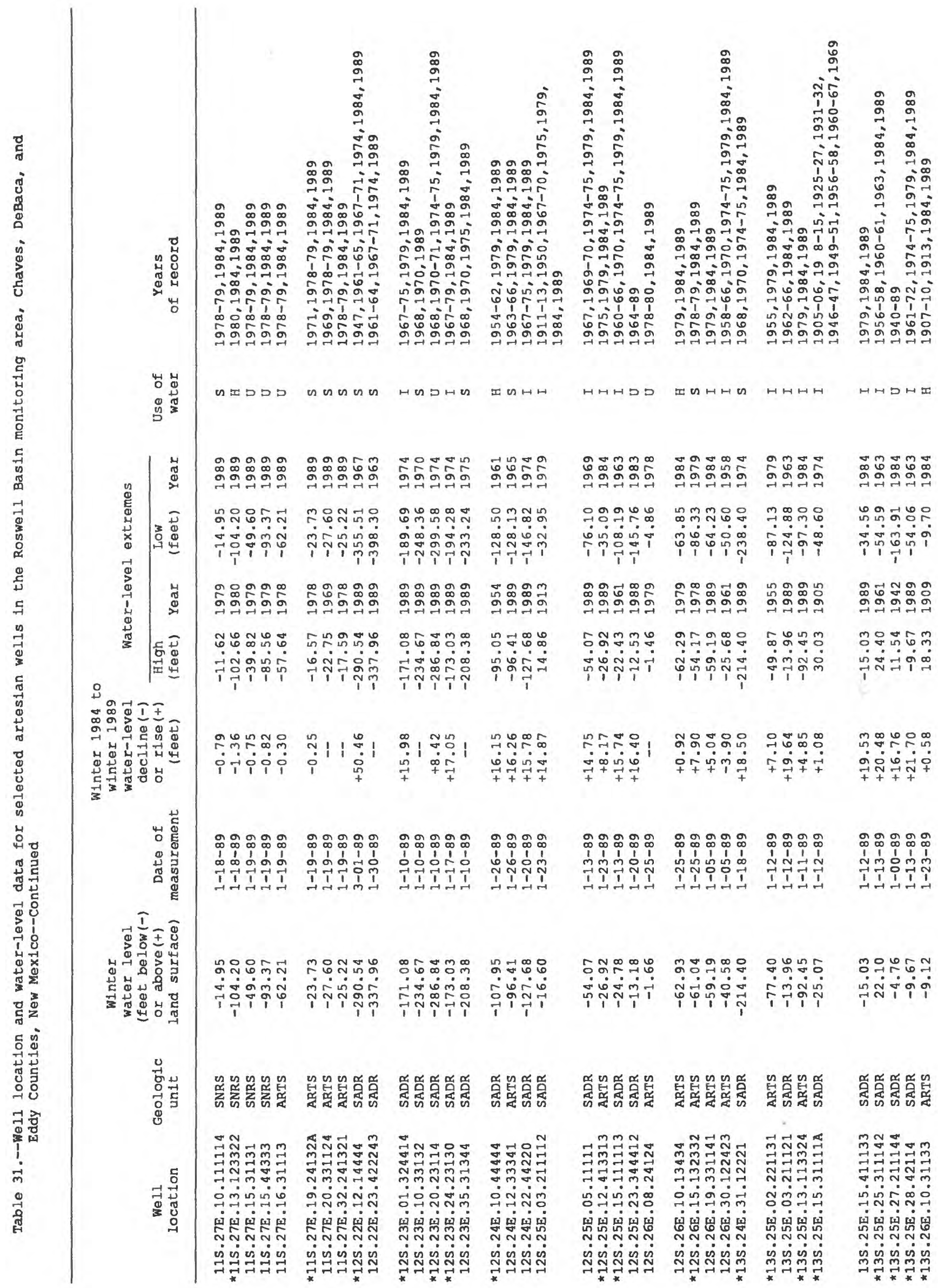




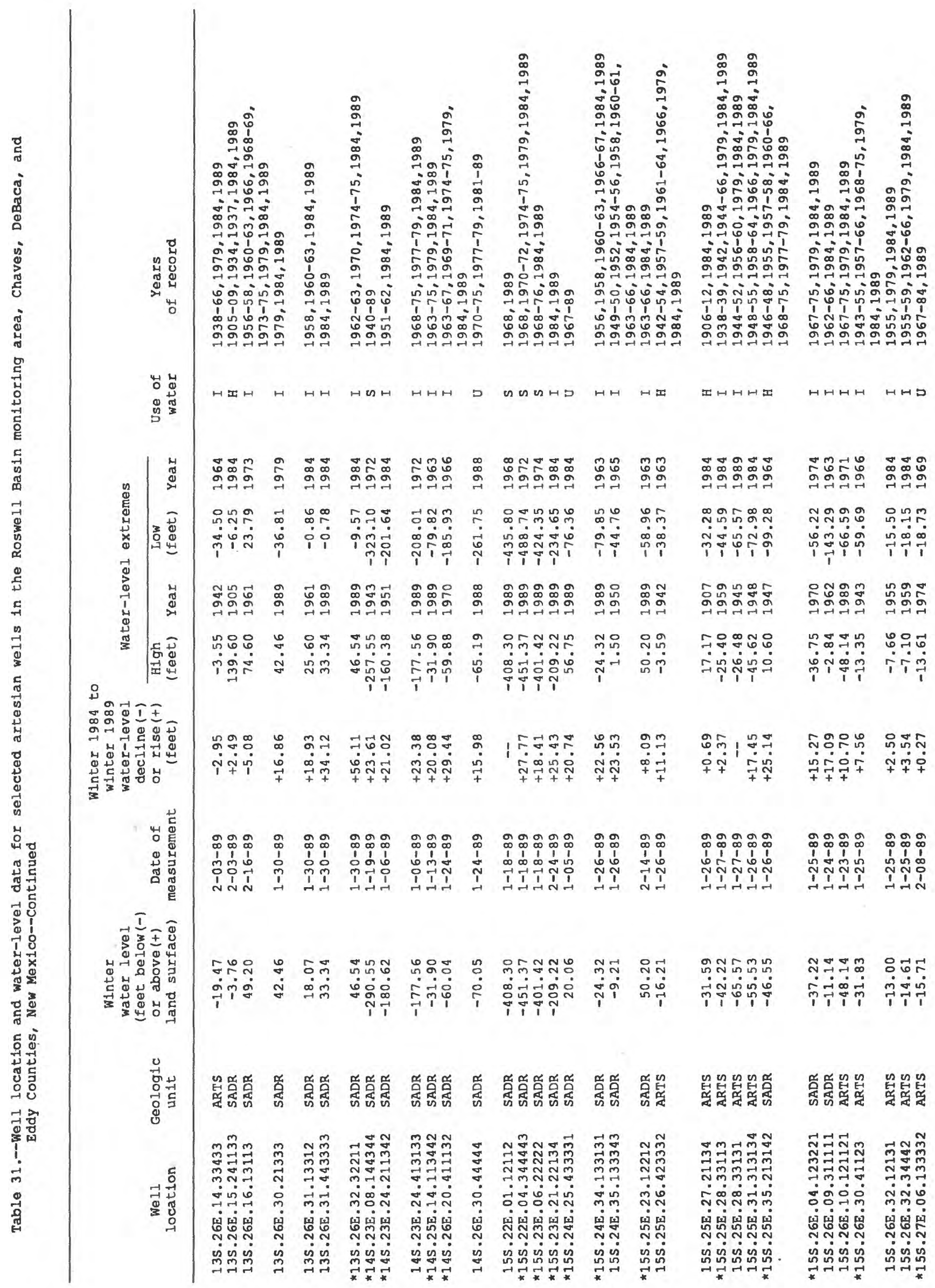




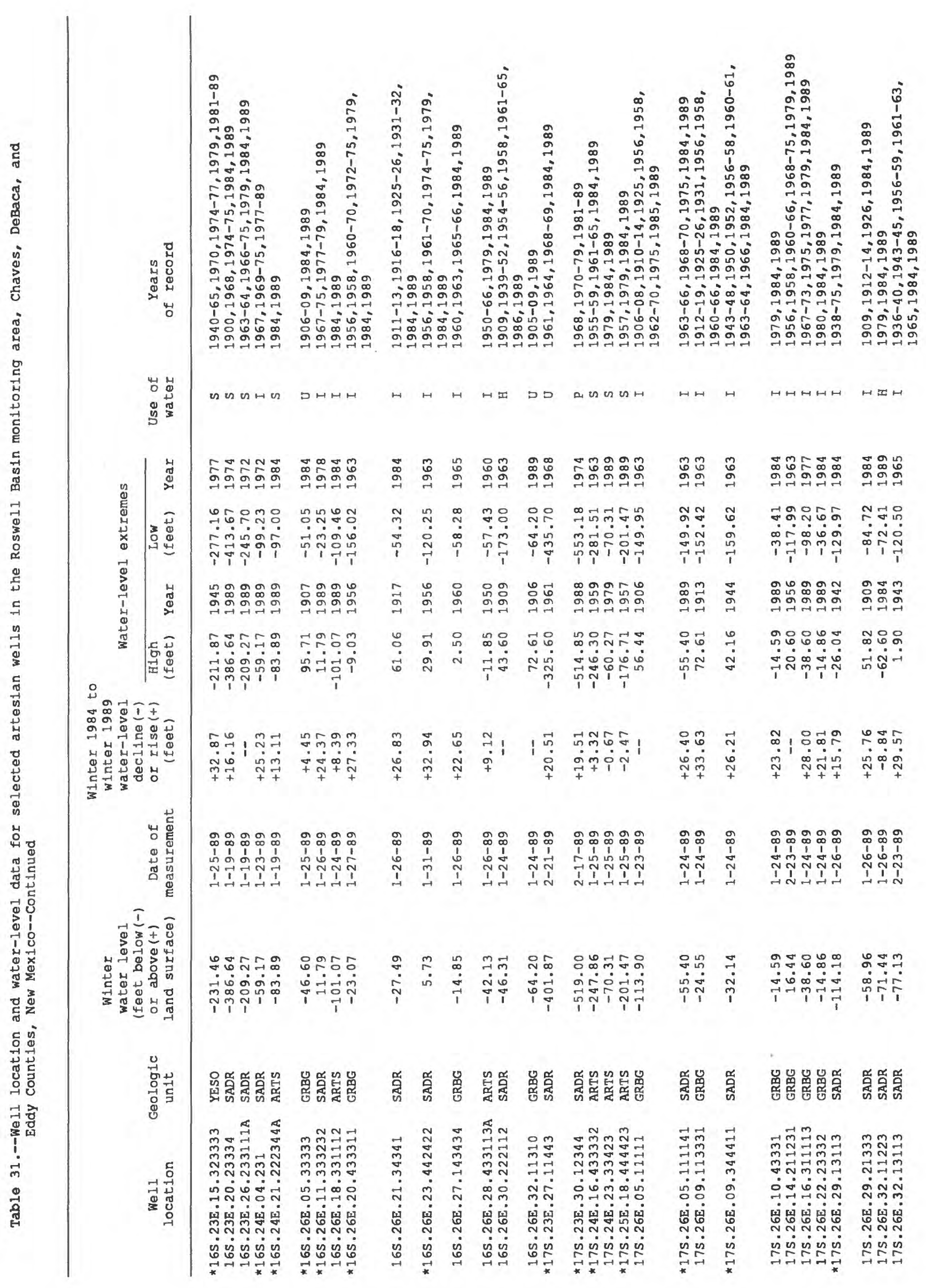




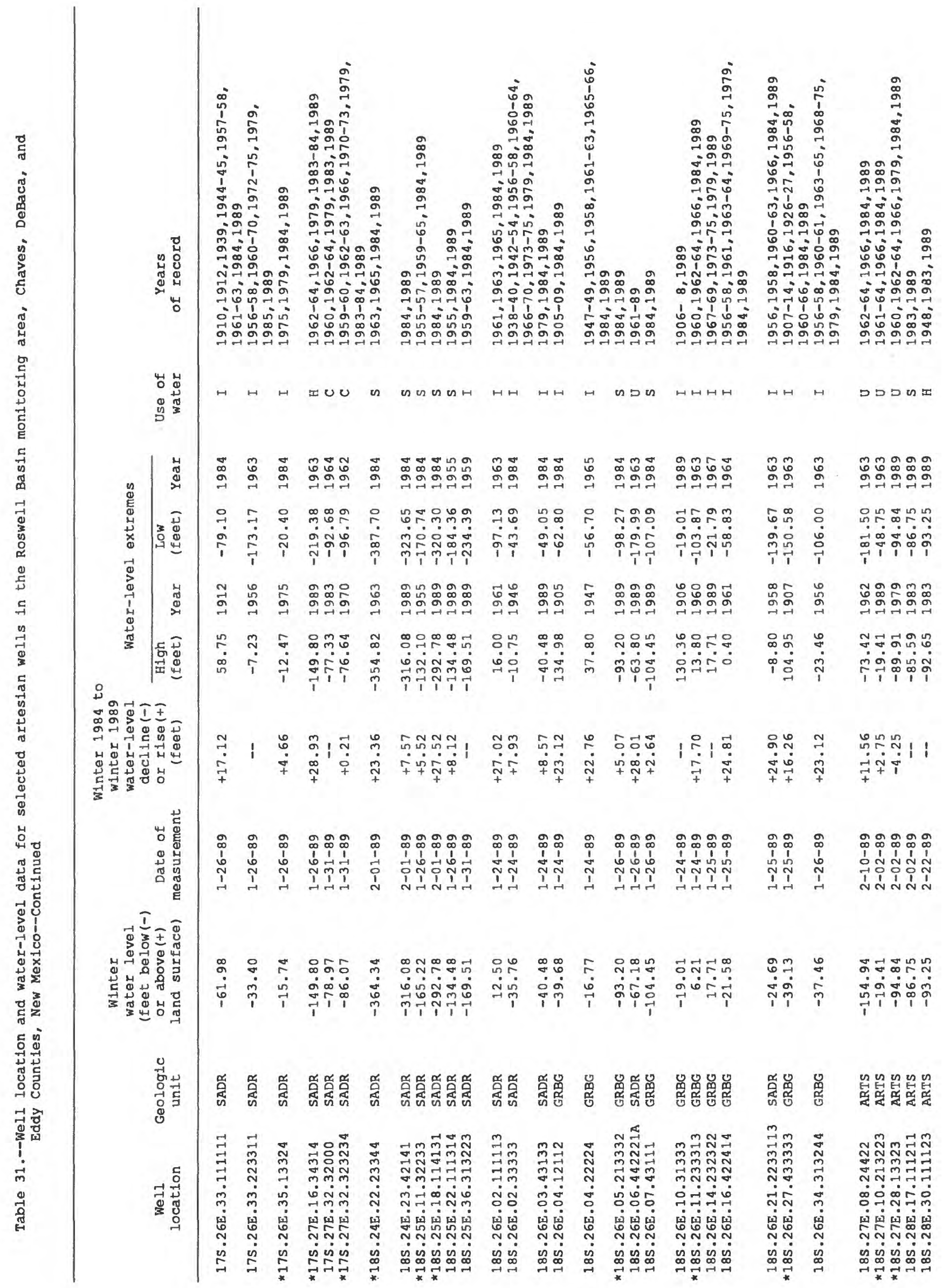


For each monitoring area this report includes a map showing the change in water level from the previous 5-year measurement and two or more hydrographs for selected wells. Hydrograph data are presented for each monitoring area through the last year of measurement. The hydrograph data include all data and water levels that may be affected by recent pumpage in the measured well or by nearby pumping wells. Differences may result between the high and low water levels presented in tables for each monitoring area and data presented in the hydrographs because all water-level data, including measurements influenced by pumping effects, are used to construct hydrographs but these data are not used in the selection of high and low extremes. Only actual water-level measurements made during the non-pumping season are used in determining the high and low values. Bar graphs also may be included that show annual precipitation at climatological stations that are within or adjacent to monitoring areas. Descriptions of water-level changes do not include references to accompanying figures and tables. Any reference to a figure or table is for the monitoring area being discussed.

Water-level data for the San Agustin Plains and San Juan Basin monitoring areas were not collected in one of the designated years required to compute the 5-year change. Maps of these areas show the most recent measured water level instead of 5-year water-level change.

The Roswell Basin and Carlsbad monitoring areas have two distinct aquifer systems within identical monitoring area boundaries. In the Roswell Basin monitoring area water-level changes in wells in the shallow aquifer system are reported separately from water-level changes in wells in the artesian aquifer system. Traditionally the two distinct aquifer systems in the Carlsbad area have been identified by different names. In the Carlsbad monitoring area water levels in wells completed in the alluvial aquifer system (Carlsbad monitoring area) are reported separately from water levels in wells completed in sediments other than alluvium (Capitan Reef monitoring area).

There may be multiple aquifer systems in other monitoring areas. For each area the geologic unit in which the well is finished is presented in the appropriate table. Wells finished in different geologic units in the same monitoring area may or may not be in different aquifer systems. Determination of aquifer systems is beyond the scope of the program or of this report. 


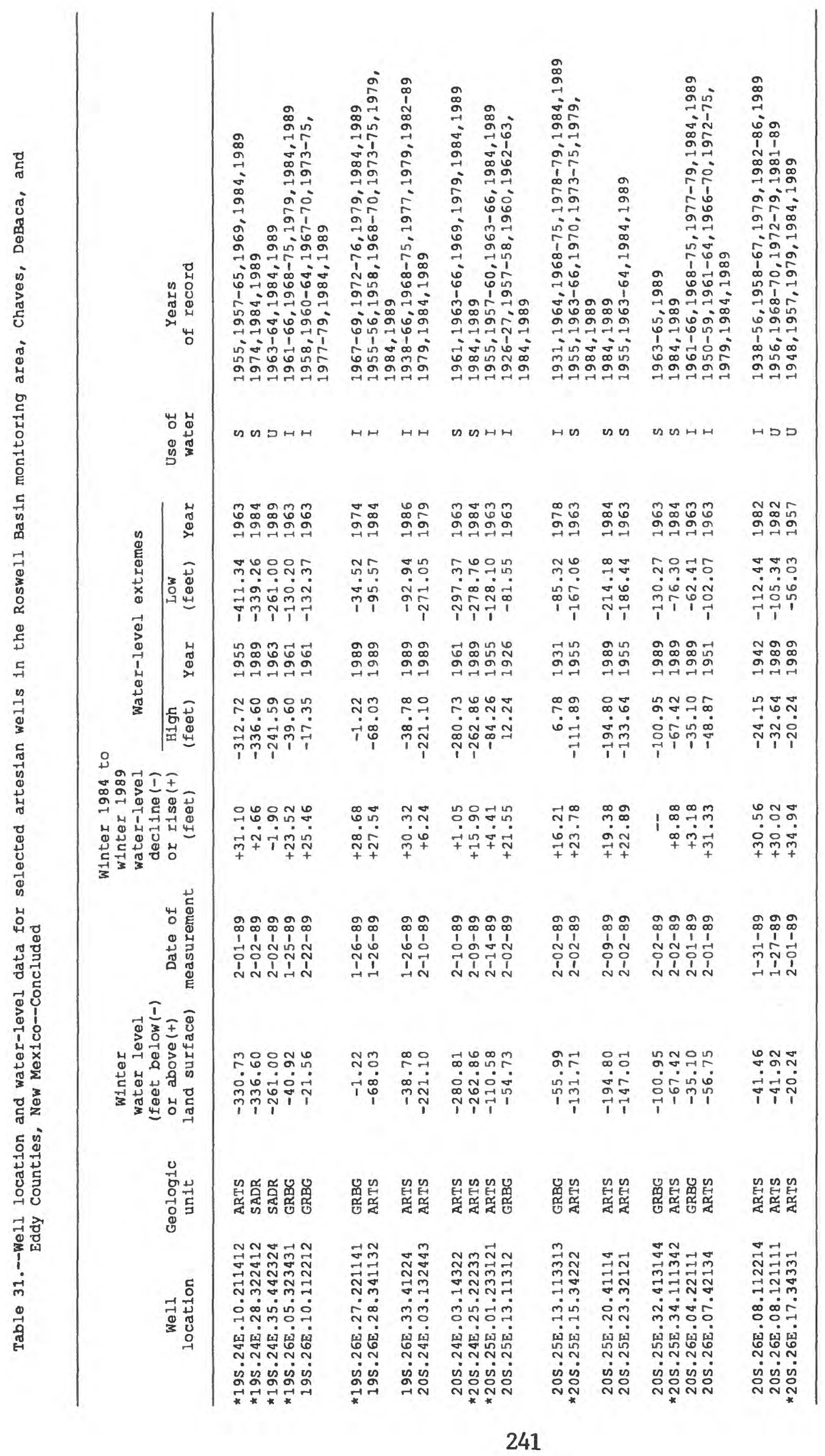




\section{Rio Hondo Monitoring Area}

The Rio Hondo monitoring area is in Lincoln County, southwestern New Mexico. Waterlevel measurements indicate rises and declines throughout the monitoring area. Rises range from less than 1 foot to more than 9 feet. Changes in two small areas are declines: one is northwest of Hondo for about 3 miles along the Rio Ruidoso and Salado Creek; the other area is along the Rio Hondo just west of Riverside. Declines throughout the area range from less than 1 foot to more than 5 feet. 

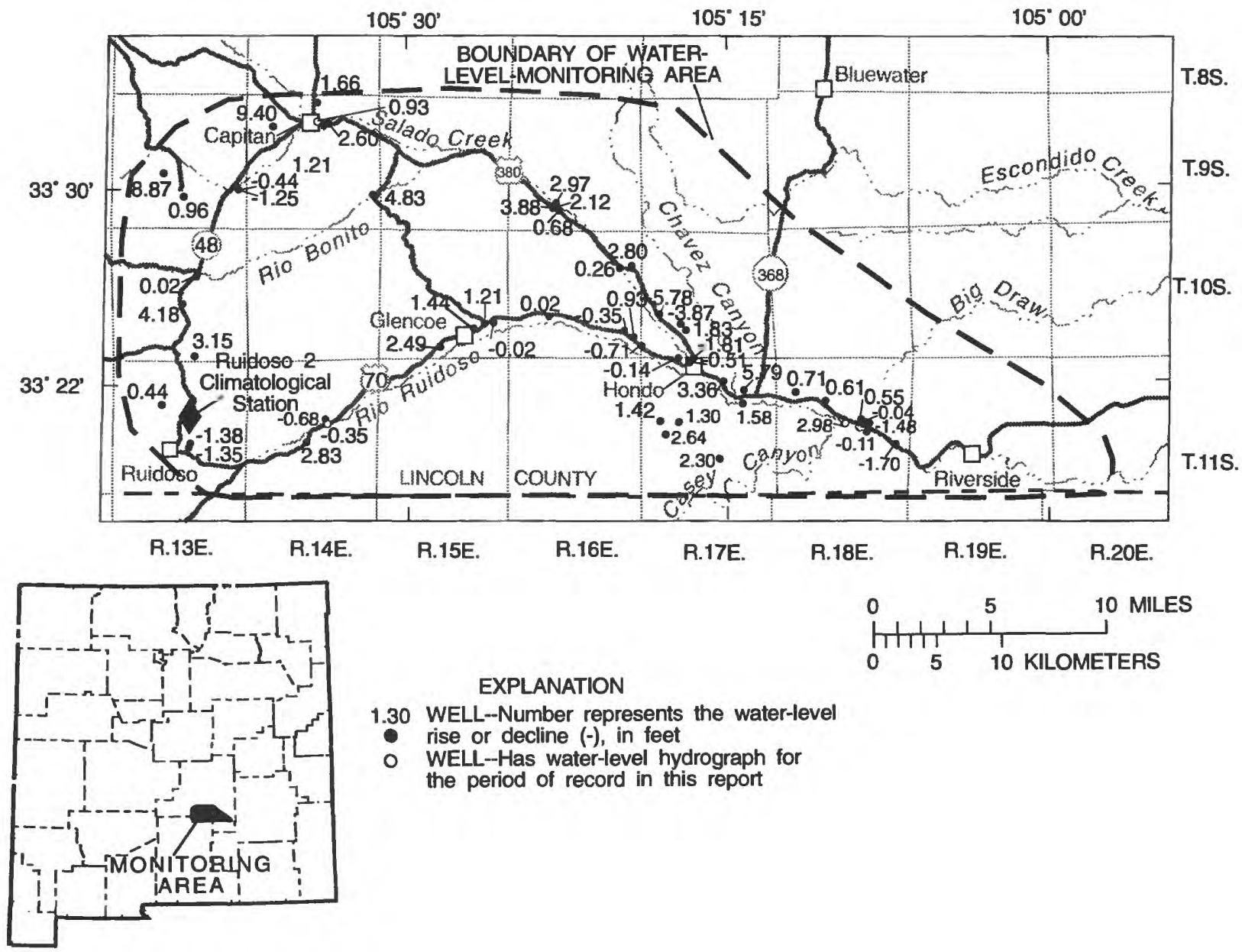

\section{EXPLANATION}

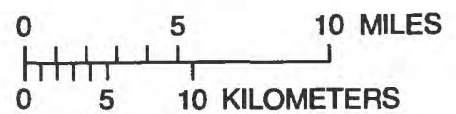

1.30 WELL--Number represents the water-level

- rise or decline $(-)$, in feet

- WELL--Has water-level hydrograph for the period of record in this report

Figure 65.--Water-level changes for wells in the Rio Hondo monitoring area, 1984-89. 

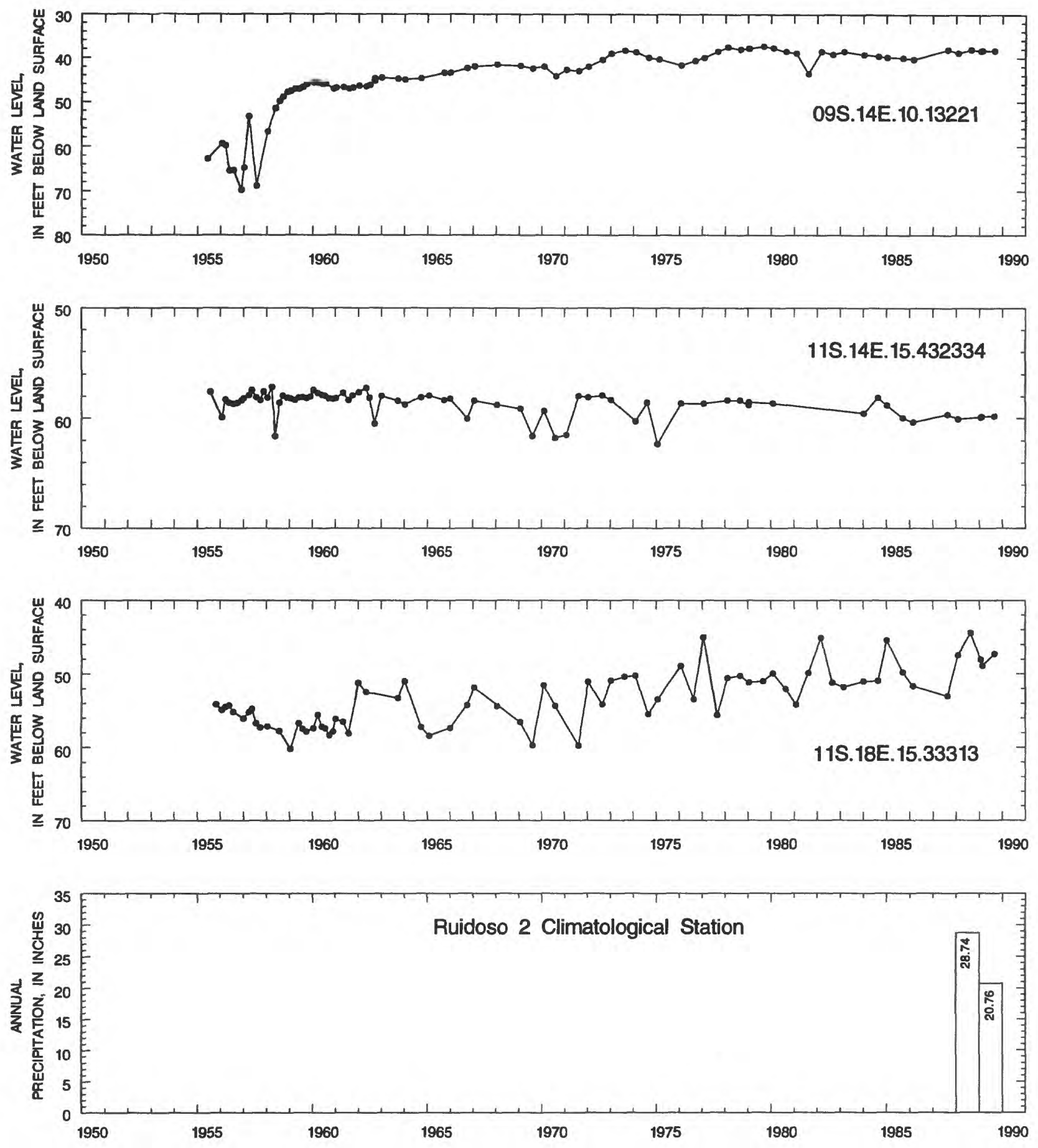

Figure 66.--Water-level data for selected wells in the Rio Hondo monitoring area and annual precipitation at the Ruidoso 2 Climatological Station. See figure 65 for location of wells and station. 


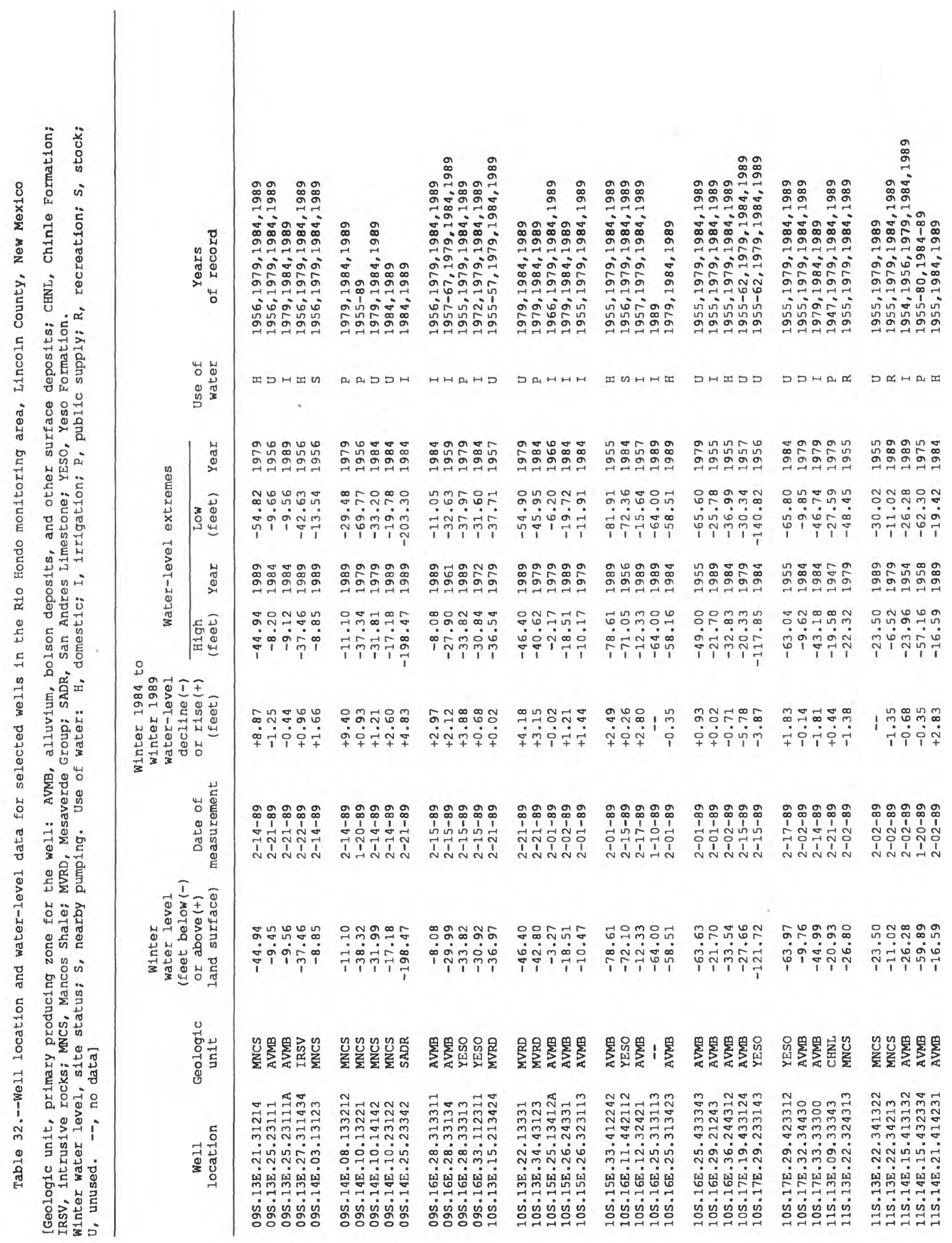




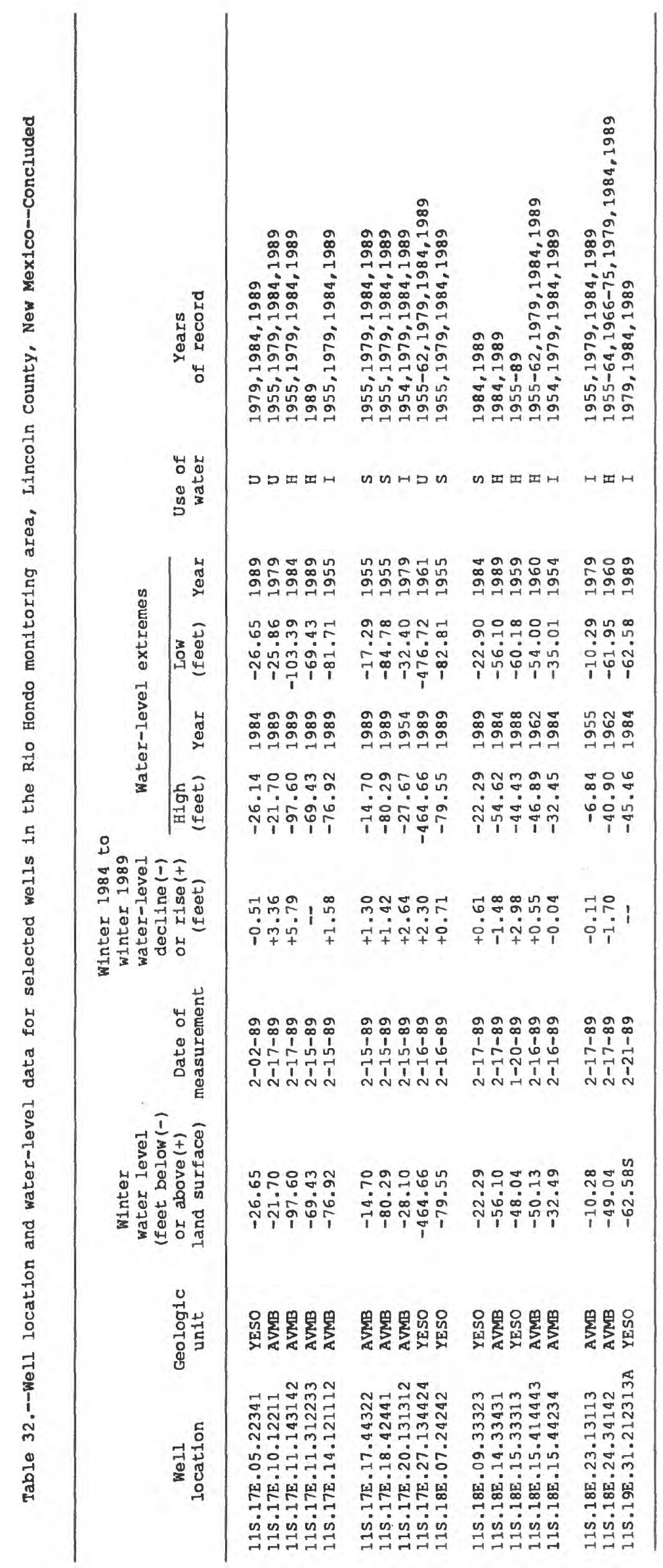




\section{Rio Peñasco Monitoring Area}

The Rio Peñasco monitoring area is in Chaves and Otero Counties, southeast New Mexico. All but two water-level changes are rises ranging from less than 1 foot to more than 81 feet. The wells with declining water levels are in the northwest part of the area and show declines ranging from less than 7 to more than 16 feet. 

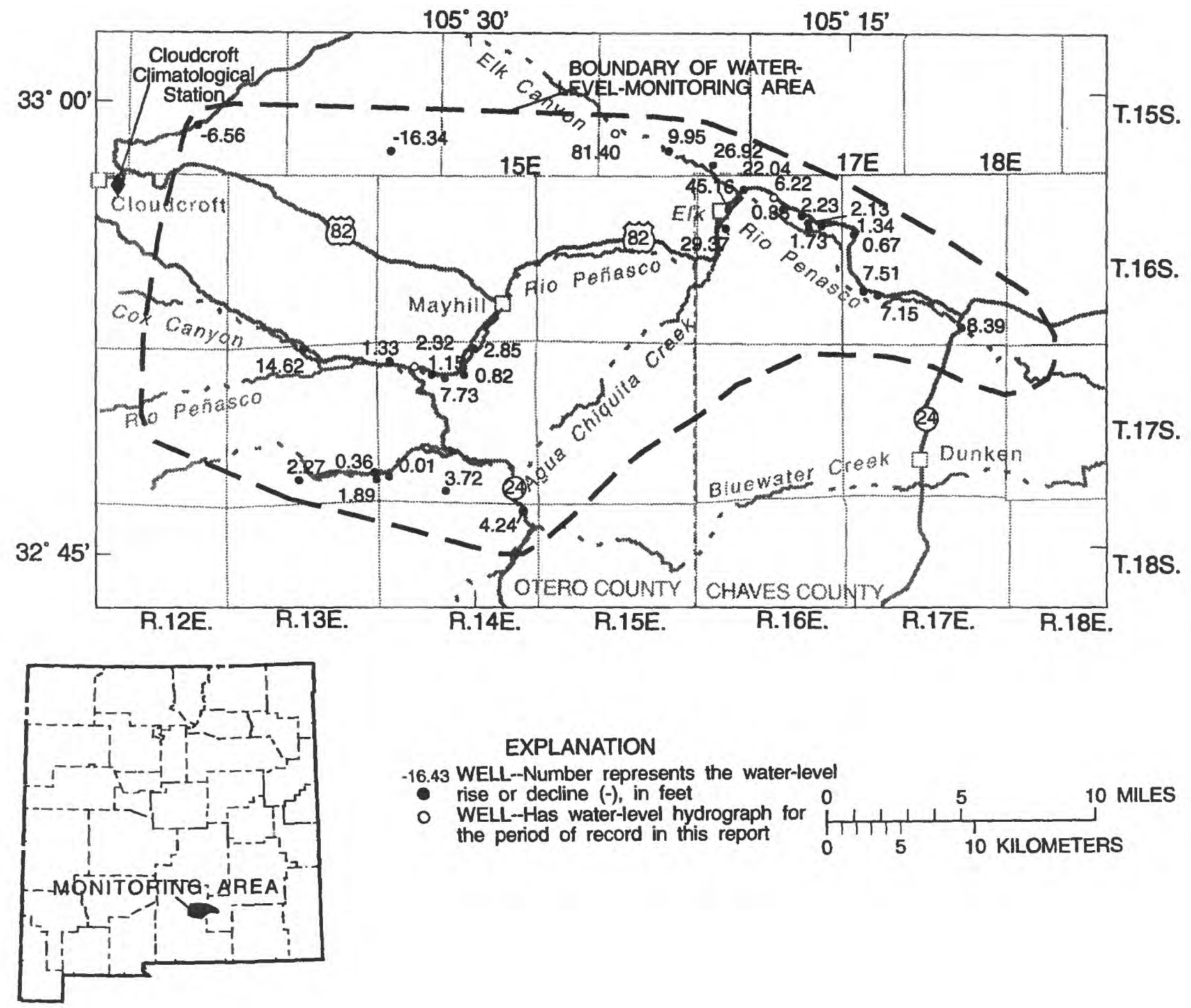

\section{EXPLANATION}

-16.43 WELL-Number represents the water-level

- rise or decline $(-)$, in feet

- WELL-Has water-level hydrograph for the period of record in this report

Figure 67.--Water-level changes for wells in the Rio Peñasco monitoring area, 1984-89. 

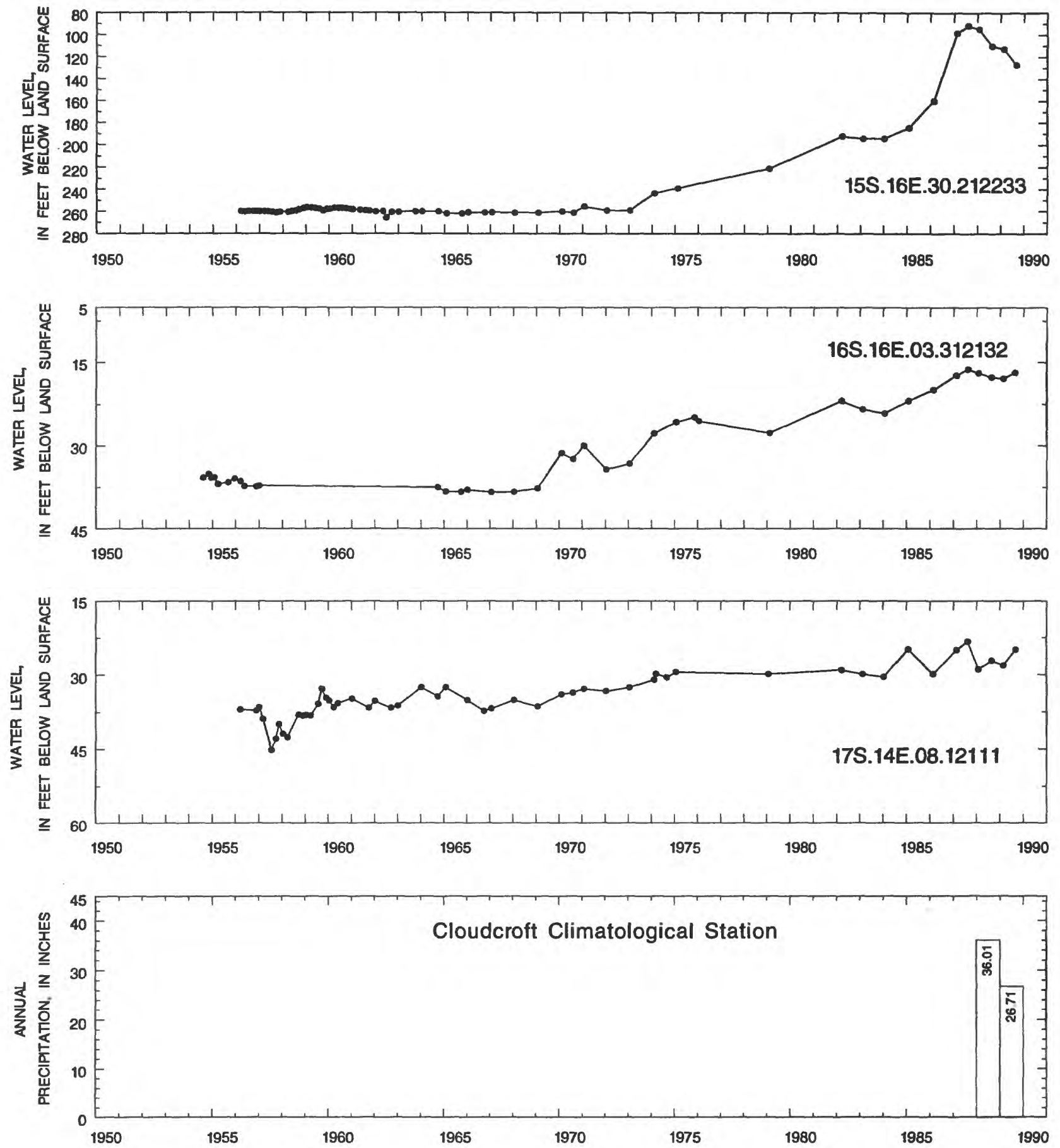

Figure 68.--Water-level data for selected wells in the Rio Peñasco monitoring area and annual precipitation at the Cloudcroft Climatological Station. See figure 67 for location of wells and station. 


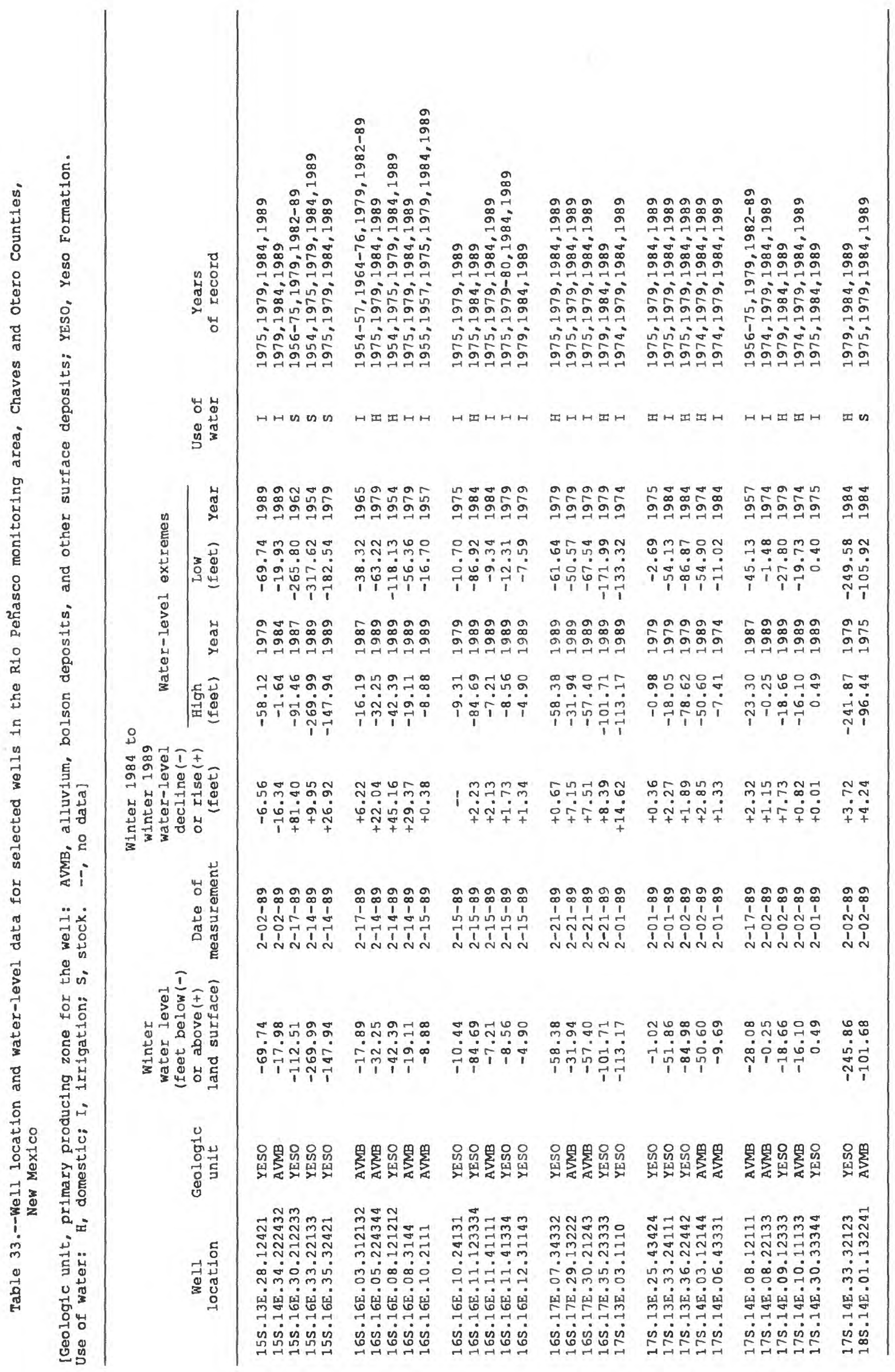




\section{Causey-Lingo Monitoring Area}

The Causey-Lingo monitoring area is in southern Roosevelt and Chaves Counties, eastcentral New Mexico, and Bailey and Cochran Counties, Texas. Not all water-level changes are shown on the map; however, all well locations and water-level data are listed in the table. Well locations marked with an asterisk (*) in the table are plotted on the map.

The monitoring area was extended in 1989 and 1990 to the west to include Rs. 30 and $31 \mathrm{E}$. The table includes data for wells in these areas, but well locations are not plotted on the map because 5-year change data are not available.

Water levels were measured in January, February, and March of 1985 and 1990; water levels in about 200 wells were measured in November and December of 1989 . Because all data were winter water-level measurements, all wells with water-level data in 1985 and 1989 or 1990 were used in computing the 5-year water-level change.

Water-level declines range from less than 1 to more than 3 feet. Rises range from less than 1 foot to more than 16 feet. Water-level measurements show a rise in most of the Causey-Lingo monitoring area; however, a decline is shown in a small area west of Milnesand in parts of Tps. 7 and $8 \mathrm{~S}$. and most of R. $34 \mathrm{E}$. In the northeast corner of the monitoring area measurements indicate declines and rises. 


\section{Grants-Bluewater Monitoring Area}

The Grants-Bluewater monitoring area is in Cibola County, west-central New Mexico. Water-level rises range from 2.06 to more than 14 feet. One water level declined 6.05 feet. 

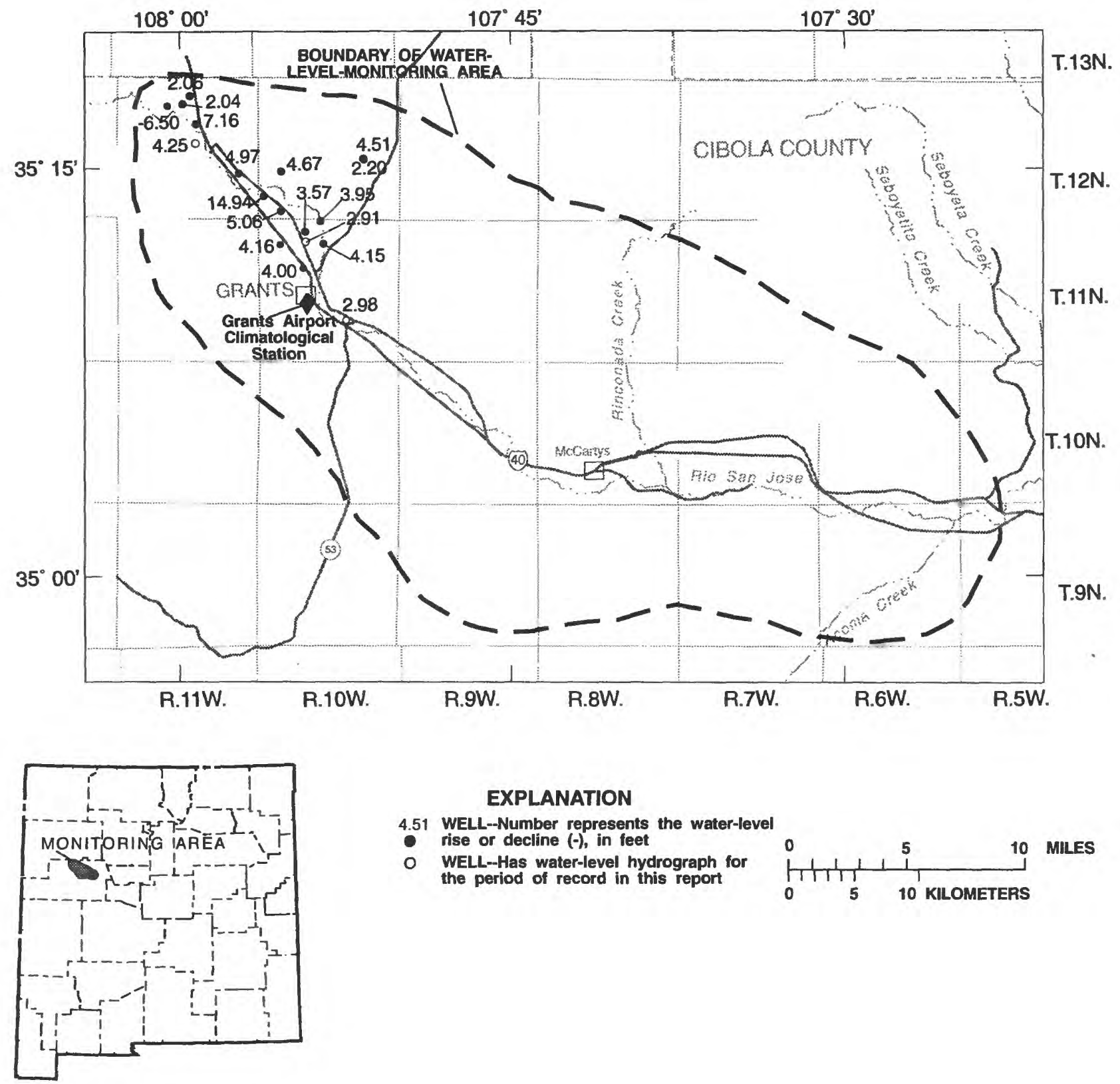

\section{EXPLANATION}

4.51 WELL--Number represents the water-leve

- rise or decline $(-)$, in feet

o WELL--Has water-level hydrograph for the period of record in this report

Figure 69.--Water-level changes for wells in the Grants-Bluewater monitoring area, 1984-89. 

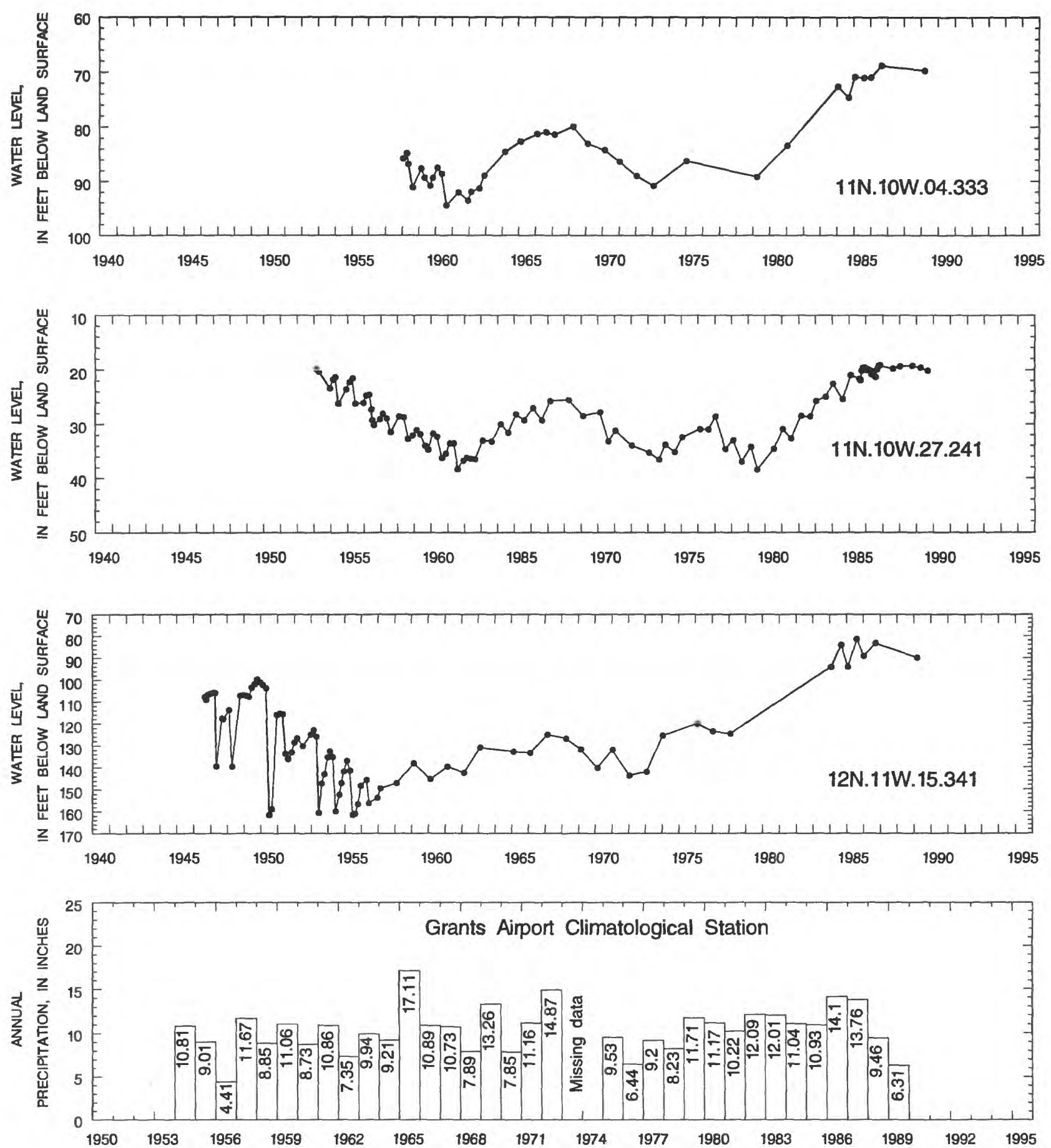

Figure 70.--Water-level data for selected wells in the Grants-Bluewater monitoring area and annual precipitation at the Grants Airport Climatological Station. See figure 69 for location of wells and station. 


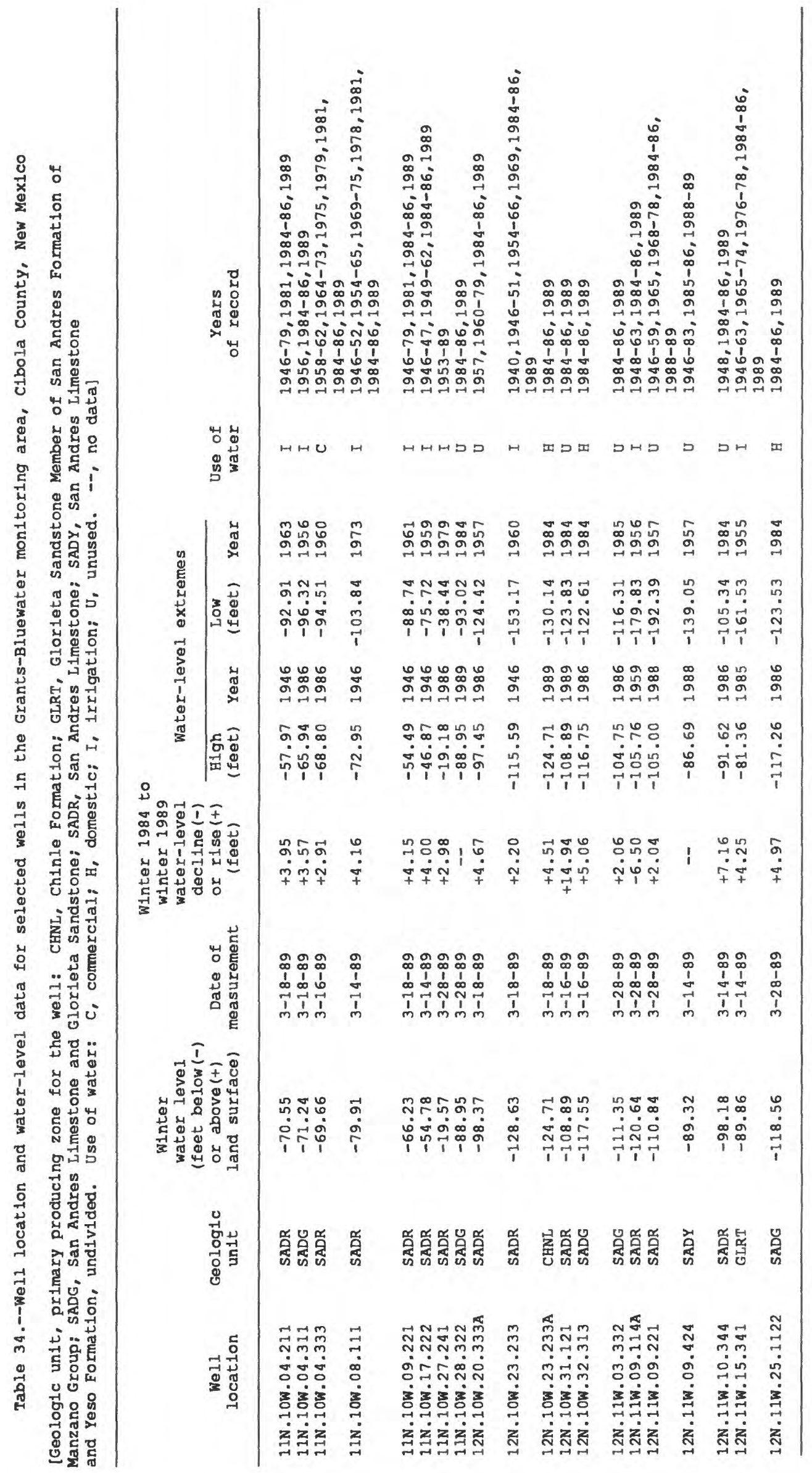




\section{Lower Rio Grande Monitoring Area}

The Lower Rio Grande monitoring area is in Sierra and Doña Ana Counties, south-central New Mexico. Water levels have risen and declined throughout the area. Two small areas in the southern part of the monitoring area have declines. One area is in Tps. 27 and 28 S., Rs. 1 and 2 W.; the other area is immediately adjacent to the Rio Grande in T. $28 \mathrm{~S}$. and Rs. 2 and $3 \mathrm{E}$. Rises in the monitoring area range from less than 1 foot to more than 44 feet. Declines range from less than 1 foot to more than 44 feet. 


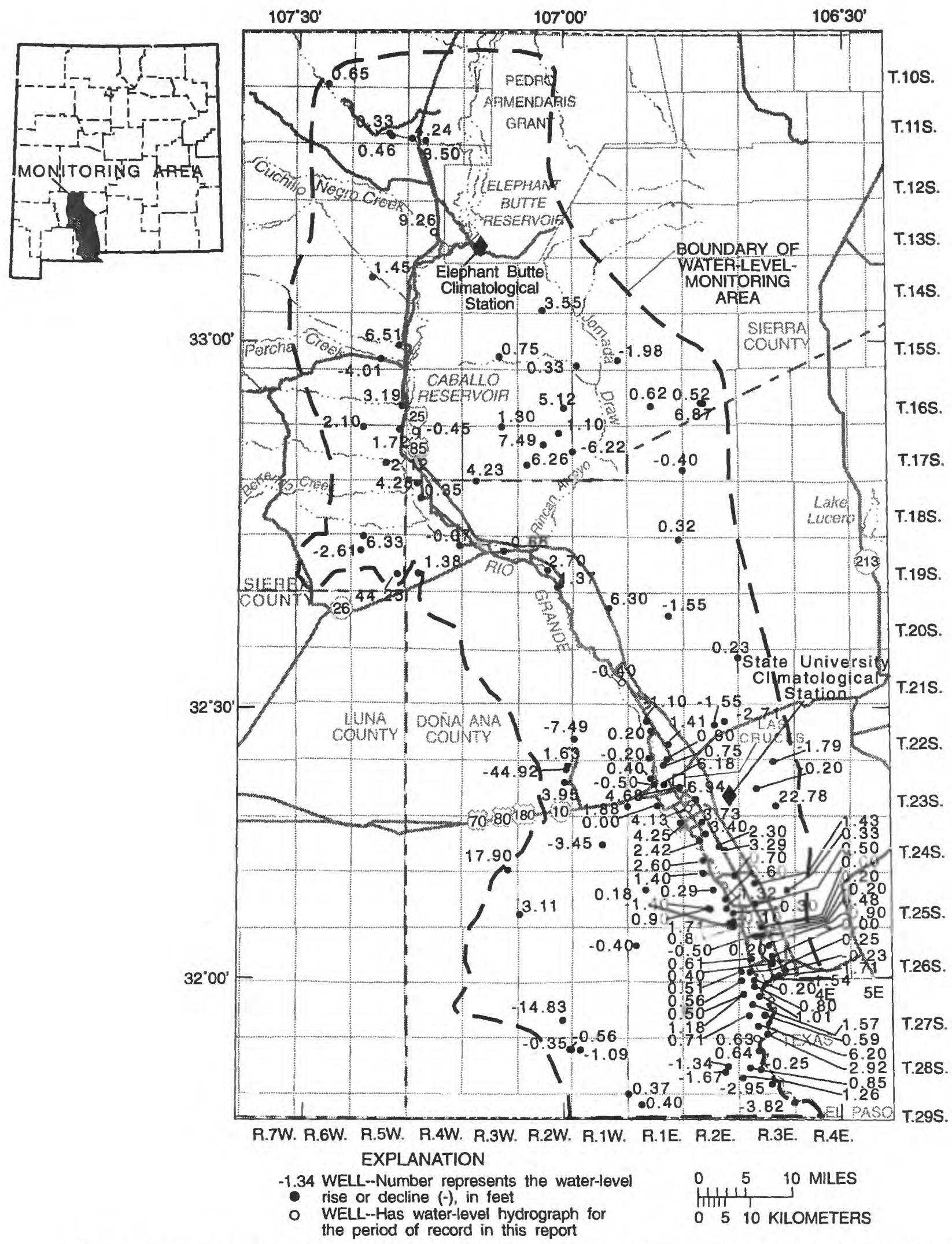

Figure 71.--Water-level changes for wells in the Lower Rio Grande monitoring area, 1984-89. 

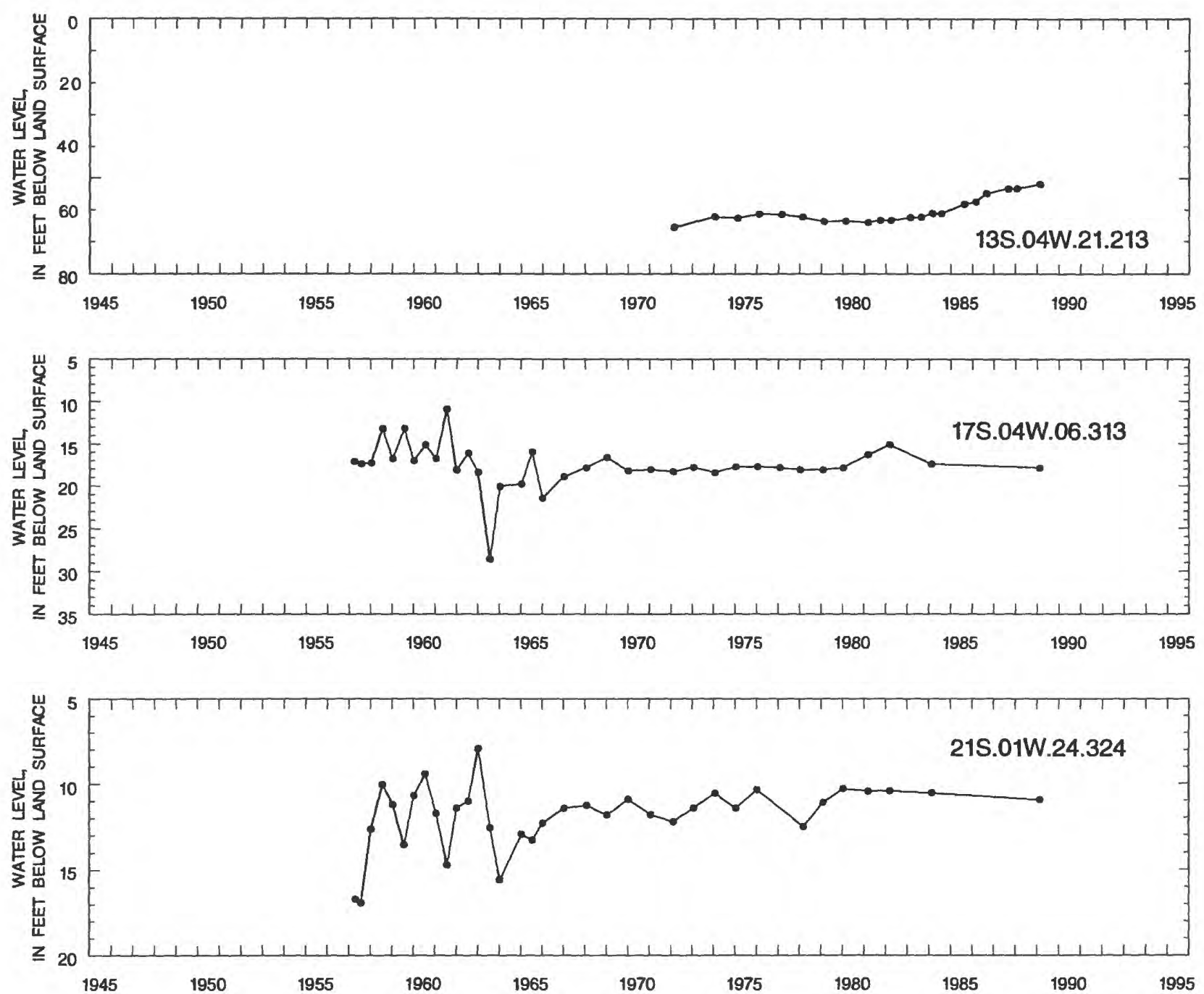

Figure 72.--Water-level data for selected wells in the Lower Rio Grande monitoring area and annual precipitation at the Elephant Butte and State University Climatological Stations. See figure 71 for location of wells and stations. 

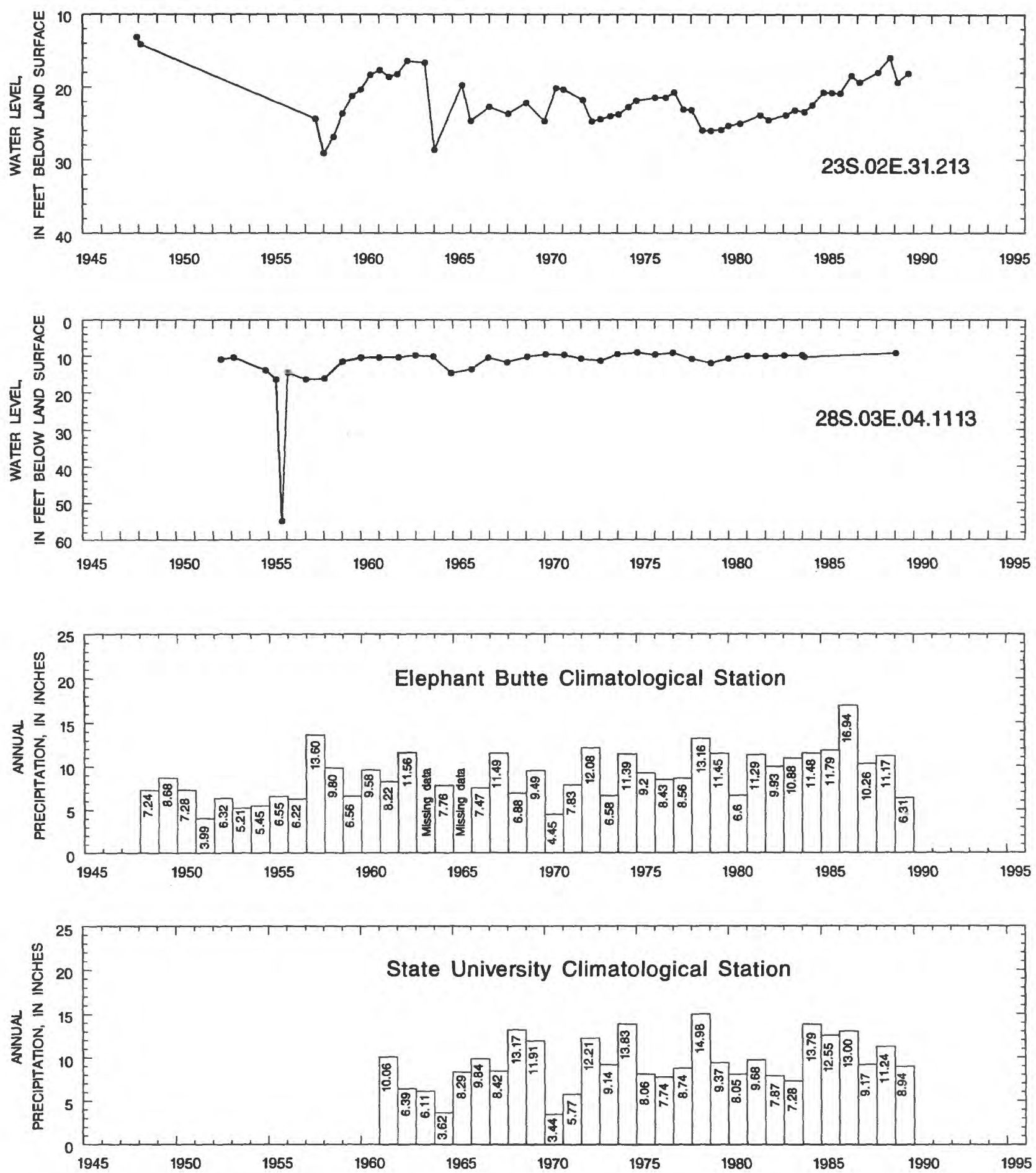

Figure 72.--Water-level data for selected wells in the Lower Rio Grande monitoring area and annual precipitation at the Elephant Butte and State University Climatological Stations. See figure $\mathbf{7 1}$ for location of wells and stations--Concluded. 


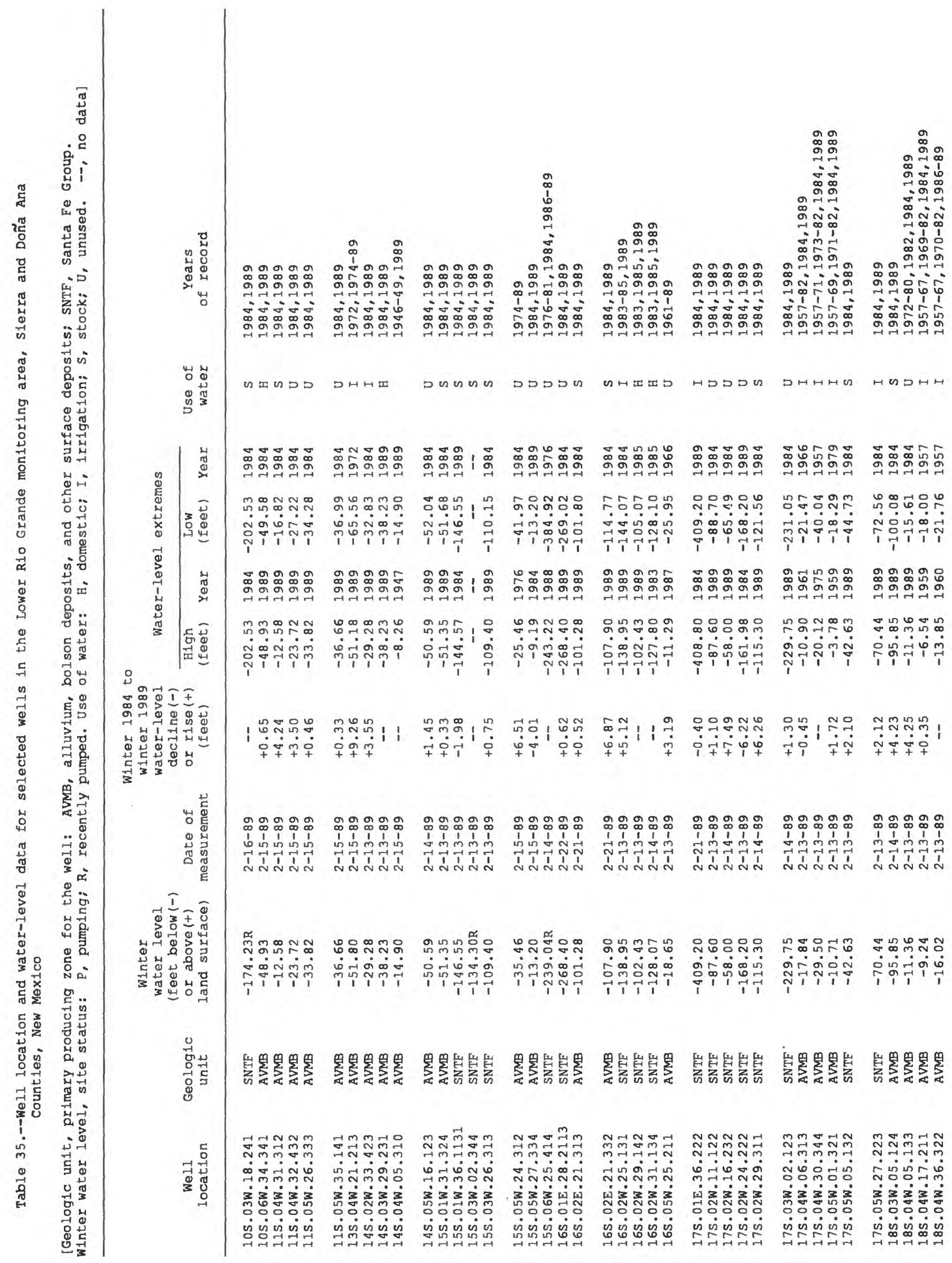




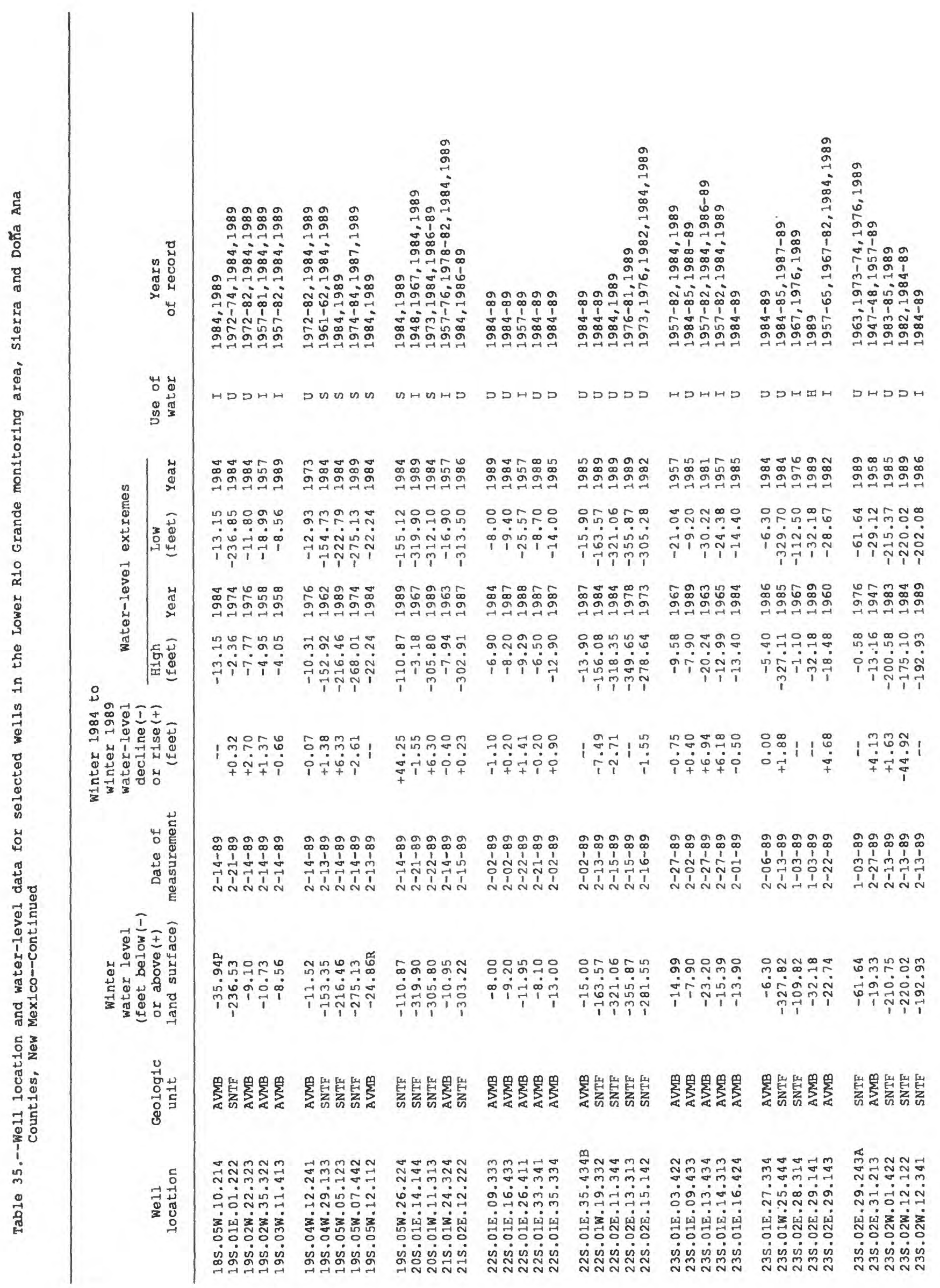




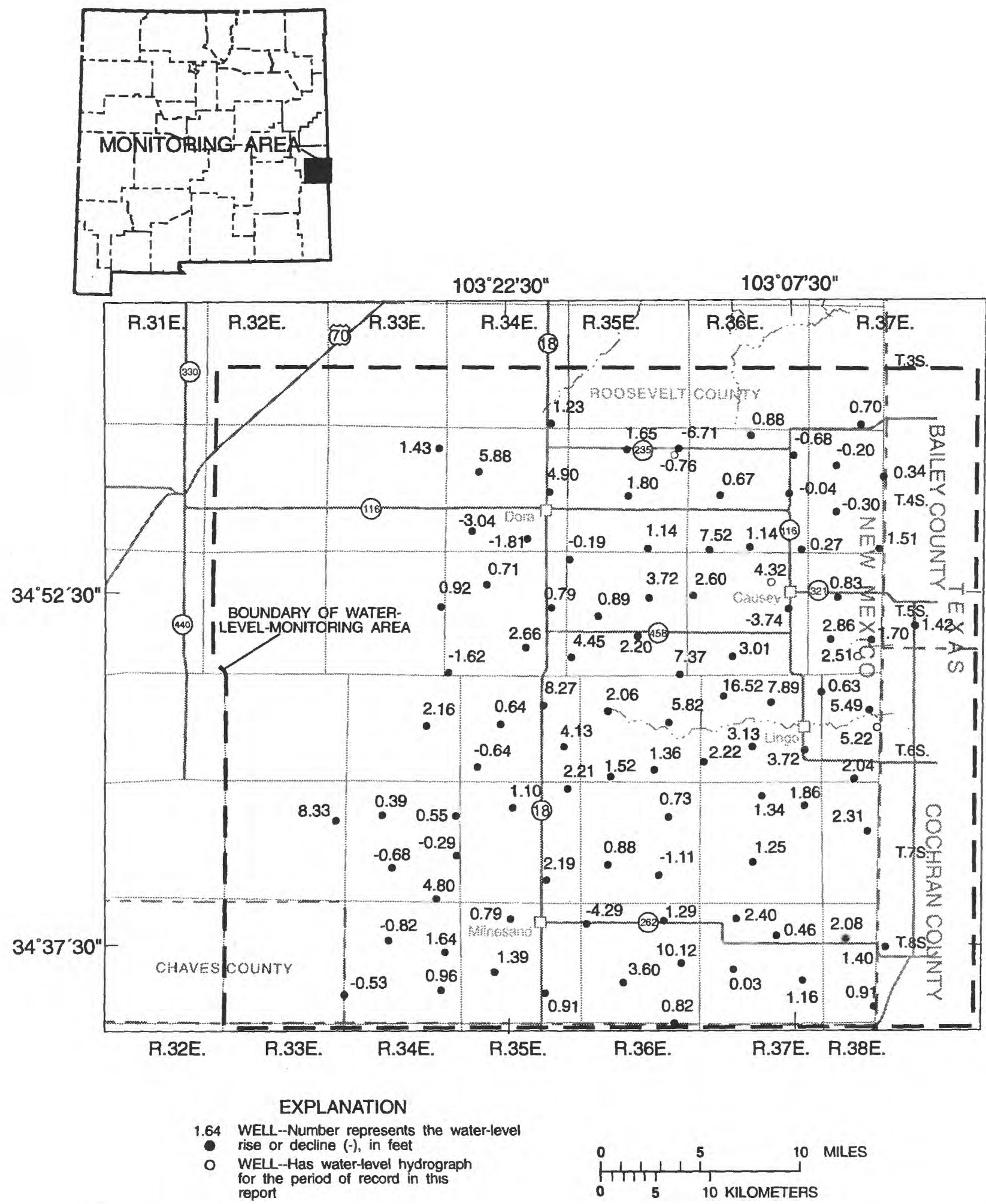

Figure 5.--Water-level changes for selected wells in the Causey-Lingo monitoring area, 1985-90. 


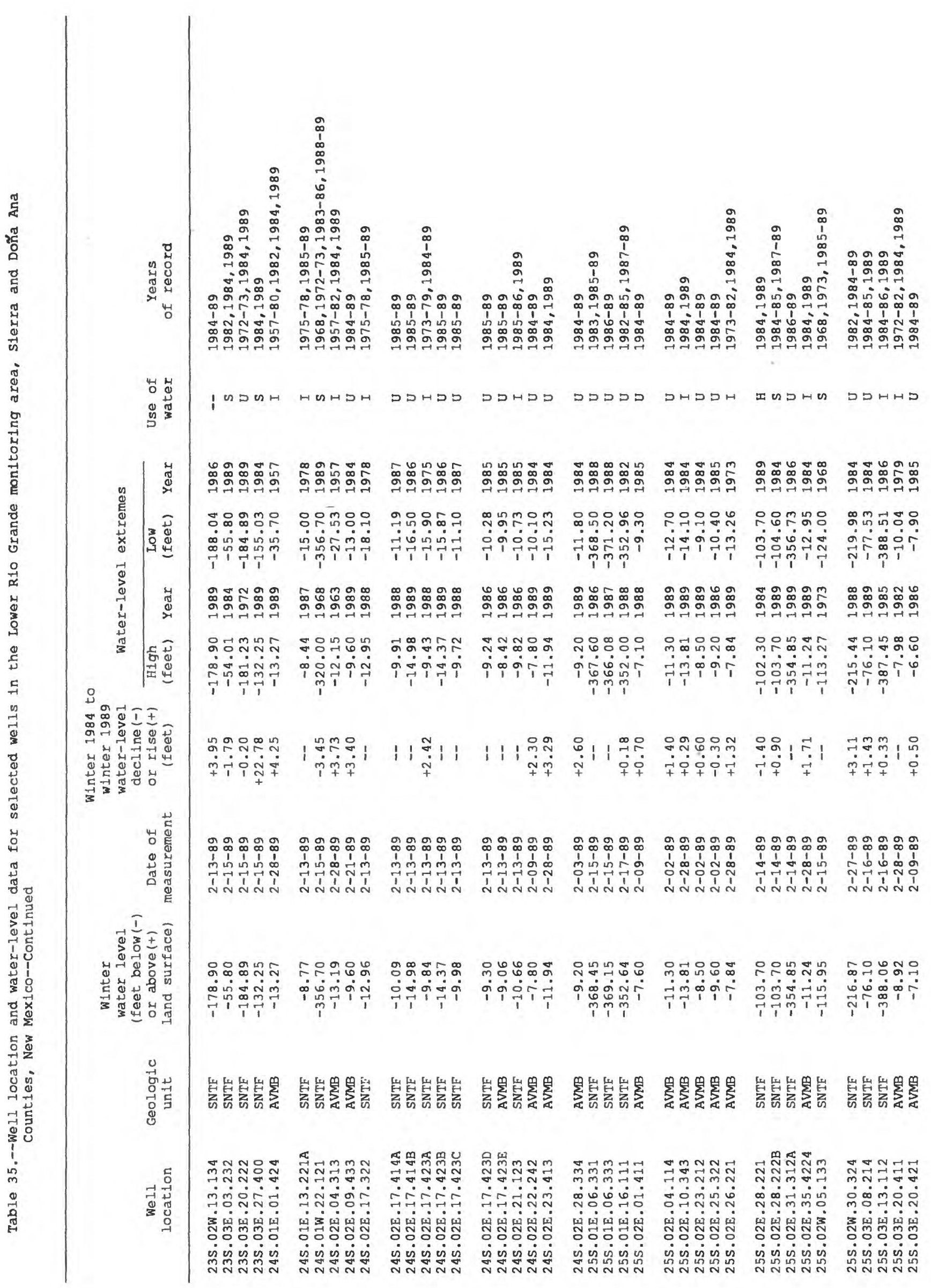




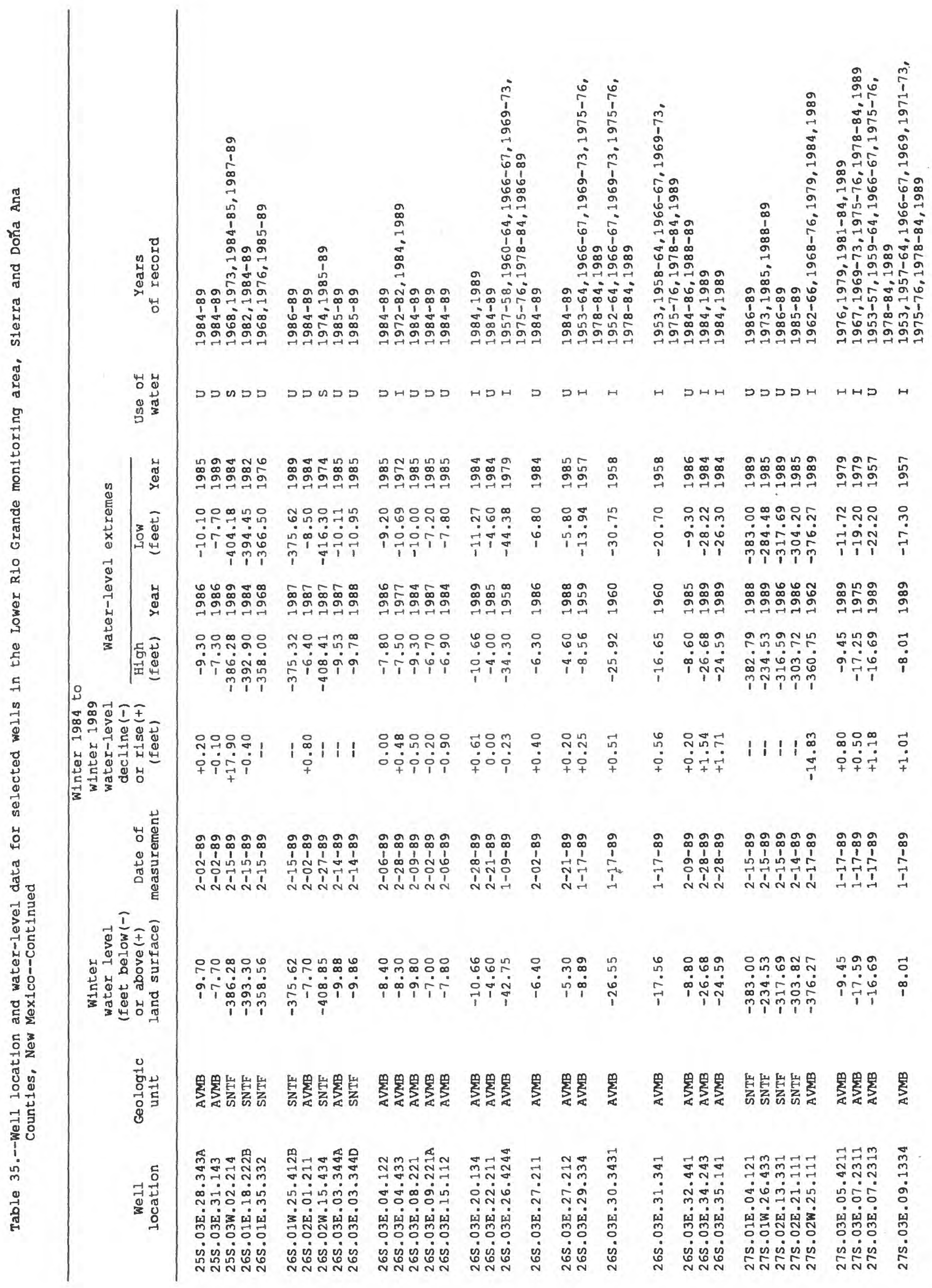




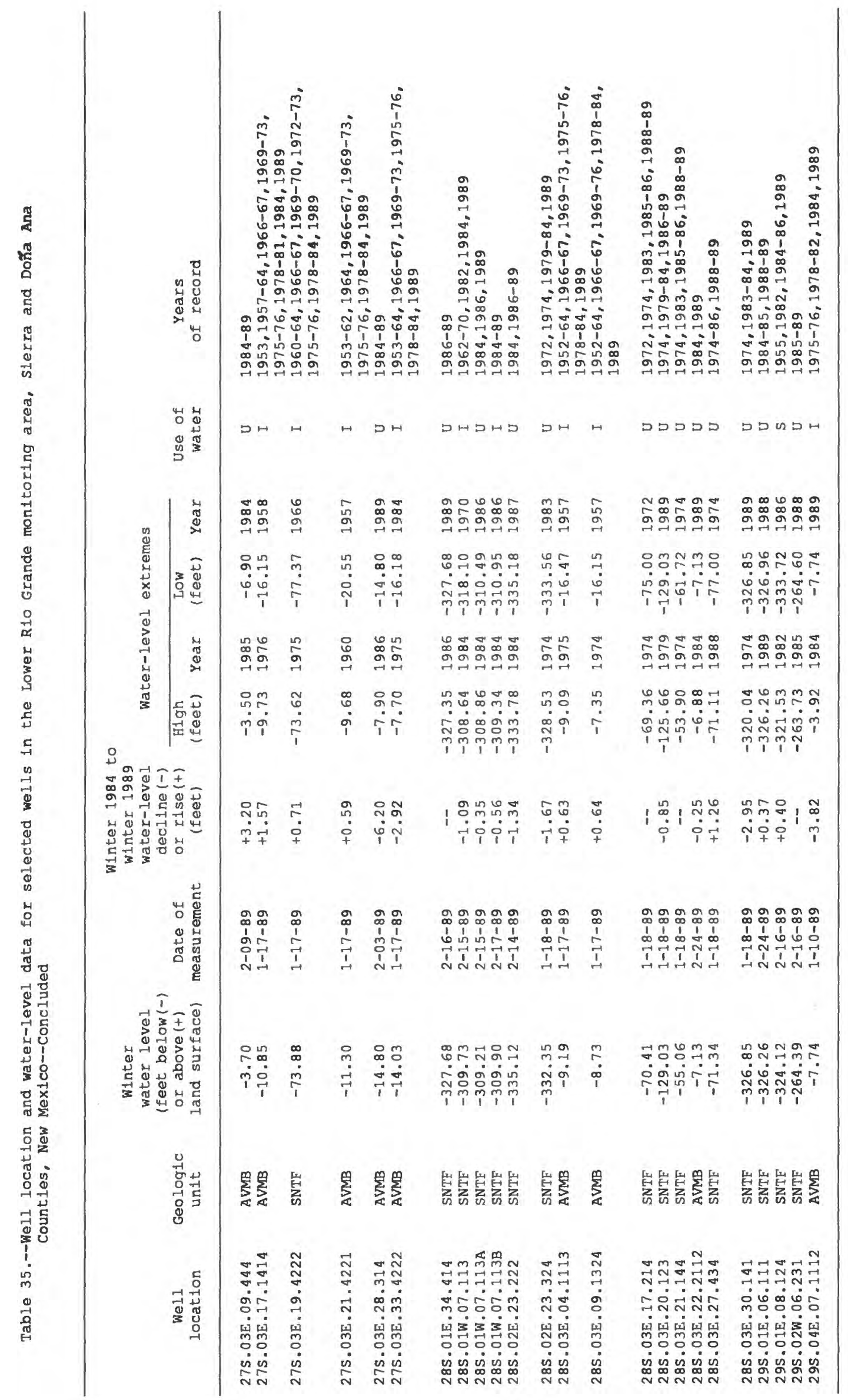




\section{Hueco Monitoring Area}

The Hueco monitoring area is in Dona Ana County, southern New Mexico. Most changes are declines ranging from less than 1 to more than 5 feet. Two water-level changes were rises ( 0.29 and 4.13 feet). 

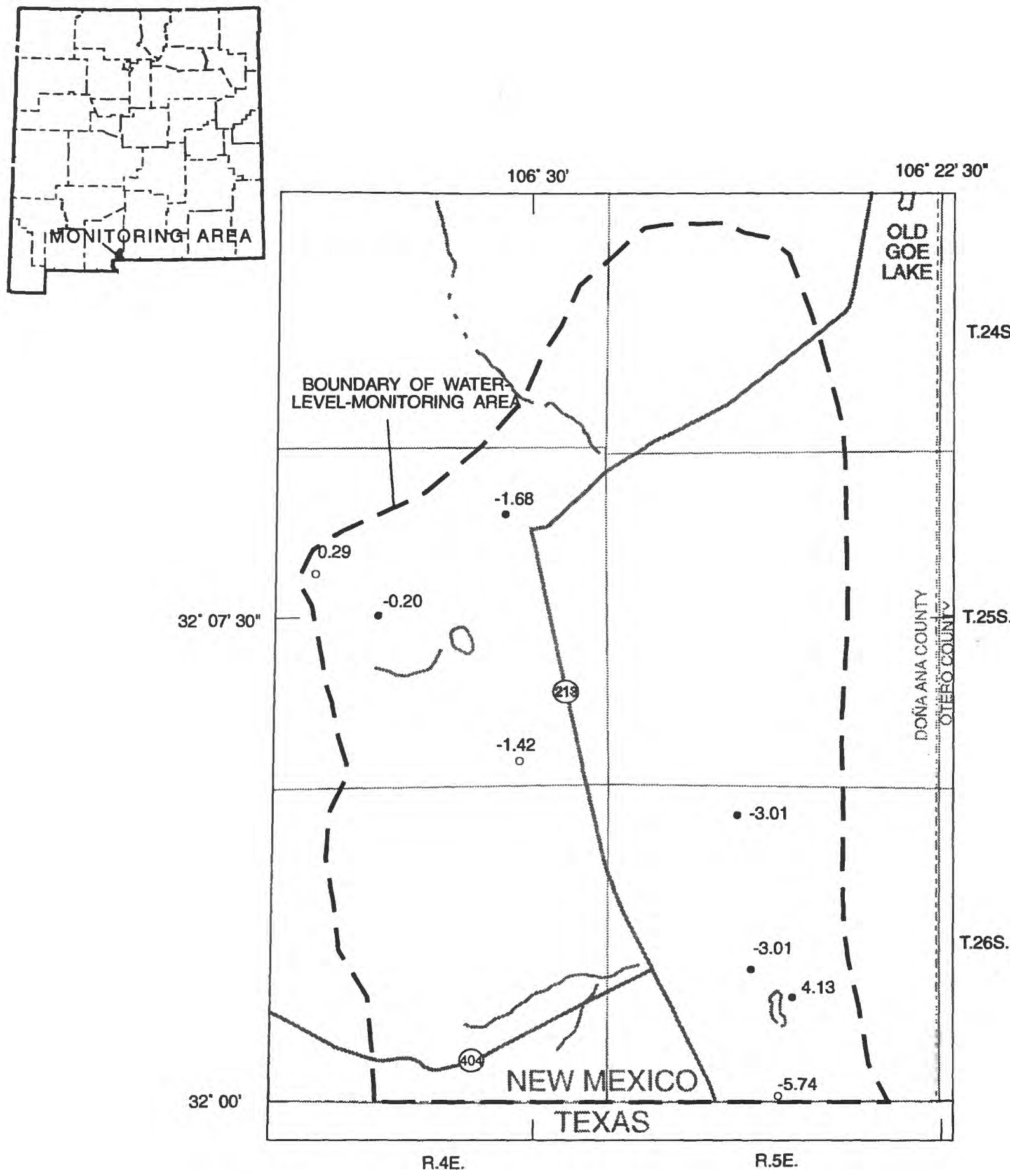

T.25S

T.26S.

\section{EXPLANATION}

-0.20 WELL--Number represents the water-level 0

- rise or decline $(-)$, in feet

WELL--Has water-level hydrograph for the period of record in this report

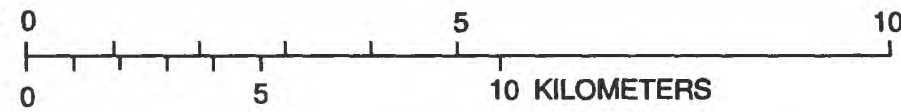

Figure 73.--Water-level changes for wells in the Hueco monitoring area, 1984-89. 

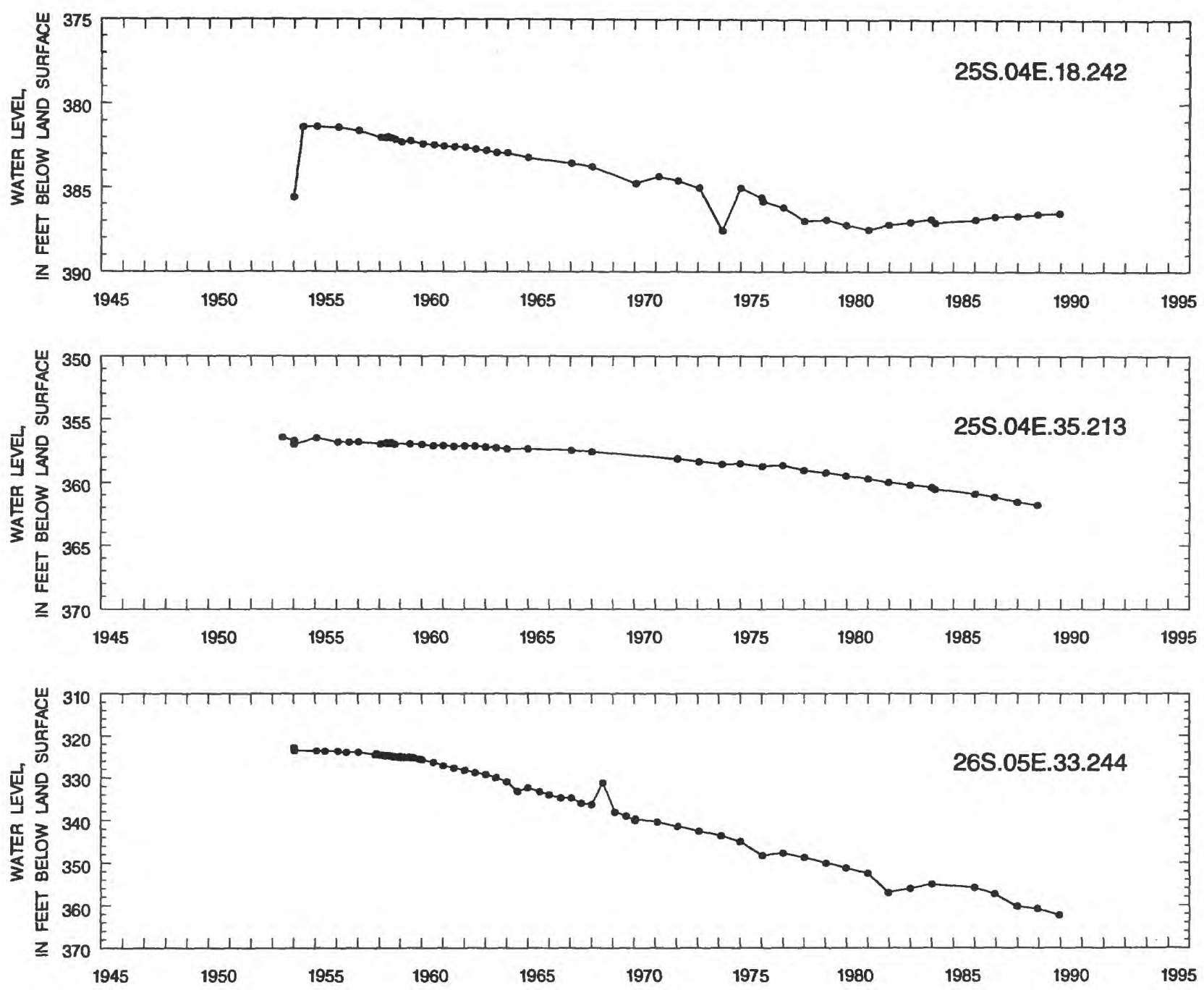

Figure 74.--Water-level data for selected wells in the Hueco monitoring area. See figure 73 for location of wells. 


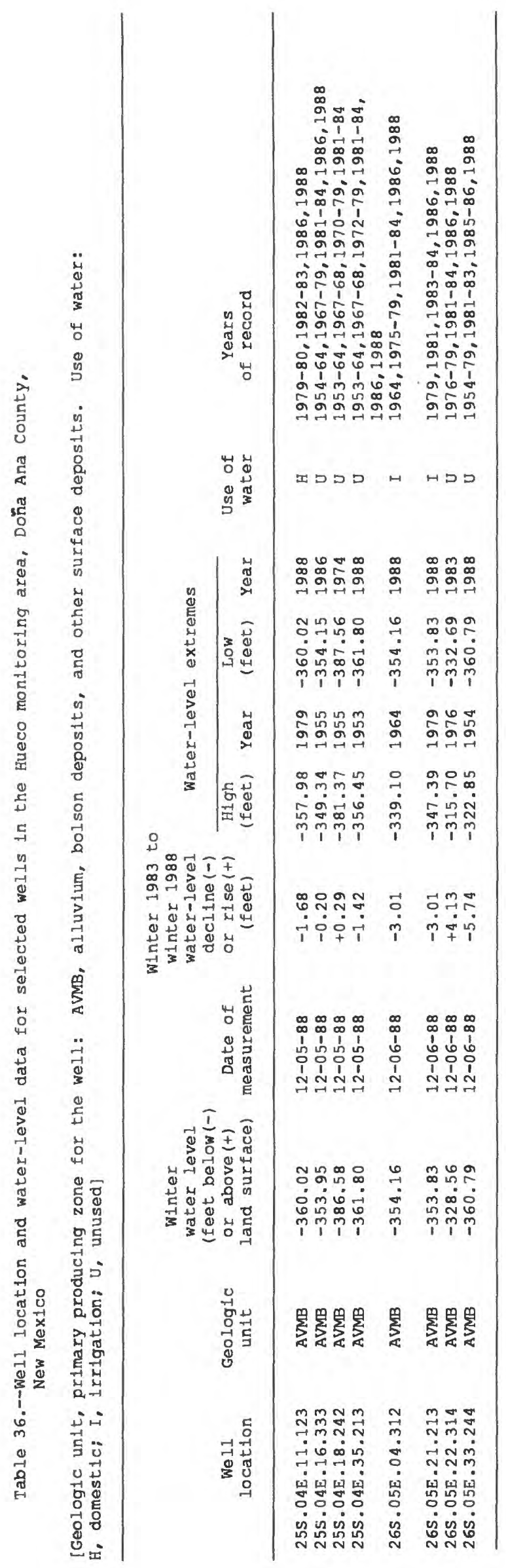






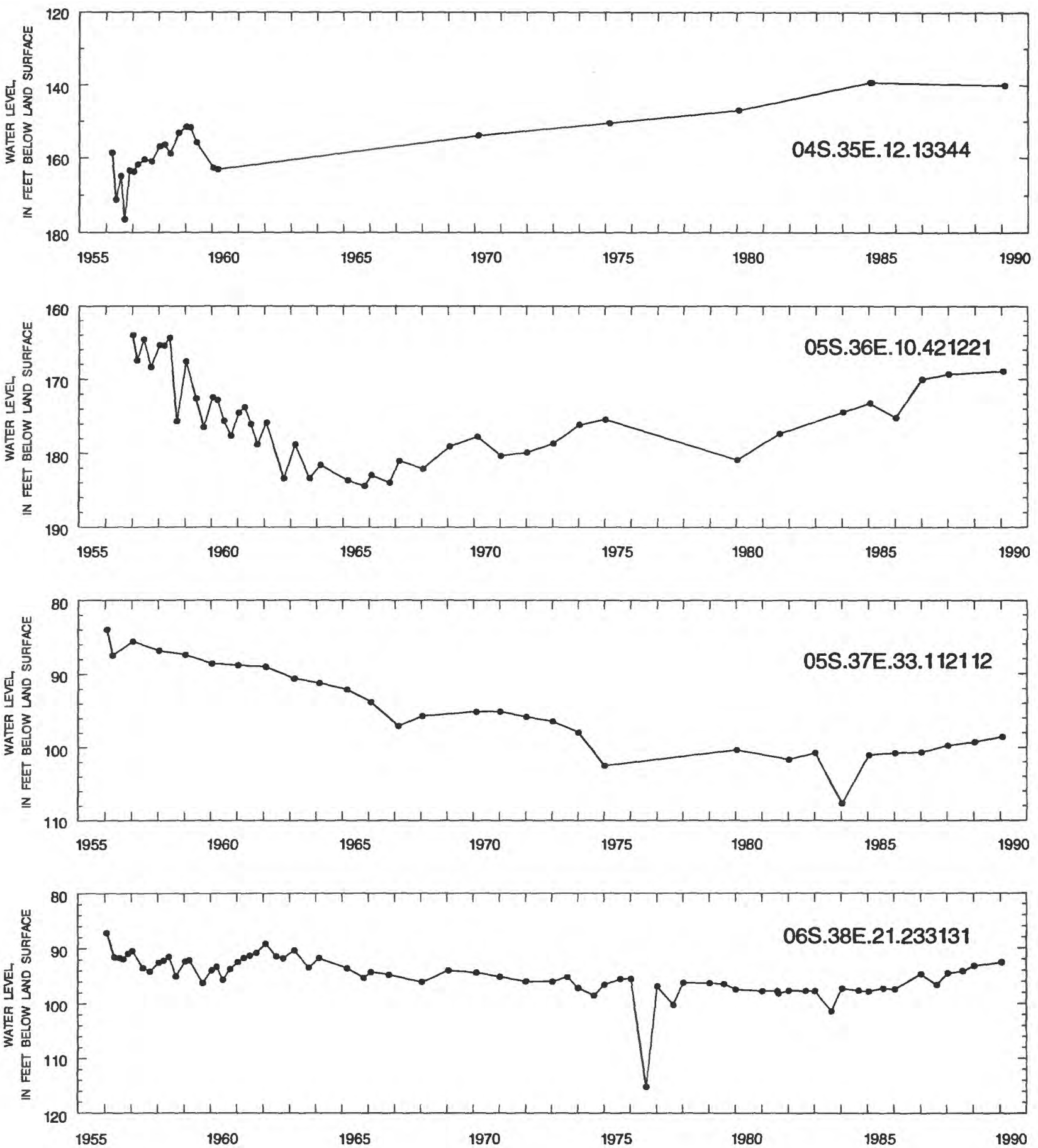

Figure 6.--Water-level data for selected wells in the Causey-Lingo monitoring area. See figure 5 for location of wells. 



\section{웅잉ㅎㅀ}

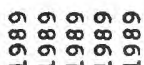

œ2020

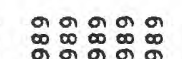

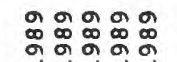

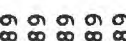

00000

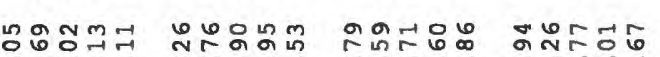

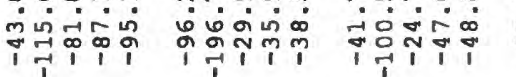

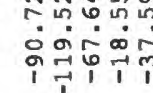

융워

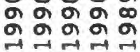

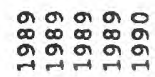

(1)

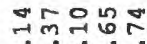

1िi

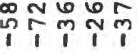

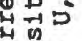

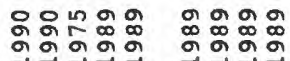

응유국 웅응

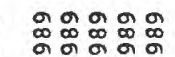

옹요용

०ूक

مo

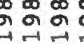

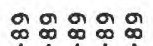

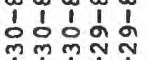

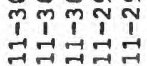

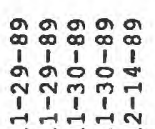

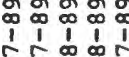

ón

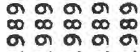

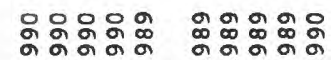

ภำกำ

꾸ํํำ

웅유융

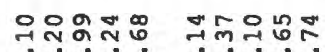
लिख

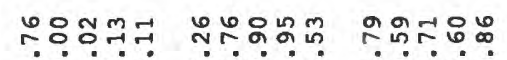

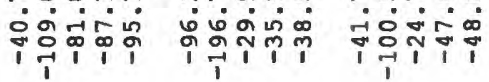

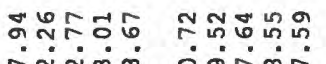

NָNָ๊

운우융ํㅇ (1)

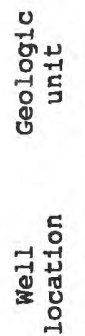

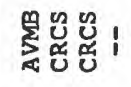

mำฟ लुฟ मिल्लिंड

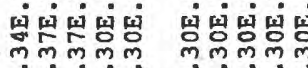
मेंघं

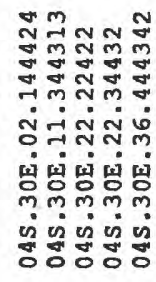

i i i i :

곯ำำ

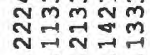
ธ่ำ 거

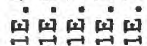
लिलेलि

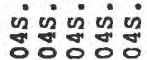

4114141114

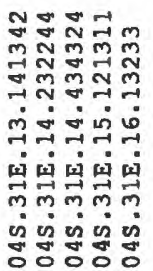

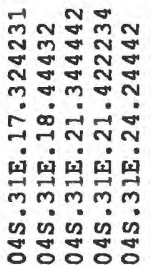

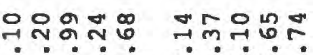

윽응용요욣영 1ำ1ㄴำ

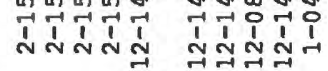

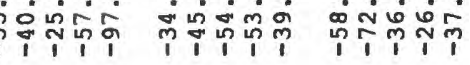




\title{
U.S. DEPARTMENT OF THE INTERIOR
}

\section{BRUCE BABBITT, Secretary}

\section{U.S. GEOLOGICAL SURVEY}

\author{
Gordon P. Eaton, Director
}

For additional information write to:

District Chief U.S. Geological Survey Water Resources Division 4501 Indian School Rd. NE, Suite 200 Albuquerque, New Mexico 87110-3929
Copies of this report can be purchased from:

U.S. Geological Survey Earth Science Information Center Open-File Reports Section Box 25286, MS 517 Denver Federal Center Denver, Colorado 80225 


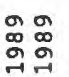

กั

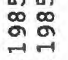

우일

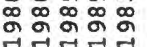

نำ

50ㅎㅎํ

नㄱㄱㄱ

sivis (1)

我的果里

a $x$

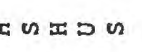

ñno

$D$ 幽口

UA UDD

エロロロ

(1)

(2)

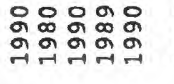

노운웅요

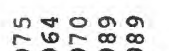

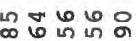

우웅응

땡ํㅇㅇㅇㅛ

돈둥웅

부읙ㅇ

ฟิํํำ

유웅주

กㅇํ

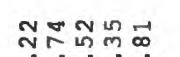

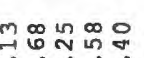

न국ㄷ

किं山ु

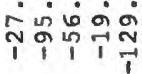

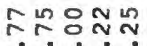

政

\section{รัฒㅇํㅇㅇํ}

onon नननतन

ตำm

กู่

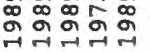

응요응

응용ㅇㅇ응

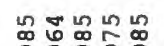

ज्रेंगे

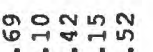

ज行

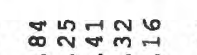

N Nma

TmN-7 列

양응ㅇㅇㅇ

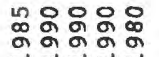

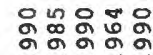

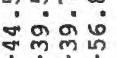

영요웡

구ำกำ

양유뭄

용ํ워

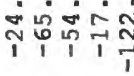

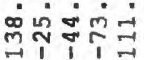

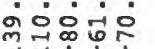

तู่ळक

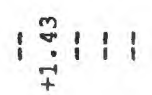

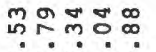

눙요연

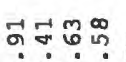

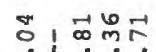

ถูำ

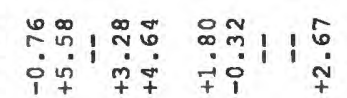

\section{으응으 \\ ำำ}

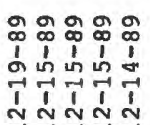

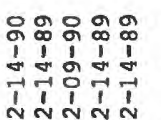

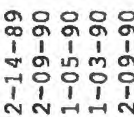

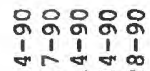

거선ㅁำ

응응응요

윟ํํㅇํㅇ

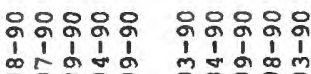

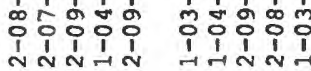

\section{ตำ 꾹워} ํㅓㅇㅝำ

๘

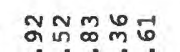

जक ज्ञ

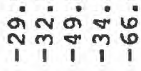

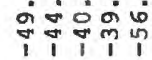

ำ $\stackrel{\infty}{\sim} \stackrel{\infty}{\sim}$ 웅

$\because \div$ ำก

ธํํํ유유

등ํำ 1 .

宫:

봉봉롱병령

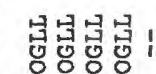

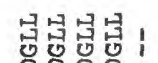

봉봉봉블

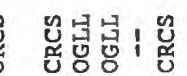

ราำ

角似

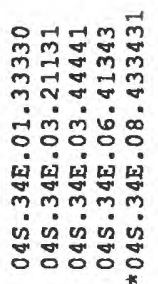

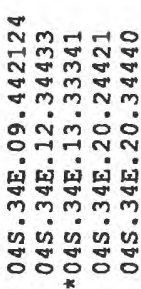

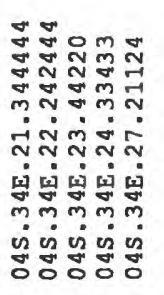

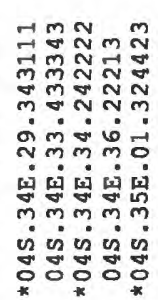

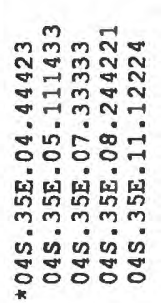

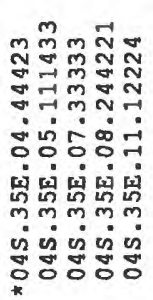

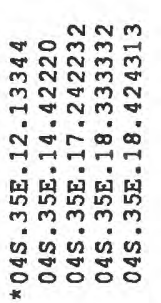

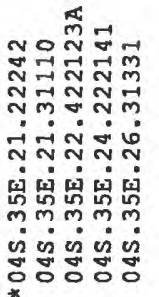




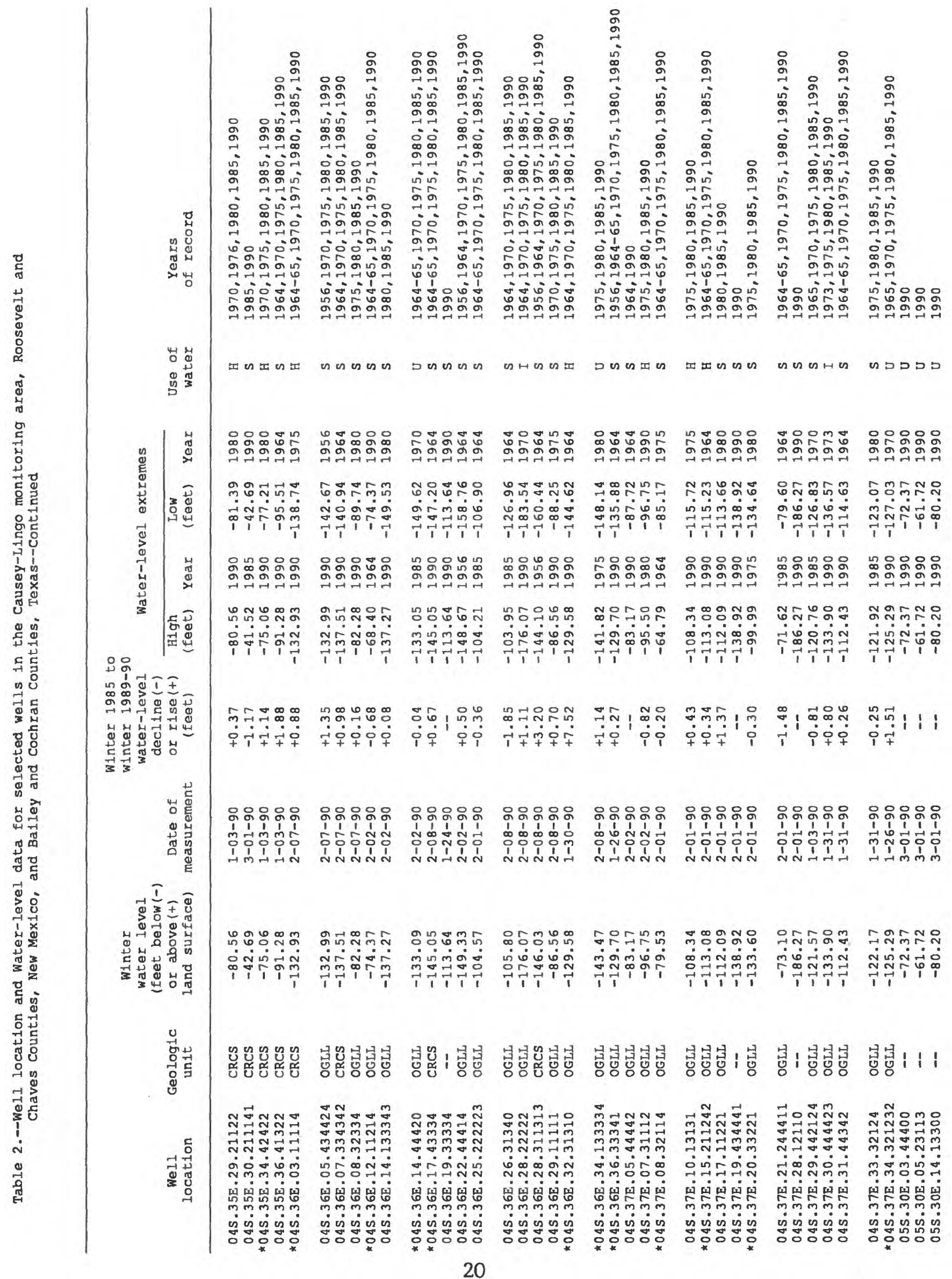




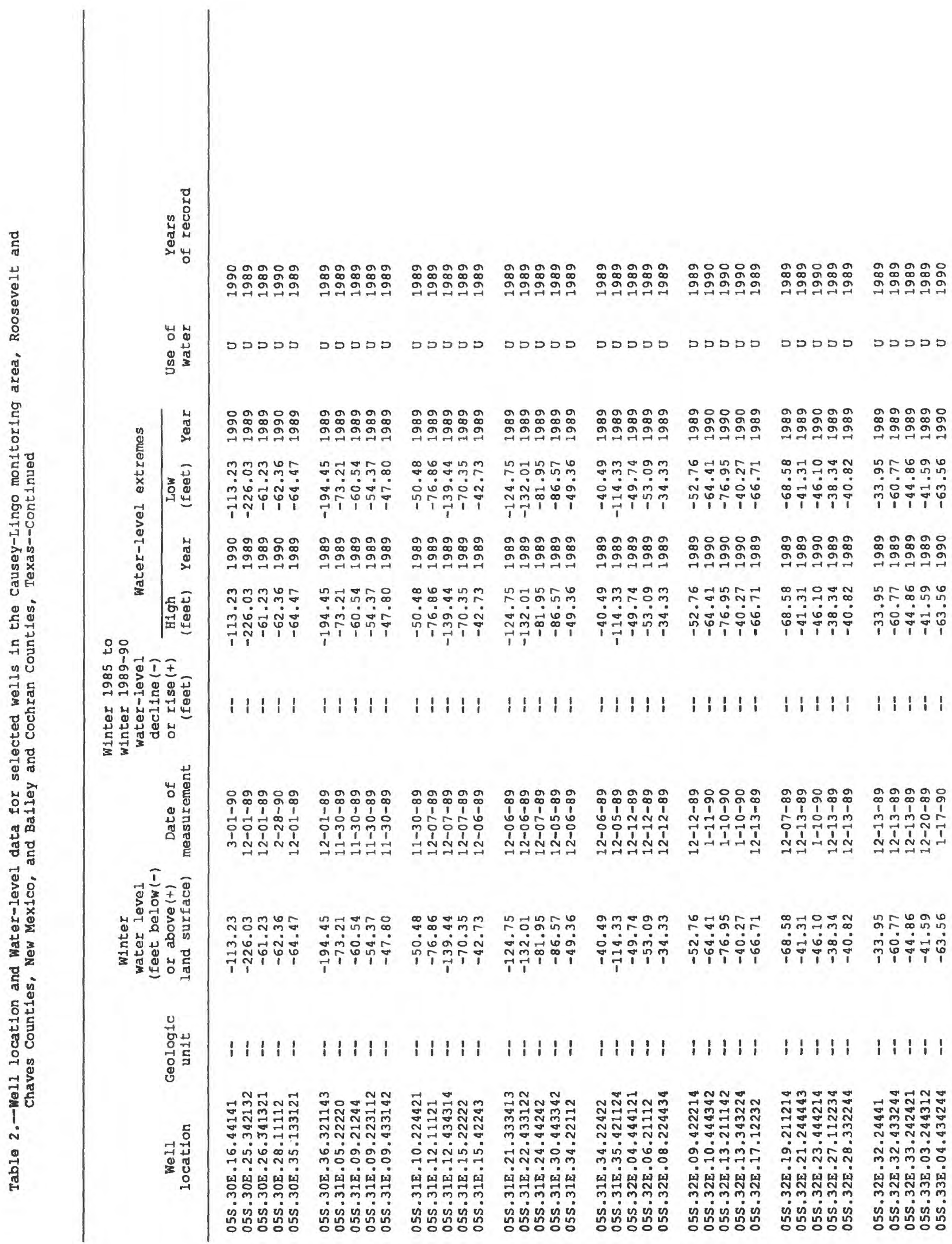




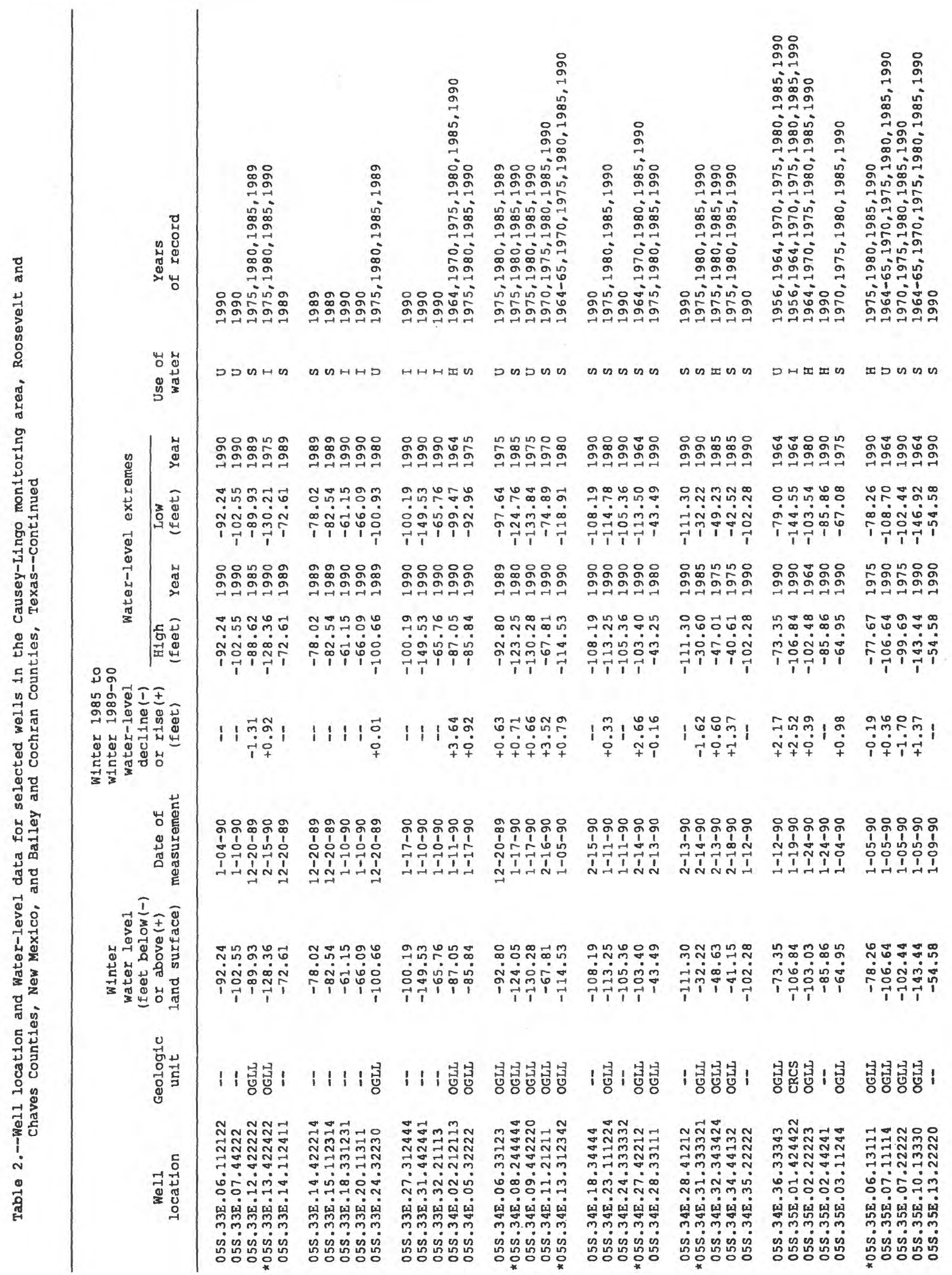




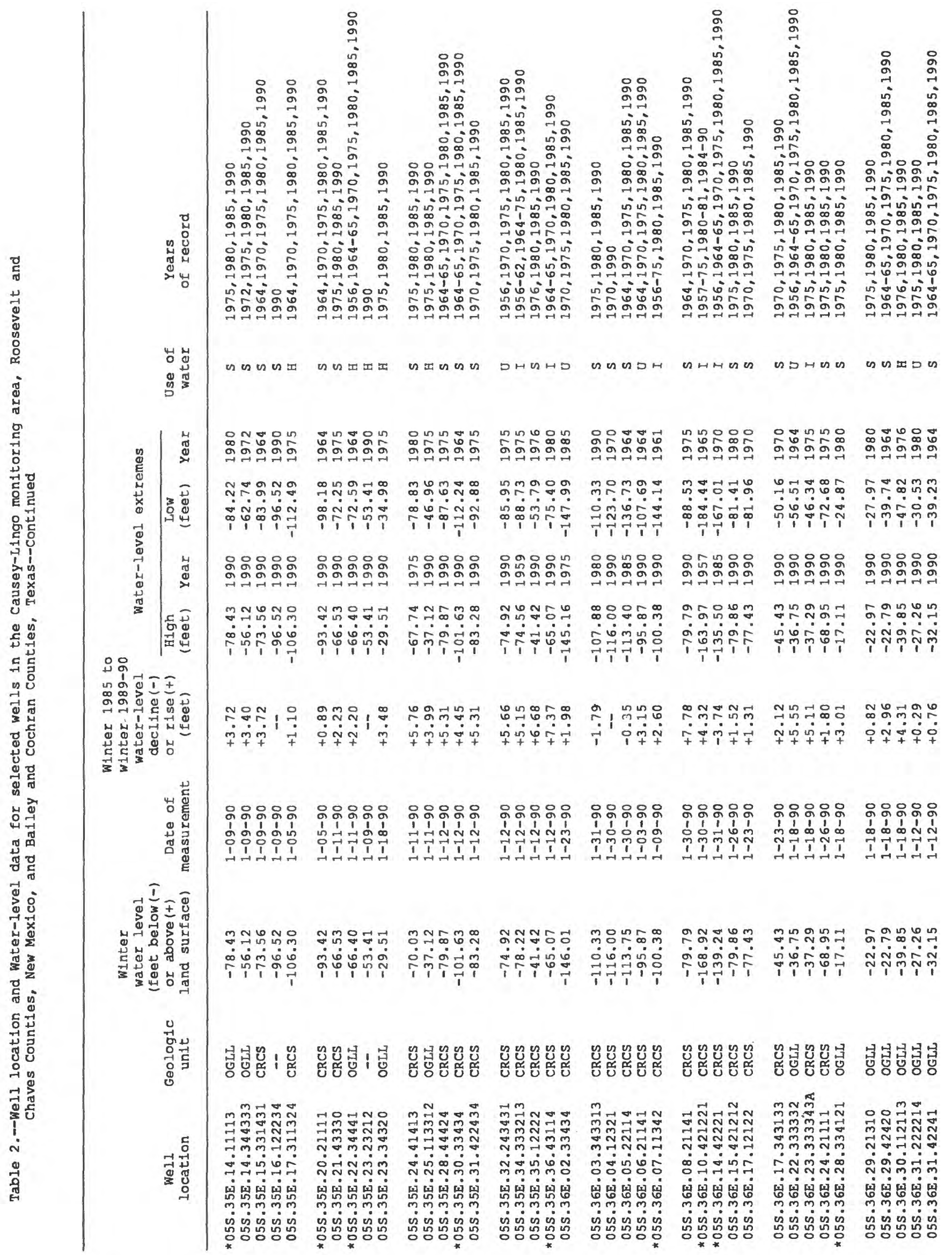




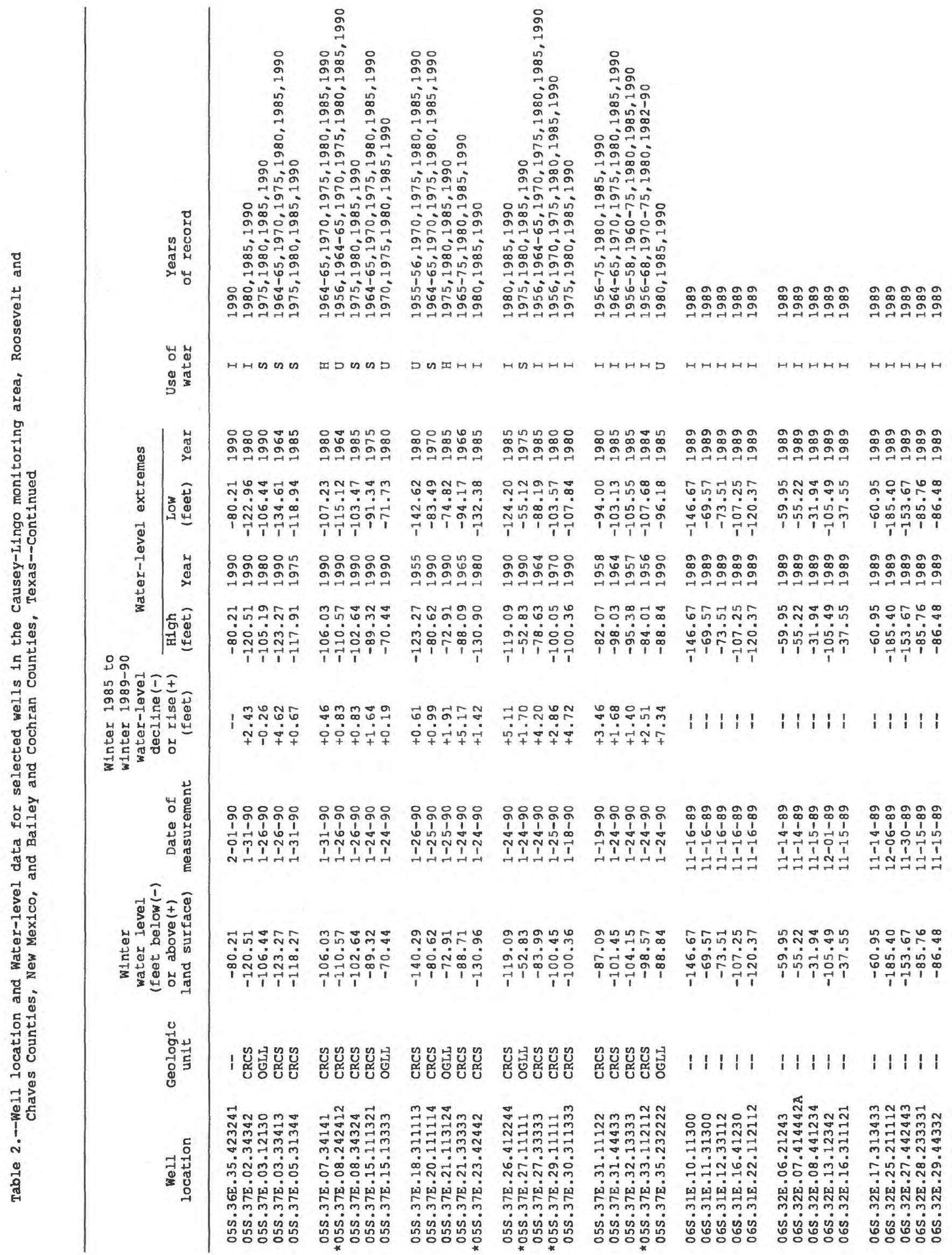




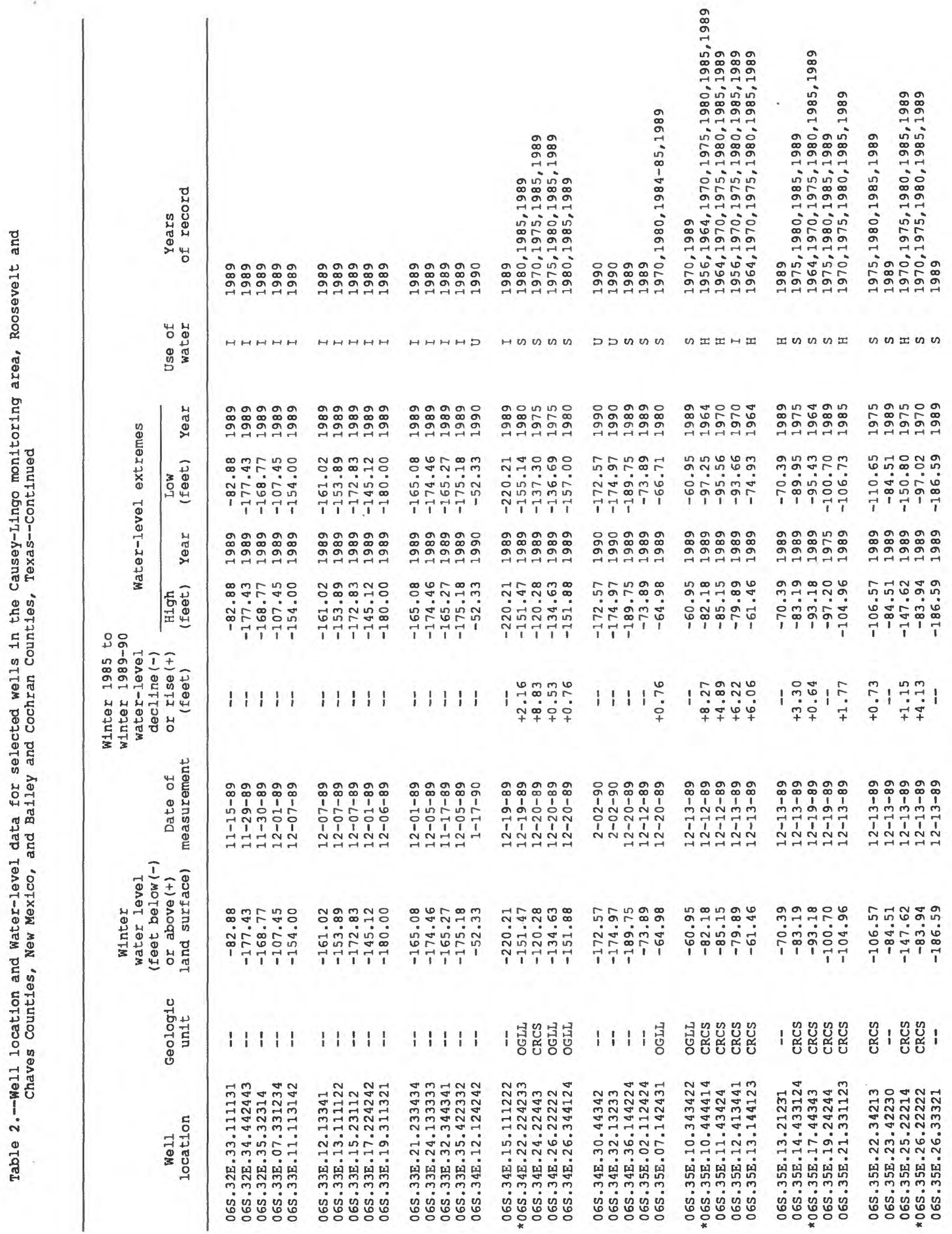




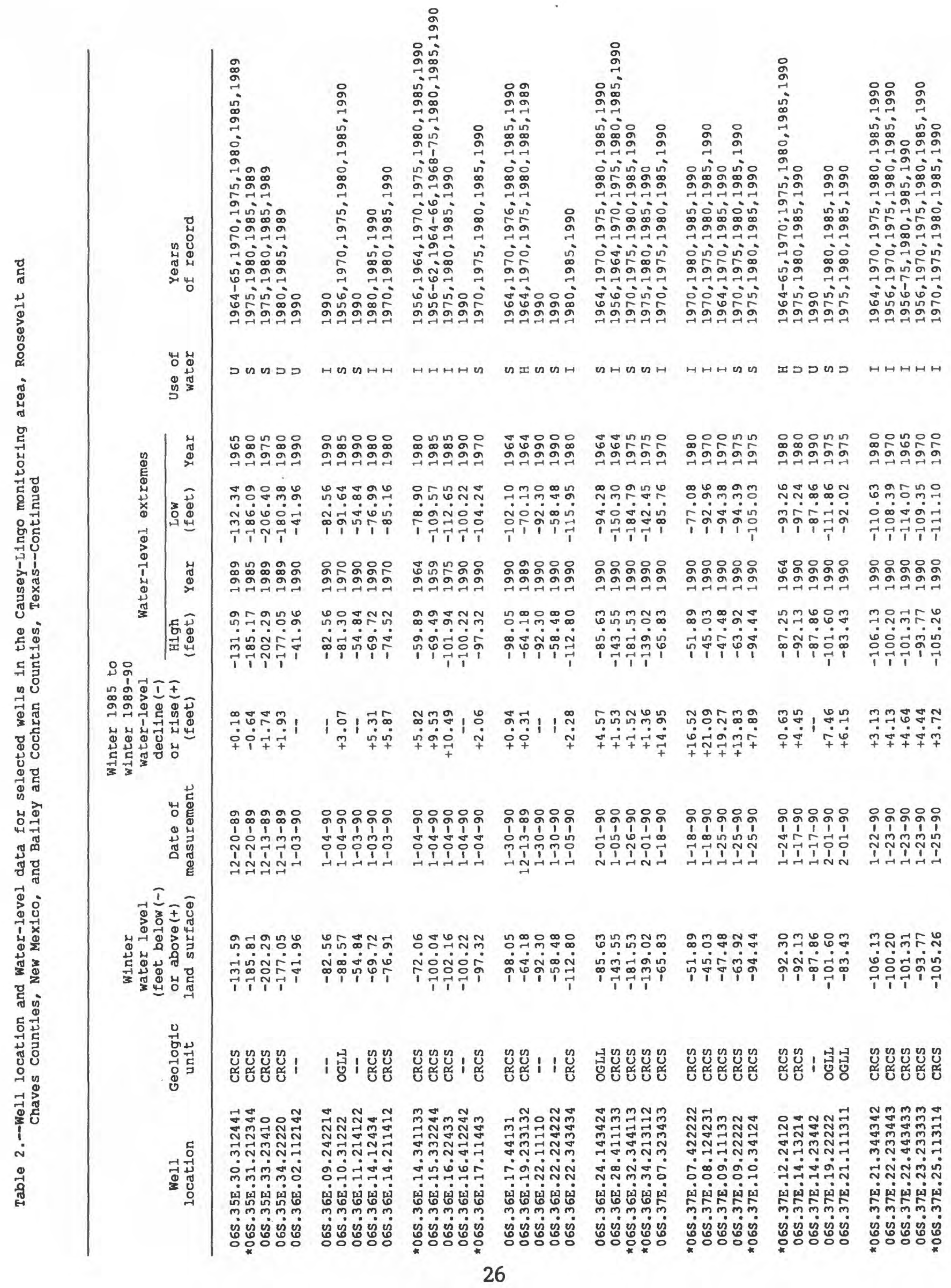




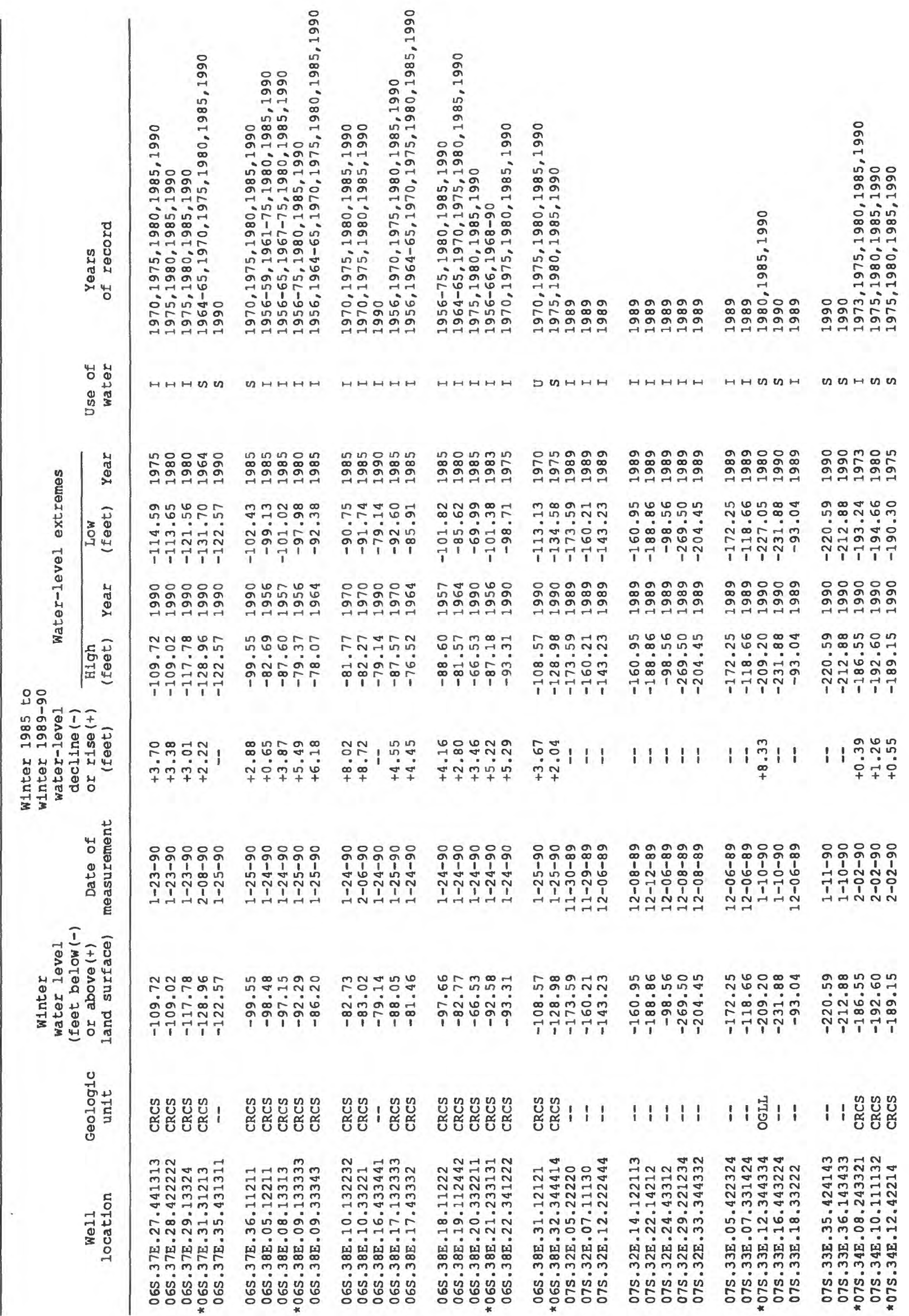




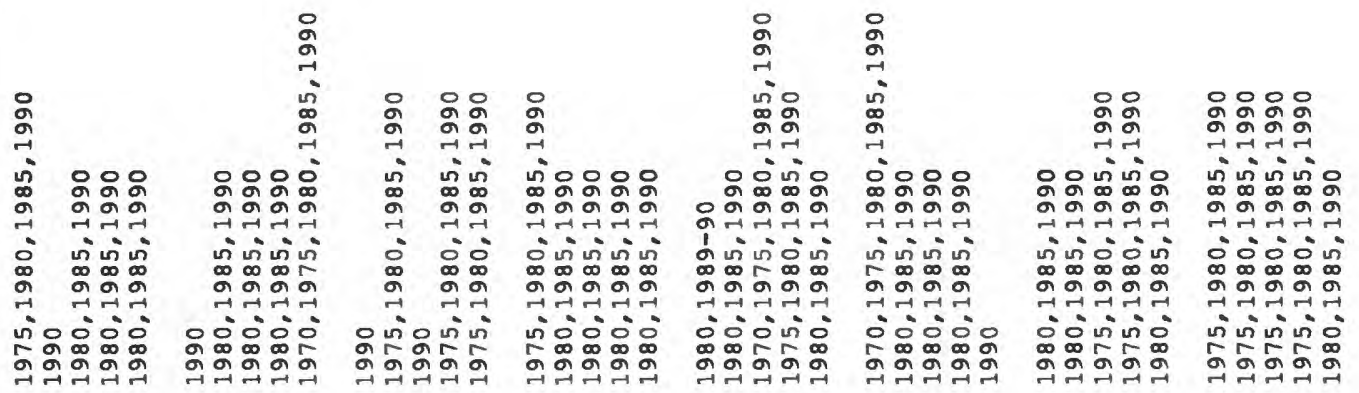

우응

응이욤ำ

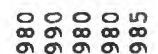

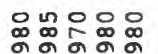

옹응요

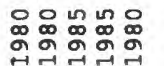

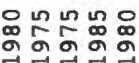

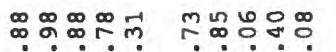

กํㅠㅁำ

웅뇨 7

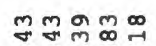

ana

뜽ํํ용

중우워

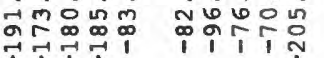

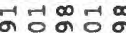

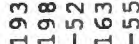

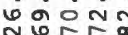

9.

-

की

१ิน

†ิतก

1ิ77

तิ1

117

†ิतज十

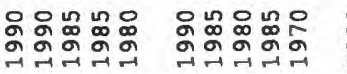

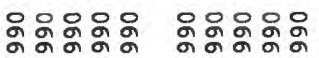

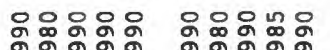

응ㅇㅇㅇㅇ

รัํํㅇํㅇํㅀ

กำ

యु어요

orwa

त舟文-

ก๊ำ

o웅두

बंलिंक्ष

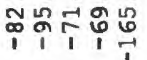

ดี용ํำ

तू कूष

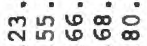

मค

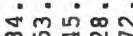

क्षेत

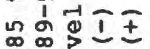

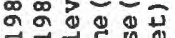

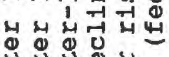

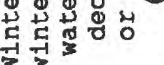

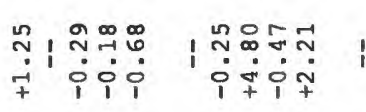

|

ํำ 굼

1ำกำำ

1)

१ิतन

औ11

응요응유 응응응요

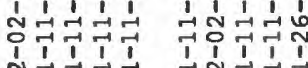

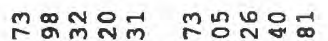

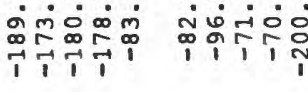

ํㅜㄱㅂㅜㅀㅀ

ลี่뾰

नत्ञात

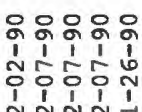

은육연영여

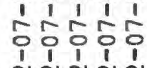

욱응융요

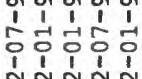

융융용요

0
and

은오융요요

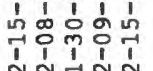

응용ㅇㅇㅇㅇㅇ

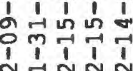

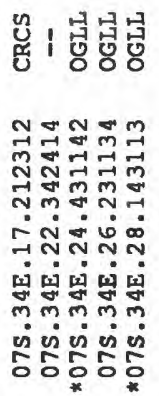

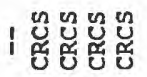

|

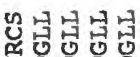

구ㄴㅜㅜㅇำ

Nूळ

우ㅇㅝㅠㅇํำ

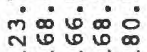

푼유요

i்

ㅊํำ- ด็

வ்

음등응

$\vec{\imath} \overrightarrow{1} \vec{\imath}$

$\overrightarrow{1} \overrightarrow{1} \overrightarrow{1} \overrightarrow{1}$

ज्ञात

$\rightarrow-1-1$
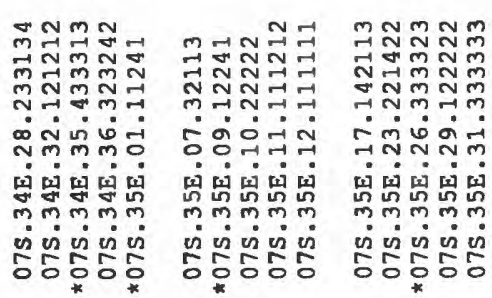

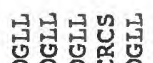

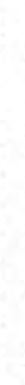

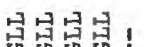

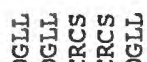

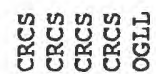
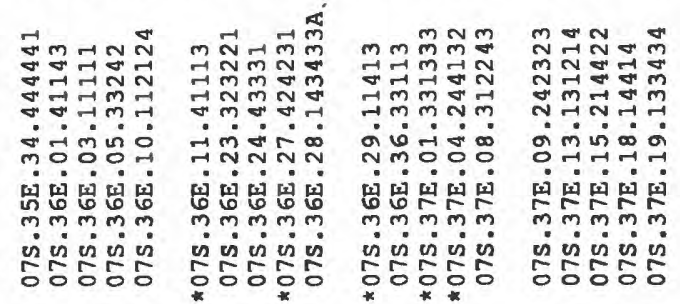


\section{CONTENTS}

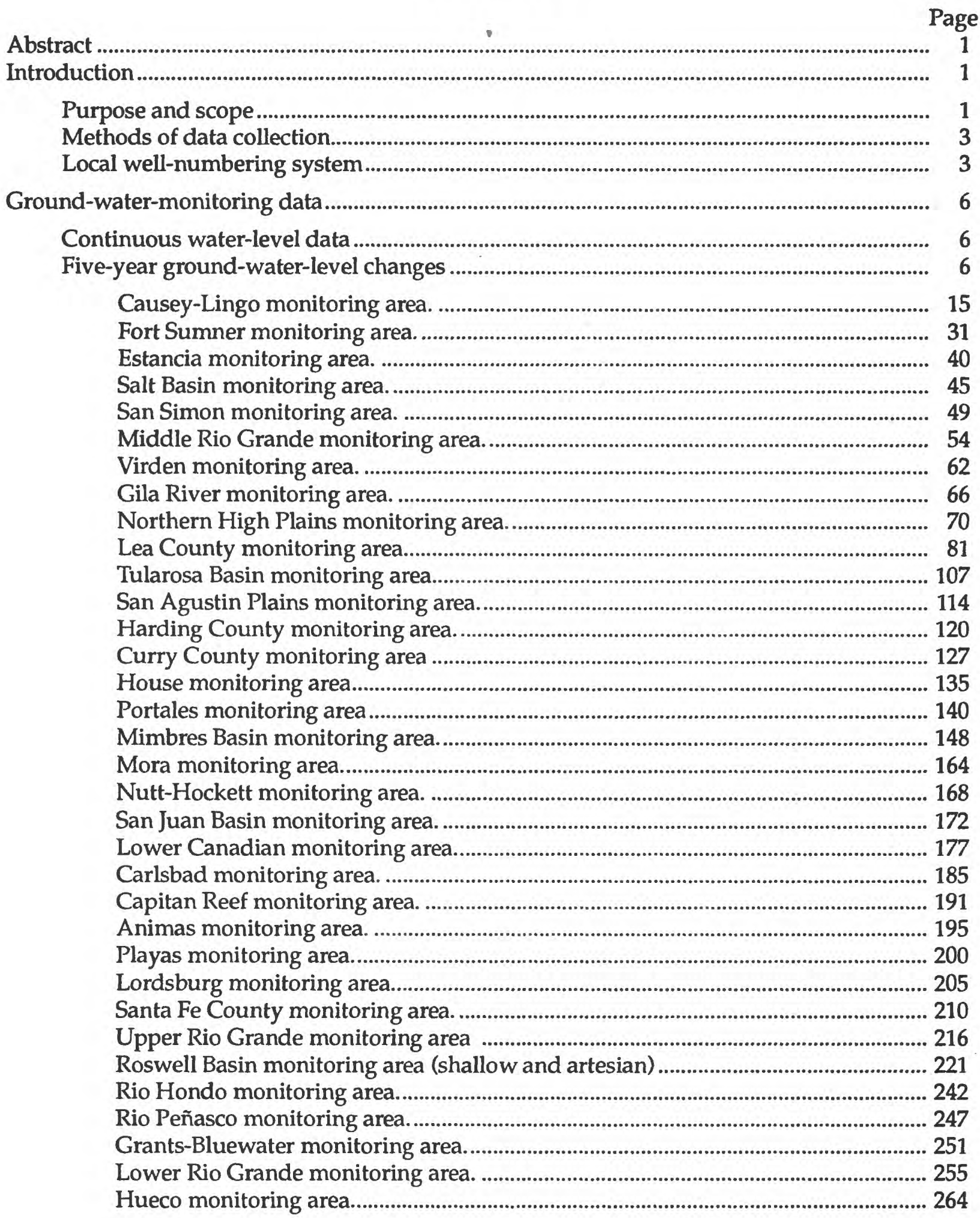




\section{응ํํㅇㅇํ}

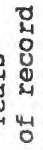

넝 노

ज苋

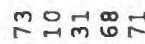
में

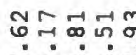

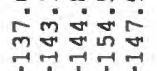

นึำำด

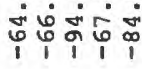
红・江的 नेन्न ज्ने

ஸัดัตุำ

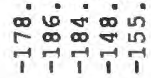

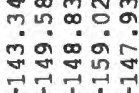

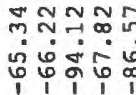
응윽윽을 응응용

同品出

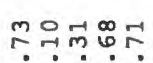

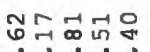

늉연동ㅇㅇ

ज小

的宓的家

ธึंतुํํㅇ

는둥융ㅇㅇ

ติำํำ

กำกั

하두누

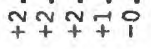

+ंक्षिक

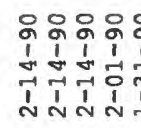

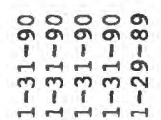

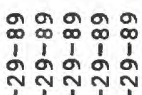

$11+1 \frac{1}{1}=1$ १ิत

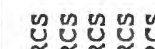

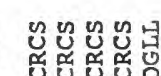

붑봅봅

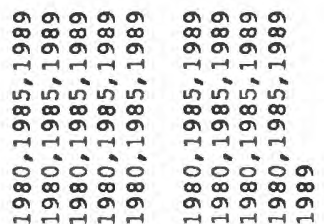

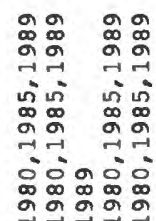
잃잉

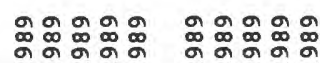

的口的

踏的

ungur

DDong Doses

ํํํㅇํㅇำ

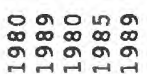

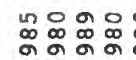

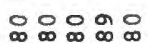

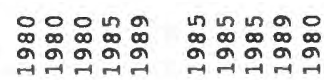

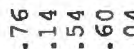

땍ㄲㅇㅇㅇㅇㅛ

の丁n $\infty$

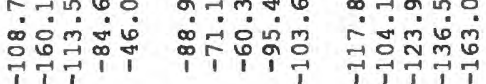

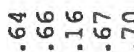

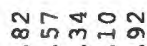

ก०o

우의의

oक 0 या

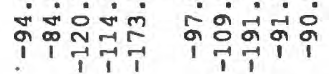

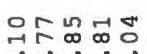
नᄀन

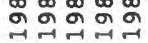

\%ัฒ

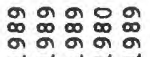

क्वंध

ำำำ

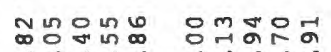
ती

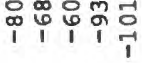

ज७ञ

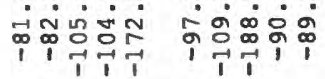

然

พิํㅠ논ำ

근,

สีनำกิ

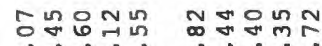

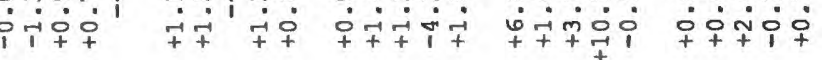

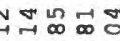

mo용ำ

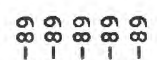

ic

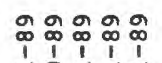

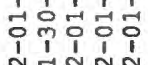

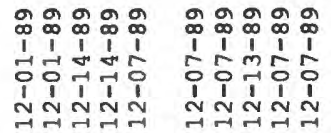

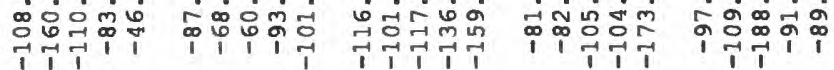

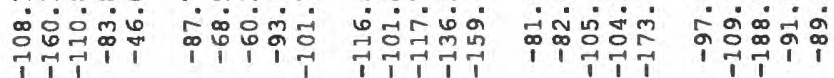

ํำ

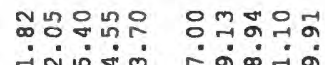
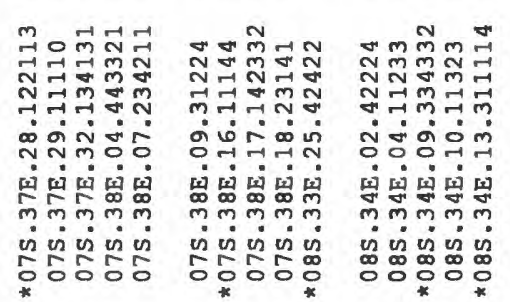

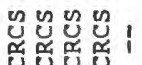

ปै匕

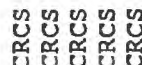

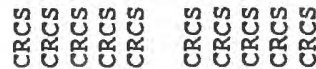
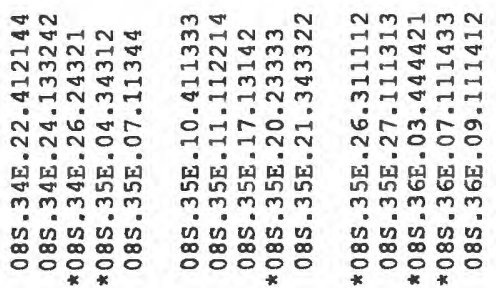

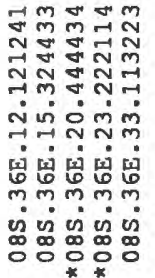

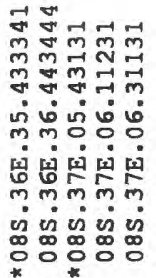




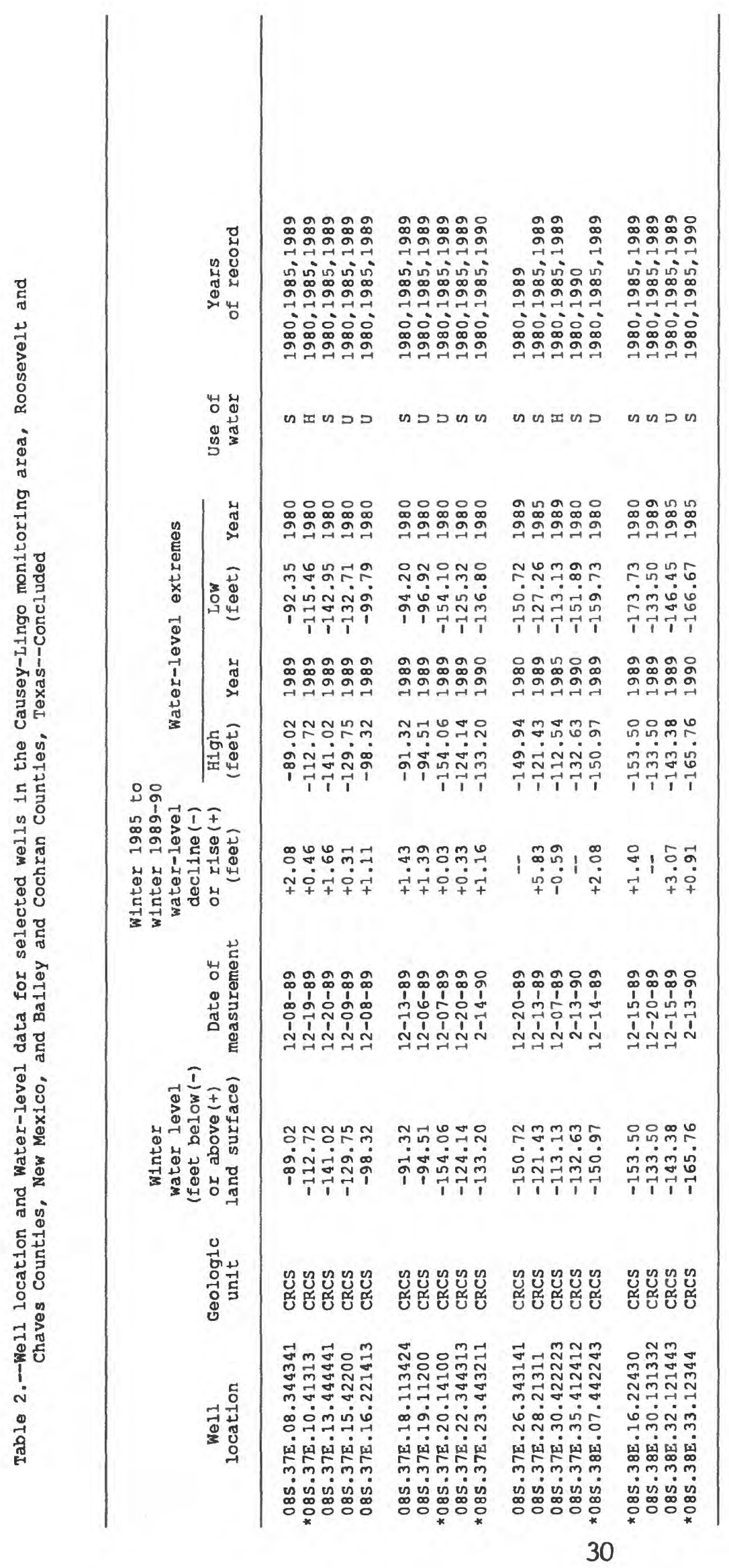




\section{Fort Sumner Monitoring Area}

The Fort Sumner monitoring area is in DeBaca and Guadalupe Counties, east-central New Mexico. Rises in water levels range from 0.04 to 3.45 feet; declines range from 0.01 to 6.77 feet. South of Fort Sumner water-level changes include rises and declines. East of Fort Sumner declines range from 0.01 to 1.28 feet and rises range from 0.09 to 3.45 feet. 

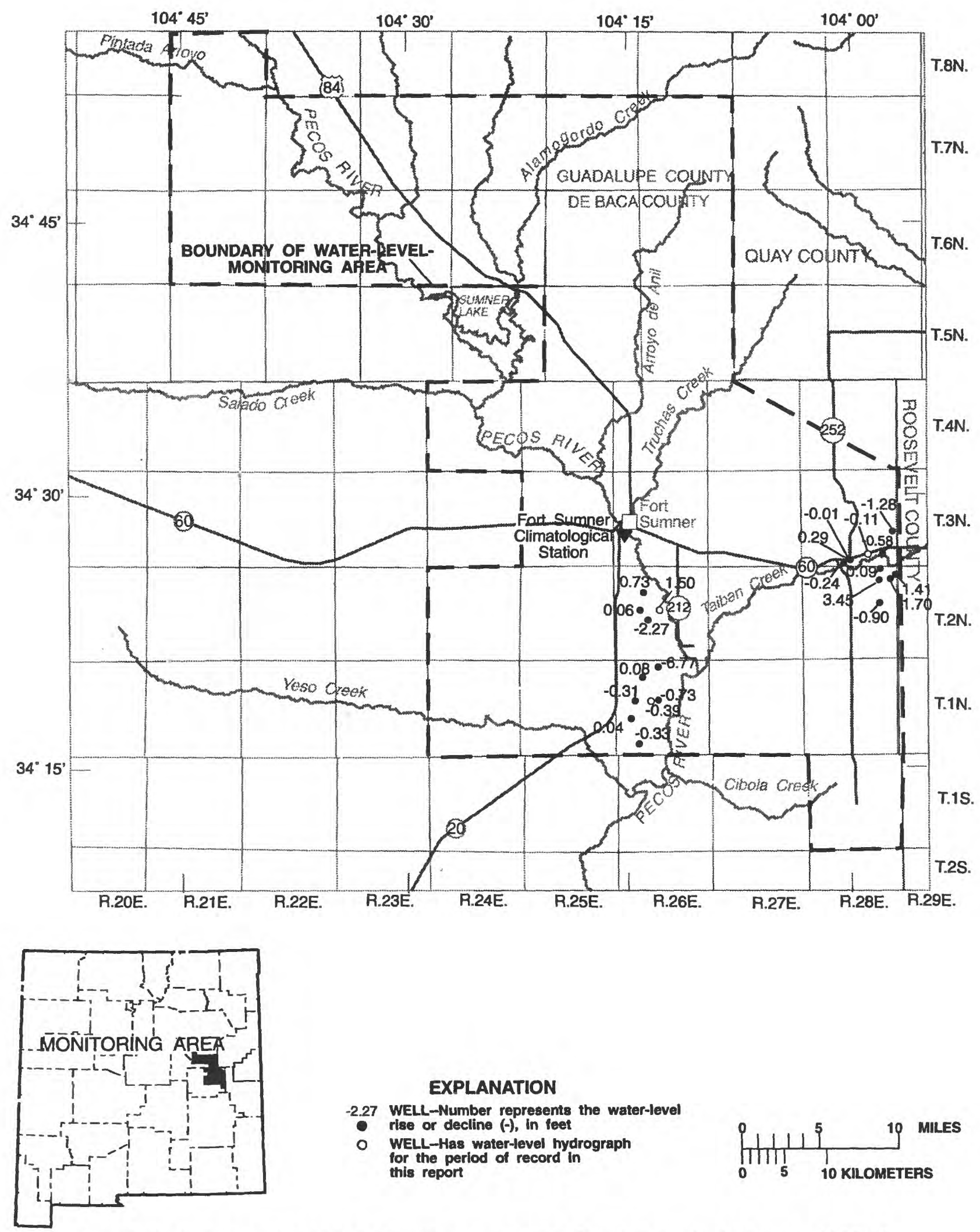

\section{EXPLANATION}

-2.27 WELL-Number represents the water-level

- rise or decline $(-)$, in feet

o WELL-Has water-level hydrograph

for the period of record in

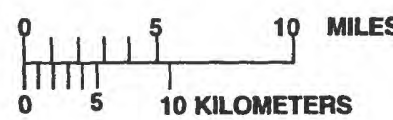

Figure 7.--Water-level changes for wells in the Fort Sumner monitoring area, 1985-90. 

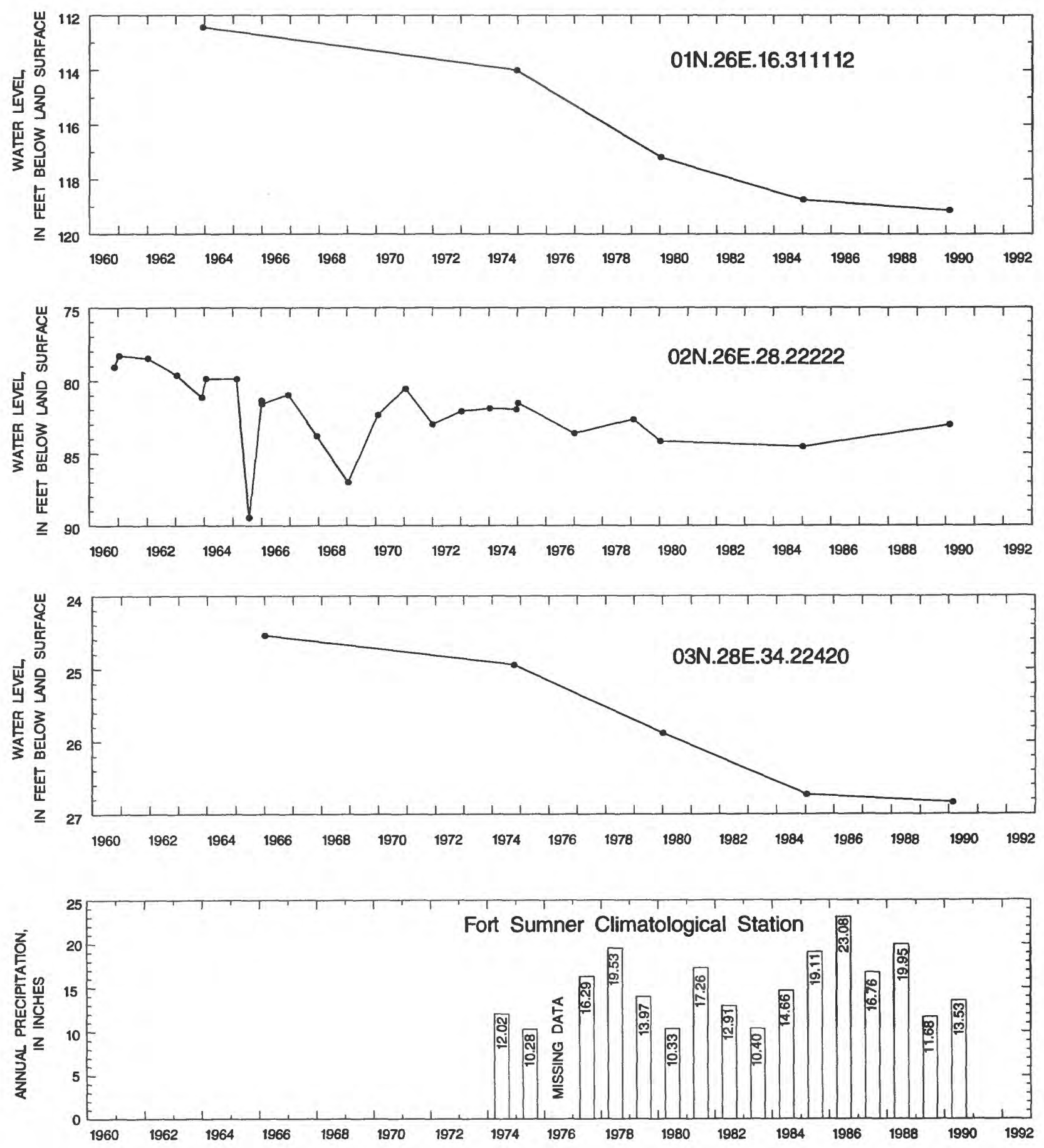

Figure 8.-Water-level data for selected wells in the Fort Sumner monitoring area and annual precipitation at the Fort Sumner Climatological Station. See figure 7 for location of wells and station. 


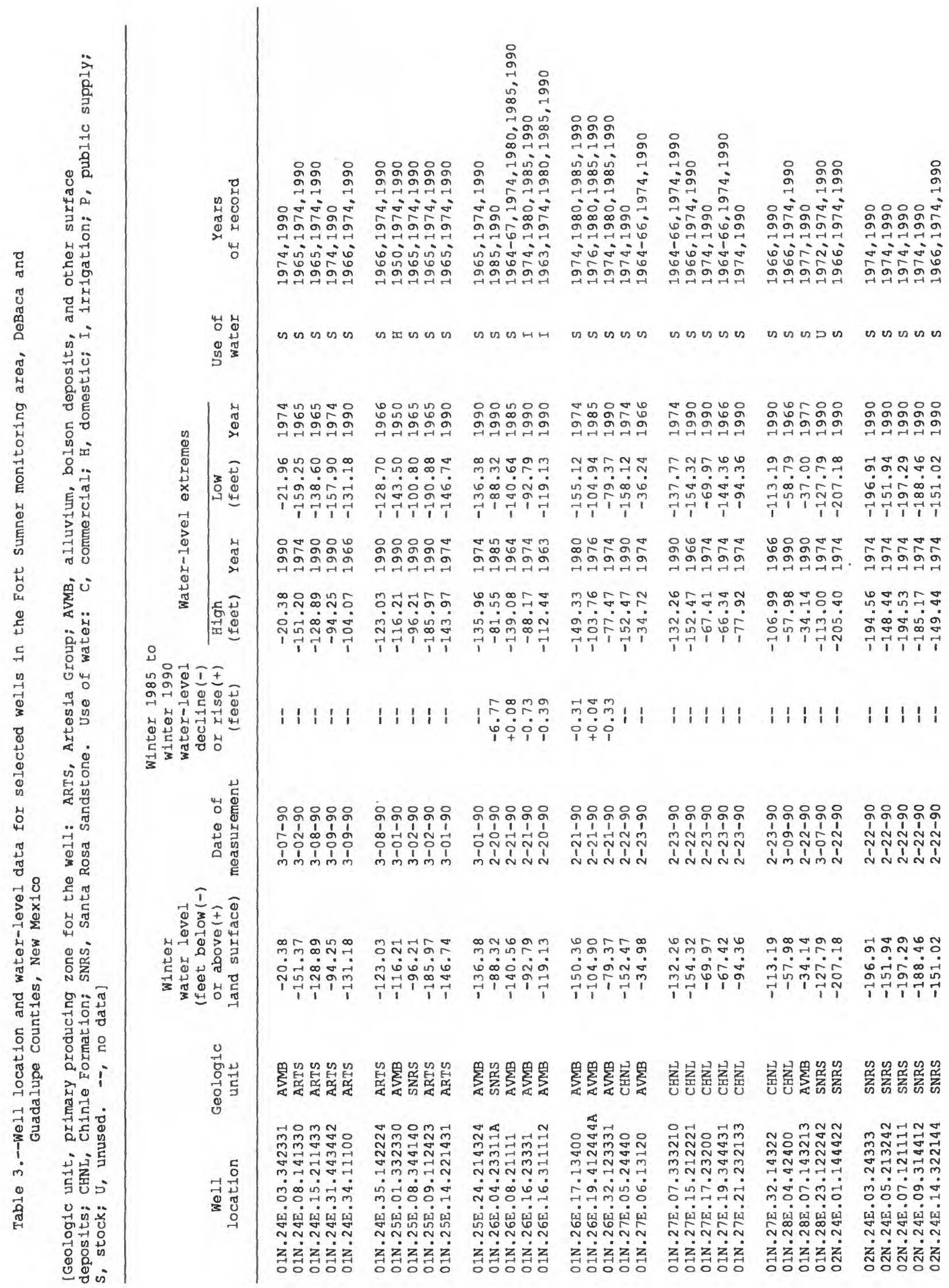




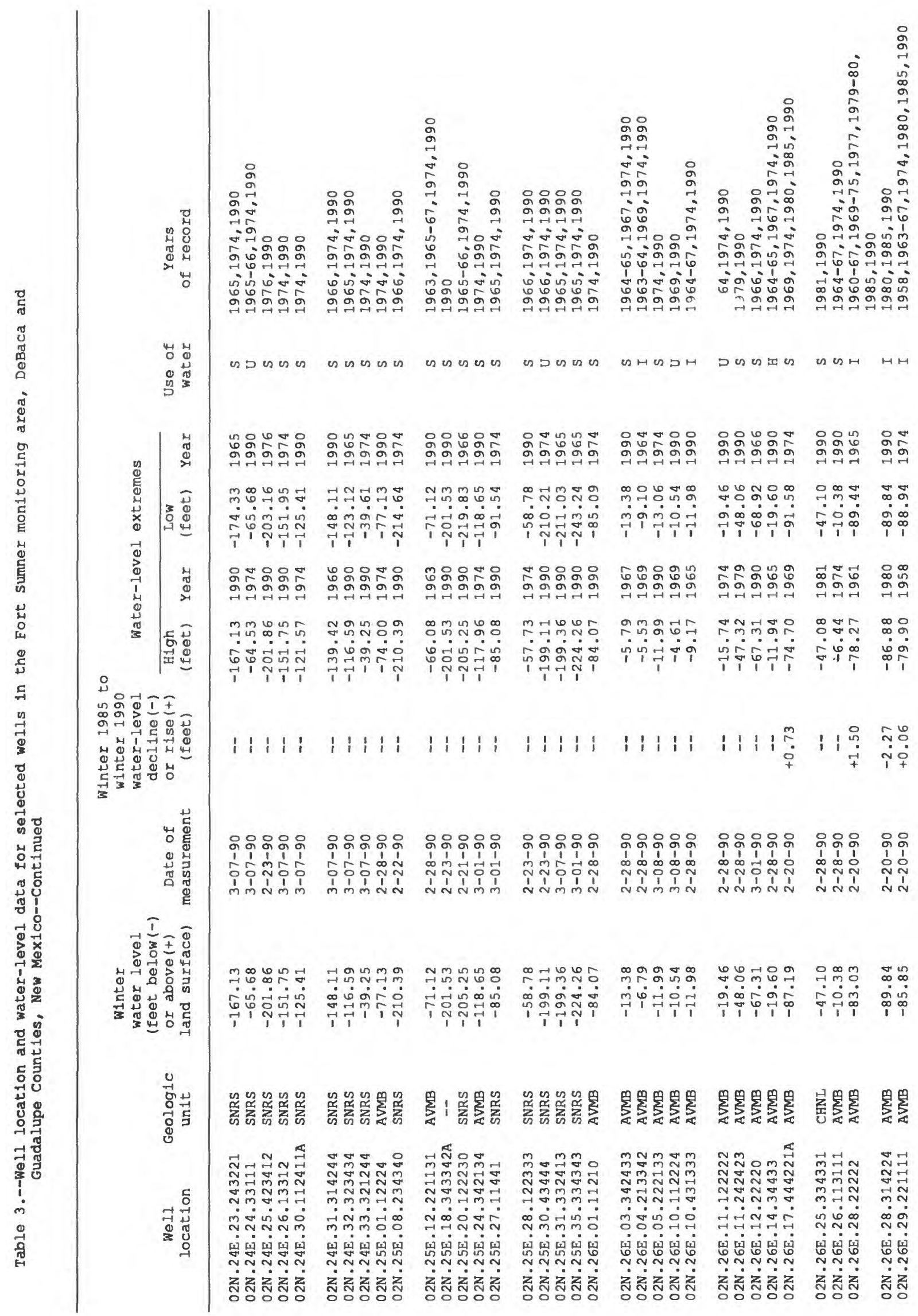




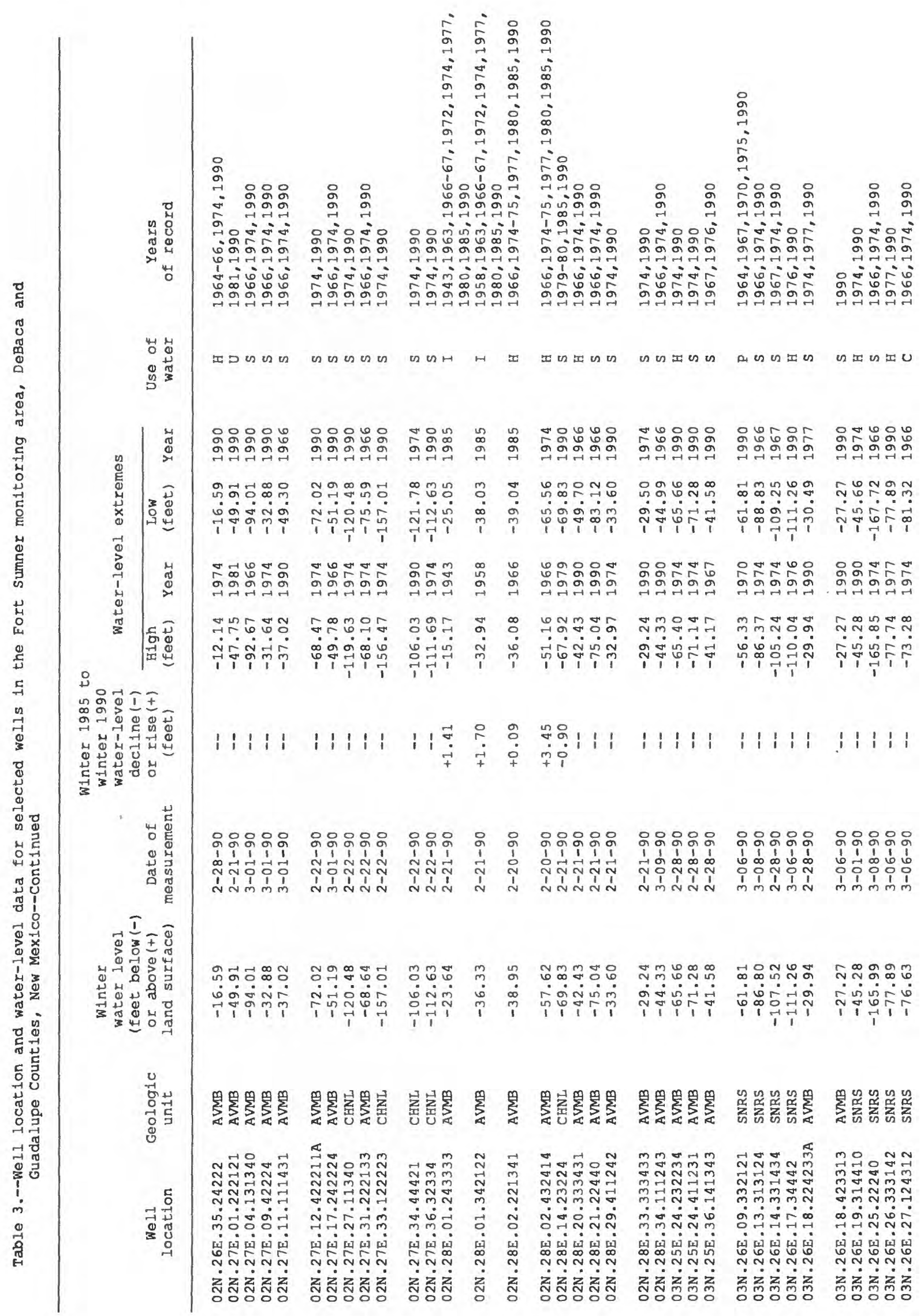




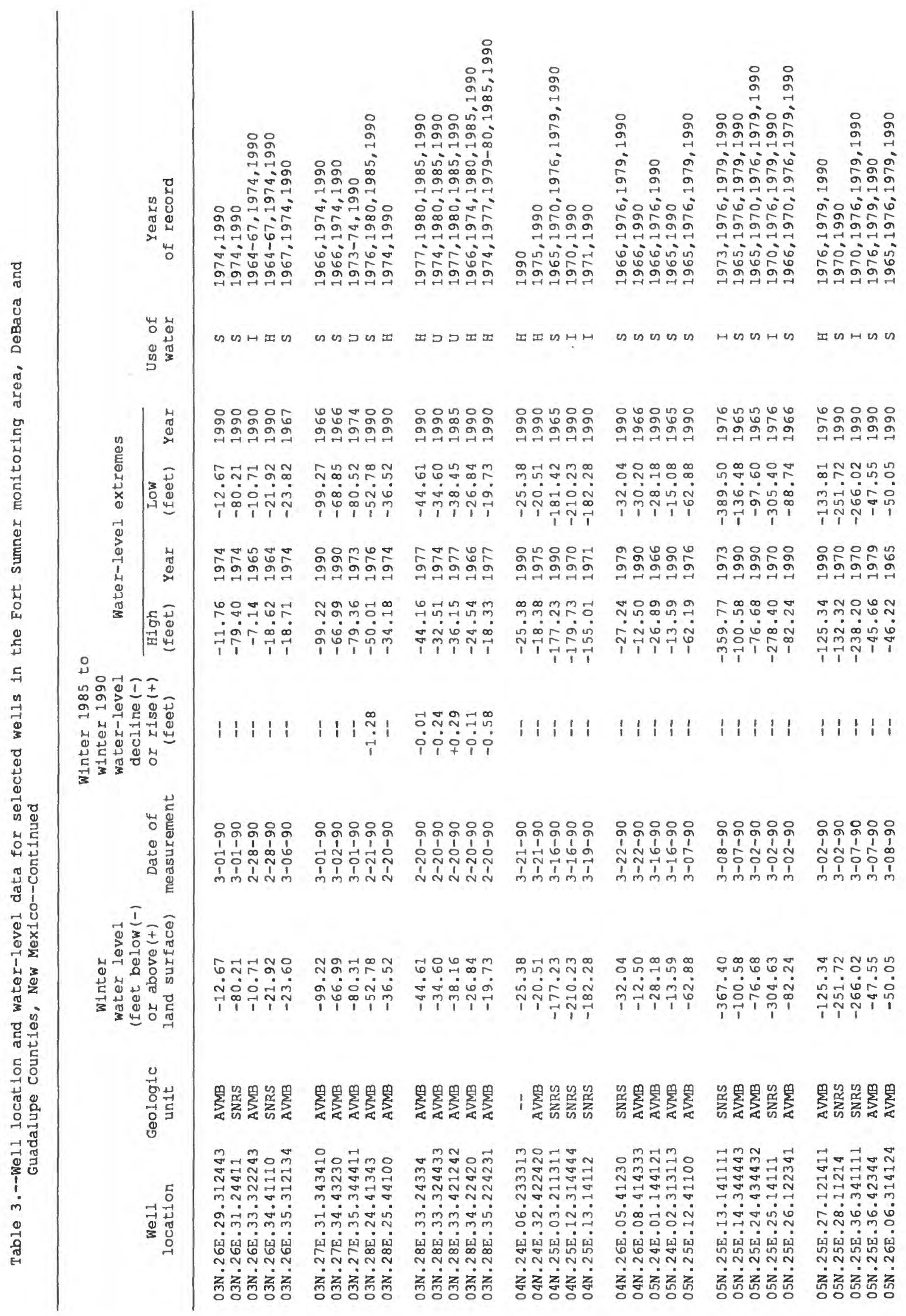




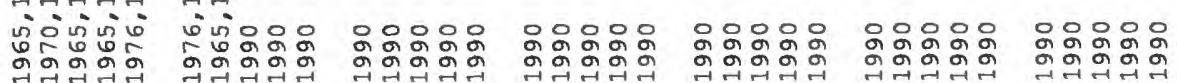

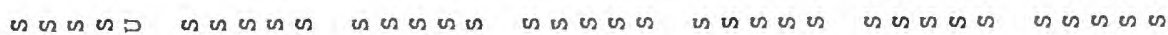

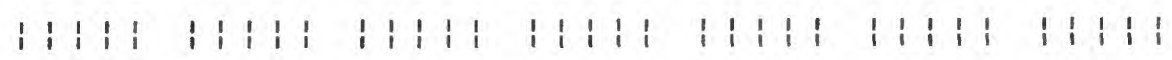

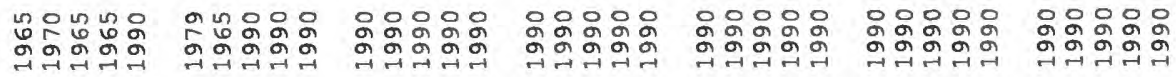

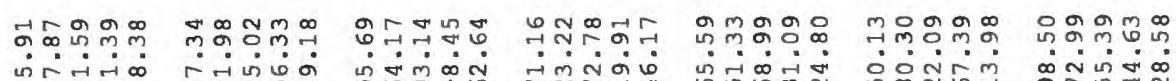

mo

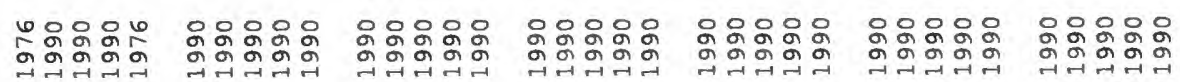

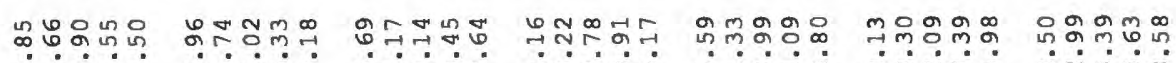

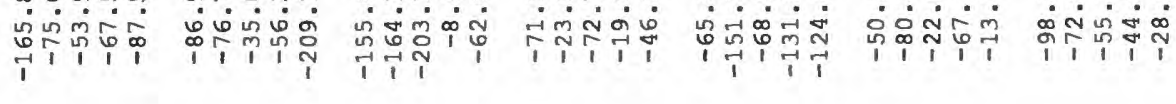

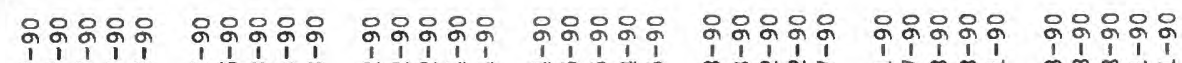

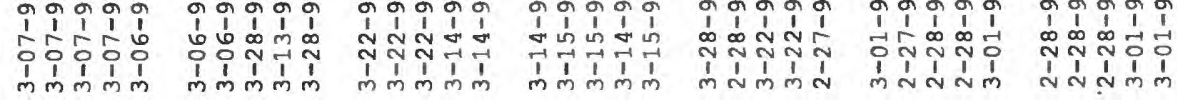

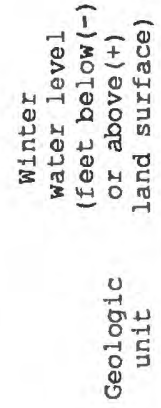
m的的

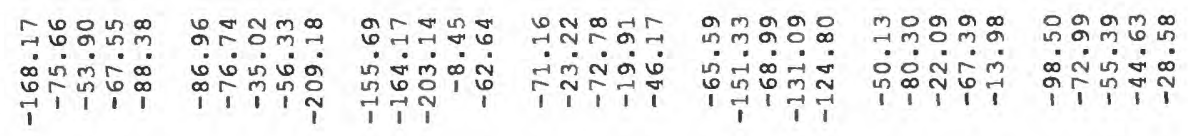

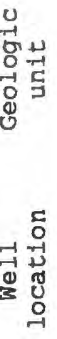

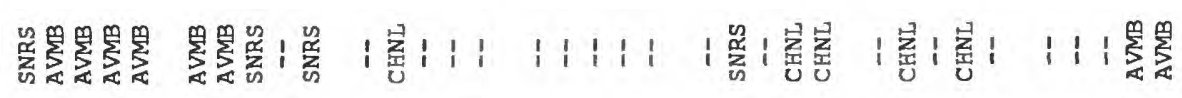

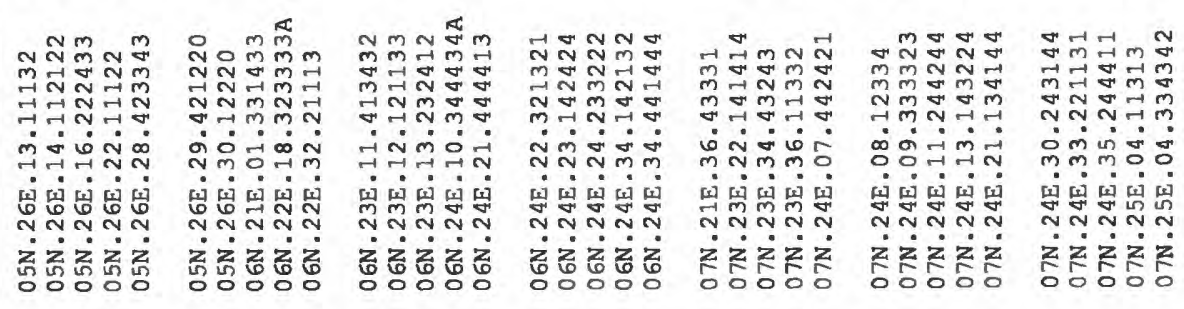




\section{FIGURES}

Figure 1. Map showing location of water-level-monitoring areas and years measured, 1984-93.

2. Map showing location of continuous recorder wells

3. Map showing well-numbering system used in New Mexico..

4. Plots showing continuous water-level data for selected wells.

5. Map showing water-level changes for selected wells in the Causey-Lingo monitoring area, 1985-90

6. Plots showing water-level data for selected wells in the Causey-Lingo monitoring area.

7. Map showing water-level changes for wells in the Fort Sumner monitoring area, 1985-90

8. Plots showing water-level data for selected wells in the Fort Sumner monitoring area and annual precipitation at the Fort Sumner Climatological Station.

9. Map showing water-level changes for wells in the Estancia monitoring area, 1985-90

10. Plots showing water-level data for selected wells in the Estancia monitoring area and annual precipitation at the Estancia Climatological Station .

11. Map showing water-level changes for wells in the Salt Basin monitoring area, $1985-90$

12. Plots showing water-level data for selected wells in the Salt Basin monitoring area.

13. Map showing water-level changes for wells in the San Simon monitoring area, 1985-90

14. Plots showing water-level data for selected wells in the San Simon monitoring area.

15. Map showing water-level changes for wells in the Middle Rio Grande monitoring area, 1985-90

16. Plots showing water-level data for selected wells in the Middle Rio Grande monitoring area and annual precipitation at the Albuquerque Airport and Bosque del Apache Climatological Stations

17. Map showing water-level changes for wells in the Virden monitoring area, 1985-90

18. Plots showing water-level data for selected wells in the Virden monitoring area.

19. Map showing water-level changes for wells in the Gila River monitoring area, 1985-90

20. Plots showing water-level data for selected wells in the Gila River monitoring area and annual precipitation at the Cliff 11 SE Climatological Station 


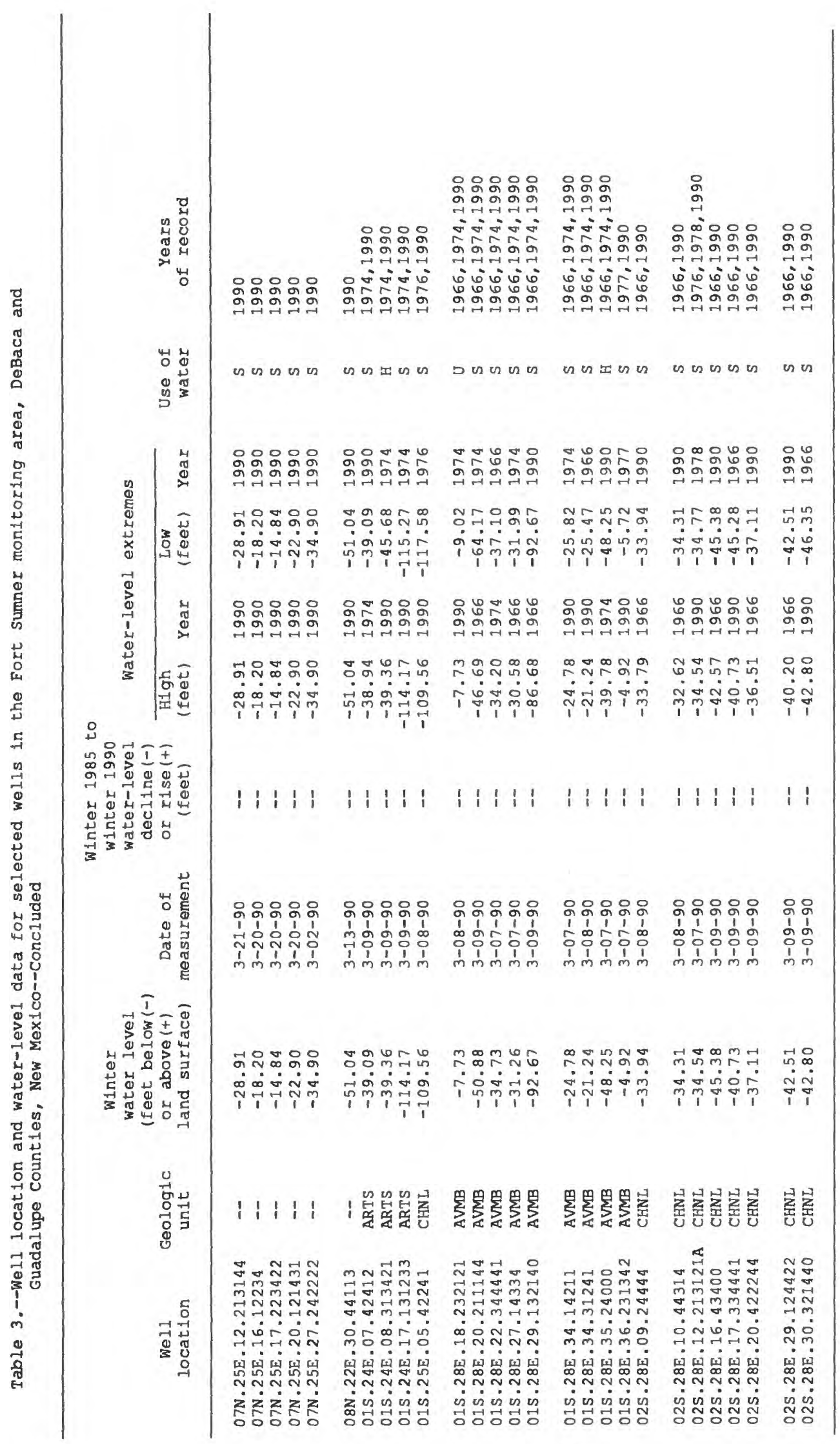




\section{Estancia Monitoring Area}

The Estancia monitoring area is in northern Torrance County and part of Santa Fe and Bernalillo Counties. Water-level declines range from less than 1 to more than 5 feet. Water-level rises range from less than 1 to more than 56 feet. From Tps. $9 \mathrm{~N}$. to $11 \mathrm{~N}$. most water-level changes are declines. Two wells in the eastern part of this area show rises. Most water-level changes in the remainder of the area are rises. Three wells south of Willard have a water-level decline. 


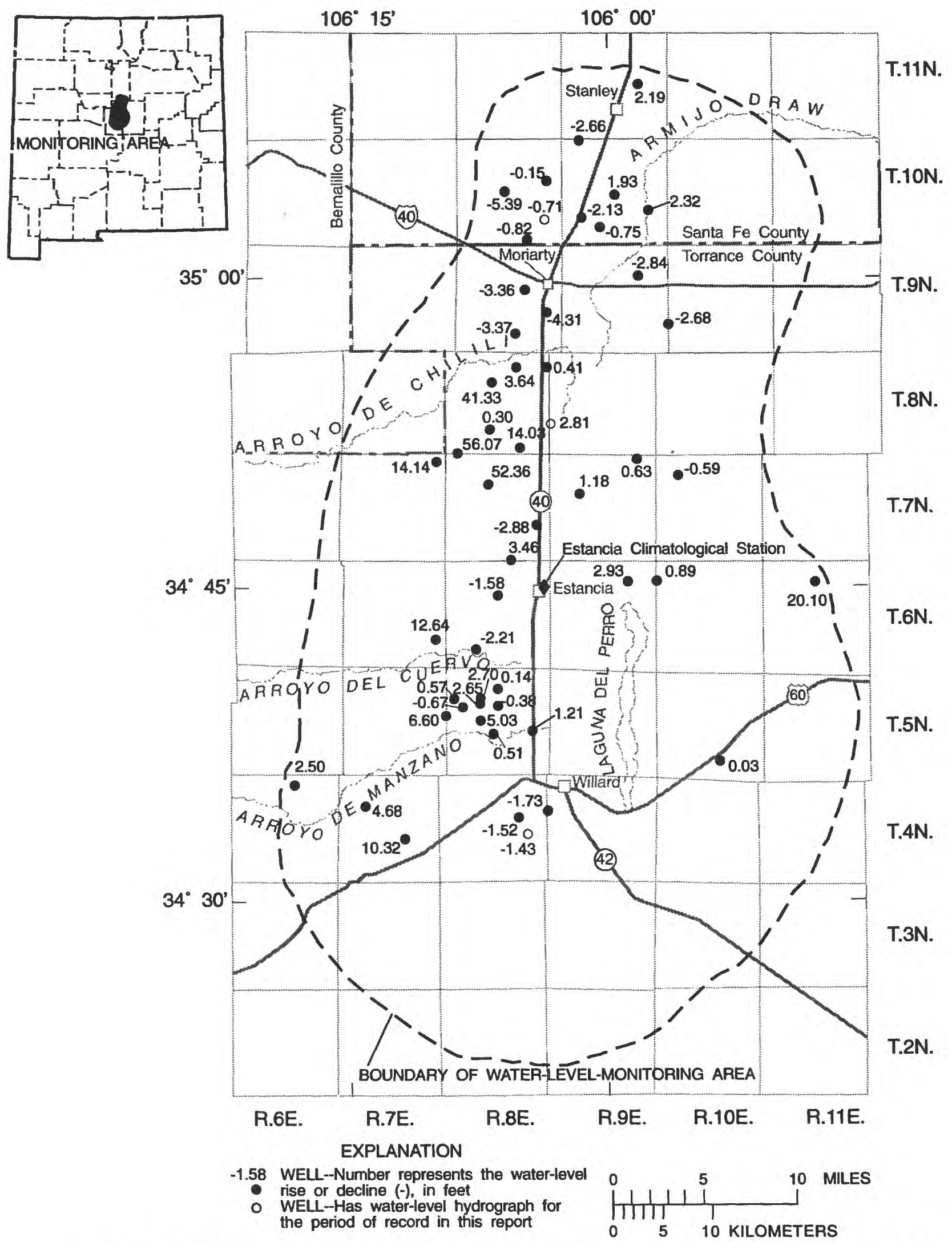

Figure 9.--Water-level changes for wells in the Estancia monitoring area, 1985-90. 

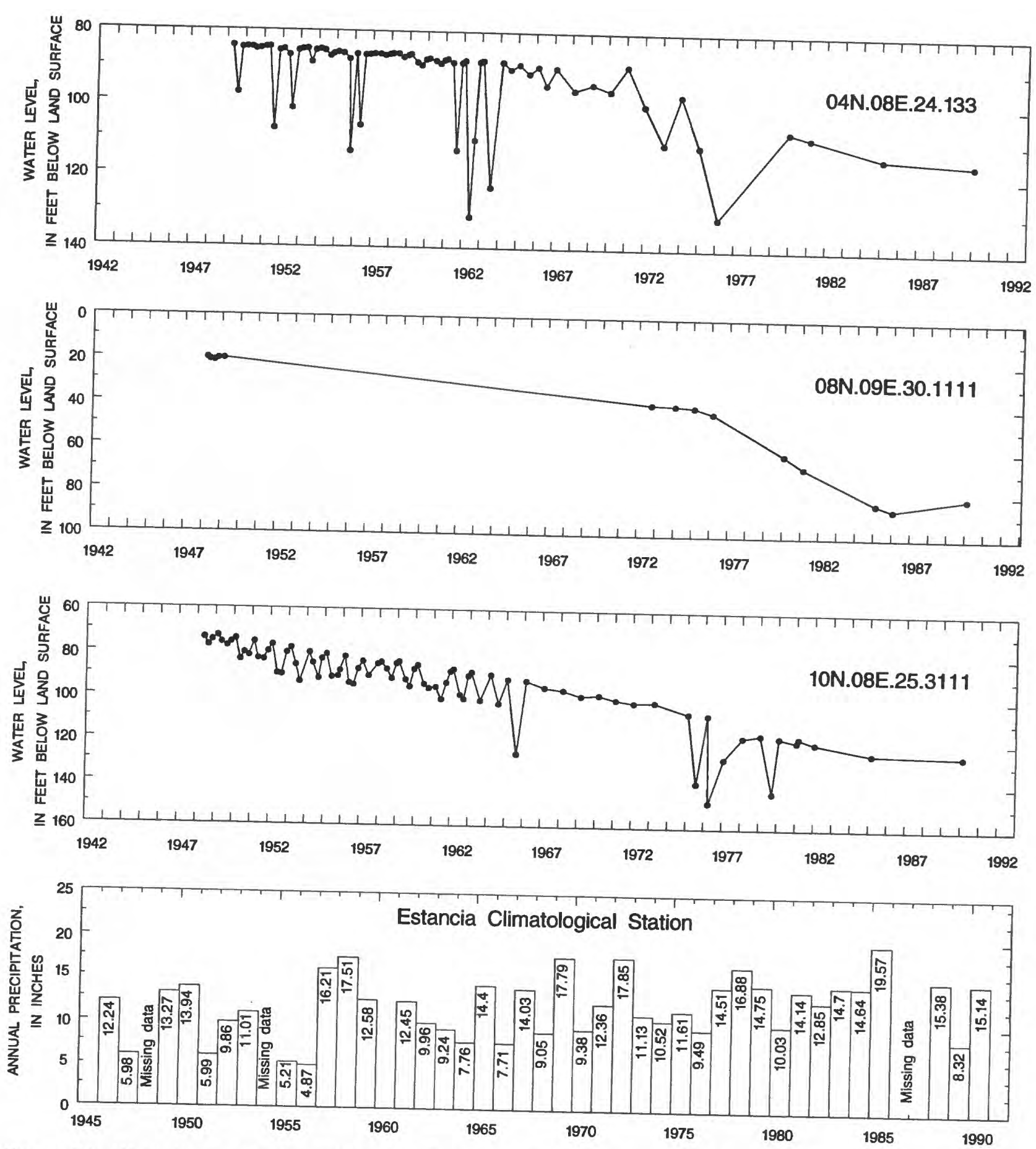

Figure 10.--Water-level data for selected wells in the Estancia monitoring area and annual precipitation at the Estancia Climatological Station. See figure 9 for location of wells and station. 


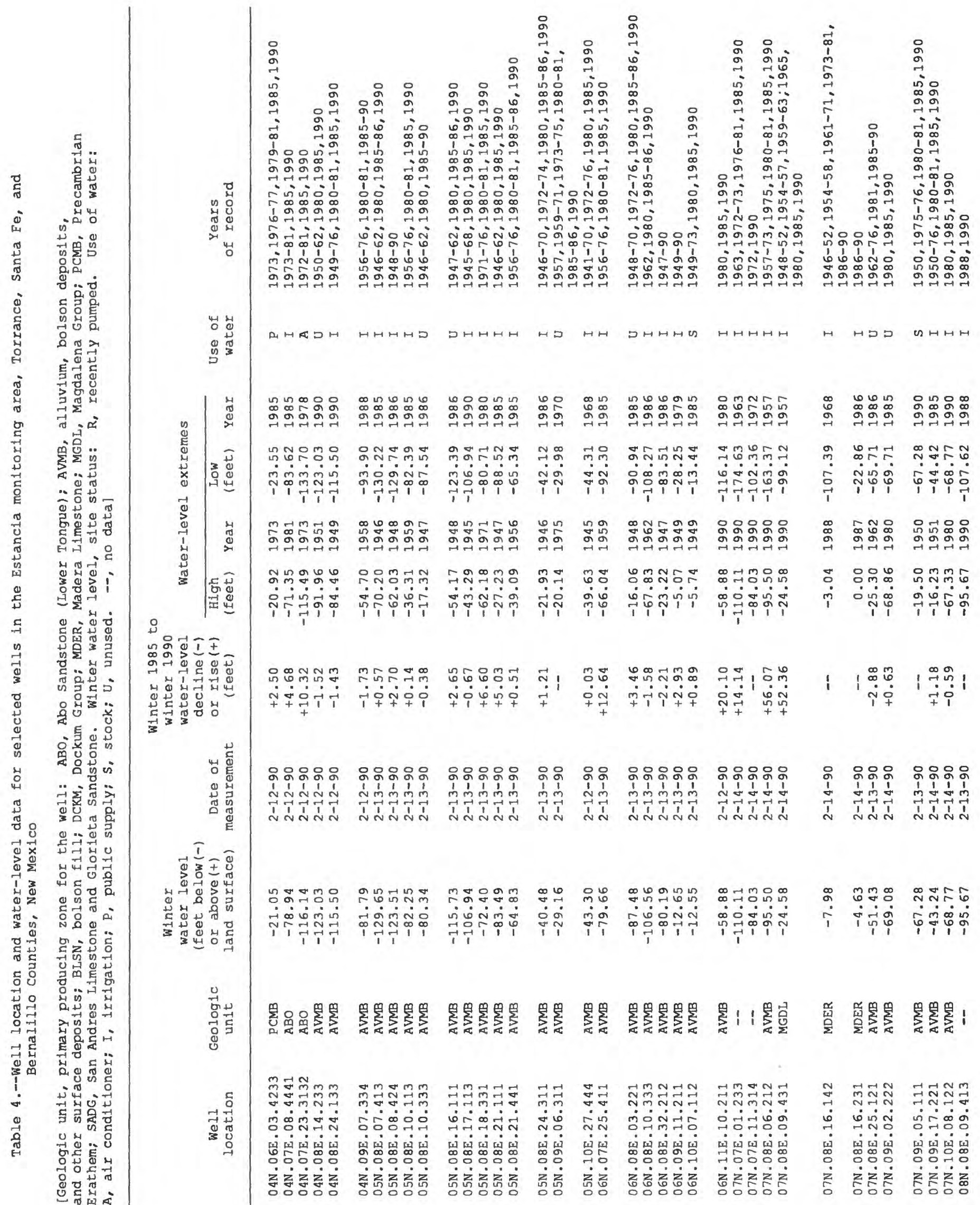




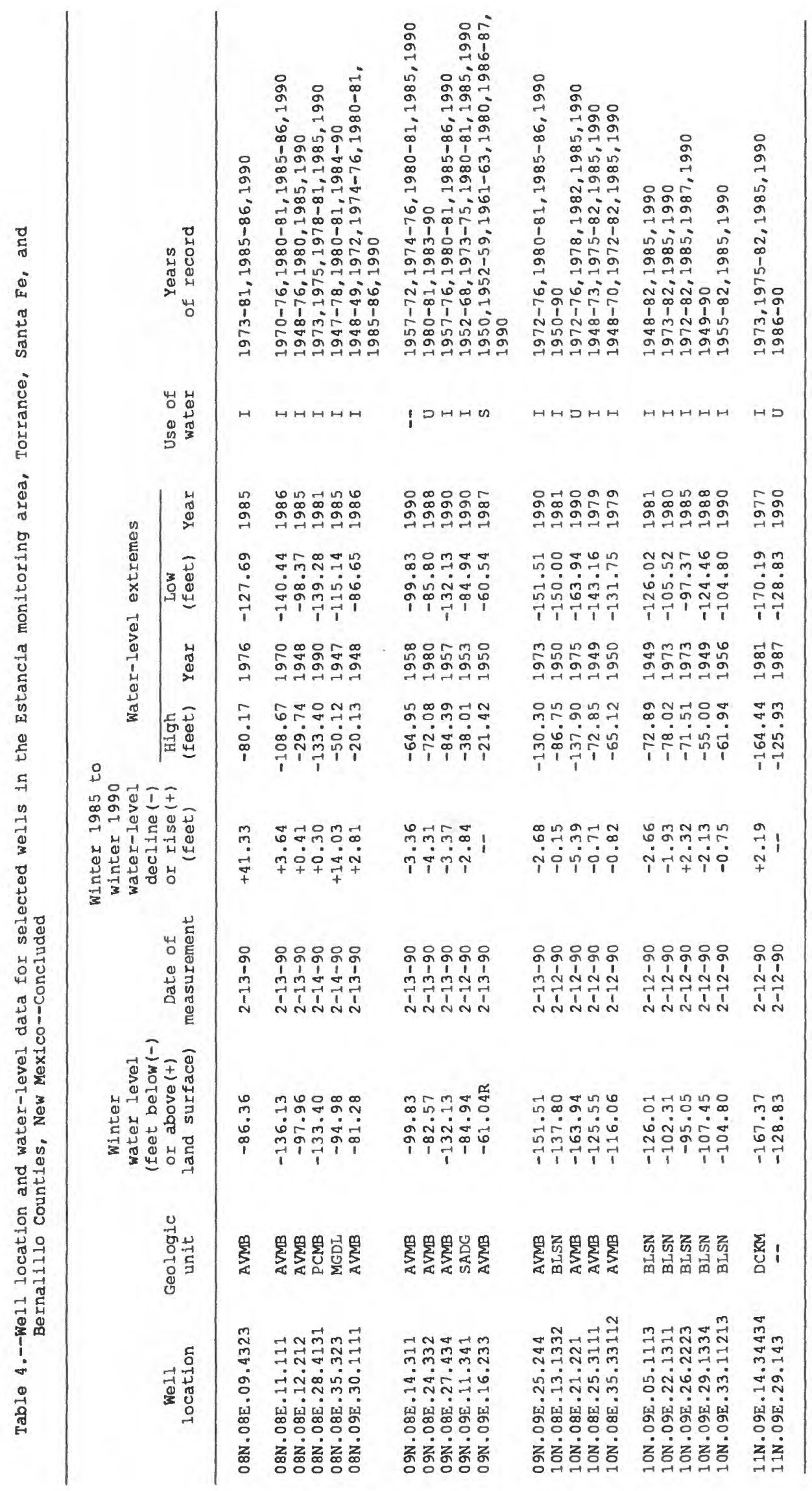




\section{Salt Basin Monitoring Area}

The Salt Basin is in Otero County, south-central New Mexico. Both water-level changes are rises of less than 1 foot. 

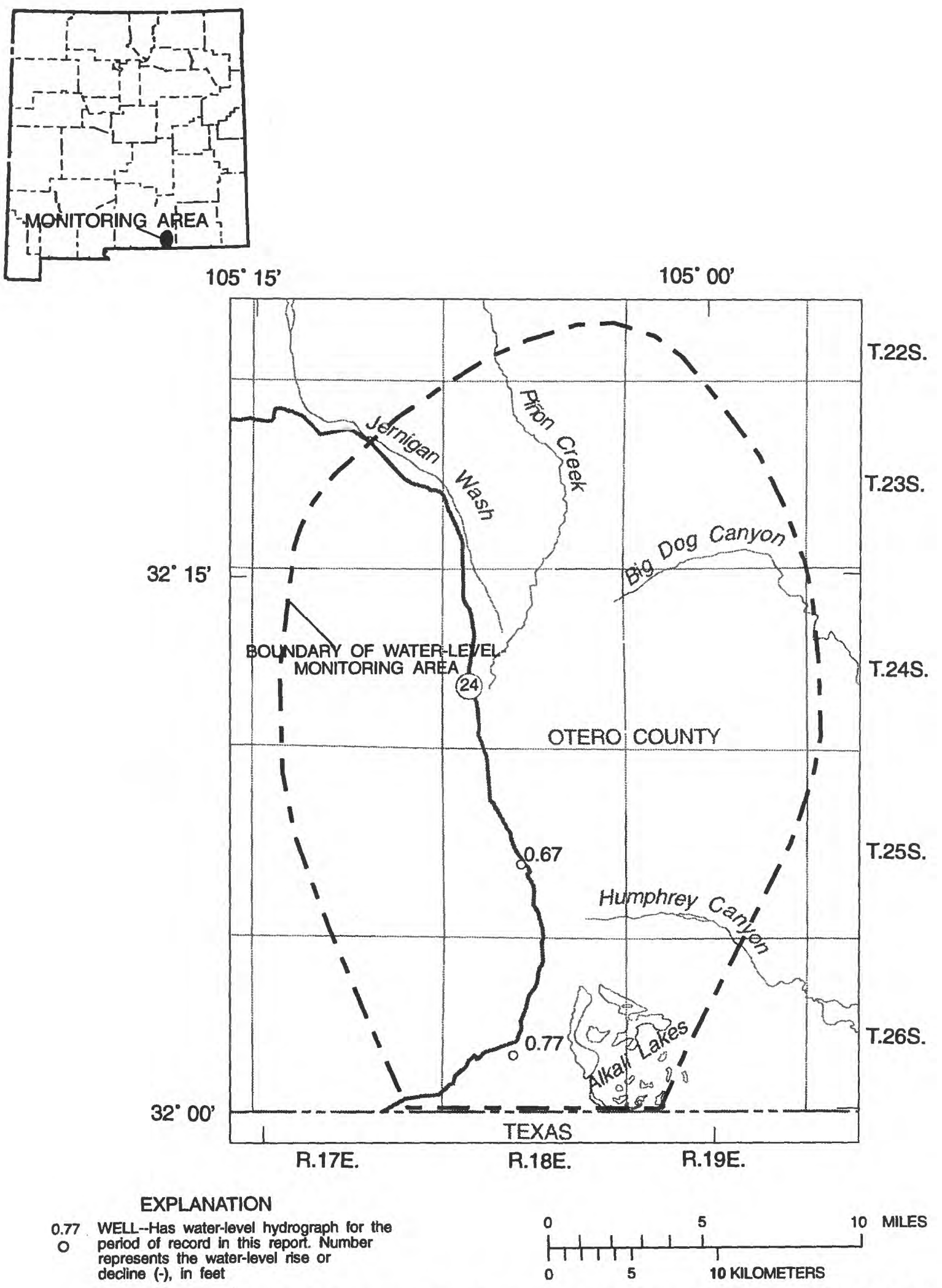

Figure 11.--Water-level changes for wells in the Salt Basin monitoring area, 1985-90. 

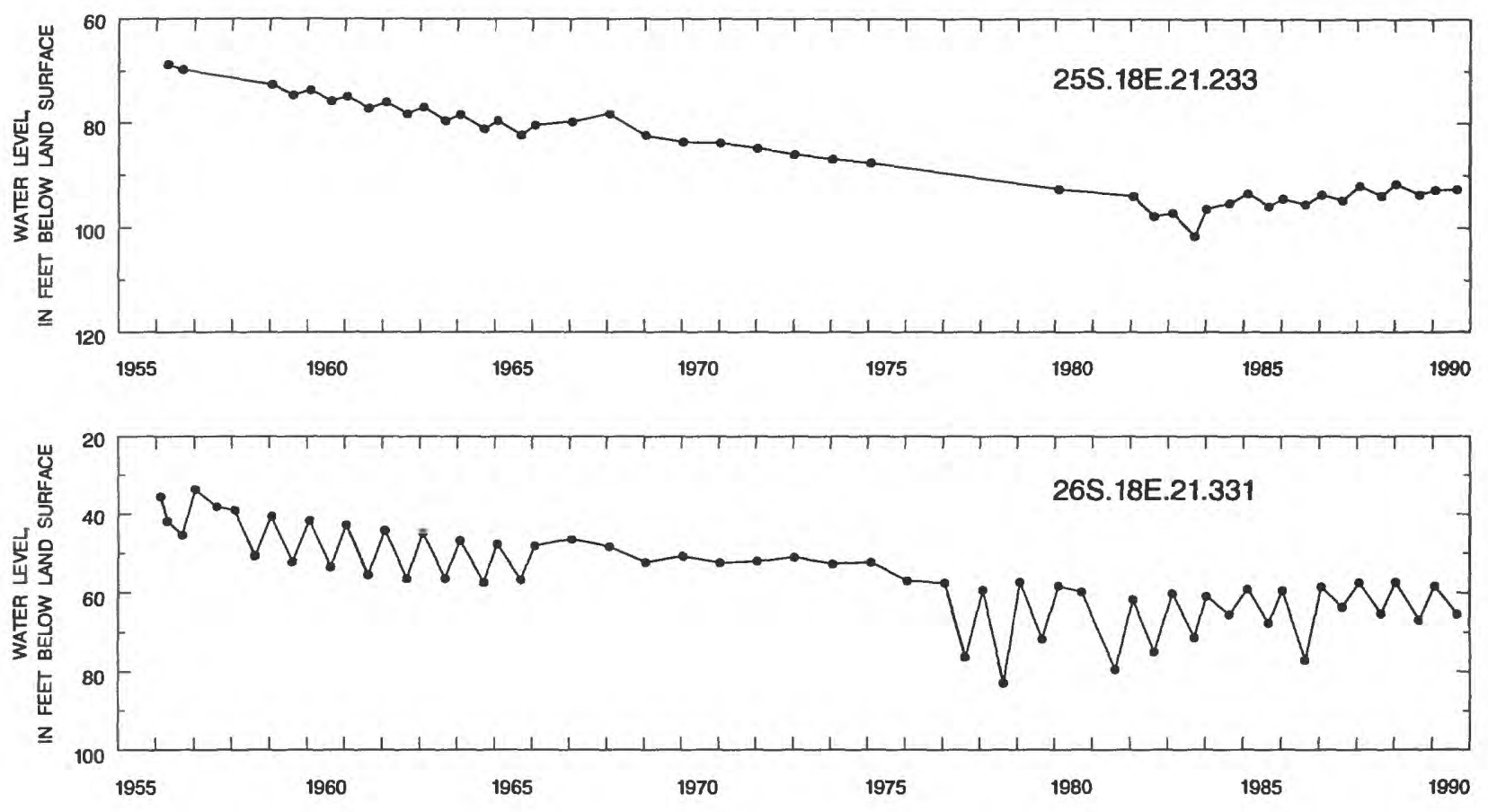

Figure 12.--Water-level data for selected wells in the Salt Basin monitoring area. See figure 11 for location of wells. 


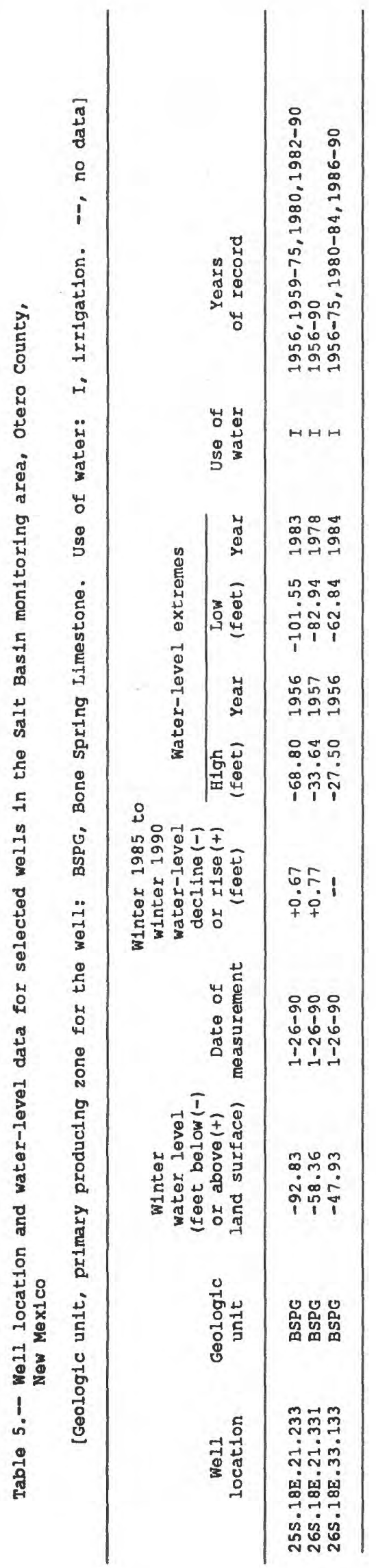




\section{FIGURES--Continued}

Figure 21. Map showing water-level changes for selected wells in the Northern High

Plains monitoring area, 1986-91

22. Plots showing water-level data for selected wells in the Northern High Plains monitoring area and annual precipitation at the Clayton WSO Airport and Des Moines Climatological Stations

23. Map showing water-level changes for selected wells in the Lea County monitoring area, 1986-91

24. Plots showing water-level data for selected wells in the Lea County monitoring area and annual precipitation at the Tatum and Ochoa Climatological Stations

25. Map showing water-level changes for wells in the Tularosa Basin monitoring area, 1986-91

26. Plots showing water-level data for selected wells in the Tularosa Basin monitoring area and annual precipitation at the Carrizozo and Alamogordo Climatological Stations

27. Map showing water levels for wells in the San Agustin Plains monitoring area, 1991

28. Plots showing water-level data for selected wells in the San Agustin Plains monitoring area and annual precipitation at the San Agustin $2 \mathrm{E}$ Climatological Station

29. Map showing water-level changes for wells in the Harding County monitoring area, 1987-92

30. Plots showing water-level data for selected wells in the Harding County monitoring area and annual precipitation at the Mosquero Climatological Station

31. Map showing water-level changes for wells in the Curry County monitoring area, 1987-92

32. Plots showing water-level data for selected wells in the Curry County monitoring area and annual precipitation at the Clovis $13 \mathrm{~N}$ Climatological Station

33. Map showing water-level changes for wells in the House monitoring area, 1987-92

34. Plots showing water-level data for selected wells in the House monitoring area and annual precipitation at the House Climatological Station

35. Map showing water-level changes for wells in the Portales monitoring area, 1987-92

36. Plots showing water-level data for selected wells in the Portales monitoring area and annual precipitation at the Portales Climatological Station

37. Map showing water-level changes for selected wells in the Mimbres Basin monitoring area, 1987-92 


\section{San Simon Monitoring Area}

The San Simon monitoring area is in Hidalgo County, southwestern New Mexico. Waterlevel declines range from less than 1 foot to more than 10 feet. Rises range from less than 1 foot to more than 31 feet. In the northwest corner of the monitoring area water-level changes are mainly declines; four measurements indicate rises of less than 1 foot. In Tps. 28 and $29 \mathrm{~S}$. most changes are rises from about 1 foot to more than 31 feet. A well southeast of Rodeo has a waterlevel decline of more than 7 feet. 


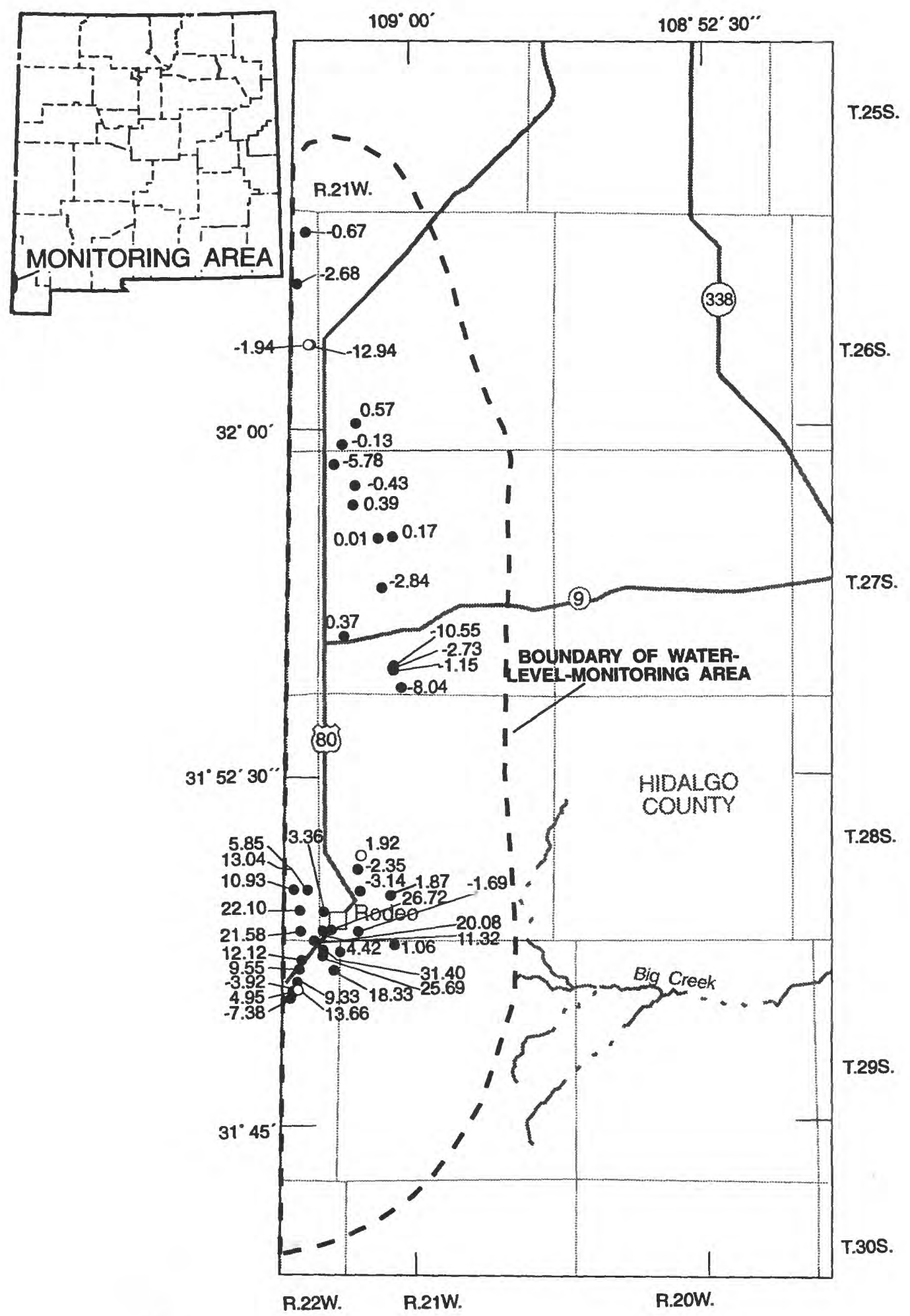

\section{EXPLANATION}

WELL-Number represents the water-level rise or decline $(-)$, in feot

WELL-Has water-level hydrograph for

the period of record in this report

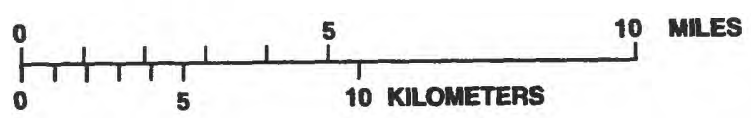

Figure 13.--Water-level changes for selected wells in the San Simon monitoring area, 1985-90. 

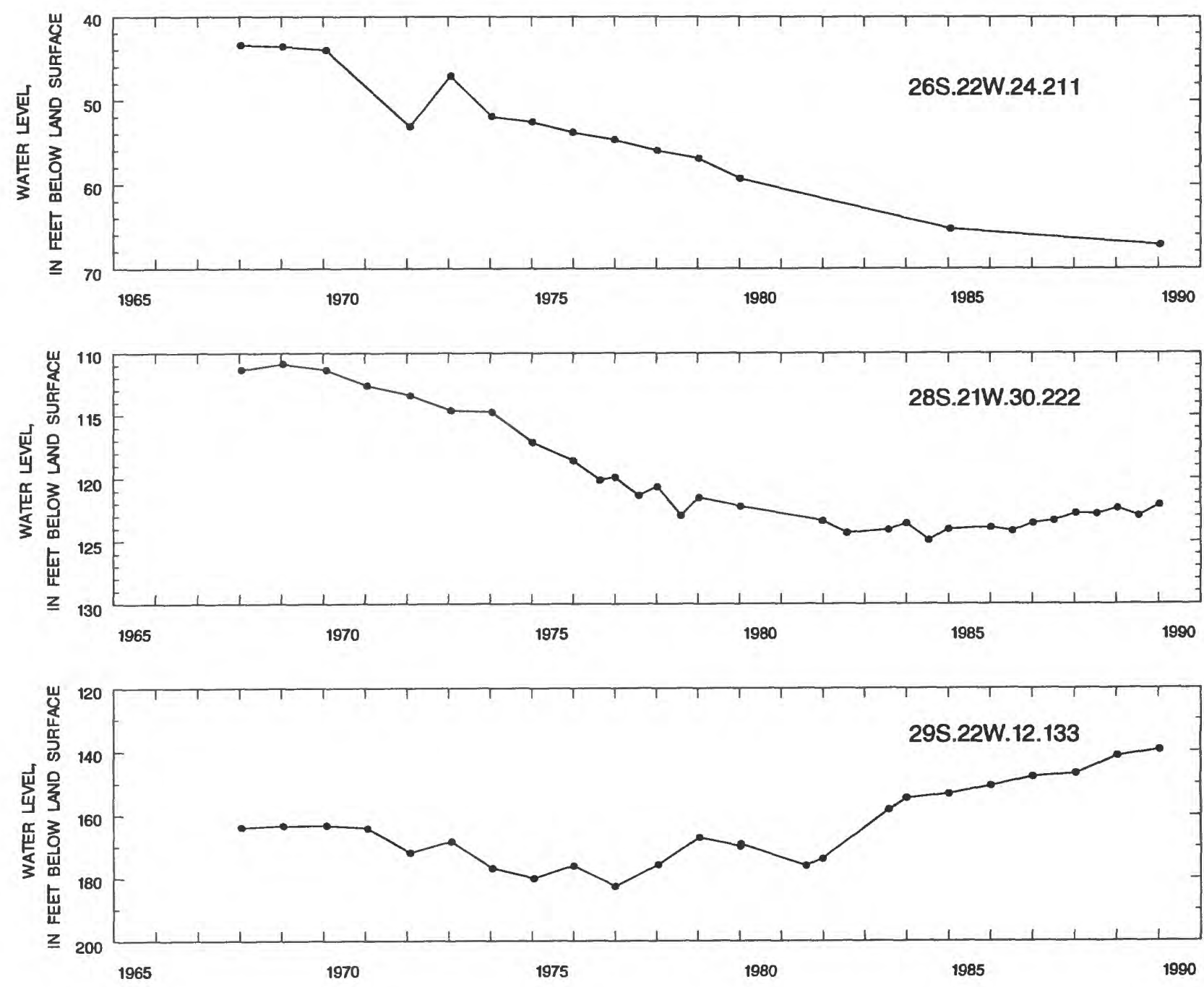

Figure 14.--Water-level data for selected wells in the San Simon monitoring area. See figure 13 for location of wells. 


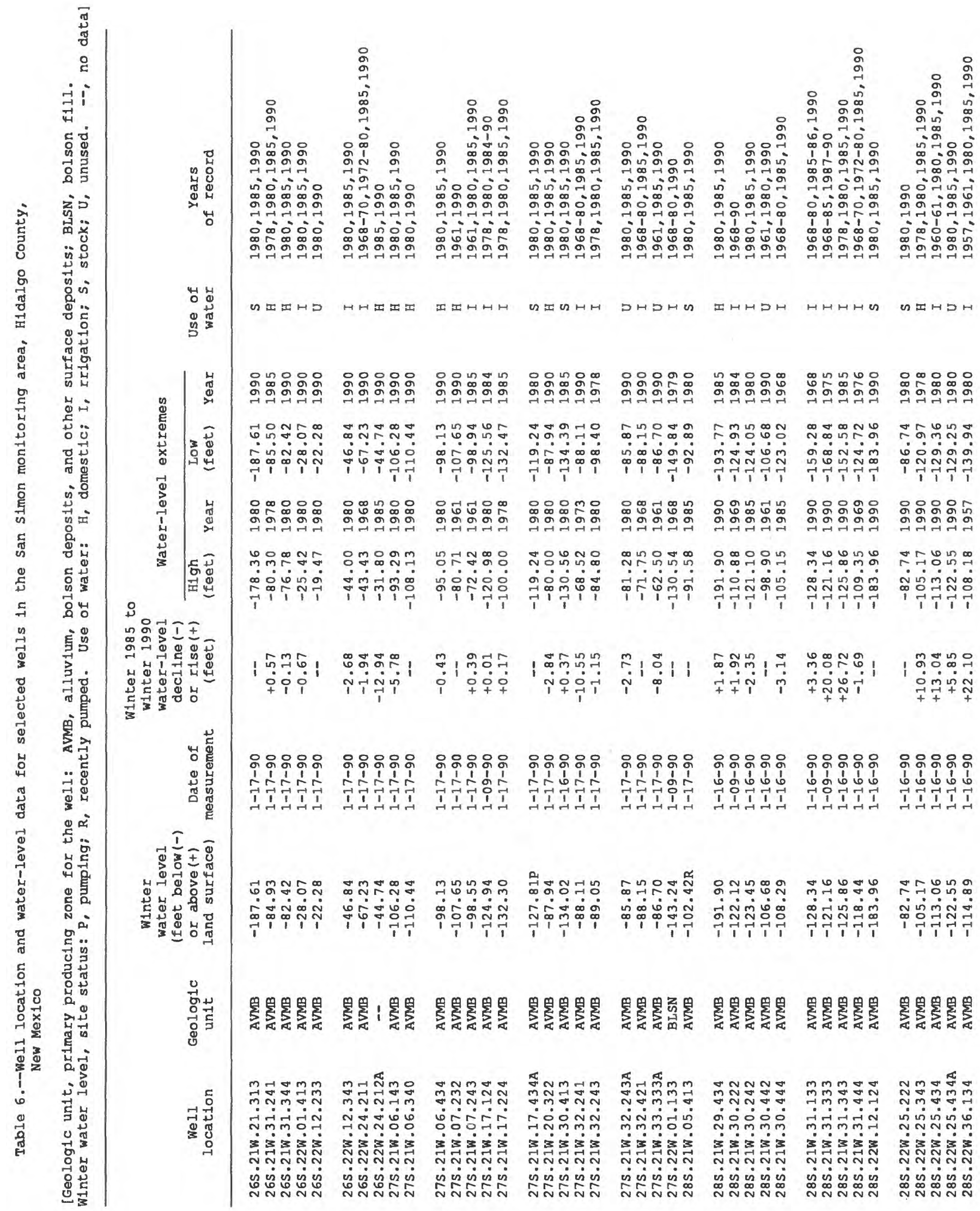




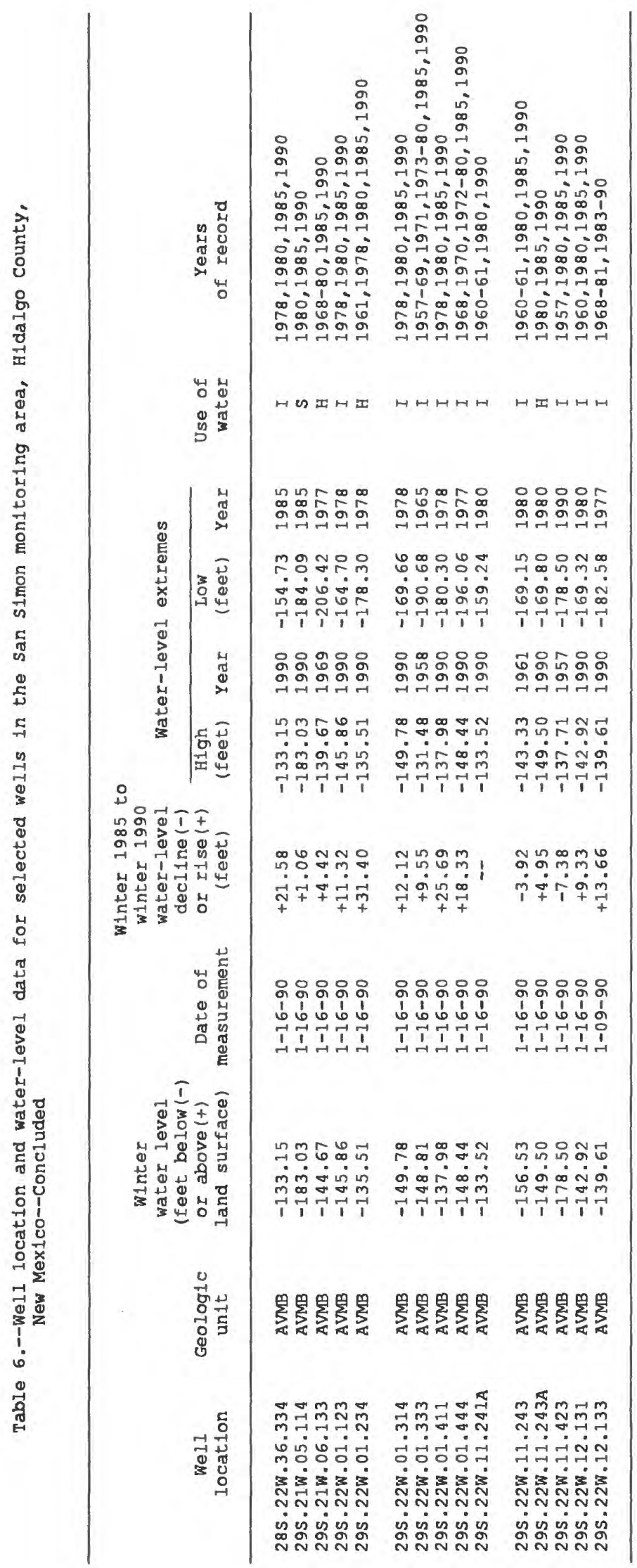




\section{Middle Rio Grande Monitoring Area}

The Middle Rio Grande monitoring area is adjacent to the Rio Grande and extends from near Jemez Canyon Reservoir to about 35 miles south of Socorro. The area is in parts of Sandoval, Bernalillo, Valencia, Torrance, and Socorro Counties, central New Mexico. Waterlevel declines range from less than 1 foot to more than 13 feet. Rises range from less than 1 to more than 21 feet. From Tps. 8 to $14 \mathrm{~N}$. most water-level changes are declines, ranging from less than 1 foot to more than 7 feet. South of T. $8 \mathrm{~N}$. to T. $1 \mathrm{~S}$. water-level changes east of the Rio Grande are mostly declines of less than 1 to more than 2 feet; west of the river declines are mixed with rises. Water-level changes south and west of Socorro are mostly declines. East of the Rio Grande and south of Socorro rises predominantly range from less than 1 foot to more than 11 feet. 

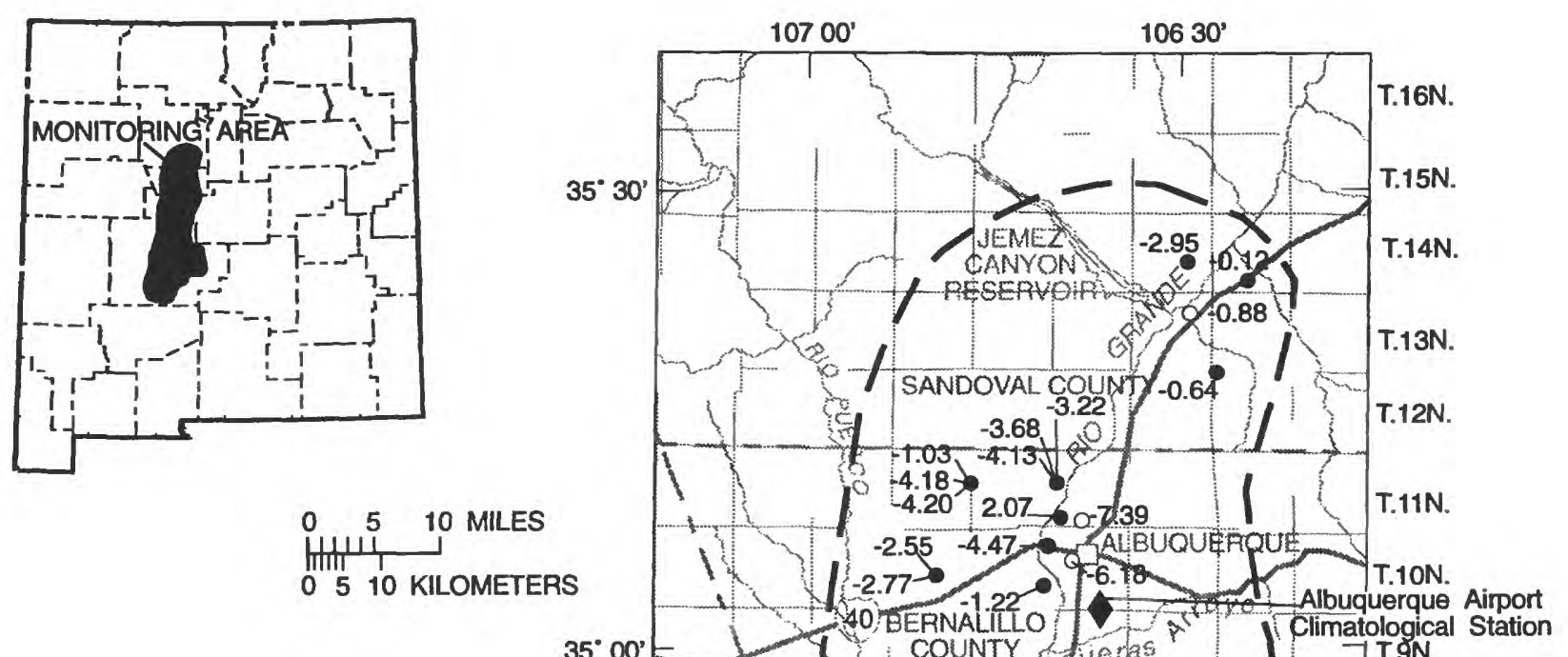

\section{EXPLANATION}

0.63 WELL--Number represents the water-level

- rise or decline $(-)$, in feet

- WELL--Has water-level hydrograph for the period of record in this report

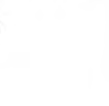

$35^{\circ} 00^{\prime}$
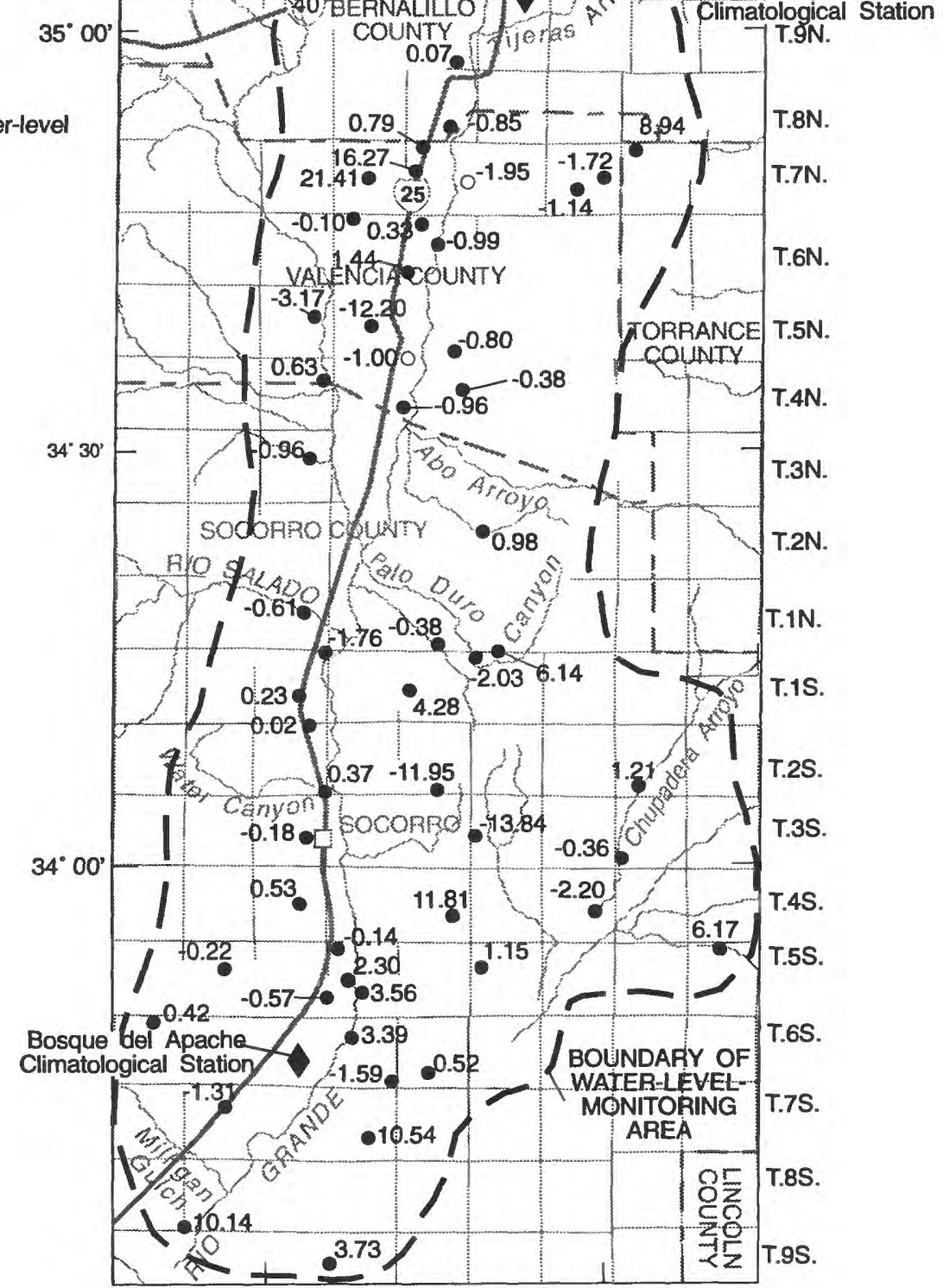

R.3W. R.2W. R.1W. R.1E.R.2E. R.3E. R.4E. R.5E. R.6E.

Figure 15.--Water-level changes for wells in the Middle Rio Grande monitoring area, 1985-90. 

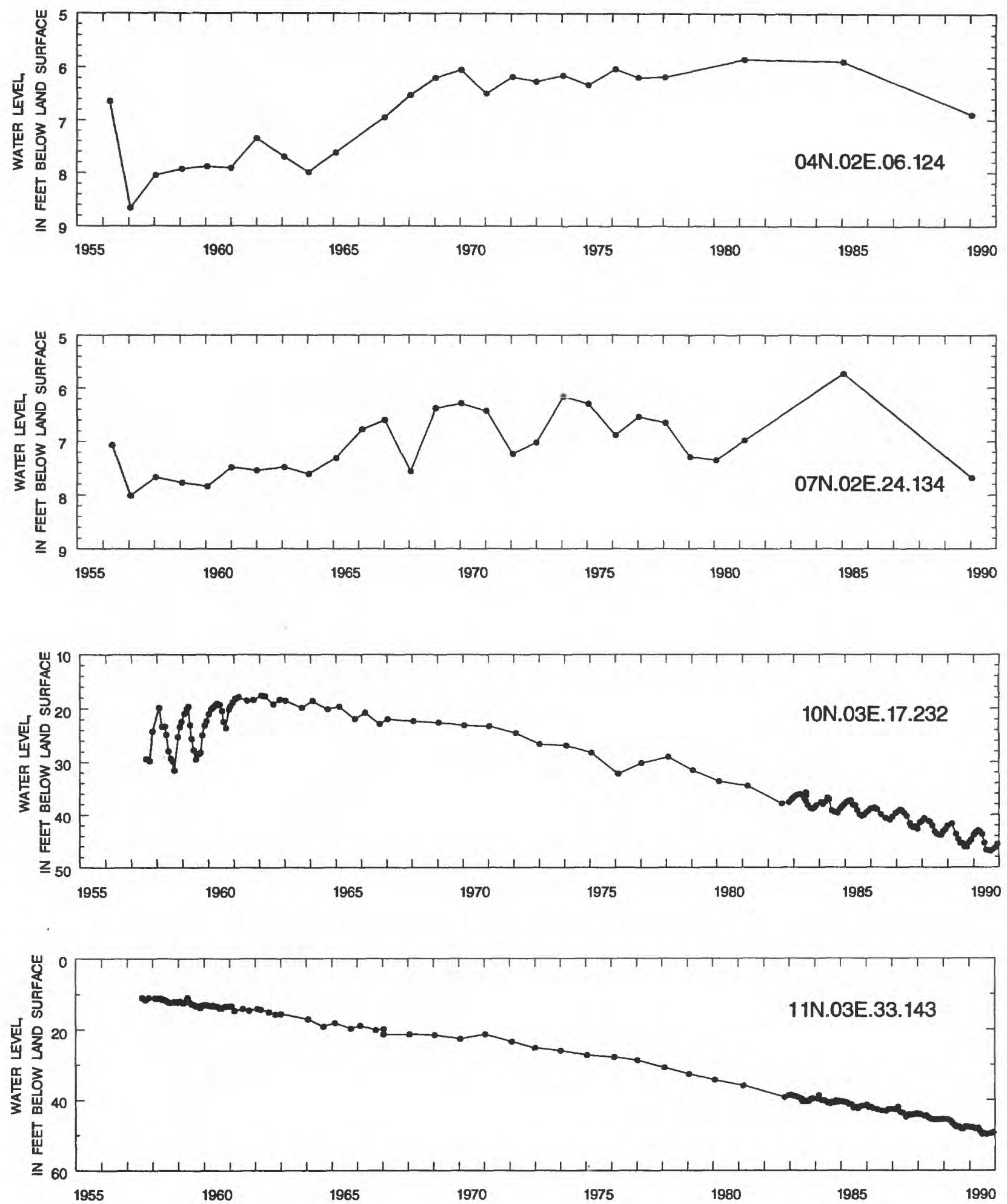

Figure 16.--Water-level data for selected wells in the Middle Rio Grande monitoring area and annual precipitation at the Albuquerque Aiport and Bosque del Apache Climatological Stations. See figure 15 for locations of wells and stations. 

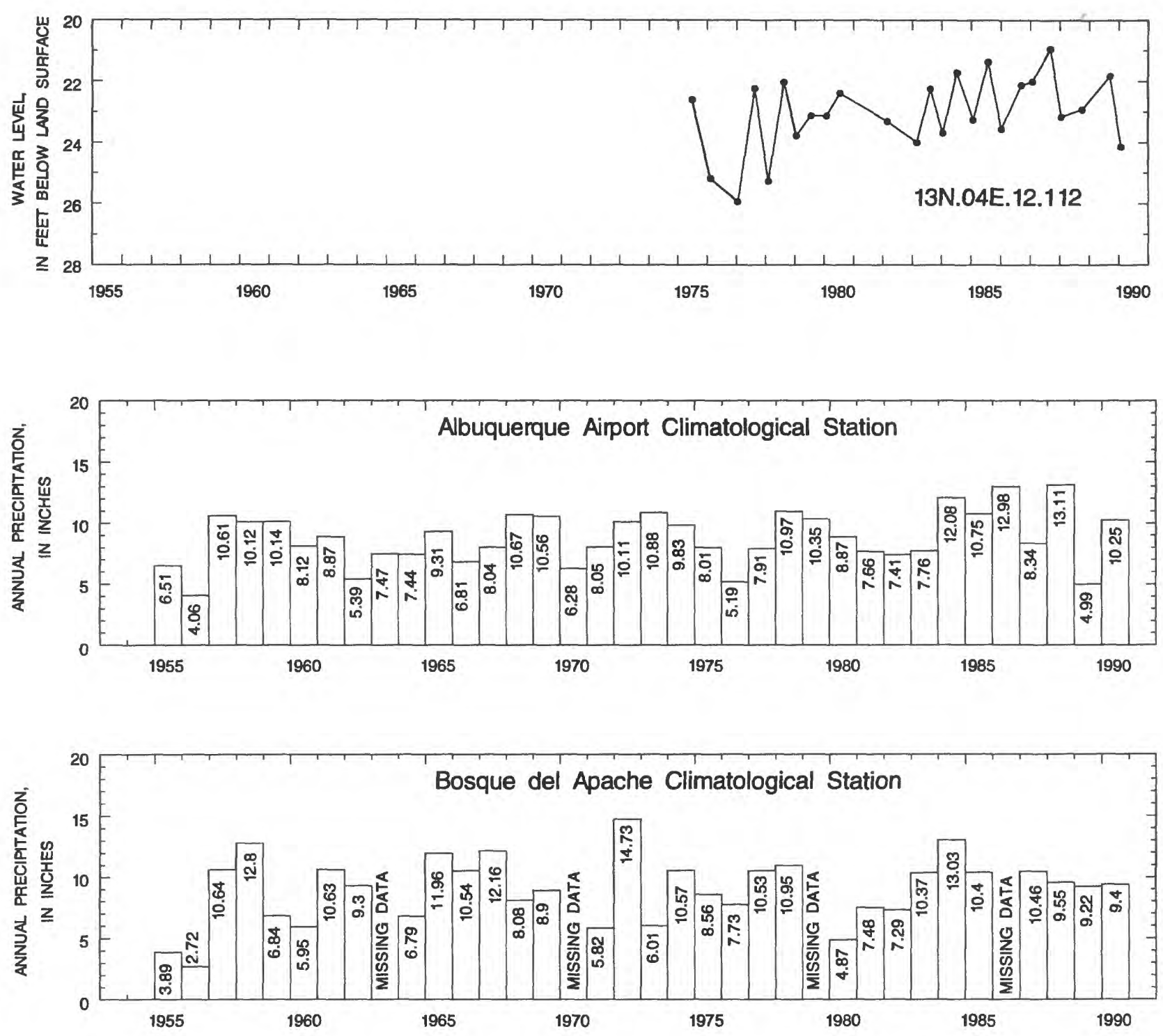

Figure 16.--Water-level data for selected wells in the Middle Rio Grande monitoring area and annual precipitation at the Albuquerque Airport and Bosque del Apache Climatological stations. See figure 15 for location of wells and stations--Concluded. 


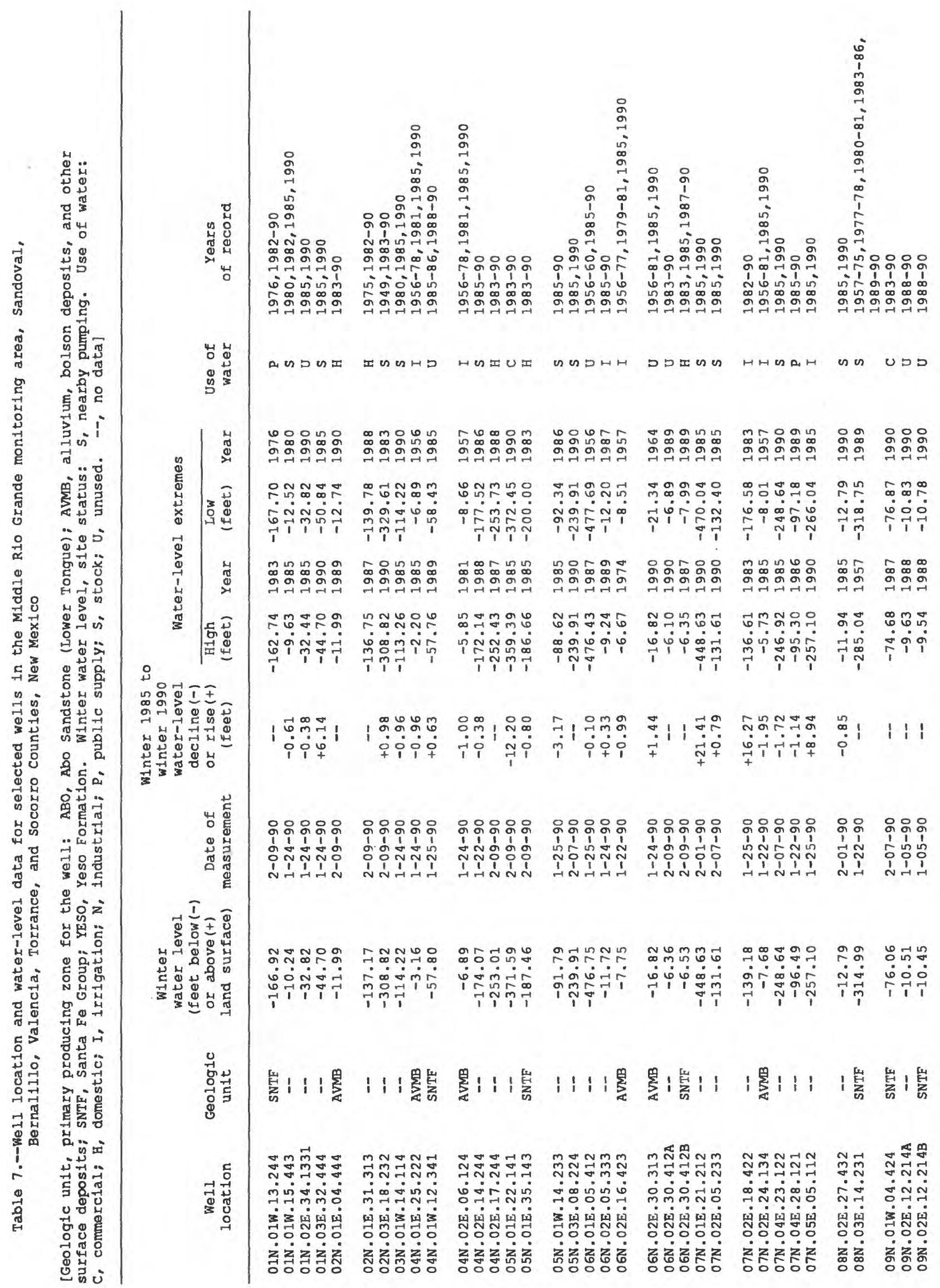




\section{FIGURES-Continued}

Figure 38. Plots showing water-level data for selected wells in the Mimbres Basin monitoring area and annual precipitation at the Mimbres Ranger Station and Deming Climatological Stations

39. Map showing water-level changes for wells in the Mora monitoring area, 1987-92.

40. Plots showing water-level data for selected wells in the Mora monitoring area and annual precipitation at the Valmora Climatological Station

41. Map showing water-level changes for wells in the Nutt-Hockett monitoring area, 1987-92

42. Plots showing water-level data for selected wells in the Nutt-Hockett monitoring area and annual precipitation at the Florida Climatological Station

43. Map showing water levels for selected wells in the San Juan Basin monitoring area, 1992.

44. Plots showing water-level data for selected wells in the San Juan Basin monitoring area and annual precipitation at the Shiprock, Chaco Canyon National Monument, and Gallup FAA Airport Climatological Stations

45. Map showing water-level changes for selected wells in the Lower Canadian monitoring area, 1988-93

46. Plots showing water-level data for selected wells in the Lower Canadian monitoring area and annual precipitation at the San Jon Climatological Station

47. Map showing water-level changes for selected wells in the Carlsbad monitoring area, 1988-93

48. Plots showing water-level data for selected wells in the Carlsbad monitoring area and annual precipitation at the Carlsbad Climatological Station.

49. Map showing water-level changes for wells in the Capitan Reef monitoring area, 1988-93

50. Plots showing water-level data for selected wells in the Capitan Reef monitoring area

51. Map showing water-level changes for wells in the Animas monitoring area, 1988-93.

52. Plots showing water-level data for selected wells in the Animas monitoring area and annual precipitation at the Animas Climatological Station

53. Map showing water-level changes for wells in the Playas monitoring area, 1988-93.

54. Plots showing water-level data for selected wells in the Playas monitoring area and annual precipitation at the Hachita Climatological Station 


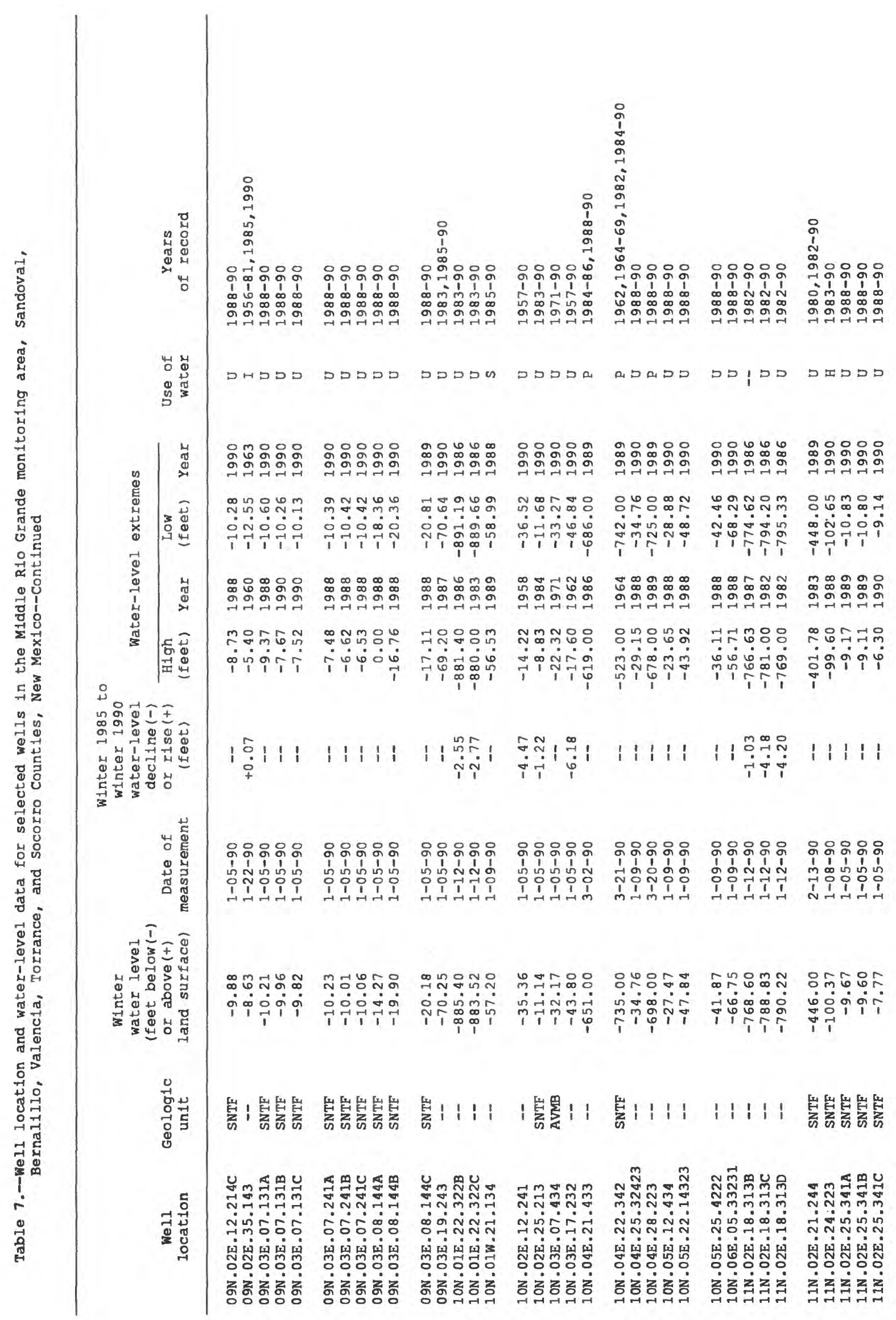




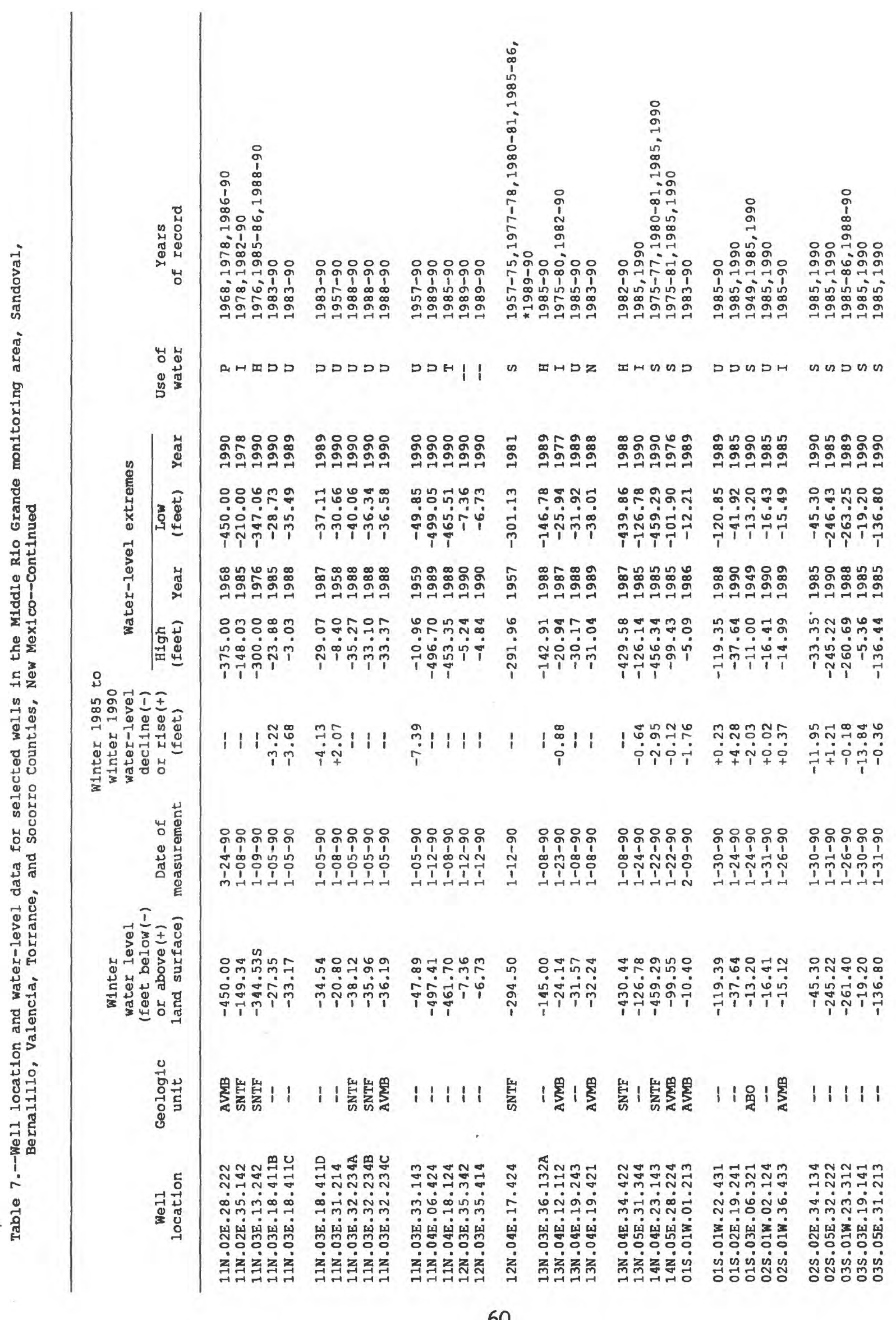




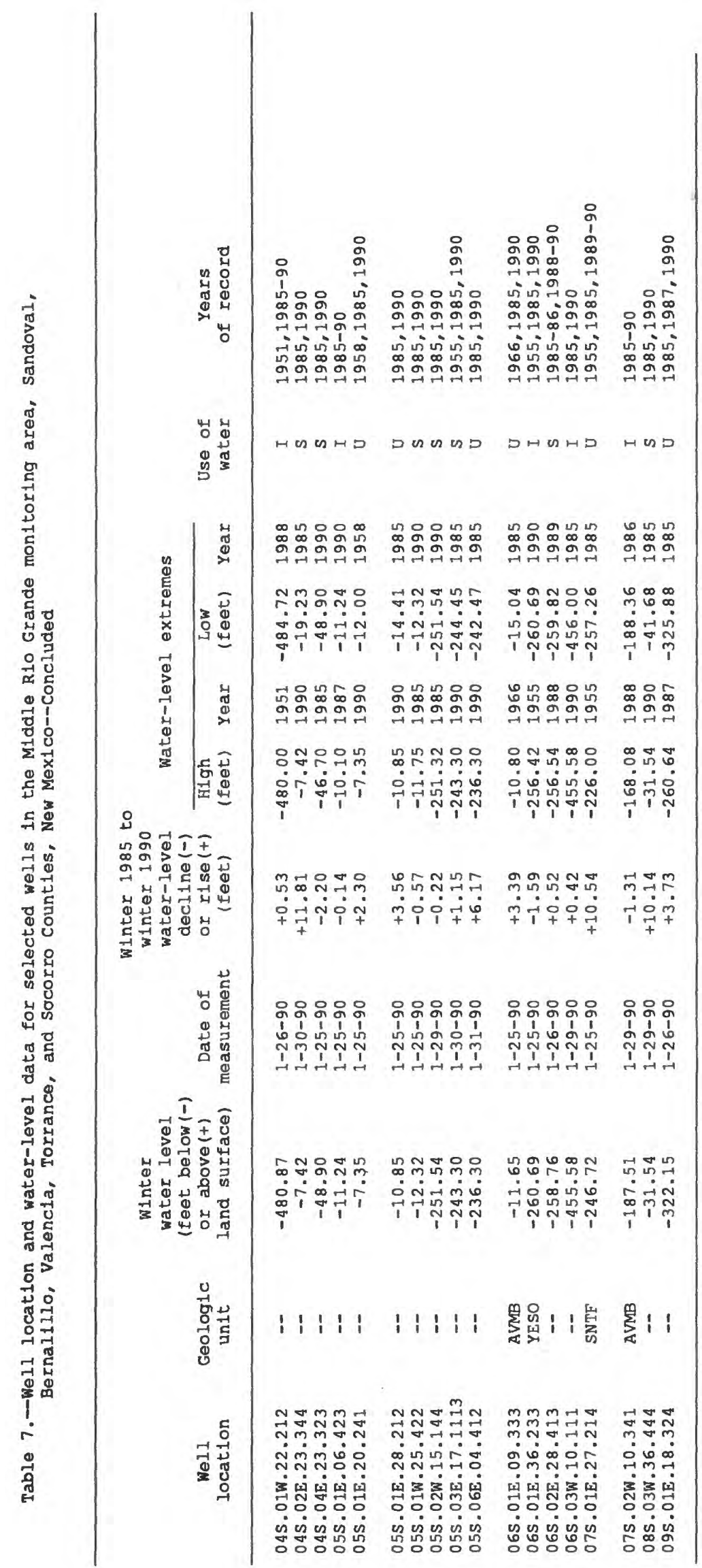




\section{Virden Monitoring Area}

The Virden monitoring area is in Hidalgo County in western New Mexico. All changes are declines ranging between 1.26 and 2.30 feet. 


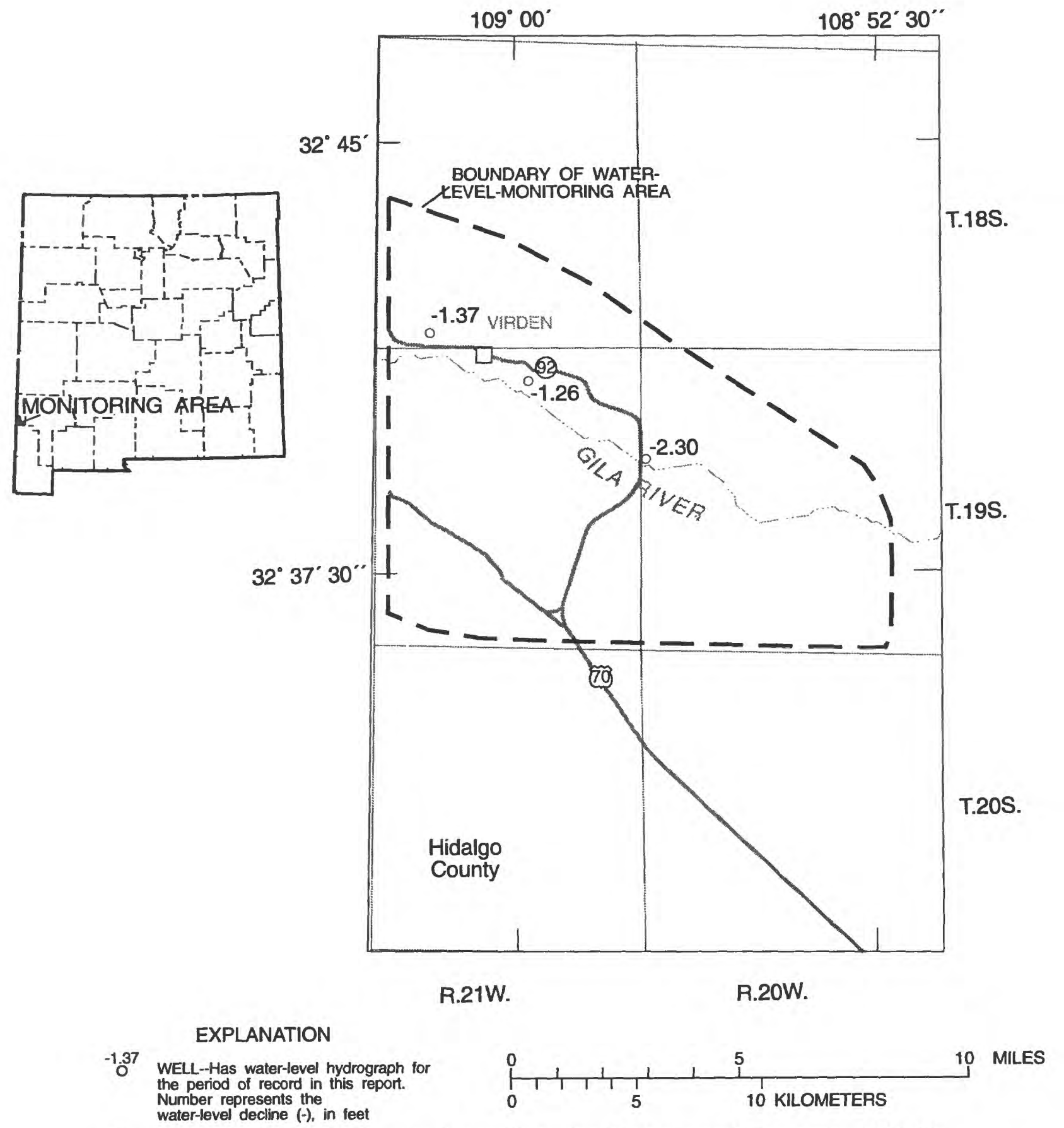

Figure 17.--Water-level changes for wells in the Virden monitoring area, 1985-90. 

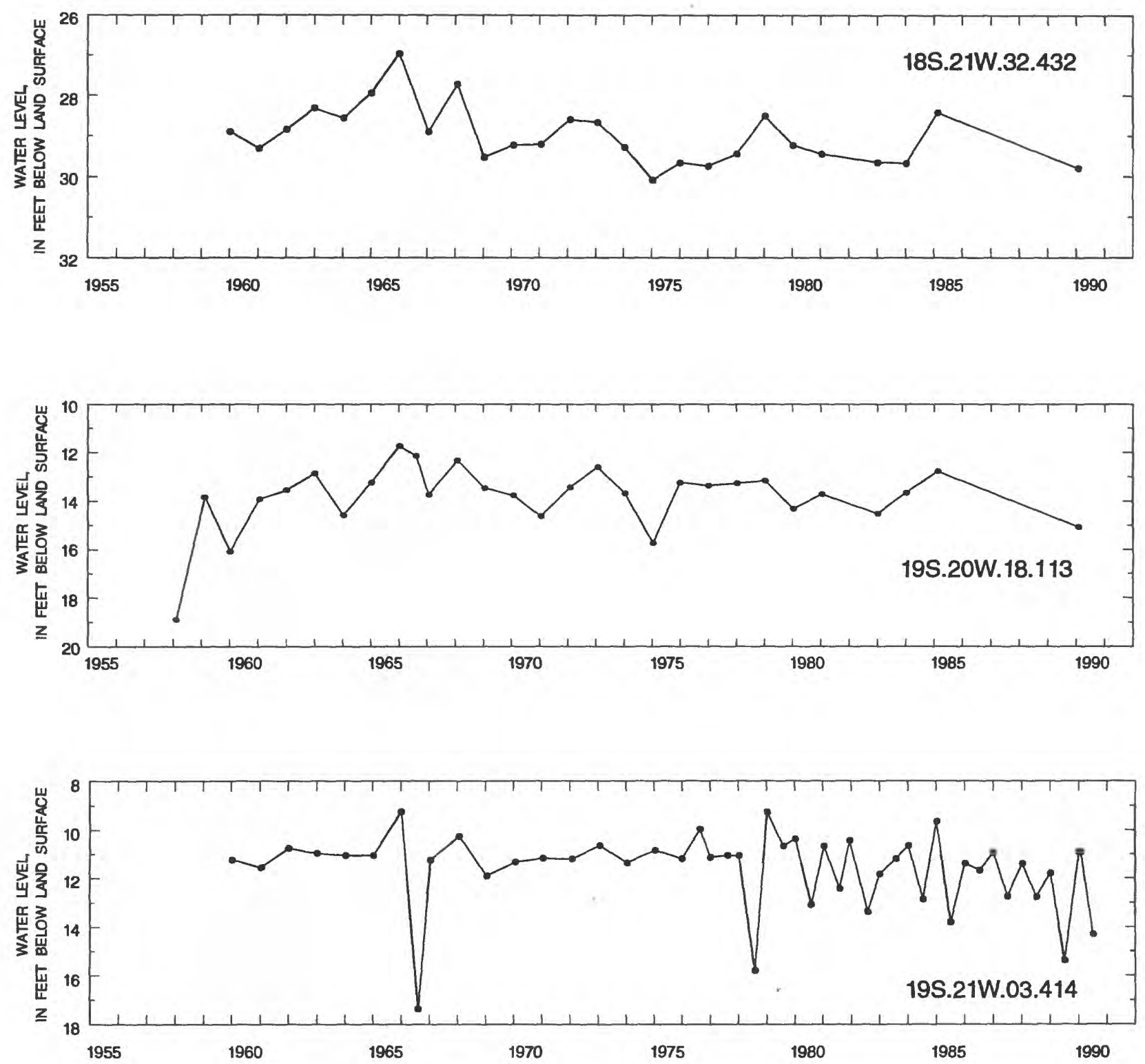

Figure 18.--Water-level data for selected wells in the Virden monitoring area. See figure 17 for location of wells. 


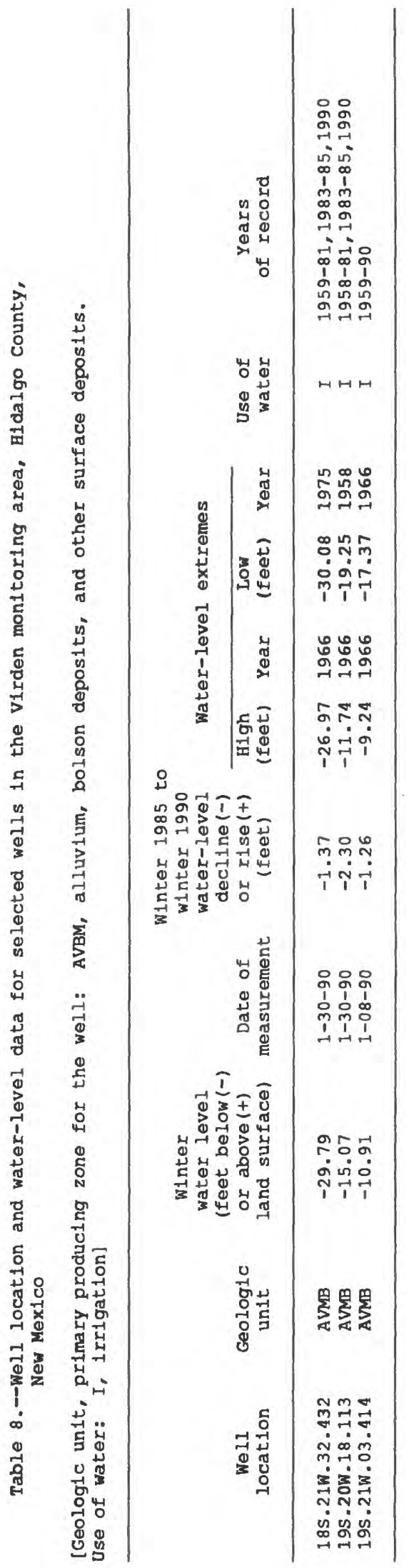




\section{Gila River Monitoring Area}

The Gila River monitoring area is in Grant County, southwestern New Mexico, along the Gila River and its tributaries. Water-level declines range from less than 1 to more than 8 feet. Rises range from less than 1 foot to more than 11 feet. Two wells just south of Gila have waterlevel rises. A rise of more than 11 feet has occurred in a well in T. 17 S., R. 16 W. 


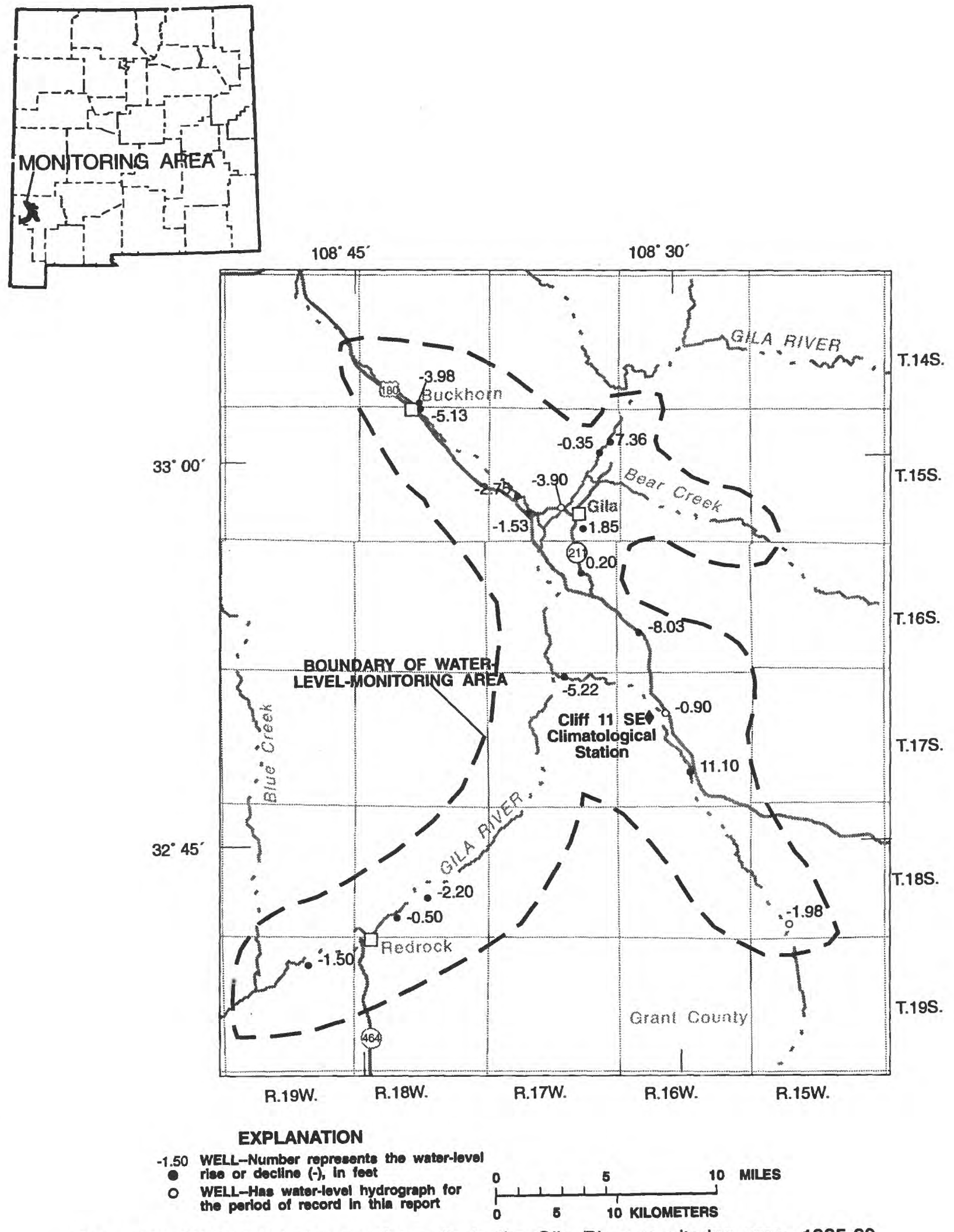

Figure 19.--Water-level changes for wells in the Gila River monitoring area, 1985-90. 

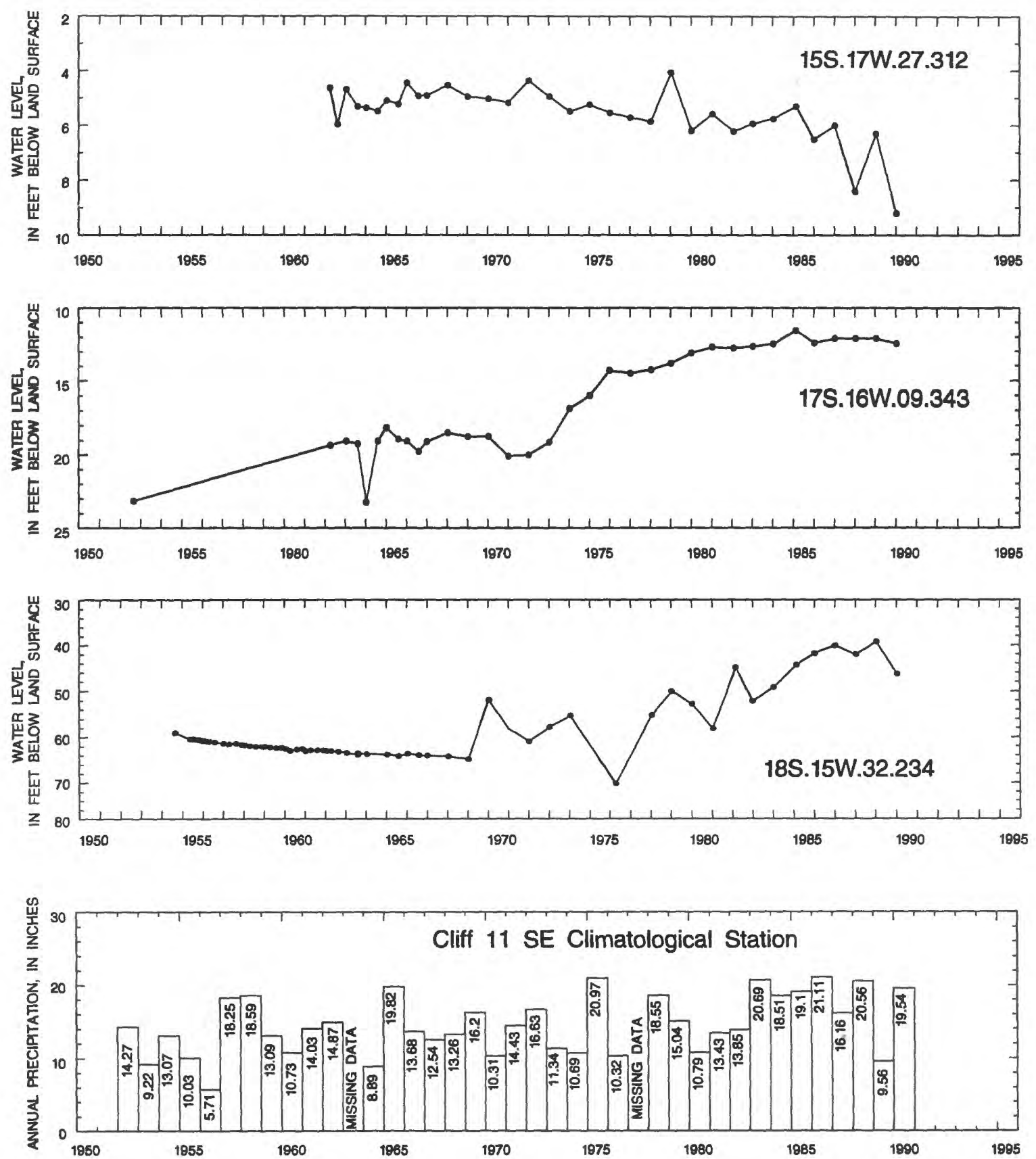

Figure 20.--Water-level data for selected wells in the Gila River monitoring area and annual precipitation at the Cliff 11 SE Climatological Station. See figure 19 for location of wells and station. 


\section{FIGURES--Continued}

Figure 55. Map showing water-level changes for wells in the Lordsburg monitoring area, 1988-93.

56. Plots showing water-level data for selected wells in the Lordsburg monitoring area and annual precipitation at the Lordsburg 4 SE Climatological Station

57. Map showing water-level changes for wells in the Santa Fe County monitoring area, 1988-93

58. Plots showing water-level data for selected wells in the Santa Fe County monitoring area and annual precipitation at the Santa Fe 2 Climatological Station.

59. Map showing water-level changes for wells in the Upper Rio Grande monitoring area, 1988-93

60. Plots showing water-level data for selected wells in the Upper Rio Grande monitoring area and annual precipitation at the Cerro Climatological Station.

61. Map showing water-level changes for selected shallow wells in the Roswell Basin monitoring area, 1984-89.

62. Plots showing water-level data for selected shallow wells in the Roswell Basin monitoring area and annual precipitation at the Hope Climatological Station

63. Map showing water-level changes for selected artesian wells in the Roswell Basin monitoring area, 1984-89.

64. Plots showing water-level data for selected artesian wells in the Roswell Basin monitoring area and annual precipitation at the Bitter Lakes Climatological Station.

65. Map showing water-level changes for wells in the Rio Hondo monitoring area, 1984-89

66. Plots showing water-level data for selected wells in the Rio Hondo monitoring area and annual precipitation at the Ruidoso 2 Climatological Station

67. Map showing water-level changes for wells in the Rio Peñasco monitoring area, 1984-89.

68. Plots showing water-level data for selected wells in the Rio Peñasco monitoring area and annual precipitation at the Cloudcroft Climatological Station.

69. Map showing water-level changes for wells in the Grants-Bluewater monitoring area, 1984-89

70. Plots showing water-level data for selected wells in the Grants-Bluewater monitoring area and annual precipitation at the Grants Airport Climatological Station 


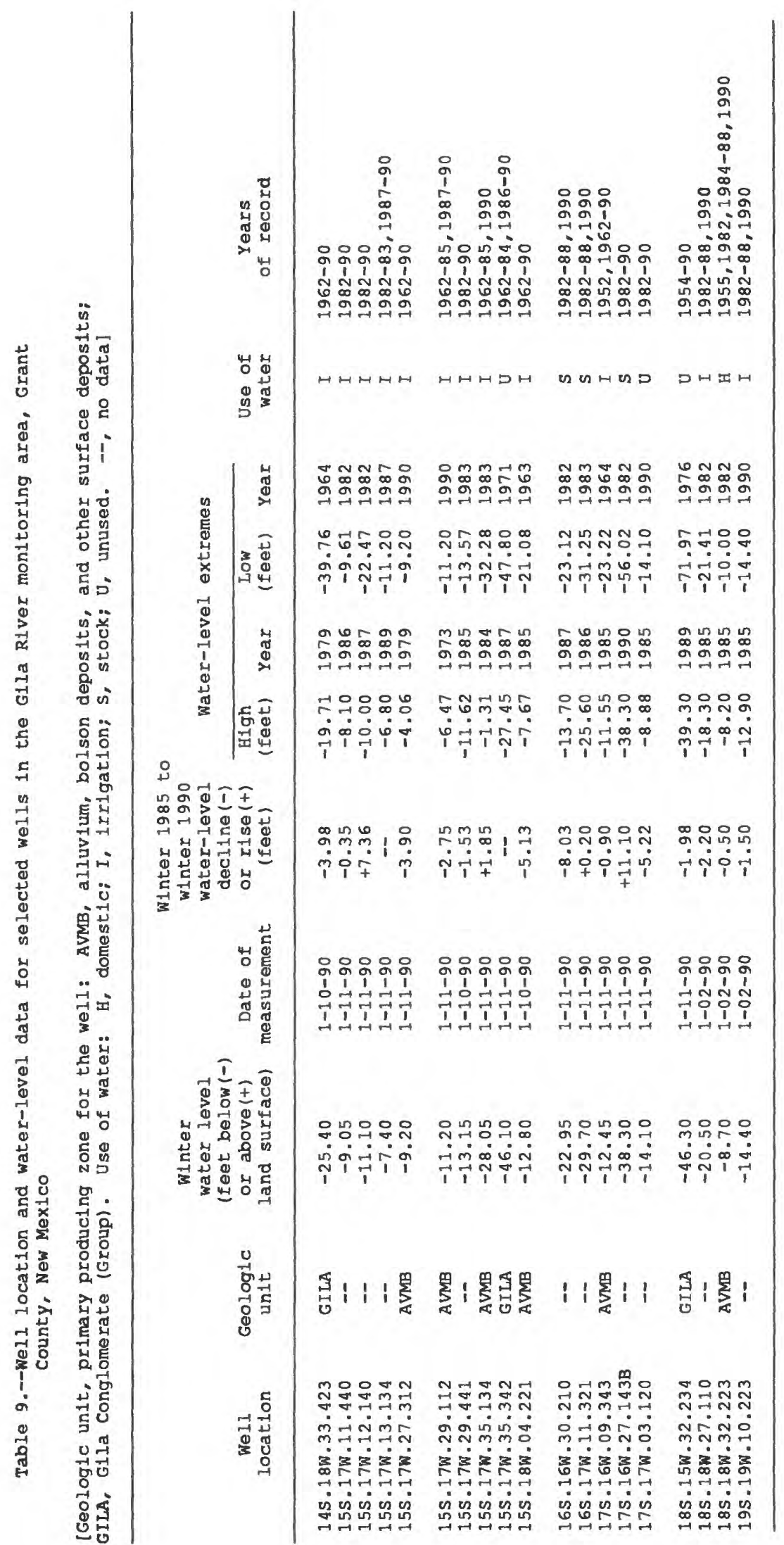




\section{Northern High Plains Monitoring Area}

The Northern High Plains monitoring area is located in Colfax and Union Counties, northeastern New Mexico. Not all water-level changes are shown on the map; however, all well locations and water-level data are listed in the table. Well locations marked with an asterisk (*) in the table are plotted on the map.

Most water-level changes in the area are declines. These declines range from less than 1 foot to more than 32 feet. Rises in water levels range from less than 1 foot to more than 28 feet. Mostly rising water levels are found in Rs. 28 to $33 \mathrm{E}$. within Tps. 24 and $25 \mathrm{~N}$. South of Clayton most changes are declines. 


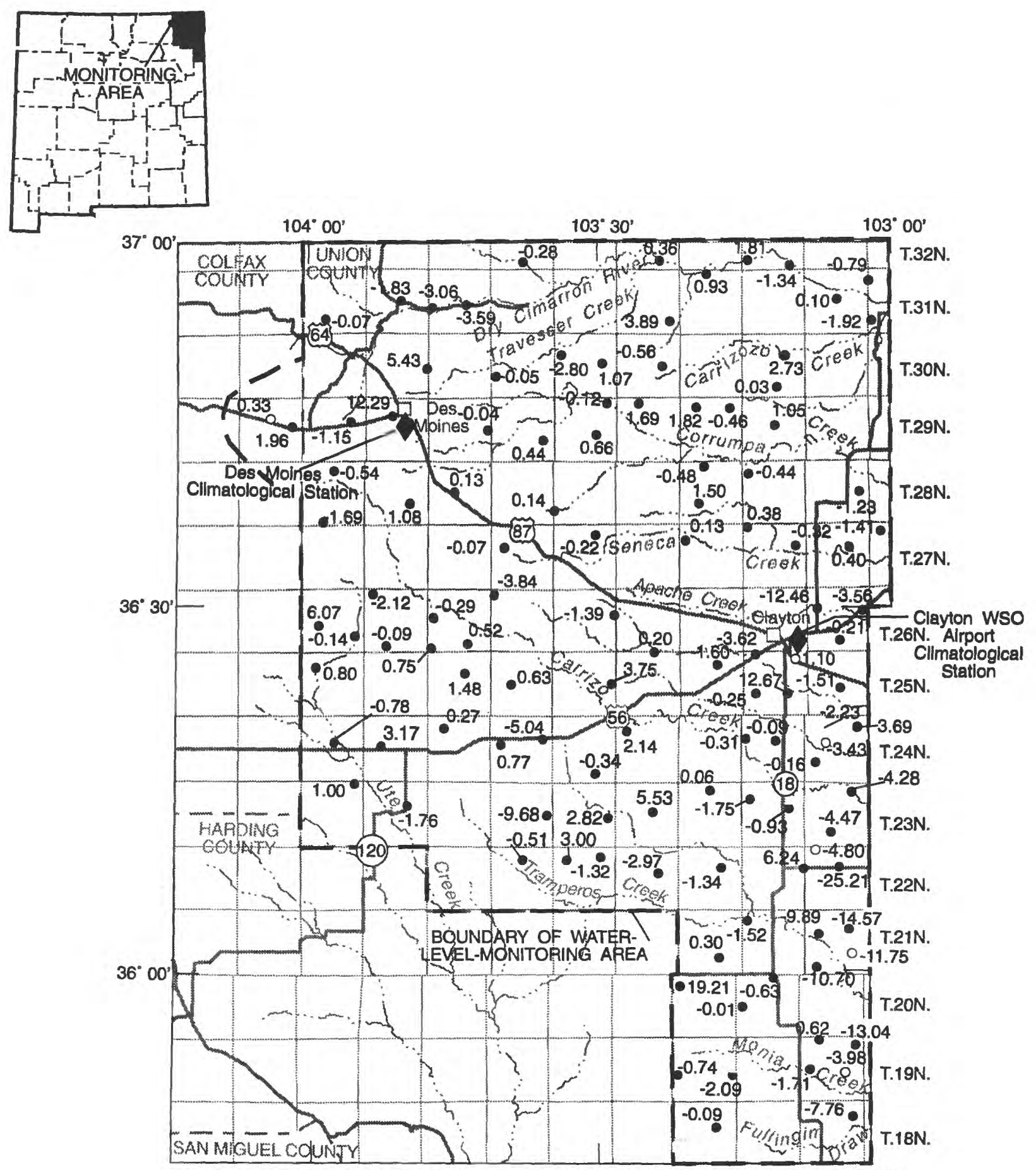

R.26E. R.27E. R.28E. R.29E. R.30E. R.31E. R.32E. R.33E. R.34E. R.35E. R.36E. R.37E.

\section{EXPLANATION}

1.48 WELL-Number represents the water-level

- rise or decline $(-)$, in feet

- WELL-Has water-level hydrograph for the period of record in this report \begin{tabular}{l|l|l}
0 & 5 & 10 \\
0 & 5 & 10 \\
0 & MILOMETERS
\end{tabular}

Figure 21.--Water-level changes for selected wells in the Northern High Plains monitoring area, 1986-91. 

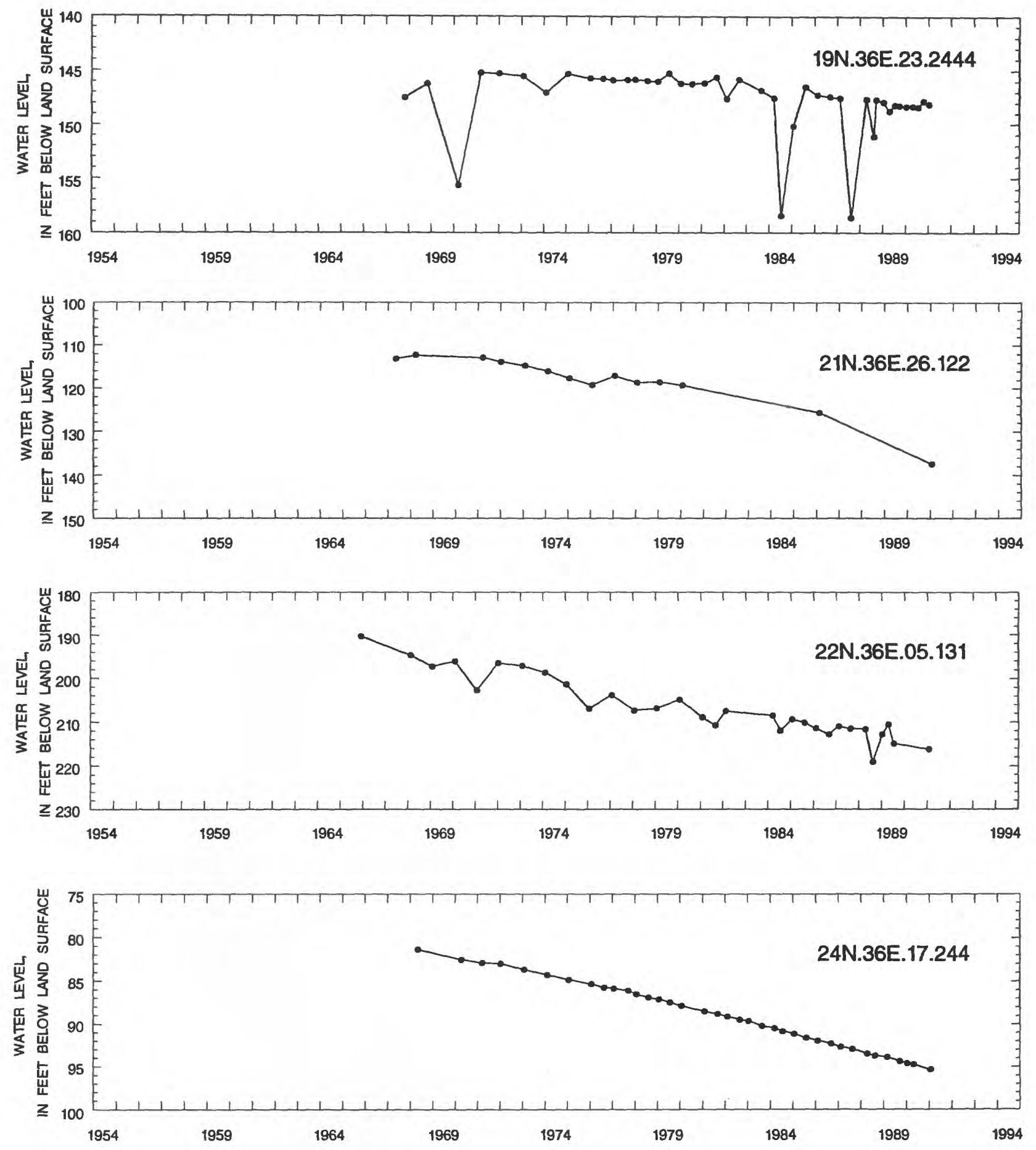

Figure 22.--Water-level data for selected wells in the Northem High Plains monitoring area and annual precipitation at the Clayton WSO Airport and Des Moines Climatological Stations. See figure 21 for location of wells and stations. 

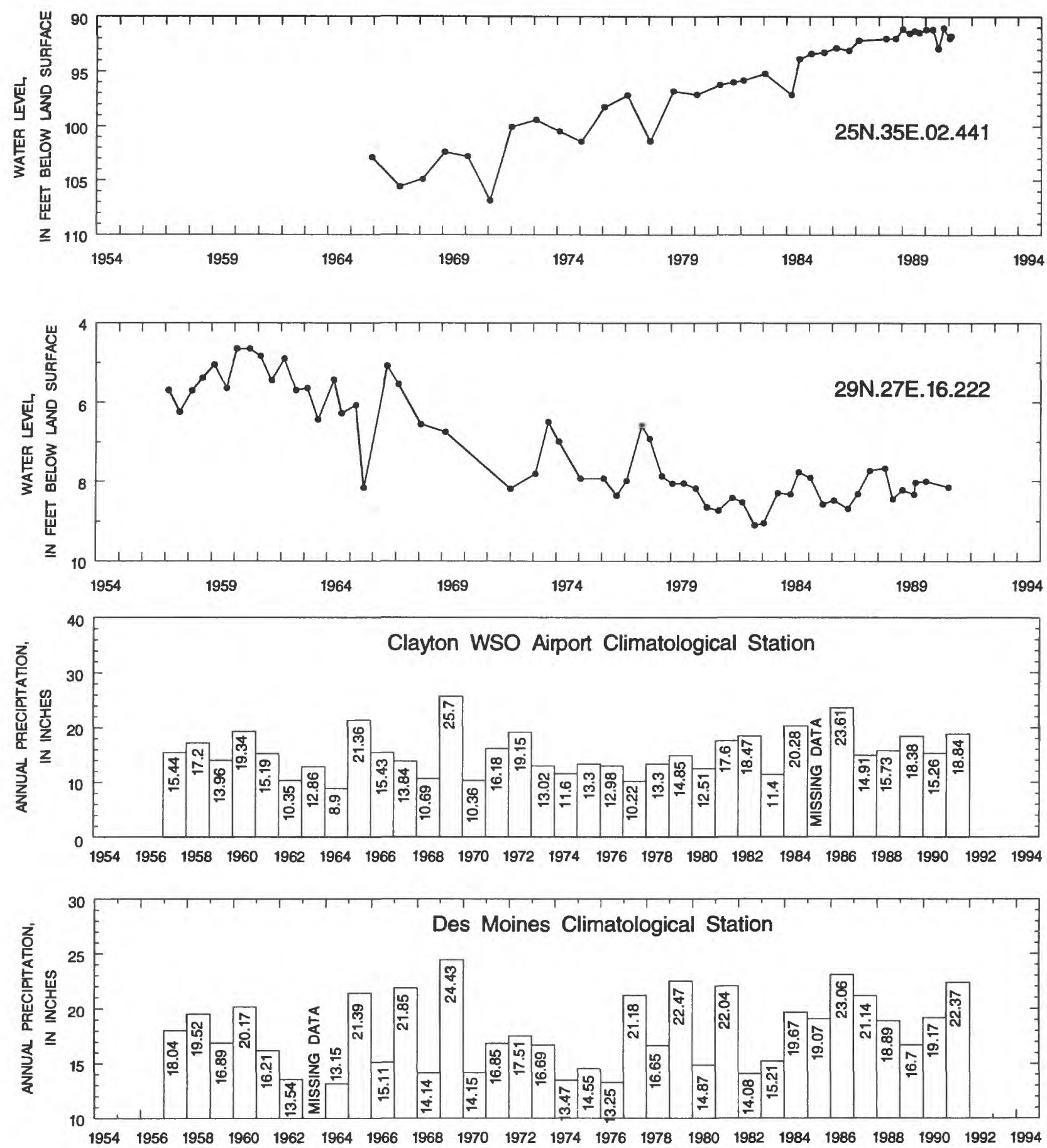

Figure 22.--Water-level data for selected wells in the Northem High Plains monitoring area and annual precipitation at the Clayton WSO Airport and Des Moines Climatological Stations.

See figure 21 for location of wells and stations--Concluded. 


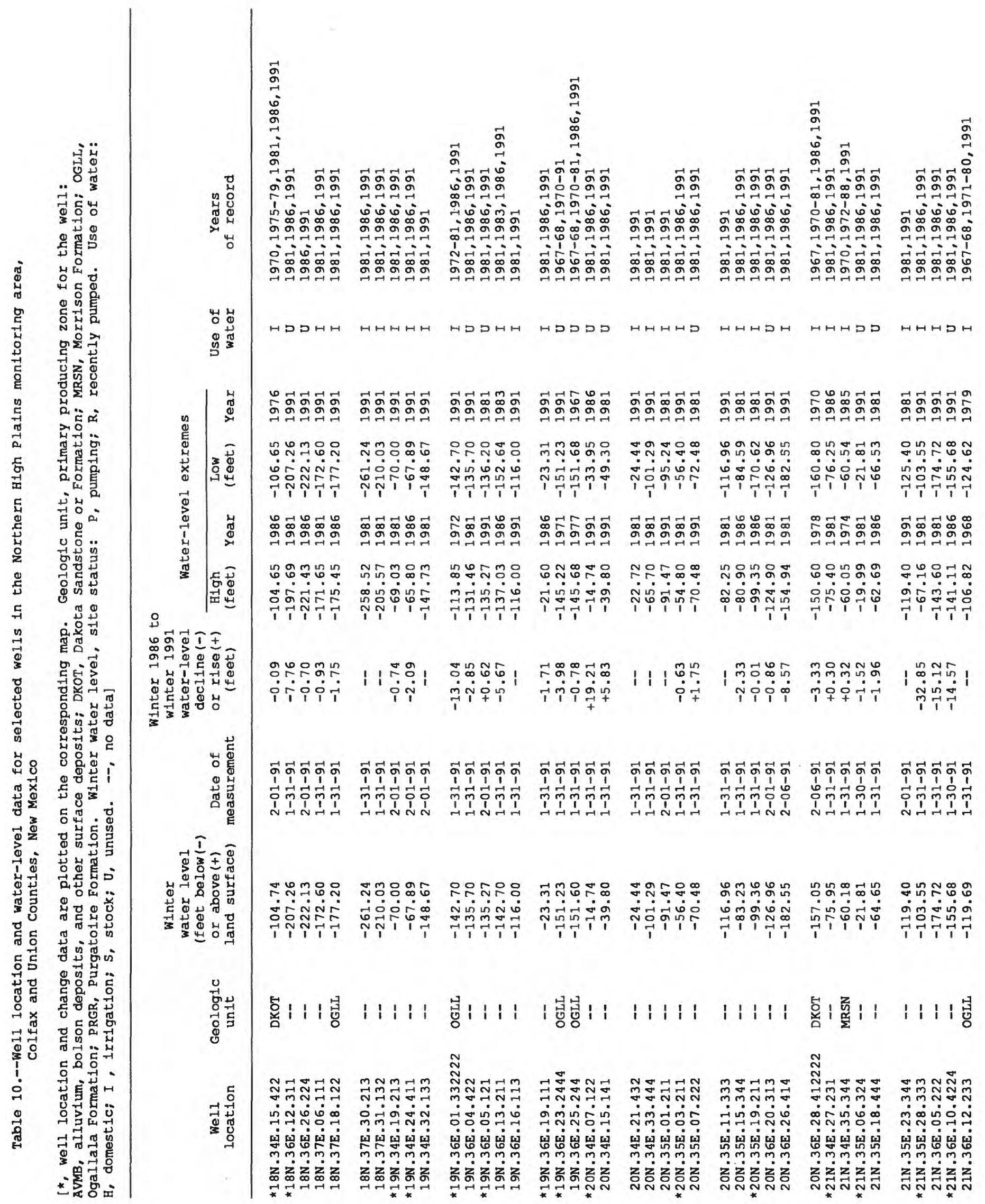


운

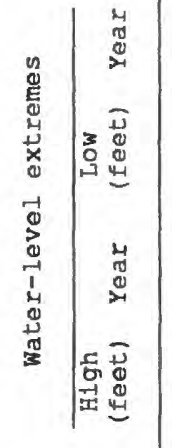

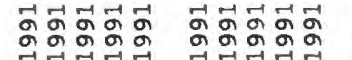

늊유메 突

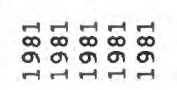

모ํํำ जิ

ํํำฏ王

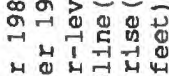

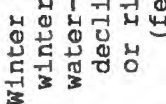

㟧

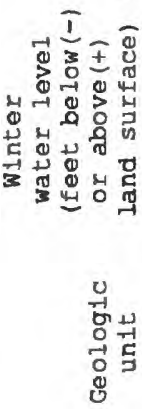

0
0
0
0
0
0
0
0
0

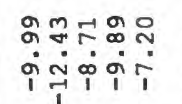

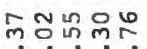

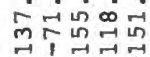

1

군?

ज्ञ

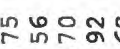

望

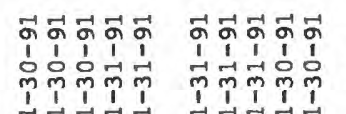

जननन

जनतन

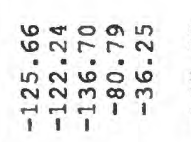

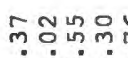

जिए

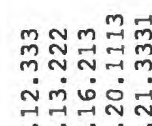

ร요우

쉬ำ

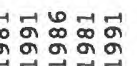

รั

नै:

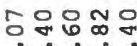

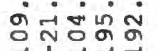

min

సี్ㅠㄲㅠ

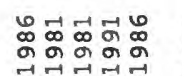

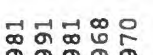

돈용요

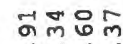

꼻ำ?

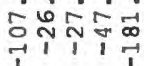

ำธำำ

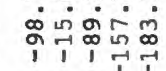

จㅇ 0

जिते

ที่ํำ

玄

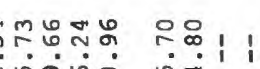

iिभ

난항

iि

नีनีनีन

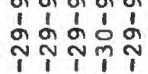

नีรีनีन

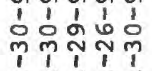

जनㅎํำ

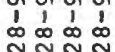

N

जनतन

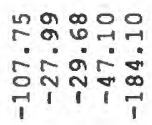

ธิธํํำ

वंगु

몯ำ

तิํํำ

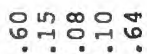

तิํํㅇํำ

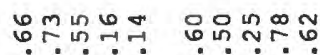

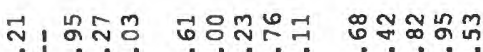

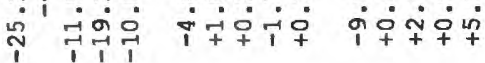

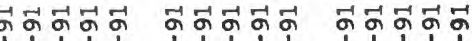

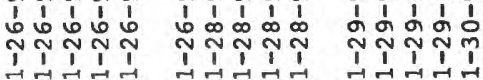

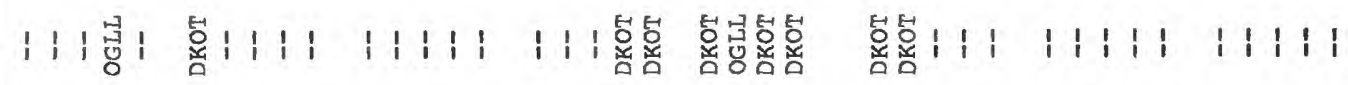

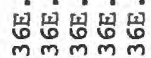
minmm

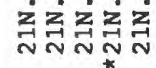

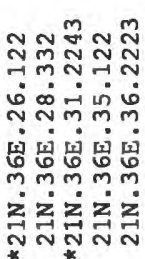

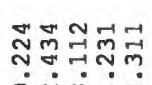

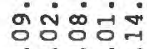

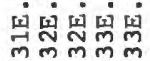

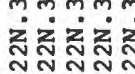

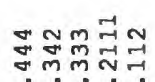
○ं

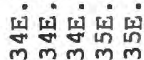
minnm

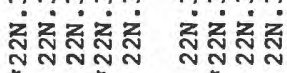

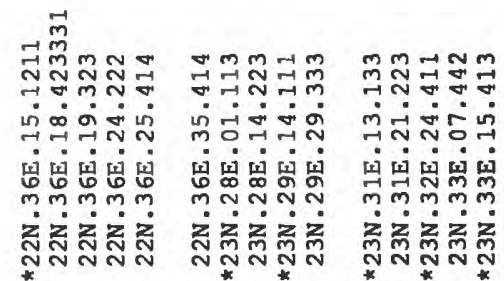




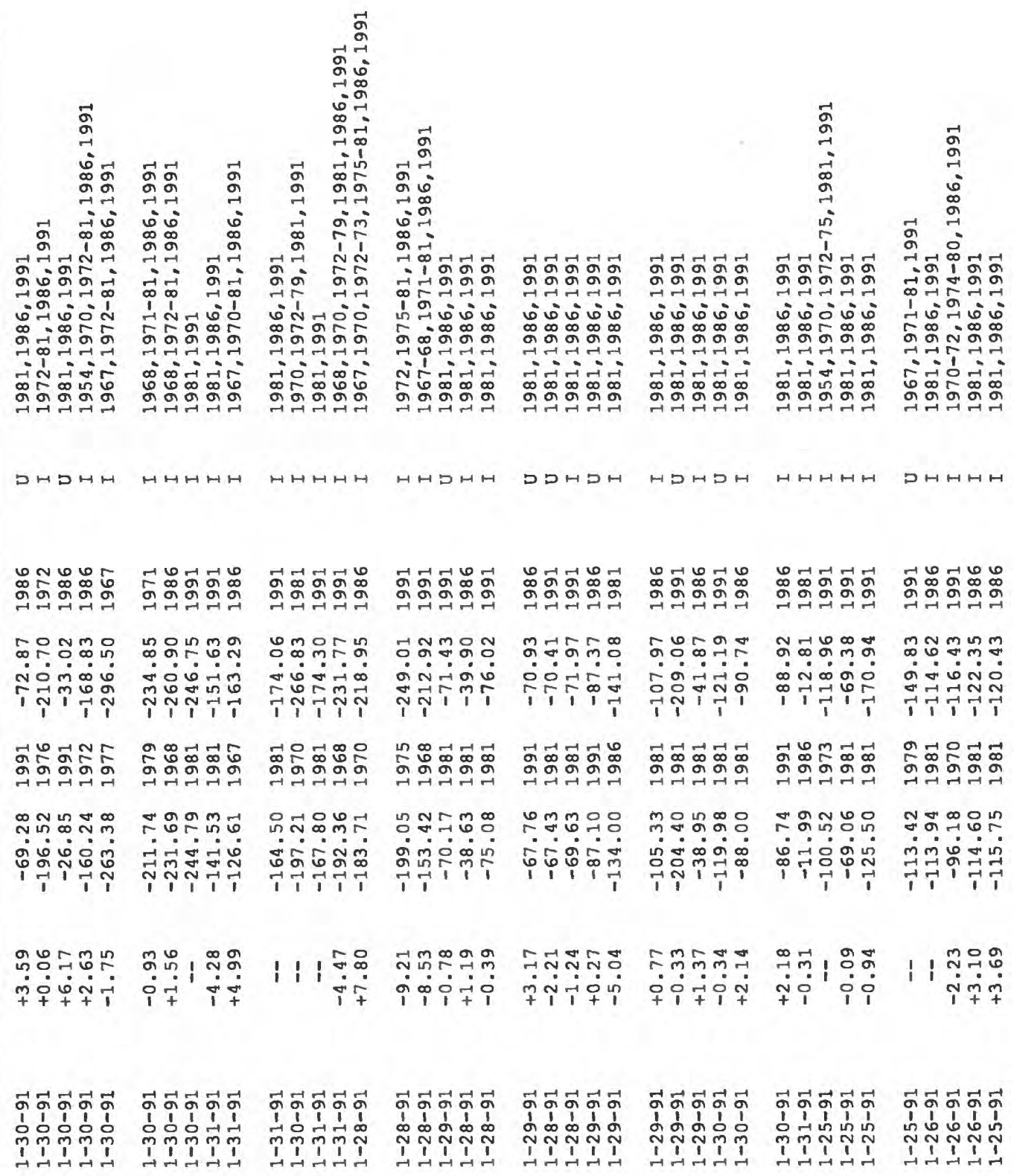

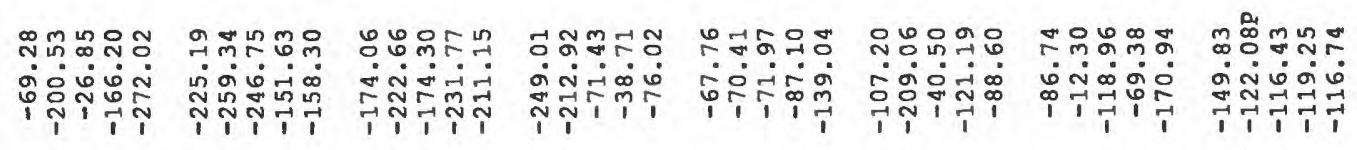

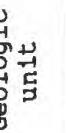

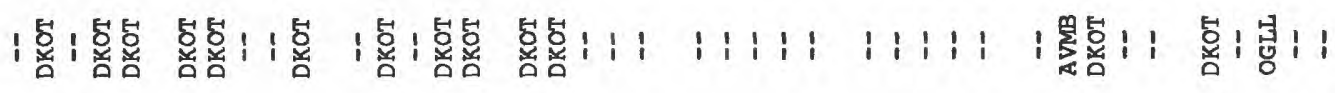

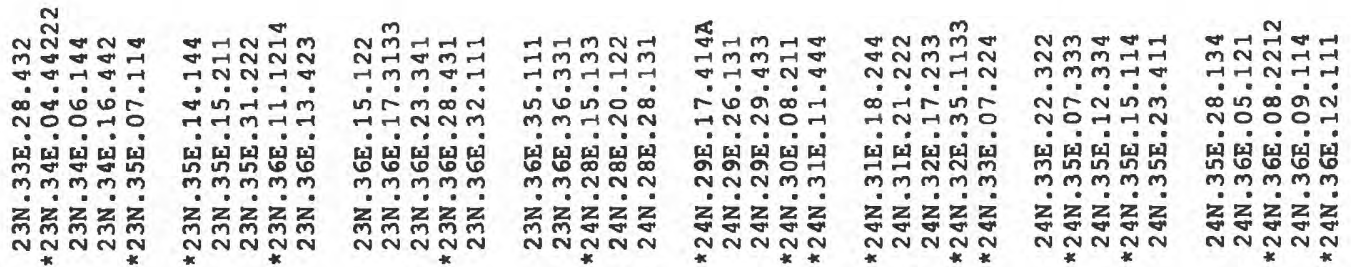




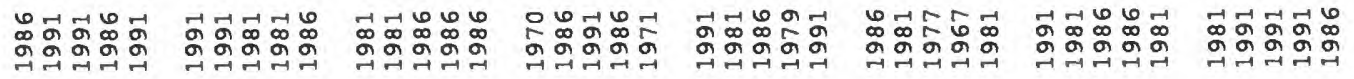

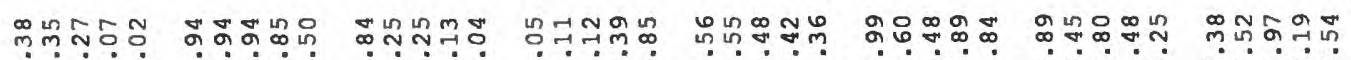
तิ

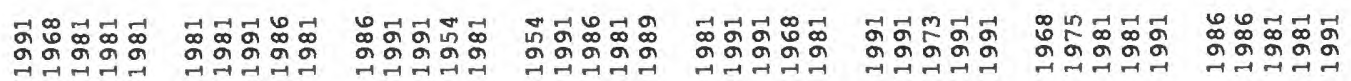
꾺

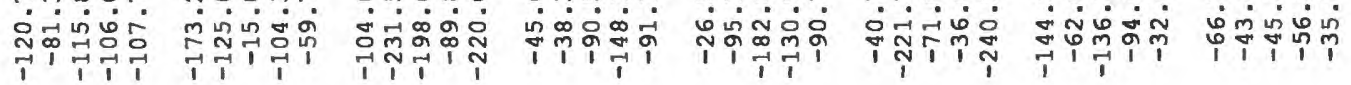

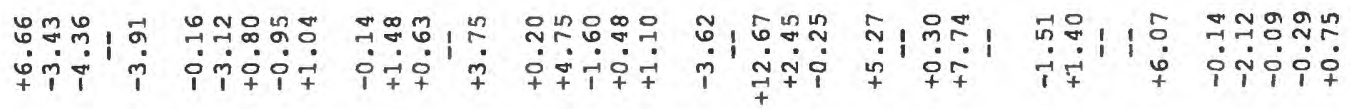

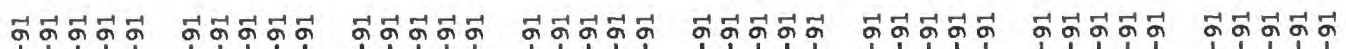

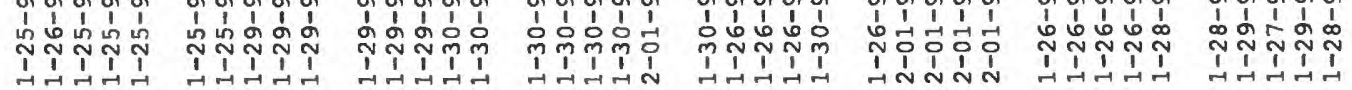

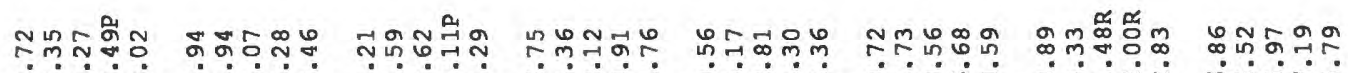

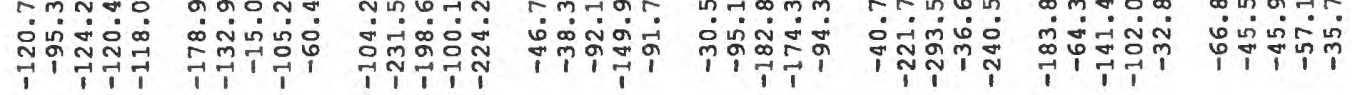

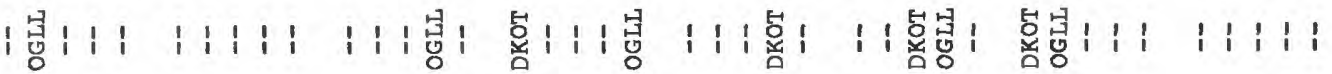

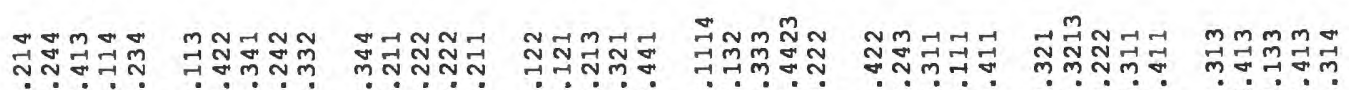

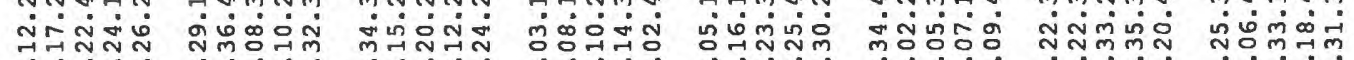

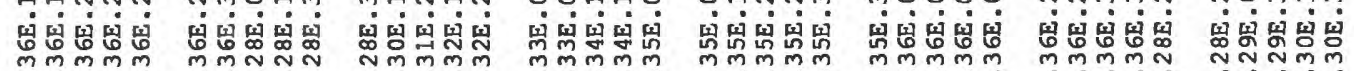

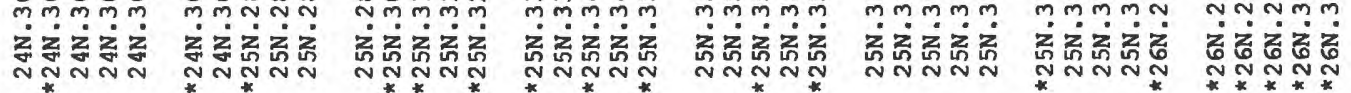




\begin{tabular}{|c|c|c|c|c|c|c|c|}
\hline 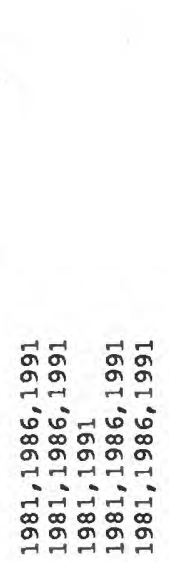 & 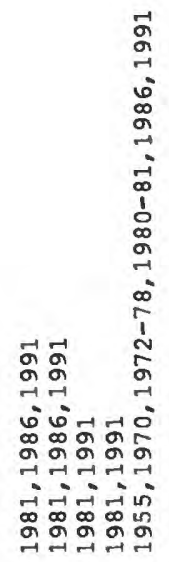 & 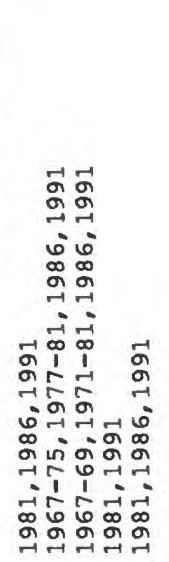 & 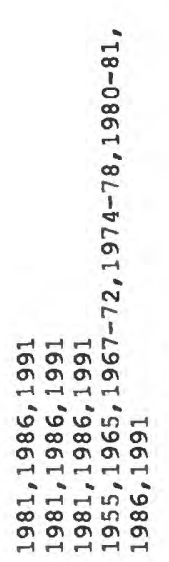 & 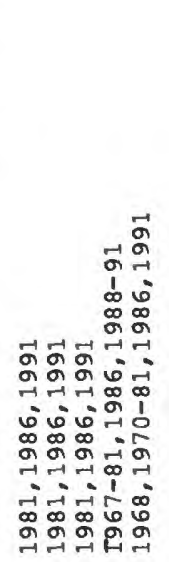 & 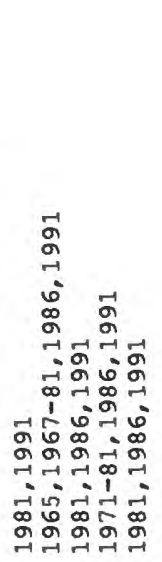 & 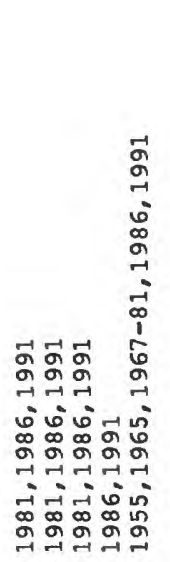 & 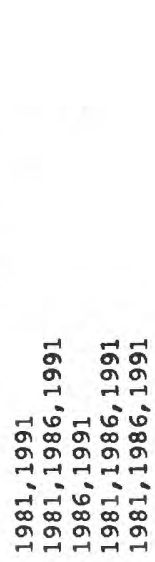 \\
\hline HDHつH & DHHDH & DHHHA & DHDE & मேमサカ & HHHHH & ОРН & HHつHH \\
\hline 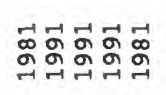 & 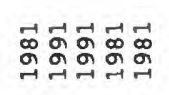 & 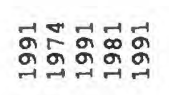 & 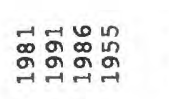 & 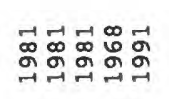 & 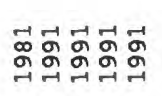 & 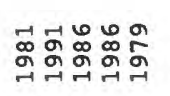 & 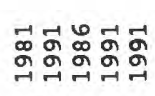 \\
\hline 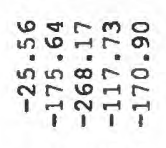 & 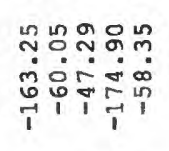 & 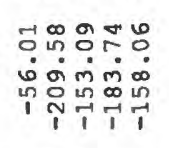 & 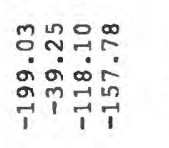 & 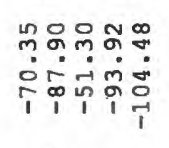 & 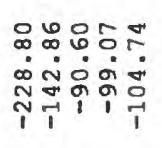 & 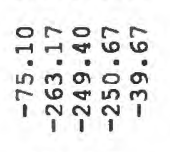 & 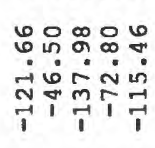 \\
\hline 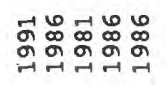 & 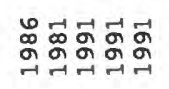 & 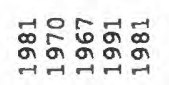 & 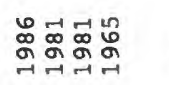 & 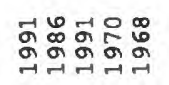 & 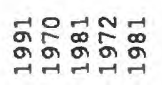 & 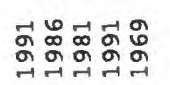 & 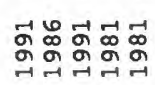 \\
\hline 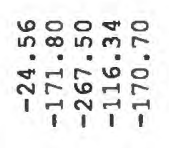 & 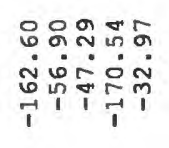 & 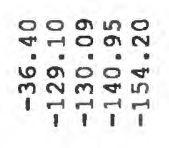 & 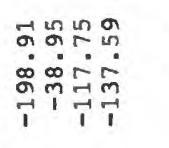 & 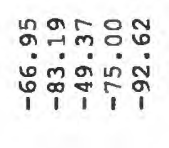 & 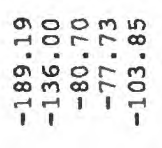 & 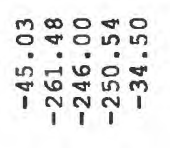 & 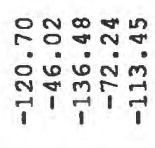 \\
\hline 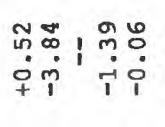 & 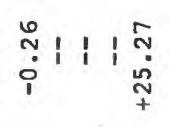 & 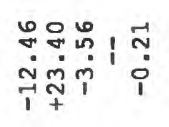 & 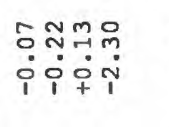 & 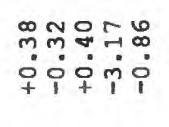 & 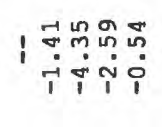 & 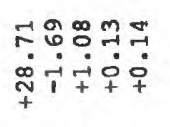 & | $\begin{array}{l}\infty \\
\text { in }\end{array}$ \\
\hline 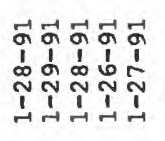 & 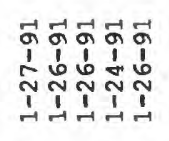 & 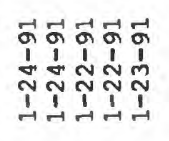 & 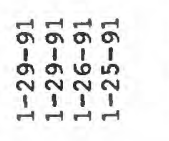 & 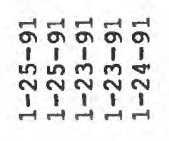 & 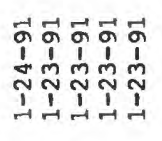 & 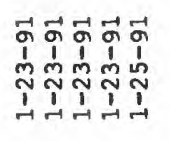 & 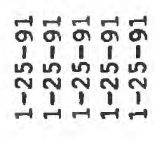 \\
\hline 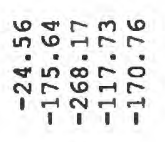 & 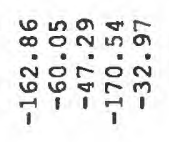 & 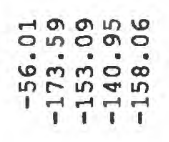 & 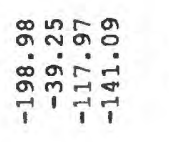 & 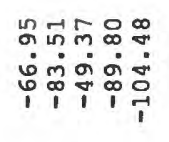 & 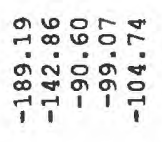 & 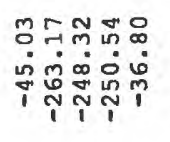 & 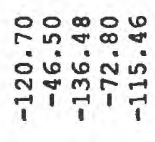 \\
\hline 11111 & 111:突 & 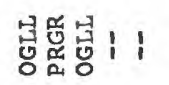 & |1总 & 111勻脗 & |总|炰| & ｜｜｜｜总 & 11111 \\
\hline 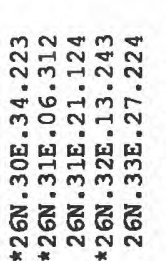 & 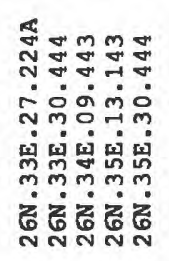 & 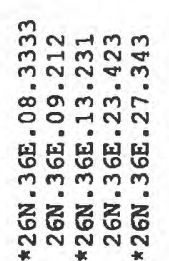 & 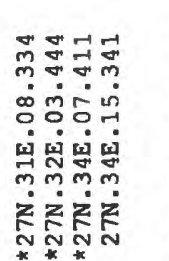 & 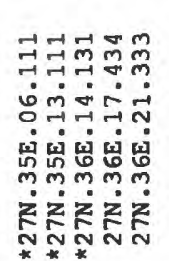 & 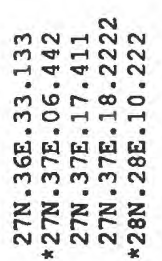 & 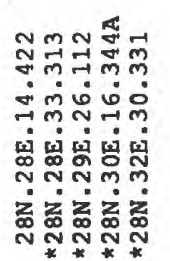 & 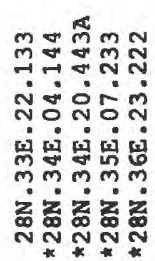 \\
\hline
\end{tabular}




\section{FIGURES--Concluded}

Figure 71. Map showing water-level changes for wells in the Lower Rio Grande monitoring area, 1984-89

72. Plots showing water-level data for selected wells in the Lower Rio Grande monitoring area and annual precipitation at the Elephant Butte and State University Climatological Stations

73. Map showing water-level changes for wells in the Hueco monitoring area, 1984-89

74. Plots showing water-level data for selected wells in the Hueco monitoring area.

\section{TABLES}

Table 1. Well location and water-level data for wells equipped with continuous water-level recorders.

2-16. Well location and water-level data for selected wells in the:

2. Causey-Lingo monitoring area, Roosevelt and Chaves Counties, New Mexico, and Bailey and Cochran Counties, Texas 18

3. Fort Sumner monitoring area, DeBaca and Guadalupe Counties, New Mexico

4. Estancia monitoring area, Torrance, Santa $\mathrm{Fe}$, and Bernalillo Counties, New Mexico.

5. Salt Basin monitoring area, Otero County, New Mexico. 48

6. San Simon monitoring area, Hidalgo County, New Mexico 52

7. Middle Rio Grande monitoring area, Sandoval, Bernalillo, Valencia, Torrance, and Socorro Counties, New Mexico. 58

8. Virden monitoring area, Hidalgo County, New Mexico 65

9. Gila River monitoring area, Grant County, New Mexico. 69

10. Northern High Plains monitoring area, Colfax and Union Counties, New Mexico.

11. Lea County monitoring area, Lea, Chaves, and Eddy Counties, New Mexico

12. Tularosa Basin monitoring area, Otero, Lincoln, and Socorro Counties, New Mexico

13. San Agustin Plains monitoring area, Catron and Socorro Counties, New Mexico .118

14. Harding County monitoring area, New Mexico ..........................................................123

15. Curry County monitoring area, New Mexico............................................................130

16. House monitoring area, Quay County, New Mexico..................................................138 


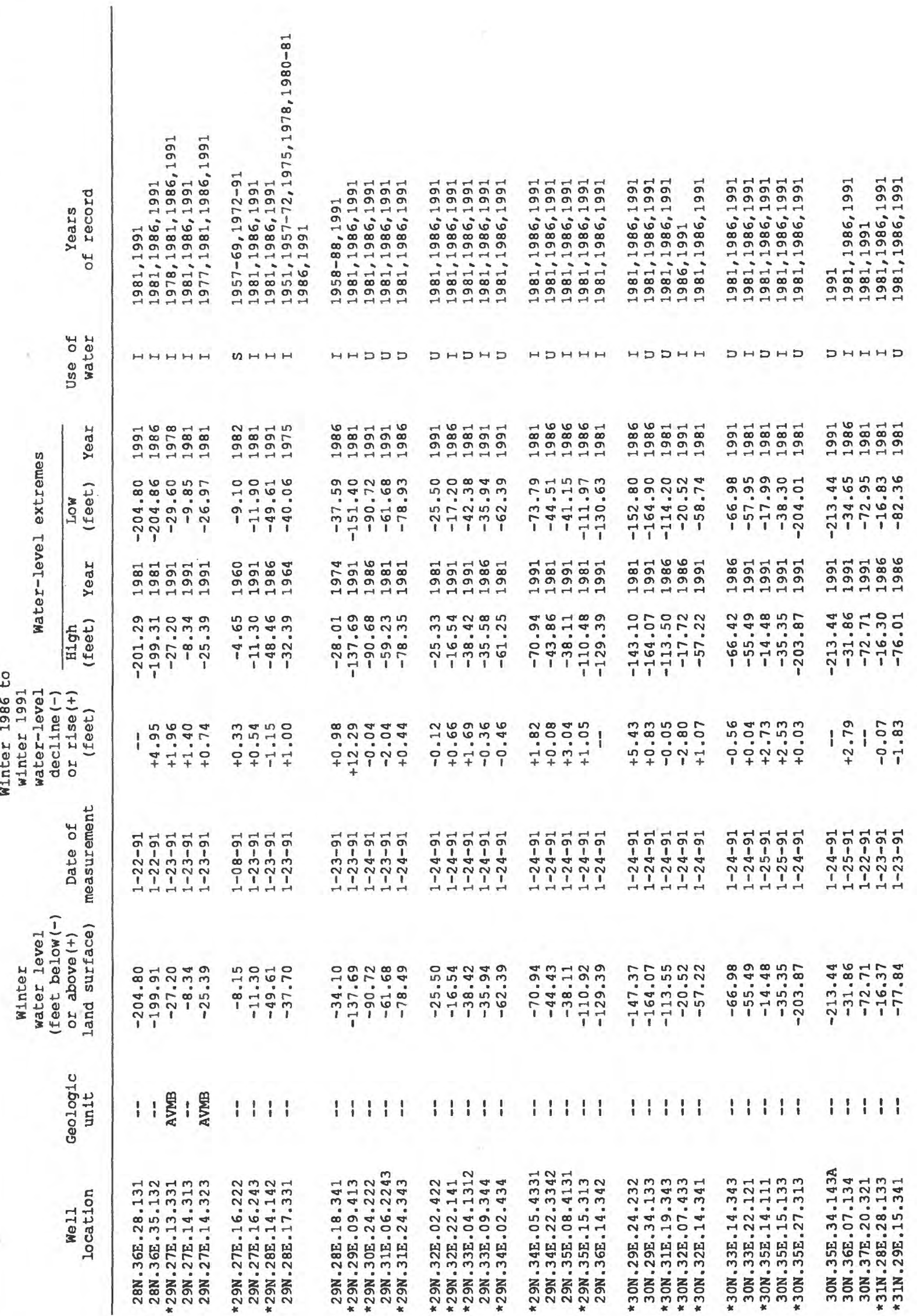




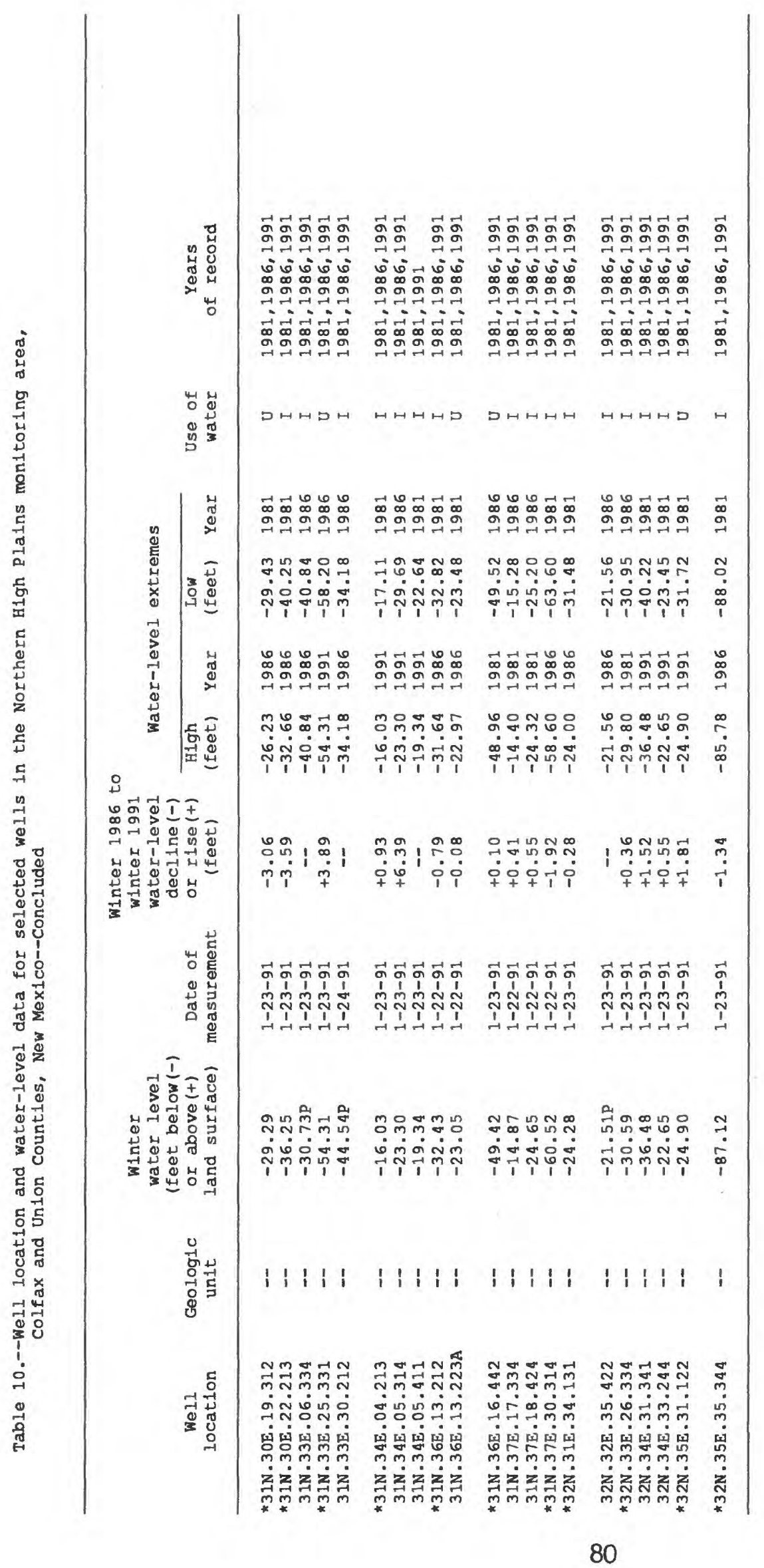




\section{Lea County Monitoring Area}

The Lea County monitoring area is in Lea, Chaves, and Eddy Counties, southeastern New Mexico. Not all water-level changes are shown on the map; however, all well locations and water-level data are listed in the table. Well locations marked with an asterisk (*) in the table are plotted on the map.

Most water-level changes are declines that range from less than 1 foot to more than 9 feet. Rises range from less than 1 to more than 8 feet. In the northwest part of the monitoring area water-level data indicate rises, in some cases more than 6 feet. A small area southeast of Lovington has rises from less than 1 to more than 6 feet. 

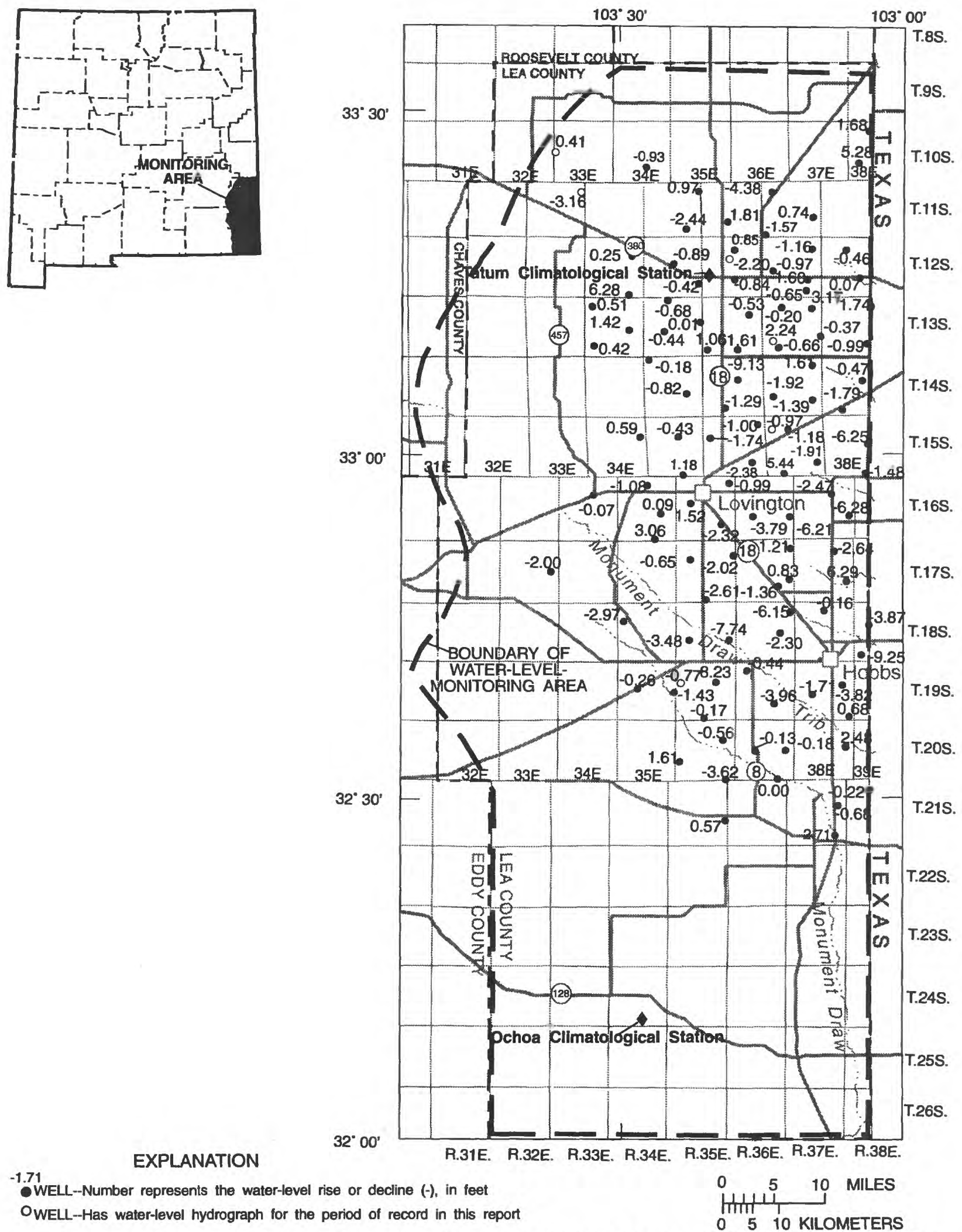

-1.71 WELL--Number represents the water-level rise or decline (-), in feet

OWELL--Has water-level hydrograph for the period of record in this report

Figure 23.--Water-level changes for selected wells in the Lea County monitoring area, 1986-91. 

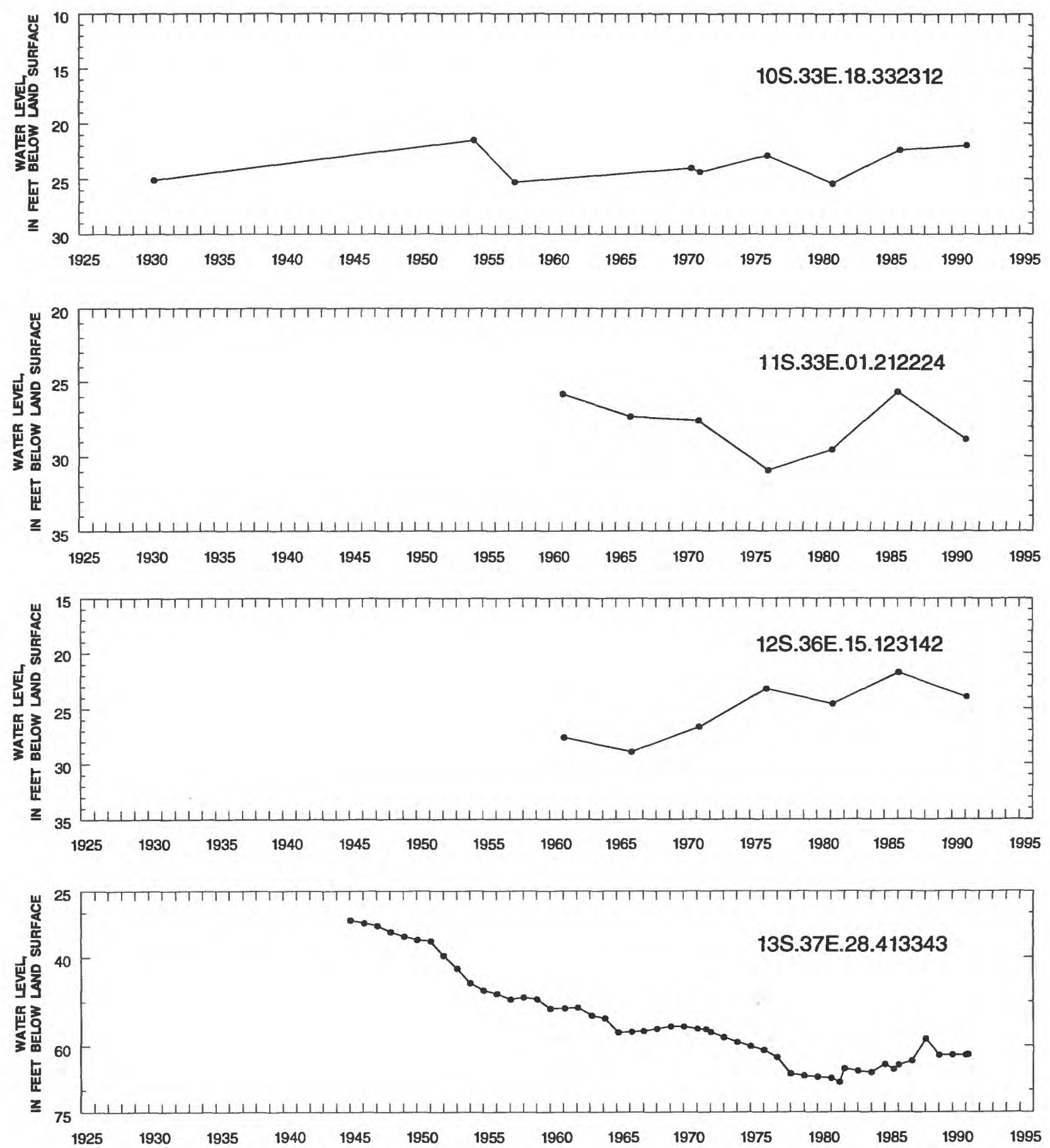

Figure 24.--Water-level data for selected wells in the Lea County monitoring area and annual precipitation at the Tatum and Ochoa Climatological Stations. See figure 23 for location of wells and stations. 

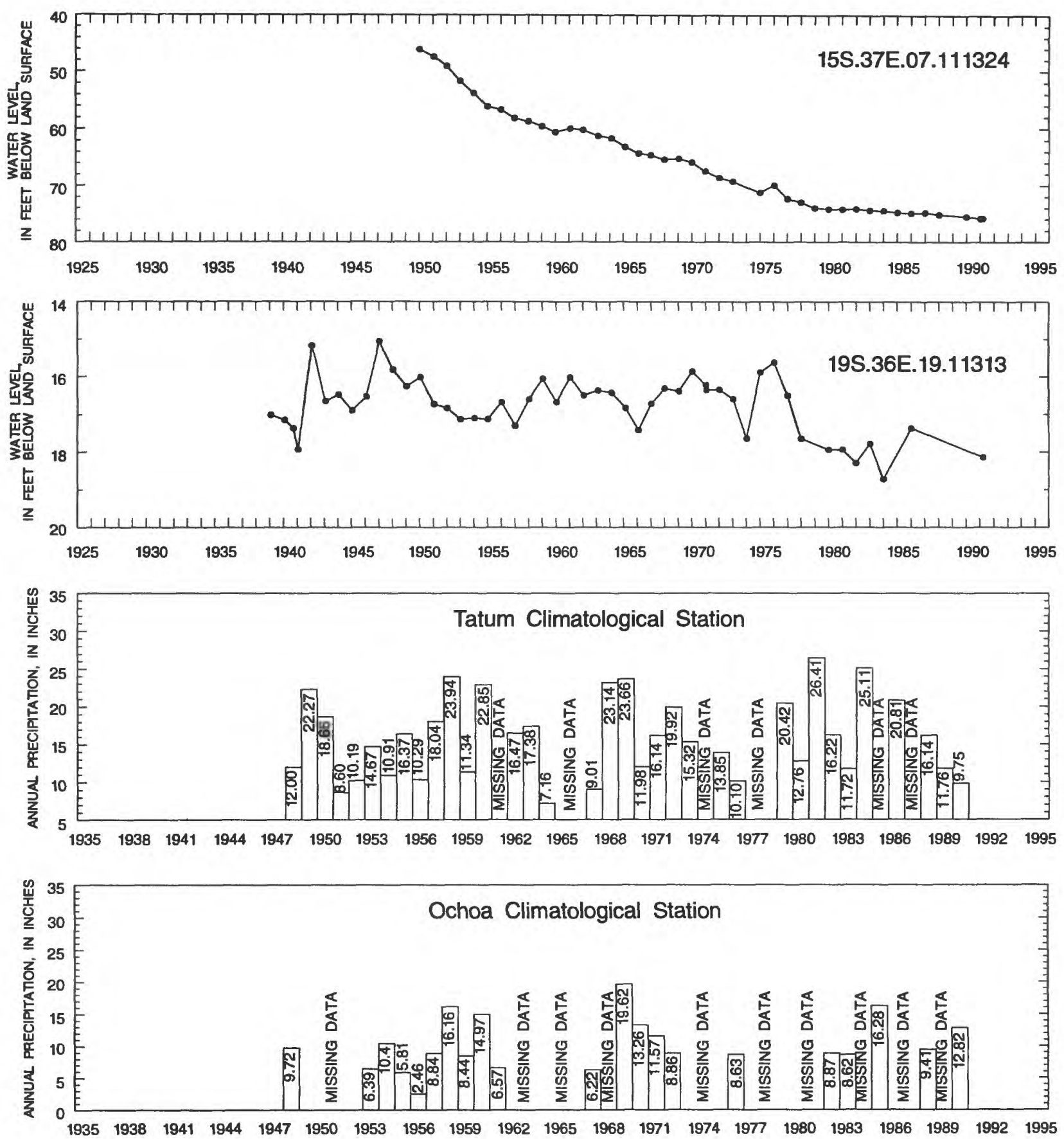

Figure 24.--Water-level data for selected wells in the Lea County monitoring area and annual precipitation at the Tatum and Ochoa Climatological Stations. See figure 23 for location of wells and stations--Concluded. 


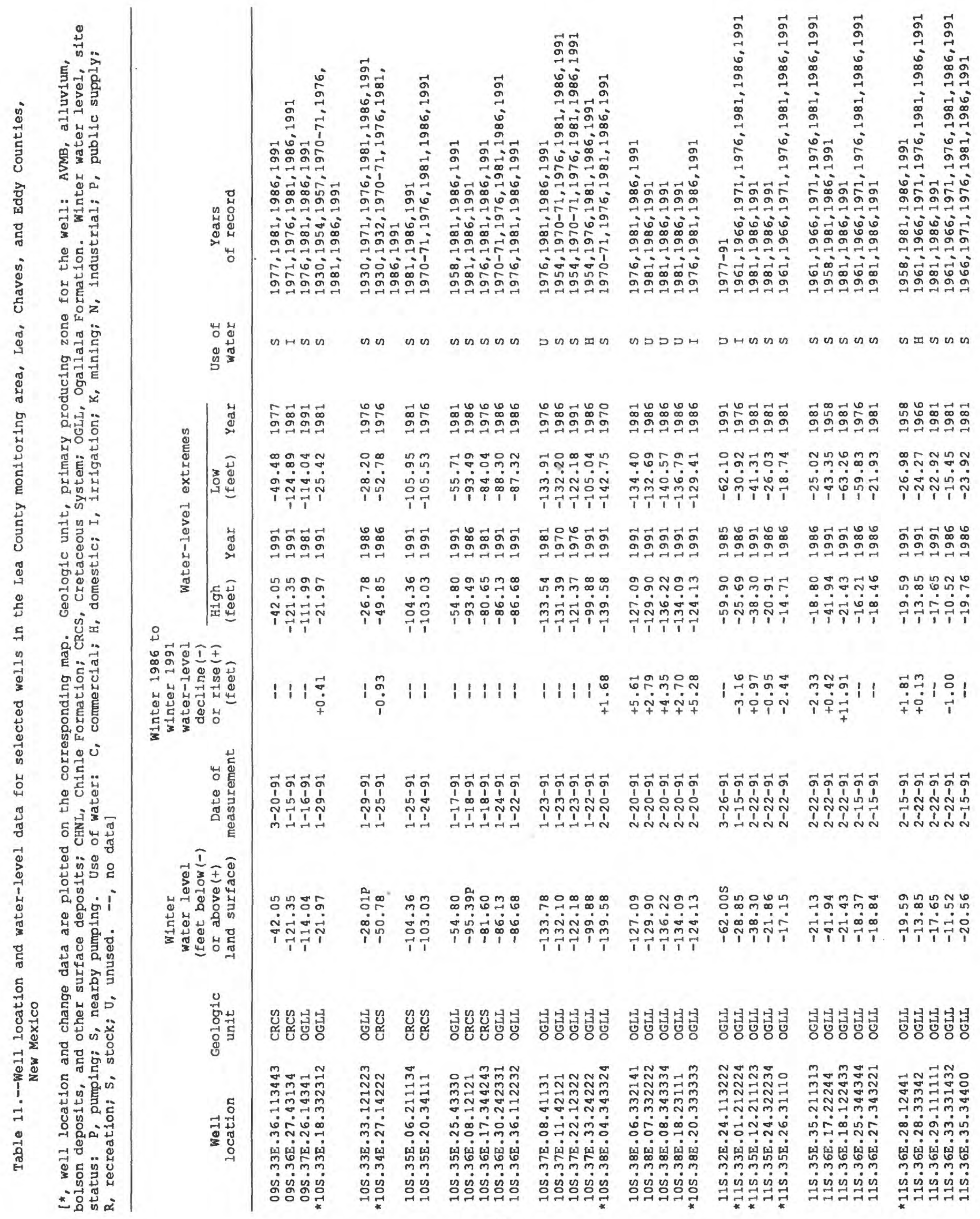




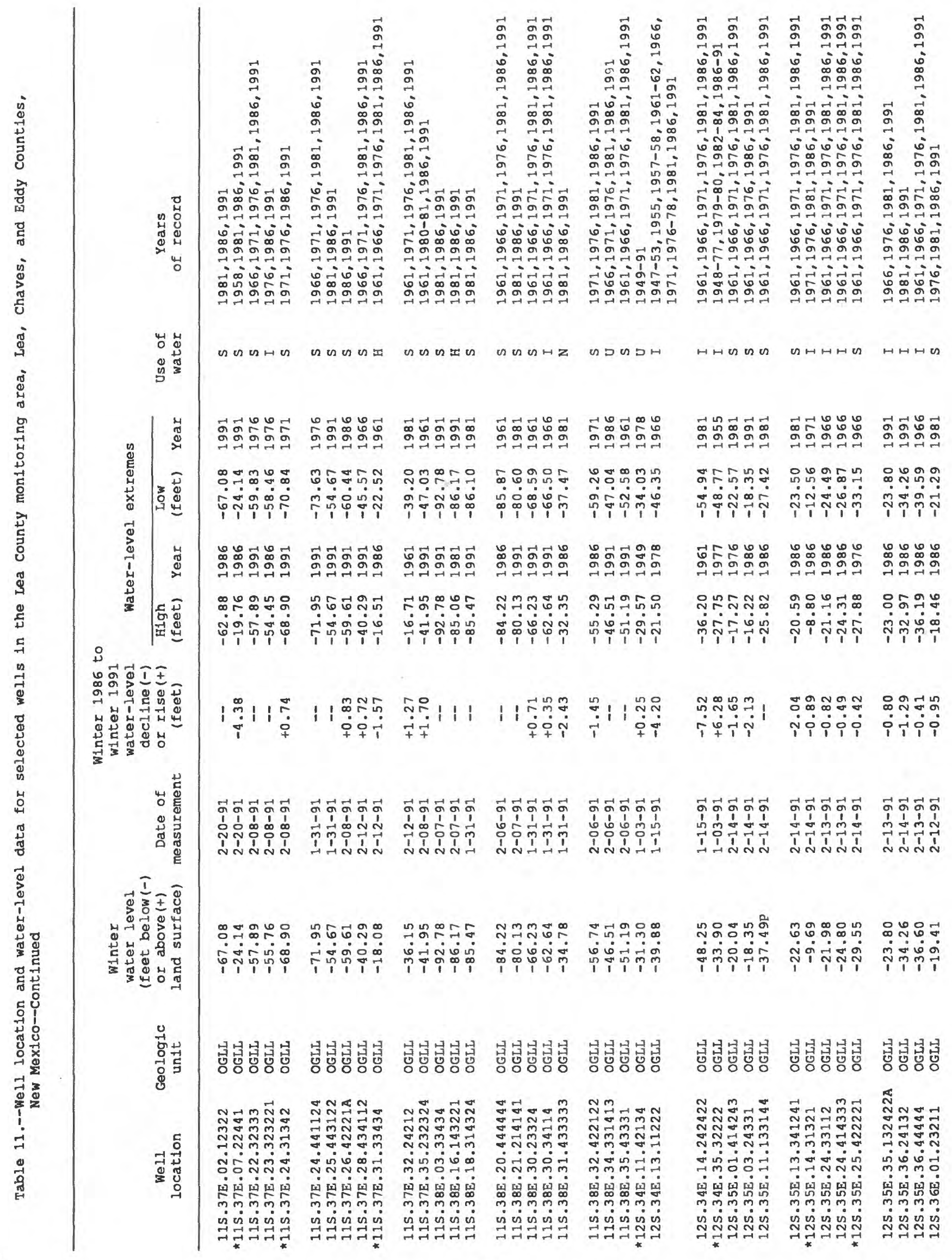




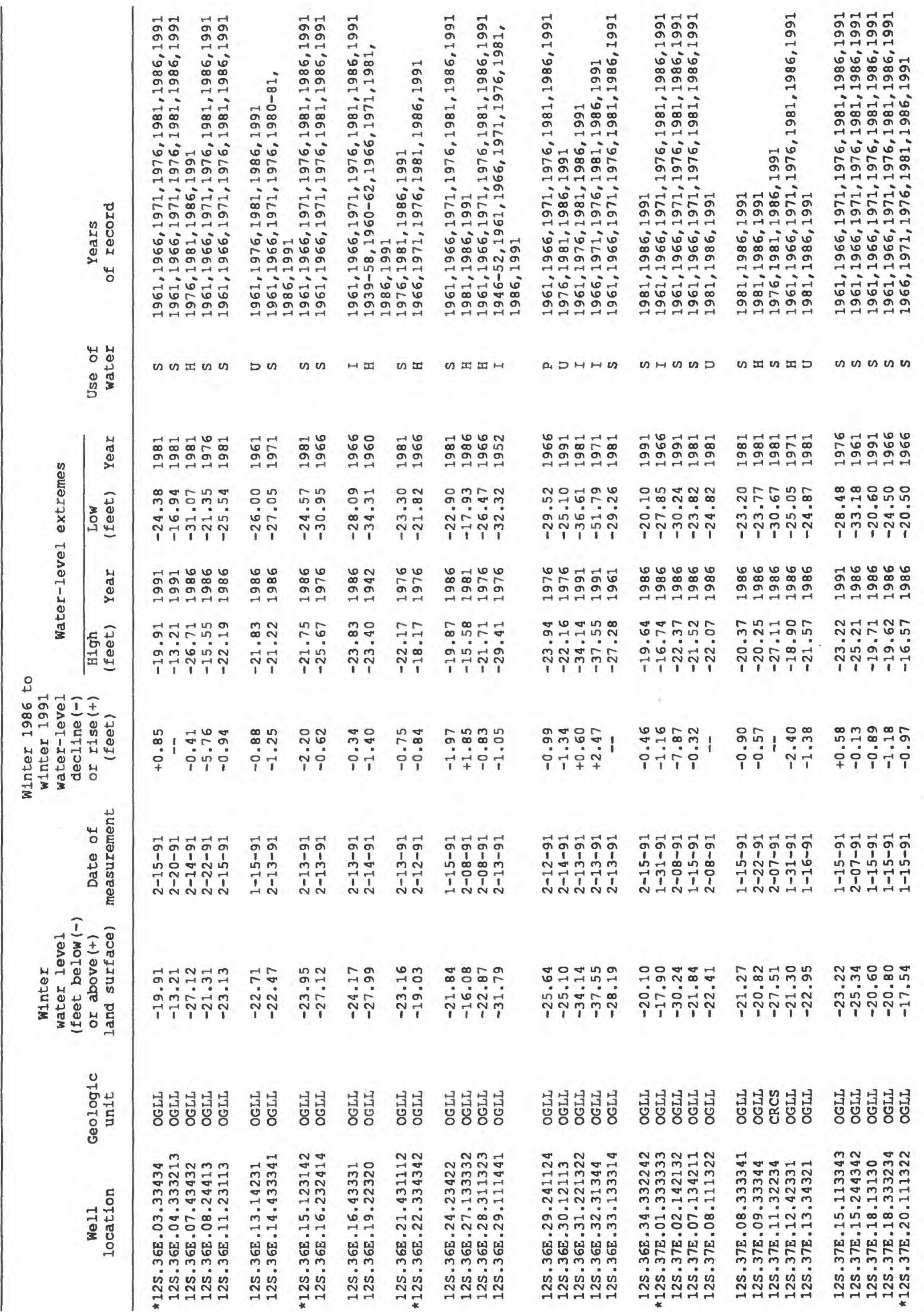




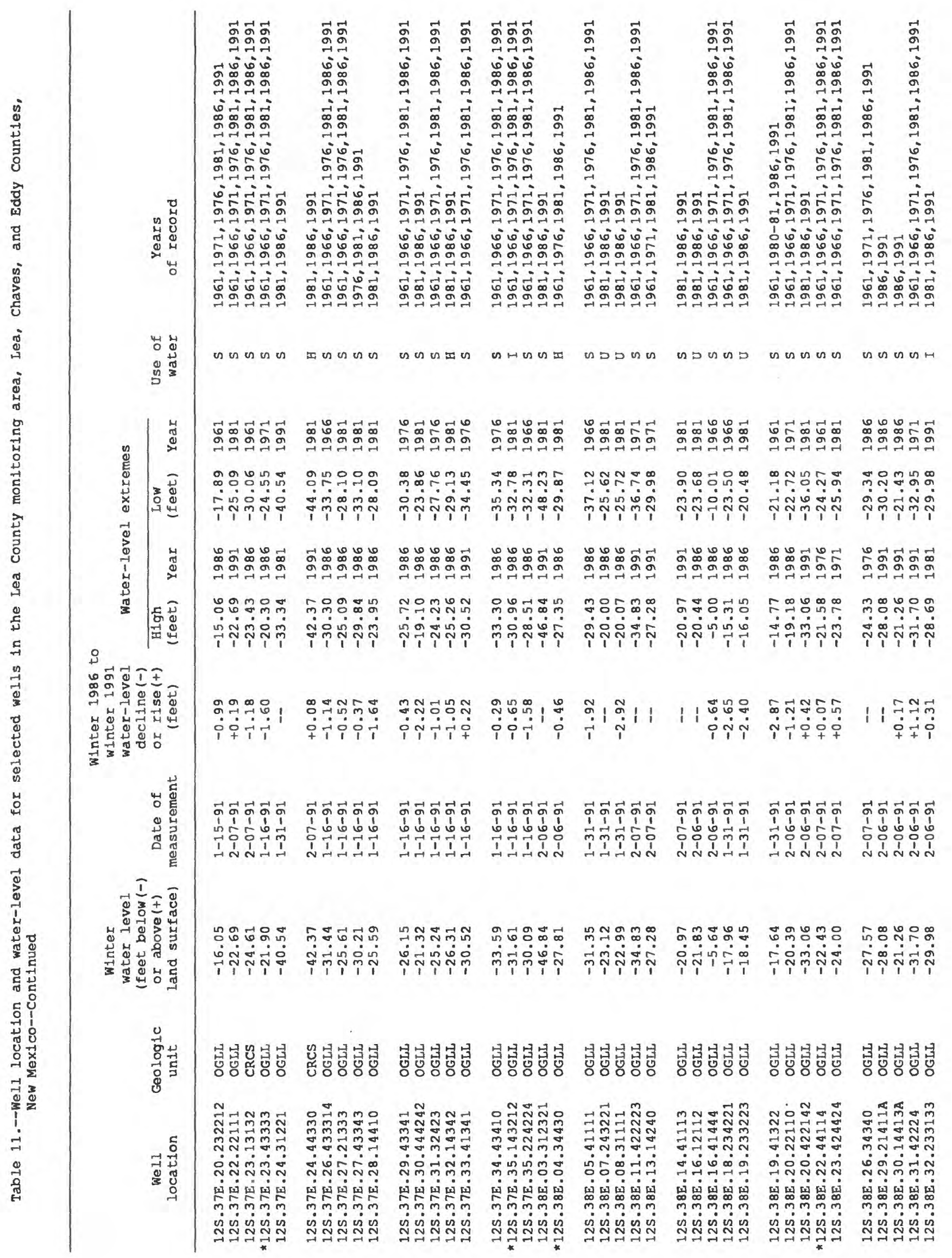

